WESTFÄLISCHE

WILHELMS-UNIVERSITÄT

MÜNSTER

The Ritual Calendar of South Acèh, Indonesia

Abdul Manan

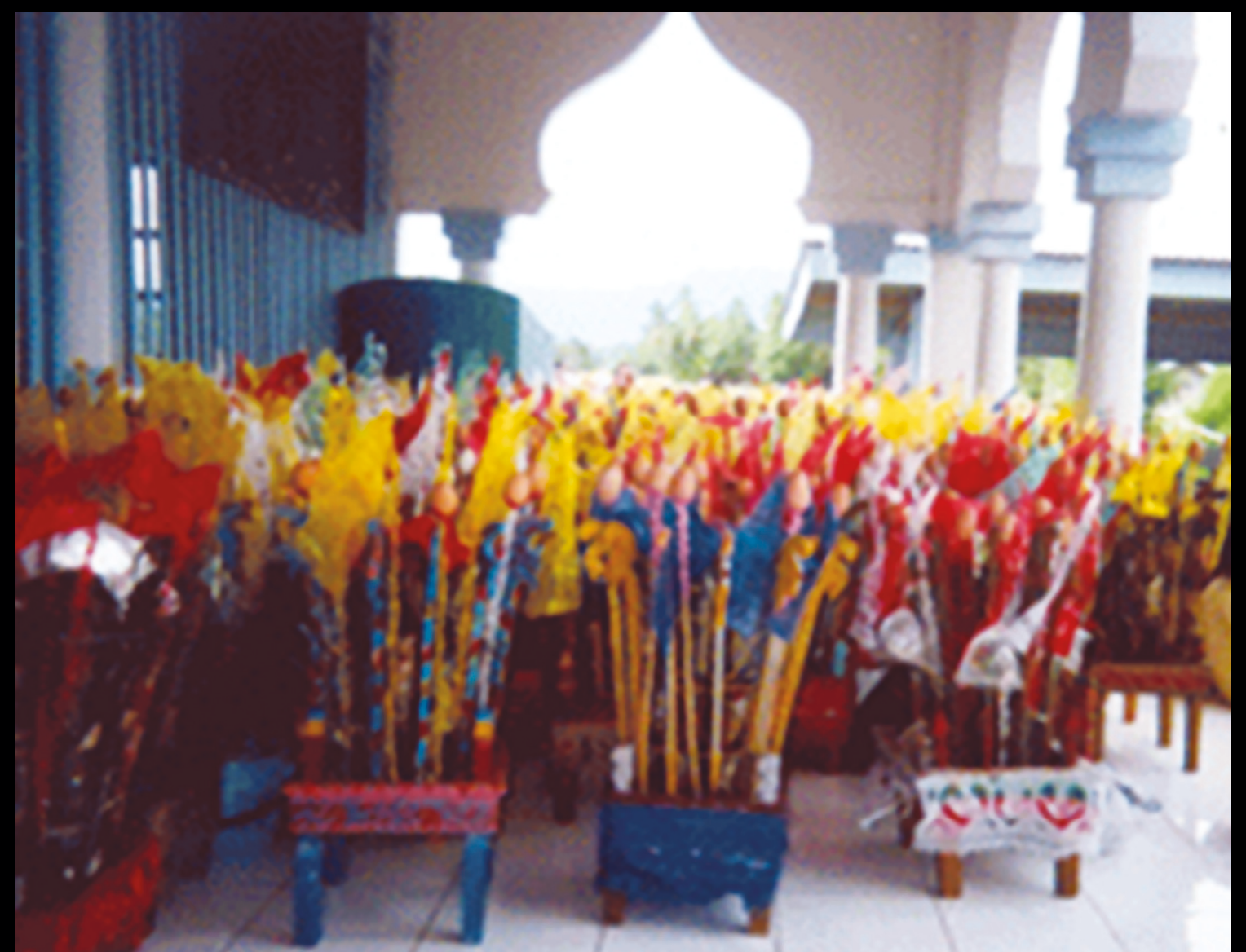


Abdul Manan

The Ritual Calendar of South Acèh, Indonesia 
$\underline{\underline{=}}$

WESTFÄLISCHE

WILHELMS-UNIVERSITÄT

MUNSTER

Wissenschaftliche Schriften der WWU Münster

\section{Reihe X}

Band 22 
Abdul Manan

The Ritual Calendar of South Acèh, Indonesia 
Wissenschaftliche Schriften der WWU Münster

herausgegeben von der Universitäts- und Landesbibliothek Münster

http://www.ulb.uni-muenster.de

Bibliografische Information der Deutschen Nationalbibliothek:

Die Deutsche Nationalbibliothek verzeichnet diese Publikation in der Deutschen Nationalbibliografie;

detaillierte bibliografische Daten sind im Internet über http://dnb.d-nb.de abrufbar.

Dieses Buch steht gleichzeitig in einer elektronischen Version über den Publikations- und

Archivierungsserver der WWU Münster zur Verfügung.

http://www.ulb.uni-muenster.de/wissenschaftliche-schriften

Abdul Manan

"The Ritual Calendar of South Acèh, Indonesia“

Wissenschaftliche Schriften der WWU Münster, Reihe X, Band 22

(C) 2015 der vorliegenden Ausgabe:

Die Reihe „Wissenschaftliche Schriften der WWU Münster“ erscheint im Verlagshaus Monsenstein und Vannerdat OHG Münster

www.mv-wissenschaft.com

Dieses Werk ist unter der Creative-Commons-Lizenz vom Typ 'CC BY-NC-ND 3.0 DE' lizenziert: http://creativecommons.org/licenses/by-nc-nd/3.0/de/

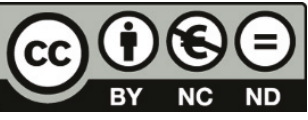

ISBN 978-3-8405-0125-8

URN urn:nbn:de:hbz:6-49229498097

(Druckausgabe)

(elektronische Version)

direkt zur Online-Version:

(C) 2015 Abdul Manan

Alle Rechte vorbehalten

Satz:

Titelbild:

Umschlag:

Druck und Bindung:
Abdul Manan

Abdul Manan: Sanggèn offerings on the verandah of the mosque MV-Verlag

MV-Verlag
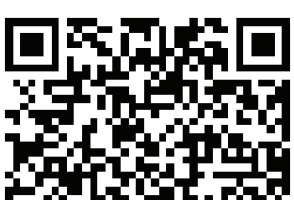

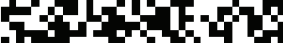
a 
"Adat is where you are; wherever you walk on this earth it is under this sky that you live".

"The people who have no adat resemble a ship that has no a captain".

"The law of religion without adat is tasteless, adat without religion does not exist".

Jamee elders 



\section{Table of Contents}

LIST OF FIGURES ...................................................................................................................... VI

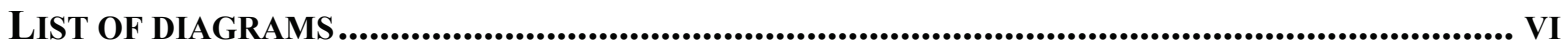

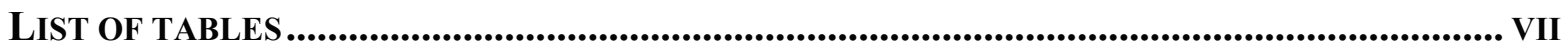

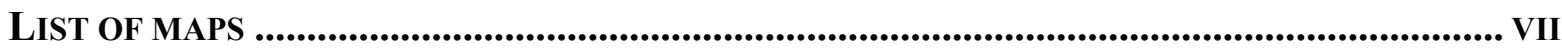

ACKNOWLEDGEMENTS ................................................................................................................. VIII

CHAPTER 1 .................................................................................................................................. 1

Introduction $\quad \mathbf{1}$

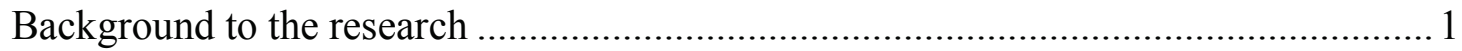

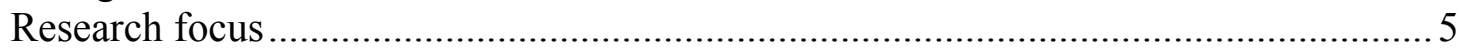

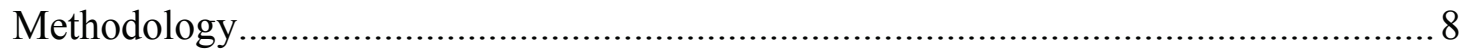

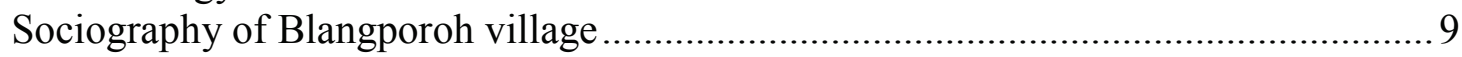

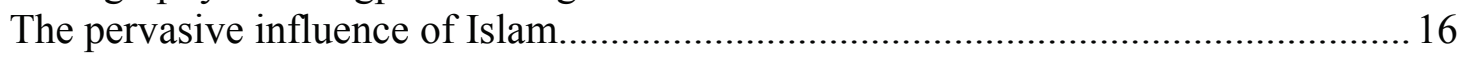

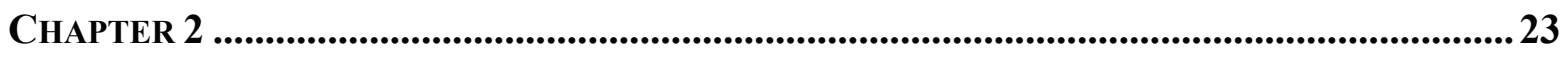

$\begin{array}{ll}\text { The Aneuk Jamee cosmology } & 23\end{array}$

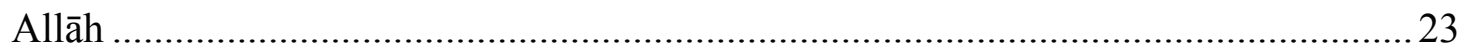

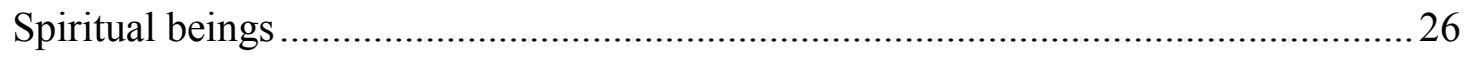

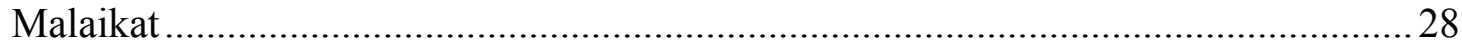

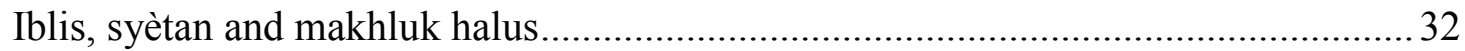

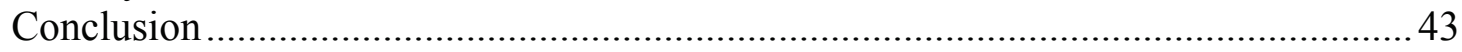

CHAPTER 3 ................................................................................................................................... 44

The Aneuk Jamee kinship $\quad 44$

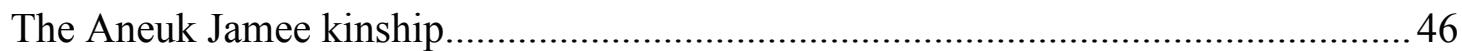

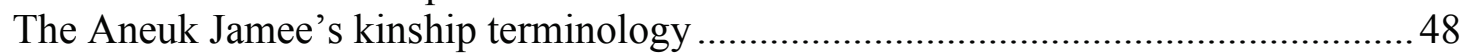

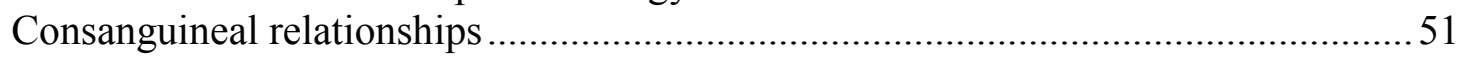

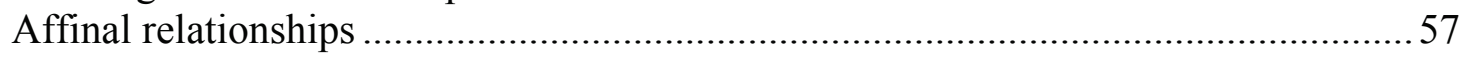

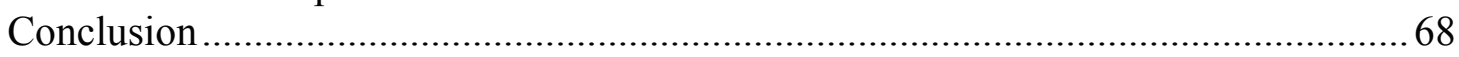

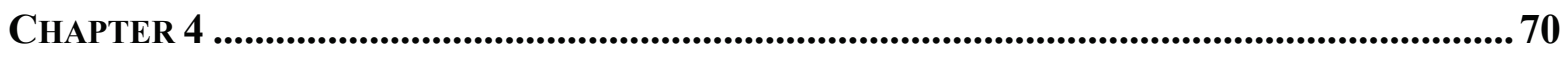

$\begin{array}{ll}\text { The ritual of marriage } & \mathbf{7 0}\end{array}$

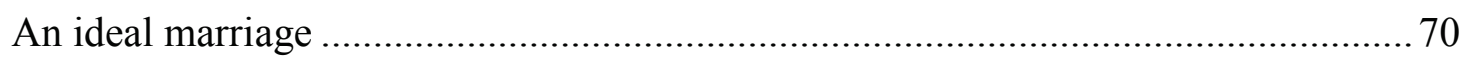

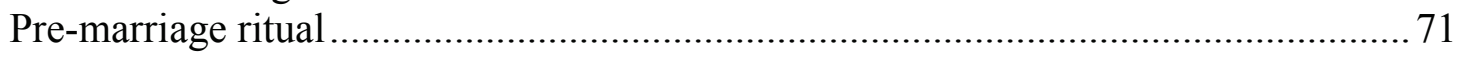

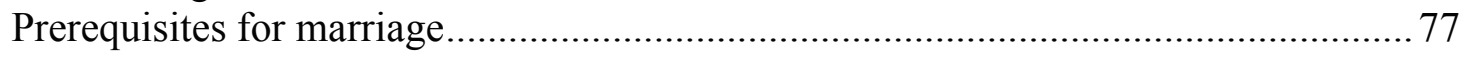

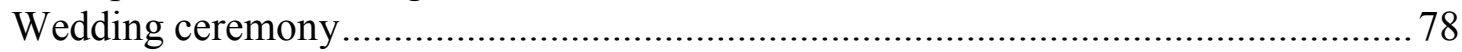

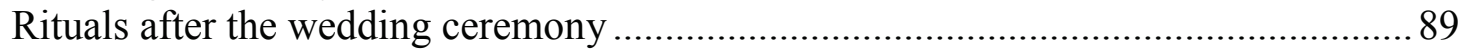

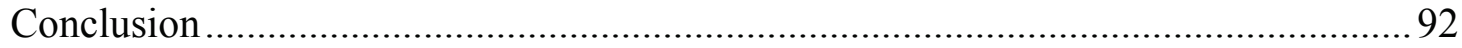

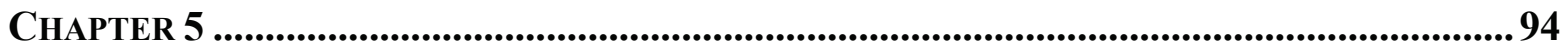

$\begin{array}{ll}\text { The ritual of ' } \bar{a} \boldsymbol{s} y \bar{u} r \bar{a} & 94\end{array}$

The mythical valorization of the month and the days .................................................94

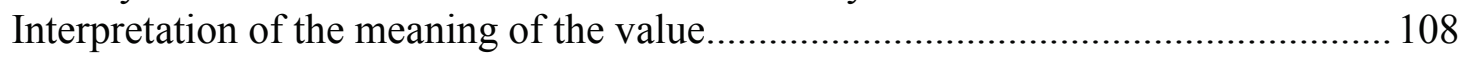

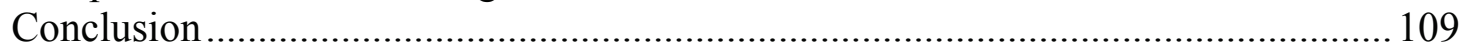




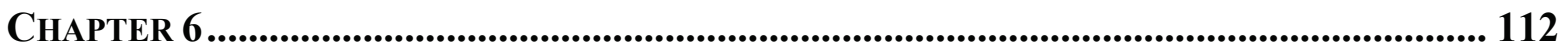

The ritual of tulak bala 112

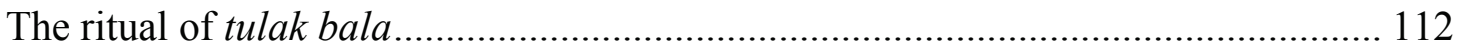

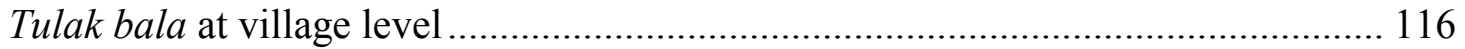

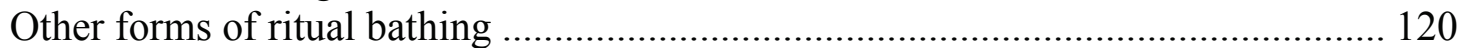

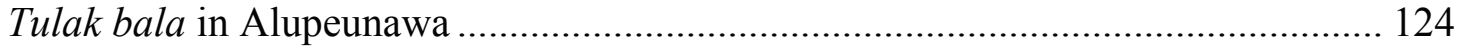

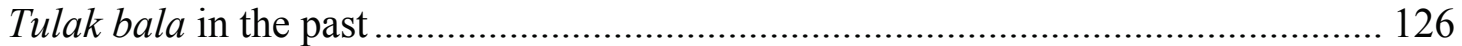

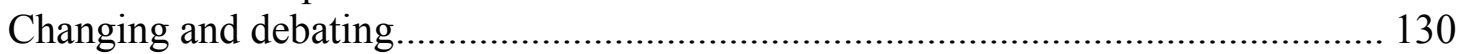

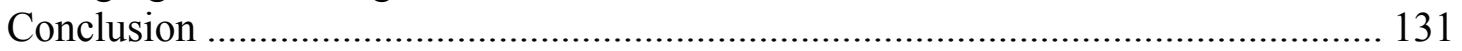

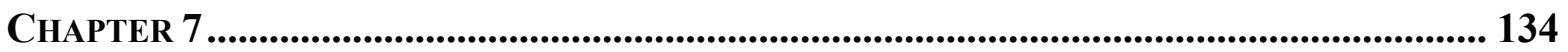

The ritual of khanduri mò'lōt 134

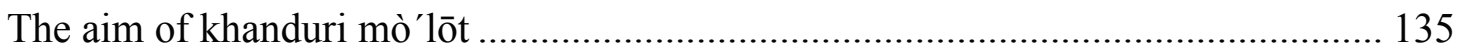

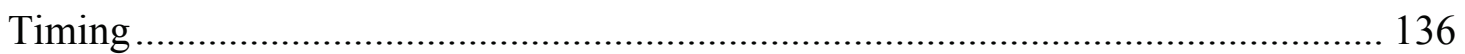

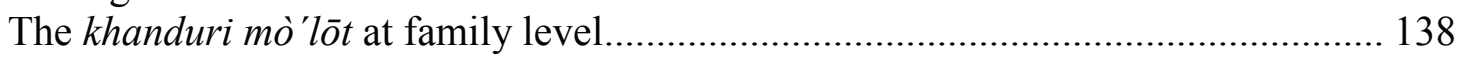

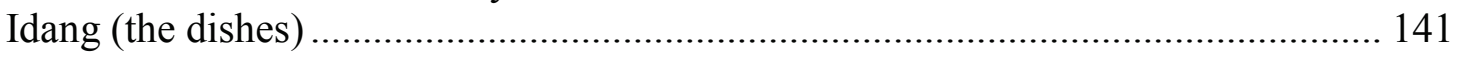

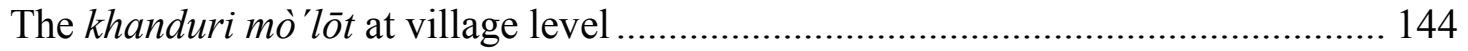

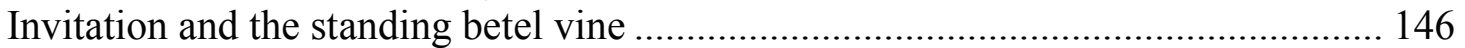

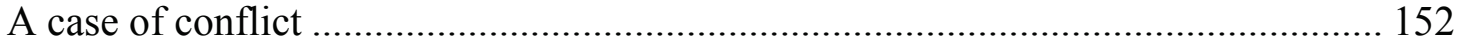

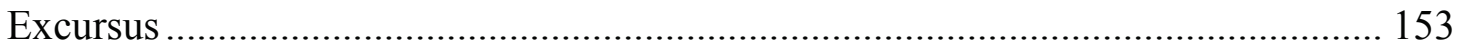

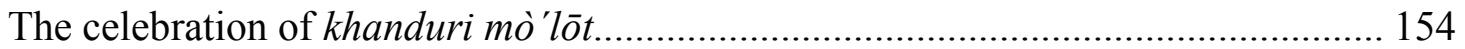

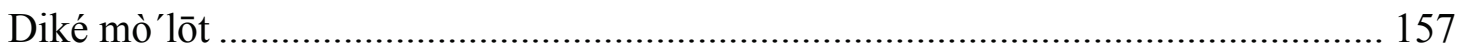

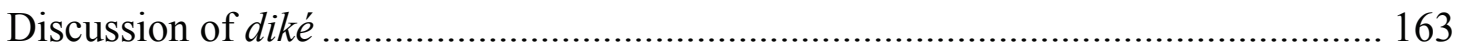

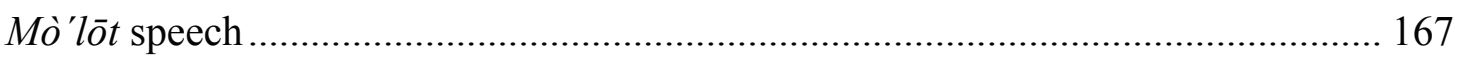

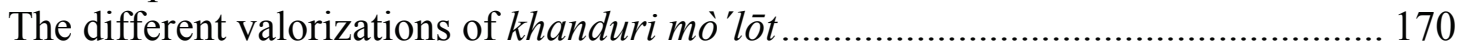

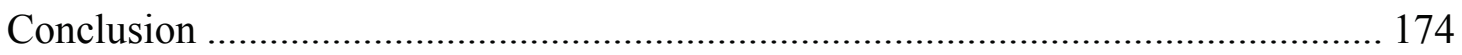

CHAPTER 8 .................................................................................................................. 177

$\begin{array}{ll}\text { The ritual of khanduri bungong kayèe } & 177\end{array}$

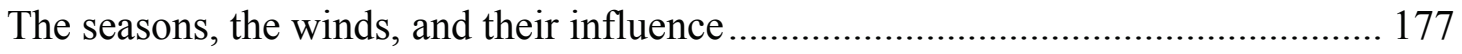

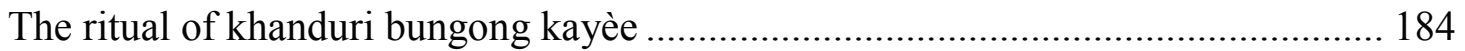

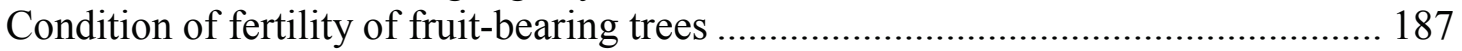

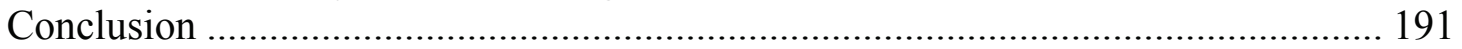

CHAPTER 9 ................................................................................................................................ 194

The ritual of khanduri apam 194

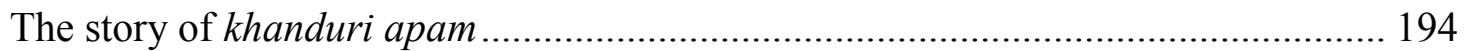

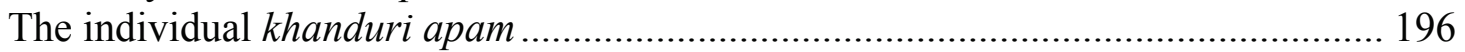

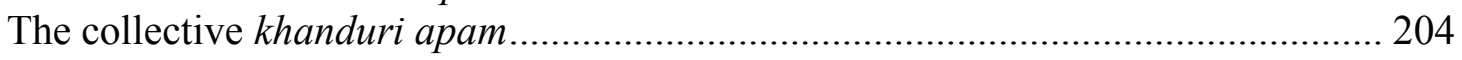

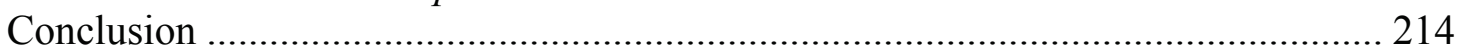

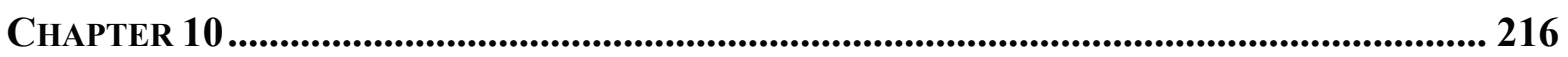

The ritual of khanduri bu 216

The aim of khanduri bu .................................................................................... 218

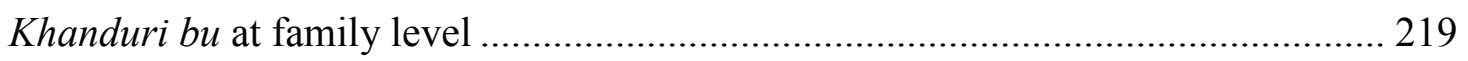

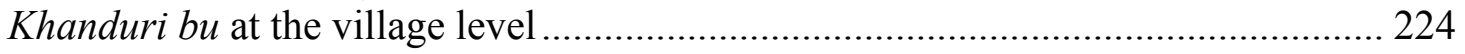

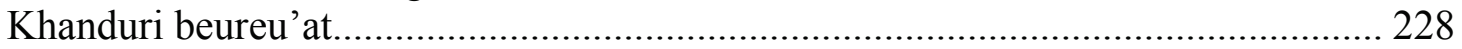

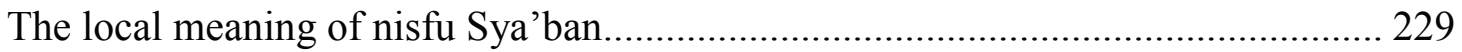

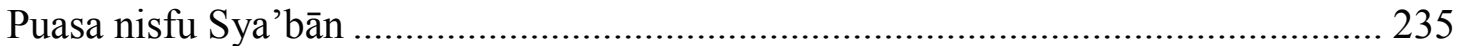

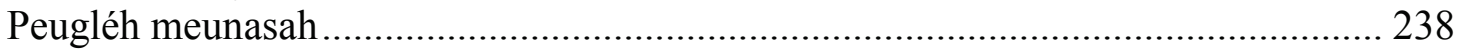

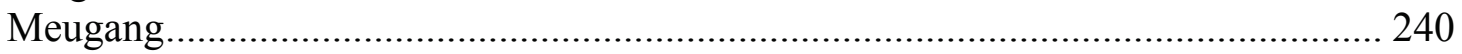




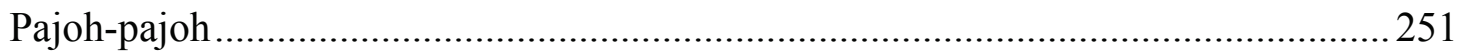

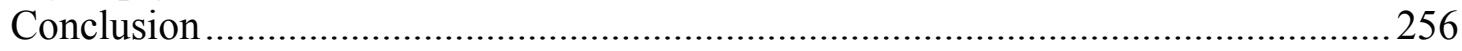

CHAPTER 11 ....................................................................................................................................... 258

$\begin{array}{ll}\text { The ritual of Ramadhan } & \mathbf{2 5 8}\end{array}$

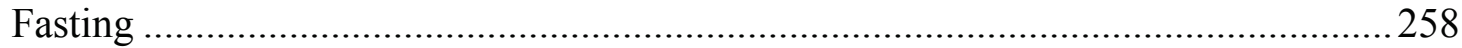

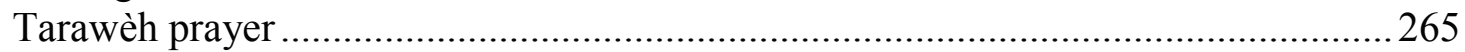

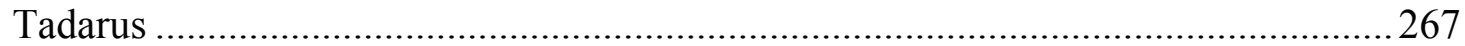

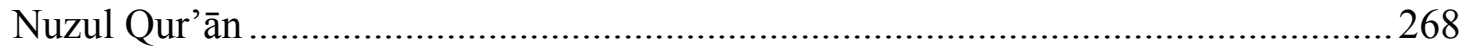

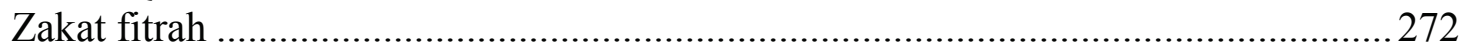

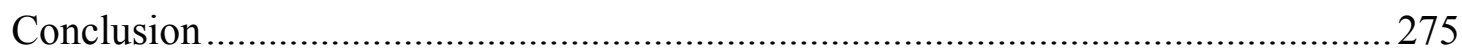

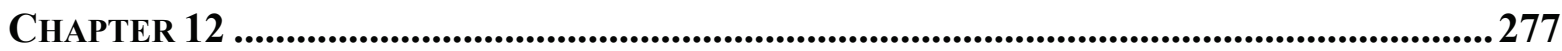

$\begin{array}{ll}\text { The ritual of uroe raya puasa } & 277\end{array}$

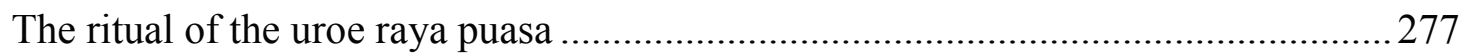

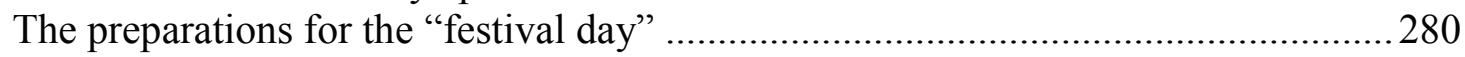

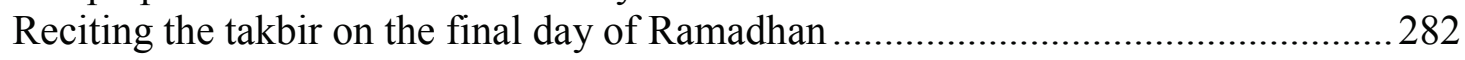

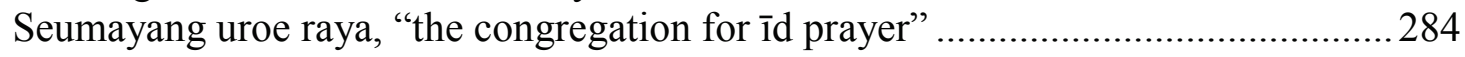

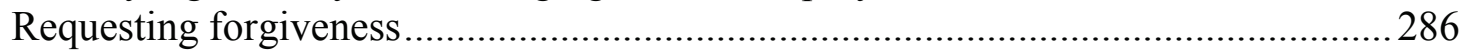

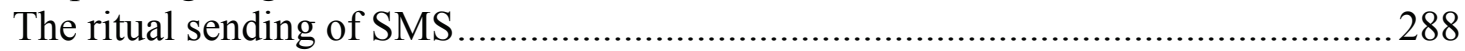

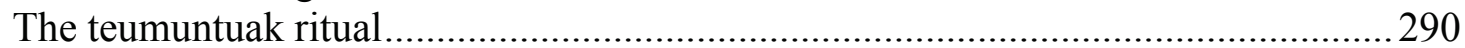

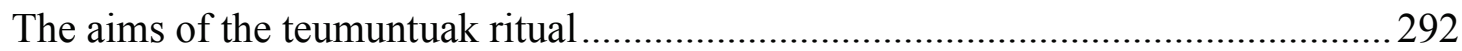

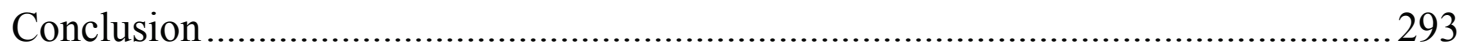

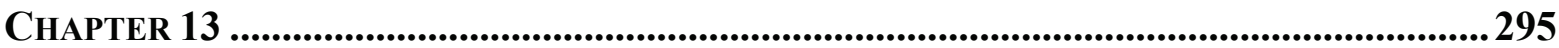

The ritual of uroe raya haji 295

The celebration of uroe raya haji and the performance of animal sacrifice ...............295

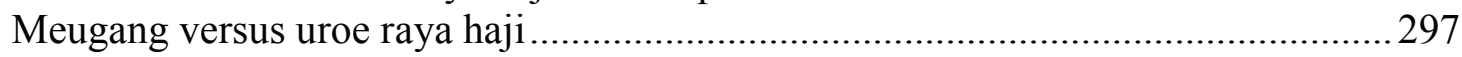

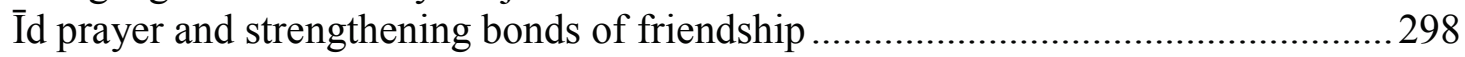

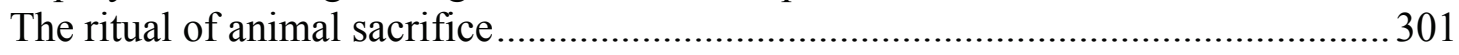

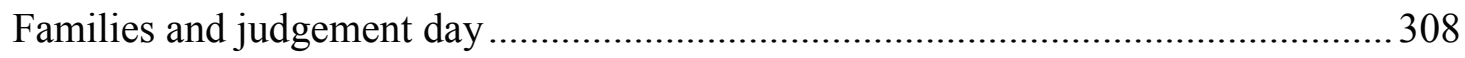

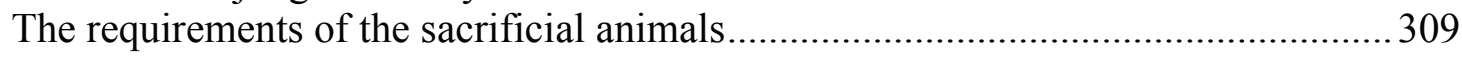

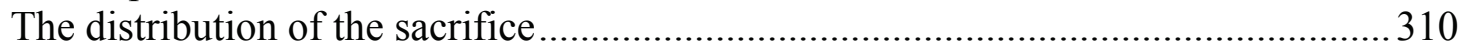

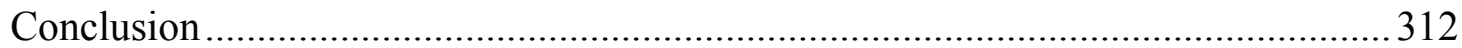

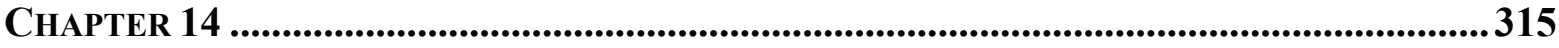

Concluding remarks ..................................................................................................315

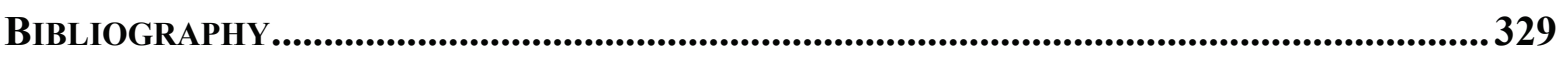

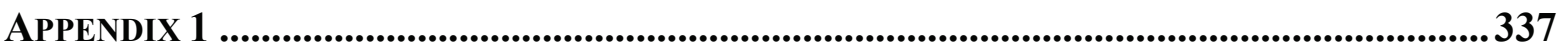

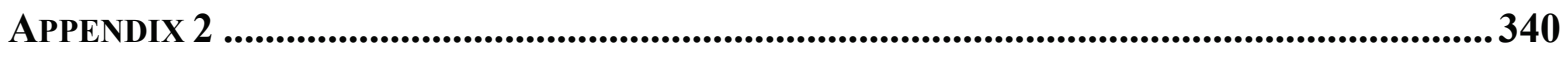

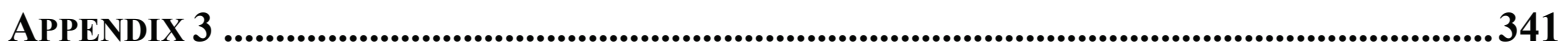

GLOSSARY OF ANEUK JAMEE TERMS......................................................................... 342

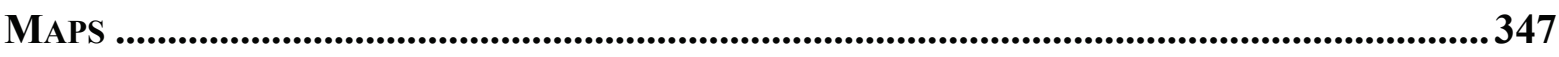

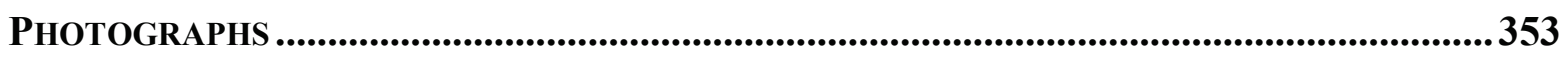




\section{LIST OF FIGURES}

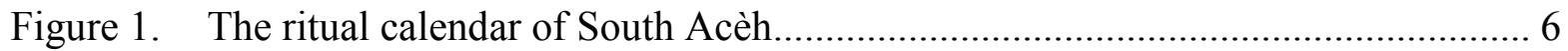

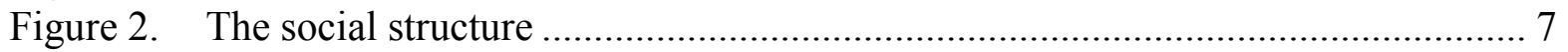

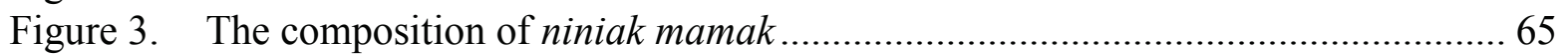

Figure 4. The relation of khanduri mò 'lōt at home/family level ................................... 142

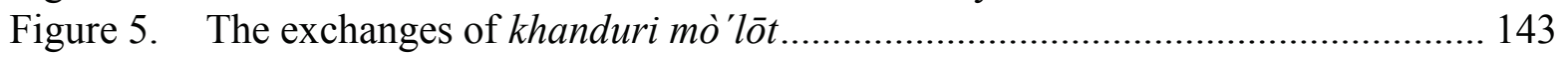

Figure 6. Young men fight over the nubility of young girls......................................... 154

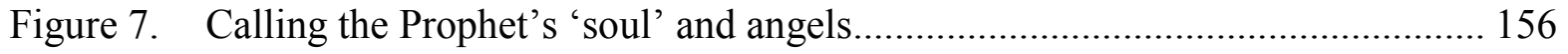

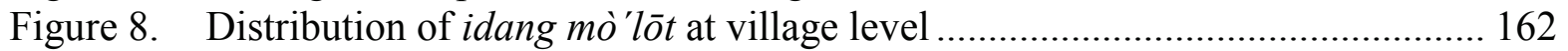

Figure 9. The location of the khanduri mò 'lōt at the village level .................................. 167

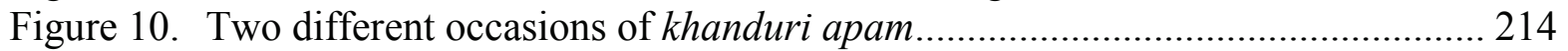

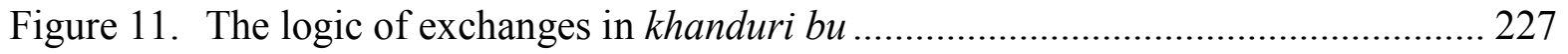

Figure 12. The affinal relation in the context of meugang tradition.................................. 251

Figure 13. The practice of pajoh-pajoh constructs the next generation ............................ 255

Figure 14. The destination of the parts of the sacrificial ram .......................................... 305

\section{LIST OF DIAGRAMS}

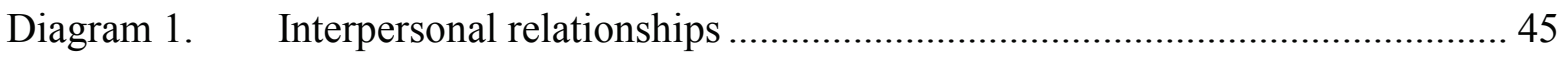

Diagram 2. Ampèk kaum (four groups) and delapèn pihak (eight sides) ........................ 47

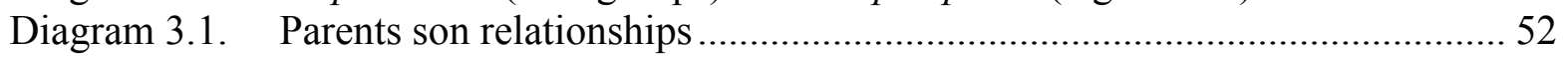

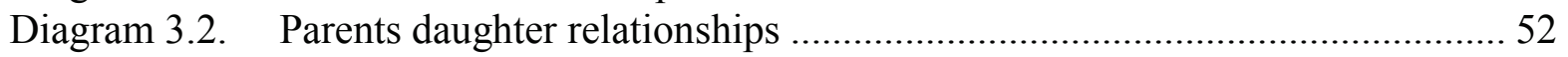

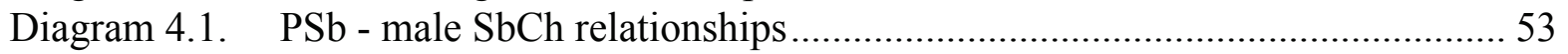

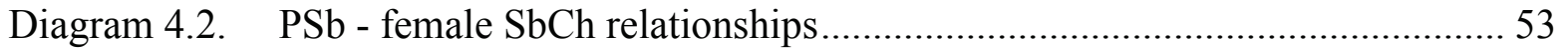

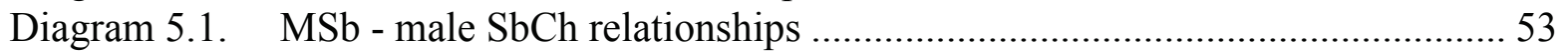

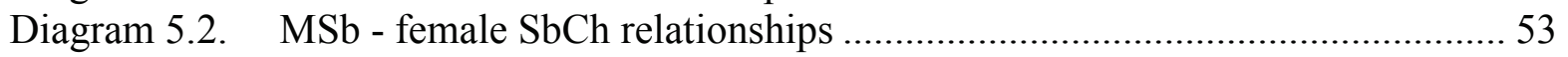

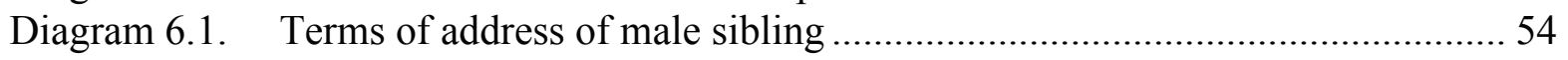

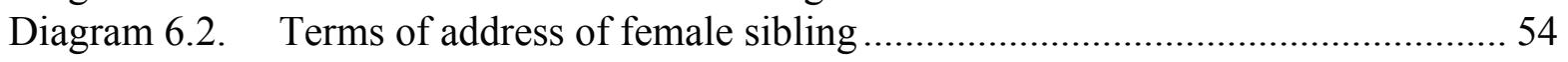

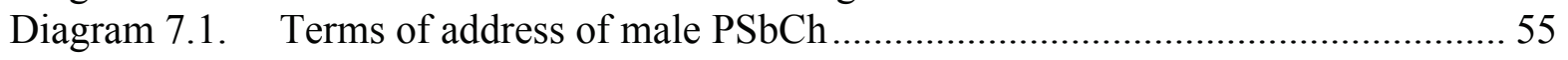

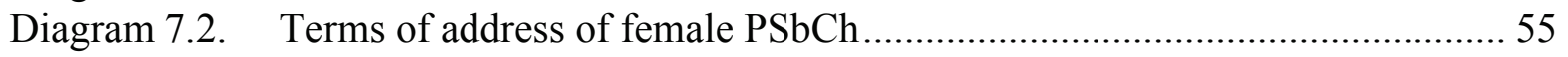

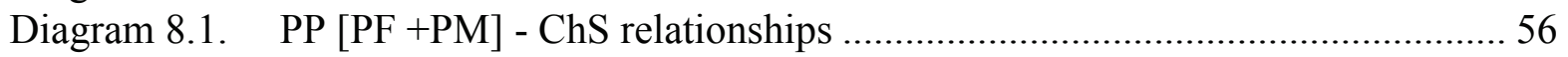

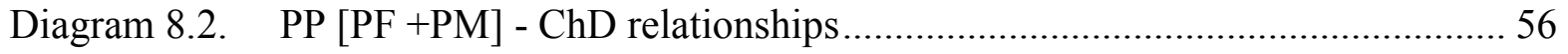

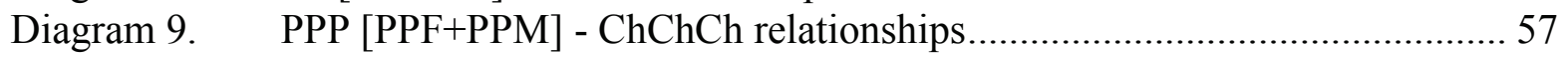

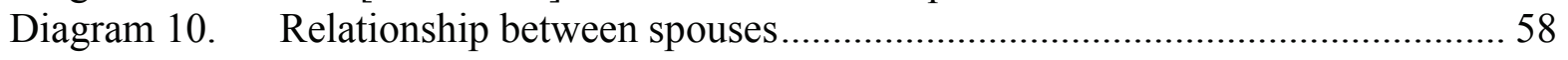

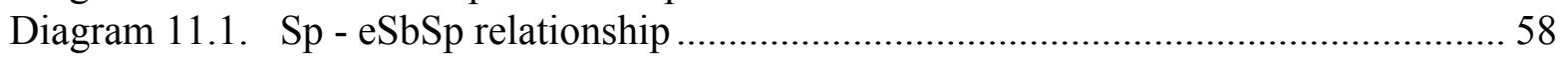

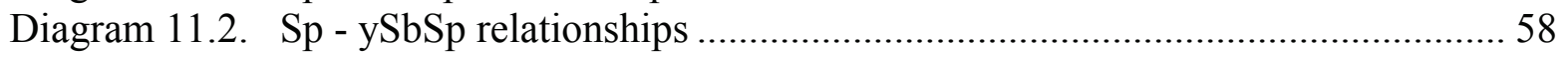

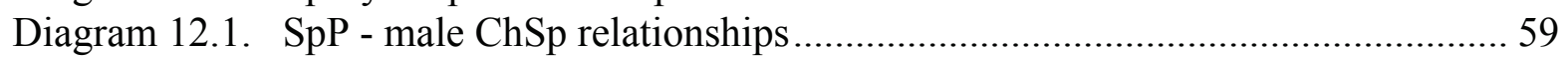

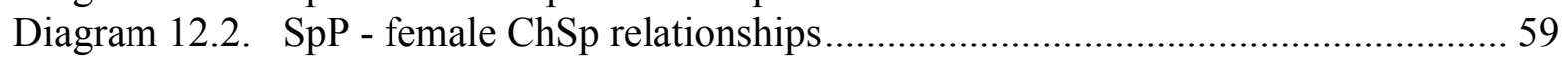

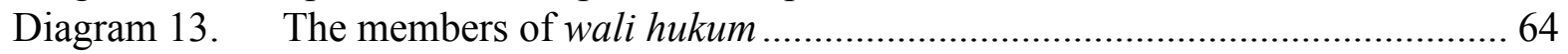

Diagram 14. Kinship relations of those holding the white cloth over the sacrificial

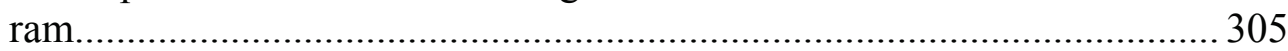




\section{LIST OF TABLES}

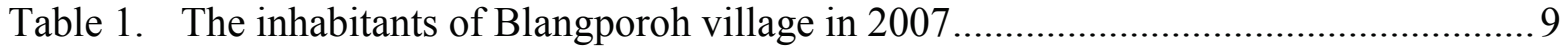

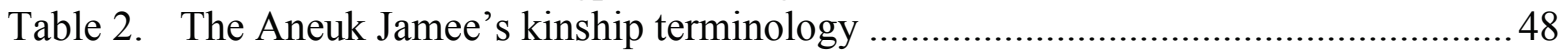

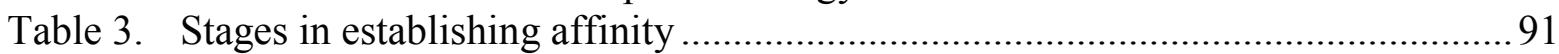

Table 4. A particular set of characteristics and functions of each wind .......................... 179

\section{LIST OF MAPS}

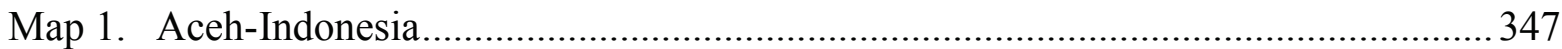

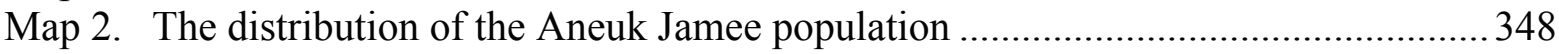

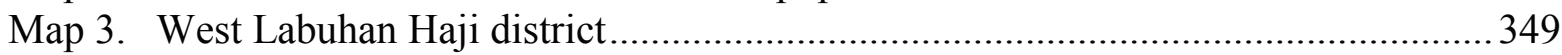

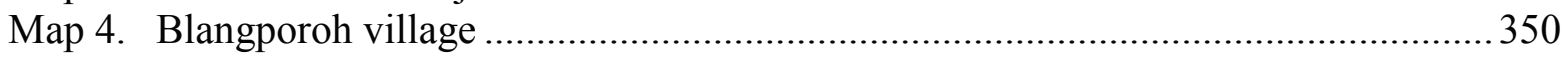

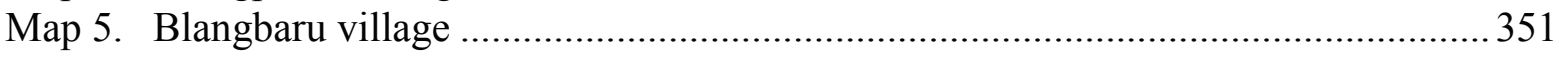

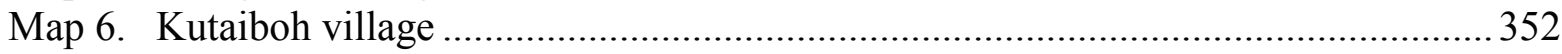




\section{ACKNOWLEDGEMENTS}

This study was sponsored by the Deutscher Akademischer Austauschdienst (DAAD) which generously provided the funds from October 2006 April 2007 and from January 2008 - November 2010 and also for the kind assistance rendered at the various stages of this research by the DAAD officers, particularly by Ms. Ilona Krüger Rechmann, Ms. Hannelore Bossmann, and Ms. Schwarz Bergmann of the DAAD office in Bonn.

The supervisory committee that brought this work to fulfilment was made up of Professor Dr. Josephus D. M. Platenkamp, Prof. Dr. Guido Sprenger and Prof. Dr. Hanns Wienold. To these persons I wish to convey my considerable thanks and gratitude. In this respect, I owe an invaluable debt to my primary supervisor, Prof. Platenkamp whose teaching, tutorials and painstaking guidance contributed a great deal to the production of this work. I also thank my secondary supervisor, Prof. Sprenger for having been ever willing to help and answer the many questions I had. Their efforts in proposing an additional DAAD scholarship meant very much in bringing this work to a conclusion.

I am also obliged to the people of Blangporoh, Blangbaru and Kutaiboh and other neighbouring villages who gave enthusiastic support when I carried out my research, to all my informants, especially to Mukim Hukom and Teungku Usman who quite often invited me to discuss the results at their houses, and to all distinguished teungku from various dayah (boarding schools) in West Labuhan Haji district. Without their help and co-operation this research would never have been completed. I am greatly indebted to them, and to those whose names remain unmentioned in the text of this thesis, for their confidence and their concern for my well-being during my field work. I am particularly grateful to my friends M. Nazar and Mak Kètèk who facilitated the actual fieldwork in the area and who from the first day onwards guided me through the Jamee world and to Mr and Mrs. Musfizar with whom I shared a home in Blangporoh village.

My thanks and gratitude are also extended to all individuals whose advice and suggestions have contributed to shaping this work: Dr. Alexander Horstmann who first suggested to me to pursue my Ph.D studies in Münster and brought me in touch with Prof. Platenkamp; my fellow students Yulia Sugandi, John Combey, Laila Prager, Niko Gebauer, Lydia Seibel, Catharina Weule, Eva Sevenig, Ramona Weber, Robin Schnenegaß, Salman, Habiburrahim, Musirwan, 
Muhammad Dinar, Hazal Fitri and Fahrul Razi. I am particularly grateful to Mina Bahar for sharing her perspective insights during many hours spent discussing this research, who gave me valuable advice on literature and insisted on the many diagrams and figures in the thesis. Many thanks go to Kak Khairiyah Syahabuddin for proof-reading and Karen Paterson for the English language editing. My thanks also go to all colleagues and administrative staff at the Institute for Ethnology at the University of Münster who have helped me in many different ways to complete this study. In this respect, many thanks to Ms. Osterheider, the secretary of the Institute for her support in administrative matters and to Melanie Duch and Dominik Wellmann for helping me format the manuscript.

Finally, I cannot conclude these acknowledgements without mentioning my family. I owe a deeply-felt gratitude to my beloved wife, Cut Intan Salasiyah, S. Ag, M. Pd who has graciously supported me with her unfailing attention to this research and who has been of invaluable help over the years and who has always encouraged me whenever time, money, and my patience ran short. I would not have been able to accomplish as much without my son, Mushlih Abdul Manan (8.8 year) and my daughter, Mazna Abdul Manan (1.8 year) whose carefree joy and love of play have helped to erase the load and tensions associated with the writing of this thesis. Their endless love, passion and patience as well as their sharing in our joint happiness and sadness in Münster, Germany has motivated my everyday efforts and inspiration in producing this thesis. In addition, I owe a deeply-felt gratitude to my beloved parents, Baharuddin bin Tgk. Akop (alm) and Hj. Zainab bin Tgk. Usman (alm) who had brought me up, educated as well as prayed for me any time to become a successful man. It is to them I wish to convey my considerable thanks, and to whom I would like to dedicate this valuable work. 



\section{CHAPTER 1}

\section{Introduction}

\section{Background to the research}

Islam can be divided into two forms: normative Islam and historic Islam. Normative Islam is what is described in the Qur'ān (the revelation of Allāh), the hadith or sunnah, ${ }^{1}$ the 'ulamā' (Islamic scholars) interpretation of the Qur'ān and the sunnah. Historic Islam is what has been practiced by Muslims at ritual and social levels in various societies (Denny 1985:77; Rahman 1985:189; Nur 1996:3). Different terms are employed to indicate this distinction. Eickelman (1976) used the term "formal" for normative Islam and "informal" for historic Islam. Waardenburg (1979) employed the term "official" for normative Islam and "popular Islam" for historic Islam. Normative Islam may also be called "universal" or orthodox Islam, while "local" or "heterodox" Islam are terms which refer to historic Islam.

In general, "formal Islam" is understood to include beliefs and practices which are validated in Islamic law and which refer to the "reflective" or "explicit" ideology of the educated as articulated by religious scholars. Beliefs and practices which deviate from Islamic law are labelled "informal Islam" and refer to "unreflective" or "implicit" ideologies of the mostly uneducated masses (Butelaar 1993; Nur 1996). The two manifestations of Islam can be explained by the fact that Islamic scholars are concerned with the Qur'ān, the sunnah and their interpretation at the expense of everyday religious understanding and practices. The main topic of discussion for them is the question of how to understand the texts of religious tradition properly: the Qur'ān, the hadìth and the commentaries on each (Nur 1996:3).

Unlike Islamic scholars, anthropologists who study Islam focus on locally distinctive traditions and less on the religiously shared traditions. The anthropologists who are concerned with local forms of culture study what is quintes-

1 Hadith is a traditional collection of stories relating words or deeds of the Prophet Muhammad. It is the chief source of guidance for understanding religious questions, while sunnah refers, in common, to the normative example of the Prophet Muhammad, as recorded in traditions known as hadith about his speech, his actions, his acquiescence to the words and actions of others, and his personal characteristics. Based on this definition, it is clear that sunnah is a broader field than hadith. 
sentially characteristic of a particular people or region, such as the rites, myths and the representations (Bowen 1993:5). The anthropologists refer to the way of life of people, in all its variations, as their culture; they translate cultures and their premises to make them understandable in terms anthropologists' ideas (Rosman \& Rubel 2004:1). They generally show a preference for the uniqueness in Islamic cultures, paying particular attention to religious practices and views which deviate from doctrinal prescriptions (Denny 1985). They also attempt to juxtapose the particular cultures in order to show the variability and mutability of religious ideas across the Muslim world, as in Geertz's (1968) comparison of very different forms taken by Islamic mysticism in Java and Morocco. He has placed in the forefront the features of cultural life that distinguish between these cultures and their religion. Ritual activities such as acts of prayer, sacrifice, fasting etc are by and large left to those specialists interested in the "high culture" of Islam. "The point of departure for many anthropologists has been the social life of religious discourse: how written texts and oral traditions are produced, read and reread to close the gap between the decontextualized reading of normative texts, on the one hand, and an ethnographic approach that paid close attention to the social life of texts, on the other" (Bowen 1993:7).

Rituals (Jamee [Jam] kanduri; Acèhnese [Ach] khanduri) ${ }^{2}$, religious ceremonies consisting of a series of actions performed according to a prescribed order, are the core of the social identity of all communities. Every society will vary in its view of what is ritual and what is not. Ritual is defined with the emphasis on the ceremonial aspect, with attention to emotional meaning, with regard to repetitions (Rappaport 1999), or formalized activities without words while words without action are myths (Parkin 1994:18). Rituals are about the expression of a wish or a fact in symbolic form. In other words, "they refer to another reality behind the directly observable one". "Rituals are a form of communication about deeper values, norms and relationships. Rituals bring society together as they manifest with each individual the feeling of the dependence and strength gained from membership and participation in the social group" (Durkheim 1915). To broadly summarise the theory on ritual, the schol-

2 The Acèhnese sometimes say kenduri, kanduri, kawuri, kauri, kenuri and kanuri instead of the word khanduri. Khanduri (Indonesian [Indon] kenduri) is a popular Islamic term in Southeast Asia, indicating a ritual meal given for a number of occasions. Islamic prayers and blessings are often part of the khanduri and include Islamic elements to the ritual meal in order to make it essentially an Islamic festivity (Federspiel 1995:125). 
ars note rituals as communicating [ritual says something to its participants] and clarifying social reality, as well as actually establishing it.

In the anthropological study of religion, the expressive power of ritual symbolism has become a popular theme. Turner (1968), for example, is mainly interested in the instrumental aspects of symbols. He considers rituals as periodic restatements of the terms in which men of a particular culture must interact if there is to be any kind of a coherent social life. "It actually creates or recreates the categories through which men perceive reality" (Turner 1968:6-7). Furthermore, he argues that "it is the strength of religious symbols which enables integration and establishs unification. In his analysis of symbols, he concentrates on what symbols refer to and how they facilitate social change such as in rites of life crisis". Geertz considers rituals as symbols that "sum up ... what is known about the way the world is, the quality of emotional life it supports and the way one ought to behave while in it" (Geertz 1973b:127). He characterizes the religious perspective in terms of commitment and faith, arguing that the acceptance of authority that underlies the religious perspective that the ritual embodies flows from the enactment of ritual itself (Geertz 1973a:113). In line with this, Ortner (1978:2-5) suggests that ritual performances "dramatize basic assumption of fact and value in the culture...shaping actors in such a way that they wind up appropriating cultural meaning as personally held orientation".

Any ritual can be placed in one of two major categories: calendrical rites and life-crisis rites (Alland 1980:468). The calendrical rites follow a fixed schedule, whereas life-crisis rites simply occur when the need arises. Based on the ideal that "the study of ritual is the study of actual behaviour as it is the mastery of ideal form" (Denny 1985:77; Nur 1996:4), I attempt in this ethnographic research to convey the ideas and values expressed by the Aneuk Jamee Muslims in performing Islamic calendrical rituals in South Acèh. ${ }^{3}$ I observe that these rituals were more rigorously performed after the tsunami had struck Acèh on December $26^{\text {th }}, 2004 .^{4}$ I argue that the close observation and compara-

3 Nanggroe Acèh Darussalam is divided governmentally into eighteen regencies: Kotamadya Banda Acèh, Kotamadya Sabang, Pidie, Bireuen, North Acèh, East Acèh, Acèh Tamiang, Central Acèh, Gayo Lues, Southeast Acèh, Acèh Besar, Acèh Jaya, West Acèh, Nagan Raya, Southwest Acèh, South Acèh, Acèh Singkil and Simeulue (see map of Acèh province). The capital city of this province is Banda Acèh.

4 The western coastal areas of Acèh, including the cities of Banda Acèh, Calang and Meulaboh, were among the areas hardest-hit by the tsunami resulting from the Indian 
tive analysis of these rituals enable us to interprate the ways in which the Aneuk Jamee society in West Labuhan Haji district react upon and valorize the historical and contemporary events that occur amongst them.

The population in Acèh consists of several groups: Acèhnese, Gayo, Tamiang, Alas, Simeulue, Kluet and Aneuk Jamee. They have all adopted the Islamic religion. Nevertheless, the Hindu/Buddhist religion strongly influenced the culture long before the arrival of Islam. As a result Islam in Acèh has been malleable, tentative, multi voiced, resembling "a marbled layer cake" (Ach kuwe lapéh marmer); witness the various religious beliefs expressed in certain ritual performances. It is correct to say that not all religious activities in Acèh today are based on normative Islam; and some clearly belong to the historic Islam. This fact has inspired me to conduct a social-anthropological research in Acèh, North Sumatra, which is known as The Verandah of Mecca (Ach seuramo Mekkah).

The early history of Acèh was influenced by India. Snouck Hurgronje (1906) speculated that it was indeed more than probable that Acèh, like other countries of the Indonesian Archipelago, was influenced by both Muslims and Hindu Indian traders (kléng). As a result, the representations from the cultures of the various people in the Middle East and India were mixed with the indigenous (animistic and Hinduised) beliefs and practices (Noer 1973:301). The "heterodox mysticism" of Shams al-Dīn al-Sumātrānī in the $17^{\text {th }}$ century and its forerunner Hamzah al-Fansūrī might have come from India. The greatest ruler of Acèh, Iskandar Muda, who ruled from 1607 to 1636, supported Shams al-Dīn al-Sumātrānī, but his successor, Iskandar Thani (1636-41) banished these mystics from his court and burned their books. ${ }^{5}$ Thereupon the Acèhnese Islam mainly followed the "orthodox tradition". However, today some preIslamic influences can still be encountered in current ritual ceremonies, arts, customs, and everyday life even though the Islamic reforms, especially advocated by the modernist movements are still being propogated in Acèh province.

Ocean earthquake on December $26^{\text {th }}, 2004$. While estimates vary, about 230,000 people were killed and 500,000 were left homeless in Acèh (Apridar 2005).

5 The history of mysticism in Acèh in the $16^{\text {th }}$ and $17^{\text {th }}$ century can be found in Snouck Hurgronje. He stated that not all the books which embody Hamzah al- Fansūrī's teaching were burnt, but many of his books escaped the flames (Snouck Hurgronje (1906 II:12-3). 


\section{Research focus}

This social anthropological research focuses on ways in which Islam manifests itself in the culturally specific representations and actions of the society of South Acèh. Several scholars conducted their research in Acèh (e.g. Snouck Hurgronje (1906), Siegel (1969), Jayawardena (1977), Bowen (1993)), no attention, however, has been paid so far to the region of South Acèh. This research explores the relations between the so-called normative Islam - as laid down in the canonical texts of the Qur'ān and hadith - and the ways in which these normative ideas, preceptions and values are expressed in rituals in the society concerned. It pays particular attention to the ways in which the latter forms of ritual expression entail a culturally specific adaptation and valorisation of the trans-cultural representations laid down in these Islamic text corpora and to the ways in which - according to local understanding and exegesis - these ritual actions generate a reproduction of the social relationships and their moral foundation in the society concerned. To answer these research questions requires a meticulous observation of the ritual actions. The latter entail the performance of certain series of actions, the enactment of transfers of gifts, commodities, words and gestures, and the mobilisation of particular social and religious relations. It also requires conducting in-depth discussions with the participants about the symbols, meanings and values, which they attach to these actions as to their effectiveness in achieving particular social, religious, political and moral aims. In addition, a systematic survey of relevant published sources has complemented this field research.

The calendrical rituals on which this research focuses are the following: 1) The ritual of ' $\bar{a} s y \bar{u} r \bar{a}$, lasting for one to three days, and taking place at the beginning of the Islamic New Year, Muharram. 2) The ritual of tulak bala lasting one day in the month of Safar. 3) The ritual of mò 'lott, one to seven days in the month of Rabiul Awwal or Rabiul Akhir or Jumadil Awwal. 4) The ritual of khanduri bungong kayëe, performed for one to three days in the month of Jumadil Akhir. 5) The ritual of khanduri apam on the night of the israk mikrāj celebration, conducted for one to seven days in the month of Ra'jab. 6) The ritual of khanduri bu performed during the month of Sya'ban, including khanduri beureu'at, peugléh meunasah, meugang and pajoeh-pajoeh. 7) The ritual of Ramadhan in the whole month of Ramadhan. 8) The ritual of uroe raya puasa, lasting one to three days in the beginning of Syawwal. In addition, 
the ritual of teumuntuak is also discussed in this context, and finally 9) The ritual of uroe raya haji performed for one to three days in the month of Zulhijjah, the last month of the Islamic year (see figure 1).

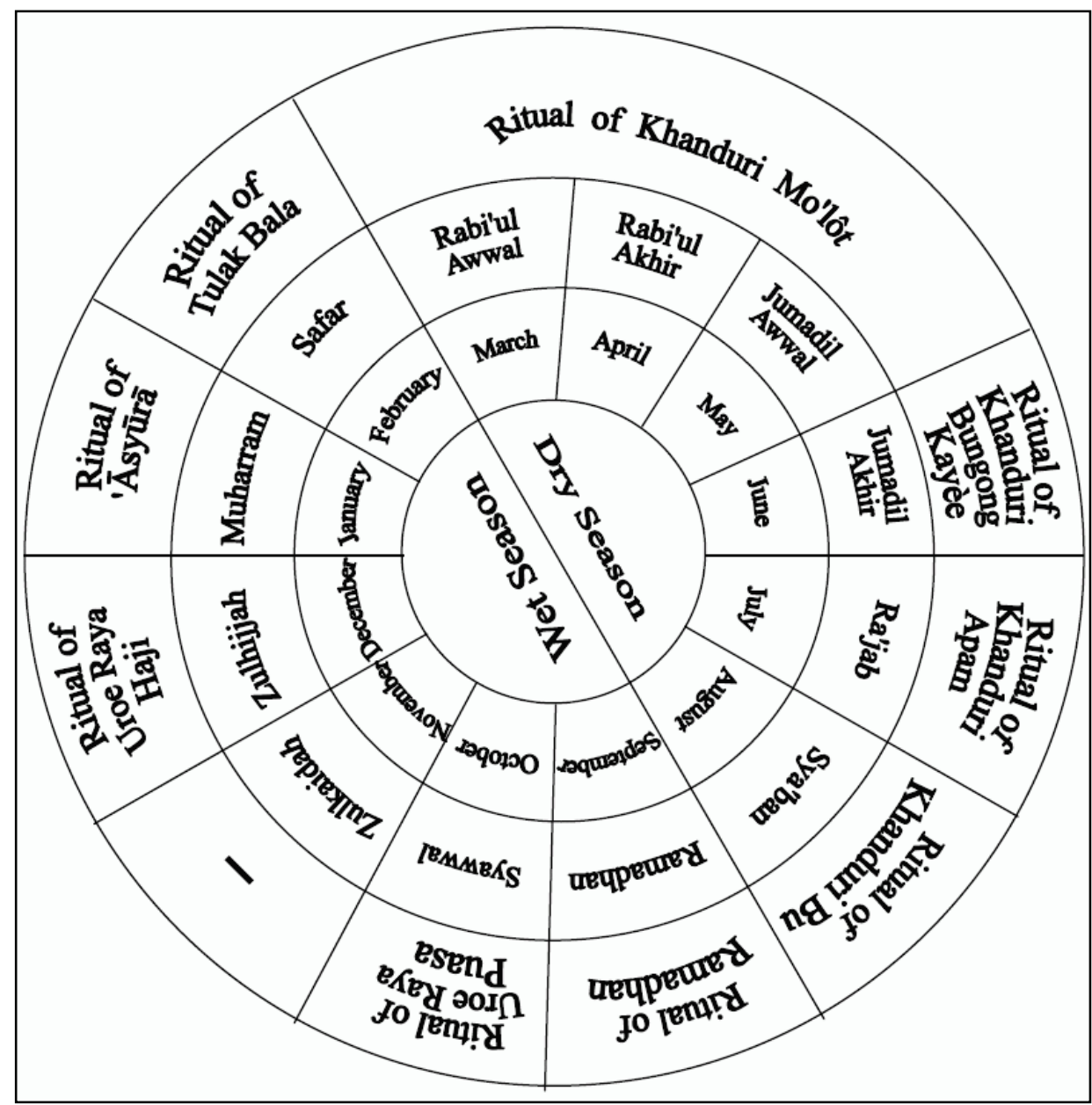

Figure 1. The ritual calendar of South Acèh

Figure 1 shows a concordance between the lunar and the solar calendar due to the fact that in the years 2007-2008 they coincided. These rituals constitute in their totality the annual ritual cycle and are the foundation of the socioreligious order of the society of South Acèh. Although Muslims in all Islamic societies recognise these rituals, to some extent, the meaning of such rituals varies from one society to another, and this variation, of course, is related to the socio-cultural background of each society.

To conduct such a research, the unity of time and place of the rituals performed is a basic methodological requirement. Rituals in Southeast Asian societies form part of systems. Their periodicity is defined either in terms of overall 
temporal and/or religious cycles - usually organised on an annual basis - or in terms of the lifecycle of individual persons - hence ranging from pregnancy and birth to death and ancestral rituals. To analyse the significance of any such particular ritual, it is of utmost importance to be able to assess it in its relations to the other rituals constituting such overall ritual cycles (Barraud \& Platenkamp 1990). Moreover, such individual rituals need to be studied within the same population in order to explore their interdependence. The observation of partial rituals observed in different places hampers an integral understanding of such interrelationships.

In order to fulfil these methodological requirements a field research was conducted, lasting from the beginning of March 2007 when the ritual of $m \dot{o}$ ' $l \bar{o} t$ is performed until the end of February 2008, when the ritual of 'āsyūrā is conducted. In this way, the entire calendrical cycle of rituals in West Labuhan Haji district, South Acèh could be systematically studied. The requirement to study all rituals among the same research population was met by selecting a single village, that is, Blangporoh as a focal community, in which the ritual cycles in their totality were studied. This village is part of a group of villages, including Blangbaru and Kutaiboh in the district (Indonesian [Indon] kecamatan) of West Labuhan Haji, in the regency (Indon kebupaten) of South Acèh (see figure 2), whose populations constitute a single culturally homogeneous group. In these other villages the insights gained from the field research in Blangporoh were counterchecked as well.

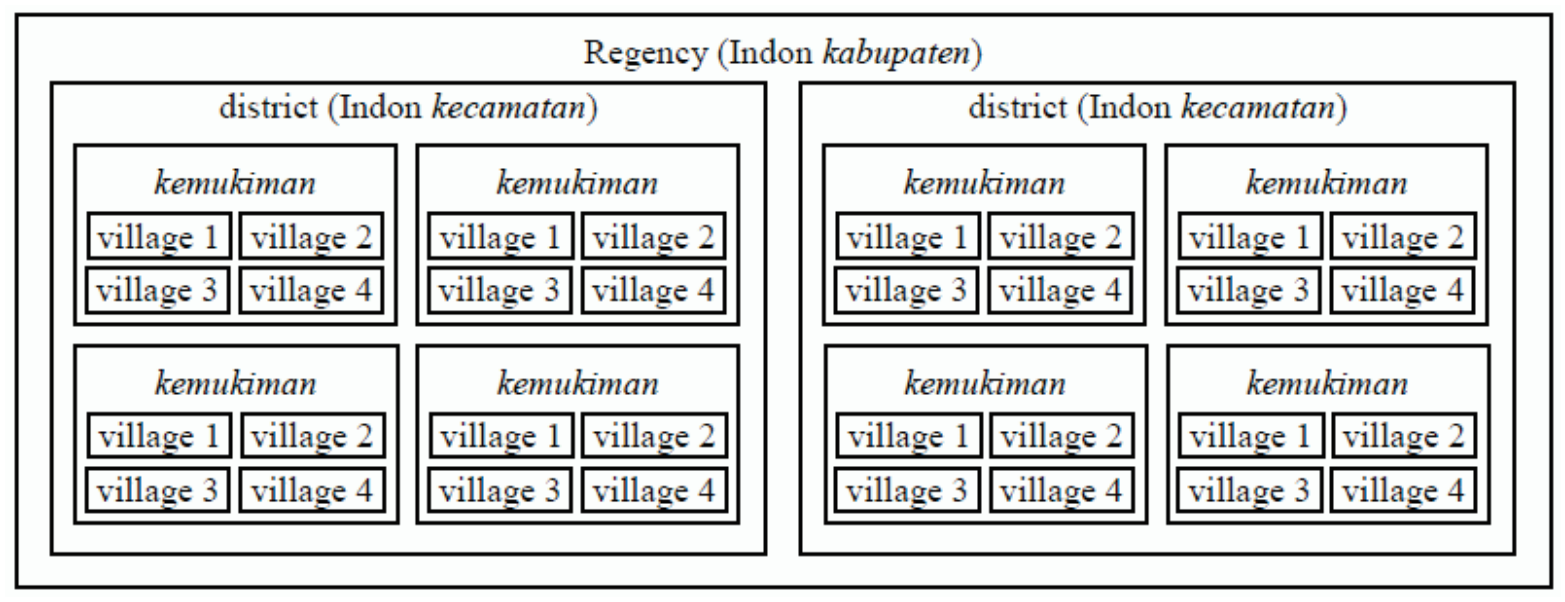

Figure 2. The social structure 


\section{Methodology}

The field researches were conducted by means of participant observation as the principal method of this empirical study. Participant observation method means that the researcher is involved directly with the community in order to observe and document people's activities. Besides a meticulous observation of the ritual actions and the library research mentioned earlier, I also used in-depth interviews, discussions, recording and audio-visual registrations with the main protagonists of the ritual performance as an instrument to gather information. All interviews were conducted in the Acèhnese language (my mother tongue), Indonesian (my national language), and the Jamee language (local language). For interviews conducted in Jamee language-spoken by some members of the population the assistance of a local interpreter had to be solicited. The interviews and discussions enabled me to communicate with a large number of people in West Labuhan Haji district, and to explore the meanings, symbols, and values people attach to these calendrical rituals, the ways in which their ritual practices are embedded in the local world view.

In exploring the ritual question, I followed Brown's perspectives (Brown 1979:51-2) in studying and understanding rituals. He develops three considerations for analysing a ritual: (1) consideration of the purpose or reason for the rite; (2) consideration of ritual meaning or symbolism; and (3) consideration of the effect of the rites, both individual and social. As to the selection of samples, I chose the method of purposive sampling. Purposive sampling is "the assembling of a sample by intentionally seeking individuals or situations likely to yield new instances and greater understanding of a dimension or concept of interest" (Krathwohl 1993:690). The power of purposeful sampling lies in selecting information-rich cases for in-depth study. This type of nonprobability sampling $^{6}$ is most often used in qualitative research. I intentionally chose certain villages in West Labuhan Haji district, South Acèh as my sample; the village of Blangporoh (see map 4), Blangbaru (see map 5) and Kutaiboh (see map 6) because these villages could provide information-rich cases for the in-depth study I envisaged.

6 Nonprobability samples are those that do not involve random sampling at some stages in the process. 


\section{Sociography of Blangporoh village}

West Labuhan Haji district (Indon kecamatan) consists of three subdistricts (Indon kemukiman): Blangbaru, Blangkeujèrèn and Kutatrieng. Blangporoh village is one of the villages in the subdistrict Blangbaru. The territory of this village is $7 \mathrm{~km}^{2}$ inhabited by 330 families. The number of inhabitants is 1866: 1086 are male (including many students of the boarding school) and 781 are female. The Blangporoh village is divided into four 'clusters' (Indon dusun): Dusun Darussalam, Dusun Gaya Baru, Dusun Tengah, and Dusun Ujung (table 1). To the north the village is bordered by the village of Madatpaya, to the east by the village of Kutaiboh, to the south by the Indian Ocean, and to the west by the village of Blangbaru. ${ }^{7}$

\begin{tabular}{|l|l|l|l|l|l|}
\hline No & Names of Dusun & Family & Male & Female & Male + Female \\
\hline 1 & Dusun Tengah & 77 & 160 & 174 & 334 \\
\hline 2 & Dusun Darussalam & 109 & 596 & 267 & 863 \\
\hline 3 & Dusun Gaya Baru & 96 & 210 & 218 & 428 \\
\hline 4 & Dusun Ujung & 48 & 119 & 122 & 241 \\
\hline & & 330 & 1086 & 781 & 1866 \\
\hline
\end{tabular}

Table 1. The inhabitants of Blangporoh village in 2007

Blangporoh village comprises a number of houses gathered closely together and separated by paths, one mosque and two 'prayer houses' (Ach meunasah), rice fields, gardens, and bush woods. The villagers have different jobs; fishermen, farmers, gardeners, civil servants, tailors, fishmongers, sellers, healers, peddlers of toys and goods, traders etc. In general, their jobs can be divided into two groups: farmers and fishermen.

From an economic perspective, Blangporoh village is a strategic area because it is flanked by mountains and the sea. Between these lie fertile rice fields allowing residents to earn a living and in the mountains they can grow various types of crops, but mostly nutmeg. In their paddy fields they grow rice and peanuts while at sea they can catch fish and shrimps. Men work at sea, in paddy fields and gardens, and in the mountains. Females also work in the paddy fields and gardens. However, there are lands that have not been cultivated.

$7 \quad$ See map of Blangporoh village. 
Blangporoh village's population of 1,866 inhabitants does not match the minimum number of 2500 required by the Village Administration Law according to a decree of the Minister of Internal Affairs (Sulaiman 1997). As a consequence, national branch offices such as the Public Health Service (Pusat Kesehatan Masyarakat), banks specializing in a small low interest loans for farmers and fishermen (BRI Unit Desa), the cooperation specializing for the farmers and fishermen (Koperasi Unit Desa), and national representatives such as Instructors for Agricultural Extension (Penyuluhan Pertanian Lapangan) only exist in the principal town of the district of Labuhan Haji. The main activities in the village take place in the mosque and 'prayer house' (Jam surau;Ach meunasah) located strategically in the middle of the village. In the mosque complex, there is a pavilion called Balai Pemberdayaan dan Kesejahteraan Keluarga (Family Welfare Empowerment). The mosque functions, firstly, as the place where the people of the village perform ritual prayers, particularly the five daily prayers and the tarawih (non-obligatory evening prayers during the month of Ramadhan), and the annual idul fitri and idul adha prayers, Secondly, it is the place where young women recite the barzanji-prayer every Friday night and young men recite the dalaél khairat-prayer together every Saturday night. Thirdly, it is the place where religious teaching is taught at noon, where all people in the village share religious sentiments with each other. Thus the mosque and 'prayer house' function as the places for worship and education. A religious atmosphere pervades in Blangporoh village. Stage entertainment and cinema are absent. Such places are still considered taboo. This does not mean that the Blangporoh communities do not need entertainment. They can entertain themselves by watching television at home or visit coffee shops.

In addition, the mosque and 'prayer house' also function as places where the people of the village perform the social and government activities. The mosque and 'prayer house' are places where the people of the village assemble to perform rituals at the village level. It also functions as a place where the representatives of the national or local government give instructions about matters pertaining to the government program of development. In consequence, the mosque and 'prayer house' are places where the entire villagers share their communal life and sentiments with the each other.

The inhabitants of Blangporoh village do not descend from ancestors so that its community does not have a genealogical character but there has been intermarriage among its inhabitants or between its inhabitants and those of the 
neighbouring villages. There is still a household descending from a noble family. The villagers respect the members of this family although they now no longer hold the power in the village. The inter-marriage among its inhabitant has strengthened the integration of the village (see Ch.4). This is shown by the fact that Blangporoh people practice matrilocal principles which certainly have an effect on the formation of groups and socialization. Therefore, a village is divided among groups based on female relatives, while children are closer and more familiar with their mother's relatives than their father's relatives (see Ch.3).

Besides the medium of kinship, the integration process takes place through the $a d a t^{8}$ (from an Arabic term 'a dat) and reusam institutions. Adat, signifying 'custom', are sets of rules or norms that must be adhered to, respected, and become a framework. The adat has two senses. In one sense it represents all regulation already recognized by the rulers that have judicial effect. In another sense, the adat covers all rules or habits concerning the 'custom tax' (Sulaiman 1997). The reusam represents all the ways in which a villager behaves during village activities such as agricultural and religious, activities, the life-cycle rituals and calendrical rituals based on the principles of reciprocity. The adat and reusam characterize the social process of the people in the village. As Muslims, Islam also plays an important role in integrating the people of the village. Its role reflects not only through the values of the adat and reusam but also through any rituals performed in the mosque and 'prayer house'. These rituals give people a common orientation that in turn can strengthen village solidarity.

The village integration of adat and reusam, the religious and the kinship solidarity does not mean that the villagers are isolated from the outside world. Certain media play an important role in connecting a village with neighbouring villages and other regions. Syafiite law school for instance, demands that 40 adult male followers perform the shalat jum'at (communal prayer obligatory for men every Friday noon) and this made some neighbouring villages join together in a mukim administration based round a mosque. This federation is naturally strengthened by the fact that the people of those villages have the

8 The term adat is in fact an Arabic term 'ädat which means "custom". Through his works of the late nineteenth-century, Snouck Hurgronje had used the Arabic word adat, signifying 'custom' in order to discriminate between the Islamic law (syarī'ah) and the 'customary law' (adat) in Acèh. 
same language and culture. Besides the Jamee world, the religious solidarity associates the people of the village with the Muslim world such an association is tied by religious brotherhood (ummat) and the common orientation to Mecca as 'the mother of the country' (Ach mak nanggroe) while worshipping Allāh. Thus a villager has solidarity with the village where he or she lives and at the same time he or she also has solidarity with the outside world through the mukim solidarity or religious solidarity. The solidarity with the other regions is often strengthened by the intermarriage between villages.

The Aneuk Jamee way of life, based on the adat, reusam, and Islam, are also reflected in the social structure of the village. The village, which in Jamee is called kampuang (from Ach gampōng and Indon kampung or dèsa) is the smallest administrative territory led by kapalo kampuang (Ach keuchik/geuchik). The kapalo kampuang means the village headman who is selected and trusted by the community and is officially appointed by the district government to lead the kampuang. He takes care of the daily administrative affairs in the village. Although the kapalo kampuang is the adat elite, he also has authority over the various activities in the village and defends his jurisdiction interests against the outsider. The Aneuk Jamee, therefore, values the kapalo kampuang's position like a father (Jam ayah) in the household. The code of the kapalo kampuang in executing his tasks is naturally based on the Aneuk Jamee way of life, namely adat, reusam and Islam. He also consults with his superiors in rank, namely the imeuem mukim, ${ }^{9}$ the head of mukim level of administration and adat judiciaries (Indon pemangku adat). In addition, the kapalo kampuang is responsible for everything related to the administration of the kampuang. For khanduri, for instance, he mobilizes the people to participate and bring various food and amounts of money.

In executing his daily tasks in term of religious matters in the village, the kapalo kampuang is assisted by tuangku imam (Ach teungku imuem). The tuangku/teungku literally means 'my lord' and comprises of tuangku imam mesjid who manages the mosque and tuangku imam meunasah who manages a meunasah 'prayer house'. The tuangku imam mesjid has the duty of organizing the jum 'at prayer and all rituals in the mosque's jurisdiction, while the tuangku imam meunasah acts as religious leader organizing the congregation and rituals. The Aneuk Jamee, therefore, value the tuangku's position like a mother

9 A leader of a collection of several villages is called Imuem Mukim. 
(Jam umak) in the household. He is the person who is responsible for leading community activities at kampuang level related to enforcement of syari'ah law and any ritual performances in the village. In khanduri, for instance, he guides the people in the recitation of $d o$ ' $a$. The village's mosque has the grounds (land) for these religious ceremonies called tanoh wakeuh or umong meusara. These grounds are cultivated by the tuangku imam mesjid/teungku imam meunasah and other mosque staff such as the preacher (khatib), the one who calls to prayer (bileu), and the mosque's cleaning service (khadam). ${ }^{10}$ In addition, tuangku imam also receives gifts and great respect from those who have enjoyed their services in the village.

In executing his daily tasks beyond religious matters, the kapalo kampuang is assisted by a number of personnel: they are 1) wakil "the deputy" he is the kapalo kampuang's assistant. He has the duty of delivering the messages to the villages or assisting kapalo kampuang in mobilizing the villages for all village activities. 2) sekretaris kampuang "the secretary of the village", he is the village head's "employee" providing administration services to the head of the village. 3) keujruen blang "the surveyor of the rice field" or "rice [ritual] specialist", he manages the village irrigation. 4) panglima laot "the inspector of the sea" takes charge of the customs and traditional practices concerning fishing, including fishing areas and settling disputes. 5) tuwo ampèk (Ach tuhu peut) is the body at kampuang level comprising of religious leaders, adat leaders, community leaders and scholars. Tuwo ampèk is responsible for providing advice to the kapalo kampuang and imuem mukim in the fields of governance, adat law, customs and community practice as well settling disputes at kampuang and mukim level. And 6) haria peukan is the person responsible for order, security, market hygiene and for collecting the market fee. ${ }^{11}$

As an agent of village bureaucratization, kapalo kampuang has been charged with new duties, the duty of tax collection, population registration,

10 In Blangporoh village, there are 16 arèe [32 liters] of the grounds (land) for religious purposes (Ach tanoh wakeuh). 4 arèe for tuangku imam mesjid, 4 arèe [8 liters] for preacher (Jam tuangku khatib), 4 arèe for a person who calls to prayer (Jam tuangku bilal), and 4 arèe for the mosque's cleaning service (Jam tuangku khadam).

11 Other adat institutions such as tuwo delapèn (tuha lapan) "the body at kampuang and mukim level comprising of the government, religious leaders, adat leaders, community leaders, scholars, the youth/women and people organisation groups"; peutua seuneubok "the leader in regulating land use and land clearing for agriculture/plantation". Syahbanda "the person responsible for leading and managing boat mooring posts and boat traffic in sea, river and lake transportation" is not found in Blangporoh village. 
signing the various civil certificates, and helping the national administration representative in implementing the various development projects in his village. He obtains various remunerations in return for his services including the honorarium (Indon uang jerih payah) from the government. Therefore, the kapalo kampuang plays a double role; as an agent of the national administration and as a traditional leader. Owing to his duties, the people still call him kapalo kampuang although officially his new post is called kepala désa (Sulaiman 1997:7).

Blangporoh village has its own cultural patterns taken from many elements, not only from the elements of Acèhnese but also from outside Acèh, such from Minangkabau, West Sumatra. Although the influence of the outside culture is so strong, the Blangporoh villagers maintain their local culture that has been handed down from one generation to the next. For instance, the culture of khanduri is still conducted at each birth and death; at the beginning of each year when they cultivate the rice fields and at harvest time. The religious chanting such as reciting shamadiyah, wirid, yāsinn and barzanji, dalaél khairat is still held at night in the mosque (Ach meuseugid), prayer house (Ach meunasah) and boarding school (Ach dayah). In addition, the calendrical rituals are also held on a large scale in the village. The ritual events are often filled with didactic lectures they are also accompanied by the Qur'ān recital competition, dalaél recital competition and so forth.

The presence of pupils in the elementary and at the boarding school in Blangporoh has not entirely changed the social process in the village. They only follow the rules given by the national government when they are at school. On the other hand, when they are interacting with their relatives or neighbours, they must adapt their conduct to the village way of life in order to avoid the adat or social sanctions. It is apparent that in Blangporoh the so-called changes have have only taken place on paper and not really. The kapalo kampuang still preserves his traditional role particularly in settling the conflicts among the people of the village and in organizing the various activities and ceremonies of the villages. If there are unresolved disputes at the village level, they can be submitted to mukim level as an appeal to be settled by the imuem mukim. At mukim level, disputes are generally settled peacefully. This is especially applicable for civil cases. Parties who feel dissatisfied by the resolution can take the case to court but taking it to court takes a considerable amount of time and money. 
The real change that has been taking place in Blangporoh due to the development program can be observed through the improvement and presence of new media communication. Blangporoh village is not only no longer isolated, but is also integrated with Tapak Tuan, South Acèh and other places in the Archipelago. The better conditions and the transportation network have certainly facilitated the social economic mobility of the people of the village. Most people from the village travel everyday by bus, motor cycle, or bicycle between their village, selling their commodies or shopping, or going to school. These do not mean that the central government does not have authority on the people of the village. The people of the village always have contacted with national power through its representatives on each administrative level. The presence of the national power in the people's eyes is certainly strengthened by the monetary and the political parties having a branch on village.

The presence of new media has made Blangporoh village more open to the outside world. The people soon know what is happening outside the village, on national and international issues, fashion, music, songs, etc. Their presence, however, does not mean that they have completely changed the social values and the local culture. The local media also promotes the local culture through its programs. For example, a government radio program from South Acèh quite often plays songs in the Aneuk Jamee language. In such a way this new media of communication has also become an important means to strengthen the local culture. Besides that, Blangporoh village still preserves the various traditional communications, such as holding religious teaching in the mosque or meunasah, the life-cycle rituals and ritual calendar. These institutions preserve and socialize the traditional values based on sentiment and togetherness.

Blangporoh villagers are religious people. It can thus be ascertained that the whole population is Muslim. Dichotomy of understanding and religious practices, however, is still prominent in the neighboring villages. On the east of the village, that is the Tutong village and Panton Pawoh, there are groups of reformists or modernists while in the west the villages of Blangporoh, Kutaiboh, Ujongpadang, Pulo Ie are dominated by a group of traditionalists or conservatives. These two groups differ in their understanding of Islam. Consequently, its implementation is different too. Reformist groups named themselves the reformers. That is, the group seeks to purify Islam from the influence of superstitious teachings and heresy, and return to the Qur'ān and hadìth. The group calls itself a defender of traditional aqidah ahlussunnah waljama'a (fol- 
lowers of sunnah of the apostle and his companions). The most fundamental difference between them is that the reformists do not subscribe to one of the four schools (Hanafi, Maliki, Shafi'i, and Hanbali) (Basri 1998:14). This group refers directly to the Qur'ān and the hadìth of the Prophet, whereas the traditional groups tend to adopt one of the four schools (mazhab). In this case, they embrace the school of Shafi'i. Because of this disagreement two major organizations have emerged; first Muhammadiyah with reformist ideas, and second Persatuan Tarbiyah Islamiyah (Perti) with traditional understanding.

Among the traditionalist group, respect for "religious teachers" (Arabic [Arb] 'ulama') is still strongly felt. The santri (students) at the dayah (boarding school) stand to honor their teachers when the teachers walk in front of them and they kiss their hands of teachers when greeting them. For Blangporoh society, especially for those who are traditionalists, the gestures, clothing, and behaviour associated with Islam are important. In everyday life, there are strong differences between santri for ordinary people. The santri tend to wear a cap or turban, a shirt and sarong. This type of dress is considered to be characteristic of 'pious people' (Indon orang taat) although sometimes the people who wear it are not pious. A 'clerical person' (Indon keulamaan) is also marked by the clothes he wears (Basri 1998:15). This is in marked contrast to the reformists who prefer unseen but practiced and constant inner piety to the obvious outer accoutrements and attributes of a Muslim. Dress code characteristic of 'pious Muslims', especially at Dayah Darussalam, has begun to disappear. There are even students who wear jeans with T-shirts (ibid). For the reformists, clothing is not important. Pious Muslims may wear any clothes but must be clean and covered aurat. ${ }^{12}$ Characteristics of the 'ulama ' in terms of outward appearance are not a criterion in this group.

\section{The pervasive influence of Islam}

This district is situated in the western-most coastal area of Sumatra Island, about $500 \mathrm{~km}$ south of Banda Acèh, and consists of 14 villages. $^{13}$ It is said that in the past, the town of Labuhan Haji had a glorious history as a port city, through which pilgrims travelled to and from Mecca. Every year this city

12 The part of the human body that is to be covered when a person is outside the confines of the family.

13 See map of West Labuhan Haji district. 
was visited by many pilgrims from various regions. To commemorate this, the city is called Labuhan Haji "the port of pilgrims". Historically, the kingdom of Acèh had opened this harbour for pilgrimages not only from the western coastal areas of Sumatra: "We must remember that before sailing ships were replaced by steamers as a means of conveyance of visitants to Mecca, Acheh formed a great halting-place for almost all the pilgrims from the Eastern Archipelago" (Snouck Hurgronje II 1906:19). That is why the Acèhnese used to speak of their country with some pride as 'the gate of the Holy Land' (Indon pintu gerbang tanah suci). Many Acèhnese pilgrims remained in Mecca a considerable time to study Islamic teaching, among which Sufism became prominent; some Acèhnese even settled their as traders or teachers for the remainder of their lives. This direct contact with Mecca as the spiritual centre of Islam was very important in the late nineteenth century. As men who had been to the Holy Land, they had a direct opportunity to improve communication with the rest of the Islamic world.

The number of Acèhnese and pilgrims from other parts of the Indonesian archipelago performing the hajj steadily increased. Some two thousand Indonesian pilgrims had departed by 1860 , ten thousand by 1880 , and fifty thousand by 1926 (Geertz 1968:67). These pilgrims became aware of the developments in other parts of the Muslim world, particularly the expansion of European imperialism and the political and intellectual responses this provoked: jihad, mahdi-ism and later, the Islamic reform movement (van Bruinessen 1990:151). Upon their return, they founded religious boarding schools in their home region to instruct young men in what they had learned in Mecca. They became teungku in Acèh, kyai in Java and the leaders of santri communities all over Indonesia (Geertz 1968:67). Some of the returning hajji fiercely opposed the Dutch rule and called for disobedience; that is why the Dutch Indies authorities became increasingly suspicious of the hajj.

Through this port city, Islamic values were quickly absorbed and disseminated in the surrounding community. It is there that the religious organization of Nahdlatul Ulama "old group" and Muhammadiyah "young group" originated (Waly 1997:56). The west coast area of Sumatra consisted of many socio-ethno linguistic groups and southern Acèh absorbed many culture elements of immigrants from various regions. As a result the Islamic culture in southern Acèh has become a "beautiful rainbow of cultures" (Hasjmy 1989:10). 
The Aneuk Jamee people live along the southern and western coast of Acèh (see the map of the distribution of the Aneuk Jamee population in the southern and the western coast of Aceh). Based on narratives from senior village people, Aneuk Jamee originated from the regions of Minangkabau, Rao, Pariaman, Lubuk Sikaping, Pasaman, Indrapura, Painan, Pariaman and Padang Panjang and Barus [now Middle Tapanuli] and Natal [now South Tapanuli]. Minangkabau migrants came to the southern and western coast of Acèh at the end of the 17th century (Sulaiman 1978:1). Zainuddin (1961:211), however, mentions that Minangkabau people moved to the southern and western coast of Acèh in the wake of the Padri war led by Tuangku Imam Bonjol (1805-1836). To escape from the disasters of war, many Minangkabau fled by sailing down the western coast of Sumatra to the southern and western coast of Acèh. They then opened a new residential area in the fertile lowlands that were hardly cultivated by local residents. They planted pepper, nutmeg and other garden produce. Many of them who lived at the coastal areas worked as fishermen. They settled along the coastal districts of Labuhan Haji, Tapak Tuan, Susoh, Manggéng, and Samadua. People of Minangkabau descent also live in some villages on the southern and western coast of Acèh for instance in Kuala Baro, Singkil and in the coastal area of Meulaboh (West Acèh) (Sulaiman 1978:2). ${ }^{14}$ Many Acèhnese also live in these Aneuk Jamee areas. In fact immigrants were regarded as guests (Ach jamee), who eventually assimilated with the local Acèhnese community members. This assimilation process went smoothly because 'hosts' and 'guests' shared the same religions (Islam). As a result of this assimilation process, the people identify themselves neither as Minangkabau nor as Acèhnese, but as Aneuk Jamee meaning "children of guests", having their own language and culture. Their mother tongue is Aneuk Jamee, but they can understand Acèhnese.

There are several striking features of West Labuhan Haji district. There is a shrine of Syeikh Muda Waly (1917-1961) in Blangporoh village. This Syeikh is regarded as a person who received the 'blessing' (Arb barakah) from Allāh (Ach ureuëng keuramat -from Indon orang keramat) because of his obedience to and knowledge of Islam. He was the founder of a large traditional boarding school (Ach dayah) in South Acèh and a guide (mursyid) of the

14 See map of the distribution of Aneuk Jamee population on the southern and western coast of Acèh. 
Nakhsabandiyah order (tharīqah Nakhsabandiyah) in Acèh (Baihaqi 1983:149). In addition, he was a highly respected 'ulamā' in Acèh. Many of his students have now become 'ulamā' and the leader of many dayah in Acèh and in other places in Indonesia.

Like the tomb of saints in other Islamic societies, the tomb of this Syeikh is deemed to be a good place to seek 'blessing'. Therefore, many men and women perform a 'pilgrimage' (ziarah) to the Syeikh's tomb in order to enrich their lives both spiritually and socially and to receive spiritual strength from it. Many people with different intentions come to his tomb, not only from South Acèh but also from other parts of Acèh to take the 'spiritual vows' (Ach peuleh kaoy) and to pray at his tomb to be protected from disasters. ${ }^{15}$ Because of the strength of this tradition rooted in the community in West Labuhan Haji district, the visitors deem the Syeikh's tomb as that of a 'spiritual teacher' (Indon guru spiritual) (Basri 1998:14).

In almost all Islamic societies, the saints whilst alive and their tombs are deemed as a source of 'blessing' (Evans Pritchard 1973; Trimingham1971; Nur 1996:7). Visiting tombs is therefore a common practice in all Islamic societies; the social and religious meaning of visiting the tomb of a saint varies from one society to another and is shaped by everyday life experiences. In Indonesia it is generally accepted that visiting a saint's tomb brings the saint's blessing, since this is regarded as a remedy for various kind of illness (Jamhari 1994; Nur 1996:7).

The tomb of the Syeikh is located near the mosque in the dayah complex of the village, and is easily reached by any visitors. Performing a 'pilgrimage' to the Syeikh's tomb touches the realm of belief and assumptions about the way the world is constituted. Men and women who visit the tomb share the faith and their sympathy.

Historically, in the nineteenth century many Acèhnese on the hajj in Mecca joined the standard thariqah orders of the Qādiriyyah and Naqshbandiyah. ${ }^{16}$ They had a direct contact with the spiritual centre of Islam after the Suez

15 Many Acèhnese people also perform the same also at the shrine of Poteu Meurehom Daya in Lamno district, Acèh Jaya (see Nur 1996: 7), Teungku Syeikh 'Abd Al-Ra'ūf Al-Singkīlī in Syiahkuala, Banda Acèh and so forth. They consider these Teungku as people who received the "blessing" (Arb barakah) from Allāh.

16 This kind of Süfi order can also found in east Java (Geertz 1976), in Minangkabau, west Sumatra (Young 1994). The history of early Sumatran Süfì in the highland, Gayo, Cen- 
Canal (which changed shipping routes) was opened in 1869. This contact became the most important in the late nineteenth century because it coincided with the rise of modernism in the Middle East- a vital movement of reform and doctrinal renovation. ${ }^{17}$ Famous Muslim teachers like Muhammad Abduh and Jamal Ad-Din Al-Afghani were turning away from what they saw as religious obscurantism; instead they advocated the pursuit of learning and science, confident that rigorous pursuit of modern thought could only uphold the religious truth of Islam (Geertz 1968:67). Although two different Sufi sects have penetrated Acèh, the one of major importance in South Acèh, especially in Labuhan Haji is the Naqshabandi (Naqshbandiyya) ${ }^{18}$ Sufi order. Sheikh Muda Waly developed this thariqah in 1939, he founded a traditional boarding school called Dayah Darussalam in Blangporoh village. He obtained the thariqah from a great 'ulamā' in Batu Bersurat, Kampar, West Sumatra, Sheikh Haji Abdul Ghani al-Kamfari. Since then Blangporoh has become an important region and ritual center. Practitioners of the Sufi ritual (suluk) go to Bangporoh every Ramadhan month from their homes, bringing their own food, sharing everything together, engaging in mystical repetition and preparing for the death.

Another important element of the dynamics of Islam in West Labuhan Haji district is the existence of several dayah (Islamic boarding schools) with their teungku (religious leaders). Dayah with its teungku in the past still has a great influence within Acèhnese society, not only in dealing with religious matters, but also in solving social problems (Siegel 1969:11). In the wars of the colonial era, for instance, the military leadership of the Acèhnese passed into the hands of religious leaders. Therefore, Snouck Hurgronje (1906) argued that the Dutch should suppress the teungku and confine their activities only to religious matters.

tral Acèh can be found in Bowen (1993:124). In the lowland of Acèh can be found in Snouch Hurgronje II (1906:311-12), and in van Bruinessen (1990:143-146).

17 The government believed that the Naqshbandiyah ulama had contact in Mecca with religious teachers of pan-Islamic sympathy. Through pilgrims moving to and from Mecca, they were certainly in contact with the ulama of Acèh with who the Dutch were at war. Even allowing for the prejudices of government personnel, the colonial regime had reason to be worried about these trends (Young 1994:118).

18 The word Naqshbandi is Persian, taken from the name of the order, Baha -ud- Din Naqshband (d.1389) who lived in Mawarannahr, central Asia region west of the Pamirs (Gladney 1999:119). 
Dayah or rangkang ${ }^{19}$ in Acèh or pondok or pesantrén in Java, or surau in West Sumatra, is composed of teachers to-be, who disdain rather than desire office, or of those whose parents set a value thorough course of religious instruction (Snouck Hurgronje II 1906:24). There are several dayah in West Labuhan Haji district. The largest one is the Dayah Darussalam in Blangporoh village. This dayah observes a traditional form of education and only follow mazhab, Syafi'i and other dayah in West Labuhan Haji district are also the same. The founder of this dayah was the Syeikh himself and he was highly appreciated by the Indonesian government as he was a convinced nationalist who never opposed the government during his life. The alumni of this dayah have spread into many regions in Acèh. The Dayah Darussalam has successfully educated thousands of santri to become teungku ('ulama') among them, and the leaders of dayah in Acèh: Teungku Adnan Mahmud in Bakongan, South Acèh; Teungku Muhammad Daud Zamzami in Acèh Besar, Great Acèh; Teungku Abdul Azis Saleh Mesjid in Samalanga, North Aceh; Teungku Muhammad Amin (Tu Min) in Blangbadeh, Bireun; and other religious leaders in Acèh. ${ }^{20}$

Many santri from this dayah went on labour migration (Indon merantau) to Makassar (Sulawesi), Padang Panjang (West Sumatra) Barus, Java, Madura and even to Malaysia and Brunai Darussalam. There, they also founded the same types of dayah continuing to teach the Arabic language (balaghah), ${ }^{21}$ jurisprudence (ushul fiqih) from various Islamic books, the science of mustalhah hadīth, the science of Prophet tradition (Arb $\underline{h} a d \bar{i} t h)$, Quranic exegesis (Arb tafsir), and the science of rhetoric (Arb mantiq), literature (a'rudh), and Sufism (Arb tasawwuf). ${ }^{22}$ One thing that makes these dayah different from

19 A rangkang is built in the form of a dwelling-house, but with less care; instead of three levels of different elevations/heights. It has only one level throughout, and is divided on either side of the central passage into smaller chambers, each of which serves as a dwelling-place for from one to three santri (students).

20 See the website of Pondok Pesantrén Dayah Darussalam, http://www.al-shia.com $/ \mathrm{html} /$ id/service/Info Hauzah/Dayah\%20Darussalam.htm.

21 Arabic language (Arb balaghah) teaching consists of the science of the form of language (ma'ani), the science of translating meaning with different methods (bayan), poem/story related in verse form-using (badi').

22 The great Muslim father, al-Ghazali (1058-1111) describes the study of the law (Ach pikah) as the indispensable bread of life of the believers, the dogmatic teaching (usuy) being the medicine of mankind, threatened with all manner of heresy and unbelief, is constrained to use as preventive and as cure. Moreover, he considered mysticism (Ach teusawōh) the highest and most important element in man's spiritual education, since it 
other dayah in Acèh is that there is a teaching of Naqshbandiyya's order. This mystical teaching is still performed by many santri and thousands of other followers. ${ }^{23}$

Dayah Darussalam is now led by Teungku Ruslan Waly, a son of the Syeikh, and a person who has a strong influence within West Labuhan Haji district and is widely respected by the people. He also holds 'religious discussions' (Indon pengajian) each week in the Blangporoh mosque. In these discussions, people can meet him, kiss his hand and ask him questions about specific religious problems. The importance of his influence within the district is also evident from his eminent role in determining the first day of the month of Ramadhan. During the last few days of Sya'ban, predicting when Ramadhan will begin is a favourite discussion among West Labuhan Haji people: sometimes the decision of the State Department of Religious Affairs is contradicted by what is decided by several teungku in Acèh. His decision is eagerly awaited as definitive by most people in West Labuhan Haji district. The maintenance of the tomb of the Syeikh, the practice of suluk "Sufism" as well as the existence of many dayah in West Labuhan Haji district provides evidence that this society is strongly influenced by Islamic tradition.

serves to digest the bread of life and the medicine, that a true knowledge of God and of the community of mankind with the Creator may spring there from (Snouck Hurgronje II 1906:9).

23 Like other pesantrén in Indonesia, Dayah Darussalam use two education systems, (1) Qadim method, means traditional system with the emphasis of mastering religious books (Indon kitab-kitab agama) such as Nawawi's Minhāj Attālibīn (Ach mènhòt) and various commentaries such as the Fath al-Wahhāb (Ach peuthōwahab), the Tuhfah (Ach tupah) and Mahalli (Ach mahali). In this method, a santri must finish learning religious books. In the process of learning, the santri not only know how to read religious books but also know to translate and understand the meaning in them. (2) Madrasah, means lecturing method in the class room with the emphasis of finishing learning religious books and more discussion in order to have in depth understanding on the given materials. And the main purpose of learning at this dayah is the syari'ah law as revealed through Muhammad in the Qur'ān and his sunnah, and as in the lapse of time (with the help of Qiy $\bar{a} s$ or reasoning by analogy) confirmed and certified by the general consensus (ijmán') of the Muslim community. Apart from teaching the religious books, the thariqah Naqsyabandiyah is also introduced to the santri and to the surrounding community. Currently, therefore, the thariqah Naqsyabandiyah is carried out by many adherents in Acèh. This dayah is thus as center of teaching as well as for practice of the thariqah Naqsyabandiyah's sciences (see Waly 1997 and see also http://www.alshia.com/html/id/service/InfoHauzah/Dayah\%20Darussalam.htm). 


\section{ChAPTER 2}

\section{The Aneuk Jamee cosmology}

The Aneuk Jamee cosmology reflects the people's history, social, moral values and religious beliefs. Their cosmology has been deeply influenced by Islam which is considered the fundamental source of knowledge and morality. It also contains myths about the creation, and origin of the universe as well as that of humankind. One acknowledges the reality of Allāh, but the cosmology does not define Him, one believes that the universe consists of two interconnected levels: the visible and the invisible. Human beings live on the visible level, while Allāh and spiritual beings (malaikat (angels), iblis (devils), syètan (satan) and jinn (genies)) exist on the invisible one. This chapter describes these two interrelated levels.

\section{Allāh}

The Aneuk Jamee believe that Allāh whom they worship is the same God worshipped by Jews and Christians. It is the God of Abraham whose selfrevelation was given through the prophets, beginning with Adam and continuing through Moses, Jesus, and finally Muhammad. In speaking about God, Aneuk Jamee use the two phrases, "I bear witness that there is no God but Allāh and I bear witness that Muhammad is His messenger". In the first phrase God's unity (Arab tawhīd) is emphasized. God is one and has no companion. God is not begotten and does not beget (QS 112:3). The unity of God asserts the transcendence of God as the creator of the world. Nothing can be compared to God. Nothing is like God (QS 112:4). The greatest sin in Islam is shirk, "association". All idolatry is rejected. To abrogate the unity of God is to deny that God is the Omnipotent, Omniscient creator, and the Lord and Sovereign ruler of all worlds. The second phrase about the Prophet Muhammad emphasises that he is the founder of the Islamic religion and is regarded by Muslims as a messenger of God, the last and the greatest law-bearer in the series of Islamic prophets as taught by the Qur'ān. The first phrase is called syahadat tauhid "confession of faith of God's unity" and the second phrase is called syahadat rasul "the confession of faith of the apostle". The formal recitation of syahadat takes place at particularly crucial moments of the life-cycle ritual that is, at the time of circumcision and marriage. 
There are two obligatory requirements of these syahadat: 1) declaring with the tongue and 2) affirming with the heart. These must be added to two other requirements to show a full understanding; that is the one who utters syahadat must know through knowledge both rational arguments and arguments that refer to relevant passages of the Qur'ān and must be convinced in his heart and then be able to ratify the essence, attributes, and the work of Allāh as well as the trueness of Muhammad. Ignoring these elements is said to mar the recital of syahadat and makes one only a superficial Muslim. If one denies that one is created by Allāh and does not confirm this, his or her syahadat is destroyed. Uttering syahadat is the declaration of allegiance of every Islamic adherent and one must declare this belief out loud. After finishing reciting syahadat, one automatically becomes a Muslim. But a mere pronouncement of syahadat and performing prayers five times a day is not enough to become a good Muslim. A deeper awareness in the reciter's heart and a good relationship among human beings are also required to form the required balance in human behaviour.

To the question who Allāh is, the Aneuk Jamee give various answers. One says that Allāh is the Being who created heaven and earth together with their contents. Others answer that Allāh is the Creator and Sustainer of the sky and the earth and all things within them. Besides Allāh as the Creator (maha pencipta), the villagers also regard Allāh as the Sovereign (maha kuasa) whose sovereignty is absolute and omnipotent as well as the Ruler (maha pengatur). These ideas are consistent with the ideas of Allāh's absolute omnipotence over men on the one hand, and men's total dependence on Him on the other. Everything is totally under His control and nothing in the universe is unseen to Him. $\mathrm{He}$ is All-powerful and Omniscient and the source of Divine will and decree. Allāh says: "Verily; We have created all things with qadar (Devine Preordainments of all things before their creation as written in the Book of Decree) (QS 54:49).

The dependency relation of Creator-created is deeply imprinted in the cosmology; it manifests itself for example in oral traditions, and more apparently, in exclamations. When one begins to perform a task, it is traditional to recite bismillähirrahmanir rạīm ('in the name of Allāh, the beneficent, the merciful'). When something good happens (facing desirable things, the response is alhamdulillāh ('praise be to Allāh')). In contrast, when something bad or unwanted happens or when one is frightened, one will spontaneously respond: illallāh ('except Allāh'), Allāh Tuhan, Muhammad Nabi ('Allāh is God, 
Muhammad is the Prophet'), even sometimes with the full recital of the syahadat; or masya Allāh, ('that is not Allāh's will') or astaghfirullāhal'adhīm ('I beg Allāh the Greatest's pardon') or la hawla walaquwwata illa billahil 'aliyyil 'adhim ('there is no power and strength except from Allāh the Greatest'). Similarly, these expressions are used when one is shocked by something or has an accident. In a more serious situation, when hearing that someone has died one will exclaim inna lillahi wa inna ilaihi raji'ūn ('lo, we belong to Allāh and lo, unto Him we return'). Although these expressions do not necessarily reflect religiosity, in the sense that users need not necessarily be devout, they are indications that Islam has indeed penetrated deeply into the traditions of the Aneuk Jamee social life in West Labuhan Haji district.

Allāh cannot be reached by thought or vision but He knows everything. Islām prohibits its followers from thinking about the substance of God or imaging His essence. He cannot be compared with anything. One informant said "we are created without having the software to understand His essence". They are told to think about His creatures in order to understand Him. Questions such as, "What does Allāh look like?" are strictly discouraged as it is beyond the reach of the human understanding. Any attempt to describe Allāh will result in the identification of His names in term of attributes called 'Allāh's attributes' (sifat sifat Allāh). These include 'the "must"-attributes' (sifat wajib), 'the "must not"-attributes' (sifat mustahil) and 'the "may" attributes' (sifat jaiz). 'The "must"-attributes' (sifat wajib) correspond to an affirmation of divine perfection, qualities that must be ascribed to Allāh. There are twenty of these and hence they are known as 'the twenty attributes' (sifat duo puluah). Thirteen of them are said to be unanimously agreed on by theologians, while the other seven were added later by others (Muhaimin 2004:46). The thirteen attributes are: 'existence' (wujud), 'eternal' (qidam), 'permanence' (baqa'), 'dissimilarity with the created' (mukhalafatu lilhawaditsi), 'self-subsistence' (qiyamuhu binafsihi), 'oneness' (wahdaniyat), 'power' (qudrat), 'will' (iradat), 'knowledge' ('ilmu), 'life' (hayat), 'hearing' (sama'), 'vision' (bashar), 'speech' (kalam). The other attributes do not intrinsically describe Allāh's essence; they designate what Allāh can do and usually does, they are kaunuhu (He is in a state of being): 'powerful' (qadiran), 'willing' (muridan), 'knowing' ('aliman), 'alive' (hayyan), 'hearing' (sami'an), 'seeing' (basiran), 'speaking' (mutakalliman). 'The 'must not"-attributes' (sifat mustahil) correspond to the negation of any defective qualities and, therefore, must not be ascribed to Allāh. There are also 
twenty 'the "must not"-attributes': 'non-existence' ('adam), 'recency' (huduts), 'perishability' (fana'), 'similarity with the created' (mumatsalatu lilhawaditsi), 'non-self-sufficiency' (ikhtiyaju bighairihi), 'plurality' (ta'addud), 'weakness' ('ajzu), 'unwillingness' (karahah), 'ignorance' (jahlu), 'unanimated' (mawtu), 'deafness' (ashammu), 'blindness' (a'ma), 'speechlessness' (bukmun). $\mathrm{He}$, who or that which could be in a state of being: 'powerless' ('ajizan), 'unwilling' (karihan), 'ignorant' (jahilan), 'dead' (mayyitan), 'deaf' (ashamman), 'blind' (a'man), and 'non-speaking' (abkaman). There is, however, only one “may”-attribute' (sifat jaiz): Allāh's prerogative to do or not to do something. ${ }^{24}$ Besides describing Allāh in terms of these attributes, He can also be described in terms of the 'most Beautiful Names' called Asma ul Husna. The phrase Asma ul Husna, made up of the word asma, the plural form for "name", and husna, meaning "beautiful". There are ninety-nine names of Allāh in total and these can be found in the Qur'ān and the hadīth. ${ }^{25}$

It is the teungku among Aneuk Jamee, who command this knowledge and instruct the people. Thus to fully understand the depth and meaning of all of these beautiful names, one teungku said that one really needs to ponder and think about them. For example, Allāh is the All-Hearer (al-Basir). Think about it - Allāh hears everything, from the buzz of a mosquito's wings to the rustle of the wind. Every conversation spoken, every thought that you keep to yourself, etc is known by Him as language and there is no barrier for Allāh to understand all. Understanding Him through His attributes and names, realizing His Omnipotence and Majesty is said to make us humble. Such information indicates that the Aneuk Jamee's concept of God derives entirely from Islam.

\section{Spiritual beings}

There is a general agreement among the Aneuk Jamee on the existence of spiritual beings, although the details of these beings are perceived differently

24 There is a similarity how the Aneuk Jamee describe Allāh among Muslims in Cirebon, a region in the north-coast of eastern West Java, see Muhaimin (2004:46-47).

25 For Allāh's Beautiful Name, see Qur'ān in Sūrah Al -A'raf, verse 180, Sūrah Al-Isra, verse 110; Sūrah At-Taha, verse 8 and Sūrah Al-Hashr, verse 22-24. The imām said that ninety-three of the names that were mentioned in the hadith were also in the Qur'ān, while the meanings of the other six names had been attributed to Allāh with different words. According to a hadīth narrated in Bukhari and Muslim, Prophet Muhammad said the following about the Asma ul Husna: "Allāh has 99 names. Whoever memorizes and embraces these qualities will enter Paradise." 
from one individual to another. The existence of spiritual beings is seen as a corollary of the existence of physical beings. As physical beings exist, nonphysical or spiritual beings also exist. The commonly known spiritual beings are: 'angel' (malaikat), 'devils' (iblis), 'satan' (syètan) and 'genies' (jinn). However, detailed information about these beings is incomplete and speculative. Their nature, essence and actions are described differently by various people. The six Decrees of Creed are: the belief in Allāh, His angels, His Books, His messengers and the Last Day, and the belief that destiny ${ }^{26}$, both good and evil, comes from Allāh. The villagers in Blangporoh know that they constitute the Decrees of Creed. In relation to the fourth belief, all village teungku say that Muslims should believe that there are so many messengers (prophets) of Allāh it is impossible to count them. Nevertheless, every single Muslim should know twenty-five of prophets. ${ }^{27}$ The villagers know the prophets' names and many of them name their children after the prophets' names ${ }^{28}$. Nonetheless, a number of them cannot remember the prophets' names in the correct order. Some, however, can list the names perfectly.

There are four Holy Books (Scriptures) that Allāh has already revealed to the chosen prophets: Zabur to the Prophet Dawud, Taurat to the Prophet Musa, Injil to the Prophet Isa, and Qur'ān to the last apostle, the Prophet Muhammad. There will not be any apostles after the Prophet Muhammad. Muslims believe that of the three preceding Holy Books, Qur'a $\mathrm{n}^{29}$ is the perfect one as it provides a conclusion of everything already revealed in the previous Scriptures and contains the exact words, recorded and transmitted without error as they were revealed. The others Holy Books have been corrupted by people over centuries with some parts added, some deleted, and some changed.

26 The Arabic word for destiny ' qadar' implies the measuring out of something or fixing a limit to it. Thus, in a technical sense, destiny is the divine decree in its fixing limits for existent things, or its measuring out the being of things. See Gardet (1980:366).

27 The name of the prophets are Adam, Idris, Nuh, Hud, Saleh, Ibrahim, Luth, Ismail, Ishaq, Ya'qub, Yusuf, Ayub, Zulkifli, Syu'aib, Musa, Harun, Daud, Sulaiman, Ilyas, Ilyasa, Yunus, Zakaria, Yahya, Isa, Muhammad. See for example: Salim (1987).

28 I find one family in the village whose children's names are Muhammad, Zakaria and Yahya.

29 The Qur'ān, as a holy book, consists of 114 chapters or sürah . Each sürah contains verses called ayat or "sign" of Allāh. The sürah are not in order in which the revelation was received. In general, the longer sürah were revealed in Medina; the shorter in Mecca. It is Allāh's miracle. It is incapable of being imitated and sublime in its form and content. 


\section{Malaikat}

One class of the commonly known spiritual beings is that of malaikat. Malaikat were created from light (Arb nür) by Allāh to serve and worship Him. They belong to a level of existence beyond the perceptible called alam gaib (Arb 'alam al-Ghayb). Malaikat carry out Allāh's commandments in nature and the universe. The 'forces of nature' become active because of the presence of malaikat behind them, working at the command of Allāh. Belief in the existence of malaikat is one of the Decrees of Creed (Ach rukon ${ }^{30}$ iman) in Islam.

The word malaikat known by the villagers comes from malak, the Arabic plural form of malaikah. This term refers to the heavenly creatures, the servants of Allāh acting as intermediaries between the divine world and the human world, carrying out His commands and praising Him. The village teungku explains that malaikat are different from human beings. They are intangible, sentient entities, who do not possess free will. They were created for the sole purpose of serving Allāh. Being made of light, they can assume almost any form, and can travel as fast as light or faster. In addition, malaikat are neither male nor female, and do not need food and drink. They are not born nor do they give birth, do not marry or have children and are free from all appetites and selfish desires. However, they are always loyal to Allāh, do what Allāh wishes and never sleep, forget anything nor feel tired. This idea is based on the Qur'ān (66:6) "...the angels do not disobey Allāh in what He commends them but do what they are commended". They are perfect in carrying out their tasks because there is nothing in their nature that would make them disobedient to Allāh.

The teungku further articulate this. Thus one of them explains the number of malaikat is countless and they number more than humans. Hence only Allāh knows how many they are. They have many different tasks and roles. There are some malaikat worshipping Allāh, idolizing Him and never raising their heads. Some guard and protect-they are called 'guardian malaikat'. Some accompany each person and pray for him. Others travel around and seek out those who remember Allāh so they can receive special blessings. Every Muslim should know at least ten of them". The teungku named the following: Jibril, Mikail,

30 The word 'rukon' is derived from Arabic word 'rukn' ( $\mathrm{pl}$ arkan) meaning 'pillar'. It is used in such reference as the pillar of faith (Ach rukon iman), the pillar of Islam (Ach rukon Islam), the pillar of prayers (Ach rukon seumayang), the pillar of ablution (Ach rukon wudhu'), the pillar of hajj (Ach rukon haji), the pillar of fasting (Ach rukon pua$s a)$ etc. 
Israfil, Izrail, Raqib, 'Atib, Munkar, Nankir, Malik Zabaniyah, and Malik Ridwan. The first four are called malaikat mukarrabun. ${ }^{31}$ Each of these has a specific duty with many other malaikat acting as his subordinates. Lay people in Blangporoh offer their own exegesis of this class of being. One rice seller argued "the world is also like a state on a small scale. The state should have a president and there are many ministers helping the president to manage it. The owner of the world is Allāh acting as president and the ten angels are His ministers who are always loyal to Him and do what He wishes to manage the world". Jibril's duty, for instance, is to convey revelations to the prophets, verse by verse. He is known as malaikat who communicates with (all of) the prophets. Another teungku argued "as far as he could remember from the kitāb (books or written sources of santri reference), Jibril has revealed divine revelations (wahyu) to the Prophet Adam twelve times, the Prophet Idris four times, the Prophet Ibrahim forty times, the Prophet Ja'cub four times, the Prophet Musa forty hundred, the Prophet Ayyub three times, and the Prophet Muhammad twenty-four thousand times". ${ }^{32}$ Mikail has the duty to control rain, thunder, giving livelihood to all living things both in the sea and on the earth such as food, nourishment and knowledge to all living creatures, particularly to human beings whether they are believers or unbelievers. Everything available in sea, on earth and in the earth which are useful for sustaining for all living creatures are said to be under the control of Mikail. The livelihood for all living creatures has already been determined by Allāh but human beings and animals have to make an effort to obtain it. In other words, human beings and animals must work hard first; their livelihood will then be secured, but its amount has already been determined by Allāh through Mikail.

Israfil blows his huge trumpet (Ach terompèt $<$ Dutch trompet) on two occasions: the first blow will signal the coming of Judgement Day, the world will vanish altogether. The second blow will bring all human beings back to life again from their graves, explains one teungku. ${ }^{33} \mathrm{He}$ adds that after resurrection

31 Malaikat mukarrabun (Arb al-Malak al-Muqarrabūn) means that these malaikat are always close to Allāh and their duties are harder than others. Muqarrabūn is also the highest degree from Allāh to malaikat. Some teungku in Blangporoh village say that these malaikat became the witnesses as Adam and Eve got married in paradise.

32 See also Effendie (1979:26).

33 Israfil's trumpet will be blown in the Judgement Day three times. The first blow is to die all civilization. The second blow is to flatten the world so that it all becomes land. The third blow is to resurrect all human beings and to revive them (Effendie 1979:27). 
from their graves, every human being will have his or her 'soul' (Jam nyawo) and body again but no clothes at all. All are naked and will stand/wait 40 years besides their graves while waiting for a command from Allāh to go to the gathering place on the Day of Resurrection. All human beings will then be truly thirsty as the sun will only be an inch over their heads. Only people who observe the fasting in the month of Ramadhān and other recommended fasting ${ }^{34}$ during their life will receive water from Allāh. It is said that now Israfil is still waiting for the command from Allāh to blow his trumpet.

Izrail, 'the malaikat of death' acts as a 'king' of all malaikat of death and is responsible for separating the 'soul' (nyawa) of all human beings from their bodies. When the time comes, no one can escape death or postpone it even for a second. The actual process of separating the 'soul' from the body depends on the person's record of good and bad deeds. For righteous persons who live according to the Qur'ān and hadìth, Izrail cannot take their 'soul' without first permission from Allāh. Teungku Alimi in Blangporoh village says that as Izrail wants to take out the 'soul' from a righteous person, he first appears at his head. The head would say to Izrail "there is no entrance here". Izrail then goes to the eyes, nose, mouth, hands, and feet. All parts of the body give the same answer to Izrail. Izrail reports to Allāh that he cannot take out the 'soul'. After hearing this, Allāh asks Izrail to go to paradise to take a shining fruit called boh nafal on which is written 'in the name of Allāh' (bismilläh). Izrail then shows this fruit to the righteous and faithful person whose 'soul' he wants to take. Only after showing this fruit can Izrail separate the 'soul' from the body quickly like a "drop of water dripping from glass" while he or she is looking at this fruit. The malaikat of death have "a most pleasant appearance" when he comes for the 'souls' of good people, so that the deceased's face looks happy. In contrast, Izrail recklessly takes out the 'soul' of non-righteous people from any part of his or her body. This person will truly feel pain, ${ }^{35}$ thirst and hunger. In this

Muhaimin (2004:54) also wrote that Israfil will blow his trumpet on three occasions: Firstly to signal the calamity, secondly, when the earthly world has vanished altogether, and finally, on the day when the dead are resurrected to receive the Final Judgement.

34 The recommended fasting, such as fasting 6 days in Syawwal lunar month, fasting on the day of Arafah (a day in which pilgrims gather together in Arafah field in Mecca), fasting on day of ' $\bar{a} s y \bar{u} r \bar{a}$ (the tenth day of the month of Muharram), fasting on every Monday and Thursday.

35 Some villagers in Blangporoh village say that when Izrail rips the 'soul' (Ach nyawong) out from the body it is truly painful. They say, "it is like a goat which is skinned while it 
case the malaikat of death will look like "a "terrifying beast or demon" so that the deceased's face looks nervous as if afraid of something. According to Teungku Alimi, Izrail and his many subordinates control a tree in paradise called sidratul muntaha. On every leaf of this tree has been written the name and life-span of every human being on earth as well as the time and place of his death. If a person's leaf turns yellow, that person will die soon. As one's time to die arrives (Ach katroh ajai), the yellow leaf falls from its stalk. Another malaikat who helps Izrail brings the leaf to him then he asks his subordinate to take the 'soul'.

The malaikat Raqib and 'Atid ${ }^{36}$ record the human activities: words, actions and intentions whether good or bad. Everyone has these two malaikat at their sides: Raqib is on the right side -some said on the right shoulder- and "Atid is on the left side or the left shoulder. Raqib records good deeds while 'Atid records the bad ones. Raqib and 'Atid will first begin recording human activities when men begin to produce sperm and women have their first menstruation. From then on people will be responsible for what they do till they die. It is said that people with good intentions are credited with "a minor good point" by Allāh; "a full point" is given when an intention is turned into action; this will be recorded by Raqib. By virtue of Allāh's mercy, there are "no minor points" for bad intentions; "a full bad point" is given only when a bad deed is performed. ${ }^{37}$ In this case, 'Atid judges whether a person who does something bad is aware of this. If this is the case he utters 'I ask Allāh for pardon' (astaqfirullāhal'azìm) and not to do that anymore for instance, giving back someone else's stolen belongings, 'Atid will then not record this as a bad deed. On Judgment Day the one whose bad deeds surpass his good ones will receive a written record from 'Atid in his or her left hand, meaning this person will have "a bad ending" (Jam celoko from Indon celaka) and will be thrown into hell. In contrast, the one who has done more good than bad deeds will receive a record from "Atid in his or her right hand, meaning this person will have "a happy ending" (Jam bahagio; Indon bahagia) and eventually will be sent to paradise.

is still alive" (Ach lagée kamèng gepulik udép-udép lagèe nyan keuh sakét nyawong geuhila).

36 Some villagers also said Malaikat Kirāman instead of Malaikat Raqib and Malaikat Kātibīn instead of Malaikat 'Atid.

37 See also Muhaimin (2004:55). 
Two more malaikat are Munkar and Nakir. Munkar -some villagers say Mangkaron- is an angel that interrogates the dead in their graves about the Islamic catechism reminding the deceased of the basic tenets of his or her religion. If these questions can be answered, 'mercy of the grave' (Ach nikmat $k u b u$ ) will be rewarded by Allāh. If the dead cannot answer Munkar's questions, he or she will be beaten by Nakir until the Day of Resurrection. Finally there are Malik Ridwan and Malik Zabaniyah. Malik Ridwan is the head of the benevolent malaikat responsible for controlling paradise, assisted by a large number of subordinate malaikat. According to the imām of Blangporoh village, Teungku Hasbi, the righteous and faithful people who fear Allāh will enter paradise; its keepers are happy and say, "Peace be upon you; you have become pure; so enter it to abide eternally therein". In contrast, Malik Zabaniyah is the head of malevolent malaikat responsible for guarding hell, assisted by a large number of subordinate malaikat. Those who disbelieve in Allāh will enter hell, and its keepers say "Have not messengers come to you, reciting the verses of Allāh and warning of this meeting on this Day (Resurrection Day). They say, "Yes, the word of punishment has come into affect upon the disbelievers". The imām's exegesis is in accordance with Qur'anic ideas (QS 39:71 and 73).

\section{Iblis, syètan and makhluk halus}

Blangporoh, Blangbaru and Kutaiboh villagers employ the term syètan ('Satan') to refer to any kind of bad spirits who induce people to sin. The villagers often classify syètan further as: iblis, syètan, makhluk malus, and jinn.

\section{Iblis and syètan}

Blangporoh imām and teungku relate how before Allāh created the world he created angels out of light (Arb nūr ). Before creating man, Allāh created the earth as a place for man to live. The earth and the natural world with its contents were made out of nothing. After creating the world, ${ }^{38}$ Allāh created Adam from the soil (Ach tanoh), then He created Eve, "the first beautiful woman"

38 It is said "On Sunday, Allāh created the earth. On Monday, He created mountains. On Tuesday, He created trees, plants and animals. On Wednesday He created the sky. On Thursday He created the sun, the moon and stars. On Friday He created angels, and on Saturday He created Adam. All are created from nothing except Adam created from clay". 
from Adam's rib. ${ }^{39}$ At first, Adam and Eve lived in paradise in the company of malaikat. After creating Adam, Allāh called all angels to honour Adam by bowing down to him. He also told them that He intended to make Adam a khalifah $^{40}$ on earth. The malaikat, however, protested if the man is placed on earth, there will only be bloodshed and destruction because man has carnal desires; he will not be perfectly faithful to Allāh. Allāh then said "Indeed, I know what you do not know". Allāh taught Adam the names and purpose of things but He did not teach the malaikat these. Adam recited the names and the purpose of things on earth, and thus demonstrated the superiority of man to the malaikat. After hearing Allāh's explanation, the malaikat understood and were no longer doubtful why man, and not they, would become khalifah on earth.

In one 'religious discussion' (Indon pengajian) ${ }^{41}$ I attended in Blangporoh village, Teungku Alimi explained that man is superior to malaikat because he has intellect (Ach akai) and has better adapted himself to earth as he has carnal desires. That was why all malaikat honoured Adam. Iblis ${ }^{42}$ who also lived in paradise, however, was reluctant and arrogant. He refused to bow down to Adam for three reasons: (1) compared to Adam, he was a senior dweller of paradise having been created by Allāh (2) iblis was superior to Adam, since the latter was created from clay while iblis was created from fire and fire should rank higher than clay (3) iblis had already worshipped Allāh for years before Allāh created Adam. Iblis was full of envious resentment as he felt that he had more dignity than Adam. Iblis, therefore, thought that bowing down to Adam would negate his own dignity. Allāh then said, "Descend from paradise, for it is not for you to be arrogant therein. So get out; indeed, you are of the debased (QS 7:12)." Since then iblis was no longer allowed to live in paradise. Yet Allāh still granted iblis's requests when he begged Him to postpone his punishment till the day of resurrection, prior to which he would lead his rival Adam astray and his human descendants till the end of the world. Iblis will tempt

39 Some Blangporoh villagers argue that Eve was created from Adam's left rib; hence she has more sensitive feelings than a man.

40 Khalifah (Arb khalïfah) is the title of rulers in Islam.

41 Pengajian consists of a formal instruction, followed by question and answer on the subjects discussed.

42 It is said that the name of iblis that did not want to bow down to Adam is Izzazil or 'Azazil, the 'iblis's king'. He added that this iblis also got the title muqarrabün as he was the leader of all malaikat in the sky. Due to iblis's disobedience to Allāh, iblis then lost his title and later on he was called syètan. 
Adam's descendants on all sides (at front, behind, their right and their left sides). Furthermore, iblis will sit in wait for humans on Allāh's straight path and mislead them all except for Allāh's most pious servants performing sincer religious service in His honour. Allāh said that those who fell into iblis's trap would become his followers, and after the Day of Judgement they would stay together with him in hell. Iblis did not waste any time after Allāh approved his requests and immediately started working. The first victim was Adam himself and his wife, Eve, who were tempted while they were still in paradise.

In another 'religious discussion' in the village, Teungku Yunus related how Adam and Eve fell into iblis's trap. At first, iblis came from the first layer of the earth to paradise through the seven layers of sky but iblis could not enter as its door was locked by a malaikat while Adam and Eve were therein. Iblis cried loudly while standing in front of Paradise's door. The iblis' cries were heard by a snake. The snake in paradise then lifted up its head and looked at iblis through a hole in paradise. Iblis said to the snake "I cannot enter into paradise without your help, I want to go to the khuldi tree, the 'eternity tree' (Arb syajarah al-khuld) in paradise". The snake then helped iblis by showing its mouth through a hole in paradise then the iblis immediately jumped into the snake's mouth and entered paradise. There, meeting Adam and Eve, iblis told them confidently that Allāh placed Adam and Eve in a bad position. Iblis pretended that he was very sad and sorry. Adam and Eve, therefore asked, "Why are you so sad? Iblis answered: "I was so sad and deeply concerned about your problem. I heard that Allāh prohibited both of you (Adam and Eve) to approach the khuldi tree, if you did you would have to leave paradise. I was so worried that you would approach the tree as your God did not forbid you to eat the $k h u l d i$ fruit. But if you eat the khuldi's fruit, you would become immortal or malaikat and then you could stay in paradise forever". Iblis swore to Adam and Eve that "he was a sincere advisor". Allāh instead banned them from paradise and was going to make them live on earth where life would be hard. He then insisted that the only thing that might help would be to pick and to eat the khuldi fruit secretly without Allāh knowing so that they would not be driven out from paradise.

Hearing this, Adam and particularly Eve felt that iblis's words were sensible and asked him if there was any way to stay in paradise forever and to avoid staying on earth. Iblis was pleased that his deception had worked. Tempted by his insistence, Eve and Adam approached the khuldi tree, picked its fruit and 
ate them. One fruit eaten by Adam became stuck inside his throat as malaikat's hands wrapped around his throat. This later became his 'Adam's Apple' (Ach aneuk tok) as a sign of a mature male. Another fruit swallowed earlier by Eve did not become stuck and went out through Eve's vagina. This later became menstruation each month as a sign of a mature female. ${ }^{43}$ At that moment, Allāh called to Adam and Eve, "Did I not forbid you to eat from that tree and tell you Iblis is a clear enemy". Their clothes from their bodies disappeared as they had already transgressed the first of Allāh's prohibition; that is, eating the khuldi fruit. They were sinful and paradise is only for the 'holy' people. Adam and Eve were then chased away to different places on earth far from each other. On earth they covered their body with leaves of the trees. Only after a long search did they get together again in an Arafah field ${ }^{44}$ field in Mecca.

In the other 'religious discussion' in the village, Teungku Usman explained that the word 'khuldi fruit' (Ach boh khuldi) in the Qur'ān is a metaphor. He contends that all fruits are not on their stalks forever, they all fall down except the 'fruit' the human being has. What Allāh prohibited in paradise was not the fruit of khuldi tree but the 'eternity fruit'. Teungku Usman quoted from the Qur'ān, Allāh said “....when they tasted of the tree, their private parts became apparent to them..." (QS 7:22). From this verse, it is clear Allāh said "Dzāqasysyajarata" or "felt the trunk of tree" and Allāh did not say "Dzāqatstsamarata" or "the fruit was eaten" but it was only felt by the body. Teungku Usman concluded that Adam was prohibited to have sexual intercourse with Eve in paradise but could do so on earth with the aim of creating men and women. The problem here is not Adam having sexual intercourse but why he followed iblis's temptation; not that Allāh's prohibition was not followed.

43 Another version said that two khuldi fruit were eaten and swallowed even earlier by Eve then became stuck inside her breast and they turned into breasts, a sign of a mature female (Muhaimin 2004:57). Teungku Sa'dan argued that several symbols of women's character are based on Eve's behaviour as she ate and swallowed the khuldi fruit ('prohibited fruit'): first, women are easy to be persuaded by anyone. Second, women cannot stand keeping secrets for long even though she tries hard, (eventually it will be proved) and third, women cannot restrain their desires. When I discussed this to several village women, some really did not agree with these ideas claiming that the characteristics of men were the same as those of women but some others said "let the myth continue as it is.

44 Arafah means "knowing again" or "meeting again" after such a long search. It is located in Mecca and till now used by pilgrims as the place to gather (Arb wuquf) there. Wuquf in Arafah field is one of the pillars of hajj. When pilgrims do not perform wuquf in the Arafah field at the appointed time in the pilgrimage season, their hajj is not valid. 
Allāh has already told Adam not to approach the khuldi tree. If he did so, he became a sinner. Adam and Eve realized that they had already made a mistake and repented to Allāh as follows: "Our Lord, we have wronged (ourselves); and if You do not forgive us and have mercy upon us, we will surely be among the losers" (QS 8:23). Allāh granted His forgiveness to Adam, but time could not be turned back; Adam and Eve had to continue living a hard life on the earth.

Teungku Usman proceeded: whereas iblis was banished from paradise for his disobedience and generated his descendants called syètan ('Satan'), ${ }^{45}$ Adam and Eve's descendants were called manusia ('human beings'). Unlike human beings, however, none of iblis's descendants are mortal. Both iblis and syètan still exist. Their number has multiplied tremendously as they only die at the end of world. It is not clear whether iblis and syètan are differentiated by gender. From the time iblis had persuaded Adam and Eve to follow his advice, iblis and his descendants, syetan, have been zealous, working hand in hand and using all their power, intelligence and experience to lead Adam's descendants astray. ${ }^{46}$ Their daily task is to tempt and to trap human beings to follow their path so as to increase the numbers of their followers and worshippers among the doomed who will share their fate. They know that their destination is fire and they take human beings out of envy, hatred, disbelief and stubbornness with them.

According to Teungku Usman, iblis and syètan often try to 'steal' information from laukh makhfudz ${ }^{47}$ by spying on the scenarios in the universe, especially those relating to individual human's lives and using them effectively to establish cooperation with fortune tellers, black magicians etc in order to lead human beings astray. ${ }^{48}$ It is believed that fortune telling, black magic and astrology and other possible astral projections are all affected by or involved in the powers and knowledge of iblis and syètan and can often be used by them for their own purposes. In addition, it is said that iblis or syètan can mislead people through their dreams, whereas many dreams are mainly the product of people's minds and these are just confused and easily forgotten. Opposing iblis

45 It was said that on the day Allāh banished iblis from paradise. Iblis changed its form into a syétan. Iblis was at first the leader of malaikat. Because he transgressed Allāh's command, his prior religious service to Allāh was no longer accepted. Allāh cut off His mercy to him because of his disobedience.

46 See also Muhaimin (2004:57).

47 Laukh makhfudz refers to the tablet where the record of decisions of the divine are preserved.

48 The same idea found in Cirebon, see Muhaimin (2004:58). 
or syètan's methods, Angels guarding and protecting human beings called 'guardian angels' may take harsh measures against iblis and syètan and beat them so severely so that they take on weird shapes called makhluk halus.

\section{Makhluk halus}

Of all the spiritual beings in which the Aneuk Jamèe believe in, makhluk halus is the most vaguely defined. Not deriving from Qur'anic sources, $m a-$ khluk halus is believed to be a type of malevolent spirit that disturbs human beings. Unlike the terms malaikat, iblis, syètan and jinn which all derive from Arabic, makhluk halus is an Indonesian construct meaning 'delicate creature' that cannot be seen with the naked eye as they have a 'very tiny body'. The villagers know many kinds of makhluk halus:

1. Buruang tujuh likes disturbing children. If a child is possessed, his eyes will be wide open and he is unconscious. Soon after a healer has cured the child its consciousness is an indication that this 'delicate creature' is no longer in the child's body.

2. Balum beudé usually makes a sound to bother human beings. One says that it can be found along coasts or in a river. If this 'delicate creature' shows himself, it will most likely be as a red mat spread out. Therefore, it is often called 'the rolled mat' (Ach gulong ingka).

3. Geunteut is black. It often shows itself on the streets walking with a long stride and going into bushes on the road side. It is said that it often disturbs a person by taking him or her into bushes or taking someone far away from crowded places.

4. Beuno prefers bothering those sleeping by choking a person in his dream. This often happens to those who do not recite 'prayer' as they want to sleep.

5. Buruang punjuik is found at night wrapped in white clothes and is believed to derive from a woman who died in childbirth; people who buried that woman have forgotten to open the ropes that tied her enshrouding cloth. ${ }^{49}$

6. Tulang tagak is like a 'standing bone' (Ach tuleueng dong). It is said to be found on a dark rainy night on street crossroads.

7. Hantu buru possesses hunted animals i.e. deer, antelopes etc. It revives dead animals for a moment. For example a dear is caught in net traps. Before it is slaughtered, pawang rusa, ${ }^{50}$ a man who is an expert at catching deer has to recite a spell. Failing to do so, the deer becomes wild and difficult to slaughter as hantu

49 See also Snouck Hurgronje I (1906:412).

50 One says that if one wants to hunt deer in forests, he must be accompanied by others and led by a pawang rusa who has magic powers so that all dear hunters are safe and will not be disturbed by hantu buru. 
buru still occupies the deer's body. In addition, it is said that if a spell is not recited, the deer's fur will 'stand on end' like wire (Indon kawat).

8. Hantu panasaran, it is believed to derive from a person who died because of accident or torture. Some said it is a kind of 'delicate creature' from a woman who died from losing too much blood in childbirth. Others say that hantu panasaran can be from a dead person who committed suicide. His or her 'soul' becomes a ghost as he or she does not believe in Allāh and performs religious services when he or she was alive. Having died, his or her 'soul' (Ach aruwah) is disappointed. It often appears like a human being and wants to talk and follows the people in the area where it stays.

9. Buruang stays on the roofs of houses or trees at night. It sometimes possesses animals in trees. It sounds like a person crying with a sad sympathetic melody. Sometimes its sound is similar to that of a fowl or children. It is believed that $b u$ ruang is derived from the 'soul' (Ach roh) of a woman who died from losing too much blood at childbirth. It cries to let the people know that it is sad in order to attract attention.

10. Urang bunian lives in a forest. Someone looking for rattan or resin of certain trees for trade in the forest will sometimes be kidnapped by urang bunian for several days. And other people will know only after the person is released. ${ }^{51}$

11. Sanai, it is an illness caused by a 'delicate creature' that sits on dead wood floating and drifting in swamps, rivers, lakes, and estuaries where water does not flow. Some villagers say that if one step on these dead trees, one's feet will be swollen and painful ${ }^{52}$ if one touches them with one's hands, his or her hands become bent and stiff. Others say that sanai perches on floating wood. If someone touches it, he will be sick.

12. Panunggu is occupying swamps and other haunted places. If one wants to enter those places, one has to ask for permission first. Failing to do so, panunggu will ruin a person who goes there. ${ }^{53}$

Aneuk Jamee distinguish 'diseases' caused by 'delicate creatures' and other 'roaming souls' (Indon roh yang bergentayangan) such as tasapo, marampot, kemasukan, sijundai and pohon lumbè.

51 An example of a person who has been affected by urang bunian can be seen in Emtas (2008:49-53).

52 See also Snouck Hurgronje I (1906:409).

53 The khanduri for makluk halus "delicate creature" are often held when a bridge is built and when the land is made available for agriculture in the mountain. Some say that the aim of this khanduri is to ask permission to makluk halus living around the location so that the workers do not come to any harm. Some say that its aim is to ask malaikat to tell the workers in their dreams whether they can continue building the bridge/ cultivating the land and some others say its aim is to remove makluk halus to it site and claim ownership of these locations. 
1. Tasapo afflicts someone who has met a 'delicate creature' that is angry with him or her. Some say syètan's child has been stepped on so that its parents are angry with the person who did it. As a result, he or she falls ill. Others say that tasapo can be also caused by a 'roaming soul' encountered on walks or during a visit to the grave. A dead person addresses him or her without his or her knowing it, and such contact of an earthly nature with the subtler one which appertains to the realms of the dead, is sure to be have evil consequences (Snouck Hurgronje I 1906:412). A healer has to be invited to heal this person.

2. Meurampot, it is believed that meurampot is caused by 'delicate creatures' when one goes to places where 'delicate creatures' live. To heal this illness, the leaves of the tree where that person is believed to have become sick are taken. The leaves of the tree are then milled and placed on the sick person's forehead after being spelt.

3. Kemasukan is a 'roaming soul' that permeates one's 'soul' (Jam jiwo) when his or her 'soul' is weak. It is said that the 'roaming souls' are from people who die improperly. Their 'souls' want to occupy the body of the living. The behaviour of a person is similar to that of the dead person when he or she was alive. Such a person can be healed by a teungku reciting Qur'anic verses and a healer reciting spells. The victim's affliction depends on the ability of the healer to ward off the 'delicate creature' from the victim's body.

4. Sijundai is a kind of 'disease' causing a person to lose his or her 'healthy mind' (Indon akal sehat). It is said that it usually happens to a woman who has just given birth. Her body becomes hot and she does not talk much. Her strange actions such as climbing a high tree, climbing a house roof while crying sadly or singing melodiously which are not acceptable. ${ }^{54}$

5. Pohon lumbè is a kind of tree in which 'delicate creatures' often stay and make their nest. If someone drinks water from the root of these trees, his neck will swell up under his chin. This disease is called penyakit chukong ('goitre'). Meanwhile a person's hands or feet will also swell up if he makes contact with water coming from the root of this tree. ${ }^{55}$

\section{Jinn}

The word jinn is derived from the root word janna meaning 'hidden, closed or unseen'. Malaikat, according to jahiliyah, ${ }^{56}$ are also included in the category of jinn as they cannot be seen (Labib \& Ali 2003:7). The villagers believe another form of life exists created by Allāh before human beings were created, which is unseen called jinn. According to the Qur'ān, jinn is another type of spiritual being made out from scorching fire (QS 15:27) or the smoke-

54 An example of a person who has been affected by sijundai can be seen in Emtas (2008:55-56).

55 See also Snouck Hurgronje I (1906:412).

56 "Age of pagan ignorance preceding the Islamic era". 
less flames of a fire (QS 55:15). They were created before Adam. Nothing, however, is mentioned about when the jinn were created. Some teungku say that jinn have some qualities like human beings; intellect, discrimination, freedom, and the power to choose between right and wrong, between true and false, and between good and bad. In addition, it is said that they can change their forms and can travel very fast over great distances, including through what human beings perceive to be solid objects. This enables them to obtain knowledge that is not normally available to human beings. They can communicate with human beings and interact with them sometimes and can permeate the bodies of humans and animals.

It is said that jinn are like human beings; drinking, getting married and having children but their ways are not known to us. Human beings are only able to know if it is Allāh's will. Jinn are also said to be aware of revelations, angels, prophets, and messenger from Allāh and have free-will to decide between good and evil. Villagers argue that they can be 'Muslim' (good) and 'non Muslims' (bad). Those jinn that are good, pious and faithful are called 'Islamic jinn' (Ach jén Islam) or 'faithful jinn' (Ach jén mukmin). Good jinn are benevolent to human beings. They make friends with human beings and help them do hard work and magical acts. It is said that good jinn always look for the truth, provide guidance and perform good deeds and help human beings in critical situations. When the tsunami in December 26 $6^{\text {th }}, 2004$ hit Acèh, 'Islamic jinn' are said to have guarded mosques by warding off the blows of gigantic waves toward the mosques. As a result, many mosques lying near the sea coast of Acèh province were not destroyed and could still be used as places of worship. Some people, however, said that the mosques were guarded by angels called guardian angels not by 'Islamic jinn'. Some others said that 'Islamic jinn' together with guardian angels as 'the army of Allāh' guarded mosques from the powerful earthquake and giant waves. In addition, it is said that they saved people by floating wood on the water so that they could hang on until they reached the branches of the trees and remain there until the tsunami subsided. All such 'rescuers' then disappeared. Many people contended that Allāh helped save people, animals and children through 'Islamic jinn' resembling 'rescuers' and many other forms so that a number of people were saved as the tsunami swept over the Acèh province. The 'faithful jinn' or benevolent jinn can be taken as servants of the one who masters the mystery of jinn and learns about the mysterious world (Ach ileume gaeb). My informant says that some teungku 
in the Blangporoh, Blangbaru and Kutaiboh village are known to have mastered this.

Meanwhile malevolent jinn are called 'infidel jinn' and are companions of iblis. 'Infidel jinn' tempt human beings and the 'faithful jinn'. They always disturb and try to mislead human beings from the right path and during the period of death. It is said that 'bad' jinn that always disturb children are often called Ruh. When jinn act arrogantly they are named Marid. Jinn that have a strong imagination are named Ifrit and if they do bad things as well as misleading human beings they are called syètan. Many teungku argue that the 'doors' that 'infidel jinn' come to human being through are: 1) Carnal desires, as a man responds to his carnal desires, he is driven by an 'infidel jinn' and will be lead away from Allāh. 2) Stupidity, a stupid man can make his heart 'blind'. The stupid man, therefore, becomes the main object of 'infidel jinn' 3) Anger is a big door for 'infidel jinn'. Anger will influence the mouth of person. One will say something without thinking first due to thoughtlessness. In addition, anger will also influence other parts of the body such as the hands to beat or to kill and the heart of a person to feel jealousy, envy, and revenge.

It is believed that there are more jinn than human beings in the world. As they have very tiny bodies, jinn cannot be seen. Many villagers say that if they could be seen, human beings would be in trouble as the world is full of jinn. "Jinn live on the earth close together with human beings but their world is different from that of human beings. For example, many jinn's houses and their place of business" are found in drainage ditches (Indon combèran)". Jinn are also said to have 'faith' and 'religion'. They also learn and help each other. They can fly and change their forms to those of human beings, cattle and other form of animals such as a snake, dog, camel, cow, goat, lion, donkey and cat etc as they wish. Many of them have strong faith, good conduct and are very confident etc. Nonetheless, there are also those that are stupid and weak. Some believe in Allāh but many of them do not believe in Allāh. Jinn can live in all places and establish societies and have kings. Azrak is said to refer to a jinn country although no one knows where it is. ${ }^{57}$ Jinn prefer living in dirty and dark places to which human beings rarely go. They occupy and establish centers of their government in water. There are also centers of their government in oceans, rivers, and estuaries. In addition they also occupy wide and isolated

57 See also Muhaimin (2004:60). 
deserts, forests, including deep caves in forests, long unoccupied houses, ruins, rubbish tips, toilets, cemeteries and other frightening and silent places which are far from human beings. Some of them even live in the houses or roofs of houses. Teungku Yunus says "for those who enter their houses mentioning the name of Allāh, the 'infidel jinn' cannot stay over night in that house. Similarly, if people of the house mention the name of Allāh before eating the 'infidel jinn' will then not be able to eat with them".

According to the villagers, there are three categories of jinn. 1) Jinn that can fly. 2) Jinn that is like a snake and dog. 3) Jinn that dress up and always travel. They are all created from fire; their foods are steam and smell. A person who makes a 'friend' with jinn usually burns incense to call them before continuing the friendship. One teungku says that bones and dried dirt are among their food, that is why human beings are not allowed to 'perform the ritual of washing clean' (Arb istinja $\bar{a}^{\prime}$ ) with bones and dried dirt. He adds further that if jinn pass away, they will return to their origin, to fire. They, therefore, do not have graves, whereas when human beings pass away, they will return to earth as they are created from it. In addition, jinn are usually totally black. Black is believed to be better at accumulating the power of the 'infidel jinn' compared to other colours as black contains the heat. "Killing or beating such a pseudoanimal is risky enough because their friends or kin may take deadly revenge. The risk is more serious than when someone is merely disturbing or destroying their places" (Muhaimin 2004:61).

These jinn can be chased away by reciting Qur'anic verses. To protect oneself, one should recite verses from the Qur'ān, thus jinn can be avoided and their power can be nullified after hearing someone recite certain verses of Qur'ān. Teungku Juned, for example, explained "the one who recites talismans cannot be scared nor possessed by them". Verses and sürah for talismans considered most effective are: Ayat kursi or "the verse of the Throne" (QS 2:55), Qulhu (al-Ikhlās, QS 112), Qula 'udzu birabbinnās (an-Nās QS 114) and Alhamdulillāh (al-Fātihah Q QS 1). For this practical purpose, Teungku Juned adds that it is advisable that everyone has some knowledge of some of these verses or sürah. Recital of the bismillāh ('in the name of Allāh') before doing something or going somewhere is one way to avoid the possibility of their interference. He adds further that performing 'the call to prayer' (Arb adhān) is also another way to ward off 'infidel jinn', 'delicate creatures', syètan, and iblis 
(see Ch.6) and they all will bow down (Ach tundok) before human beings if the verses of Qur'ān are recited.

\section{Conclusion}

The Aneuk Jamee believes that the universe consists of two interconnected domains: the visible and the invisible. Human beings live on the visible level, while God and spiritual beings; malaikat (angel), iblis (devil), syètan (Satan) and jinn (genies) exist on the invisible level. Both levels are interrelated and they interact through belief in and rules given by Allāh. The Aneuk Jamee idea of God derives entirely from Islam. The essence of the Aneuk Jamee's theology is its monotheism - the belief in Allāh as the creator of all things. Nothing has happened or shall happen without His knowledge or His will. $\mathrm{He}$ is the only everlasting and unique reality, the eternal and absolute, to whom alone all worship is due.

Meanwhile malaikat are believed to act as intermediaries between the divine world and the human world, working at the command of Allāh. Belief in malaikat is closely connected to a belief in other spiritual being such as iblis, jinn, syetan and makhluk halus. The two realms are opposed but complementary so that each makes the other understandable and acceptable. Malaikat, iblis, jinn, syétan have their original roots in the Qur'ān but makhluk halus do not. The Aneuk Jamee believe that makluk halus are part of the spirits that have their original roots in the Qur'ān. These beliefs are maintained and derived from a pre-Islamic Aneuk Jamee culture of religion. It has been integrated into the local Muslim belief system. As detailed information about these spiritual beings is incomplete and speculative, their nature, essence and actions are described differently by different people. The Aneuk Jamee thus integrate many non-Muslim ideas into this belief system, the Qur'ān and the Prophet's tradition tend to be cited to add value and authority to these ideas. 


\section{Chapter 3}

\section{The Aneuk Jamee kinship}

This chapter examines the Aneuk Jamee system of kinship in Blangporoh village. Like other indigenous peoples in the region of Acèh, the Aneuk Jamee recognize kinship as one of the most basic principles for organizing individuals into social groups, roles, and categories. Through this system, family relations can be presented concretely or abstractly as degrees of relations. When a social role is played by one of the family members vis-a-vis other members, such roles are obligatory. As a consequence, the social relation forms an intricate part of what Murdock (1949) identified as reciprocal behavior characterizing relationships between kin. The analysis of the Aneuk Jamee kinship here is oriented on Platenkamp's analysis of the Tobelo kin terminology system (Platenkamp 2001). His analysis of Tobelo society reveals that it is the brother-sister relation that is able to encompass such incompatible and oppositional categories such as alliance-descent, alive-dead, affinity-consanguinity and so forth. These relations encompass the difference between relations among the living which are classified as temporary and gendered, and those relations with those no longer living, which are valued as timeless and not gendered. The kinship system is analyzed by means of the consanguineal relationships between parents and their children, siblings (Sb), parents'siblings (PSb) and siblings'children ( $\mathrm{SbCh}$ ), parents'siblings'children (PSbCh), as well as the relations between the second and third ascending and descending generations. In addition, the affinal relations are analyzed as well. These include the relation between spouses ( $\mathrm{Sp}$ ) and their affinal kin as well as between their parents (SpP) and their spouses' siblings ( $\mathrm{SpSb}$ ) (diagram 1). 


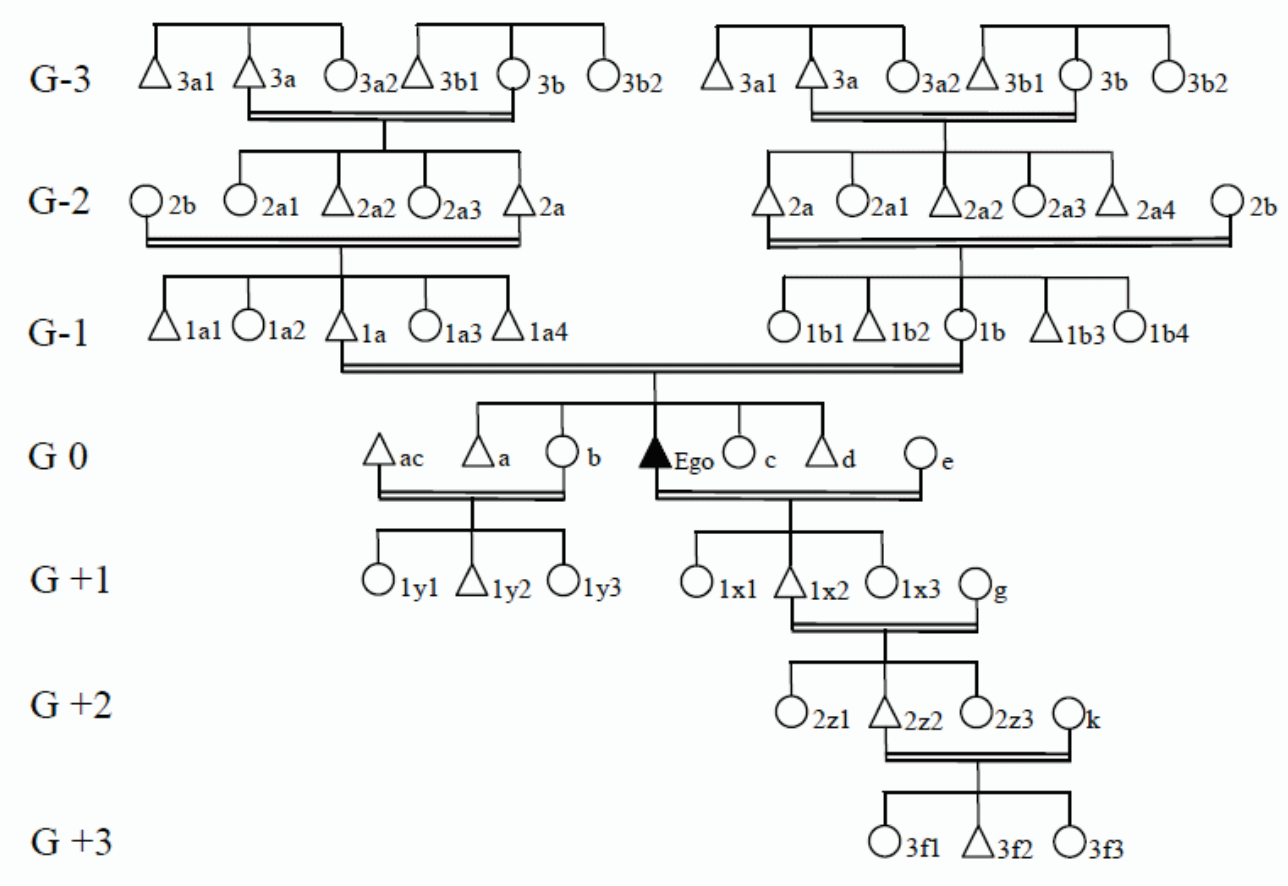

\section{Diagram 1. Interpersonal relationships}

Explanation

\begin{tabular}{|c|c|c|c|}
\hline$\triangle$ & $=$ male & $1 \mathrm{a}$ & $=a v a h$ \\
\hline$\bigcirc$ & $=$ female & $1 b$ & $=u m a k$ \\
\hline Ego & $=$ self & 1a1 & $=\operatorname{pak}(t) u w o$ \\
\hline 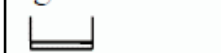 & $=$ marriage & $1 \mathrm{a} 2$ & $=$ mak tangah $/ \mathrm{mamak}$ \\
\hline 1 & $=$ lineage $/$ descent line & $1 \mathrm{a} 3$ & $=\grave{e} t e ̀ k / m a k c i k / m a k l o t$ \\
\hline 门 & $=$ siblings & $1 \mathrm{a} 4$ & = bapak/mamak/pak kètèk/pak cik/ayah lôt \\
\hline ac & $=$ tamudo/ubang/udo & 1b1 & $=$ mak $(t) u w o$, mak unieng \\
\hline $\mathrm{a}$ & $=u b a n g / u d o / u w o$ & $1 \mathrm{~b} 2$ & $=$ pak tangah \\
\hline $\mathrm{b}$ & $=$ unieng $/$ kakak & $1 \mathrm{~b} 3$ & $=$ the same term of address with $1 \mathrm{a} 4$ \\
\hline $\mathrm{c}$ and $\mathrm{d}$ & $=$ adiak and calls ubang to Ego & $1 \mathrm{~b} 4$ & $=$ the same term of address with $1 \mathrm{a} 3$ \\
\hline $\mathrm{e}$ & = binie/urang rumah & $2 \mathrm{~b}$ & $=$ manèk/uci \\
\hline $1 \mathrm{y} 1,1 \mathrm{y} 2,1 \mathrm{y} 3$ & = kamanakan & $2 \mathrm{a}$ & = andueng/ondong/nènèk/ayah nèk \\
\hline $1 \times 1,1 \times 2,1 \times 3$ & $=a n a k$ & $2 \mathrm{a} 1,2 \mathrm{a} 3$ & = nènèk/manèk/uci \\
\hline $2 z 1,2 z 2,2 z 3$ & $=\mathrm{cucu}$ & $2 \mathrm{a} 2,2 \mathrm{a} 4$ & = nènèk \\
\hline $3 \mathrm{f} 1,3 \mathrm{f} 2,3 \mathrm{f} 3$ & $=$ buyut & $3 \mathrm{a}$ and $3 \mathrm{~b}$ & $=$ muyang $/$ moyang \\
\hline g & $=$ minantu padusi & $3 \mathrm{a} 1$ and $3 \mathrm{a} 2$ & $=$ muyang $/$ moyang \\
\hline $\mathrm{k}$ & $=$ cucu padusi & $3 \mathrm{~b} 1$ and $3 \mathrm{~b} 2$ & $=$ muyang $/$ moyang \\
\hline
\end{tabular}

The Aneuk Jamee society is structured by a system of interpersonal relationships which include a framework of kinship terminology. It reflects the principle of gender differences, age and status within the family. This system is not only concerned with one's relationship with relatives but also involves the 
relationship with one's wife or her husband's relatives. In an interpersonal relation system one uses a variety of terms of address (diagram 1 above). The interpersonal relation system can sometimes be vague or confusing if the repetition of marriage takes place so that the terms used to address or greet someone may sound funny. For example, one who is older is addressed as paman (uncle) or bibik (aunt) by a person who is younger. This is due to the fact that the Aneuk Jamee society does not embrace exogamy apart from showing respect for the older level of marriage which is called tuwo bibit "old seed".

The social stratification in the Aneuk Jamee society is now not so firmly stressed. In the days before independence, the social stratification was strongly felt. For instance, on the top level were the datuk group and their relatives. This group practiced endogamy marriage. The second level was the group hulubalang who had authority below the datuk, then followed by the group of 'ulam $\bar{a}$ ' (including tuangku, imām and kadhi) and at the bottom were the common people (Sulaiman 1978:7-8). Besides these groups, there is also the group of sayéd claiming to be from Quraish's tribe. Nowadays the social stratification in Aneuk Jamee society is said to be based on wealth, education and power (ibid). Unlike in the past which demonstrated that social stratification in the Aneuk Jamee society was based more on the descent, today's stratification in the Aneuk Jamee society is no longer so rigid, one can become respected by the society if he or she obtains a higher education or appears affluent. The datuk group no longer practices endogamy marriage. It is different with the sayéd's group; they now practice exogamy marriage although there is a small group of sayéd that still maintains the practice of endogamy marriage.

\section{The Aneuk Jamee kinship}

In the Aneuk Jemee language, there is no special word to address family but two or more people living in one house designate each other as sabuah pariuk "one rice pot". The rice pot is located inside the house, so that this constructs metaphorically belonging in one's house. Another term to address family is rumah tanggo "household", which consists of parents and their children sharing living quarters as a nuclear family. Sex is not distinguished in the children's generation but one's own children are distinguished from one's sibling's children by the term kamanakan. Relatives on the mother's side are called niniak mamak while the relatives on the father's side are called wali hukum (see below). General term for the relatedness as kin is dusanak "sibling". In addi- 
tion, it is also said that dusanak are descendants of muyang or moyang "ancestors" but their names and identities may be forgotten. A colloquial form of the question "are you kin?" is apo kito badusanak - "are we siblings?" Close relatives (affinal or consanguneal) are designated as "close dusanak" (Jam dusanak dakèk), meanwhile non-related neighbors are designated as "village dusanak" (Jam dusanak kampuang). Kin are commonly distinguished as dakèk (near) or jauah (far), but seldom with precision. The descendants of a single grandparent usually regard one another as near, but the descendants of siblings of grandparents are distant and can be forgotten. First the nature of the links, then their very existence disappears from memory. In life-cycle rituals such as weddings, circumcisions, and funeral rituals, kamanakan, wali hukum and dusanak are invited to attend the meeting of niniak mamak. Through these meetings, the kinship connections are known. In addition, hari rayo idul fitri, the celebration at the end of the fasting month of Ramadhan and hari rayo haji, the celebration of the "feast of sacrifice" are the media through which kinship is acknowledged as well. In life cycle rituals, 'four groups' (Jam ampèk kaum) and 'eight sides' (Jam delapèn pihak) must be invited. Should these kin groups be unable to attend, the rituals are cancelled. They are the mother $(\mathrm{M})$, the mother's mother $(\mathrm{MM})$, the mother's father (MF) and the father $(\mathrm{F})$, the father's father (FF), the father's mother (FM) from the groom's side and $\mathrm{M}, \mathrm{MM}, \mathrm{MF}$ and F, FF, FM from the bride's side. The concept of ampèk kaum (four groups) and delapèn pihak (eight sides) is the same as that of the Acèhnese called peut kawôm and lapan pihak (diagram 2).

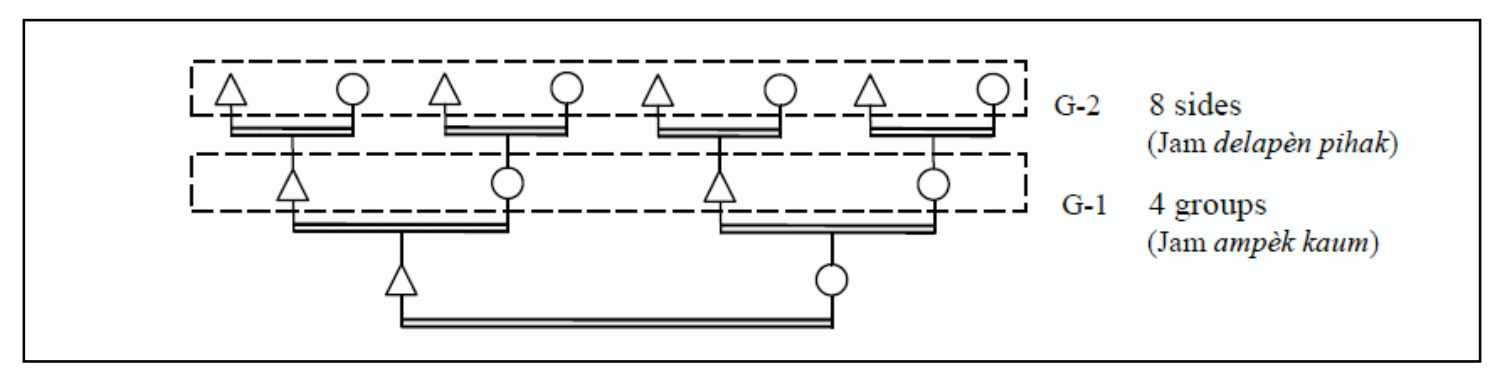

Diagram 2. Ampèk kaum (four groups) and delapèn pihak (eight sides) 


\section{The Aneuk Jamee's kinship terminology}

Table 2. The Aneuk Jamee's kinship terminology

Generation +3

\begin{tabular}{|l|l|l|l|}
\hline Gloss & $\begin{array}{l}\text { Kin } \\
\text { type }\end{array}$ & Term of address & Term of reference \\
\hline father's father's father & FFF & muyang/moyang & muyang/moyang \\
\hline mother's father's father & MFF & muyang/moyang & muyang/moyang \\
\hline father's mother's mother & FMM & muyang/moyang & muyang/moyang \\
\hline mother's mother's mother & MMM & muyang/moyang & muyang/moyang \\
\hline
\end{tabular}

Generation +2

\begin{tabular}{|c|c|c|c|}
\hline father's father & $\mathrm{FF}$ & ndong/yah nèk & ondong/ayah nék \\
\hline mother's father & MF & $n e ̀ k / c i$ & nènèk/manèk/uci \\
\hline father's mother & FM & ndong/nèk/yah nèk & ondong/nènèk/ayah nék \\
\hline mother's mother & MM & $n \grave{k} k / c i$ & nènèk/manèk/uci \\
\hline
\end{tabular}

Generation +1

\begin{tabular}{|l|l|l|l|}
\hline father & F & yah & ayah \\
\hline mother & M & umak & umak/mandé \\
\hline father's elder brother & FeB & uwo & pak $($ t)uwo/mamak \\
\hline father 's elder sister & FeZ & ngah & mak tangah \\
\hline father's younger sister & FyZ & cik/lôt & mak cik/mak lôt/ètèk \\
\hline father 's younger brother & FyB & kètèk/cik/lôt & $\begin{array}{l}\text { pak kètèk/pak cik/pak } \\
\text { lôt }\end{array}$ \\
\hline mother 's elder sister & MeZ & uwo/unieng & mak (t)uwo/mak unieng \\
\hline mother's elder brother & MeB & ngah & pak tangah/mamak \\
\hline mother's younger brother & MyB & kètèk/cik/lôt & $\begin{array}{l}\text { pak kètèk/pak cik/pak } \\
\text { lôt }\end{array}$ \\
\hline mother 's younger sister & MyZ & cik/lôt/bundo/ètèk & $\begin{array}{l}\text { mak cik/mak } \\
\text { lott/bundo/ètèk }\end{array}$ \\
\hline father's brother's wife & FBW & uwo & pak(u)wo \\
\hline father's sister's husband & FZH & uwo & mak $(u) w o$ \\
\hline mother's brother's wife & MBW & cik/tèk & mak cik/mak tèk \\
\hline mother's sister's husband & MZH & cik/pak uwo & pak cik/pak uwo \\
\hline
\end{tabular}


Generation 0

\begin{tabular}{|l|l|l|l|}
\hline elder brother & eB & ubang/uda & ubang/uda \\
\hline younger brother & yB & diak & adiak/diak \\
\hline elder sister & eZ & kak/unieng & kakak/unieng \\
\hline younger sister & yZ & diak & adiak/diak \\
\hline father's brother's son & FBS & ubang/diak & ubang/adiak \\
\hline father's brother's daughter & FBD & $k a k / d i a k$ & $k a k a k / a d i a k$ \\
\hline father's sister's son & FZS & ubang/diak & ubang/adiak \\
\hline father's sister's daughter & FZD & kak/diak & kakak/adiak \\
\hline mother's brother's son & MBS & ubang/diak & ubang/adiak \\
\hline mother's brother's daughter & MBD & kak/diak & kakak/adiak \\
\hline mother's sister's son & MZS & ubang/diak & ubang/adiak \\
\hline mother's sister's daughter & MZD & kak/diak & kakak/adiak \\
\hline
\end{tabular}

Generation -1

\begin{tabular}{|l|l|l|l|}
\hline son & S & nak & anak laki-laki \\
\hline daughter & D & nak & anak padusi \\
\hline brother's son & BS & nakan & kamanakan laki-laki \\
\hline brother's daughter & BD & nakan & kamanakan padusi \\
\hline sister's son & ZS & nakan & kamanakan laki-laki \\
\hline sister's daughter & ZD & nakan & kamanakan padusi \\
\hline
\end{tabular}

Generation -2

\begin{tabular}{|l|l|l|l|}
\hline son's son & SS & cu & cucu laki-laki \\
\hline daughter's son & DS & $c u$ & cucu padusi \\
\hline daughter's daughter & DD & $c u$ & cucu padusi \\
\hline son's daughter & SD & $c u$ & cucu laki-laki \\
\hline
\end{tabular}

Generation -3

\begin{tabular}{|l|l|l|l|}
\hline son's son's son & SSS & buyut & buyut \\
\hline daughter's son's son & DSS & buyut & buyut \\
\hline daughter's daughter's daughter & DDD & buyut & buyut \\
\hline son's daughter's daughter & SDD & buyut & buyut \\
\hline
\end{tabular}


Affinal kinterms

\begin{tabular}{|c|c|c|c|}
\hline Gloss & Kin type & Term of address & Term of reference \\
\hline $\begin{array}{l}\text { daughter's husband } \\
\text { daughter's husband's father } \\
\text { daughter's husband's brother } \\
\text { son's wife's father } \\
\text { so's wife's mother } \\
\text { son's wife's brother } \\
\text { daughter's husband's mother } \\
\text { son's wife } \\
\text { son's wife's mother }\end{array}$ & $\begin{array}{l}\text { DH } \\
\text { DHF } \\
\text { DHB } \\
\text { SWF } \\
\text { SWM } \\
\text { SWB } \\
\text { DHM } \\
\text { SW } \\
\text { SWM }\end{array}$ & $\begin{array}{l}\text { minantu/name } \\
\text { bisan } \\
\text { ipa/name } \\
\text { bisan } \\
\text { bisan } \\
\text { ipa/name } \\
\text { bisan } \\
\text { minantu/name } \\
\text { bisan }\end{array}$ & $\begin{array}{l}\text { minantu laki-laki } \\
\text { bisan laki-laki } \\
\text { ipa padusi } \\
\text { bisan laki-laki } \\
\text { bisan padusi } \\
\text { ipa laki-laki } \\
\text { bisan padusi } \\
\text { minantu padusi } \\
\text { bisan padusi }\end{array}$ \\
\hline $\begin{array}{l}\text { husband } \\
\text { husband's father } \\
\text { husband's mother } \\
\text { husband's younger brother } \\
\text { husband's elder brother } \\
\text { husband's younger sister } \\
\text { husband's younger sister } \\
\text { husband's brother's wife }\end{array}$ & $\begin{array}{l}\text { H } \\
\text { HF } \\
\text { HM } \\
\text { HyB } \\
\text { HeB } \\
\text { HyZ } \\
\text { HyZ } \\
\text { HBW }\end{array}$ & $\begin{array}{l}\text { laki/ilén } \\
\text { yah } \\
\text { umak } \\
\text { diak ipa/name } \\
\text { uban/name } \\
\text { diak ipa/name } \\
\text { kakak/name } \\
\text { kak/udo }\end{array}$ & $\begin{array}{l}\text { laki/ilén } \\
\text { ayah tuan } \\
\text { umak tuan } \\
\text { adiak ipa } \\
\text { ubang ipa } \\
\text { adiak ipa } \\
\text { kakak ipa } \\
\text { kakak/udo }\end{array}$ \\
\hline $\begin{array}{l}\text { wife } \\
\text { wife's father } \\
\text { wife's younger brother } \\
\text { wife's younger sister } \\
\text { wife's brother's son } \\
\text { wife's brother's son's son } \\
\text { wife's father's brother } \\
\text { wife's mother } \\
\text { wife's sister } \\
\text { wife's sister's husband }\end{array}$ & $\begin{array}{l}\text { W } \\
\text { WF } \\
\text { WyB } \\
\text { WyZ } \\
\text { WBS } \\
\text { WBSS } \\
\text { WFB } \\
\text { WM } \\
\text { WZ } \\
\text { WZH } \\
\end{array}$ & $\begin{array}{l}\text { binie/urangrumah } \\
\text { yah } \\
\text { diak/name } \\
\text { diak/name } \\
\text { nakan/name } \\
\text { cu } \\
\text { uwo } \\
\text { umak } \\
\text { kak/diak } \\
\text { ubang/udo } \\
\end{array}$ & $\begin{array}{l}\text { binie/urang rumah } \\
\text { ayah tuan } \\
\text { adiak ipa } \\
\text { adiak ipa } \\
\text { kamanakan laki-laki } \\
\text { cucu laki-laki } \\
\text { pak (u)wo/mamak } \\
\text { umak tuan } \\
\text { kakak/adiak } \\
\text { ubang ipa/udo } \\
\end{array}$ \\
\hline $\begin{array}{l}\text { sister's husband } \\
\text { sister's husband's father } \\
\text { sister's husband's bother } \\
\text { sister's husband's brother's } \\
\text { sister's son } \\
\text { brother's wife's father } \\
\text { brother's wife's brother } \\
\text { brother's wife's brother's son } \\
\text { sister's husband's mother }\end{array}$ & $\begin{array}{l}\mathrm{ZH} \\
\mathrm{ZHF} \\
\mathrm{ZHB} \\
\text { ZHBZS } \\
\\
\text { BWF } \\
\text { BWB } \\
\text { BWBS } \\
\text { ZHM } \\
\end{array}$ & $\begin{array}{l}\text { ubang } \\
\text { pak/cik } \\
\text { ubang/diak } \\
\text { nakan/name } \\
\text { pak/cik } \\
\text { ubang/diak } \\
\text { nakan/name } \\
\text { cik/tèk }\end{array}$ & $\begin{array}{l}\text { ubang ipa } \\
\text { bapak/pak cik } \\
\text { ubang/adiak } \\
\text { kamanakan laki-laki } \\
\text { bapak/pak cik } \\
\text { ubang/adiak } \\
\text { kamanakan laki-laki } \\
\text { mak cik/mak tèk }\end{array}$ \\
\hline $\begin{array}{l}\text { sister's husband's sister } \\
\text { brother's wife's mother } \\
\text { brother's wife's sister }\end{array}$ & $\begin{array}{l}\text { ZWM } \\
\text { BWM } \\
\text { BWZ }\end{array}$ & $\begin{array}{l}\mathrm{kak} / \text { diak } \\
\mathrm{kak} / \mathrm{diak} \\
\mathrm{kak} / \text { diak } \\
\end{array}$ & $\begin{array}{l}\text { kakak/adiak } \\
\text { kakak/adiak } \\
\text { kakak/adiak } \\
\end{array}$ \\
\hline $\begin{array}{l}\text { mother's sister's husband } \\
\text { mother's brother's wife } \\
\text { father's sister's husband } \\
\text { father's brother's wife } \\
\text { sister's son's wife } \\
\text { sister's daughter's husband } \\
\text { brother's son's wife } \\
\text { brother's daughter's husband }\end{array}$ & $\begin{array}{l}\text { MZH } \\
\text { MBW } \\
\text { FZH } \\
\text { FBW } \\
\text { ZSW } \\
\text { ZDH } \\
\text { BSW } \\
\text { BDH }\end{array}$ & $\begin{array}{l}\text { cik/uwo } \\
\text { cik/tèk } \\
\text { cik/uwo } \\
\text { cik/tèk } \\
\text { nakan/name } \\
\text { nakan/name } \\
\text { nakan/name } \\
\text { nakan/name } \\
\end{array}$ & $\begin{array}{l}\text { pak cik/pak uwo } \\
\text { mak cik/mak tèk } \\
\text { pak cik/pak uwo } \\
\text { mak cik/mak tèk } \\
\text { kamanakan padusi } \\
\text { kamanakan laki-laki } \\
\text { kamanakan padusi } \\
\text { kamanakan laki-laki }\end{array}$ \\
\hline
\end{tabular}


The kinship terms of address are essential guides to social behavior, placing people into categories and assigning them status and roles. The terms of address reflect one's own generation as well as between generations. The order of birth is recognized in these terms as long as the person addressed is older than the speaker (see term generation 0). In the same way the Aneuk Jamee distinguish between age and sex. The greater elaboration is in ego's generation in which discrimination is made between older and younger and sometimes between intermediate positions in the order of birth. The terminology is enriched by a variety of synonyms. The recognition of kin is limited to three descending and three ascending generations. There are the parents'parents's parents (PPP), parents'parents (PP), parents (P), Ego, and children (Ch), children's children $(\mathrm{ChCh})$, and children's children's children $(\mathrm{ChChCh})$. Beyond these boundaries, kin are not terminologically acknowledged. In this category fall all who are more than three ascending and descending generations removed from Ego. In some cases, however, the kinship, reaching back even four or five generations through the father's side, is remembered more scrupulously than the kinship through the mother. But this depth exists only in the aristocratic stratum, ulama's families and datuk or when there is a prospect of inheriting valuable property. The fourth or the fifth generations in such special cases are designated by the terms muyang muyang/moyang moyang for the ascending generation and the term buyut buyut for the descending one.

\section{Consanguineal relationships}

\section{1. $P$ and $C h$ relationships}

A man addresses his son anak laki-laki. The term anak meaning 'child' and the term laki-laki refers to his sex, meaning 'male' (diagram 3.1). Reciprocally the son designates his father by the term ayah. The father addresses his daughter by the term anak padusi. The term padusi refers to her sex, meaning 'female' (diagram 3.2). She calls her father by the same terms as her brother ayah. A woman uses the same term to address her son and daughter. Here three criteria are found; first, there is an absolute distinction between generations, second, there is no relative age among the children and third, there is no sex identity assigned. 


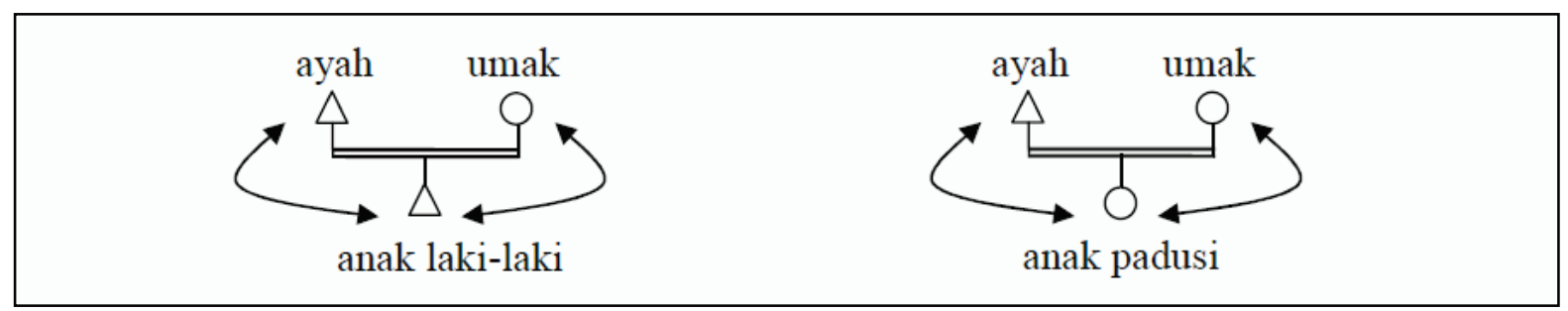

Diagram 3.1. Parents son relationships
Diagram 3.2. Parents daughter relationships

\section{PSb and $\mathrm{SbCh}$ relationships}

\section{A. FSb - SbCh relationships}

The parents' brothers (PB) are designated by different terms of address. A child designates his/her father's elder brother $(\mathrm{FeB})$ with the term pak $(t)$ uwo. The word pak tuwo consist of the word pak meaning father and the word tuwo meaning old. In the literal sense of the word it means "old father" or "superior father". The reciprocal term for the younger sibling's son (ySbS) is kamanakan laki-laki (diagram 4.1) and for younger sibling's daughter (ySbD) is kamanakan padusi. For the father's elder sister (FeZ), one designates mak tangah. Mak or umak is a synonym of mother and the word tangah used as a suffix means middle. The word mak tangah literally means the "middle mother" and she also reciprocally addresses her ySbS as kamanakan laki-laki and ySbD kamanakan padusi. In addition, a child designates his/her father's younger sister (FyZ) with the term mak cik/mak lott. The word cik used as a suffix means 'small' or the suffix lot means 'the last'. In the literal sense of the word mak cik/mak lot means the "small mother" or the mother who is inferior. Father's younger brother (FyB) is addressed as pak kètèk/pak cik/pak (yah) lôt. The word kètèk means 'small'. Literally pak kètèk/pak cik/pak (yah) lôt means the "small father" or the father who is inferior. FyZ addres their elder brother's children (eBCh) in the same way the FyB does, with the term; kamanakan lakilaki for ySbS and kamanakan padusi for ySbD (diagram 4.2). 


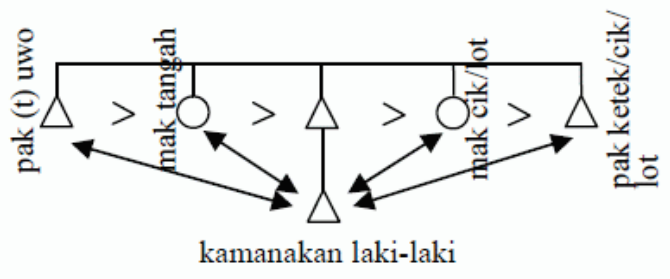

Diagram 4.1. PSb - male SbCh relationships

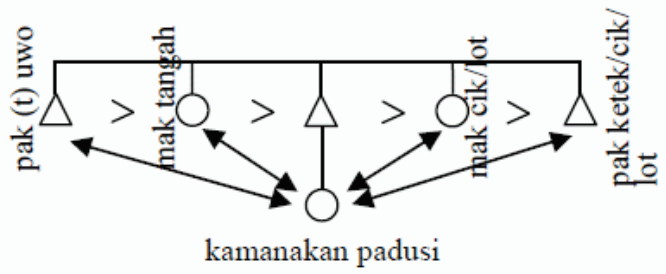

Diagram 4.2. PSb - female SbCh relationships

\section{B. MB- ZbCh relationships}

Mother's elder sister (MeZ) and mother's elder brother $(\mathrm{MeB})$ are addressed differently. MeZ is addressed $m a k(t) u w o^{58}$ by her younger sister's son (yZS). The word mak meaning 'mother' and ( $t$ )uwo means 'old'. In the literal sense of the word it means the 'old mother' or 'superior mother'. Meanwhile $\mathrm{MeB}$ is addressed as pak tangah. The word pak meaning 'father' and tangah means 'middle'. Literally it means the "middle father". In addition, mother's younger brother (MyB) addresses the same term used by FyB above, pak kètèk/pak cik/pak (yah) lott. The mother's younger sister (MyZ) is addressed with the same term used by FyZ above, mak cik/mak lot ${ }^{59}$ She reciprocally addresses eSbS or ySbS as kamanakan laki-laki (diagram 5.1) and eSbD or ySbD as kamanakan padusi as well (diagram 5.2).

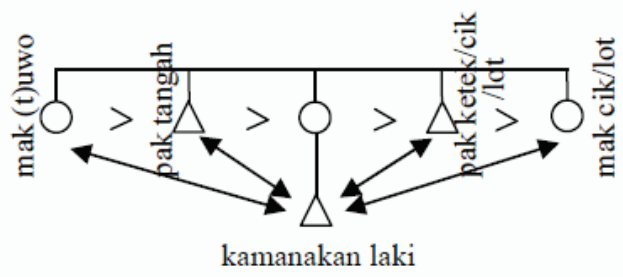

Diagram 5.1. MSb - male SbCh relationships

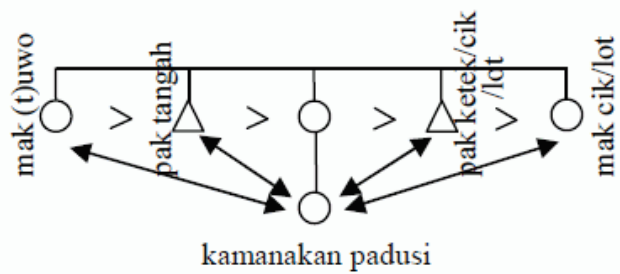

Diagram 5.2. MSb - female SbCh relationships

The relationships between PSb [FeB, FeZ, FyZ, FyB and MeZ, MeB, $\mathrm{MyB}, \mathrm{MyZ}]$ and SbCh show that there are sex and age distinctions in the upper generations. These are the distinctions between pak 'father' and mak 'mother'

58 Sometimes mother's elder sister (MeZ) is also addressed mak unieng.

59 Sometimes father's younger sister (FyS) and mother's younger sister (MyZ) are addressed ètèk or bundo. 
and the distinctions between ( $t$ )uwo 'old', tangah 'middle' and kètèk/lôt 'small'. Thus children designate their parents' siblings according to their relative age and respect the order of birth of their parents' generation. Hence the orientation in time is a main characteristic of their relationship. Not only is the relative age important to this relationship, a sex specific distinction is made clear as well. There is a terminological distinction as to the question whether it is a woman who is a younger or older sister of the parents or whether it is a man who is an older or younger brother of the parents. Meanwhile for the lower generation there is a sex but no age distinction assigned. Siblings' children $(\mathrm{SbCh})$ are not designated by the same term; $\mathrm{SbS}$ is addressed as kamanakan laki-laki while $\mathrm{SbD}$ is addressed as kamanakan padusi. From the perspective of their PSb, they do not have the same status and are not considered as identical. One distinguishes terminologically whether it is the male or female child of their younger or older sibling.

\section{Sibling relationships}

A man addresses his brothers as ubang/uda. The latter reciprocally addresses his adiak (yB) or just diak (diagram 6.1). A younger brother (yB) addresses her elder sisters (eZ) by the term kakak/unieng. Reciprocally she addresses him with the same term used by her elder brother (eB), adiak/diak. A sister designates her eZ in the same way a brother addresses his eZ, $k a$ kak/unieng. She also calls her adiak/diak (diagram 6.2). In addition, a sister addresses her elder brother (eB) by the term ubang/uda and he calls her adi$a k / d i a k$ as well.

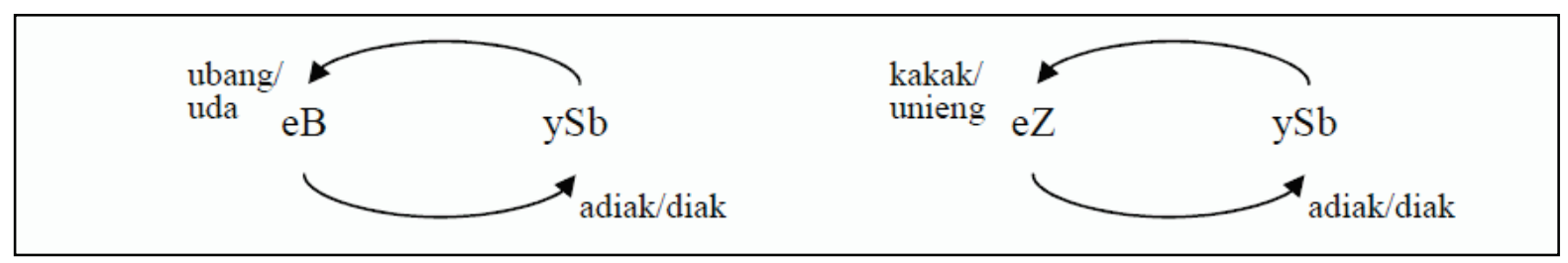

Diagram 6.1. Terms of address of male sibling
Diagram 6.2. Terms of address of female sibling

This diagram shows that younger siblings are not distinguished by sex. They are all addressed as younger siblings. They are not assigned a gender identity through their respective terms of address. Reciprocally, however, this gender distinction is made. The terms employed already indicate that the person 
addressed is older and one knows whether the person addressed is male or female. This shows that the attribute of sex is subordinated to the ordering principle of relative age. Among elder siblings this gender distinction is made but among younger siblings it is not as in the case in the relationships described above, the order of birth is an important principle for the relationships between siblings. The orientation according to time is a main characteristic of the relations among siblings.

\section{PSbCh relationships}

In the Aneuk Jamee society, the relation with one's sibling's children $(\mathrm{SbCh})$ is not distinguished from those of one's siblings. Sibling's children designate each other in the same way as siblings do. The birth order determines the way in which the relations between the respective children are oriented over time. A man denotes his parents' sibling's son (PSbS) as adiak/diak when he is older than that PSbS. It is their relative age that orders their relationships. Reciprocally, the parent's siblings'son denotes him as ubang/uda (diagram 7.1). Likewise, a woman addresses her PSbD as 'eZ' as kakak/unieng if the latter is older, and as adiak/diak if the latter is younger than the speaker (diagram 7.2). This indicates not only that the orientation of the relationship in time is significant, but also that children's absolute order of birth is not subordinated to the order of birth of their respective parents. The absolute age of PSbCh is important here. Therefore, this principle cannot be spoken of as an inherited one. The children do not take on their respective parents' birth order and are not subordinated under their parents' age but depend on the order of their birth. Absolute age can, therefore, be identified as a main structuring principle for the relationships among $\mathrm{PSbCh}$.

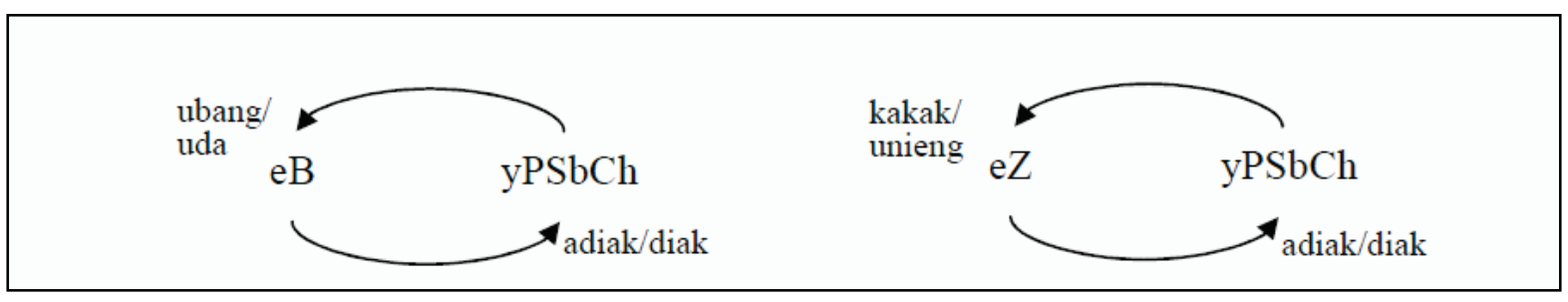

Diagram 7.1. Terms of address of male PSbCh
Diagram 7.2. Terms of address of female PSbCh 


\section{The second ascending and descending generation relationships}

The second ascending (+2) and descending (-2) generations are differentiated by various terms. Father's father (FF) is designated as ndong/ayah nèk and father's mother is designated as nènèk/manèk/uci. Reciprocally, they address their child's son (ChS) with the term cucu laki-laki (diagram 8.1) and their child daughter's son (ChD) with the term cucu padusi (diagram 8.2). Here there is also a gender specification assigned in the descending direction and in the ascending one. In other words, PF or PM qualifies cucu as either male or female but there is no gender assigned for the lower generation. So what we have here is an absolute sex identity in generation +2 and -2 . No relative gender specific and absolute distinctions in generation are assigned.

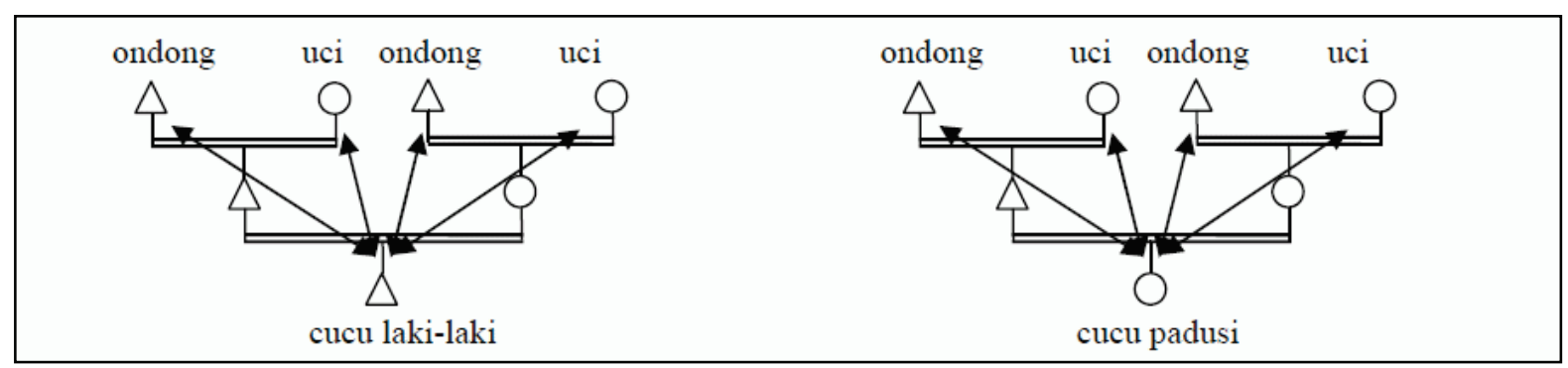

Diagram 8.1. PP [PF + PM] - ChS relationships

Diagram 8.2. PP $[\mathrm{PF}+\mathrm{PM}]-\mathrm{ChD}$ relationships

\section{The third ascending and descending generation relationships}

The third ascending $(+3)$ and descending $(-3)$ generations are not differentiated by sex or relative age. All great grand parents is called muyang or moyang. The word moyang comes from the Malay word nènek moyang meaning 'ancestor'. All great grand children (ChChCh) are called buyut (diagram 9). Here there is no gender identity assigned, neither in the ascending nor in the descending generation. In addition, no distinctions are made between paternal and maternal relatives. Only the membership in the third ascending or descending generation is stressed. In explaining a distant link, an individual traces the connection until a sibling relationship at the third ascending generation and stops there. The farthest back the kinship reckoning goes is to say that "our muyang/moyang are siblings", rather than identifying the relationship between persons as descendants of a linking ancestor. In other words, what the Aneuk Jamee tend to say is that, "We descend from siblings". 


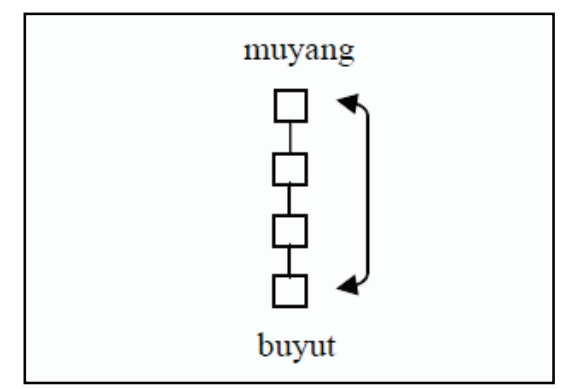

\section{Diagram 9. PPP [PPF+PPM] - ChChCh relationships}

This diagram shows that there is no terminological distinction made between matrilineal parents' parents' parents and patrilineal parents' parents's parents nor between the collateral members of the same generation: the term muyang/moyang is also used to address the siblings of the mothers' parent's parents (MPPSb) as well as the siblings of the fathers' parent's parents (FPPSb). The terms do not indicate whether the person addressed is male or female or belongs to one's mothers' side or to one's fathers' side. Reciprocally, the term buyut designates a member in the third descending generation. The members of the third descending generation are not distinguished by own children's children's children ( $\mathrm{ChChCh}$ ) or sibling's children's children's children ( $\mathrm{SbChChCh)} \mathrm{nor} \mathrm{do} \mathrm{they} \mathrm{indicate} \mathrm{whether} \mathrm{this} \mathrm{child} \mathrm{is} \mathrm{male} \mathrm{or} \mathrm{female.} \mathrm{The}$ recognition of kinship is thus "horizontal" rather than "vertical", in that an apical ancestor is not the point of orientation of kinship, rather it is siblingship.

\section{Affinal relationships}

\section{Spouse relationships}

A man denotes his wife as binie, ${ }^{60}$ a woman denotes her husband as lakililén (diagram 10). As these terms are not reciprocal, it indicates a relationship between non-identical positions.

60 In the Aneuk Jamee speaking area a wife is also sometimes addressed by her husband with the term urang rumah. The term urang rumah is similar to the Acènnese term peurumoh, originally 'po rumoh' and can be translated as the "person who owns the house" or the "owner of the house" and is, therefore, acting as the first indication for the special relation between women and house. 


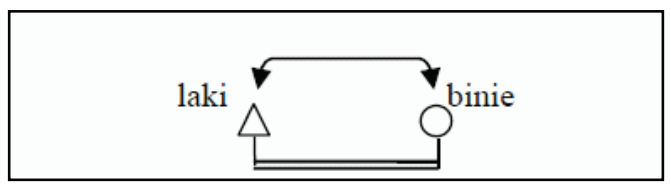

Diagram 10. Relationship between spouses

\section{A. $\mathrm{SbSp}$ and $\mathrm{SpSb}$ relationships}

The social network between spouses and their affinal kin differs from that among consanguineals. They, therefore, distinguish them terminologically. A sister's husband $(\mathrm{ZH})$ is addressed as unieng by the wife's brother (WB) and wife's sister (WZ) (diagram 11.1). The spouse acquires the same relative age or 'status' as that of its spouse. If the spouse is an elder sibling (eSb), then the husband/wife is addressed as an eSb. If the spouse is younger sibling (ySb), then the husband/wife is addressed by his/her husband/wife's siblings as a ySb. In addition, it is quite often that tumudo is also denoted as ubang or udo although the affinal relations are subject to rules of avoidance. This term is the same for his/her own elder brother. The affinal relative is reciprocally taking over his spouses' kin terms of address. Accordingly the term for the spouses' younger sibling ( $\mathrm{SpySb}$ ) as well as for the spouse's youngest siblings are adiak/diak which are those for a younger brother or younger sister. The same absorption principle is valid for relations between younger siblings and their spouses. A younger sibling's spouse (ySbSp) is also addressed as adiak/diak. Reciprocally the spouse addresses his spouses' sibling as ubang/udo for an elder brother (SpeB) and as kakak/unieng for an elder sister (SpeZ) (diagram 11.2).

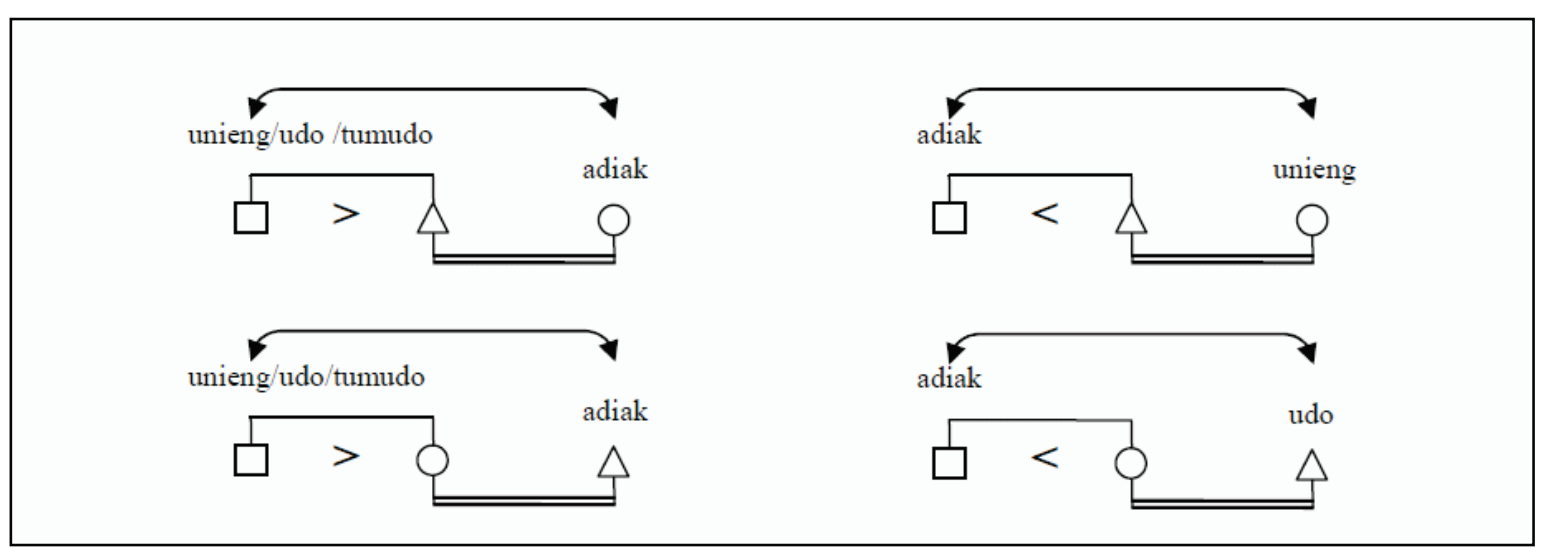

Diagram 11.1. Sp - eSbSp relationship

Diagram 11.2. Sp - ySbSp relationships 
The older siblings' spouses (eSbSp) are addressed in a different way from the younger sibling spouses (ySbSp). By using these terms a person knows that the person addressed is the spouse of an older or younger sibling. These relations stress the absorption of social relations through affines. This is because the Aneuk Jamee society has an uxorilocal residence principle whereby the husband takes up residence in the parental home of his wife. As the husband moves into the house of wife's parents, he adopts his wife's terminological systems. In other words, affines are incorporated terminologically as consanguines or the affinal relation is subordinated under the consanguine. Affinity is subordinated under the order of birth and thus relative age. Affinity is negated since one also calls one's sister's husband, uda/ubang, instead of tamudo. Only here it becomes clear why the absorption of kin terms is valid in one direction i.e. from the affine to the spouses' consanguines.

\section{B. SpP and $\mathrm{ChSp}$ relationships}

Parents designate their children's spouses $(\mathrm{ChSp})$ by the term minantu. The reciprocal term for spouses' parents ( $\mathrm{SpP}$ ) or parents-in-law is tuan. The word tuan means 'superior' being. It describes someone with a high social position and to whom tribute/respect is paid. The term of address for a spouses' father $(\mathrm{SpF})$ in the Jamee is ayah tuan and for the mother (SpM) umak tuan. This term is used when ChSp does not address SpP. When greeting each other one calls one's mother-in-law umak for mother-in-law and one's father-in-law bapak/ayah. Reciprocally, parents-in-law refers to their son-in-law as minantu laki-laki (diagram 12.1) but address him as laki si anu "the husband of so-and-so" or call ayah si anu "the father of so-and-so" if he already has a child. They call their daughter-in-law minantu padusi (diagram 12.2) when they do not address each other. If they face each other, they call binie si anu "the wife of that so-and-so" or umak si anu "the mother of that so-and-so" if she already has a child. The usage of these terms indicates a relation of high respect between ChSp and SpP.

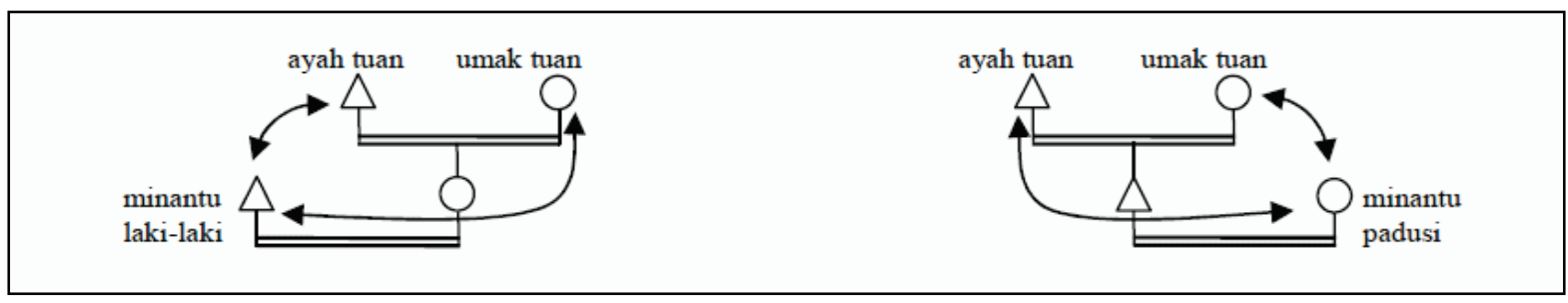

Diagram 12.1. SpP - male ChSp relationships
Diagram 12.2. SpP - female ChSp relationships 
This diagram shows that SpP qualify minantu as either male or female. Similarly, ChSp also qualify their $\mathrm{SpP}$ either male or female. In other words, the gender of the person addressed is significant but here no age distinction is made.

\section{The Aneuk Jamee system of kin categories}

\section{A. The nuclear family}

The nuclear family in the Aneuk Jamee community is called rumah tango "house + ladder", with the semantic meaning 'household', which consists of a father and a mother and their children who share living quarters. It is sometimes found that a husband has more than one wife (polygamy). In the sense of nuclear family in the Aneuk Jamee society it also includes the newly married daughter who stays together with her parents before the ritual of "separation of the cooking pot" (Jam paasing pariuk) is performed (Ch.4). The nuclear family is a unit of economy and adat. The members of the family group meet their individual members' basic needs; and available resources are divided among them. The role of the nuclear family is explicitly divided in daily life although in practice the family members can help and advise each other. A husband is considered to be more responsible for his family. He is the legal and economic authority in the family. His tasks are outside the house, focusing more on responsibilities of a business nature and community relations while the tasks of a wife are in the house. Her responsibility is raising children and educating them, preparing food, keeping the house clean, acting as mediator between children and their father as well as helping the husband in many other jobs such as in financial matters and house activities.

In the household division of labor, male children help their father. They are potential additional support for a father in everyday life. Their help is expected in domestic life, for instance, raising the domestic animals after school hours. If the household economic situation is not good, they will fish (Jam malauik), peddle goods (Jam manggalèh) or conduct regular trade (Jam baniago) for a living to support the household's needs. But many affluent parents do not want to disturb their children's education. The parents hope that their sons succeed in their education and get a job and position in society so that they can elevate their family status, protect and care for their parents when they are old. In addition, the male children especially the first son is the father's 
representative in his absence and his confidant. As the family guardian, the first son is expected to assume external responsibilities until the younger siblings can stand on their own feet.

Meanwhile the tasks of the female children are more household chores after school hours. They help their mother do the laundry and cooking for the family under her guidance, they are also trained for motherhood. The eldest daughter feeds and looks after her young siblings. The basic norm of behavior of sisters towards one another is that of affection and mutual assistance in almost every daily task, especially in domestic work. They exchange clothes and trinkets and also advise each other during menstruation. In farming (Jam $b a$ sawah) and gardening (Jam bakabun) activities all family members participate in accordance with their capabilities and skills. In addition, the daughter spends more time with her mother and the mother is the closest person for her in the family so that she orients herself towards her mother rather than towards her father. From the mother she learns feminine skills and also takes on her character.

Both father and mother pass on physical and mental attributes to the children. However, the mother is considered more trustworthy as she gives birth, raises and educates the children. Not only because of the belief that "heaven is under a mothers' feet" (Indon syurga dibawah telapak kaki ibu) but also because the mother is the person responsible for managing both household and financial activities. In addition, since the father spends much time away from the house, the mother has much time with the children so that the relation between children and a mother is closer than the relation between children and a father. Although the Aneuk Jamee society appreciates the position of a woman, a boy occupies a more important position within the kinship system because the boy is an heir and 'successor of the degree of his descendants' (Indon penerus gelar keturunan) in his family in addition to acting as a wali hukum (guardian or protector) for his female brothers if his father dies.

In everyday social life, the household is led by a father. Sometimes it is led by a mother or an eldest son when there is a divorce or the father dies. There is a code of conduct which has to be followed by all family members; for instance, it is considered impolite if a child says his/her parents' name directly. The children feel hesitant talking with their father. If they have a wish, it is enough to say it to the mother. Conversation between parents-in-law and a sonin-law is not desired and even impolite. The relation between the son-in-law 
and the parents-in-law is limited. The son-in-law feels malu "ashamed" with his parents-in-law. According to adat, the son-in-law who just gets married is only allowed to go back to his wife's house at night, during the day he should be at other places. Because he seldom goes back during the day and seldom meets his parents-in-law and his wife's relatives, their relationship is superficial, behavioral weaknesses are not apparent and they are able to maintain a good relationship. In addition, it is common for the son-in-law to earn money outside the home called marautau and he returns home at irregular intervals. When he returns home he signalizes his arrival through loud coughing so that the parents-in-law have the opportunity to leave the house (Snouck Hurgronje 1906; Siegel 1969). During his stay, the wife's parents and the son-in-law usually do not cross each other's paths. If he wants to say something to his parents-in-law, he quite often delivers a message through his wife. Although this relationship does not seem so close, it does not mean that they do not pay attention to each other and love each other. They are merely maintaining a relationship of great respect between the children's spouse $(\mathrm{ChSp})$ and spouse parents $(\mathrm{SpP})$.

Children are forbidden to scold their parents using impolite words. If they do so, they are labeled as not knowing their manners and even as rebellious children (Indon anak durhaka). Between brother and younger brother, there is a distance, for example; if a brother is in a coffee/rice stall, and at the same time the younger brother appears, the younger brother will not go in because there is a feeling that brother and younger brother sitting together is "unpleasant" (Indon tidak enak). In general this situation is the same as that in the Acèhnese in which a man is malu "ashamed" with all his male consanguine and affine, while a woman is free and close to all her female consanguine and affine (Jayawardena 1977). The closest relationship in the Aneuk Jamee kinship is between female consanguine of the same generation.

The Aneuk Jamee society has the uxorilocal residence principle in which newlywed couples settle or reside in the house of the wife's parents. The husband staying at the house of his wife's parents is regarded as urang samando "a person who marries into a family" by the family of the wife. As such, he is respected by the other family members when he behaves himself in such a way that meets the traditional norms and attitudes agreed on in the family and the community life. The husband may not make an excessive joke in the presence of the wife's family. He attends any ritual held by his wife's family, warmly greets and welcomes his wife relatives when they pay a visit to the house. Al- 
though he is bound by customary norms in maintaining the respect of his wife's relatives, it does not mean all the rights and obligations within his own family are discarded because as a boy he had a close relationship with his own parents and brothers. Equally, the wife also has to show the similar attitudes that fit the traditional norms in order that her husband and his family respect her. During the festive days, for example, on the day of meugang, the wife pays a visit and presents certain gifts such as lomang and juadah to the husband's parents to strengthen the family relationships (see Ch.10).

At his wife's parents' house, the husband has no responsibility for the household. The wife's parents are responsible for this. This situation continues until the ceremony of "separating the cooking pot" (Jam paasing pariuk) is performed. After performing this ceremony, it does not necessarily mean that the couples leave the wife's parents house, this is dependent on their economic situation. When the couples can stand on their own feet, they will move and build a house on land given by the wife's parents in the form of inheritance. Nonetheless, they often remain at the wife's parents' house if the wife is the only daughter in the family and the husband can cultivate the rice fields owned by his wife.

In the Aneuk Jamee kinship context, wali hukum and niniak mamak are used. They live together as an extended family and feel a greater security and belonging. This is an advantage of an extended family because this family contains more people to serve as resources during a crisis and provides more role models for behavior or values.

\section{B. Wali hukum}

Wali hukum consists of two words; wali and hukum. Wali is an Arabic word wali meaning guardian, protector or heir. Hukum is an Indonesian word meaning law, but in the Aneuk Jamee and the Acèhnese it refers to the syari' $a$, the religious law derived from the Qur'ān and the hadìth. Wali hukum are said to be the relatives on one's father's side. The indigenous concept of wali hukum refers to all male collateral patrilineal descendents in the direct line of a common male ancestor. This Arab Islamic notion of wali hukum correspond to the kaum mentioned by Snouck Hurgronje (1906:145-53) although in practice they are restricted to patrilateral kins. Wali hukum members (diagram 13) have the authority to marry off the young girls. They are the persons who arrange the marriage contract and sign it in the name of the respective girl. In addition, they 
also become the guardians of those whose fathers are deceased. The wali hukum are (see diagram 13):

Father (F) (ayah)

Grandfather (FF) (kakèk)

Brother (B) (saudara laki-laki seibu seayah)

Brother from the same father (saudara laki-laki seayah)

Son from B of the same F and M (anak laki-laki dari saudara laki-laki seibu seayah)

Son from B of the same $\mathrm{F}$ (anak laki-laki dari saudara laki-laki seayah)

Brother from same M + F from F (saudara laki-laki seibu seayah dari ayah)

Brother, the same father from F (suadara laki-laki seayah dari ayah)

Son of B, the same M + F from F (anak-laki dari saudara laki-laki seibu seayah dari ayah)

Son of B, same F from F (anak laki-laki dari saudara laki-laki seayah dari ayah).

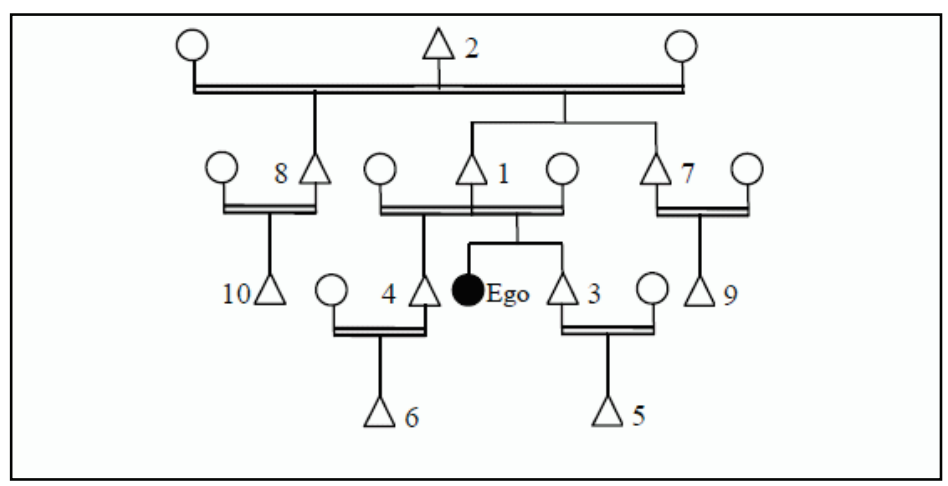

Diagram 13. The members of wali hukum

These people are patrilineal relatives and are also designated as wali nasab meaning guardian that has a blood relationship. The father is known as wali aqrab meaning 'the closest wali of the married daughter'. If the father is dead, the grandfather then becomes the wali aqrab and the rest (no.3-10) is called wali ab'ad. Meanwhile wali mujbir are the wali who have a special authority (Indon hak istimewa). They are the father and the grandfather who may marry off their virgin daughter/grand daughter without asking her permission. The marriage is valid as long as there is no hostility between the wali mujbir and the virgin girl. Also, there should be no hostility between the prospective groom and the virgin girl. If there are no wali hukum or wali nasab, a judge of a religious court (Arb qadī; Indon kadhi) which is designated as wali hakim can replace the wali hukum or wali nasab to marry off one's daughter. 
In addition, wali hukum exact vengeances if an individual is killed, enforce compensation for injury, or pursue a dispute in the courts. These functions are not now as important as they were in pre-colonial time, yet they have not vanished and received a valued obligation. There are still ambushes and assaults to balance a wrongdoing, and prosecution in courts is common (Jayawardena 1977). The wali hukum are also the guardians of those whose fathers are deceased, especially nubile girls and are responsible for taking care of and educating the orphans and gaining permission from the deceased. In reality, not all wali hukum carry out their tasks well, such as educating the orphans, although they know their position as the heir of the deceased's wealth. It could be because of poverty.

\section{Niniak mamak}

Niniak mamak consists of two words; niniak and mamak. Niniak is a Minangkabau word meaning grandparent. Mamak is also a Minangkabau word meaning mother's brother. Niniak mamak is the male adat leader (Indon penghulu) from matrilineal descent who are appointed to become a tribe leader (Rusmali 198:1985). Niniak mamak consists of a man's maternal kin as well as his wife's maternal kin. In the past it is said that the niniak mamak consisted of mamak rumah who were sometimes called tungganai, male siblings on the mother's side, mamak kaum, who was one of the selected mamak rumah and mamak suku who became a leader of the tribe. On the kinship level, mamak suku is said to play an important role both in the level of kaum and in communities (figure 3).

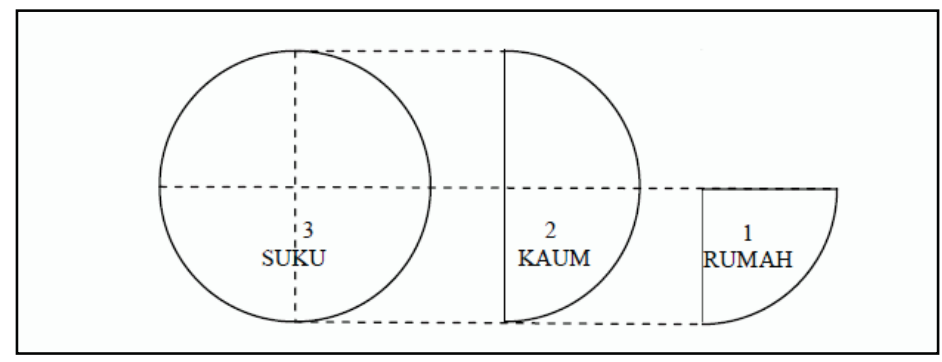

Figure 3. The composition of niniak mamak

Nowadays, this composition of niniak mamak is no longer found in the Aneuk Jamee society in Blangporoh village. They address niniak mamak as all the relatives on one's mother's side. 
In the traditional order of the Aneuk Jamee society, niniak mamak has a big role, especially for sisters' daughters (Jam kamanakan padusi). Niniak mamak's role covers most areas of life. They are the persons who are said to "whiten" and "blacken" their kamanakan [sisters' daughters] in all areas of life (Emtas 2005:122). They are fully responsible for their kamanakan in addition to their own families. Their position is personified in the following proverb, "Niniak mamak is like a banyan tree in the middle of a city, its trunk is a place to lean on, its leaves are a place for sheltering and its roots are a place to sit. If one wants to go/leave, they are the people to ask. If one returns, they are the people where the news is brought". Every life and death ritual of a household must be discussed and negotiated first with the niniak mamak; for instance, when one of the nieces is engaged to a young man by her parents. The girl's father may not talk about it with others including the members of her male collateral patrilineal kins (see wali hukum above). Should the father consult other people before he consults niniak mamak about this, an adat sanction will be imposed on him. (Emtas 2005:124). In addition, when a kamanakan wants to build a house, he or she should first consult his or her niniak mamak. In the past it was said that it was an obligation for niniak mamak to take care of their kamanakan in building a house even though their kamanakan had to have bought their own land (ibid). The decisional performances of the life and the death-cycle are thus in the hands of the niniak mamak. Their functions in the field of social security are the same as those of wali hukum in the Acèhnese society. The niniak mamak are the people who guarantee peace and are responsible for their kamanakan (Soelaiman 1989:114). If new land is made available, the kamanakan who do not have land yet will be given some first. If the members of kamanakan are in trouble, the members of niniak mamak will help them so that one feels more secure if he or she is in the middle of his/her niniak mamak because the security and safety of a person is the responsibility of all members of the niniak mamak. It is important to note, however, that even though the indigenous Aneuk Jamee area are familiar with the institutions of niniak mamak such as in the words niniak mamak or rapat niniak mamak (the meeting of niniak mamak), the understanding of niniak mamak in this area has been much changed from its original form of Minangkabau, in West Sumatra. Niniak mamak here are not just limited to the male brothers from the mother's side but also include wali hukum which are similar to kaum in the Acèhnese 
society into the members of niniak mamak but wali hukum do not play a dominant role when the life-cycle and mortuary rituals are performed.

Relatives on the side of the mother and father are a single entity for the children but since the nuclear family in the Aneuk Jamee society is on the mother's side, the role of niniak mamak has a huge social aspect. Like the roles of wali adat "relatives on one's mother's side" in the Acèhnese society, the roles of niniak mamak in the Aneuk Jamee society are also protectors for they are the people there on the spot when trouble arises. Sometimes they are referred to as the people who gather in the kitchen during trouble and take the first necessary steps including informing the wali hukum. In addition, they are described as the people who give help without hoping to inherit property. A well-known maxim containing a satire on the society is as follows, "karông bak iku jingki, wali yang tueng hareuta", meaning "karông is at the "tail of the rice pounder" and wali receives the wealth". The mother's relatives are burdened with work and the relatives on the father's side get the inheritance. In other words, the niniak mamak in the Aneuk Jamee society are not the inheritors of one's property. Moreover, because residence of niniak mamak is matrilocal, they are the people one lives with so that the joys and sorrows of a family are shared by the niniak mamak as compared to the wali hukum. Like wali adat in the Acèhnese society (Jayawardena 1977), the niniak mamak are the people with whom an individual is closer to and from whom he or she requests favors, loans, and daily companionship.

In addition, the niniak mamak takes the role of a middle man in divorce and remarriage and reconcile them in marriage again. ${ }^{61}$ If he succeeds, they will rejoin in marriage through a rujuk (remarriage) procession before the period of grace, idah for the wife is over. If the husband has consciously uttered the

61 The practiced custom of marriage, divorce and remarriage in the Aneuk Jamee is very much in line with the teaching of Islam. Talak and pasah are two types of divorce commonly occurring in the community. The former is when a man deliberately and consciously utters the intended divorce, be it the first, the second or the third divorce, to the wife either in written or verbal expression. Whereas the latter has to do with a woman pleading to divorce her husband to the district religious office (Indon kantor urusan agama kecamatan) or court of law (Indon mahkamah syari'ah). This matter is under the jurisdiction of Islamic court. There are many reasons leading to dissolution of marriage. In the talak cases, the reasons are, among others; the wife is incapable of procreating, irreconcilable dispute among the man and woman and dispute with the spouse's parents etc. In the pasah case, however, the causing factors are that the husband is leaving his wife behind without fulfilling his rights as a husband and his whereabouts is unknown, or the husband suffers an infectious incurable disease, or the husband is crazy. 
third expression of talak and wants to remarry his wife, the proceedings are rather complicated, the wife has to undergo a so-called bacino buto (a wife has to marry any person she likes and then she is divorced by her new husband) so that her former husband can possibly remarry her after the grace period of her idah is over. Otherwise, she is totally prohibited to remarry her former husband (Sulaiman 1978:38). In the case of unsolved dispute and the divorce did occur, their possessions during the time of marriage which are called harto sapancaharian or harto duo ka duo would be divided and equally distributed amongst them. Their children are offered the right to stay in the mother's house. They are both responsible for looking after their children, as usual.

\section{Conclusion}

The Aneuk Jamee kinship becomes apparent in life-cycle rituals such as weddings, circumcisions, and funeral rituals. In addition, hari rayo idul fitri, the celebration at the end of the fasting month of Ramadhan and hari rayo haji, the celebration of the "feast of sacrifice" are the media through which kinship connections are acknowledged. The recognition of kin is limited to three descending and three ascending generations. Beyond these boundaries, kin are not terminologically acknowledged. In addition, the recognition of kinship is "horizontal" rather than "vertical", in that an apical ancestor is not the point of orientation of kinship, and rather it is siblingship. Kin are commonly distinguished as near or far, but seldom with precision. The descendants of a single grandparent usually regard one another as near, but the descendants of siblings of the grandparents are distant and can be forgotten. In explaining a distant link, an individual traces the connection until a sibling relationship at the third ascending generation and stops there. The farthest back the kinship reckoning goes is to say that "our muyang/moyang are siblings", rather than identifying the relationship between persons as descendants of a linking ancestor. In other words, what the Aneuk Jamee tend to say is that, "We descend from siblings".

The order of birth is an important principle for the relationships between siblings and orientation according to time is a main category for the relations among siblings. The children's absolute order of birth is not subordinated to the order of birth of their respective parents. Therefore, this principle cannot be spoken of as an inherited one. The children do not take on their respective parents' birth order and are not subordinated under their parents' age but depend on the order of their birth. Absolute age can, therefore, be identified as a main 
structuring principle for the relationships among parents' siblings'children. The children designate their parents' siblings according to their relative age and respect the order of birth of their parents' generation. Hence the orientation in time is a main characteristic of their relationship. Not only is the relative age important to this relationship, a sex specific distinction is made clear as well.

Blangporoh people practice the uxorilocal principles which certainly have an effect on the formation of groups and socialization. Therefore, a village is divided among some groups based on daughterly relatives, where children are closer and more familiar with their mother's relatives (niniak mamak) than their father's relatives (wali hukum). In addition, in the traditional order of the Aneuk Jamee society, niniak mamak (mother's relative) plays a big role, especially for sisters' daughters. Niniak mamak's role covers most areas of life. They are the persons who are said to "whiten" and "blacken" their kamanakan [sisters' daughters] in all areas of life. 


\section{Chapter 4}

\section{The ritual of marriage}

This chapter explores the ritual of marriage in Blangporoh village. It also describes commonly practiced rituals before and after the wedding ceremony itself.

\section{An ideal marriage}

In the Aneuk Jamee society, traditional marriages continue to be seen as ideal. Marriages occur among cousins and among those who occupy a similar socio-economic status. Marriage of a man with his matrilateral cross cousin is preferred by most parents although patrilateral cross cousin marriage is also permissible. This is evident from the following expression, "It is better to shelter one's own salt than other people's salt". ${ }^{62}$ This expression beautifully illustrates that it is advantageous to marry kin to keep property within the kin because their customs are known. ${ }^{63}$ Many villagers said that in the past marriage within the village was preferable, the reasons being similar to those given for marrying kin. ${ }^{64}$ Snouck Hurgronje I (1906:299) wrote that a man wishing to marry outside the village required the permission of the village head, and this was not readily given. Today this permission is freely given.

Parents in Aneuk Jamee society wish their son to marry a woman who is not only attractive in appearance but is also well behaved, as illustrated in the following expression, "Parents want a wife who is like a 'flower' for their son and a comfort for the parents-in-law". ${ }^{65}$ Today, however, marriages do not have to be endogamous. Modernization has paved the way to a rather flexible social structure that has inevitably brought about changes in the pattern of malefemale interactions. Men and women find themselves interacting in different communities and with different people. As a result, the number of non-kin marriages has increased. Parents also prefer their daughters to marry a man working for the government as a civil servant, he should be affluent, or have honorable descendants (Indon keturunan terpandang) as they can sustain the

62 Jamee, "Dari pado manaduah garom urang labiah baiak manaduh garom sandiri".

63 But some people say that it is foolish to do so because of the rupture it could cause if the marriage breaks up.

64 See also Jayawardena (1977).

65 Jamee, "Nan kajadi disunting kan anaknyo, nan ka jadi pamaenan ka uwaik ayahnyo". 
future life as well as improve the social status of their daughters. This was even more evident during the colonial period. Those who had a superior social status would not allow their daughters to marry men of an inferior one. They could not afford the children of aristocratic descent losing that status. In contrast, those of a lower social status would like to marry their daughters off to those of a higher status so that they could improve their social status as well.

Marriage restrictions are formulated in accordance with the teachings of Islam. Hence it is forbidden for a man to marry his mother and her sisters' father and his sisters, daughter's sisters, sister's daughters, 'sisters' by nursing and step-sisters. These relations are called muhrim. It is also forbidden to marry someone of a different belief unless he or she converts to Islam.

\section{Pre-marriage ritual}

The traditional marriage procedure is divided into four main phases, namely risiak, bisiak, dohai, and menendei.

\section{Risiak}

Risiak is an initial step where the prospective groom's side (Jam pihak calon marapulai laki) collects information (Ach coh rhot) about the prospective bride (Jam calon marapulai pausi/nak daro). In this process, a respected and wise man belonging to the groom's matrilineal kin (Jam niniak mamak) who is experienced in representing the prospective groom's side called talangkai (Ach seulangkée) is sent to seek information regarding the prospective bride's side. This mission is secret. The representative pretends as a guest and does not show any particular intention. His task is to obtain information from the parents and their closest kin. This mission is said to be "like looking for lice on the head where one combs the hair, going down each hair strand until the lice are found and removed". Afterwards the talangkai reports the results to the parents of the prospective groom.

After a prolonged thoughtful discussion between parents and their son in a 'meeting of the family members' (Jam rapat bilik), the parents then go and report the name of the prospective bride to a 'clever person' (Indon orang pintar) who is consulted about the character, habits and behaviour of the girl by looking at the 'habits' of nature and animals (Indon kebiasaan alam dan binatang) and predictions from the stars (Jam mancaliak parajo) and the precise auspicious date and month (Jam mancaliak langkah) for the engagement, mar- 
rying and holding the khanduri for both candidates. The aim of mancaliak parajo is more or less the same as predicting the fate of both spouses after their wedding. One of the most important things in mancaliak parajo is the name of both candidates. The names of the man and the woman are also given an animal's name based on the last syllable (vowel) of their names in Arabic. For example; the name of a person is Mukhtar. The word ta (Arabic $ت$ ) is taken. The word ta $(ت)$ means frog (Indon kodok). A frog has a bad character because it is fond of sticking out its tongue to catch insects and it likes kicking things with its legs.

The following formulas are used in mancaliak parajo: I (alif) = moon, ب (ba) = sun, $\vec{\Xi},($ ta $)=$ frog, ج (jim) $=$ plant/wood, $ح(\underline{\text { ha }})=$ hen, $\dot{\tau}(\mathrm{kha})=$ duck, د

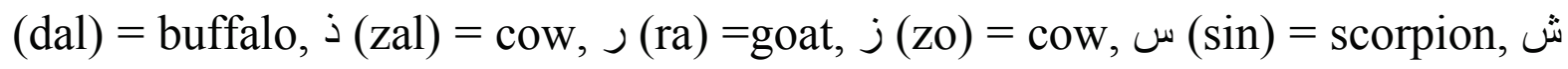

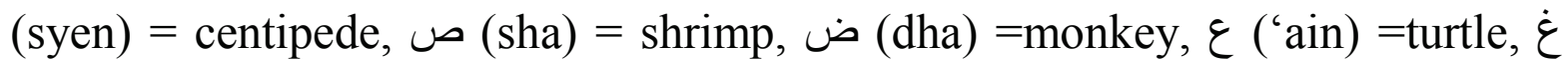

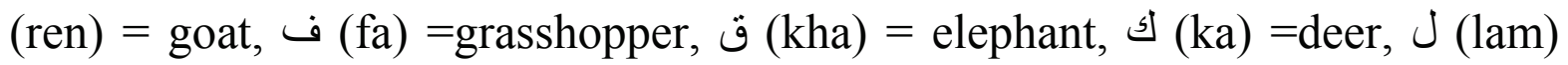
=snake, , $(\mathrm{mim})=$ peacock, ن (nun) = eagle,, (waw) = river, $ه($ ha $)=$ hen, and ي (ya) = horse. It is said that this stipulation is very important especially in choosing a marriage partner. When the names prove incompatible, it is believed that there will later be a bad influence on the household. For example, Munawar (ending with the vowel $g$ (waw)) who has a river character (Jam $p a$ rajo sungai) marries Lestari (ending the vowel ra $(J)$ ) who has goat character (Jam parajo kambiang). This marriage will not last long as this couple has contrasting and conflicting characters. If Munawar who has river character marries Masyitah who has a frog character (Jam parajo kodok), they will be happy because both of them have similar characters. It is like if Muntadhar who has a monkey character (Jam parajo monyet) gets married to Khatijah who has plant/wood characters (Jam parajo kayu). They are said to be compatible. Thus, the name is very important to determine the parajo. After knowing the parajo, the human characters and the destiny of the future household of the prospective spouse can be predicted. Therefore, if the parents find that their prospective son/daughter does not have compatible characters after uniting both prospective names, they look for alternatives, for instance, changing one of the prospective spouse's names, especially the last vowel of the name.

Names are believed to have a direct relation to character and fortune. In choosing a name, the chooser must know the science of names. The name is said to be like a prayer (Indon $d o^{\prime} a$ ). Any time a person is addressed by his or her name it means that people give a gift to Allāh so that a good name must be 
chosen. It is said that after a prospective bride or groom's name is changed, the parents often offer glutinous rice to the men presiding over the ritual so that the name will 'sit well' with the bride or groom throughout their life. It is not surprising that the parents in the village often change their daughter's name or their son's name in order to render it suitable for the prediction of the parajo at the marriage contract. Modernists, however, do not agree that predicting a name determines the destiny of the future household of the prospective spouse. They contend, "the future destiny is the secret of Allāh. If it is predicted, the human beings thus have preceded His secrecy. It thus deviates from Islamic teaching". The imām said that predicting the unseen such as predicting a mate, livelihood (Indon rezeki), and death and the Day of Judgement are supernatural problems, only Allāh can know them as He says, "Say, no one in the sky and on earth knows the unseen except Allāh, and they do not perceive when they will be resurrected"'(QS 27:65). Added to this are fortune-tellers, witches, healers, astrologers, who all belong to one 'group'. They are the people who admit knowing unseen things (Indon perkara gaib), their acts are clearly unlawful and this makes them unbelievers. Should the names be considered compatible, the next phase in looking for the son's marriage partner can begin.

\section{Bisiak}

Bisiak (Indon berbisik, to 'whisper') means sending a representative from the groom's side (Jam talangkai) to deliver news confidentially and quietly to the prospective parents of the bride's side. Here the representative plays a vital role in ensuring that the proposal is welcomed. Once he arrives at the house of the prospective bride, he explains the purposes of his presence and asks the parents graciously for their daughter's hand in marriage. If the parents do not accept the proposed marriage, they should refuse with a polite excuse, e.g., their daughter still wants to continue going to school or at the moment their daughter is not thinking about the marriage. The process is kept confidential as there is a possibility that the prospective bride's side may refuse the proposal. An expression articulates this in the following way, "Whispering in the water, walking in the earth, an ant does not know". ${ }^{66}$

If the prospective bride's parents agree to the proposal, they still need the consent of the other family members. As such, they would ask for some time to

66 Jamee, “Babisiak dalom ayie, bajalan dalom tanah, samuik saikue indak tau”. 
put the proposal before their niniak mamak. The prospective bride's parents say diplomatically to the representative from the groom's side, "It is right that she is our daughter, but she is somebody's niece". ${ }^{67}$ A meeting is then held with her matrilineal relatives. While waiting for this meeting, the represntative from prospective bride's side is sent to the prospective groom's side to investigate the characters of the prospective groom, examining whether he can become a son-in-law in their family. After detailed information about the prospective groom is obtained by the representative of the prospective bride, the family of the prospective bride's side says to the representative of the prospective groom's side, "The door is now open and the prospective groom's side can come to our house". When the proposal is accepted, the next phase in looking for the son's marriage partner is then continued.

\section{Dohai}

Dohai is a phase in which the parents of the groom and bride begin to make their consultations public. Although the parents have a more dominant role in deciding their children's marriage, the proposed married needs to be discussed with the entire family. The parents of the prospective groom invite niniak mamak (the relatives on the mother's side) and wali hukum (the relatives on the father's side) to attend a family gathering called rapat niniak mamak to let them know that risiak and bisiak have been performed. Before the meeting, the parents of the prospective groom ask one of the niniak mamak to lead the family meeting. In the meeting he says:

We are here on behalf on the niniak mamak to convey that we will soon search for our sister's son's (ZS), name..., marriage partner. Everything has been initiated by the talangkai of the family. Our party has tried to clear any branches blocking the way and to remove the intertwined roots. ${ }^{68}$ Tonight we look for an agreement to take a sign (Jam maantèk tando) to the prospective bride. For this reason, we need to send an official representative of our families to the prospective bride's house. His task is to ask the prospective bride's side how much dowry (Jam jinamu) should be made, asking the prospective bride's side if they are willing to accept the prospective groom's side to take the 'mark' (Jam maantèk tando), and asking for other requirements of the engagement that must be presented by the prospective groom on the day of the engagement.

67 Jamee, "Ini betul anak kami, tapi kemenakan di urang".

68 Jamee, "Pihak kami alah berusaha mengabuang kayu yang melintang, dan maratèh aka yang bajalin". 
Through all stages of the ritual the wali hukum, the patrilateral kin are present and consulted the essential role in deciding and performing the ritual is in the hands of the niniak mamak, the matrilateral kin. This is not as elaborate as the niniak mamak, wali hukum and the other family members accept the decision made by the parents and their son, as expressed in the saying: "If the parents of the bride and the person who possesses the body [the bride] like the marriage, then we also like it". ${ }^{69}$ Having reached an agreement, the parents of the prospective groom will soon let the talangkai know about it and proceed to the next phase, menendai.

\section{Menendei}

Menendei is the ceremony of engagement. In the past, it was held prior to announcing the intended marriage but now it is held on the same day. Like the Acèhnese adat, the marriage proposal is always made by the man's family, never by the woman's as the expression says, "The well never seeks the bucket" (Ach hantom mon mita tima). In the Aneuk Jamee adat, there is no term for nikah bajapuit "picking marriage" as found in Minangkabau, West Sumatra, in which the marriage proposal is made by the woman's family. The group of menendei consisting of niniak mamak, wali hukum, imām, keuchik (village leader), and tuwo ampék (village elders) is sent by the groom's family. They take betel leaves with them filling a tray of leaves (Indon cerana sirih) called bungkusan adat 'the packing of tradition' and a gold ring called tando 'mark' as a part of brideprice. In the bride's house, they are warmly welcomed by old respected people and after a while the menendei ceremony begins. Afterwards, the groups are served with glutinous rice (Jam nasi sipuluik).

Soon after the manendei ceremony is performed, the ceremony of making a 'sign of engagement' (Jam maulu tando) to the prospective bride's side takes place, showing that a girl is now traditionally 'bound' to a young man: "Trees are bound by their roots, promises are bound by signs". ${ }^{70}$ The tando is presented along with a tray containing betel leaves and is considered a part of the bride price to be completed at the marriage contract ritual.

There are two kinds of tando known in the Aneuk Jamee speaking areas in South Acèh; tando dohai and tando suruk. This classification refers to the

69 Jamee, "Kok umak ayahnyo dan nan punyo badan alah suka, kamipun suka pulo".

70 Jamee, "Maikèk kayu samo aka, maikèk janji samo tando". 
magnitude of the wedding ceremonies. If it is an extensive wedding ceremony, tando dohai is presented to the bride's side and it should be held during the day. If the wedding ceremony is a simple one, it is sufficient for the groom's side to merely present tando suruk. Tando suruk is usually held in the evening and no invitations are extended to the surrounding people. There are only several of the groom's kinsmen present without the presence of traditional leaders; the tray of betel leaves (Jam jamba sirih) is not used. The latter normally happens when the bride is a young girl or still attends school or because their parents do not have ample financial means for a huge wedding ceremony. People recognize the type of wedding ceremony from these two tando. ${ }^{71}$

The tando is performed when all requirements have been agreed upon by both sides, such as the sum of the bride price and the duration of engagement. Prior to the engagement ceremony, close relatives, neighbors, the keuchik, the teungku imām, the khatib (preacher) and tuwo ampék (village elders) are invited to the house of the groom at night to discuss who will go to the house of the bride on the day of engagement on behalf of the groom's side. That night all requirements for the engagement are prepared by several village women. These include making a metal traditional holder to place the betel leaves on called cerano adat "the tray of adat" and decorating a copper silver bowl with an ornamental piece of cloth to place gold in called bungkusan adat "the wrapping of adat". These will be brought to the bride's house the following day as a mark of engagement (Indon tanda pertunangan). The people who bring the bungkusan adat consist of the groom's matrilineal relatives, patrilineal relatives, tuwo ampèk, a young man who holds a cerano adat and a wise man who is versed in diplomacy and retoric (usually the talangkai). Once they arrive at the bride's house, they are warmly welcomed by the bride's family, the village and religious leaders. The bungkusan adat containing a part of the agreed bride price and the cerano adat are handed over to the waiting group and religious leaders on the bride's side. During light conversation, they are served with coffee, tea and cakes. The official menendei ceremony then begins. ${ }^{72}$ The

71 See Sulaiman (1978:23).

72 At this ceremony, the groom is not required to be present. However, in nikah gantung marriage in which the sexual intercourse is suspended because the bride is still young in age, the groom has to be present because the marriage contract ceremony (ijab qabul lakad nikah) is also held on that day. A trusted religious leader usually stands for the parents of the bride to utter the oath of marriage. To affirm that the marriage is valid by 
speaker for the groom's side sits facing the representative from the bride's side. He greets the audience and delivers a short speech, then offers a traditional poem (Indon pantun) which is soon answere by a representative of the bride (see Appendix 1).

After reciting the poem, the groom's side is served glutinous rice. Having handed over a part of the bride price, the bride has been officially 'tied' to the prospective groom's side. A prayer is then uttered by the imām invoking Allāh's blessings of the agreement between the bride as a 'flower' (Jam bungo/Ach bungong) and the groom as a 'beetle' (Jam/Ach/Indon kumbang). They are now officially engaged and any inappropriate behavior (Indon penyelewengan) will from now on be fined. In that case, the bride's side must return the gift (Jam tando) and pay compensation equal to the gift they received during the engagement ceremony, whereas the groom's side will lose the right to marry. The bride price is legally owned by the bride, as this ritual is witnessed by the adat elders, family, and matrilateral and patrilateal kin of both sides. During the engagement period, the prospective groom may not walk or travel with his prospective wife. If there is a life-cycle ritual (Ach buet hudép) or a mortuary ritual (Ach buet matée) at the prospective groom's house, ${ }^{73}$ the prospective bride may not be picked up by the prospective groom or come alone to the prospective groom's house except when there is a representative old woman accompanying her.

\section{Prerequisites for marriage}

Prerequisites for marriage are a collection of norms regulating a matrimonial process which consists of certain procedures to be completed before the marriage contract ritual is undertaken to ensure that the marriage is lawful and valid. Among the prerequisites are physical and mental sound conditions. These prerequisites are in line with Islamic teaching because the populations of the Aneuk Jamee in West Labuhan Haji district are Muslim. As to the age, they do not particularly specify the minimum age requirement at which one is allowed

law, however, they have to get a government official agreement (Indon kantor urusan agama kecamatan) prior to the marriage contract ceremony.

73 Life-cycle rituals (Ach buet hudép) include the ritual of birth, circumcision, marriage etc. The mortuary ritual (Ach buet matée) is from one until seven days after the death of someone, the khanduri on day fourteen and on day forty, and on the hundredth day after death. 
to marry. It is common practice that men are seen as eligible to marry when they have adequately acquired basic skills to engage in certain activities to support the family, such as having a knowledge of cultivation-related activities and fishery. Women, on the other hand, are eligible to wed once they have had their first menstruation and know how to cook. Older people say that the minimum age of marriage is legally after a girl's first menstruation (around 12 years old) and after a boy's first ejaculation during sleep (around 15 years old). Nowadays, however, people ignore this requirement. Men are mostly inclined to wed between 18 and 30 while women wed between 15 to 25 years old.

Furthermore mental and physical healths are necessary. They should not suffer from infectious diseases such as leprosy, tuberculosis and be sexually healthy. The bride price (Jam jinamu;Ach jinamee) ${ }^{74}$ is assessed in measures of gold, due to the fluctuating value of money, and mostly presented in the form of a golden ring, bracelet or necklace. The bride price for the bride is jointly decided by the bride's family in a meeting with their matrilineal kin (Jam rapat niniak mamak). The amount of the bride price takes into account the current social and economic status of the bride's parents, which is well expressed in the saying, "If the bride price is high, what can be received in exchange" (Jam kalo jinamu tinggi, apo yang bisa dipulangkan). ${ }^{75}$ The amount is negotiable once the families of the groom and the bride have reached an initial agreement about the marriage. Usually the amount expected for a bride is equivalent to that which was paid for her mother. The amount of the bride price can also serve a sign of refusal to a proposal of marriage. When the bride price demanded is unreasonably expensive, it conveys that the intended bride is reluctant to engage in the marriage.

\section{Wedding ceremony}

When the day of the wedding ceremony approaches, the niniak mamak and wali hukum of both sides call a meeting to set the date. The Islamic calendar is referred to in deciding the month and the day. The marriage ritual may be performed in Sya'ban (i.e.August) (see Ch.10), the mò'lōt lunar months; Rabiul

74 A word which, Snouck Hurgronje observed, derived from the word jamee, meaning guest, is based upon the idea of a husband as a guest in the house of his wife (Snouck Hurgronje I 1906:339).

75 In other words, "If the bride price is high, what has to be made to return home". If we ask a high bride price, what must we give in return? It is not wise to ask a high bride price because if it is too high, we have to give more back. This poem can be understood as a warning against asking for a too high bride price. 
Awwal (i.e.March), Rabiul Akhir (i.e April) or Jumadil Awwal (i.e.May) (see Ch.7) but never in the Safar (i.e.February) lunar month as this is the month to "ward off calamities" (see Ch.6) days. The ceremony is often held in the period of time when the moon is ascending (the first day until the fifteenth day of a month) in Sya'ban or Mò'lōt lunar month.

Two weeks before the wedding day, both sides are busy with preparations. A meeting of niniak mamak is conducted in her house to discuss thoroughly any problems relating to the preparation work. The meeting is led by respected male members of niniak mamak. They specify any kind of help which might be provided by niniak mamak and wali hukum to support the wedding celebration. The meeting provides a well planned traditional agenda and indicates the processions for the wedding ceremony.

A week before the wedding day, another meeting is held at night at the bride's house. This is a village level meeting called pakat rami. Unlike the pakat niniak mamak's meeting which is only attended by close family, pakat rami's meeting is not only attended by close family and neighbors but also open to the entire population of the village. To this meeting, the male participants bring sugar (a half or one kilogram) or a little money while the women bring cakes to the family of the bride to show a sense of brotherhood and togetherness. At this time the meeting is led by the keuchik on the behalf of the bride or groom's family. The keuchik informs those attending about the wedding day, about sending the groom to the bride's house called maantra marapulai as well as sending the bride to the groom's house called menjelang. ${ }^{76}$ This is expressed in the saying, "When the moon appears, when the promise should be fulfilled, the debtor is waiting for repayment and the debtor is ready to pay". ${ }^{77}$ The representative of the bride's family asks the people to attend the ritual and to make it successful by saying, "If vegetables have a skin, we peel them together. If they are still raw, we cook them together. After being cooked, we eat them together". ${ }^{78}$ After this, the workers are served 'light food' (Indon makan ringan) such as cakes with coffee and tea. The bride's family then asks the traditional leaders for their authorization to conduct the ritual. Then an informal

76 In Susoh, another district of Aneuk Jamee speaking area, it is called pengaling suruit (Sulaiman 1978:25).

77 Jamee, "Kok bulèn alah nampak, kok janjipun alah pulo sampai, nan bapiutang alah manunggu nan berutangpun nandak mambayie".

78 Jamee, "Kok nan bakuliek samo-samo dikubak, kok nan mantah samo samo dimasak alah masak samo- samo pula disantap". 
meeting between the bride's family and the traditional as well as religious leaders is held. This meeting is called rapat menduduekkan keuchik meminta adat dan tampèk "seating the village head, asking about adat and place". Having been granted the authorization, the bride's family requests the traditional leaders as well as the head of the village youth to set up a committee that is responsible for performing the ceremony.

The preparation continues at the bride's house. The bride's family cleans and repairs the house to honour the coming of the groom. This expresses the respect of the bride's family towards the groom, as well as the last responsibility of a father toward his daughter since after marriage a woman obtains legal possession of the house, in accordance to the matrilocal marriage tradition of Aneuk Jamee (see Ch.10). Neighbours and kinsmen also come to the bride's house to fix and prepare things needed for the wedding reception.

Three days preceding the wedding day, the ends of the bride's hair (Indon rambut kecil) are cut (Jam/Ach meandam) and her nails are cut. Bainai (heena), a traditional process of dyeing the hands and the feet of the bride with heena is conducted in the evening. The bride wears a traditional dress and an old woman sprays the water of tepōng taweu ${ }^{79}$ onto the bride's hands and forehead and scatters husked (Jam barèh) and unhusked rice (Jam padi) over her from right to left. The bride is then asked to lay down on the mattress. Heena paste is applied in patterns on the palm, back of her hands, the fingernails and tips of her fingers as well as on the bride's feet. After a few hours elaborated patterns in red appear. In the past, the groom was also dyed with heena, but nowadays this practice has been mostly abandoned.

From the night of bainai onwards people are busy preparing for the ceremony. One group of women fixes and decorates the house and the dais (Indon pelaminan). Others cook the rice. They chop onions, garlic, ginger and other ingredients. This work is called ricieh-maricieh. Another group of women collect utensils from the neighbors and make sure that the plates, cups, glasses, forks and spoons and other utensils are clean and ready for the wedding day. Men do the heavy work. Some men set up the tents and arrange the tables and chairs for the guests. Others take firewood and make a fireplace; others collect jackfruit (Ach boh panah) and the hearts of the banana palms (Ach haté bak

79 The water of teupōng taweu consists of water and the rice flour. Sometimes the Acèhnese say tasteless flour (Ach teupong tabeu) instead of tepuōng taweu. 
pisang) for vegetables. Some fish in the river or at sea, others cut firewood and erect a hall for the audience called balairong. At the same time, various traditional narratives are recited such as kaba (kaba ungèh-bambam and kaba dangderia), rantak kudo and badampieng to entertain the men and women who are occupied with their respective tasks. In certain places, modern music performances such as orchestras and gambus are also shown. ${ }^{80}$ The duration and extent of the performances depends on the social and economic status of the bride or groom's family.

In the early morning of the day preceding the wedding, the bride performs the ritual of mandi balimau "bathing with citrus fruit" to make her body fragrant. It is done by mixing several kinds of fragrant flowers (including the leaves of civet cat's pandanus) in water to be used as a shampoo. In addition, she drinks boiled water from various kinds of leaves and plants that make her breath fragrant as well. During the day, the khanduri takes place in the bride's house. In the early morning, two goats are slaughtered and the meat has been mixed with the hearts of banana trunks (Jam hati batang pisang). Men who are unable to help with the physical work present gifts such as fish, chicken, rice, money and some other goods while women present cloth gifts or cosmetic products to the bride's house. The male guests give money placed in an envelope and the female guests bring gifts that have been wrapped in colorful paper containing clothes called kado. ${ }^{81}$ The villagers are the first to taste the khanduri and the invited guests follow.

\section{Maantra marapulai}

At night the maantra marapulai ritual takes place. ${ }^{82}$ Maantra marapulai is a ritual of taking the groom to the bride's house for the inauguration of the marriage. The groom is escorted by the keuchik, imām, ninik mamak, wali hukum, tuwo ampèk, neighbors, and male and female friends of the groom.

80 See Sulaiman (1978:26).

81 The word kado, coming from the French word cadeau, is used here rather than its more traditional meaning in Arabic equivalent with hadiya.

82 This is a tradition that has been widely practiced since the Dutch colonization period. Later, during Japanese colonization this had changed somewhat because of the economic recession and unstable and escalated political turmoil. The people, therefore, held it on the day for economical and security reasons (Sulaiman 1978:27). Now again in West Labuha Haji district and other neighboring districts conduct the ritual of sending the groom to the bride's house at about 8 at night. 
Before the groom and the group escorting him arrive at the bride's house, the bride is dressed and adorned. She wears a long black embroidered golden trousers and kebaya dress (Indon baju kebaya) with a scarf (Indon selèmpang) and the panduo cloth (Jam kain panduo), a cloth embroidered with golden thread, which is worn over the shoulder or diagonally across the body. $\mathrm{Ku}$ lahkama (Indon mahkota), a crown made of either metal or golden gilt, is worn on the bride's head. A necklace and a bracelet are also put on the neck and the hand respectively. Afterwards the bride is seated at the gaily decorated dais, usually set up in the living room next to a window. The beautiful bride is fit for a 'king' (Jam rajo; Indon raja) and is now ready for the groom to arrive.

The groom also wears the traditional wedding dress. He wears a long white sleeved shirt and a black coat. Panduo cloth made of silungkang with embroidered golden thread is put on arounds hips. The rencong "dagger" is inserted at his waist. The kupiah meuketop " 83 "head cloth" is fitted on his head. After this has been done, the imām delivers a short speech as the last advice to free the groom from his parents. The groom then deliberately comes forward to his parents seeking their 'blessing' and asking their consent to leave the house for the bride's house. Here emotion is strongly felt by the parents, especially the groom's mother. She kisses, embraces her son and then cries inconsolably whilst liberating (Indon melepaskan) him as the married son to go to live with the family of his wife and only sometimes visit his own parents. A 'cooling' ritual (Ach peupon taweue) is then performed. An old woman sprays the water of teupōng taweu onto the groom, and scatters husked (Jam barèh) and unhusked (Jam padi) over his head. The groom now may leave from the house. In front of the house, the imām utters, 'O Allāh, call down blessing on our leader, Muhammad' (Arb Allāhumma shalli 'alā saiyidinā Muhammad) three times and all people answer, 'peace be on him' (Arb shallu 'alaih) in chorus. The groom accompanied by his old and young relatives, religious leaders, invited guests, old men and women as well as by a group of pencak silat "martial arts specialists" players are then ready to leave for the bride's house. ${ }^{84}$ The number of accompanying people is decided beforehand and has been agreed on by both

83 Kupiah meuketop is a kind of Turkish headband which is worn by the groom.

84 In the capital city of South Acèh, Tapak Tuan, pencak silat players, groups of zikir rebana and gendang salusin are invited into the group, especially in berhanta-hanta marriage. On the way to the bride's house they beat drum while humming religious songs reflecting the greatness of Allāh and His messenger (Sulaiman 1978:29). 
sides. They leave for the bride's house after the 'night prayer' (Ach sembahyang isya') at about $8 \mathrm{pm}$. One of his best friends shades the groom with a gold colored wedding umbrella. The groom then confidently moves to the bride's house. This group brings along the following market goods (Ach dabeh keude) as gifts to the bride's family:

1. Bride price placed in a decorated copper silver bowl (Jam carano)

2. Betel leaves heaped up high on a rounded tray ( Jam jamba sirih $)^{85}$

3. Toilettries on a rounded tray

4. Cloth and cosmetic products in a suitcase

5. Onions, garlic, ginger, greens, chili and other food ingredients for the dishes are placed in a sanggèn (Ach ambèn) which is made of wood connected with small irons to prevent the dishes from falling when it is moved (see Ch.7).

In addition, the following garden produce is also presented as gifts for the bride's family:

1. A bunch of young coconuts. It is said that this is a symbol that the groom is still young.

2. Straight sweet sugarcanes (Ach teubè mameh teupat) together with their leaves. They are said to be a symbol of male fertility. The couple hope to have children and grandchildren like the shoots of the sugarcane plants.

All these gifts are called hantaran (Ach peunuwo). Once they are about to reach the bride's house, the imām again utters, 'O Allāh, call down blessing on our leader, Muhammad' (Arb Allāhumma shalli 'alā saiyidinā Muhammad) three times and all people answer, 'peace be on him' (Arb shallu 'alaih) in chorus. This uttering is a sign that the groom's group will soon arrive. The group stops once they are about to step into the front yard of the bride's house. Now the two groups are standing face to face. The pencak silat group of the bride's side puts on their best performance. They stop right away when a traditional leader puts the tray of betel leaves right in between the two groups. The village leader of the bride's side greets the groom's group by saying, "Are all present?" (Jam ado hadir kasadonya?) which is soon answered; "yes" (Jam

85 Betel leaves (Jam jamba sirih) are presented only when there is no engagement ceremony or in a suspended marriage (Jam/Indon nikah gantung). 
$a d o$ ), by a traditional leader on the groom's side. Then the two shake hands and the host hospitably invite them to step into the house. Once the groom reaches the feet of the house ladder, the traditional leaders come in front of the door's house to greet the groom (Jam menyapo marapulai) with traditional poem (see Appendix 2). The old women of the host spray the water of teupong taweu onto the groom and scatter husked and unhusked rice over his head. The groom is then guided by an old woman called peunganjue/mak pangapit into the house and sits on a mattress called kasue pandak which is placed on the verandah of the house. The women of the visiting group sit in the main hall where the dais stands and the men sit outside the house. After a while, the group leader of the groom recites a traditional poem (see Appendix 3) to express the handing over of the groom to the bride's side which is responded to by the representative of the bride. Afterwards, the village head of the groom's side stands in front of the men's group and delivers a traditional speech expressing the purpose of their presence and formally hands over the groom to become a new member of the house and the village. This is immediately replied to by the village head of the bride accompanied by the imām, niniak mamak, wali hukum affirming that they have warmly welcomed the groom into the house and the community. ${ }^{86}$ Afterwards, the keuchik of the groom's village hands over all the gifts mentioned above to the bride's side by symbolically presenting the bride price in the decorated copper silver bowl. The keuchik of the bride's side receives the copper silver bowl and, after a while, uncovers in to allow people to see it.

All requirements have now been fulfilled. The uttering of the marriage contract (the reciting of akad nikah) ${ }^{87}$ can be soon conducted so that the groom and the bride are then deemed husband and wife. The niniak mamak of the groom side says, "Where is the tuangku whose guidance we follow? We have

86 The speech of handing over the groom is intentionally held before eating so that everyone listens to it.

87 The marriage contract (Indon akad nikah) consists of the ijab and kabul, shortened into ijab kabul. Ijab is the utterance of the wali or kadhi of the behalf of the wali, starting that he marries the bride to the groom; the words may be like this: "Brother so and so (he mentions the name of the groom), I marry the girl named so and so (he metions the name of the bride) to you with the bride price consisting of such and such (he mentions the amount, volume and value of the bride price), paid in cash (or debt). Kabul, on the other hand, is the groom's response to the ijab, saying that he accepts the marriage of the bride to him with the marriage gift as stated by the wali or kadhi. This marriage contract is attested by two witnesses who are usually the village leader and the imām or other elders from the bride's village. 
cleared the blocked branches, so as to follow the Shari'ah law, the cutting up of the three marieh $^{88}$ is up to you". ${ }^{89}$ The authorized religious officer (Jam $t u$ angku imam/kadhi) replies with a succinct response, 'if Allāh wills it' (Arb insya Alläh). He, therefore, presides over the marriage contract ceremony in the presence of several witnesses from both parties to ensure the contract meets religious requirements. ${ }^{90}$

The contract is signed by the bride's father and the prospective groom and the bride price is paid then or at a stipulated date. Furthermore, he delivers a short marriage sermon (Indon khutbah nikah) that advises the groom on the duties as a husband and vice versa, and of the consequences should the husband leave his wife. The advice given is meant to ensure that the husband becomes a good husband and takes his responsibility as head of a family seriously. A moment later, while holding the groom's right hand, the imām pronounces the marriage contract based on the Islamic requirement and rules which must be immediately and succinctly replied by the groom. If the witnesses agree that the word of acceptance (the groom's utterance) has been made clearly and are acceptable to them and proclaim it adequate, the imām then recites the do' $a$ and wishing the newly married couple a happy life. To end the ceremony, the groom is then asked to sign all the necessary statutory documents of marriage making them valid and legal by law of the state.

The groom is now called a husband (Jam laki) and bride is now called a wife (Jam binie). The groom is carefully led to the dais on which the bride is waiting. On the floor leading to the dais, a traditional cloth called kain jajakan is laid. The old penganjue ${ }^{91}$ guides the bride to move forward to traditionally welcome the husband into the house at the other end of the kain jajakan where the groom stands still with the penganjue. The bride then wipes the feet of the husband with flowered water already prepared in a bowl. The two shake each other hands during which the groom presents a monetary gift to the bride. The

88 Marieh is the buffalo's neck consisting of veins of the neck, artery and respiratory vessel.

89 In Jamee, "Mano tuangku nan ikutan kami, kok samak nan bajalin alah kami tateh, mako untuk menjalankan hukum, mamatuih marieh nan tigo, kami pulangkan kepado tuangku kadhi".

90 The tuangku imam/kadhi marries the girl here because her wali has already asked him in advance. A woman's wali is her closest agnate, usually her father or father's father. If her father or father's father is dead, it falls onto his brothers, sons, bothers' son, etc., to assume the position in order of agnatic distance.

91 It is called induk inang in the capital city of South Acèh, Tapak Tuan (Manaf 1977:25). 
groom then walks with the bride to the dais with the guidance of the penganjue. The two take a seat on the dais. This ritual is called bersandiang duo, which can be translated as 'sitting together side by side'. At the same time the invited guests in the yard and the group of the groom's side in the house taste the various kinds of foods served.

There is a special rice with dishes on a round tray (Jam daluang) called nasi bisan which is particularly prepared for the groom's parents (Jam urang seumando). If this special rice is eaten by other persons of the groom's side, they must place some money on the round tray. It is a sign that the eaters are the people who know the adat rules or they are 'cultured people' (Emtas 2008:208). This ritual is preceded by the newly married couple eating together for the first time the food prepared on a special table in front of the dais. Watched playfully by the others, the couple, nervous and joyful, feed one another (Indon saling suap) the food and drinks seven times. This ritual is called bertimbang basawok and symbolizes togetherness, reciprocal understanding and a sense of responsibility towards one another. ${ }^{92}$

The invited guests and the group from the groom's side leave the bride's house after the batimbang basawok ritual is finished. A friend of the groom remains with the groom during the ritual of basandieng duo "sitting together with bride on the dais" which is the climax of the wedding ceremony. When all guests have left the house, the ceremony is soon concluded. The groom and the bride are allowed to leave the dais. He with his friend takes a rest on the verandah which has already been prepared. In another room, the relatives of the bride and a number of distinguished traditional leaders open up and display the gifts from the groom to all family members. The bride's family then distributes some cooked rice with various side dishes to the niniak mamak and wali hukum. Some betel leaves and some straight sweet sugarcane are distributed to the neighboring families. At night the groom and the bride are guided into a room by the penganjue. The room has been prepared with a red curtain (Jam tabia), a reddish palanguin (Jam langik-langik), and tiered pillows (Jam banta basusuen) which have been adorned with a reddish and embroidered golden thread (Jam kasab). The couples take off their traditional wedding dress and sleep on the wedding bed (Jam peratè) which is covered with a decorated mosquito net

92 See also Soelaiman (1989:141). 
(Jam caradie) also embroidered in golden thread. ${ }^{93}$ In the past, the ritual of sending the couples to the wedding bed was performed by the penganjue at midnight. During the ritual she played a decisive role in ensuring a warm and intimate feeling prevail between the two. She would suggest any necessary advice if she finds the couples are shy with each other (Sulaiman 1987:31). Now this ritual is no longer often practiced as many couples have already known each other before they get married.

At dawn on the following day, the groom and his friend go back to his house as in the afternoon he, accompanied by an old woman, has to come back to the bride's house. In that very day, the menjelang ritual takes place.

\section{Menjelang}

Menjelang is a ritual of taking the bride (Ach antat darabaro) to the groom's house escorted by a group of respected old men and women. At around 3 o'clock in the afternoon, this group arrives at the groom's house and presents the following garden produce as reciprocal gifts and market goods to the groom's family:

1. Idang nasi kunyitjamba filled up with the cooked yellow glutinous rice which is heaped up high like a pyramid form on a quadrangle made of wood with four legs and a long rounded wooden pole in the middle (Ach capah idang) and covered with thin sweet cakes called tumpi (Ach tumpo) ${ }^{94}$ In addition, there are traditional cakes attached to it such as, keukarah, kamaloyang, seupét and juadah talue, the same idang as at the khanduri mò'lōt ritual (see Ch.7). Sometimes on top of nasi kunyik/jamba, there is toasted chicken.

2. Special traditional cakes such as dodoi, meuseukat and wajéb are placed in a rounded tray.

3. A special packet of food with various side dishes filled in many sets of stacked containers for transporting food called rantang. Some rantang are filled with the ordinary cooked rice and some others are filled with side dishes such as cooked vegetables, cooked fish together with their broth, cooked meat with their broth, toasted and fried chicken, meat, and fish including boiled eggs and salted eggs, the same side dishes are used for the khanduri mò' 'lòt ritual (see Ch.7).

93 For aristocratic and religious leaders' families such as the family of the 'ulamā', sayéd etc, the room, curtain, tiered pillows, dais etc are adorned with a yellow embroidered golden thread whilst the marriage ritual takes place.

94 How tumpi (Ach tumpo) is made, see Ch.7. 
Arriving at the groom's house, the group places these gifts on the front verandah of the house. They are then asked to step into the house and are served with betel leaves while having a chat with the groom's family. The ceremony of giving these gifts to the groom's family is then held. One of the gift bringers on behalf the bride's side says, "Where are "our parents" in this house? We bring a shipful of rice, even if it is mushy, or not perfect. It is understandable we, old people cook it, whether it is salty or not. This is what we have and bring for our elder sister in this house". ${ }^{95}$ The host group answers, "Our younger sister's gifts are not seen as mushy/uncooked but we hold up our heads. The mountain is smaller; our younger sister's gifts are bigger. "We highly appreciate our younger sister's gifts. We believe that these are the best gifts ever given". Here there is the situation in which the gift exchange takes place between two parties, the bride's side (Jam pihak laki) and the groom's side (Jam pihak padusi) but they talk about these parties as if they were elder and younger sister in the context in which the bride is presented to the groom.

Right after the ceremony of giving these gifts has finished, another group of women called menjelang escorts the bride to the groom's house. The groom's side has already been well prepared for their arrival. Unlike the group who escorts the groom which consists of men and women, the group of menjelang consists of only women. The bride is shaded with a wedding umbrella by the penganjue. The bride's side is waiting for the visiting group in the front yard when the menjelang group is about to arrive. Once they arrive, an old woman warmly greets and welcomes them by presenting carano sirih. She asks the group, "Are all present?" (Jam ada datang kasadonyo) which is soon replied by the group with a brief answer, "yes" (Jam ado). The group is then asked to go into the house. When the bride and the groom step in, the two are sprayed with the water of rice flour on their hands and foreheads and sprinkled with husked and unhusked rice from right to left. Afterwards, the bride and the groom are again guided toward the dais where they take a seat and the others taste the foods served.

95 Jamee, "Mano dusanak nan urang tuo kami dirumahko, kami ko ado membawok sakapa nasi, antah lambiak, antah baratah, maklumlah buatan kami nan tuo-tuo, kok antah asin, antah hamba, ikolah nan ado kami bawok dakèk kakak di rumahko" (see Sulaiman 1978: 32).

96 Jamee, "Pembawok adikko, dikami indak kami pandang mantah, melainkan kami junjung diatèh kepalo kami, kètèk gunung, gadang pambawok adik kami ko" (see Sulaiman 1978:32). 
After the meal, the bride, guided by an old woman, is then introduced and she shakes hands with the parents and niniak mamak of the groom. The parents and niniak mamak give a monetary gift to the bride amounting to $\mathrm{Rp} 1,000$ to Rp.50,000. This ritual is called teumuntuak (see Ch.12). It is then continued by 'giving the bride' (Jam mamulangkan anak daro) to the host of the groom's side. This is performed by an old woman as the representative of the bride's side who delivers a traditional speech. The ritual of giving the food plates to the bride by the groom's side then follows (Jam memulangkan pinggan makan). This ritual symbolizes that the bride carries an obligation to look after the groom's property. The visiting group then leaves the house in the evening. Before leaving, the parents of the groom, through an old woman, presents another cloth and monetary gift called paragieh to the bride. The old woman says, "This is what his mother [groom's mother] has for you (Jam ini lah nan ado dari umaknya). It is replied with a grateful expression, "All praise and thanks be to Allāh" (Arb alhamdulillāh).

\section{Rituals after the wedding ceremony}

At about two to five days after the day of sending the bride to the groom's house, the "ritual of tracing back" (Jam maulang jajak) is held. In this ritual, the bride accompanied by several old women pay a visit to the groom's parents in the early morning. They bring along a present made up of glutinous rice. The bride does not wear the traditional wedding dress. The purpose of this visit is to get to know each other (Indon beramah tamah) and strengthen the already established relationship between the bride and the groom's families. They stay in the groom's house for a few hours. When leaving, the groom's families give a gift of cloth to them. ${ }^{97}$

Although the 'tracing back' ritual has finished, this does not mean that all adat interaction between both sides is over. The established relationship be-

97 In the capital city of South Acèh, Tapak Tuan, however, the ritual of fetching the bride (Jam manjapuik anak daro) is performed prior to the 'ritual of tracing back' (Jam maulang jajak). In the ritual of fetching the bride, the parents of the groom ask several old women to bring carano sirih to the bride's house which signifies a traditional endorsement of the invitation to the bride to pay a visit to her husband's parents. To comply with the invitation, the bride moves to the house of the groom's parents. She stays there for a night enjoying a warm welcome from the groom's family. Music and art performance such as kaba unggèh bamban and rentak kudo is presented to thoroughly entertain the bride (Sulaiman 1978:34). 
tween the two families through the traditional ceremony and ritual procedures continues. By custom, in fact, the traditional procedures are seen to be finished after one year of marriage after the bride delivers her first baby. For instance, two days before the celebration of the end of Ramadhan (Arb i $i d$ al-Fitr) and the celebration on the tenth day of Dzulhijjah (Arb $i d$ al-adhā), that is the day of meugang, the parents of the groom will send some needed materials such as meat, coconut oil, coconut, glutinous rice, etc including the materials for the making of traditional cakes for celebrating meugang days to the bride's house. In return, on the same day and on the day of 'i $\bar{l}$ al-Fitr and ' $\bar{l} d$ al-adha the bride presents the groom's parents with cakes such as lomang and juadah. Again, the parents of the groom reciprocate the gift by putting money in the place where the bride had placed the gifst to them earlier (see Ch.10). This ritual, too, applies when the bride is pregnant and when giving birth. During the days of pregnancy, for instance, the parents of the groom send required materials such as coconut, coconut oil, rice, glutinous rice, betel leaves, cooking spices etc to the bride's house to conduct the ritual of "giving rice to the midwife" (Jam kanduri maagieh nasi biden). On the day of delivery, the husband's mother will send presents (a cradle, bedclothes, and jewelry) to the daughter-in-law in preparation of the bathing ritual (Ach peutron bak ie) for the newborn baby.

The spouses stay in 'one kitchen' (Indon satu dapur) for a year or more or until they are seen as capable of financially and socially running their own family. When they have decided to live on their own, a ritual of "separation of the cooking pot" (Jam paasieng periuk) is held. It is intentionally conducted to indicate the readiness of the spouses to live on their own. In the ceremony, the wife's parents hand over needed wealth such as rice fields, garden, livestock, and domestic equipment for continuing their life to the spouse. These gifts are called panulang or peunulang. Although this ritual marks a separation of the responsibility, it does not necessarily mean a separation of house. They remain in the same house until they can afford a house of their own. If the wife is the only child or her siblings have acquired their own houses, the wife's parents' house is destined for them so that the daughter inherits the house. See the following summary of stages in the establishment of affinity (table 3). 


\begin{tabular}{|c|c|c|c|}
\hline Phases & Names & Actions & $\begin{array}{l}\text { Relations: kinship + } \\
\text { others }\end{array}$ \\
\hline Risiak & Talangkai & $\begin{array}{l}\text { Seeking information regarding } \\
\text { the prospective bride's side }\end{array}$ & Niniak mamak (MB) \\
\hline Bisiak & Talangkai & $\begin{array}{l}\text { Negotiating with the prospective } \\
\text { parents of the bride's side in } \\
\text { marriage }\end{array}$ & Niniak mamak (MB) \\
\hline Dohai & $\begin{array}{l}\text { Both parents of the } \\
\text { groom and bride, } \\
\text { niniak mamak and } \\
\text { wali hukum }\end{array}$ & $\begin{array}{l}\text { Beginning to make their } \\
\text { consultation public by inviting } \\
\text { niniak mamak and wali hukum. } \\
\text { This meeting is called rapat } \\
\text { niniak mamak }\end{array}$ & $\begin{array}{l}\text { Parents of the groom } \\
\text { and bride, niniak } \\
\text { mamak and wali hukum }\end{array}$ \\
\hline Menendei & $\begin{array}{l}\text { Keuchik, imām, } \\
\text { niniak mamak and } \\
\text { wali hukum }\end{array}$ & $\begin{array}{l}\text { Presenting a 'mark of } \\
\text { engagement' to the prospective } \\
\text { bride's side. }\end{array}$ & $\begin{array}{l}\text { Niniak mamak, wali } \\
\text { hukum and keuchik, } \\
\text { imām. }\end{array}$ \\
\hline $\begin{array}{l}\text { Wedding } \\
\text { ceremony }\end{array}$ & $\begin{array}{l}\text { Niniak mamak and } \\
\text { wali hukum, tuwo } \\
\text { ampèk, keuchik imām, } \\
\text { tuwo ampèk and } \\
\text { neighbours. }\end{array}$ & $\begin{array}{l}\text { Calling a meeting to set the date } \\
\text { and discussing thoroughly } \\
\text { problems relating to the } \\
\text { preparation work led male } \\
\text { members of niniak mamak. }\end{array}$ & $\begin{array}{l}\text { Niniak mamak, wali } \\
\text { hukum, keuchik, imām, } \\
\text { tuwo ampèk and } \\
\text { neighbours. }\end{array}$ \\
\hline \multirow[t]{5}{*}{$\begin{array}{l}\text { Maantra } \\
\text { marapulai }\end{array}$} & $\begin{array}{l}\text { Keuchik, imām, } \\
\text { niniak mamak, wali } \\
\text { hukum, tuwo ampek, } \\
\text { neighbours, male and } \\
\text { female friends of the } \\
\text { groom }\end{array}$ & $\begin{array}{l}\text { Transfering the groom to the } \\
\text { bride's house and giving the } \\
\text { market goods and garden } \\
\text { produce to the bride's family. }\end{array}$ & $\begin{array}{l}\text { Keuchik, imām, niniak } \\
\text { mamak, wali hukum, } \\
\text { village elders, } \\
\text { neighbours, male and } \\
\text { female friends of the } \\
\text { groom }\end{array}$ \\
\hline & Keuchik & $\begin{array}{l}\text { Handing over gifts to the bride's } \\
\text { side }\end{array}$ & Keuchik \\
\hline & Imām/kadhi & $\begin{array}{l}\text { Uttering of marriage conducted } \\
\text { for the groom and the bride }\end{array}$ & Imām/kadhi \\
\hline & $\begin{array}{l}\text { The father of the } \\
\text { bride }\end{array}$ & Signing the contract of marriage & Wali hukum (FB) \\
\hline & Tuwo ampèk & Paying the bride price & $\begin{array}{l}\text { Tuwo ampèk of the } \\
\text { groom's side }\end{array}$ \\
\hline \multirow[t]{4}{*}{ Menjelang } & $\begin{array}{l}\text { Keuchik, imām,niniak } \\
\text { mamak, wali hukum, } \\
\text { tuwo ampèk, } \\
\text { neighbour, male and } \\
\text { female friends }\end{array}$ & $\begin{array}{l}\text { Transfering the bride to the } \\
\text { groom's house }\end{array}$ & $\begin{array}{l}\text { Keuchik, imām, tuwo } \\
\text { ampèk, niniak mamak, } \\
\text { wali hukum, } \\
\text { neighbours, male and } \\
\text { female friends of the } \\
\text { bride }\end{array}$ \\
\hline & $\begin{array}{l}\text { An old respected } \\
\text { woman }\end{array}$ & $\begin{array}{l}\text { Giving the cooked market goods } \\
\text { and garden produce to the } \\
\text { groom's side. }\end{array}$ & $\begin{array}{l}\text { A female reprentative } \\
\text { of the bride's side }\end{array}$ \\
\hline & $\begin{array}{l}\text { An old respected } \\
\text { woman }\end{array}$ & $\begin{array}{l}\text { 'Giving the bride' to the host of } \\
\text { the groom }\end{array}$ & $\begin{array}{l}\text { A female representative } \\
\text { of the bride's side }\end{array}$ \\
\hline & $\begin{array}{l}\text { An old respected } \\
\text { woman }\end{array}$ & $\begin{array}{l}\text { Giving the foodplates by the } \\
\text { groom's side to the bride }\end{array}$ & $\begin{array}{l}\text { A female representative } \\
\text { of the groom's side }\end{array}$ \\
\hline
\end{tabular}

Table 3. Stages in establishing affinity 


\section{Conclusion}

In Aneuk Jamee society, men play a more active role in finding a match than women. That is why men are personified as "beetle" while women are passive and await the "coming beetle" and are personified as "flower". Men propose a marriage while women cannot, but they have the right to agree or disagree to the proposed marriage. Even so, the final decision is in the hands of the parents who first decide and, thus, arrange whom their children are to marry. Parents ask their son's agreement prior to proposing a woman and conversely, the agreement of the woman is more often neglected. Modernization has inevitably led to changes in the cultural and structural system of traditional society and in the traditional society of the Aneuk Jamee. Women and men are currently inclined to be more independent of their parents'choice in deciding their match. Thus, parents now have fewer roles in choosing their son's marriage partner.

The engagement ceremony carries the sign of intended marriage that a woman has been traditionally 'bound' to a man. The prerequisite for marriage is respecting the norms regulating the matrimonial processes. It consists of certain procedures to be completed before the ijab qabul ritual is undertaken to ensure that the marriage is lawful and valid. Among the prerequisites are health (both physical and mental) and wealth (bride price). These prerequisites are all in line with Islamic teaching. In all phases of the Aneuk Jamee marriage ritual, the group who negotiate, decide, perform the ritual, exchange gifts are defined or recruited on the basis of kinship and affinity; they are all the nuclear family of the bride and the groom, niniak mamak, wali hukum and in terms of authority in local organizations such the keuchik, the imām, tuwo ampèk, neighbour, and male and female friends of the bride and the groom (see summary above). The whole ritual culminates in the establishment of affinity. These people are in terms of Shari'ah law represented by the imām, in terms of adat they are represented by keuchik (the village head), in terms of the village elders they are represented by tuwo ampèk and so on. However, the whole single image is that authority in conducting a marriage relationship does not derive from the patrilineal relatives but from the matrilineal ones. Any time we look at negotiation, exchange, gifts, it is the niniak mamak that presides. On the one hand, there is a concept of patrilineal kiship which stresses patrilineal descent, that is wali hukum and on the other hand, there is a Minangkabau concept of kinship which 
stresses matrilineal descent in constructing the marriage relationship. Wali hukum do not seem to play many significant roles in the establishement of affinity. The role of the bride's father as wali hukum in this ritual is signing the contract of the marriage. Another role, that is uttering the marriage contract conducted for the bride and the groom is not performed by him but by tuangku imām/kadhi. Most parts of the ritual are performed by both niniak mamak of the bride and groom. Never are a bride and groom represented by wali hukum. Niniak mamak is responsible in marriage; most transactions are performed by niniak mamak in the rituals. The sibling of the bride and groom are not given any formal roles in the wedding ceremony.

The Aneuk Jamee's wedding is accompanied by an elaborate series of gift exchanges between the groom and the bride's parents. Apart from the exchange of money and jewelry, the gifts given from the groom's side to the bride's called hantaran are the market goods such as cloth, cosmetic products, fruit, toilet articles, trinkets, etc. These gifts are reciprocated by the bride's side to the groom's side and are not distinguished by special terms but consist of cooked food which is prepared by women in the kitchen. The notion of marriage in the Aneuk Jamee is, therefore, of some theoretical significance in understanding the domestic life of the Aneuk Jamee society. In the complex web of the reciprocal gift exchange that characterizes the Aneuk Jamee wedding and in the definition of the domestic roles in the household that are about to be established, the wife provides the home as well the cooked food for the husband. This exchange is conceptualized as a relation between the host (wife) and the guest (husband). 


\section{Chapter 5}

\section{The ritual of ' $\bar{a} \operatorname{sy} \bar{u} r \bar{a}$}

This chapter explores the ritual of khanduri 'assyūra $\bar{a}$ in the month of Muharram (the first Islamic lunar month, January). The month of Muharram and the days of 'asy $\bar{u} r \bar{a}$ have to be seen in a mythical context because this period of time is given meaning through teungku. People talk about and remember the Prophet Nuh (Noah), the war between Muawiyyah and Ali, the killing of Husén, all these things happened in this month and so give a certain meaning to this period. They give a different aspect or dimension because they refer back to events in the past that are true for believers. However, the mythical context given by different informants and put forward as explanations of the meaning of the ritual 'assyūra are very diverse.

\section{The mythical valorization of the month and the days}

\section{The month of Muharram}

Prior to the coming of Islam, Muharram was known as a 'holy month' (Indon bulan suci) when it was prohibited to wage war and shed blood. The number of lunar months, according to the Qur'ān, is twelve, and there are four lunar months classified as 'holy' (Indon suci). They are Muharram, Ra'jab, Dzulkaidah, and Dzulhijjah (QS 9:36). This does not mean that other lunar months do not have great importance. There is the month of Ramadhan, the month dedicated to fasting, which is considered the 'holiest month' of the year. My informants insist that basically every lunar month is the same, but Allāh has greatness and His wish is to choose a special month when He sends down His mercy to all human beings.

In Acèh, the lunar month of Muharram is classified as 'the month of Hasan Husén' (Ach buleuen Asan Usén or buleuen Hasan Husén). Hasan is venerated as a saint and the 'āsyūrā ritual bears his name and that of his brother Husén. In addition, the Muharram month in Acèh is also called the 'fire-month' (Ach buleuen apui). The first ten days are regarded as inauspicious and the whole month is regarded as a 'sad month' (Jam bulèn ibo;Ach buleuen seudéh), as so many tragic events are believed to have happened in this month, such as the battle between Ali and Muawiyah, between Husén and Yazid, it is the time when the people did not have enough food to eat after leaving the ark that the 
Prophet Noah had built on the hill of Judyy in the eastern area of Turkey. They had run aground about after seven months of floating. This month, therefore, is inauspicious for starting activities such as trading, cultivating, building houses, getting married, digging wells etc. If the villagers start something, the results will turn out badly. One village teungku gave two examples: Abu Adnan in Bakongan, South Acèh held the marriage ceremony for her daughter in the Muharram month, but three months later her daughter was divorced by her husband. The teungku also cited the case of Ustad Budi who began building his house during Muharram month but soon after the house was built, it burnt down. However, it is said that doing something bad such as stealing, gambling, murdering meets with the right punishment produces the intended results in this month.

In this lunar month Acèhnese people perform a ritual called the ritual 'āsyūrāa. According to Abu Dasyah, a charismatic 'ulamā' in West Labuhan Haji district, the ritual of 'āsyūrā was initiated when the deluge subsided after Allāh had ordered the earth to reduce its water and the sky to withhold its rain. The eighty followers of the Prophet Noah were safe on the ark. They were all hungry as they did not have enough food to eat. There were only the remains of some rice, corn, yams, potatoes, cassavas, squashes, etc. They made porridge with the last remaining things so that all those saved could eat.

During a 'religious discussion' (Indon pengajian) at his house, Teungku Sulaiman in Blangporoh village related that when the deluge had stopped, there were eighty people on the ark. Forty were male and forty were female, four of them were the children of Noah; they are Samma or Abu Arabi, Ham or Abu Saudani, and Yafits or Abu Narki. ${ }^{98}$ Kan'an, another of Noah's son and his wife did not survive because they did not board the ark. Even though Noah called them saying "O my wife and son, come aboard with us and do not stay with the disbelievers", "there are no safe places today except on the ark", and "there is no protector from the decree of Allāh, except for whom He gives mercy", they disobeyed Noah. They refused Noah's plea and fled to the mountain

98 Ham or Abu Saudani descended the nation of Habsyi and Zangi that have black skin. Sam descended the Roman Arab and Ajam, and Yafits or Abu Narki descended the nation of Barbar Turkish, Mongol, Ya'juj and Ma'juj. Another history version says that Noah only had two son; Ham and Yafits. Ham became a king in Egypt and Yafits became a king in Hindustan (India) (Effendie1979:139). 
instead. The waves came and they later drowned together with other unbelievers because the flood was higher than the mountains. ${ }^{99}$

In his Friday sermon in the month of Muharram in Blangporoh mosque, a preacher said that the length of the ark was three hundreds $z i r a{ }^{\prime} a h^{100}$ (about 150 meters), the width of the ark is thirty zira'ah (about 15 meters), the breadth of the ark is fifty zira'ah (about 25 meters). The ark consists of three levels. The lower level is for animals, the middle level for human beings, and the upper level for birds. The ark floated from the tenth day of Ra'jab (i.e.July) and came aground on the hill of Jūdyy in eastern Turkey on the tenth day of Muharram, "away from the wrongdoing people". The deluge took place over seven months, from Raj'ab to Muharram. After the deluge dried up, Prophet Noah ordered the people who were on the ark to collect all the remaining food supplies (Ach bekai). The types of food remaining were; 1) a handful of khinthah (wheat), 2) a handful of 'adas (a kind of peanut), 3) a handful of ful (a kind of bean), 4) a handful of himmason (yellow beans), 5) a handful of bur (rice), 6) a handful of raz (also a kind of rice), 7) and a handful of ma'asyi (a kind of seed plant). ${ }^{101}$ The Prophet Noah himself named these seven remaining food supplies 'asyūrāa. They were then cooked by him for the eighty survivors. All eighty survivors were full after eating the porridge cooked by Prophet Noah although it was not much. This is deemed the origin of the 'assyūra porridge.

\section{The day of ' $\bar{a} s y \bar{u} r \bar{a}$}

The tenth day of the Muharram lunar month is called the day of 'assyürāa. Before this day comes Blangporoh villagers start talking about it a week earlier, at the beginning of the Islamic year (the first day of Muharram). Welcoming the Islamic New Year in Blangporoh is by performing do'a to Allāh and praising the Prophet and his family (Ach seulawet) at mosques and in homes. The villagers pray that Acèh will always be in peace and that (after the tsunami) no more catastrophes will occur. When the celebration of welcoming the Isamic New Year at Blangporoh's mosque takes place, people talk about the 'āsyūrā

99 Related to this story, see the Qur'ān (11:41-48).

100 Zira'ah is an Arabic term means 'cubic'. One zira'ah is about a half meter.

101 The explanation of these seven sorts of food supplies can be found in kitāb (santri reference book) I'anah at-Thalibin Vol. II'. In some parts of Acèh, the 'āsyūrā porridge is prepared in seven colors because when the flood subsided, the remaining food consisted of seven sorts of food supplies. 
day and say "We are nearing the "āsyūrā day" (Jam kito alah dakèk hari 'àsyūrā) and are happy about it.

According to local belief, the day of 'āsyūrā recalls a number of important events and a prodigious number of other important miraculous events. Some informants said that on the day of ' $\bar{a} \operatorname{sy} \bar{u} r \bar{a}$, the Prophet Adam was created and sent down to earth; Allāh created His holy seat (Arb 'arash) and the tablet on which the record of the decision of the divine are preserved (Arb laukh ma$k h f u d z)$; Allāh gave His grace to Adam and Eve when they sought repentance (Ach tobat) after being thrown out of paradise; Allāh received the repentance of Adam; Prophet Ibrahim was born, and Allāh received Prophet Abraham's repentance; Saidina Ali, the fourth companion of Prophet Muhammad was martyred; the Prophet Noah and his followers touched land safely with their ark; Prophet Idris was endowed by Allāh with a noble position and ascended into the sky; Allāh saved Prophet Abraham from the fire after being burnt by King Namrud of Babylon; Moses received a revelation directly from Allāh on the Sinai Hill; Prophet Yusuf was set free from jail and his name was cleared of having raped Zulaikha, the Egyptian king's wife. The Prophet Yacob recovered from a serious eye disease; the Prophet Yunus emerged safely from the stomach of a giant fish. The day of ' $\bar{a} s y \bar{u} r \bar{a}$ also coincided with the recovery of the Prophet Ayyub from a serious cholera; it was the reunion of Jacob and Joseph after their separation for forty years; it was the birth day of Jesus and his ascension to heaven. The sin of the Prophet Dawud was forgiven by Allāh; Prophet Sulaiman was endowed by Allah with a noble position and given a kingdom. Prophet Muhammad's sin was forgiven. It was the first day that Allāh created the world and sent down rain to the earth. Gabriel was created. Prophet $\mathrm{Mu}-$ hammad married Khadijah; it was the day of the creation of heaven, the earth, the pen (Arb qalam), Adam, and Eve. Furthermore, it was the first time that Allāh bestowed His grace onto the earth and it is even also said that the Judgment Day will happen on the day of ' $\bar{a} s y \bar{u} r \bar{a} .{ }^{102}$

Other informants said that on the tenth day of the Muharram month, Saidina Husén who held the power inherited by his brother Hasan was martyred. The imām relates that at the end of the war between Ali and Muawi-

102 In deep discussions with several village old men, most of these ideas here are the same as found in Cirebon (see Muhaimin (2004:170). 
yah, ${ }^{103}$ there was reconciliation and they were united. But then they divided into two groups called Khawarij Ali and Khawarij Muawiyah respectively. The Khawarij Muawiyah came to oppose Husén bin Ali, the war was waged on the Karbala field in Iraq. Husén was killed on the tenth day of Muharram, that is on the 'âsyürā day. Husén was then beheaded; his head kicked around like a ball. This is said to be the origin of football (Ach asai usui meuèn bola), for this reason in the past, the Acèhnese 'ulamā' prohibited football in Acèh. ${ }^{104}$ The motivation behind the event was that Yazid bin Muawiyah wanted to take power from Husén because he felt entitled to become a khalifah. In the narrative (Indon hikayat) of Hasan-Husén, one of the verses (Indon bait) about the martyrdom of Husén runs as follows:

Bak siploh huroe buleuen Muharram Kesudahan Husén Jamali

On the tenth of Muharram

Peu na mudah ta khanduri

That is the last day for Husèn

Pota Allāh bri pahla dudoe

What we have for the khanduri

Allāh will give religious merit later

Before the martyrdom of Husén, Hasan had been poisoned by his own wife, "Laila Majnun" on the orders of Yazid bin Muawiyah. After that Husén was killed as described in the following song of Hasan Hisén.

Lheueh syahid Hasan ji prang lom Husén Ji neuk poh bandum cuco Saiyidina Ji krah pasukan bandum di yue tron Leungkap ban ban dum alat senjata
After Hasan was martyred, now it is Husen's turn They want to kill all the Prophet's grandsons All troops are ready to mobilize All complete with weapons

In relation to the 'āsyūrā day, Snouck Hurgronje I (1906:205) wrote the following:

The noisy celebrations of these festivals, which may now be witnessed year by year at Kuta Raja [now Banda Acèh] are for the most part celebrated by the Padang people who have settled there. Some Kling and Hindus take part, but the Achehnese act merely as spectators. Wherever in

103 The war between Ali and Mu'awiyah is known as Shiffin (Arb siffin) war, the site of a battle in 657 between the forces of Ali and Mu'awiyah both claiming the caliphate. During the battle Mu'awiyah's forces placed the pages of the Qur'ān on their swords and lances which caused the forces of Ali great consternation and led to their failure to press the battle. Mu'awiyah's success allowed him to consolidate the Umawi kingdom over the Muslim community (Federspiel 1995:239).

104 This is the reason when I was at elementary school; I was chased by an imām in my village because I played football. He said that playing football was forbidden (Arb $\underline{h} a r \bar{a} m$ ). He suggested that it was better for me to look for the fern leaves (Ach on paku), cook and then eat them. 
Acheh or its dependencies many Kling or other Indian Muslims had settled, the tâbut procession always took place, but the participation of the native people in these festivals is undoubtedly a later phenomenon.

It is believed that the the tâa $\bar{u} t$ processions have their origins from Indian Muslims, and Indian traders called Kléng and Hindu brought it to Acèh. The precise origin of the tâa $\bar{u} t$, however, is not certain but it can be traced in several cultural areas throughout the Muslim world. The Qur'ān mentions the word $t \bar{a} b \bar{u} t$ twice, but its significance is not the same as that of the present-day festival. Al-tābūt is first appears in the Qur'ān (QS 2:248), ${ }^{105}$ where it is cited in relation to the great ark constructed by Noah to escape the deluge. Elsewhere this same term designates the vessel in which the infant Moses was placed to float down the river in safety from the Pharaoh (QS 20:39). ${ }^{106}$ Yet $t \bar{a} b \bar{u} t$ is best understood with specific reference to Muharram observances, which commemorate the martyrdom of Husén. The other informants said that the tenth day of the Muharram month is the day of the victory of the Prophet Moses over Pharaoh. An old man in Blangporoh remembers the day of 'âsyūrā as follows:

'Āsyūrā siproh Muharram

Fir'un karam lam laôt raya

Musa ngon kawom Tuhan peuleupah

Ie laôt bekah rot jalan Musa
'Asyūra is the tenth of Muharram

The Pharaoh sank in the big sea

Allāh saved Moses and his followers

The sea water was split when Moses passed

Based on the diversity of the mythical contexts the meaning and the value of the ritual 'assyüra are derived and the Blangporoh villagers cook the porridge and celebrate having been saved from the deluge by Allāh. This ritual consists of several activities: 1) Preparing the 'assyūra $\bar{a}$ porridge commemorating the first meal consumed after the ark ran aground. 2) Observing the tasu'a (fasting on the ninth day) and the 'asyyurrāa (fasting on the tenth day) of the Muharram month. 3) Rahop ulèe of the orphan and 4) performing the 'āsyūrā prayer.

105 QS 2: 248, “And their Prophet said to them. Indeed, a sign of his kingship is that the chest will come to you in which is assurance from your Lord and a remnant left by the family of Aaron carried by the angels. This is indeed a sign for you, if you are believers."

106 QS 20:39, "[Saying], Cast him into the chest and cast it into the river, and the river will throw it onto the bank; the river will bring him as an enemy to Me and an enemy to him. And I bestowed upon you my love so that you would be brought up under My eye [i.e., observation and care]". 


\section{The ritual of ' $\bar{a} s y \bar{u} r \bar{a}$}

\section{Preparing the'āsyūrā porridge}

On the ninth day of Muharram, the leader of group of housewives willingly comes to every Blangporoh store and the houses near them to ask for donations to cook the 'âsyūra $\bar{a}$ porridge called kanji 'assyürā on the ninth day of Muharram. One of the house wives asks for a donation but she does not determine how much money or how many things the shopkeepers and the villagers should donate. They ask how much the villagers sincerely want to give (Indon seikhlasnya) for the ritual. The 'āsyürā porridge consists of sticky rice (Jam barèh sipuluit; Ach breuh leukat), coconut milk (Jam santèn karambi;Ach santan u), sugar (Jam gulo; Ach saka) and salt (Jam garom;Ach sira) mixed with various fruit cut into small pieces; such as cassavas (Ach bòh ubi), squashes (Ach bòh labu), yams (Ach bòh keutila) etc.

All the food for making the 'āsyürā porridge are from villagers' donations. One store keeper gives green beans (Ach kacang ijo), another one gives squashes (Ach bòh labu), another one gives cassavas (Ach bòh ubi), or yams (Ach bòh keutila), jackfruits (Ach bòh panah), sticky rice (Jam barèh sipuluit; Ach breuh leukat), coconuts (Ach bòh u), sugar (Ach saka), salt (Ach sira), civet cat's pandanus (Ach on seukè musang), bananas (Ach pisang wak or bòh pisang panah). Other food such as corn (Ach bòh jagong) and creeping edible tubers (Ach bòh gadong) that are not found in the market at Blangporoh, are bought by one of the committee members from a market at Manggéng, and another district near West Labuhan Haji district.

The villagers who live near the store donate money for the ritual of ' $\bar{a} \operatorname{sy} \bar{u} r \bar{a}$, and the villagers who have nothing to contribute, come and help wash and peel all the ingredients used for making the 'assyūrāa. Several women come in the morning to wash and to peel vegetables. Some young men help peel the coconuts and placing the cooking stones (Ach sinungkèe). In the early afternoon, someone begins cooking in front of the village stores on behalf of the village as a whole. ${ }^{107}$ The food is usually cooked in a very large iron pot called

107 In the past the ritual of 'āsyūrāa was usually held in a 'prayer house' (Ach meunasah). Every family brought food and after the praying led by the leader of the 'prayer house' ate together. The orphans and the poor received good meat, fish and other side dishes. During the 'ásyūrā day in some parts of Acèh, several verses from the tale of HasanHusén were read. Many Acèhnese spectators cried, because they remembered the trage- 
kancah. Housewives from other 'clusters' areas (Indon dusun) of the village also come and help cook. While cooking, the housewives talk and joke and laugh. At about four o'clock in the afternoon, the 'āsyürā porridge is cooked.

It is then distributed. The leader of the women's group first takes the hot porridge with a ladle and places it into containers presented by children. Some children eat it on the spot and others take it home. Cooked porridge is also put in plastic bags and given to each store and house for breaking the fast on that day, "This is the khanduri for breaking the "āsyürā fast" (Jam iko kandurie untuk buko puaso 'āsyūrāa). One woman explained, "the 'āsyūrā porridge is cooked and given to the whole community, especially to those who observed the fast on this day ( ' $\bar{a} s y \bar{u} r \bar{a}$ day), the poor, and the orphans, guests who have come from other areas as well as for those passing through our village by chance today". ${ }^{108}$ It is also given to the students of dayah (boarding school) and to Abu Ruslan Waly, the head of dayah in Blangporoh. One says that in the past, the 'āsyūrā porridge was also placed in a coconut shell (Ach bruek $u$;Indon tempurung) hanging at the junction of the village path (Ach babah jurong) and the main road, so that people who wanted to visit their families or returned home could easily take it. This gift of porridge is, therefore, called the khanduri babah jurong "khanduri of the junction where the village path meets the main road".

At about six o'clock in the afternoon, all the cooked porridge has been distributed; those who helped cooking and washing up receive some extra porridge from their fellow-villagers. When they have finished the women return the cooking utensils to their owners and return home.

\section{Observing the fasting of tasu' $\bar{a}$ and ' $\bar{a} s y \bar{u} r \bar{a}$}

Every devout person especially old men, old women including the majority of students at the dayah of Syeikh Muda Waly observe the fast on the ninth day of Muharram called puasa tasu' $a^{109}$ and the tenth day of Muharram called puasa 'âsy $\bar{u} r \bar{a} .{ }^{110}$ Observing fast on these days is voluntary.

dy that befell the family of the Prophet Muhammad on the 'âsyūrā day (Serambi Indonesia, December $\left.30^{\text {th }}, 2007\right)$.

108 Jamee, kanji 'āsyūrā yang alah masak diagih kepado seluruh masyarakat, terutama pado urang yang puaso pado hariko ('āsyūrā), urang-urang miskin, anak yatim, tamu yang baru datang dari daerah jugo dan pado urang-urang yang kebetulen lewat ka kampung kito pado hariko.

109 Tasu'a is from the Arabic word tis'äton means nine.

110 'Assyūra from the Arbic word asyāraton means ten. 
There are different opinions about the required observance of the fast. One housewife says "Observing fast on the ninth day of Muharram is to differentiate between Muslims and Jews. The Jews only observe the fast on the tenth day of Muharram but we here in Blangporoh observe the fast on the ninth and the tenth day of Muharram or the tenth and the eleventh day of Muharram". ${ }^{111}$ Another housewife also observes the fast of tasu'a. She says that she is not so sure that the day of ' $\bar{a} \operatorname{sy} \bar{u} r \bar{a}$ is on the tenth day of Muharram even though many Islamic scholars say so. It could be that 'āsyürā falls on the ninth day of Muharram. ${ }^{112}$ In order to ensure that she fasts on the day of 'āsyzur $\bar{a}$ thereby receives religious merit, she observes the fast both on the ninth and tenth day of Muharram. The Blangporoh imām also observes the fast of tasu'a and 'āsyürāa. He strongly insists that a law (Ach hukom) of observing a fast only on the day of ' $\bar{a} \operatorname{sy} \bar{u} r \bar{a}$ is forbidden (Arb harām) ${ }^{113}$ as the Jewish people only observe the fast on the day of 'āsyzur $\bar{a}$. Should a Muslim only observe the fast on the tenth day of Muharram, this is not acceptable as it coincides with the fasting days in Jewish tradition; this is seen to be in contradiction to Islam. The Kutaiboh imām also has the same opinion. He says that observing fasting tasu'a and followed with the fast of ' $\bar{a} s y \bar{u} r \bar{a}$ is done in order not to resemble (Arb tasyabbuh) the Jews who only observe fast of ' $\bar{a} \operatorname{sy} \bar{u} r \bar{a}$. It, therefore, is recommended to observe the fast on two days either on the ninth day and the tenth day of Muharram or the tenth day and eleventh day of Muharram. One village old man, however, is of a different opinion; he says that if a Muslim only observes the fast on the tenth day of Muharram, the law has not been broken but is considered to be makruh. ${ }^{114}$ Nonetheless, another old villager has another argument. He says that if one observes fast on the day of 'ásyūra , it is as if he or she has observed the fast for a full year. Besides observing the fast, a number of Blangporoh villagers prepare more food for their family on the ' $\bar{a} s y \bar{u} r \bar{a}$ day.

111 The Prophet Moses observed the fast on the day of 'āsyūrā as can be seen in a hadith narrated by Imam Bukhari in Ash-Shaum chapter 69. Moses and his followers fasted on the day of ' $\bar{a} s y \bar{u} r \bar{a}$ when they were saved from the Pharaoh's pursuit.

112 This ideas fits with Ibn 'Abbas School (Indon madhhab); the 'āsyūrā falls on the ninth day of Muharram. See an-Nablusi (2004:156).

113 Haram is a category of behavior which absolutely should not be undertaken by the believers, performing such action constitutes a sin.

114 Makruh, relating to an act which does not yield merit but the performance of which is not considered to be sinful. 
Many Blangporoh villagers observe the fast of tasu'a and 'āsyūrā even though some of them do not know why they fast on that day. Some female sellers at the village store state that observing fast and making the 'âsyūra porridge on the day of ' $\bar{a} s y \bar{u} r \bar{a}$ is a tradition passed on from one generation to another but they say nothing about the history of the 'āsyürā fast. My informant points out that the 'assyüra day has been the day of recommended fasting since the Prophet Noah, Moses and Muhammad fasted on this day. For this, one would obtain religious merit equivalent to kafarat (prayer to Allāh for forgiveness) for a year. One old fish monger in Blangporoh provides the 'āsyzurra porridge and drinks to the children on the day of 'āsyürā in order that Allāh will give food and drinks for him in the after life. Meanwhile one incense seller has another argument; he says that whoever gives water to the people on the day of 'âsyūrāa, will be prevented from engaging in immoral acts by Allāh. He further adds that whoever takes a bath on the day of 'àsyūrāa, will not be sick for a year. One imām in Kutaiboh, the neighbouring village, says that if someone dies on the day of ' $\bar{a} \operatorname{sy} \bar{u} r \bar{a}$, it is the same as if she or he dies in the Ramadhan month, he or she will not be tormented by the two angels, Munkar and Nakir in the grave. Moreover one teungku say "if someone visits a sick person on the day of 'āsyūrā, it is as if he or she has been visiting sick people since Adam's time". All these arguments have one thing in common; the extraordinarily high value of the acts performed on this day. This day is like one year, this day is like all time since Adam.

\section{Rahop ulèe of the orphans}

Rahop ulèe is the Acèhnese term meaning to carress an orphan's head (Ach ulee) in slow motion. Teungku said that slowly stroking the head of the orphan (Ach rahop ulèe aneuk yatim) with the right hand on the 'āsyürā day is suggested by the Islamic religion. The orphans whose fathers have passed away are called aneuk yatim and the orphans whose mothers have passed away are called aneuk mentui. Those orphans whose father and mother have passed away are called aneuk yatim piyatu. It is suggested aneuk yatim's head should be slowly stroked from the top of their head down to their face, while the head of aneuk mentui should be slowly stroked from the top of their head down to their nape. Meanwhile the head of aneuk yatim piyatu should be slowly stroked from the top of their head down to their face and one more time from the top of the head then down to the nape of the neck. 
As has been observed on the day of 'āsyūrāa, several villagers stroke the heads of aneuk yatim. Some say that stroking the head of the orphan slowly is one of the ways to show respect to the orphans. Some others, however, contend that stroking the head of the orphan is the Prophet's sunnah. ${ }^{115}$ Respecting the orphans is the "same as respecting the Prophet Muhammad". Stroking the face of the orphans is the "same as stroking the face of the Prophet Muhammad". This is preferably done on the 'āsyūr $\bar{a}$ day because Hasan and Husén were also orphans. On 'assyūra $\bar{a}$ day the people should stroke the head of the orphan with their right hand and all the hair that has been touched will ask Allāh to forgive the person's sins. In addition, it is said that whoever slowly strokes the head of the orphan with right hand and sympathizes with them, this is as if he or she has already done something good for all orphans since the time of Prophet Adam. According to one teungku, by slowly stroking the head of the orphans one will receive religious merit, but one will receive even more religious merit, if he or she gives alms to the orphans. The teungku contends that stroking the head of the orphan is one of the ways to make the orphans feel close to us all and they feel that attention is paid to them. He believes the 'blessing' (Ach beureukat) that is received when orphans receive attention from someone.

Slowly stroking the top of the head down to the face symbolizes that the orphans have no fathers, meaning no one stands in front of them for their further life and education. Slowly stroking from the top head down to the nape of the neck signifies that the orphans have no mothers meaning that there is no one standing behind them to bring them up. Meanwhile slowly stroking the top of their head down to their face and then again from the top of their head down to the nape of their neck symbolizes that there is no one who stands in front of them and behind them. In this case, all Muslims in the village, especially their niniak mamak and wali hukum have to be responsible for their further life and education.

\section{The ' $\bar{a} s y \bar{u} r \bar{a}$ prayer}

A number of students at dayah (boarding school) Blangporoh including teachers perform a voluntary 'āsyūrā prayer (Ach semayang sunat 'āsyūrāa) in the dayah mosque during the night of 'âsyūrā in Blangporoh village but they do not do it together. They arrive at the mosque late at night, make the usual

115 Sunah (Arb sunnah) is 'ways of the Prophet', describing the style of life of the Prophet Muhammad, especially his belief, his behavior and observance of religious obligations. 
two cycles (Indon raka'at) ${ }^{116}$ of prayer which is called semayang sunek masajid in respect for the mosque, then seat themselves on praying mats facing the direction of Mecca (Indon kiblat) while uttering istighfār $r^{117}$ to ask Allāh's forgiveness. I am interested in Teungku Sulaiman who was once a student and now he is one of the teachers for the seventh class of the dayah. He represents the other teungku performing the 'assyūra a prayer on this night. Teungku Sulaiman performs a four-cycle of special recommended prayer alone that continues follows; he stands up straight. ${ }^{118} \mathrm{He}$ then says the intention (Jam nièt;Ach/Indon niat) of prayer while standing; his two hands are raised to his ears with the fingers open and the palms of his hands facing towards each other. While doing this he says 'Allāh is the most greatest' (Arb Allāhu Akbar). He then folds his hands over his waist, the right over the left, while the sürah of the opening of the Qur'ān (the sürah al- Fātihah $\underline{h})^{119}$ is recited:

Bismillāhirrahmā nirrahīm

Alhamdulillāhirabbil 'alamīn

Arrahmōnirrahīm

Mālikiyaumiddīn

Iyyākanak budu waiyyākanas ta'̄n

Ihdinashshirāthal mustaqīm

Sirāthallazì na an 'am ta'alaihim

Rairil maghzū bi alaihim

Walladhdhāllīn
In the name of Allāh, the Entirely Merciful, the Especially merciful

[All] praise is [due] to Allāh, Lord of the worlds. The Entirely Merciful, the Especially Merciful Sovereign of the Day of Recompensing It is You we worship and You we ask for help Guide us to the straight path

The path of those upon whom You have bestowed favor, not of those who have evoked [Your] anger or of those who are astray.

116 The essential unit of the prayer ritual, consisting of bows and prostrations performed a number of times as prescribed.

117 Istighfär is uttering astaghfirullāh hal'adhìm (I beg the pardon of Allāh the Greatest).

118 An incorrectly struck posture invalidates the prayer.

119 Al-Fätihah : The opening of the Qur'ān. Sürah titles are not an integral part of the Qur'ān. A distinguishing word in a particular surā $\underline{h}$ or a word defining its subject matter often becomes a common means of identification among the Prophet's companion and later scholars. Although some names, such as al-Fātihah $\underline{h}$, were used by the Prophet in reference to particular sürah, they were not specifically designated by him as titles (the Qur'ān 1997:1). 
After the sürah al-Fatih $\underline{h} \underline{h}$ is recited, and he then continues reciting the $s \bar{u} r a h$ of the purification of faith (the sürah al-Ikhlās) ${ }^{120}$ which he said after the prayer.

Khulhuwallāhu ahad

Allāhushshamad

Lam yalid walam yulad

Walam yakullahu kufuwan a had
Say, "He is Allāh, [Who is] One,

Allāh, the Eternal Refuge.

He neither begets nor is born,

Nor is there any equivalent to Him."

After that a bow is then made from the waist while saying Allähu Akbar. Then the two hands are again raised, as were done at the beginning of the prayer. When his back is bent over to the ground he places his two hands on his knees and his face is turned to the ground. Then he says, 'Allāh is the greatest and is the purest' (Arb subhāna rabbiyal 'azimi wabihamdih). After this he stands up again. While rising he says 'Allāh hears those who praise Him' (Arb sami 'allähu liman hamidah). When fully straight, he lets his arms rest beside him and continues saying 'praise belongs to Allāh, our praise fills heaven and earth and anything else You wish' (Arb rabbanā lakal hamdu milussamā wāti wamil ul ardhī wamil umā syiktā min syai im ba'du). After this he makes a full bow by lowering himself first to his knees, and then putting his two hands on the ground palms down and lowering his nose and forehead to the ground. In this position he says 'Allāh the highest and the purest' (Arb subhāana rabbiyal 'aklā wabihamdih). ${ }^{121}$ The bow is repeated during the first raka'at. He kneels between the two bows and in this sitting position his and his feet are crossed; his left foot is under his right while his right is perpendicular to the ground. His back is straight and his hands are placed over his knees. While kneeling he says Allāhu akbar and then he utters:
Rabbighfirlī, Warhamn̄̄
O Allāh forgive me, be merciful to me
Wajburnī, Warfaknī
Correct my weakness and raise my sight
Warzuqnī, Wahdin̄̄
Give me livelihood and guide me
Wa'āfinī, Wa'fuannī
Give me health and pardon my mistakes

This is one raka'at. Teungku Sulaiman then repeats this another three times with the same words and movements. He then ends the prayer with the confession of faith and the pronouncement of the greeting assalāmu alaikum warahmatullāh, one time to the right side first and then to the left side. After

120 In narration by Bukhārī and Aḥmad, the Prophet described this sürah as being equivalent to one third of the Qur'ān.

121 This phrase is recommended but not obligatory; it may be repeated until three times. 
finishing four cycles of prayer, he holds up his hands and recites the $d o^{\prime} a$; the contents of the do' $a$ recited by him consist of five parts. In the first part, he praises Allāh and prays for the Prophet and his family. ${ }^{122}$ In the second, he seeks Allāh's forgiveness for their teachers, parents, grandparents, neighbors, and friends and all Muslims in the world who are still alive and those who have passed away. In the third part, he recites a special $d o$ 'a on the night of ' $\bar{a} s y \bar{u} r \bar{a}$ as follows:

O Allāh, a sinful person has come to You, and You have ordered forgiveness of the sinful men. You are good and I am sinful, with the superiority of the night of 'āsyzir $\bar{a}$ please forgive the bad things I have done with Your mercy. O Allāh, please give Your goodness for me and make me rich from Your goodness. ${ }^{123}$

Here is a clear distinction between Normative and Historic Islam. The teungku practices the Historic Islam because he did not take his ideas from the Qur'ān, that is why he prays in Jamee. That is originally cultur specific because teungku switched his prayer from Arabic to Jamee but when the teungku takes his ideas directly from the Qur'ān, they pray in Arabic ${ }^{124}$ In the fourth part, he beseeches Allāh to prevent all disasters, and requests Allāh's perpetual blessing. In the fifth part, he asks Allāh's goodness in this world and the hereafter and to keep him safe from the fire of the hell on the Judgement Day.

On the early morning of the 'âsyūrā day on January $19^{\text {th }}, 2008$, I go to Teungku Sulaiman's house asking why he performs the special religious service (Indon ibadat kusus) on the night of 'äsyürā. He answers that performing the religious service (Ach ibadat) on the night of ' $\bar{a} s y \bar{u} r \bar{a}$, is the same as if he or she performed the religious service like the 'owners of the sky' (Indon ahli langit $)^{125}$ did. He says further that whoever performs a four-cycle of recommended prayer and recites the first chapter of the Qur'ān (the süra $\underline{h} a l-F \bar{a} t i \underline{h} a \underline{h}$ )

122 My informant says that praising Allāh and the Prophet Muhammad must be uttered first before asking Allāh for something otherwise the recited $d o{ }^{\prime} a$ is rejected.

123 Jamee, "Ya Allāh alah pa $i$ kepado Angkau urang yang badoso dan Angkau alah manyuruh untuk mengampuni urang badoso. Angkau yang rancak dan ambo urang yang badoso, maka dengan kelebihan malam asyurako ampunilah keburukan yang ambo pabuek ngen kebaikan dari sisi Angkau. Ya Allāh agihlah kebaikan Angkau kepado ambo dan kayokan ambo dari kebaikan Angkau"

124 There is something similar in Lao, if a ritual is purely Theravada Buddhism, a priest prays in Pali. But if it is a non-Buddhist ritual, the priest prays in Lao.

125 Ahli langit "sky beings", according to Teungku Sulaiman, are the malaikat who always observe religious service to Allāh in the sky. 
and the süra $\underline{h}$ purification of faith (the sürah al-Ikhlās) in every cycle of prayer (Indon raka'at), will be forgiven for his sins by Allāh for fifty years.

\section{Interpretation of the meaning of the value}

Aneuk Jamee and Acèhnese people as a whole, and especially Blangporoh villagers pay a deep respect to the 'āsyürā day because it is a great day and has a great virtue. Apparently the ritual of 'āsyūra in Blangporoh village is very lively as the village people perform it on one day and it has a very high value. The interpretation of the meaning and the value of distributing 'âsyürā porridge/performing the ritual of ' $\bar{a} s y \bar{u} r \bar{a}$ has two aspects. The first the ritual has a social meaning and value of strengthening the community ties by cooking the ' $\bar{a} \operatorname{sy} \bar{u} r \bar{a}$ porridge and by sharing it. Basically it expresses the value of generosity. The villagers offer the 'assyürā porridge to be distributed to neighbors, nextof-kin and those passing through the community on that day. They do it for their fellow people, for the community as a sort of charity and because Allāh saved Noah and his followers and Moses and his followers as explained at the beginning of the chapter. The second meaning is the religious meaning and value, that is the merit that one receives from Allāh when one performs the ritual of ' $\bar{a} s y \bar{u} r \bar{a}$, and the religious value is very high. One teungku said, "whoever observes the fast on the day of 'asyūrā will receive religious merit and the religious merit of the ' $\bar{a} s y \bar{u} r \bar{a}$ fast is the same as that of the fasting of Noah with his followers and Moses with his followers". Another teungku said, "those who give the 'assyüra porridge to the fasting people on the day of 'assy $\bar{u} r \bar{a}$ will receive the same religious merit as those who observe the fast on that day" and "the people who observe the fast on the day of tasu'a and 'āsyürā are the same as those who aided Husén bin Ali in opposing Yazid bin Muawiyah" and the other teungku said, "Those who make the 'âsyürā porridge on the day of 'āsyūrā will receive great religious merit from Allāh" as the 'āsyūrā porridge is a symbol of condolence because of the martyrdom of Husén and the religious merit received from holding the 'āsyüra porridge is destined for the deceased Hasan and Husén". Villagers also pray to Allāh in order that He gives a "large grave" (Jam lawèh kubur) ${ }^{126}$ to Hasan and Husén, and they get a good place behind Him as well as condemning Yazid bin Muawiyah who killed Husén.

126 The term "wide grave" (Jam luwèh kubur) is quite often said by the villagers to invoke the dead. My informant says that the "wide grave" does not merely mean that the grave 
The 'âsyūra porridge is the rice with coconut milk containing various ingredients. The message is clear enough. The 'āsyürā porridge itself, which is of a white color symbolizes the day of ' $\bar{a} s y \bar{u} r \bar{a}$ as 'holy', whereas the various ingredients contained in the ' $\bar{a} s y \bar{u} r \bar{a}$ porridge symbolize the various events that occurred on the day of 'assyūrā. The distribution of the 'āsyürā porridge on the 'äsyürā day represents the goodness of Moses and his followers who had been saved from the Pharaoh's persecution, and Noah and the survivors of the deluge. The khanduri of the 'āsyūrā porridge is said to be the symbol of safety (Indon keselamatan) of the Prophet Noah with his followers in the ark and of the Prophet Moses from the Pharaoh's pursuit.

Offering the 'āsyürā porridge is considered good because it is charity and a good tradition. Some fairly knowledgeable and devout individuals suggests that the celebration of ' $\bar{a} s y \bar{u} r \bar{a}$ would be better if it were accompanied by some devotional undertakings such as breaking fast together, praying together, reciting special invocations of 'a syyūra together, feeding and giving alms to the orphan and to the poor in the village. He contends that when it is performed together, the luster of the 'asyürā celebration in the village can be really felt and clearly seen, besides performing these activities on the day of 'āsyūra $\bar{a}$ brings religious merit. $^{127}$

\section{Conclusion}

In the month of Muharram, people perform the ritual of 'asyzurāa. In Acèh, the lunar month of Muharram is classified as "the month of Hasan Husén". The meaning of the month of Muharram and the days of 'āsyūrā are in terms of mythical contexts. The people associate the events of Muharram and 'āsyürā with different mythical contexts. Some stress Husén, some stress Moses and Pharaoh and some others stress the ark of Noah and so forth. Particularly the

is wide but most importantly is that the dead always receive the mercy of Allāh in the grave.

127 One fishmonger (Ach mugèe ungkôt) rarely does the prescribed prayers but he feels obliged to cook the 'āsyūrā porridge. I witness that on the day of ' $\bar{a} s y \bar{u} r \bar{a}$ he also cooks the 'āsyūrā porridge in a medium cooking pot individually in front of his house. It consists of only usual rice (Ach breuh bit), coconut milk, sugar and salt. When I ask him why the porridge is not mixed with various fruit, he answers, "This is only what I have; sticky rice and fruit are currently costly" (Jam iko yang ado ambo punyo, barèh sipuluit dan buah-buahan maha kiniko)". He then offers the cooked porridge to his neighbors and close relatives because he thinks it is easier and a more convenient way through which to express his religious obligation in order to celebrate the ' $\bar{a} s y \bar{u} r \bar{a}$ day. 
myth of Noah is important because it was deemed to be the occasion that the first porridge was cooked.

The first ten days of the month are regarded as inauspicious, the month as a whole is regarded as a 'sad month'. This refers to the episode in which "Husén, the grandson of the Prophet was martyred. The Khawarij Muawiyah came to oppose Husén bin Ali so that a war was waged on the Karbala field in Iraq. Husén was killed on the tenth day of Muharram, that is, on 'asyūrā day. Husén was then beheaded; his head was kicked around as a ball. This is said to be the origins of football, for this reason in the past, the Acèhnese 'ulama ' prohibited football in Acèh. However, there are also auspicious events believed to have taken place this month. One of these is the myth of the Prophet Noah and the deluge. People relate that how after seven months [from Ra'jab to Muharram] of floating; Noah's ark ran aground on the hill of Jūdyy in eastern Turkey. The eighty followers of Noah were saved but they did not have enough food to eat. The only food left were bits of rice, corn, yams, potatoes, cassavas, and squashes. From these remains they cooked porridge for everyone to eat. This is deemed the origins of the 'āsyūrā porridge.

This day recalls a prodigious numbers of other important miraculous events in the Islamic tradition. These events include the creation by Allāh of heaven and earth, of His holy seat and of the tablet on which the records of the divine decisions are preserved (Arb laukh makhfudz); the creation of Adam and Eve; the bestowal of Allāh's grace upon Adam and Eve and later upon the Prophet Ibrahim after their repentance; the reception by Moses of the revelation from Allāh; the birth and ascension to heaven of Jesus; the Prophet Muhammad being forgiven for his sins by Allāh, and so forth. On this day, Allāh bestows His grace upon the earth and it is even also said that the judgment day will be on this day. Based on this diversity of the mythical contexts, the meaning and the value of the 'assyūra ritual are derived.

The Blangporoh villagers cook the porridge and celebrate having been saved from the deluge by Allāh. This ritual consists of four activities: 1) Preparing the 'ásyūrā porridge commemorating the first meal consumed after the ark ran aground. 2) Observing the tasu'a (fasting on the ninth day) and the 'assyürāa (fasting on the tenth day) of the Muharram month. 3) Rahop ulèe of the orphan and 4) performing the 'āsyürā prayer.

The interpretation of the meaning and the value of distributing 'assyüra porridge/performing the ritual of 'âsyūrā are twofold. Firstly the ritual has a 
social meaning and value, that is in strengthening the community ties by cooking the 'āsyzur $\bar{a}$ porridge and by sharing it; the villagers offer the 'āsyūra porridge to be distributed to neighbors, next-of-kin and people who pass through the community on that day. The second meaning is the religious meaning and value, that is the merit that one receives from Allāh when one performs the ritual of ' $\bar{a} s y \bar{u} r \bar{a}$. They do it for their fellow people, for the community on the one hand and because Allāh saved Noah and his followers and Moses and his followers on the other hand.

In addition, the people of Blangporoh commonly consider the martyrdom of Husén to be an extremely poignant and heartrending event and one of great historical importance but in the celebration, they do not involve Husén and his death [the tābūt procession] and do not ascribe creedal significance to it either. The religious merit received from performing this ritual is meant to be transferred to Hasan and Husén, the martyred grandchildren of the Prophet Muhammad, while begging Allāh to forgive their sins and allow them a "wide grave", that is, to release them from their torment. 


\section{Chapter 6}

\section{The ritual of tulak bala}

This chapter explores the ritual of 'warding off a calamity' (Ach tulak bala; also known as the ritual of bòh alén), this ritual is celebrated in Blangporoh village annually on the last Wednesday (Ach rabu habéh) of Safar (i.e. February), the second Muslim lunar month known as 'the month to ward off calamity' (Ach buleuen tulak bala). This ritual has two dimensions. On the one hand it wards off calamities by sending offerings to the sea where death, illness and calamities come from and at the same time it is an opportunity for boys and girls to meet so that they can select their marriage partners. This is a preIslamic foundation of tulak bala. The Islamic dimension is that death, illness and calamities do not come from Satan (Ach syètan), jinn and 'delicate creature' but everything is determined by Allāh. If one wants to protect oneself from death, calamities and illness, one has to invoke the protection of Allāh. Today the tulak bala contains both elements. On the one hand, all prayers, do'a, and sürah that are uttered for Allāh are cited as accepting Allāh's power to protect people but on the other hand, people still do what they used to do and say that the calamities also come from the sea. Here there are two elements; people have to pray to Allāh and they have to make offerings to the sea.

\section{The ritual of tulak bala}

The ritual was initiated by the Acèhnese ancestors (Indon nénék moyang) and is performed at several places. ${ }^{128}$ The performance brings considerable prestige and (economic) benefits to the villagers. On this occasion, many people including a large number of young men and women under the watch of their families travel in groups by trucks and cars to the designated places. In fact, this festival has been not only commonly observed in low land Acèh and some other coastal areas of Indonesia but also in many parts of the Peninsula of Malaysia including Morib in the state of Selangor, Port Duckson in Negeri Sembilan, and Bagan Luar in Penang. It is carried out "with particular zest and on an

128 For example at the river bank of Krueng Baru; the seashore of Blangporoh village in West Labuhan Haji district, South Acèh; the seashore of Calok in Sejahtera village, Manggéng, Southwest Acèh. 
elaborate scale" at Tanjong Kéling ${ }^{129}$ about seven miles north of Mélaka (Malacca), and also on the neighbouring island of Pulau Besar. ${ }^{130}$

The Safar lunar month, especially the last Wednesday of this month (Ach rabu habéh), is considered inauspicious. During this period there is an interdiction/ban on house building, on performing marriage rituals, on rice sowing or planting and other forms of land cultivation, on visiting a sick man or woman, on travelling, etc. On that Wednesday farmers are not allowed to go to their rice field and fishermen are not allowed to go fishing. Should a marriage ritual be held on this day, the couple would incur many debts throughout their life. One relates as follows:

It is taboo to look after your livelihood on the day of tulak bala. Should someone plant seeds, they will be eaten by birds. If someone goes to the sea to fish, he will get no fish because a catastrophe will happen. If someone goes to his or her garden or field in the mountains, he or she will thus be bothered by wild animals. All village people are requested to go to the seashores or river banks for the tulak bala ritual.

On this day young men and women as well as the aged gather at the seashore or at the riverbanks. They bring various kinds of food with them. Having arrived they set up camp for a few days, they will entertain themselves by singing to the accompaniment of a guitar. On the actual day of the ritual, some young men play football, and then take a ceremonial bath in the river or in the sea called manoe sapha. ${ }^{131}$ It serves to cleanse oneself of all misfortune or to release calamities (Ach peulheueh bala) that have come their way. The ritual of cleansing of the body on the day of 'warding off calamities' is believed to purify the 'soul/mind' (Indon jiwa) so that it cannot be harmed by Satan or other evil beings. It also serves to 'call back' one's own seumangat ("soul/mind") that may have "fled". The body without a 'soul/mind' is considered especially vulnerable.

The accidents, bad luck, epidemics and disasters believed to occur, particularly on the last Wednesday of this month, are attributed to Satan and other evil supernatural beings attacking human beings and cattle. The ritual of tulak

129 The term "Kéling" is the Malay form of 'Kalinga' and is a synonym for the people of South Indian origin. In Acèh the term "Kléng" refers to Indian traders still living in Acèh.

130 See Singaravelu (1986).

131 The use of the term manoe (Indon mandi) which means "bathing" especially in the sea or river as opposed to having water poured over oneself. 
bala is therefore considered crucially important to ward off all such kinds of evil and misfortune by strengthening social relations among the people. One fisherman says that the ritual of tulak bala was first performed in $19^{\text {th }}$ century by fishermen when the Dutch conquered Acèh. According to one imām, however, tulak bala has been practiced by the Acèhnese's ancestors since the 1940 in Acèh. ${ }^{132}$ Several fishermen with whom I discussed this said that the performing of the ritual of tulak bala was based on the following events:

Fishermen often caught less fish during the 19th century. They were often intercepted by giant fish, huge waves, hurricanes etc causing many fisher boats to sink and therefore they assumed that the sea goddess (Ach dewa laôt) who lived in the sea had been furious (Indon murka) with human beings because they did not honor them nor give them the offerings (Indon sesajén). For this reason, human beings had to ask for forgiveness through offerings so that the sea goddess would behave well and not disturb human beings, especially fishermen. By doing so, the fishermen could go fishing without hindrance.

Village people quite often drowned in the river Krueng Baru which is close to Blangporoh village. The village people assume that the Krueng Baru river's keeper or "guardian" is furious at local dwellers as they quite often utilize the rivers to catch fish or as transportation for wood or rattan, and other needed household goods, but do not pay their respect to the river's keepers by offering food. The river keepers always take victims when floods occur. In order to prevent this situation, therefore, the offerings are made. The offering ritual is performed on Wednesday along the river bank of Krueng Baru and many other coastal areas of Acèh. Later on the festival day, the offerings are washed away from the river to the sea.

The villagers are afraid so they perform this ritual to ensure that the sea water spirits are not furious with them. ${ }^{133}$

In the kitāb Al-Bahjatul Mardhiyah, it is said that every year about 320,000 illnesses fall down to earth on the last Wednesday of Safar month (alFathani 1987:139). The head of 'ulamā' council in Southwest Acèh says that according to Syeikh Nusfi, a saint (Jam aulia;Arb awlīy $\bar{a}^{\prime}$ ) of Allāh, there are 12,000 calamities sent down to earth by Allāh from the tablet on which the records of the decisions of the divine are preserved (Arb laukh makhfudz) on the night of the last Wednesday of Safar month. In addition, it is said that the Prophet Zakaria and Yahya were killed by their followers on the last Wednesday of Safar. Therefore, this month is considered to be the unluckiest month in

132 See Serambi Indonesia, March $8^{\text {th }}, 2007$.

133 See also Mawardi (2005:30). 
the year. The word Safar means illness in the stomach. Safar also means a big caterpillar or maggot/mite. This mite is more savage than the scabies mite (alFathani 1987:140). It is said that every Safar lunar month Allāh allows Satan to come down from the sky, to the sea, the jungle and everywhere on the earth. $\mathrm{He}$ always tries to persuade people to do something bad to each other even though the angels always protect humans from this. When Satans are on earth, they always disturb people by bringing illnesses such as the "taeun disease" (Ach penyakét taeun) ${ }^{134}$, "pustular skin eruption" (Ach nie), and "epilepsy" (Ach sawan).

In order to avoid the misfortune on the last Wednesday of Safar lunar month, people go to the seashore or to the rivers to cleanse their bodies by taking a bath. Sometimes some villagers go to an imām asking for a $d o^{\prime} a$ (prayer) to be written, especially the do'a of tulak bala. In return, they give one kilogram of sugar or a small amount of money to the imām. After that they go to the sea or rivers nearest to their houses. They take a bath together with the written $d o{ }^{\prime} a{ }^{135}$ The aim of this ritual is not only to ward off illnesses affecting human beings but also to strengthen social solidarity. One says that if a baby is born on this day, it will be safe from calamity since Satan is no longer on earth at that moment and all calamities have been pushed off to sea.

It is believed that the Safar month is "pregnant" (Jam buntieng) with evil and illness. Therefore, the villagers are implored to take a bath with the intention (Indon niat), "I take a bath on the last Wednesday to remove a small state of uncleanness (Indon hadas kecil)". ${ }^{136}$ This is not obligatory (Ach wajéb) but voluntarily (Jam/Ach/Ind sunat). The idea is that the purification of one's body is a sign of the 'soul's' (jiwa) purification' so as to ensure that they are not easily disturbed by Satan or other malevolent spirits. Bathing to ward off misfortune by calling back the seumangat "vital force" that may have "fled". If one's seumangat leaves the body, the body will be weak and can be easily harmed by Satan and other malevolent spirits.

134 Taeun is a kind of epidemic that the Aneuk Jamee and the Acèhnese are really afraid of. This epidemic can attack human beings or animals causing them sudden death.

135 Snouck Hurgronje I (1906:207) also observed that the Acèhnese came with pieces of paper which consisted of certain verses of the Qur'ān to be mingled with the water on the day of tulak bala in Safar lunar month.

136 Hadas means ritual impurity. Hadas kecil means a state of ritual uncleanness which requires ablutions. Hadas besar means a state of ritual uncleanness which requires bathing. On the day of tulak bala or rabu habéh, one is required to take a bath although he or she does not have hadas besar. 


\section{Tulak bala at village level}

Before the arrival of Safar, Blangporoh people and other village people are busy preparing food, beverages and new clothes. This preparation is nearly the same when preparing for Ramadhan. Women are usually busier than men preparing food, cookies, drinks and fruit. People who live in the town or far away from the coast or river go and stay with their families who live near the sea or rivers so that they can then take a bath, eat, drink, and hold a social gathering. This social gathering is called pajoh-pajoh (see Ch.10). Sometimes it is called meuramien or meurumok.

A newlywed husband especially has to prepare new clothes for his wife for example, a long dress, shirt, shoes or sandals and a shawl. Face powder, perfumes, bathing soap and other cosmetics are placed in a box to be given to his wife on this day. People prepare various traditional cakes and some buy cakes at the bakery for guests that come to their house on that day. A number of villagers visit each other and bring the cakes to the seashore near Blangporoh village while others go the river bank of Krueng Baru together.On the night before the tulak bala day, the activities reach a peak. The villagers make the last minute preparations. Women make the following traditional cakes:

Leumang, made of glutinous rice, thick coconut milk and salt. It is then baked in young bamboo (Ach buloh) that is layered with young coconut leaves inside it.

Keutupè (Indon ketupat) is made of glutinous rice and salt. It is then wrapped in a square young woven coconut leavesthese are boiled in thick coconut milk. The keutupèk is fried in coconut oil after it is boiled to prevent spoiling.

Leupè is a cylindrical sweet made of glutinous rice flour, salt and palm sugar. It is first wrapped with banana leaves, then cooked.

Bada (Indon pisang gorèng), fried banana, made of pisang talon banana (a kind of banana, liked by most villagers) mixed with ordinary rice flour and salt then it is fried in coconut oil. ${ }^{137}$

They also prepare cooked fish, beef and vegetables. Curry (Ach gulè), meat simmered in spices and coconut milk called rendang and other sorts of raw food are also prepared at home and later on cooked under the decorated tent at

137 The information on how to make the traditional cakes is obtained from my female informant. 
the seashore at Blangporoh village and at river bank of Krueng Baru. ${ }^{138}$ The aroma pervades the atmosphere and spreads everywhere arousing the appetite.

The ritual of tulak bala begins at 8 o'clock in morning. After having had breakfast at their houses, people go to the mosque first; the members of the governing body of the village and staff of Blangporoh's mosque are waiting there. Soon after the villagers have gathered, the village leader tells them to queue up on the street in front of the mosque facing the direction of the sea. The imām stands in front of the queue and starts reciting do' a ya lathief. This begins with the words ya lathief ("o the softest") which is known as a prayer to chase away jinn (Ach do'a let jén or do'a paroh jén). It is taken up by all participants while walking to the seashore. The complete $d o o^{\prime} a$ is as follows (see Waly (2003), my translation):

Ya lathief palah tazal

Ultuf binā pimā nazal

Innaka lathief lam tazal

Ulthuf bina wasmuslimīn

Subhāna man 'azzawajal

Wabari a minal wajal

Wa khadha likulli bil ajal

Sairal khalqi ajmainn

Nasaluka raf'al bala

Bisirri thamal mujtaba

Wal ali arbābil hijā

Washahbihil Mujahidīn

Allāhumma yā kafiyal balā $i$

Ikfinal balā

Krabla nezulihi minasamā $i$

Allāhumma yā kāfiyal balā $i$

I’nda nuzūlihi minassama $i$

Allāhumma yākāfiyal balā $i$

Ikfinal balā $i$

$B a^{\prime}$ danuzuulihi minassama $i$
Hai the softest

You always exist

Please be kind to me and to the Muslim community

When any kinds of disasters come

Exalted is He (Allāh) azza wajalla

Holy from the character of anxiety

He who determines all predestined hours of death

For all living creatures

Please keep disaster away

With the sacredness of the chosen Prophet

The family of the Prophet who is clever

The Prophet's companions who are warriors

O Allāh who prevents disasters

Keep the disasters away from us

Before they are sent down from the sky

O Allāh please keep disasters away

From us when they are sent down from the sky

O Allāh who prevents disasters

Keep the disasters away from us

After they are sent down from sky

138 In Lombok, West Nusa Tenggara, on the last Wednesday of Safar lunar month (rebo bontong), besides bathing together in the sea to clean their soul, they make white and red porridge to indicate the life cycle of human beings. The white porridge symbolizes sperm and the red one symbolizes egg cells in which both these substances form the foetus in the mother's womb. See Kompas, May $20^{\text {th }}, 2005$. 
Villagers led by the imām repeat this $d o^{\prime} a$ up to seven times till they arrive at the seashore about nine hundreds metres from the mosque. Having rested, some villagers visit each others' tents. Some slaughter chickens and ducks that have been prepared a week before to be cooked at the seashore, while others help erect tents if those set up by the young men of the village the day before are not enough.Meanwhile the invited guests start arriving and sit in the main tent together with the members of the governing body of the village and staff of the mosque and other villagers who arrive later.

The people in the main tent are served with various cakes and beverages by the villagers; they also exchange the traditional cakes mentioned above and other market cakes, eating while waiting for lunch. They talk happily, laugh and smoke. Some boys play football while others look for more fire wood to cook the chickens and ducks. Meanwhile, some young girls help their mothers with the cooking and sometimes talk to other young women and men who come from other villages. Others take photos while waiting to invoke do' $a$ together.

At about 10 o'clock in the main tent, the imām together with participants recite the sürah al-Yāsīn (QS 36:1-83) and the sürah al-Kahfi (QS 18: 1-110) from start to finish. One of the virtues of reciting these verses is that the reciter's sin will be forgiven and the verses will protect him from taèn illness (Ach penyakét taèn) that can strike someone dead. Other virtues are that the reciters will be protected by Allāh and angels from disasters. If they are recited when one has a severe illness, the virtues of these sürah could heal that person if he or she still has a life time granted to him or her (Ach mantong umu).

After reciting these sürah, people then continue to request pardon from Allāh. These are known as istighfār taken from the opening phrase: "Astaqhfirullāh....; (I ask Allāh for pardon...,). The imām then recites the phrase; the others join him repeating it three times. Next the sürah al-Ikhlās ${ }^{139}$ (QS 112:14) is recited together:

Khulhuwallāhu ahad Allāhush shamad Lam yalid walam yulad Walam yakullahu kufuwan ahad
Say, "He is Allāh, [who is] One

Allāh, the Eternal Refuge

He neither begets nor is born

Nor is there any equivalent to him"

139 Al-Ikhlās meaning purification. 
Many villagers say that this sürah is equivalent in merit to one-third of the Qur'ān, and that reciting it three times constitutes "completing the Qur'ān". This sürah is also efficacious in other ways. One old man says that those who fought in battle against the Dutch returning to Acèh in the late 1940s would use the sürah as a spell and would not be "eaten" by bullets. ${ }^{140}$ Next, they continue reciting the sürah al-Falaq ${ }^{141}$ (QS 113:1-5):

Qul a'ūzu birabbil falaqi

Min syarri mā khalaqa

Wamin syarri ghāqin izā waqaba

Wamin syarrin naffāsātifil 'uqadi

Wamin syarri $\hbar \bar{a}$ sidin izà hasada
Say, "I seek refuge in the Lord of daybreak

From the evil of that which He created

And from the evil of darkness when it settles

And from the evil of those who blow on knots

And from the evil of an envier when he envies

and then continue reciting withthe sürah $\underline{a n-N \bar{a} S^{142}}$ (QS 114:1-6):

Qul a'ūzu birabbin nāsi

Malikin nāsi

Ilāhin nāsi

Min syarril waswāsil khannāsi

Allaz̄̄ yuwaswisufì shudūrinnāsi

Minal jinnati wannāsi
Say, I seek refuge in the Lord of mankind

The Sovereign of mankind

The God of mankind

From the evil of a retreating whisperer

Who whispers [evil] into the breast of mankind

From among the jinn and mankind

It is believed that a devil that makes evil suggestions may be a person as well as a "non-believer jinn" (Ach jèn kapé). They will disappear when one remembers Allāh. It is said that both the sürah al-Falaq and the sürah an-Nās are very efficacious when seeking Allāh's protection from any kinds of evil. The leader of the committee charged with organizing the tulak bala ritual asks the imām to invoke another special $d o^{\prime} a$ of tulak bala to close the $d o^{\prime} a$ session. The imām starts reciting this $d o$ ' $a$ by holding his hands up; all participants do the same and utter $\bar{a} m \bar{m} n$ ("please accept o Allāh") at every end of the following do' $a$ :

Allāhummad fa' 'annal ghalā'a

Wal balā a wal wabā a wal fahsyāa a

Walmungkarwas suyūfal mukhtalifata

Wasy syadā ida walmiћan mā dhahara

Minhā wamā bathana mim baladinā khash

Shah wamin buldānil muslimina 'āmmah

Innaka 'alā kulli syai in qadir.
O our God, please keep us from disaster Catastrophe and calamity, despicableness Ignored, any kind of quarrel Cruel, war which can be seen Or can not be seen especially in our country And generally in Islamic countries Indeed, Allāh is competent over all things

140 See also Bowen (1993:265).

141 Al-Falaq meaning daybreak.

$142 \mathrm{An}-N \bar{a} s$ meaning people or mankind. 
In his $d o$ 'a the imām also asks Allāh to save the earth and the water to protect the village from floods, landslides and other calamities. After finishing reciting the above $d o$ ' $a$, people have lunch together at midday. While having lunch, some committee members bring the water mixed with ordinary rice flour for cooling off, called teupōng taweu. One by one each participant is sprinkled with this water with the aim of preventing illness in the hope that Allāh will strengthen his or her inner and outer "soul/mind" (Ach jiwa lahé dan batén). Before returning to their houses, many villagers take a bath together in the sea to cleanse the body so that all kinds of illness are swept away and their inner and outer "soul/mind" remains healthy. All children who return from the Blangporoh seashore have a red coloured streak or cross ${ }^{143}$ of betel juice (Ach ie ranub) $)^{144}$ brushed on their forehead by the adat leaders to protect them from illness and jinn. The participants are not allowed to call their friends very loudly (Ach teumawôk) after going back from the seashore because people are afraid that Satans could come back to earth again. Fishermen are not allowed to go fishing for three days but they are free to perform activities on land. These three days are called "prohibited days" (Ach uroe pantang). ${ }^{145}$ This adat is not written but passed on from one generation to another.

\section{Other forms of ritual bathing}

Other forms of ritual on this day of "warding off calamities" such as "bathing with the Qur'ān verses" (Ach manoe ngon ayat Qur'ān), and "flower bathing" (Ach manoe bungong) are performed individually. This too serves to purify the "soul" or to "call back" one's own "soul" that may have "fled" before spirit attacks.

\section{Bathing with the verses of the Qur'ān}

In the Acèhnese cosmology the Safar lunar month is deemed a month in which to avoid any serious undertaking because it was in this month that the

143 Red colour on the children's forehead is a sign that the children have performed the ritual of tulak bala in Safar lunar month. Sometimes the sign is very much like a Christian cross on children's forehead.

144 The ingredients of rajah seumapa or meurampot used on that day comprise of betel vine (Ach on ranub), gambier (Ach gambé), lime (Ach gapu), betel nut (Ach bòh pineng), and tobacco (Ach bakong). They are then chewed and its juice is placed on the children's forehead.

145 If fishermen go fishing on taboo or prohibited days, they will be fined. 
Prophet Muhammad had a grave illness. Moreover, my informants maintain that the ritual bathing at the end of the month of Safar is possibly connected with a feast held in memory of the Prophet Muhammad's experience of some mitigation of his final illness through such ritual bathing. Therefore, on the last Wednesday, in order to avoid any misfortune, it is customary for some pious followers of Islam to go to the seashores or the river banks to clean their bodies by bathing with special written verses of the holy Qur'ān called manoe ngon ayat Qur'ān ("bathing with the verses of Qur'ān"). This bathing is performed with the seven verses of salämun ("peace") as follows:

Peace, a word from a merciful Lord (QS 36:58).

Peace be upon Abraham. Indeed, we thus reward the doers of good (QS 37:109-110).

Peace be upon Noah among the worlds. Indeed, we thus reward the doers of good (QS 37:79-80).

Peace be upon Moses and Aaron: Indeed, we thus reward the doers of good (QS 37:120).

Peace be upon Elias. Indeed, we thus reward the doers of good (QS 37:130-131).

Peace be upon you; you have become pure; so enter Paradise to abide eternally (QS 39:73).

Peace it is until the emergence of dawn therein (QS 97:5).

The paper on which this $d o^{\prime} a$ is written is sometimes put into seawater or river water where the people take a bath (before they immersed themselves into it). Some villagers also drink the water containing the $d o^{\prime} a$ which they regard as sacred and thereby having a salutary effect on their bodies; it is also a charm against evil. Those who are unable to go the river or seaside should at least drink some of the water brought from the river or sea on this occasion to cleanse oneself of spiritual impurity and safeguard oneself against any misfortune in the future. ${ }^{146}$ In addition, the following $d o o^{\prime} a$ is also often thrown into a common well ${ }^{147}$ in the village on tulak bala day, the water of which is drunk by the village people:

Yā syadìdal khawi

$Y \bar{a}$ 'azizal 'uddati

Fījamī'il khal'ika

Akfinì'an jamì'il khalqika

Yā muhsin

Yā mukrim

Läilaha illa anta
O Allāh is the most courageous

O Allāh who has all preparations

To all creatures that are freed

Protect me from all Your creatures

O Allāh who always does good deeds

O Allāh who is the most sublime

There is no deity except You

146 See also Zainal Abidin (1949:103-104).

147 A common well can still be found in which there is one well for a group of households in the village. Cutting nails (both finger and toenails) on the last Wednesday is not allowed as it takes health from the body. However, it is good to cut nails every Friday because it is believed that $\sin (\mathrm{Jam}$ doso;Ach dèsya) leaves the body and religious merit (Jam pahalo;Ach/Indon pahala) flows into the body. 
Allāhumma akhithnīmin juhdil balā $i$

Wadarkil syakhāi wasūil khadha $i$

Wasyammātatil 'akdā $i$ wa mautil fujā ati

Wamin syarril sihri wamin darkis sāmi

Wal harami walbarashi

Waljadmi wal aqāmi

Wamin jamì'il amrādhi

Birahmatika yā arhamarrāhimīn
O Allāh help me from suffering

Appearance of misery, bad work

Cruelty of enemy, sudden death

From black magic, the danger of poison

Appearance of feebleness, discoloration of the skin

Leprosy and chronically illness

As well as all kinds of illness

With Your blessing o Allāh, the entirely merciful

The well water is drunk and taken to be sprinkled around the villagers' houses, to protect them from various illnesses. Some villagers dissolve this $d o^{\prime} a$ into a glass of water before they drink it; some others place this written $d o^{\prime} a$ into a big pail containing water, then take a bath with it.

\section{Flower bathing}

Another way to purify the body of any dangerous spirits during tulak bala is by taking a ritual bath with flowers called manoe bungong. Manoe bungong is often performed for unlucky people. For example, they may be by infertile women, women who cannot find a husband, a man who cannot find a wife. These people should be bathed with flowers on the tulak bala day in order "to call back their seumangat that have left their bodies". In the past, the ritual of manoe bungong on the day of tulak bala was quite often performed by a healer directly bathing them. Now this ritual is no longer often performed. "That is why there are many old virgins in the village", says one man. Such old virgins who "have misfortune in their bodies" are implored to perform manoe bungong in order to find a marriage partner soon. Also, those who do not have offspring should take a bath on this day. It is important to note that parents in the village are very ashamed in front of their neighbours if they have old virgins who have not married yet. To conceal their embarrassment, they are often told to perform the ritual of manoe bungong on the day of tulak bala. In addition, they are usually told to move away and live with their families in town to avoid this embarrassment.

On the day I witnessed tulak bala in Blangporoh, however, I observed a ritual of monoe bungong performed not for old virgins but for an old sick man. One male farmer brought a bunch of areca nut flowers, several leaves and a rough-skinned lime to a female healer in Blangporoh to be cast as a spell for manoe bungong on the day of tulak bala. A week before he felt something wrong with his right leg causing him difficulties in walking. He said that it was as if there were some needles in his right knee. His right knee was red and 
swollen. He was sure that someone else had given him this illness so that performing manoe bungong on the day of tulak bala is required in order to get rid of the illness. ${ }^{148}$

On his arrival at the female healer's house, he was told to take off his tshirt and to turn his back to her. Between them, there was a medium sized shallow pail containing flowers, several leaves, and a slice of rough-skinned lime. The female healer covered herself with an additional cloth and looked at him from under the cloth over her face while chanting a spell. Her right hand kneaded the mixed areca nut flowers, leaves and sliced rough-skinned lime in the water in the pail and her left hand held it steady while casting spells in a very low voice. At the end of her chanting she blew upon the kneaded flowers and slowly moved her right hand that was wet with flower water from the top of his head down to his back hip seven times. ${ }^{149}$ After that she gave the kneaded flower water which had the consistency of pineapple juice to him. Before leaving the old man gave her Rp 5,000 and she told him as follows:

Please bathe with this flower water at sunset, uttering bismilla $\bar{h}$ (in the name of Allāh) and facing the direction of Mecca (Indon kiblat).

Please let someone else clean the remainder of your flower bathing

Please return on two more afternoons and bring the same flowers: areca nut flowers, several tree leaves and rough-skinned limes.

Rough-skinned limes are often used in healing rituals. They are also quite often used as shampoo (Ach limèe) by women bathing after childbirth, at the end of menstruation, in the early morning of the festival of the fast breaking and the festival of the sacrifice, and on the last day preceding the Ramadhan month for men and women. ${ }^{150}$ In addition, in Acèh, rough-skinned limes which have been sliced are brought and sprayed on the seedbed as well with the aim of calling therice's 'vital force' (Ach seumangat padé) so that the rice plants will be fertile and safe from rice pests. But they are not allowed to use it if one

148 According to a village female healer, however, manoe bungong does not only aim at expelling the ill fortune and evil magic from the body but also at preventing disturbance from bad spirits and calling back seumangat and good luck (Ach tuah) that have "left the body".

149 Unfortunately the female healer is not willing to tell the spell she has chanted. On that day my recorder's battery is weak so that it does not record the female healer's chanting spell.

150 Meanwhile, in Perak, Malaysia, rough-skinned limes are rubbed on to the bodies instead of soaps for the "warding off calamities' bathing" (Ahmad 1949:41). 
takes a bath in the river or sea, based on the belief that crocodiles would be angry and savage because rough-skinned limes resemble the protrusions on their head.

This practice is under attack from two different corners: modern science and normative Islam. Thus, a male Biology teacher at the junior high school argued that it is no problem at all to clean the body by using rough-skinned limes, flowers and leaves because soap and shampoo themselves are made of these substances. But, manoe bungong used in the hope of cleansing the "soul $/ \mathrm{mind}$ " (jiwa) is not acceptable. The criticism from normative Islam argues:

The practice of manoe bungong, bathing with certain verses of the Qur'ān, and using talismans are kurafat ${ }^{151}$ can reduce one's faith and that will ultimately lead the performers to polytheism (Arb syirk). There is no good luck (Ach untōng) at this special time nor is it beneficial but disadvantageous in relation to certain actions. Manoe bungong is not only an old traditional Acèhnese adat but also Aneuk Jamee that has been mixed with pre-Islamic belief and "the popular Islam". Belief in manoe bungong will reduce the faith of someone to $k a d h a^{152}$ (the power of Allāh to determine all events) and to the belief of takdir (recognition that all matters of creation are determined by Allāh) of Allāh. Manoe bungong must be rejected due to the mixing of superstition (Indon tahayyul), deviation (Indon $k u$ rafat) and innovation (Indon bid'ah) in religious belief. They strongly stress that one must guard against innovation and superstition.

These ideas are from local modernists arguing that mano bungong is not an intrinsic part of Islamic belief and practice but many villagers contend that manoe bungong is good in trying to "ward off calamities" and at the same time to call back the seumangat into the body. If a part of the body is emptied of its seumangat, the power of Satan will permeate into it causing a person misfortune in his or her life.

\section{Tulak bala in Alupeunawa}

Epidemics attack not only human beings but also animals. These are said to appear especially in the Safar lunar month and to last from thirty to forty days. People, therefore, argue that they must take care during the Safar lunar

151 Kurafat is a performed action which deviates from religious teaching.

152 Kadha is an explicit point in the Muslim creed that Allāh has such power. As recognition of that power, most Muslims in Blangporoh utter the term "insya Alläh", i.e., "if Allāh wills", when using the future tense. 
month and pray to Allāh so they will not contract a 'strange illness' (Ach peunyakét aneh). In Alupenawa, one of the villages in Southwest Acèh, many water buffalos died in one particular Safar lunar month. Four villagers also passed away and nine fell ill. Four people suddenly died in Alupenawa village in February 2007. This made people afraid as there was no evidence that they were poisoned. It was said that the victims were dizzy first, then vomited and were short-winded after touching another victim. One woman admitted that she was suddenly dizzy after touching the first victim who died. On Wednesday she was unconscious. The same happened to another woman after helping the second victim and nine people got sick.

The rest of their food was sent to be examined at a medical facility. The results were negative. ${ }^{153}$ The village people then became more afraid. They believe that the epidemic attacked both human beings and buffalos causing them a sudden death. ${ }^{154}$ In order to drive off this frightening epidemic, the village people in Alupeunawa started to perform tulak balak rituals, by praying and reciting Qur'ān together.

From 2007 onwards they recite the sürah al-Yāsin and al-Kahfi three nights respectively in the last week of Safar lunar month. These süra $\underline{h}$ are first recited in the village's mosque on Thursday night, then in the boarding school Nurussalam on Friday night, and in all village clusters (Indon dusun désa) on Saturday, the last night, which occurs in the last week of Safar lunar month. After reciting these sürah, requests were made to Allāh for pardon, known as the istighfär from the opening phrase: "Astaqhfirullāh...; (I ask Allāh for pardon...,). The prayer leader recites the phrase and then the others join him for three repetitions. Next the sürah al-Ikhlās (QS 112:1-4) is recited:

Khulhuwallāhu ahad

Allāhush shamad

Lam yalid walam yulad

Walam yakullahu kufuwan ahad
Say, "He is Allāh, [who is] One

Allāh, the Eternal Refuge

He neither begets nor is born

Nor is there any equivalent to Him"

This $s \bar{u} r a \underline{h}$ is recited 30 times and $\operatorname{tahl}_{\underline{h}} l^{155}$ (the reciting of la ilāha illallāh - there is no deity but Allāh) 100 times altogether. Finally, the male villagers

153 See Serambi Indonesia, February $17^{\text {th }}, 2007$.

154 See Serambi Indonesia, February $13^{\text {th }}, 2007$.

155 It is believed by Muslims that repetitive recitation of the tahlīl will cleanse a person and gain the reciter religious merit. It is also said that Allāh sent down the calamities and $\mathrm{He}$ is able to ward them off as long as the human beings sincerely chant the confession of 
perform a torch procession (Ach pawai tot culot) around the village border facing the sea. This procession is led by local 'ulama' ' and a local healer is asked to chase away the illness caused by bad jinn. One argued that fire must be opposed by fire as Satan, jinn, and 'delicate creatures' are made of fire. Thus, they are afraid of fire. In addition, the recitation of the verses of the Qur'ān and tahlill makes them "hot" and so they retreat beneath the ocean waters. It is believed that the majority of malevolent spirits live under the sea. When they come on land, people will be attacked by many kinds of illnesses. It is said that "the ocean is larger than the earth, Satans must be chased there". This ritual is similar to that performed in Simpang Keuramat, North Acèh in the past. There, all the village men gathered together at intersections of the village where they divided into four groups, the same as the number of clusters of the village. They walked around the village uttering one of the verses of the Qur'ān in sürah al-Isrā' (QS 17:81): "And say, truth has come, and falsehood has departed. Indeed is falsehood, [by nature], ever bound to depart" (Arb waquljā al haqqu wazahaqal bāthil innal bāthilakā na zahuqā). As they arrived at the border of the village, one of them performed azan (calling to prayer) to ward off calamities or to rid themselves of danger in the village. ${ }^{156}$

\section{Tulak bala in the past}

Villagers recall that in the past on the day of tulak bala, some members of the tulak bala committee first visited the sick men and women in the village. They addressed them as follows:

Uroenyo uroe tulak bala

Teubit segala penyakèt dan minah u laôt Bek ganggu lè ureueng sakét nyo
Today is the day of tulak bala

May all sicknesses leave and move to the sea

May they no longer disturb this sick person

Some other committee members erected tents where the imām and other staff of the mosque rested and then recited the do' $a$ of tulak bala at the seashore. The young village men led by a healer went to the haunted places where they believed that Satans stayed, such as cemeteries, jungle, woods, rocks, big trees, unoccupied houses, ruins and other frightening places. They said do' $a$ of

faith (Indon berzikir) as a form of worship. The reciting of tahlīl is also called meuratéb in Acèh.

156 Serambi Indonesia, March $18^{\text {th }}, 2007$. 
tulak bala, ya lathief ${ }^{157}$ together in order to chase them away from these places to the sea. The methods used were beating bushes with palm (leaf) stalks (Ach puréh jok) that had been struck by thunder (Ach ka ditak le gelanteu). This palm (leaf) stalk was believed to have a power that Satans were really afraid of. If this kind of palm (leaf) stalk was unavailable, the healers would use the stalks of green coconut palms that would also frighten the jinn. It is said that house windows and doors were closed during the ritual in order to stop Satan from entering the house. If the owner of the house at that time felt that Satan was still in his or her house then he or she took water and poured it into a pail. He then put his fingers in it and with his mouth near to the water began reciting the following verses of sürah as-Säffāt (QS 37:1-10).

Washshaffatil Shaffā

Falzaa jirātil zajrā

Faltā liyati zikrā

Inna ilāhukum lawāhidun

Rabbussamā wāti walardhi wamā

Bainahuma warabbul masyāriqi

Inna zaiyannassamā addunyā

Biziinatil kawākibi

Wahifdhammingkulli syaithānim marīd

Là yassamma 'ūna ilal malāil 'aklā

Wayuqthafūna mingkuli janīb

Du 'uraw walahum 'azābuw wāshīb

Illaman khathifal khathfata

Fātba'ahu shihābun sākhibūn
By those [angels] lined up in rows

And those who drive the [the clouds]

And those who recite the message

Indeed, your God is one

Lord of the heavens and the earth and

That between them and Lord of the sunrises

Indeed, We have adorned the nearest heaven

With an adornment of stars.

And as protection against every rebellious devil

[So] they may not listen to the exalted assembly (of angels) and are pelted from every side

Repelled; and for them there is a constant punishment Except one who snatches [some words] by theft but they are pursued by a burning flame, piercing [in brightness].

The chanted water was sprinkled in all house corners as well as around the house. By doing this, it is believed that Satan would leave one's house.

In chasing Satan away on tulak bala day, people had "to say the do' $a$ of $y a$ lathief sincerely", otherwise Satan would be angry and make the chasers sick. It is said that about 50 year ago one man fell ill, and then died after the ritual of tulak bala in Ujong Manggéng, Manggéng district. People believed that he did not follow the rules when he performed the tulak bala ritual causing him to be attacked by Satan.

157 Blangporoh villagers are familiar with the do'a of ya lathief (' $y a$ the softest'). They know it as do'a let jèn (the do'a for chasing jinn). The work of chasing jinn (Ach jèn) on the day of tulak bala is called jak meujalatéh because the beginning of the do'a with the word ya lathief. 
While waiting lunch, the village head advisors called tuha peut and young men made a raft from banana trees for the central act of the ritual. The banana raft measured $2 \times 2$ and a half meters in size to $3 \times 3$ and a half meters in size. A small dark red flower resembling a jasmine but with a bigger bud called bungong ayeum gumbak jèn was placed on the banana raft as a "flower for the jinn to play with". It was believed that this flower enticed the jinn onto the banana raft and returned it to the sea. It is said that jinn like this particular flower and people who "befriend" jinn make use of these flowers.

After being decorated, the raft was filled with seven white rice packets and water. Sometimes a white cock was tied on the raft. ${ }^{158}$ One of the healers interviewed said that the colour white is preferred as the queen of Satan requests that colour. Chicken's blood, skin, head, feet, feather, and the rest of the food that they ate that day were also placed on the banana tree raft as offerings. It was hoped that afterwards Satan (some say malevolent spirits) would no longer attack the human beings.

No food is allowed to be brought back home that day. All the food must be eaten at the sea shore or river banks and the rest should be thrown into the water. The blood is said to symbolize impurity and since the Satan likes impure things, the food remainders are food for Satan, 'delicate creatures' and other malevolent spirits. This offering is especially for "non-believer jinn" living in the sea that eat the impure remainders human food. In addition, one says that during the reign of Raja Kanda in the 1930s, the villagers also sometimes bought a white buffalo and slaughtered it at the seashore. Its head was given as an offering for the sea water spirits. By doing so, the villagers hoped that 'malevolent souls' would no longer disturb them as they had been given their share of the meat. The offering of the white buffalo head and other offerings were placed on the banana tree raft on the day of tulak bala.

According to a village healer, jinn prefer white offerings such as white cocks, white water, white rice, white buffalo as they have a magic power (Indon kekuatan magik). Various kinds of traditional cakes such as ketupèk, leupèk $b a d a$, and leumang were also placed on the banana raft. The committee members then asked a religious leader or imām to recite $d o^{\prime} a$ of tulak bala, the

158 In Pontianak, West Kalimantan, the offerings prepared on the day of tulak bala were chicken, glutinous rice, yellow rice, and chicken's blood. Those offerings are thrown in the sea in order that malevolent spirits would no longer attack human beings because they have received the offerings, see Serambi Indonesia, March 17 ${ }^{\text {th }}, 2007$. 
sürah of Yäsin and al-Kahfi. After that they had lunch together. While having lunch, some committee members brought the water of ordinary rice flour for a cooling ceremony (Ach ie teupōng taweu). One by one the participants were sprinkled with the cooling water to be protected from illness and with the hope that Allāh will strengthen their 'inner and outer souls'. After lunch, the participants gathered around the tethered banana raft. Do' $a$ again was invoked by the imām and all attendants. The above do' $a$ of "chasing the jinn" (Ach do'a let jét) was recited seven times. The call to prayer (Arb adhān) ${ }^{159}$ was then performed:

Allāhu akbar $2 x$

Asyhaduallāilāha illallāh $2 x$

Asyhadu anna Muhammadar Rasulullāh $2 x$

Hai ya alash shalāh $2 x$

Hai ya alash falāh $2 x$

Allāhu akbar $1 x$

Läila haillallāh $1 x$
Allāh is the greatest

I bear witness that there is no deity except Allāh

I bear witness that Muhammad is His messenger

Please make haste toward prayer

Please make haste toward welfare

Allāh is the most great

There is no god except Allāh

Then the raft filled with offerings was ready to be pushed into the river or into the sea. The person to do so must be a pawang laôt (see Ch.1) as he "knew more about jinn than anyone else". After performing the call to prayer, the smoke of burned incense started rising and the rope that tied the banana tree raft was cut. The pawang laôt said, "O guardian of the sea, this food is for you, please guard us so that we were safe to seek a livelihood" (Mawardi 2005:32). The banana tree raft was then pushed into the sea on the last Wednesday of Safar lunar month. The banana tree raft started floating away from the seashore and bobbed up and down on the surface of the sea. The moving banana tree raft was continuously observed by all participants with bated breath fearing that the raft might return to the shore. Every move on the sea surface had a meaning for the people.

If it returned to the seashore, it meant that the illnesses would stay longer in the village. If it capsized in the water it signalled that the illness would remain in the village. If it sank, this symbolized that there were still many Satans that would disturb the village people. If it did not break, jerk, sink nor return to shore, but rather moved smoothly on the sea's surface and far away from land, this was what was hoped for as it boded well for the people. All illnesses that had attacked the villagers and their animals were, at that moment, all taken by the wind to the bottom of the sea (Ahmad 1992:163).

159 Although azan (the call to prayer) is usually used to call people for prayer, it is also performed on other various situations in Acèh such as when a tsunami occurs, when a fire breaks out, or when someone fights. I also witnessed someone performing the call to prayer in Lampulo, Banda Aceh when a human corpse was placed in the grave. 
After launching the banana tree raft, the ritual of tulak bala was over. Before returning to their houses, all participants bathed in the sea to clean their bodies so that all diseases were taken away by the sea water. They then bathed with fresh water, performed an ablution and a prayer at the seashore asking Allāh to prevent any kind of illness asking that all participants remain healthy, both inwardly and outwardly (Ach sehat lahé batén).

Some informants argued from the perspective normative Islam that this ritual is a good ritual because it was first performed by Sheikh Abdul Wahab Sya'rani, a Sufi man in Egypt when he ordered his followers to perform the ritual of tulak bala to chase away all disasters that had caused people's deaths. At that time all the followers of the Syeikh chased calamities away with date (leaf) stalks (Ach puréh on keureuma) and continued by reciting do'a. The Syeikh saw taeun resembling jinn but his followers did not. Jinn then were chased till the estuary of the Nile River. There, his followers were told to make a raft from decayed woods. The wooden raft was filled with the rest of the food, skins, bones, dirt as food for the jinn. It was then freed to the Nile River while reciting $d o$ ' $a$.

\section{Changing and debating}

The performance of the ritual of tulak bala in Blangporoh village and in other villages at the coastal areas of West Labuhan Haji district has changed. In the coastal areas, society is more open and easily accepts foreign influence as compared to hinterland areas where society is more closed and suspicious towards innovations. Among the things that differ is the way the ritual is carried out. For the society that lives in the coastal area, the ritual is always connected with the sea or river. Tulak bala is currently seen more as an aspect of recreation. The change in opinion about bathing in the sea or river on tulak bala day brings problems to the society (which at first had value with philosophical messages). Now the members of the governing body of the village and the local district police are busier since fighting over little things often occurs at the river banks or seashore, example of these confrontations are brushing against each other, staring at each other whilst choosing their prospective partners or because one's girl friend is being annoyed. These disturbances start with shouting and then often result in violence. Boys and girls sometimes fall into the river; they are soon saved by the people bathing. Motor bike accidents are common when people go to the river bank or seashore. Therefore, nowadays a number of 
old men in the village say that the current tulak bala ritual no longer has any meaning. What happens when the festival takes place is the opposite of tulak bala, people come into contact with calamities (Ach mita bala); such as fighting, drowning, having accidents, some people prohibit their children from taking part in this festival. Besides the ritual of tulak bala at the seashores or river banks "invites sin" (Ach mita désya) because men and women mix together freely. These people argue that all this activity is a kurafat deed. This is still practiced in the village because of the influence of pre-Islamic belief and historic Islam. The local modernists say that this belief will not only destroy the Islamic law but also a Muslim's faith. Misfortune and calamities do not only occur in the Safar lunar month. This idea should not be accepted. Allāh states in the Qur'ān 9:51, "Never will we be struck except by what Allāh has decreed for us; He is our protector". And let the believers rely upon Allāh. And the Prophet Muhammad says that there is "no illness which is contagious, no prohibition in Safar month and no accident which is marked by night birds". However, apart from being the subject of religious debate and an occasion for achieving spiritual purity, like in the pajoh-pajoh tradition (see Ch.10), the ritual of tulak bala is an opportunity for the marriageable young men and women to meet and talk and choose their prospective spouses. Soon after this ritual has been performed the traditional match-makers are busy in arranging marriage proposals with the parents of the interested parties in South Acèh.

\section{Conclusion}

The ritual of tulak bala celebrated annually on the last Wednesday of the second lunar month of Safar, as it was known in the past and is still being observed by people today, brings considerable prestige and economic benefits to the villagers. On this occasion, many people including a large number of young men and women under the watchful of their own families travel in groups by trucks and cars to the places intended for the ritual.

The lunar month of Safar, and especially the last Wednesday of this month, is considered inauspicious. During this period there is an interdiction on house building, on performing marriage rituals and other ceremonies, on rice sowing or planting and other forms of land cultivation, on visiting a sick man or woman, on travelling, etc. On that Wednesday farmers are not allowed to go to their rice field and fishermen are not allowed to go fishing. If a marriage ritual were be held on this day, the couple would collect many debts during 
their life. In addition, accidents, and epidemics and disasters are believed to occur during this Safar lunar month and particularly on the last Wednesday. Such catastrophic events are attributed to Satans and other evil supernatural beings attacking human beings and cattle. The ritual of tulak bala performed during this Safar month is therefore considered crucially important to ward off all such kinds of evil and misfortune by strengthening the social relations among the people.

On this day young men and women as well as the elderly hold a social gathering at the seashore or at a river bank. They bring various kinds of food with them and entertain themselves by singing to the accompaniment of guitar music. On the actual day of the ritual, some young men play football, and then take a ceremonial bath in the river or in the sea called manoe sapha. This ceremonial bath seems to have originally been a secular bathing festivity for the purpose of providing an opportunity for young men and women to see and get to know each other during their joint participation in dancing and music and enjoyment in the river or the sea so that they can facilitate their future betrothal. It would also seem possible that such a festivity might have well been the result of the interaction of the Aneuk Jamee traditions with the old traditions before they were endowed with an Islamic significance.

As in other forms of ritual bathing such as "bathing with the verses of Qur'ān" and "flower bathing" the ritual cleansing of the body on this day of "warding off calamities" is believed to purify the "soul" so that it cannot be harmed by Satans or other evil beings. It also serves to "call back" one's own "soul" that may have "fled" such attacks. The body without the "soul" is considered especially vulnerable.

There are two categories of tulak bala. First, tulak bala is with the help of Allāh, normative Islam, done through reciting certain Qur'anic verses such as

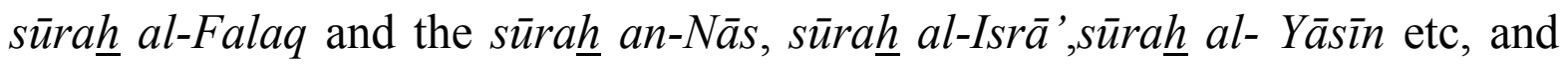
reciting tahlīl with certain do'a such as the do'a of tulak bala, ya lathief seeking Allāh's protection from all kinds of evil. These recitations are believed to rid oneself of danger in the village and makes Satans or evil beings "hot" so that they retreat to beneath the ocean waters right away. It is believed that the majority of Satans/evil beings live under the sea. Satan and other evil beings have to be chased away from particular sites, back to the deep sea where they live. It requires the marginalisation of the spirits (Satan and jinn) and demarcation of a socially ordered space that is placed under divine protection (Plat- 
enkamp 2006:9). If they stay on land, the people will be attacked by many kinds of illnesses. In the past, while reciting do'a of tulak bala together, the villagers led by a healer went to haunted places where they believed that Satans and other evil beings stayed. They chased them away from these places to the sea by beating bushes around these places with palm (leaf) stalks that had previously been struck by thunder because these palm (leaf) stalks are believed to have a power that Satans are really afraid of. Second, tulak bala is an offering ritual. Offerings are brought to spirits (Satan and to jinn) to induce them to go back to the sea and these offerings have "codes"; the red offerings are for Satan and the white offerings are for the jinn. Here there is a systematic distinction; Satan is related to jinn as a husband to a wife. It relates to jinn as red to white, it relates to jinn as bad to good. Tulak bala is to push away harm and prevent calamities but it is also performed in two different ways. On the one hand, offerings are given and these offerings are red and white. They address two apparently different types of beings. Satan is addressed with the red and jinn are addressed with the white, both offerings of food are placed onto the constructed banana raft for the beings in the sea that bring calamities. Satans are given the impure offerings marked red, blood and so forth. Jinn are offered white gifts so that Satans and jinn retreat into the sea. Such practice, however, is now longer found in the villages.

Most performances of tulak bala ritual in Blangporoh and in other parts of coastal areas in South Acèh have changed as the culture in the coastal area is more open and now accepts foreign influences. This change is also caused by the rigorous criticism from the local modernists and 'ulama ' claiming that constructing a banana raft with offerings placed on it and then released to the sea on the day of tulak bala is a pre-Islamic act. Another reason is the number of accidents that happen during the rituals on the tulak bala day. Therefore, at present, the recreational aspect is stressed more than the ritual aspect. 


\section{ChAPTER 7}

\section{The ritual of khanduri mò'lōt}

The celebration of the Prophet Muhammad's birthday in Acèh is called mò'lōt (from the Arb mawlid) meaning "birthday". Although the Prophet is also believed to have died on the same day, his death is not significant to this ritual. During mò'lōt ritual, a "ritual meal" khanduri mò'lōt is held. This khanduri has become a cultural icon in Acèh. The characteristic of khanduri is food and drink. It is a taboo for the Acèhnese to pass the mò 'lōt month without holding the ritual of khanduri mò 'lot. The preparations, for instance; fowls, ordinary rice, glutinous rice, coconuts, and cooking spices have been prepared several months before the arrival of mò 'lōt month. This is done secretly so that everyone concentrates on the preparations for the khanduri mò 'lōt postpones personal matters for after this celebration. In the past, a fine was given by "territorial chieftains" (Ach ulèebalang) to the headman of a village who did not provide for the yearly "ritual meal" in due time.

The khanduri mò'lot is held in all villages either in the mò'lōt month (on or after the $12^{\text {th }}$ day of Rabī' al-Awwal, i.e. March) or in one of the two following months of Rabī' al-Awwal. From this the two subsequent months derive

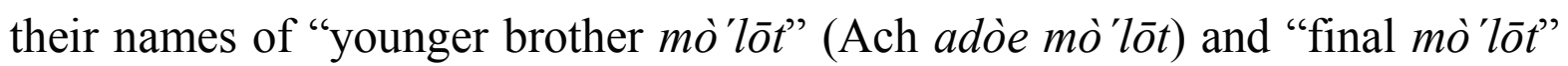
(Ach mò'lōt aké). During mò'lōt, a ritual meal called khanduri mò'lōt is prepared and consumed. Those who live in other villages belonging to the same mukim (a collection of several villages) are the guests of a single village and receive a formal invitation through a messenger of the head of the village. The khanduri mò 'lōt ritual taking place at the family level is held individually in a house. The invitation to attend the khanduri mò'lōt at family level is extended to relatives, to the imām, the head of the village and to the orphans. Meanwhile the khanduri mò'lōt ritual at village level is held on behalf of the village community. The inhabitants of neighbouring villages are also invited. The villagers of the neighbouring villages will reciprocate with a counter invitation to their khanduri mò'lōt ritual in that or the following year. This practice is done by any village in Acèh, so that participating in village khanduri mò'lōt rituals is always done in pairs repaying each others' invitations. In addition, both levels of these "ritual meals" are not just perceived as a commemorative celebration but as a part of an exchange relationship. The villagers have a different valori- 
zation of the ritual and various interpretations of the diké mò lot implicating broader issues of religion, society, and culture.

\section{The aim of khanduri mò'lōt}

The mo' $l \bar{t} t$ celebration is held to commemorate the birth of the saidina (our leader) ${ }^{160}$ that is the Prophet Muhammad. The khanduri mò'lōt in Acèh is therefore often called khanduri keu pang hulèe or khanduri keu saidina. ${ }^{161}$ The aim of the celebration of khanduri mò'lot $t$ is to honor the Prophet by reciting seulawet (prayers) for him and for his family and at the same time to commemorate the service of the women who breastfed him. There were three women who breastfed him; Aminah (his own mother), Tsuaibah (a slave of Abu Lahab), and Halimah as Sa'diyah (a Bedouin wet nurse from Bani Sa'd Ibn Bark). Apart from his own mother, Aminah, these two women are called "Muhammad's nursing mothers" (Indon ibu susuan Muhammad). It is said that the celebration of the first or "old mó 'lōt" is to commemorate the service of his mother Aminah. The intention of the "younger brother or middle mó 'lōt" is to commemorate the service of Tsuaibah while the intention of the "last or final $m o ̀$ ' $l \bar{o} t$ "' is to commemorate the service of Halimah as Sa'diyah. It is emphasized that, "Without their help, Muhammad would have died at that time".

The imām of Blangporoh village, Teungku Hasbi says that the aim of khanduri mò'lōt is to commemorate as well as to practice living a good life as the apostle of Allāh. He related a short history of the Prophet emphasizing his role as a reminder to follow his good example:

When he was still young, he had already received the title "al-amin" (can be trusted) from his group for he never told a lie. When he was a trader who sold merchandise belonging to Khadijah before she became his wife, he never practiced dishonesty, deception, counterfeiting or disappointment in his trading. In heading his household after getting married, he was also praiseworthy.As a father, he treated his children fairly and did everything he could to make his wife happy. As a leader of the community of believers (Arb ummah), he had also praiseworthy qualities for he always prac-

160 Saidina from the Arabic sayyidināh (Ach panghulèe) is a title meaning "our leader". The title is assigned to important personages in Muslim history, such as to the Prophet, his family and the righteous caliphs.

161 In Cirebon, Yogyakarta, and Surakarta, the celebration of mò'lōt is called sekatèn or grebeg mulud. This term is from the word syahadatain referring to the profession of faith: There is no deity other than Allāh and Muhammad is His messenger (see Muhaimain 2004: 177). 
tised what he preached.As the leader of war, he not only commanded, but he was also very brave at the frontline, attacking enemies. He was a true hero and never afraid of death. There was only one motto for him; "a martyr's death for the sake of the religion of Allāh and the religion of Allāh's teaching on the earth led by him". He obviously had a good and noble character, high morality etc. All his fine qualities and behaviour are an exemplary model for believers because every aspect of his life is very admirable. He had brought people from the uneducated world (Indon alam jahiliyah) to the educated world (Indon alam ilmu pengetahuan). Due to his service to human beings, the khanduri mò'lōt ritual is, annually held to commemorate his struggle and his good service during his life time.

\section{Timing}

Based on the Acèhnese calendar, "the month of the birth" (Ach buleuen $m o ́$ ' $l \bar{t} t$ ) in Acèh lasts for three months: Rabi' al-Awwal (the third month of the Islamic calendar or March), Rabi' al-Akhir (the forth month of the Islamic calendar or April) and Jumadil-Awwal (the fifth month of the Islamic calendar or May). Rabī' al-Awwal is known as the first or "old mò'lot $t$ " (Ach mò'lot awai or tuha) started from 12 Rabī' al-Awwal till the end of this lunar month. Rabī' al-Akhir is known as "younger brother or middle mò' lot $t$ " (Ach adoe $m o ̀$ 'lót or mò'lot tengoh) started from the beginning till the end of this lunar month; and Jumada'l-Awwal is known as "the last or final mò 'lōt" (Ach mò'lōt aké, tulot or keuneulheuäh) started from the beginning till the end of this lunar month. These three months are called "the month of the birth" (Ach buleuen

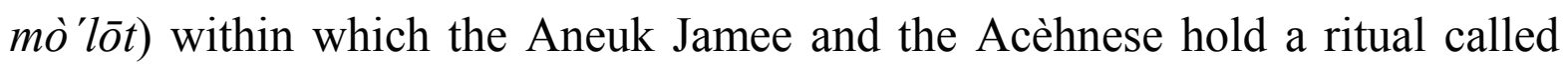
the ritual of khanduri mò 'lott.

The villagers have different opinions as to why the "the month of the birth" is held for three months. According to one informant, three months refers to the time needed to announce to the people that the Prophet Muhammad was born. He added that after he was born, the Arab people who were very happy needed three months to report to other faithful people sailing with boats from other Middle Eastern lands. Other informants, however, have other opinions, saying that the Acèhnese choose three months for the khanduri mò'lōt in order to give the Acènnese a longtime to choose when they want to hold the ceremonybecause all Acèhnese have a strong motivation to hold the "ritual meal" for the Prophet. If they cannot hold it due to their business or finance in the first phase, that is in the month of Rabì' al-Awwal, they can postpone it and do it in the second phase, that is in the month of Rabī' al-Akhir. If they still can not 
hold it in the month of Rabī' al-Akhir, there is one more opportunity in the third phase that is in the month Jumadal-Awwal so that it rarely happens that the Acèhnese cannot hold it. If all people held the khanduri mò'lōt on 12 Rabì' al-Awwal only (the date of the Prophet's birth), no one would eat it because everyone is preparing on that day. The Aneuk Jamee and the Acèhnese may then freely choose whenever they want to hold the khanduri mò'lōt within the above three months. It is said that the one who holds the khanduri mò 'lot ritual outside "the month of the birth" (Ach buleuen mò'löt) will receive no religious merit and people will laugh at him or her.

The khanduri mò 'lot held for the Prophet during the above three months is also called mò'lot sayéd (from the word saidina ("our leader"). According to one informant, the term mò'lōt sayéd refers to the khanduri mò'lōt during the three months which is the best or which khanduri mò'lōt is the most satisfactory for the participants. Some young men in the village have different views about mò'lōt sayéd. Most of them contend that mò 'lōt sayéd refers to any occasion when they get very good food without payment.

The mò'lot celebration has been the subject of controversy from the start. It has always met with opposition from purist movements that condemn it as a bid'ah, a religious innovation that contradicts Tradition. Between the 12th and 15th centuries, a genre of figh (study of law pertaining to ritual obligation) specialized in the decision of bid'ah emerged. This genre, which first appeared among Mālikī scholars in Andalusia but spread throughout the Islamic world, became part of a debate that developed mainly between the supporters and opponents of Sufi rituals. The most prominent representative of this genre, although not its creator, was Ahmad ibn Taymīya (d.728/1328), a highly controversial figure even in his lifetime. ${ }^{162}$ Part of the current within Islamic scholarship devoted to the purification of ritual and morality, he followed the footsteps of earlier scholars such as at-Turtušī (d.520/1126), Ibn al-Ğawzī (d. 529/1200), Abū Šāma (d. 665/1268) at-Turkumān̄i (14th century and Ibn al-Hāğğ al'Abdarī (d. 737/1336). ${ }^{163}$ The topics and arguments developed in kutub albid'ah (the tractates against innovations) belong to a repertoire that became standard in the critique of ritual, and which gained new dynamics following the

162 See al -'Azma, 'Azīz (Azis al-Azmeh) (2000) and Memon (1976).

163 Fierro, “The tractates against innovation”, pp. 207-209. 
revival of Ibn Taymiya's writings with the rise of Islamic reform movements at the beginning of the 18th century.

In Islam there are only two holidays: The festival of the fast breaking (Arb 'id al-Fitr) and the festival of the sacrifice (Arb 'id al-Adha $)$. Other festivals apart from these are bida' $a h^{164}$ for Muslims to be commemorated because there are no religious sources which are explicitly commanded by Allāh. Moreover, the Prophet never introduced and performed it when he was still alive, explains one modernist. When I discuss it with the village imām, he admits that the tradition of the khanduri mò'lot ritual is bida'ah, yet it has been widely accepted as a legitimate activity in the villages. The khanduri mò'lot $t$ ritual is, therefore, always performed in the villages. It takes place at the family level and at the village level including not only the proper birth ritual, but also the exchange relationship that becomes a part of its celebration.

\section{The khanduri mò' 'lōt at family level}

The khanduri mò'lōt taking place at family level is held individually in a house. This kind of khanduri mò'lōt is called mò'lot nadzar (Arb nazr) ${ }^{165}$ or $m o ̀$ 'lōt kaôy ("vow mò'lōt") to release individuals from a spiritual debt. It is held in order to bring about "the spiritual vow" because one has made a promise to Allāh if his or her will is granted with Allāh's help he or she will return this by doing a good deed. If the wish is fulfilled then he or she should pay it by providing food to other Muslims. That particular individual utters the vow verbally. The imām whom I disscuss this with says that the law of uttering "the spiritual vow" is not prohibited (Jam bulieh;Ach jeut) although it is less preferred by the ' $u l a m \bar{a}$ ' because behind it, there is a hidden behavior (which less good toward Allāh). For example; "If Allāh brings about my wish, I will be close to Him, if not, I will not be close". It is as if one performs a certain religious service (Ach ibadat) Allāh would grant whatever he or she desires. This person is identified as 'mean' (Ach ureueng kriet). Basically "the spiritual

164 Bid'ah can be classified into two classifications; 1) Bid'ah hasanah meaning an innovation regarded as beneficial. 2) Bid'ah madzmumah meaning an innovation regarded as blameworthy. The khanduri mò'lōt celebration thus belongs to the first classification (Arb bid'ah hasanah), explained one imām.

165 Nadzar (Arb nazr) which means "offering", in its verbal form it means "to offer" or "to make a spiritual vow." Nazr is also used in Arabic in a totally different way also "to warn," that is not applicable in this context. The Qur'ān has used the word "nazr" in both meanings. I only use here the first usage which is of relevance to our discussion. 
vow" must be paid, if it has been uttered (QS 22:29). It can no longer be cancelled because it is a promise to Allāh. This is proven by the story of Hazrat, Maryam (Mary of the Christian scriptures)'s mother. She had to give Maryam up to the temple even though she was a girl and it was against all accepted tradition to let a girl be a maid at the temple. The Qur'ān tells the story of Maryam's mother in which her families fulfilled the "spiritual vow" as they had promised their Lord (QS 3:35). ${ }^{166}$ Nevertheless, the "spiritual vow" may still be canceled if the promise has not yet come true. But cancellation after one knows that the request to Allāh has been granted is not allowed at all. If one does so, he has deceived Allāh and he has lied to himself, says the imām. The imām adds that if "the spiritual vow" contains wickedness, this kind of "spiritual vow" may not be paid. Vice versa, if there is a person who makes observes religious service for the sake of Allāh without any requirement, this kind of "spiritual vow" is not disliked by the Prophet. The "spiritual vow" itself is a religious service, which thus must be directed to Allāh and the person who brings about it is loved by Him. At the end of the discussion, however, the imām himself recommends that when you are facing a really difficult or distressing situation, it is better to make a "spiritual vow" but when the problem is over you have to offer special prayers or invite the poor or orphans for a meal for the sake of Allāh.

Even though it contains a hidden behavior less liked by Allāh, "the vow $m o ́$ ' $l \bar{o} t$ " is made by the villager at family level. The way to hold the khanduri $m o ̀$ 'lōt at the family level is done with the "spiritual vow" that has been uttered at the beginning. If the "spiritual vow" is uttered with a sacrificial buffalo, one must slaughter it. Should the "vow" be uttered with a ram one must slaughter it and so on. In Blanporoh, the "village chickens" "167 which are more delicious in taste than others are killed to fulfill the "spiritual vow" because they are the

166 In 5:27-31, the Qur'ān tells the story of the two sons of the prophet Adam (Habeel and Qabeel, Anglicized names: Able and Cain) who made an offering to their Lord. In 19:26, the Qur'ān relates the story when Prophet Jesus is born without a father and the Jews ask of Maryam about such an implausible situation. 'So eat and drink and refresh the eye. Then if you see any mortal, say: Surely I have vowed to fast to the beneficent Allāh. So I shall not speak to any man today'. And in the first twelve verses of sūrah alDahr (sürah 76) the Qur'ān tells the story of nazr performed by the Prophet Muhammad's family (Arb ahlul bait).

167 The "village chickens" (Jam ayam kampuang; Ach manok gampōng) are chickens, which are raised without being purposely fed, which also known as 'free range chicken'. They look for food by themselves but their owner provides a coop for them. 
smallest animal that could be properly dedicated to Allāh by cutting its throat and pronouncing bismillāh meaning "in the name of Allāh". A fish is too small and cheap and a ram would be too expensive for most people (see also Bowen, 1993).

Unlike a khanduri mò'lōt at village level, a khanduri mò 'lōt at family level is performed during the day as well as at night and does not need the committee members and no special meeting is heldas it does not involve many people. The one who has a dominant role here is the person who has made the "spiritual vow" and who is helped by his or her nuclear family: husband, wife and children, nephew, and niece. In relation to the "vow mò 'lōt", I witnessed one family who held the ritual of khanduri mò'lōt individually in the mò'lōt lunar month. Last year Muslém, the head of a household uttered the following vow, "If nothing befalls my rice plants and they have a good harvest next year, I will hold a khanduri mò 'lōt for the saidina". Eventually after he had a good harvest he performed the khanduri mó 'lōt to redeem his "spiritual vow". He fulfills it because based on his judgment Allāh has in fact rendered some assistance for his good harvest.

On March 13th, 2007, he went to a market and bought the required foodstuffssuch as several "village chickens", white glutinous rice (Ach breueh leukat or pulott), white ordinary rice (Ach breueh bit), coconut (Ach bòh u), jackfruit (Ach bòh panah), yam (Ach bòh ketila), cassava (Ach bòh ubi), pumpkin (Ach bòh labu), salt (Ach sira), sugar (Ach saka), cooking spices (Ach bumbu masakan), and certain kinds of banana called bòh pisang talōn and brought them home after payingthe seller at Manggéng market. He did not purchase fish and vegetables on that day because he already had them at home. At home, his wife helped by his son and daughter cook the food for "the vow mò'tōt". All the expense of this "ritual meal" is borne by him including the expense of preparing the servings and side dishes.

Two weeks before the ritual meal of "vow mò 'lot $t$ " occurs, he invited his parents and his wife's parents. The invitation to attend his ritual meal would have also been extended to the grandfather and grandmother from both sides if they were still alive. In other words, the invitation is extended to both kin groups called "4 groups" (Ach peuet kaôm), generation -1 and "8 sides" (Ach lapan pihak), generation - 2 (see Ch.3). In addition, the religious leader in a village, the village leader and orphans who live near his house are also invited.There are only a small numbers of guests who are invited to eat this 'ritual 
meal' at his house. There are only 15 people. The orphans are invited in the afternoon and his parents, his wife's parents, the head of the village, and the religious leader are invited to his house at night.

\section{Idang (the dishes)}

A special food with various side dishes are offered to the invited guests at his house called idang. There are two special kinds of idang prepared by the family head for collective consumption (Ach pajoh sama-sama) at the family level:

\section{Idang buleukat kuwah tuhèe}

This idang is prepared for the orphans who live near his house. The glutinous rice is not cooked together with its broth (Ach kuwah). Only after it and its broth are cooked are they mixed together. ${ }^{168}$ Its broth is made of coconut milk (Ach santan $u$ ), banana, salt, and sugar. Besides the cooked rice, a variety of side dishes are also served for the invited orphans.

\section{Idang buleukat kuwah peungat}

This idang is prepared for his parents, his wife's parents, the religious leader, and the village leader. It is made of coconut milk mixed with a certain kind of banana called pisang raja ("king banana") or pisang abin, jackfruit, yam, cassava, salt and sugar.They are cooked together with glutinous rice that has been wrapped with banana leaves (Ach on pisang) in triangle form and tied with a palm leaf (Ach puréh). Kuwah peungat is nearly the same as kolak or sènok. ${ }^{169}$ After they are cooked they are eaten with the cooked glutinous rice (Ach bu leukat or pulot). I also observe a plate of cylindrical sweets (Ach leupèk) made of glutinous rice flour and palm sugar that night. They are wrapped with banana leaves then steamed. The banana leaves are wiped with a little coconut oil so that they do not fall apart before they are wrapped.In addition, there is a plate of fried banana (Ach bada) made of pisang talōn (a kind of

168 In Tapak Tuan, the capital city of South Acèh, the glutinous rice mixed with its broth is called nasi tuai.

169 Kolak or Sènok is made of coconut milk (Ach santan u), jackfruit (Ach bòh panah), yam (Ach bòh keutila), and cassava (Ach bòh ubi), pumpkin (Ach bòh labu), salt (Ach sira) and sugar (Ach saka). The glutinous rice for making kolak or sènok is cooked together but it is not wrapped with a banana leaf. 
banana, preferred by most villagers) first mixed with ordinary rice flour (Ach teupōng breueh bit) and salt then fried with coconut oil (Ach minyeuk $u$ ). ${ }^{170}$ That night the ritual meal of "vow mò 'lōt" is held. It consists of the recitation of Qur'anic verses and prayers followed by the enjoyment of the food. Before he begins to recite the $d o^{\prime} a$, the imām declares quietly in low voice that the khanduri mò'lot $t$ is intended to fulfill the "vow" made earlier by the family head and host of the khanduri. The teungku invokes do' $a$ and all participants follow it and intone $\bar{a} \min$ (please accept o Allāh) at certain parts of the recited do'a. The collective recitation for the ritual meal of "vow mò 'lot" is not long, consisting of only twenty Qur'anic verses of sürah al-Baqarah recited by the teungku. On this occasion the "ritual meal" emphasizes "the safety in the world and in the hereafter" (Ach seulamat di dônya dan akirat), the words of dedication and the prayers for the Prophet Muhammad's welfare. But at other "ritual meals", for instance: the "ritual meal" for the dead and for the farm, the collective recitation is central to the events. After finishing reciting $d o$ 'a, the village leader welcomes the participants to eat by saying, "that which we have brought here must be finished, in the name of Allāh" (Ach peu yang kana ta peuhabéh, bismillāh). The following figure 4 shows the relation of khanduri mò'lōt at home/family level.

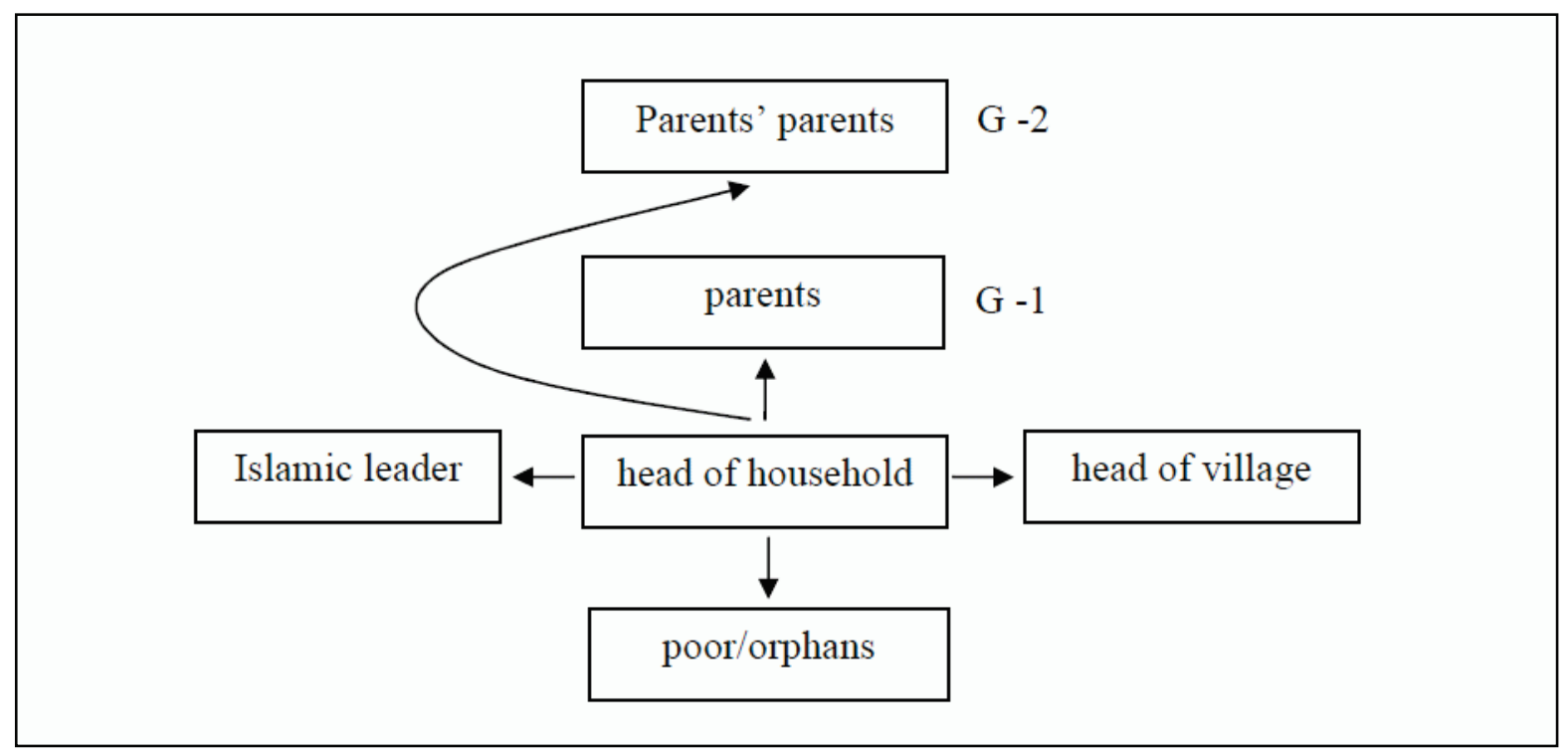

Figure 4. The relation of khanduri mò'lōt at home/family level

170 The information how to make idang buleukat kuwah tuhèe, idang buleukat kuwah peungat, kolak or sènok, leupèk and bada was obtained from a female informant. 
The following figure 5 also shows the reciprocal relation of khanduri $m o ̀ ' l o ̄ t$ at home/family level:

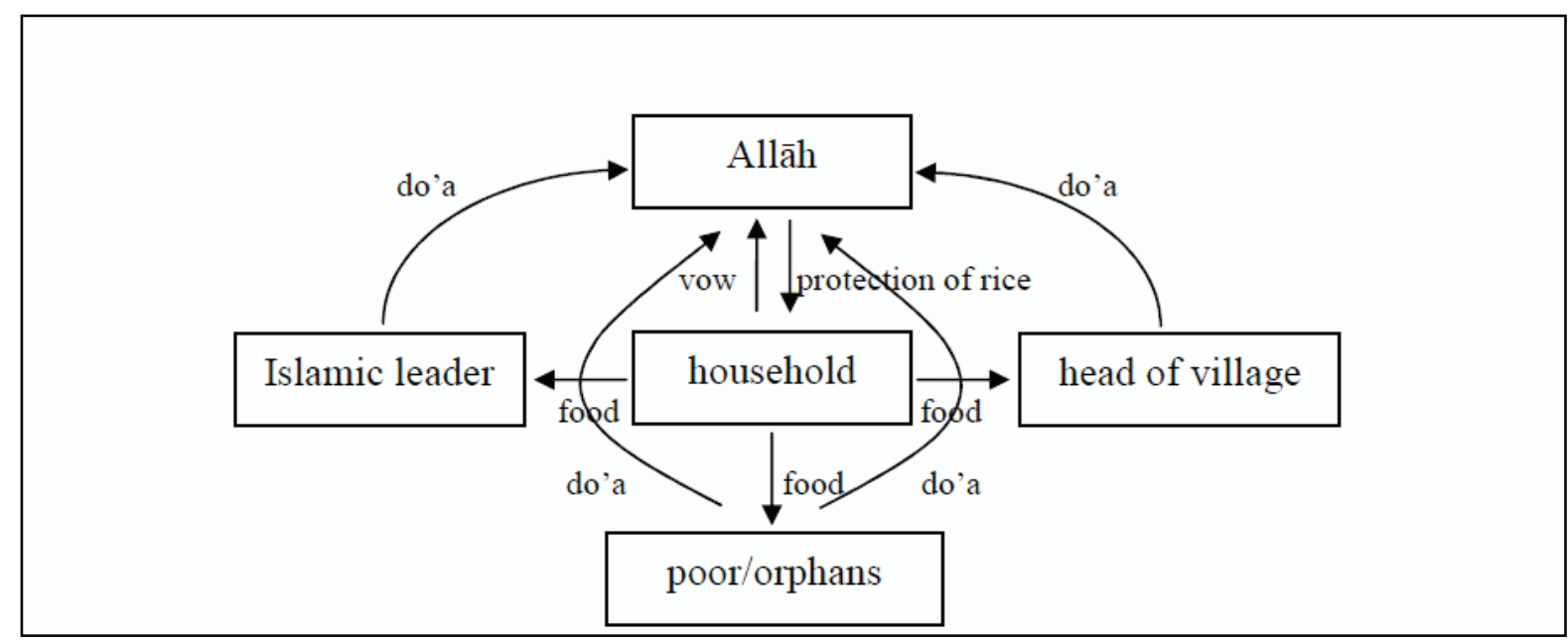

Figure 5. The exchanges of khanduri mò̀ lōt

Nazr is not an obligatory act in Islam. It is only done when a Muslim feels a need to do so. However, once a "spiritual vow" is taken by a Muslim, it becomes obligatory to complete the nazr if his or her wish is granted by Allāh. The basic concept of nazr is to offer something less valuable in the hope and expectation of receiving something of higher value. (The "value" does not have to be material. It could just be honour and dignity). In the case of khanduri mò'lōt nazr at family level in Blangporoh village, the head of the household who has made the "spiritual vow" invites not only both sides of his kin but also others (see figure 4). If he only invites his own kin for the khanduri it means that he kills something from his own belongings just for himself.This meal is considered to be no different from other meals because he shares his luck (the good harvest) only among his own kin and he does not make other people happy. There is no exchange relationship in this case as the luck is not shared with others.

Based on the assumption that he received a good harvest with aid of Allāh, he releases his spiritual debt by holding the khanduri mò'lōt nazr or mò'lōt kaoy because he received something from Allāh and now he has to give it back by killing the "village chicken" to constitute a relationship to Him and society. The meat of the killed chicken and the cooked rice with a variety of side dishes are given to the orphans, teungku, keuchik, and his parents and his parents' parents for both sides (see figure 4), meanwhile the secret $d o^{\prime} a$ recited by the 
teungku and the chicken's "soul" (nyawa) are destined for Allāh. The exchange with Allāh is through the societal relations (i.e. sociability) as expressed by his relationship with others. By inviting the teungku, this khanduri is a cosmological representation of the pious people in the village in which the villagers regard the teungku as pious and close to Allāh and who becomes the intermediary in thanking Him through his recited $d o^{\prime} a$ at the khanduri. By inviting the keuchik, this khanduri also has an adat relation in which keuchik is the head of the adat holder in the village. By inviting the orphan children, this khanduri also marks a social relationship. Children are like angels; they never commit sin and are innocent. Giving food to them is like giving money to the mosque because they are a part of the mosque.Rich people give money the mosque and the mosque gives money to the needy. By mobilizing those people, the household head brings his khanduri to the public sphere in order to show his personal happiness and at the same time to have witnesses that he has redeemed his "spiritual vow" although at the beginning it is made by him individually. All these people help the family head who uttered the "spiritual vow" to thank Allāh in the hope and expectation of receiving more mercy from Him and in keeping the social relationship with the others as expressed in figure 5 above.

\section{The khanduri mò' 'lot at village level}

On the second day of Rabì'al -Awwal, the imām looks in the direction where the moon rises. He says, "Welcoming the guest" (Arb rabbi warabbukallāh) that is the mò 'lōt lunar month. The imām then reports to the village leader. The village leader then reports to the council of "elders" called ureueng tuha "the men of experience" who are knowledgeable about adat in the village. The imäm, village leader, and "the men of experience" and the components of the governing body of the village (Ach perangkat gampōng) determine when the meeting or "assembly" (Ach meusapat or mupakat from the Arb muwāfakat) for the khanduri mò 'lot $t$ will be held. The secretary of the village, Syarkani, then announces to the villagers using a microphone and loudspeaker that the meeting will take place on the Friday after Jum'at prayer (Ach seumayang Jum 'at). The meeting is set for the mò'lōt ritual on Thursday night on February $28^{\text {th }}, 2007$. The fixed date of $m o ́$ ' $l o ̄ t$ ritual is very important. It should not clash with village activities. Care is taken and they fix the date for mò'lōt ritual so that no two villages shall celebrate it on the same day or too close together because special villagers in the same mukim are invited to each other's village, 
the members of the governing body of other villages in the same mukim are also invited to eat the khanduri.

The people who follow the meeting for mò'tōt ritual in Blangporoh are themselves members of the governing body of the village and some male villagers. The meeting is led by the village leader as the president of the assembly and imām at the men's house (Ach meunasah), ${ }^{171}$ which is a stone's throw from Blangporoh's mosque. They exchange opinions and reach an agreement from all those attending. After getting an agreement from both sides; society and the representative of the governing body of the village who attend the meeting, they then decide how and when the khanduri mò'lōt will be carried out. The decision is then made as follows:

The khanduri mò'lōt starts at 14 o'clock and finishes at 18 o'clock.

The day of the khanduri mò'lōt falls on March 29th, 2007.

Blangporoh village invites the neighbour village that is Blangbaru village and all students (Ach aneuk dayah) of the boarding school in the village.

Every household is asked to contribute Rp 2000 and it is collected by each cluster leader (Ach ketua duson) for providing drinks.

These decisions are written down by the secretary of the village, Syarkani. The head of the village, Anasjuddin, hopes all participants will spread the news about the preparation of the khanduri mò'lot at the end of the meeting that night as this event is as important as the timing of marriage rituals to all villagers. The period of preparation from the day of the meeting till the khanduri is held takes about a month. During this period the villagers prepare the needed materials, for instance; cooking spices (Indon bumbu masakan), ordinary rice (Ach breueh bit), glutinous rice (Ach breueh leukat), coconut oil (Ach minyeuk u), ordinary rice flour (Ach teupōng breueh bit), glutinous rice four (Ach teupōng breueh leukat), and sugar flour (Ach teupōng saka); especially for those who do have them yet although many have prepared these ingredients long before the mò 'lōt month comes.

171 Formerly the meunasah (prayer house or the men's house) was the place in which mature youths gathered after sun down. At present it is now often used for this purpose and in many villages the meunasah are deserted. The building serves instead as a house of prayer, school, village guesthouse, meeting place or occasionally as a place to formalize important ceremonies such as signing of marriage contracts (Dall 1982:1). 


\section{Invitation and the standing betel vine}

On March $1^{\text {st }}, 2007$, the following day after the meeting, a messenger from Blangporoh goes directly to meet the village leader and the imām, and the imām of Blangbaru village at their houses to invite them officially. This official invitation is called meuròh. The messenger brings with him an offering called ranub baté. Ranub (Jam/Indon sirih) and baté (Jam carano), a copper silver bowl covered with an ornamental piece of cloth contains several betel vines (Ach on ranub), several split areca nuts (Ach bòh pineng teuplah), several cloves (Ach bòh lawang), a gambier (Ach gambé), and wet lime (Ach gapu basah) in a tiny container, and several betel vines which already folded and contain the ingredients called "ripe betel vine" (Ach ranub masak), which is ready to be chewn. ${ }^{172}$ Soon after the messenger arrives at the ritual specialist's house, he greets him by saying assalāmualaikum (peace be unto you). The ritual specialist's replies, wa'alaikum salām warahmatullāhi wabarākātuh (peace be unto you too and Allāh's mercy and His blessing as well). The messenger says to the ritual specialist; "we request you on behalf of Blangporoh village that you come and take part in khanduri mò'lot held by Blangporoh society on March $29^{\text {th }}, 2007^{\prime}$ ". At the same time he gives a ranub baté to the ritual specialist who takes "the ripe ranub" from it and consumes it then he hands back while chewing it and answers "it is well" shaking his head a little bitmeaning that he is counting how many people from his village will be able to come so thatsufficient rice and meat can be prepared for the khanduri mò 'lot ritual. The messenger repeats the same phrases and gestures when he invites the imām of Blangbaru the Teungku, and the chairman of students at the boarding school (Ach aneuk dayah) in Blangporoh village. Although this official invitation is for the village leader and the religious leaders only, all the inhabitants of Blangbaru village and all students at the boarding school in Blangporoh are included.

Refusing the ranub baté means refusing an invitation which is considered anti-social and shameful. "The elongated betel vine is the male counterpart of the round areca nut with which together with lime is associated with fertility"

172 The aim of preparing 'ripe betel vine' (Ach ranub masak) which already contains the ingredients of betel chewing and "raw betel vine" (Ach ranub hana masak) which does not contain the ingredients of betel chewing is to allow the invited guests to choose the betel vine offered freely in a copper silver bowl covered with an ornamental piece of cloth containing betel chewing ingredients (Ach ranub baté). 
(Martin, 1992). The form of a betel quid (Ach sugo ranub) is a prerequisite to all social relationships. Meuròh with ranub baté is also primarily a sign of respecting guests, by accepting it the guests show that they are visitors with a good intention, trusting the host village, having no fear of poisoning.Refusing ranub baté means that the guests do not want to take part in the khanduri and considered to be an insult. In the past a refusal was the equivalent of a declaration of war.

The meuròh offering a ranub baté as a gift to officially invite other people is still an adat in Acèh. It is not only for the khanduri mò'lōt ritual but also for other life-cycle rituals; such as the ritual of akikah (Arb 'aqīqah), marriage, and circumcision which are performed by male and female villagers. ${ }^{173}$ Meeting the ones who will be invited strengthens their personal relationships and sometimes the talks are extended. Nowadays, however, this tradition has become rare. Instead, the village people use a mobile phone to communicate directly because it saves time. The betel vine with its ingredients for betel chewing is also brought in baté to the mosque for the invited guests on the day of khanduri $m o ̀$ 'lōt ritual. In the past, on the day of khanduri mò'lōt, piles of betel vines were heaped up high on a rounded food tray called dalong with a detachable wooden standing in its midst and in between them sliced areca nut, cloves, gambier, and tobacco were placed. This gift is called 'standing betel vine' (Ach ranub dong). ${ }^{174}$ The 'standing betel vine' is also presented in the same way as a betrothal gift (Indon hadiah tunangan).

Besides these invited guests, each individual has his own private guests or relatives who live elsewhere who are welcomed to take part in the khanduri. They come without invitation as according to adat they are at liberty to regard the khanduri mò'lott provider as their own family. If there are many such guests to entertain, the expenses of the feast will beborne by their host since the adat directs that he should providethem with a complete separate mealand its various side dishes in addition to his contribution to the general feast (Snouck Hurgronje I 1906:211). This adat still exists in West Labuhan Haji district, South Acèh. The Blangporoh village as host village invites the Blangbaru village and in return the Blangbaru village invites the Blangporoh village reciprocating the

173 Meureò (an official invitation) with offerings of a ranub baté as a gift to the midwife (Ach bideun) of a woman in her fifth month pregnancy is also performed by husband's mother in the villages.

174 See also Snouck Hurgronje I (1906:210-211). 
idang (gift) on another khanduri mò'lōt ritual in that or the following year. The same practice is performed by any villages in West Labuhan Haji district in which they invite each other to eat the khanduri mò'löt. In other words, the khanduri mò'lōt is always performed in pairs.

Two days preceding the khanduri mò 'lōt celebration is called "the day for buying fish" (Jam hari bali lauk;Ach uroe bloe ungkôt). Fish is bought by the head of the family. On this day, there are many fishmongers (Jam panggalè lauk; Ach mugèe ungkôt) coming to sell fish. On that day the fish is more expensive as nearly all villagers purchase it. If the villagers want to aquire them for a cheaper rate they go directly to the port where the fishermen sell the fish directly to the buyers in that district. Fishmongering is a male job. A fishmonger said that during mò 'lōt season (Ach musém mò 'lott) he is very happy as he sells a great quantity of fish. The villagers rarely say "fish is more expensive" (Jam lauk maha;Ach ungkôt meuhai) than on the other days. They do not care if the price is a little bit expensive as the money for buying fish has already been saved long before the arrival of the "the month of the birth".

A day preceding khanduri mò 'lōt celebration is called "the day of steaming the glutinous rice" (Jam hari mangukus barèh sipuluik;Ach uroe seume ob) in which glutinous rice is steamed (Jam nasi sipuluik; Ach bu leukat). It is done by housewives with the help of their female children. The glutinous rice is soaked and washed clean so it does not spoil quickly (Ach bagah basi) then it is mixed with pounded turmeric (Ach kunyét) before it is steamed. It is then mixed with coconut milk in a large metal vessel (Jam dalom dandang; Ach lam dandang). "The day for buying fish" and "the day of steaming the glutinous rice" are often done within a day preceding the ritual of khanduri mò'lōt if there are many family members helping cook the meat, fish, vegetables, ordinary rice and glutinous rice.

\section{Kinds of idang}

Idang is a parcel of prepared food with a variety of various side dishes brought to the mosque on the khanduri mò'lōt day. The idang is offered for collective consumption (Ach pajoh sama-sama) at the mosque and the rest is to be brought home right after the khanduri with the hope that the donations will procure merit for the donors on the ritual day. There are several kinds of idang $m o ̀$ 'lōt offered to the guests at the village level: daluang, sanggèn, idang nasi kunyik, idang gadang, and idang golèk. 


\section{Daluang}

Daluang [a covered round tray] is used to place the cooked rice and side dishes. It is circled with twelve drinking glasses bordered with a cylindrical piece of tin or other metal called glong which serves to prevent the various dishes in the drinking glasses from falling when it is moved. In the middle, the cooked rice is placed in cylindrical form and covered with the heated banana leaves. On the top, there are many heated banana leaves that have been folded as "plates" for eating. Its content is shared by four to six people. The whole stand of the rounded tray is decorated with a beautiful cover in the shape of a great truncated cone (Ach kurucut), the summit of which is sunk inwards so as to resemble a crater. This cover is called sangè. It is made of pandan leaves (Ach on seukè) and is adorned on the outside with colored threads and on the inside with gold leaf. It is said that the tray symbolizes unity and its cover symbolizes protection in life.

\section{Sanggèn}

Sanggèn (Ach ambèn) is made of wood connected with small wire to prevent side dishes from falling as it is moved. It consists of seven layers with no less than thirty dishes. Each layer consists of glasses to place fried fish, cooked fish, baked fish, fried meat, cooked meat, boiled meat, and vegetables. In the middle is the unhusked rice ${ }^{175}$ in a plastic bowl to infuse them with the diké $m o$ 'lōt, the plastic bowl is also used to stabilise the glasses. Between the connected sanggèn's wood, there are ten to twelve boiled eggs (sometimes they are coloured) on the palm leaf rib stick (Ach puréh on $u$ ) which are the same hight as the connected sanggèn's wood. Each stick is decorated with different colour kite paper. Below its base the wood quadrangle is also decorated with different coloured papers. Its content is shared by seven to ten people.

175 Soon after the diké mò'löt has begun, the plastic bowl containing the unhusked rice is placed in the middle of the people who recite a kitāb barzanji called ureueng mediké. They take the container back after reciters finish reciting this kitāb. As they arrive at home they soon mix the rice seeds that have been brought to the mosque with other rice seeds at their houses. By doing so they believe that their rice seeds have contained baraka (a special blessing assigned by Allāh) from the recital of the kitāb at the mosque in order to keep danger away from rice plants that lead to a failed harvest. 


\section{Idang nasi kunyik}

Idang nasi kunyik or jamba is a small idang comprising of the cooked yellow glutinous rice (Jam nasi sipuluit kunieng or nasi kunyik;Ach bu leukat kunéng). It is heaped up high like a pyramid on a quadrangle made of wood with four legs and a long rounded wooden pole in the middle (Ach capah idang) and covered with sweet thinned cakes called tumpo. A tumpo is made of glutinous rice flour, egg and other ingredients then it is fried with coconut oil. It is covered again with banana leaves that have been heated (Ach dilayu) earlier in order to make them soft. Its content is shared by ten to fifteen people.

\section{Idang gadang}

Idang gadang (Ach idang rayeuk or raya) or big idang consists of several layers. This idang is not often made by villagers. However, affluent villagers and the members of the governing body of the village make it. It consists of the steamed yellow glutinous rice that is also heaped up high on a quadrangle made of wood with four legs and a long rounded wooden pole in the middle of the pyramid form and covered with tumpo. There are several Acèhnese traditional cakes belonging to the idang gadang:

Keukarah is made of ordinary rice flour and glutinous rice flour mixed with warm water. Mixing is done in a coconut shell called bruk takue that has holes in the bottom. Through small holes from bruk takue, the mixed flour which is like threads falls over the heated coconut oil till it is cooked. Kamaloyang, made of ordinary rice flour mixed with coconut milk is fried with coconut oil. Seupét (crispy round flatted crackers), made of ordinary rice flour mixed with coconut milk and eggs is baked. Juadah talue (Ach juadah bò manok) is made of glutinous rice flour mixed with eggs. They are fried first with coconut oil then sugar flour (Ach teupōng saka) is sprayed on them. They are also attached to every end of the rattans on the idang. Small juadah talue are also attachend to every end of the rattans. Big juadah talue are also tied at the end of a stick made of bamboo then they are also attached to the idang. They are in the form of cocks, birds, and flowers. At the top is a bird as the official symbol of the Republic of Indonesia (Indon burung garuda). In addition, it is also decorated with various colours of small rounded fried flour called "necklaces" (Ach manék-manék) using the ingredients of juadah talue. They are connected with threads sewn the middle of them. Likewise various coloured flags made of kite paper are also tied at the end of the sticks. They are also stuck to the big idang. 
This all takes a week to make. The villagers spend from twelve to sixteen litres of glutinous rice to makean idang gadang,the same idangas used at a marriage ritual placed before guests arrive called a "groom's idang" (Ach idang lintō). It costs from Rp 500,000 to 800,000. One says that the bigger the idang brought to the mosque for khanduri mó 'lot, the bigger the religious merit (Jam pahalo) for the donors.

\section{Idang golèk}

Idang golèk means an idang that is ("circulated") passed round from one person to the next (Ach golèk). It is smaller than a sanggèng which is not included in the main idang but as a supplement on the khanduri mò'lōt day. They are only made by certain families that have young men (Ach aneuk muda) and young couples. On the day of khanduri mò'lot, idang golèk are placed in a house near a mosque where the khanduri is held. After the khanduri mò'lot is finished, they are given to the invited guests. This exchange is called "planting idang" (Ach tanom idang) to the invited guests. They are reciprocated in that or the next year of the khanduri mò'lōt season. However, the village imām condemns this reciprocity because it is no longer a sincere khanduri and can hamper the value of the khanduri mò'lōt ritual itself since the receivers have to give them back to their givers. He emphasizes that the given khanduri must be sincere if not it may not be called khanduri. No matter who will eat it, the giver will certainly get religious merit by providing it. Here is clear that the idang has direct reciprocity among the villagers, hence condemned by the imām. Even though the imām does not allow reciprocation, a number of villagers perform this exchange without the imām's blessing because there are two advantages: 1) they are keen to prepare the khanduri on the móltot day, and to reciprocate the received idang golèk and 2) the children at home will definitely get the khanduri on this day without trying to outdo (Ach meurebôt) each other.

Outdoing each other, particularly in eating the cooked meat, is done by children at the khanduri mò 'lōt ritual. Some get more meat, some get less and some do not get any cooked meat at all. Meat which the villagers seldom eat on ordinary occasions is indispensable for the idang mó 'lōt; the khanduri is preceded by slaughtering animals. Such general slaughterings takes place on no other occasions except the last days of the eight month (Ach huroe or uroe makmeugang puasa), Sya'ban and the last two days of the nine month (Ach 
huroe makmeugang uroe raya puasa), Ramadhan and at the "great" feast of the sacrifice on the $10^{\text {th }}$ day of the twelve month (Ach uroe raya haji), Zulhijjah.

\section{A case of conflict}

Two years ago, there was a conflict concerning the idang golèk. During that mò'lot season, the Blangporoh villagers were invited to eat the khanduri $m o$ ' $l o \bar{t}$ by the Kutaiboh village, a neighbouring village. Bang Dinpasi in Blangporoh received the returned idang golè which according to him was not enough. The returned idang golek was not the same amount and value of what he had already "planted" to M. Ali in Kutaiboh a year earlier. In other words, Bang Dinpasi received less then he gave to $\mathrm{M}$. Ali so that he refused to accept it from the village Kutaiboh. He was angry and made noise in front of the crowd. This reciprocity becomes problematic because its value was not the same. M. Yusuf teased him by saying "that is enough, take it. It is still better than if M. Ali had given you no reply. Please see that the returned idang golek which is not enough as a charitable act (Ach seudekah) so that you will feel ok about it and can also obtain religious merit from Allāh". At the end the owner of the idang, M. Ali heard about it and felt really embarrassed. He together with other young men from the Kutaiboh village came to Bangdinpasi's house and gave him clothes, sugar, coffee and cigarettes in order to conceal his embarrassment.

From this conflict up till now the Kutaiboh villagers no longer invites the Blangporoh village to the khanduri mò'lott. The conflict experiences between the Kutaiboh village and Blangporoh village is because the exchange of idang golèk is not mutually satisfactory. The mutually satisfactory gift-exchange relations will arise from a balancing of "benefit" between parties. Because the returned idang golek is inadequate, the relation between the giver and the receiver is threatened. The inadequacy of a returned idang golèk becomes a source of vile gossip "that can travel across the seas over hundred of miles to the home of the offender" so that some additional gifts have to be given to the receiver right away as a precondition to the continuation of the relation between the parties. 


\section{Excursus}

The reciprocity of idang golèk is just the same case as giving and receiving a henna tray (Ach dalong gaca) performed by the village women. It seems that it has become an adat in the villages in South Acèh in which the village women prepare the henna tray for a family who holds khanduri (Ach alekk); such as, akikah, circumcision, and the marriage ritual. The henna tray consists of milled henna, clothes, cakes, 1 kilogram of sugar, half a kilogram of coffee, face powder, soap, perfume, a pair of sandals, a rimless cap for a male, headgear for a female, a mirror, scissors, a towel, a comb and so on. The receiver writes down the name of the givers. As the giver holds a party later, the henna tray receiver will give it back with the same contents and even more. The basic aim of the reciprocity of the henna tray is to strengthen the social life and to develop or maintain a social relationship between parties In contrast; commodities are exchanged strictly in relation to other commodities without any implied residual obligations or relationships between the people involved (Gregory 1982). If the receiver does not return the henna tray, the village women will condemn the receiver and in the end none of them wants to attend her future celebration. Teungku Usman with whom I discuss the reciprocity of idang golèk and the henna tray contends that casually the reciprocity of these both exchanges is no different to the exchange of salām (Muslim's greeting) in which giving salām is voluntary but answering is obligatory. The people who receive saläm are obliged to answer better or at least answer in a like manner to the saläm giv$\mathrm{er}^{176}$

In the past, the idang mó $l \bar{o} t^{177}$ brought to the village mosque consisted of several layers. The first layer was filled with oranges, sugarcanes, and bananas.The second layer was filled with cooked vegetables. The third layer was filled with cooked fish together with their broth. The fourth layer was filled with boiled eggs, salted eggs, and sunset eggs. The fifth layer was filled with fried fish, fried chicken, and roasted chicken. The sixth layer was filled with cooked meat with their broth and the seventh layer was filled with fried meat and baked meat. Every layer comprised of seven plates; six plates were placed around it and the other one was placed in the middle. The arrangement of such

176 But unlike the reciprocity of idang golèk and the henna tray, saying salām is one of the Prophet's sunnah.

177 My informant does not specify which idang he means. I think the idang he means is sanggèn. 
plates and layers were performed in order to be loved by the deceased persons (Ach aruwah) of the family. According to the head of Acèh Adat council of West Labuhan Haji district, Guru Budiman, such idang prepared for the khanduri mò 'lōt ritual symbolizes a nubile girl (Ach aneuk gadih yang ka jeut meukawén) because young men fought over her. The nubile girl is very valuable and brings happiness to her parents. Parents who postpone marrying her are seen as objecting to the khanduri mò'lōt. This khanduri brings great religious merit from Allāh. This action is assumed less useful if the parents continuously refuse to marry her off. She certainly would become old and eventually a young man in the village would be reluctant to marry her because she is less attractive due to "less affection" (Ach kureueng rasa). As said in Haba Madja "Idang meulapéh bèk tapeuthen, aké jameun ka kureueng rasa", means "the layered idang is not to be kept because later it will be less tasty". The following figure 6 shows the young men fight over the nubility of young girls.

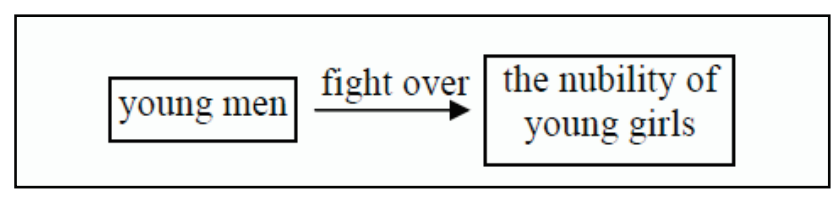

Figure 6. Young men fight over the nubility of young girls

\section{The celebration of khanduri mò 'lōt}

Monday, March $29^{\text {th }}, 2007$ at $14.00 \mathrm{pm}$ the khanduri mò'lōt ritual in Blangporoh village is performed. Each head of the household brings his idang with Rp. 2,000 to the Blangporoh's mosque and men and women together with children have gathered there. The students (Ach aneuk dayah) who are from the boarding school of Syeikh Muda Waly and the village's orphans sit in the mosque, while the invited guests who are from Blangbaru village and strangers sit outside the mosque. The imamm welcomes the invited guests using a microphone.

All idang are given to the mó 'lōt committee members and placed on the terrace of the mosque. One said that the committee members take 5 sanggèn with the cooked rice and bring one to the children of the Syeikh: Abu Ruslan Waly's house, to Abu Nasir Waly's house, to Abu Abdurrauf Waly's house, to Abu Amran Waly's house and to Ummi Halimah Waly's house in the complex of the boarding school which is not so far from the mosque where the ritual takes places. At any public khanduri held in Blangporoh village (and even 
sometimes out of Blangporoh village) the villagers always give them food because they are charismatic 'ulama ' in the village and at the same time show their respect to them. The idang should be eaten first by them due to the villagers' assumption that they are close to Allāh and have rendered services for the village mosque.I also see the same practice in Kutaiboh village in which the villagers also give an idang to Abu Hamid as a charismatic 'ulama' ' in that village. Another one goes to Iskandar, the teacher who teaches Qur'ān in the mosque and the other one goes to a labourer, Ahmad who helps make the mosque. Every khanduri mò 'lōt, each of these people is always given an idang for they have rendered a service (Jam bajaso;Ach ka meujasa) for the village. Both 'ulama' and those who have rendered services to the mosque and the village are served the idang mò'lōt first.

Prior to reciting diké $m o{ }^{\prime} l \bar{o} t^{178}$ in Blangporoh village, the imām as leaders of diké from Blangbaru village, Teungku Imran lightsa small bit of white benzoin incense in a coconut shell in order to call the Prophet Muhammad's 'soul' (roh from Arb rūh ) to be together with the people who recite diké. The villagers named a benzoin incense keumeunyan which is very important for healing in the village. In Acèhnese, keumeunyan means "that is what I want". According to Teungku Jauhari, the word keumeunyan is from the Arabic word "burru da 'wāhum" meaning "calling something"; for instance, the 'soul' of the Prophet at khanduri mò'lōt ritual, angels at any religious ceremony, and Satan (Ach syètan). Abu Baihaqi says that burning the benzoin incense at the khanduri mò' 'lōt ritual is to follow the Prophet's interests. But Cut Mad says that burning it at the khanduri mó'lōt is also to call the Prophet's "soul", to call angels from the sky to take part in the feast then they will bring up the religious merit of diké mò'lōt (Ach pahala mediké mò'lōt) to Allāh. He adds that the angels themselves like the pleasant aroma provided by the benzoin

178 Most diké recited are from kitāb barzanji in Arab Jawi (non Arab) and some are from Acèhnese as practiced in Blangporoh village. But in Blangmanggéng, another village in Manggéng district all diké recited are taken from this kitāb (book). Diké is not the same as dzikir (from Arb dhikr). Dzikir is the repetition of the names of Allāh and certain religious formulae as a means of demonstrating piety or, in the case of mystics, also to induce a mystical trance. In zikir jahar, the repetition is spoken aloud, while in zikir khafi, the repetition is done silently. The most frequent formula used is as follows: La ilaha illal Lāh (there is no deity but Allāh), Allāhu Akbar (Allāh is great), Alnamdulillāh (all praise to Allāh), and Subhanallāh (Allāh is holy) (Federspiel 1995:295) 
incense. The following figure 7 shows that burning benzoin incense is to call the Prophet's 'soul' and angels from the sky.

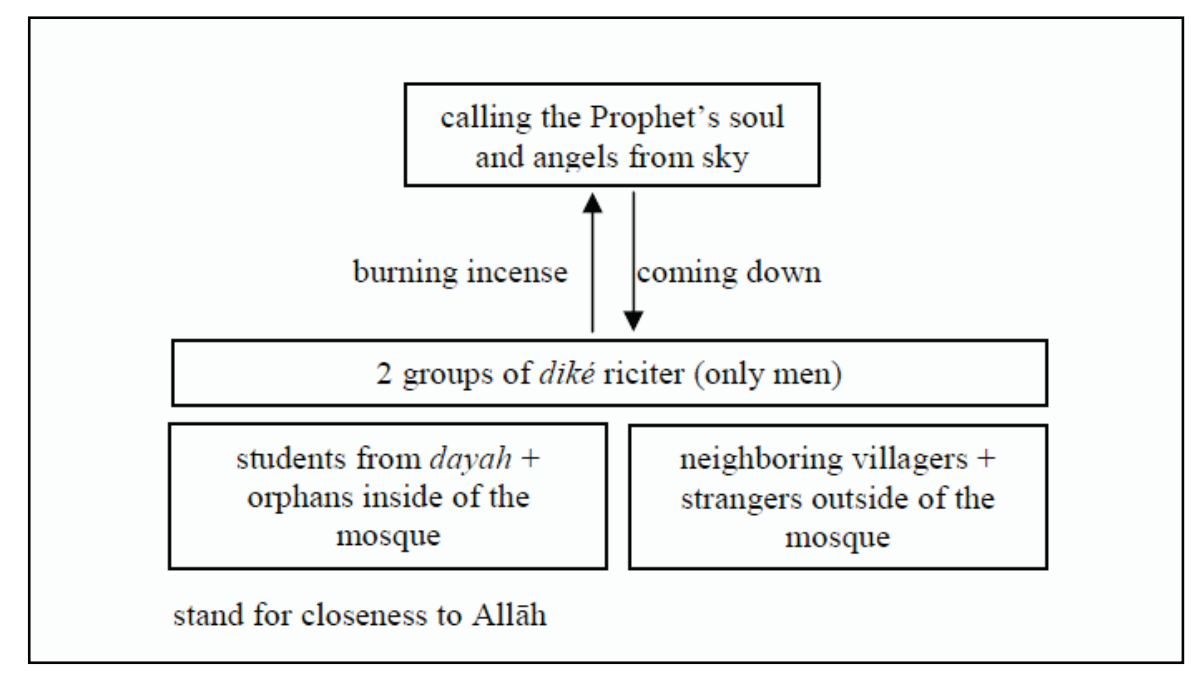

Figure 7. Calling the Prophet's 'soul' and angels

There are two kinds of incense that are often burned: white incense (Ach keumeunyan putéh) and black incense (Ach keumeunyan itam or hitam). White incense is burned as a tool for prevention (Ach peunuléh) whereas black incense is burned as a destructive tool for bad purposes; for instance, for the aim of destroying, taking revenge, and killing. Burning black incense is often associated with mystical properties (Ach meurajah), which are connected with black magic (Ach ileumè hitam). A healer says that both white incense and black incense are from paradise then they were sent down to the earth together with Adam and Eve. The ritual of using incense directly came from the Prophet Muhammad, who discovered benzoin's powers as he emigrated from Mecca to Madina on a camel with a flock of sheep driven behind them to cover their tracks. He and Abu Bakar hid in a cave in Mount Tsur (Arb jabal tsur) to elude their Mecca pursuers. In the cave, the Prophet Muhammad picked up a piece of benzoin and, scratching it with his fingernails, released its characteristic smell. He said to the wood: "just as I am honest and straightforward, so you must carry straight to Allāh whatever is required by the people who burn you." "The wish that he not be discovered, upon which an acacia blocked the entrance, a spider web which was spun over the opening of the cave and a dove's nest with eggs in front of it. It seemed that no one had entered the cave. As his pursuers saw the large web

179 The same idea of using incense (Ach keumeunyan) found in Gayo, Central Acèh; see Bowen (1993:231). 
and the dove's nest with eggs, they passed by without checking inside. ${ }^{180}$ However, the local modernists avoid using the benzoin incense because of its implied function of transmitting requests to angels and other spirits.

\section{Diké mò'lōt}

There are two groups of diké reciters. One group is from Blangbaru and the other group is from students of the Boarding School in Blangporoh. The diké reciters are recruited from students who have been well trained by their seniors at boarding school. Learning by heart the diké mò'lot has become an additional course for many boarding schools (Ach dayah or rangkang) in Acèh province. The mò'lōt months for boarding school's students are the busiest month in the year. There are many invitations from other villagers to recite diké $m o ̀ ' l \bar{o} t$ at their villages. In addition, the mò'lōt months bring them many advantages. The more invitations come, the more good food they will get. They rarely get good food at the boarding schools. The only opportunity to consume good food for them is during the mò'lot $t$ seasons. Therefore, they call the mò 'lōt months as "the month for repairing nutrients" (Indon bulan perbaikan gizi). ${ }^{181}$

The diké reciters sit on mats in rectangular formation facing each other. In front of the diké leader, there is a kitāb barzanji ${ }^{182}$ placed on a pillow. Beside it there is a coconut shell with some charcoals in it. When the most respected diké reciters are present, the performance begins. There is a lack of formality but the solemnity is significant. As it is about to begin, a small white incense is burned and its fragrance helps intensify the spiritual atmosphere. The sürah al-Fätiha $\underline{h}$ is recited and its merit flows directly to the Prophet, his wives, his descendants, his companions his followers, those who are dead and still alive. As the white incense is burned at the opening of the diké at the khanduri mò'lōt, the following $d o$ ' $a$ is uttered:

180 The history of his concealment in the cave is mentioned in the Qur'ān 9:40.

181 Not only Blangporoh village recruits students of boarding schools (Ach aneuk rangkang or aneuk dayah) to recite the diké on the mò'lōt day but also other villages in Acèh do the same thing. See Acèh daily newspaper, Serambi Indonesia on April 14 $4^{\text {th }}, 2008$.

182 In Acèh, kitāb barzanji is used as the main source and it has already inspired the 'ula$m \bar{a}$ ' of the boarding school to write other similar works in the summary of seulawet and the biography of the Prophet Muhammad. The difference is that the summary works of the Prophet's birth is written in non Arabic (Arab Jawi). It is not the same as the original kitāb which is written in Arabic. The name of barzanji is taken from the writer of the kitāb (book). That is, Syekh Ja'far al- Barzanji bin Husén bin Abdul Karim. 


\section{Bismillāhir-Rahmānir-Rahīm}

Hai kěměnyan putiah, ambo tau asal mulo angkau

Angkau jadi dari sir Allāh dan sir

Muhammad

Angkaulah yang banamo burru da 'wāhum

Angkaulah yang ambo imbau dan suruah sakatiko

Angkaulah yang menyamapaikan niaik ambo.
In the name of Allāh, the merciful, the especially merciful

Hai white incense, I know the origin of your creation

You are created from the secretness of

Allāh and Muhammad

You are named burru da'wahum (calling something).

You are the one whom I call and ask for a moment.

And you are the one who fulfils my intention.

Another $d o^{\prime} a$ that is uttered when the incense is burnt is:

Alief (Arb $\left.{ }^{1}\right)$ nurullāh

Ba (Arbe) kalamullāh,

Hai keumeunyan ambo paluah Rasulullāh

Angkaulah yang menyampaikan niaik ambo
Alief (Arb $\left.{ }^{\mathfrak{l}}\right)$ is the light of Allāh

$\mathrm{Ba}(\mathrm{Arb}+)$ is the word of Allāh

Hai my incense, you are the sweat of the apostle of Allāh

You is the one who fulfils my intention.

These $d o$ ' $a$ are deemed as the $d o$ 'a for burning incense (Ach do'a tot keumenyan) The leader, Teungku Imran, who is well acquainted with kitāb karzan$j i$ and who has a good chanting voice takes several Arabic lyrics of verses from it. Each contains appeals to Allāh to give the highest dignity to the Prophet, his ancestors and his descendants and merit to his companions, his followers, participants and all Muslims. At the same time as the smoke of incense is billowing, the first diké is recited by the leader as follows:

Astaghfirullāh

ya Allāh lanā walahū

min zambinā wamin zambihī,
I ask Allāh for pardon

O Allāh, for us and the Prophet families

from our sin and their (the Prophet families) sin

This diké is repeated by the diké reciters in chorus ten times; the same diké is chanted in response to the leader each time. As the recitation of the first diké is over, he then continues reciting the second diké:

Astaghfirullāhal 'adhìm

mingkulli zambil adhìm

Wal awwalau wal akhirau

waldhahirau wabathina,
I ask Allāh for pardon

from every sin;

the previous and the latest sin

the outer and the inner sin

This diké is repeated in chorus ten times. As the followers repeat diké, their bodies and heads are shaken from the right to the left and their elbows are "locked" with each other; for instance, the elbow of the right hand of B is "locked" with the elbow of the left hand of $\mathrm{C}$ and the elbow of the left hand of 
B is "locked" with the elbow of the right hand of A in order to strengthen their body and heads to be shaken at the same times (Ach bak sabé lingik). The leader continues reciting the third diké:

Allāhumma shalli'alā saidinā Muhammad O Allāh [please] exalt our leader, Muhamammad Yā Rabbī shalli 'alaihi wa sallìm $\mathrm{O}$ Allāh [please] exalt him and give him peace (iii)

This diké is repeated in chorus ten times. At this point, the diké reciters are still shaking their bodies and heads but their voice keeps increasing. The spectators comprising of men, women and children of different ages are coming closer and closer to them. They are also very happy to see the diké reciters. The leader then continues reciting the fourth diké:
Ya nabì salam 'alaika,
O prophet peace be upon you
Ya rasul salam 'alaika,
$\mathrm{O}$ apostle peace be upon you
Ya habibus salam 'alaika,
$\mathrm{O}$ beloved peace be upon you
Salawatul Allāhi 'alaika,
Allāh's exaltation be upon you

This diké is repeated again and again in chorus for another ten times in response to the leader each time he chants the diké but the melody is not the same as the previous one. The leader then continues chanting the fifth diké in Acèhnese version which is not found in kitāb barzanji:

Adam Nabi, Nabi Adam

Mula jadi Nabi Adam

Geyu sujud bak Nabi Adam

Yang hantem sujud Iblis Syétan
The Prophet Adam, the Adam Prophet The beginning of the Prophet Adam was created Asked to bow to the Prophet Adam

This dike is repeated in chorus another ten times and the melody is different than the previous one. Sometimes a participant takes the initiative to change the melody. While standing solemnly then the leader starts with the sixth diké in a new melody:
Marhaban ya nur al-'ain
Marhaban jadd al- $\underline{\text { Husein }}$
Welcome the light of the eyes
Marhaban ahla wa sahla
Welcome grandfather of $\underline{\text { Husen }}$
Marhaban ya khair al-da'i
Welcome and best regards

This diké is repeated for another ten times. Then the last diké with another new melody is recited:
Marhaban ya marhaban
Umar, Usman
Ya Ali ya Abubakari
Welcome ya welcome
Umar, Usman
Ya Ali and ya Abubakar


This last diké is repeated ten times. The diké reciters recite it loudly while standing and jumping (Jam ba ila or malompèk-lompèk;Ach grôp-grôp) to show their spontaneous respect, honour and joy due to the Prophet's birth. They are all sweaty and some of them sometimes fall down then stand up again and jump again like other diké reciters. The imām, however, does not jump up and just stands near the jumping diké reciters while reciting the diké. Meanwhile, the spectators are coming closer and closer to them. After finishing reciting diké at about 17 o'clock, they sit on the floor again. The committee members give them lemonade. ${ }^{183}$ While taking a rest for several minutes, some diké reciters say that they are tired due to reciting diké while fanning their bodies with their clothes and some say nothing while wiping their sweaty bodies with their small towels. Some are looking at the terrace of the mosque where all idang are placed. They are so happy (Ach/Indon gembira) because the idang together with their broths will be soon served for them. They sit in several straight rows like in group prayers but facing each other. There is space in the middle to place the idang later.

The last step is reciting $d o^{\prime} a$ as the conclusion of diké. The imām recites it holding up his two hands followed by all participants and at the certain part of $d o^{\prime} a$, they intone with the word $\bar{a} m \bar{i} n$ (please accept o Allāh). At the end of $d o^{\prime} a$ the imām together with all participants intone together:

Amìn āmīna yārabbal 'alamīna Istajeb du'a anā kullanā ajma inā
Please granted our request oh Lord of the world Please accept our $d o$ 'a that we have already recited.

See the outlines below for the above ritual actions

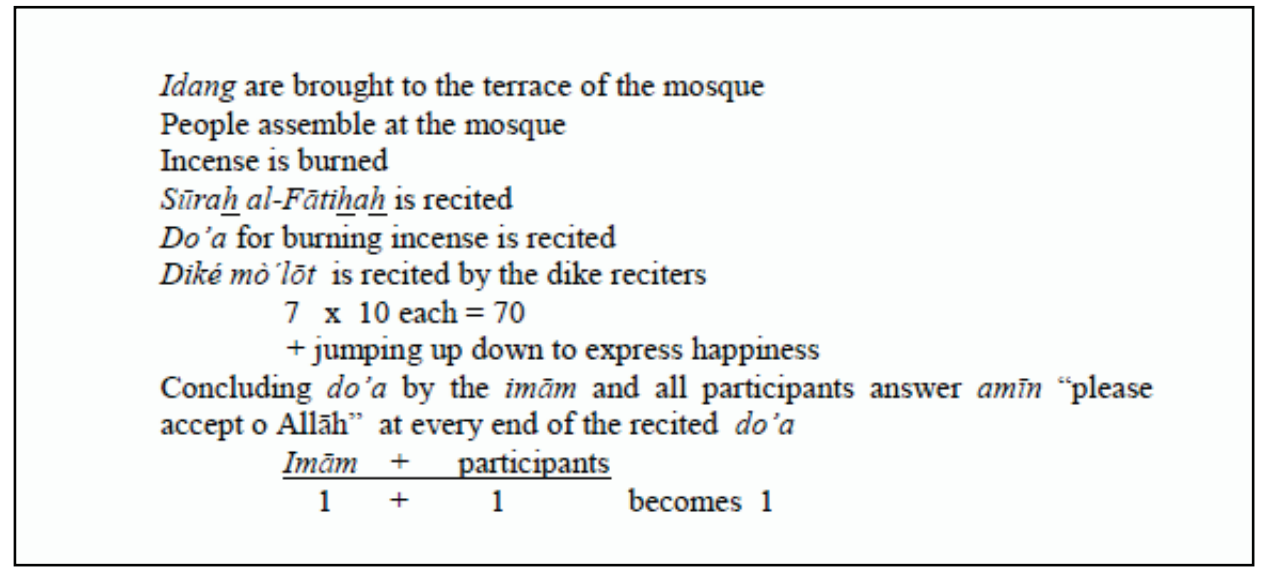

183 The money for buying lemonades is taken from household heads who bring idang to the mosque. 
The committee members are then busy taking the idang from the terrace of the mosque for all participants after the diké finishes and place them in front of the diké reciters. As all idang are ready in front of the diké reciters, Anasjuddin, the village leader of Blangporoh village welcomes them to take and consume the idang. Most of them then struggle (Ach mereubôt) eagerly to get a portion of the cooked and fried meat, fish and boiled eggs from sanggèn and also glutinous rice from idang nasi kunyik, and idang gadang for collective consumption and bring the rest home. The situation is very noisy which is like "the sinking Chinese" (Ach lagèe cina karam), say the attendants. In such situations, M. Yamin says "This is the khanduri for our leader, eating fully and bringing the rest home" (Ach nyo khanduri keu saidina, pajoh beu tro puwo beuna). The committee then also eat together on the terrace of the mosque. Soon after the khanduri mò'lōt is over, the young leader of the village rechecks the orphans and the poor who are absent on that day, the committee members then bring meals and side dishes to their houses. There the committee members share ordinary rice with side dishes then they share the sticky rice. Vice versa, in Kutaiboh and Blangbaru village, the committee members share the sticky rice first then they share the ordinary rice together with side dishes.

Meanwhile big idang are served more for the governing body of the invited village than others in Blangbaru and Kutaiboh village, idang gadang is served more for the diké reciters and orphans than for others. These idang are less in Blangporoh village and Blangbaru village, but they are more in Kutaiboh village. In addition, there is no daluang there. The owners of daluang, sanggèn, idang nasi kunyik and idang gadang directly share them with the participants in Blangporoh and Kutaiboh village. Therefore, the situation at the time of eating khanduri mò 'lót is better. The interesting thing is that the diké reciters and the orphans in Blangbaru village are allowed to fight to get a portion (Ach merebott) of meat, fish, and glutinous rice. The imām of Blangbaru, Teungku Imran says on the day of khanduri mò'lot celebration, "If the drinking glasses are broken due to fighting to take the portion of meat, fish and other side dishes, I will replace them for you all because today is a happy day".He adds that fighting to take the portion of meal and side dishes is one of the expressions of happiness in commemorating the Prophet's birth. In Blangbaru village, the people who share the meal and side dishes on that day are not the owners of the idang so that the participants are not reluctant to fight to take the served food with side dishes. "This situation makes khanduri livelier, and lets 
them fight over the provided food", say some old men who are watching the diké reciters with smiles. The following figure 8 is the distribution of the idang $m o ̀ ' l o ̄ t$ at village level:

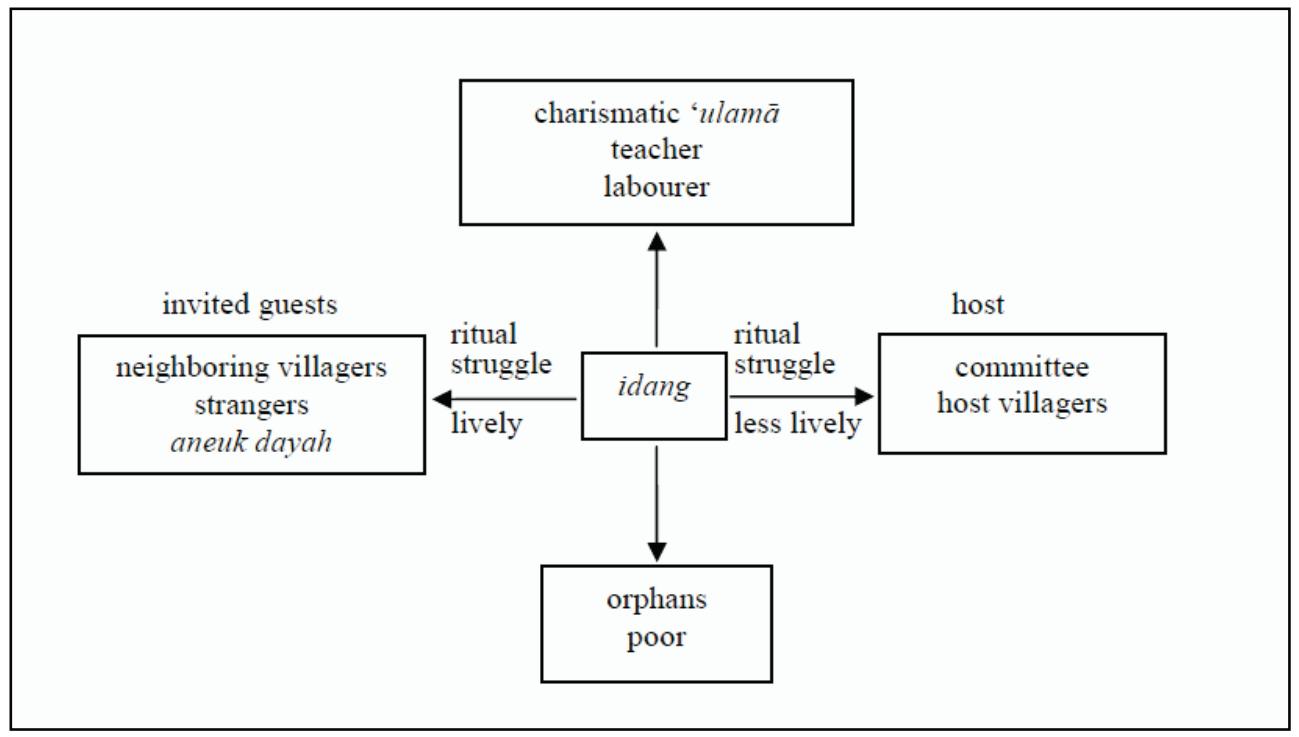

Figure 8. Distribution of idang mò' 'lōt at village level

When the khanduri mò'lōt takes place in Blangporoh village, there are only several students of the boarding schools who go to the grave of Syeikh Muda Waly to perform a recommended prayer (Ach seumayang sunat) and recite $d o$ ' $a$ in order to get a blessing from him. They go there not in the context of mò'lōt celebration as is admitted by Teungku Mulyadi, rather they go there because of the students' habit of seeking their teachers' blessing (Ach beureukat gurèe). The boarding school students who are sometimes called aneuk rangkang or aneuk dayah by the villagers believe that the 'soul' (roh) of their deceased teacher (Ach gurèe) could guide their life to the right path sothey go to the Syeikh's tomb to seek the teacher's "blessing" which they refer to to gain the supernatural powers andthe special mystical powers for good fortune and protection (Arb käramāt) of theirformer teacher is somehow transferred to them even though they now learn with his son, Abu Ruslan Waly at the boarding school. ${ }^{184}$ However, Cut Hukom in Suak Berumbang Manggéng, a neighbour

184 Unlike the khanduri mò'lōt ritual in Blangporoh village, in Banten thousands of people go to the complex of Agung mosque for doing ziarah (visiting tomb) at the grave of Sultan Hasanuddin by taking turn on the mò'lot ritual day. A number of the visitors take a bath in Sultan's pond in order to get baraka "blessing" Some of them bring the pond water back to their homes as medicine. In Cerebon on 11-12 Rabì' al-Awwal, many Muslims go to the grave of Sunan Gunung Jati, one of the nine pious leaders (wali son- 
district of West Labuhan Haji does something different on the night of the Prophet's birth in which he intercepts and retains the falling rain directly from the sky if it is raining that night. He adds that the raining water will be the best prevention (Ach peunuléh) for all sickness because the night of the Prophet Muhammad' s birth is a holy, blessed night, light night, valuable night, and a happy night for all Muslims and even the world is all submersed in light onthe night of his birth.

\section{Discussion of diké}

The dikérecited at the khanduri mò'lōt ritual contains appeals to Allāh to give the highest dignity to the Prophet, his ancestors and his descendants and merit to his companions, his followers and to all participants and isthe reaction tothe historical events attached to it.

Diké 1 and 2 contain do'a called istighfār (asking forgiveness from Allāh). Diké 3 and 4 contain the prayer for the Prophet's welfare called seulawet. Reciting istighfar and seulawet respectively are the courtesy of a do'a and are a must before asking something else of Allāh, says the imām. The diké reciters shake their body and head while reciting diké 1, 2, 3 and 4 . It is said that shaking the body and head while reciting istighfär at the khanduri mò'lōt is a symbol of happiness (Indon kegembiraan). It refers to the grand father of the Prophet, Abdul Muthalib who shook his body and head when he heard his grandson, Muhammad was born. In addition, it also referred to Abu Lahab (the Prophet's father's brother) who also shook his body and head when he heard that the Prophet was born although he himself never acknowledged that $\mathrm{Mu}-$ hammad was an apostle of Allāh. In addition, he set Tsuaibah free as his slave because she told him that Muhammad was born on that day (12 Rabī' alAwwal $571 \mathrm{M}$ ) as an expression of his happiness. Some villagers in Blangporoh, Blangbaru, and Kutaiboh village whom I discuss this with say that the torment for Abu Lahab in hell is lightened on every Monday because he was happy as the Prophet was born.

go) who spreaded Islam in west Java, to get baraka. In all Keraton, the celebration of panjang jimat is performed on the day of the Prophet's birth. Panjang jimat means watering the Keraton's heirloom inherited by Sunan Gunung Jati. Many people fight over the water that has been used to wash the Keraton's heirloom because it is believed that the water will bring the luck for the users, see Harian Pikiran Rakyat, Bandung May $2^{\text {nd }}$, 2007. 
Diké 5 emphasizes that Satan is a clear enemy for Muslims (QS 2:208 and 35:5) from Adam's creation till the end of the world.It is believed that there is a devil upon each misguided path, calling people towards him. Satan is the one who is deprived from the mercy of Allāh and promised hell as an eternal dwelling. Satan said, "Because You have put me in errors, I will definitely sit in wait for them [i.e., mankind] on Your straight path)" (QS 7:16). He asked Allāh to give him respite and took it upon himself to misguide the offspring of Adam (QS 7:14). A participant comments that diké 5 reminds us not to follow Satan and to always see him as an enemy who leads us away from Allāh.

Diké 6 is livelier, in which the diké reciters are standing solemnly and start reciting loudly to welcome the Prophet's 'soul' (roh) to be together with them.

The last diké (diké 7) is very lively. The diké reciters are all happy (Indon gembira) and do it sincerely because they believe that the prophet's 'soul' (roh) and his four companions; Umar, Usman and Ali are together with them. They therefore do not mind being tired and sweaty. Some other diké reciters and a $m o ̀$ 'lot speech deliverer at the boarding school in Blangporoh contend that jumping up and down is an expression of happiness.It refers to the days of jubilation approaching his birth (see mò'lōt speech). Teuku Nyak Silan says that jumping up and down while reciting diké at khanduri mò 'lót celebration is also the expression of happiness but it refers to all creatures (Ach lat batat kayèe batee) that are so happy that the Prophet was born except Satan. He adds, "Fish in the sea are jumping up and down; their hearts are so happy because they have their Prophet" (Ach ungkôt dilaôt di grôp-grôp tunjak, haté jih galak nabi jih kana). Abu A.Rahman Badar says that jumping up and down at khanduri $m o$ 'lot $t$ celebration also refers to the tale of Tsuaibah ${ }^{185}$ in which she ran and jumped to report to Abu Lahab. He adds, as a slave of Abu Lahab, Tsuaibah was always asked to accompany Aminah (the Prophet's mother) during her pregnancy every night. In the early morning of 12 Rabī'al Awwal $571 \mathrm{M}$, she ran happily to report to Abu Lahab that the Prophet Muhammad had just been born. According to many villagers, however, not only animals, like fish and other living creatures but also angels in the sky jumped up and down due to their happiness that the Prophet was born. It is also said that jumping up and down at khanduri mò 'löt when the last diké is recited is the influence of Syiah

185 Tsuaibah was the slave of Abu Lahab and also the one who breastfed the Prophet after his own mother, Aminah, and then he was breastfed by Halimah as Sa'diyah. She is believed to become the queen of bidadari (fairy or a beautiful woman) in paradise. 
Islam in Acèh. Many years ago Muslims in Trumon, another district in South Acèh, performed a dance and jumped up when they celebrated Hasan-Husén feasts round fires. ${ }^{186}$ Nevertheless, according Abu Nasir Waly, jumping up and down at a khanduri mò'lòt celebration is no indication of Syiah's influence but it is only a shanging history. People probably used to be (Ach ureueng jamén) so absorbed reciting diké that they jumped up and down. It does not mean that people are not allowed to recite diké like that but it has become acceptable for Blangporoh society, while Abu Dasyah, one of the charismatic 'ulamà' in Panté Geulima, West Labuhan Haji district says that jumping up and down at khanduri mò'lōt celebration has no basis at all. If one wants to recite the diké, one is not allowed to jump up and down and even his or her body is not allowed to shake. He further says that he has no power to change what people do when the celebration of khanduri mò'lōt takes place.

The last episode of the dike is the most interesting for the spectators so that many of them comprising of men, women and children from the Blangporoh village and beyond, look at, and listen to diké reciters. One says that spectators are the symbol of angels as the Prophet was born because when he was born, there were so many angels from sky going down toearth to to have a closer look at him. Many spectators becomes volunteers to fan (Ach pôt-pôt) their clothes in order to cool the diké reciters down and to motivate them jumping while reciting diké. When I ask one of the female spectatorswhy she wants to come, look at, and listen to diké reciters, she answers that the recitation of diké $m o ̀$ 'lōt will grant the listeners rewards not only worldly but heavenly as well. Worldly reward is that she has the opportunity to get to know people and afterwards the khanduri mò'lōt celebration occurs. This opportunity enables her not only to meet people casually but also to exchange ideas, and to help each other. Her small son also gets some wrapped glutinous rice from the mò 'lót committee members. Heavenly reward, according to her is that the diké reciters will get religious merit. According to the imām, however, heavenly reward is that the listeners will get 'help' (Ach syeufeuat) from the Prophet Muhammad in the hereafter. Syafä'ah is the intercession of the Prophet Muhammad on behalf of Muslims on the judgment day. The first syafä'ah from him is received when one passes a bridge called titi sirathal mustaqim in the hereafter. Passing it is obligatory for all believers and Allāh will save those who fear Him and

186 See also Snouck Hurgronje 1(1906:206). 
those who pray (recited seulawet) for the Prophet's welfare as His messenger and will leave the wrongdoers within it. ${ }^{187}$ Every person's good deeds will be weight by angels before passing this bridge. If the pair of scales (Jam dacing;Ach céng) is heavy on the left side, the Prophet will then add his own turban (Ach seureuban) ${ }^{188}$ to the right side in order that the pair of scales will be heavy on the right side. The believer then will go to paradise, and if the pair of scales becomes heavy on the left side, the believer will go to hell. The Prophet Muhammad will perform this only for the ones who have already prayed for him during their lifetime, says the imām. The biggest syafä 'ahgiven by the Prophet to thosewho have alreadyprayed for him on the day of judgement, according to my informants, is that he will pick the believers up inhell as other prophetshave no power to help other believers in the hereafter. After a long discussion about syafä'ah, my informant says the following Acéhnese expression:

Lepah geunaséh nabi Muhammad

Geujak cok umat dalam nuraka

Nuraka tutông hana geuingat

Nabi Muhammad umat geumita
The Prophet Muhamamad truly loves his ummah He will pick his ummah up in hell He will not care about the heat of hell The Prophet Muhammad will look for his ummah.

This expression is quite often recited in Blangporoh's mosque, Blangbaru's mosque and Kutaiboh's mosque. The one who calls to prayer (Arb muazzin) uses a microphone to recite it after calling to prayer (Arb azan) and before praying together. This is considered the basic idea why Muslims in Blangporoh, Blangbaru and Kutaiboh village and other villagers in South Acèh are motivated to hold the khanduri mò 'lōt and recites diké for the Prophet $\mathrm{Mu}-$ hammad on the khanduri mò 'lót celebration day. The following figure 9 shows the location of the khanduri mò'lōt at the village level.

187 The explanation that every Muslim will have to pass the bridge on the Last Days can found in the Qur'ān (19: 71 and 72).

188 Some villagers says that the Prophet Muhammad will add his jubah (a cassock, often worn by saintly individuals among Muslims) for those who pray for him when his good deed will be weighed by angels before passing the bridge for the believers on the Last Day (Ach titi nuraka or titi sirathal mustaqìm). 


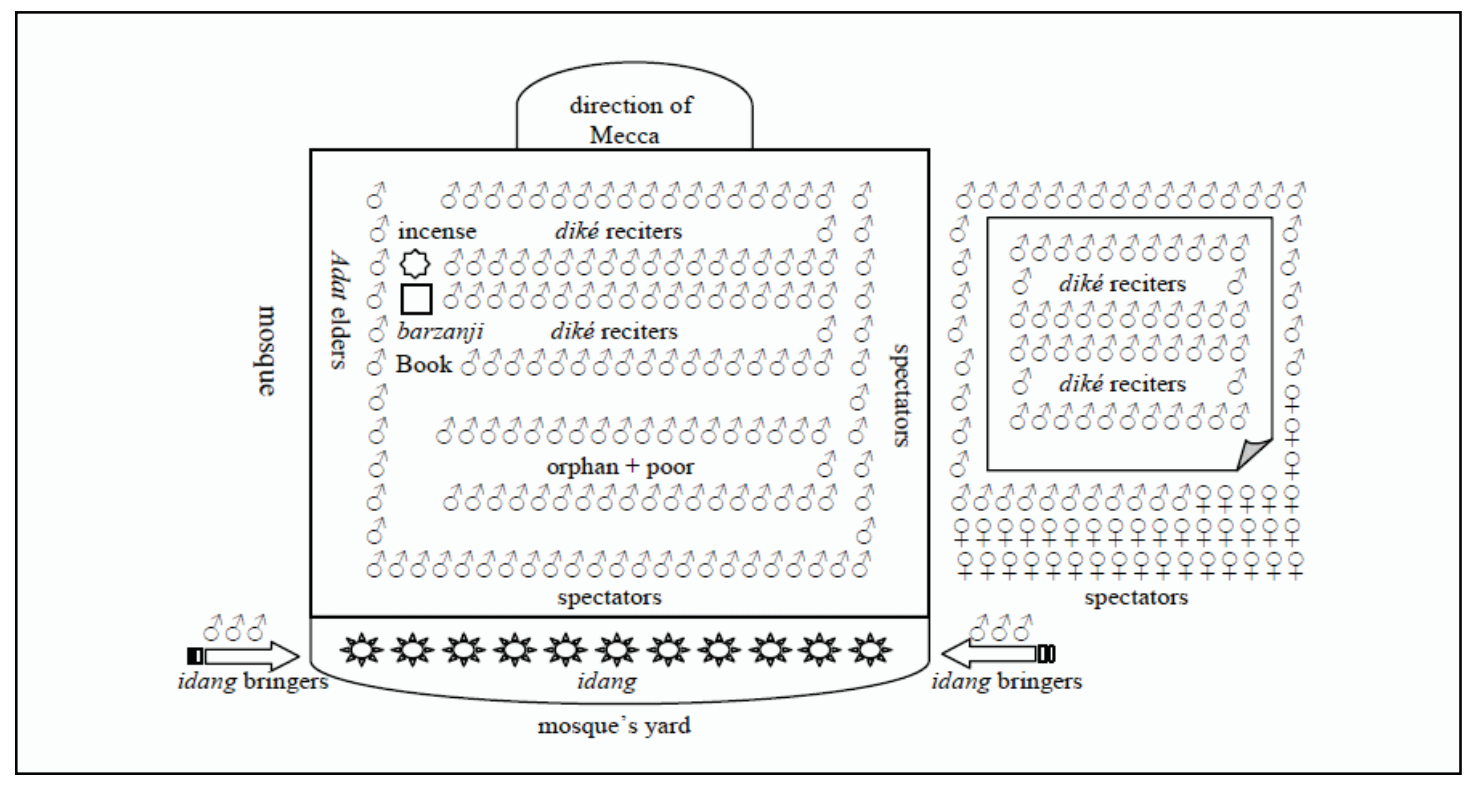

Figure 9. The location of the khanduri mò'lōt at the village level

\section{Mò'lōt speech}

I have observed the khanduri mò'lōt three times in different villages; Blangporoh, Blangbaru, and Kutaiboh in West Labuhan Haji. The khanduri $m o ̀$ 'lot $t$ in Blangporoh village was the best attended that year. Unfortunately, I did not hear a $m o ̀$ ' $l \bar{o} t$ speech or a $m o ̀$ ' $l \bar{t} t$ lecture about the Prophet's birth before or after the khanduri mò'lot in these three villages.It is only held at the boarding school in Blangporoh on March 30th, 2007. ${ }^{189}$ It seems that khanduri is more important than a lecture at the three villages. The villagers assume that this ritual has become an obligation that has to be performed. Everyone whom I discuss this with agrees that it is held to commemorate the Prophet's birth. Some villagers add that the food's essence provided are also enjoyed by the angels who go down from the sky on the day of khanduri mò'lōt. For them, the central events in khanduri mò'lōt are setting out daluang, sanggèng, idang nasi kunyik, idang gadang and even idang golek rather than listening to the lecturer. They see it more as a khanduri and the hosting of one village by another. Some other people whom I discuss this with, however, emphasize the importance of lectures and didactic discussions about the Prophet's life and find the khanduri

189 The mò 'lot speech held at boarding school in Blangporoh is sponsored by students (Ach aneuk dayah) and teachers (Ach gurèe) of that boarding school. There are more than five hundred people coming to listen to it. Most listeners come from out of Blangporoh village. 
to be at cross-purposes with the holiday's commemorative events. For instance, Teungku Kamaruddin says that a lecture about mò'lōt is more important than a khanduri mò'lōt itself. A mò'lōt lecture shows the appropriate expression of love and honour for the Prophet which is by following him, obeying him, carrying out his commands, upholding and reviving his sunnah both inwardly and outwardly, spreading his message and striving in this, with the heart, the hand and the tongue. Such is the path of the companions who follow him.

Below I present excerpts from the mò' $l \bar{t} t$ speech at the boarding school in Blangporoh omitting mainly repetitive parts. The general flavour of the mò'lōt speech is the significance of the exchange saläm (Muslim's greeting) as a part of the Prophet's teaching. Besides the information about the Prophet's histories, the social and spiritual purposes of $m o \dot{\prime} l \bar{o} t$ ritual are addressed as well. It begins, after the customary Arabic formulae "I take refuge in Allāh from the accursed devils" and "In the name of Allāh the beneficent and merciful" with a qur'anic text, sürah al-Ambiyā':107 “And We have sent you, [O Muhammad], except as a mercy to the worlds" and sürah al-Ahzāb: 40 stated that Muhammad, the messenger of Allāh is the last of the Prophet. The mò 'lōt speech is then continued:

All "fathers" and "mothers" (Indon bapak-bapak and ibu-ibu sekalian), I wish Allāh would bless you all for having attended the mò 'lōt celebration this night. The Qur'ān says that Prophet Muhammad is the last messenger of Allāh. He has done mankind a great favour by sending the Prophet, who is also among the human beings. In another interpretation, Qur'ān also says that Allāh relieves you great relief by sending you the prophets for the benefit of all humanities. In this special context, therefore, the coming of the Prophet Muhammad is seen as the seal of all the prophets (Arb khätaman nabiyyin) and must be regarded as a great mercy and a great comfort for mankind. This is because, if he were not to have been sent to this the earth, mankind would have still been living in "the world of darkness". As the various qur'anic verses repeatedly point out that the most fundamental task of the Prophet has been to guide humanities from "the world of darkness" to "the world of enlightenment".

Sadly, there are some people who are ready to show disrespect and their lack of knowledge in their expressive dishonesty and harmful references on the Prophet Muhammad, as they often say: "He was a person just like any other person, whose life ended a long time ago, why we should waste our time commemorating his birthday? May Allāh forgive those people. This particular line of thinking is very dangerous because it can create some misunderstandings and ignorance. Even though the Prophet was chosen from among human beings, nonetheless, his unique human, moral, and spiritual qualities are very different from those of other human beings... 
All "fathers" and "mothers", the Prophet Muhammad was born in $571 \mathrm{M}$ in Mecca and died in 632 in Medina. His father was Abdullah, who died before the birth of his son. His mother was Aminah, and his grandfather was Abdul Muthalib. At the age of 25, he married Khadija who supported and protected him and his family and belonged to the clan of Hasyim, a branch of Quraysh tribe. Most importantly, many of his companions followed him, and knowing quite clearly that he was an individual and, above all, as said a human being like them. Just for the sake of argument, supposing Allāh did not send the Prophet, who was among the human beings like us, but, instead, if Allāh had sent us an angel to come to this earth to guide mankind, some people would not have accepted that angel, and they would have found all sorts of reasons to ridicule him, just as they did with the other prophets.

All "fathers" and "mothers", the birth of the Prophet Muhammad is a matter of great historical significance ever recorded in the history of all mankind. As in the days approaching his birth, there was such a loud proclamation of joy and jubilation from the heaven and from the earth just to welcome the apostle of Allāh, the Prophet Muhammad. This great jubilation was of symbolic purpose intended to greet and to welcome the Prophet with such kindness and such pleasure, who was sent for the benefit of all humanity. If the mò'lot tritual is organised in such a way that the participants do not know each other, or do not even greet each other with such joy and happiness, in this sense, then the real purpose and the significance of $m o{ }^{\prime} l \bar{l} t$ is lost.

All "fathers" and "mothers", what is required for the mò'lōt celebration is therefore to bring together the community spirit and the unity of purpose within association. This, however, will enable people to have the opportunity not only to meet casually but also to get to know each other, and then exchange ideas, and help one another in creating this communal and spiritual atmosphere in order that we can fulfil the basic condition of love and affection for the Prophet Muhammad. Therefore, it is of utmost important to bear in mind that we meet and organise mò'lōt celebration and indulge ourselves in such festivities, but if our hearts and minds are notguided and influenced by his spiritual teaching, then in such a situation, I am afraid to say that we are just troubling ourselves for nothing.

All "fathers" and "mothers", one of his spiritual teachings is saying saläm. It is important to know the meaning and significance of Muslim's greeting "Assalāmu 'alaikum [salām]". The salām greeting is in fact a superior supplication, and a declaration or announcement meaning that you will be safe from any harm by hands or tongues. To give saläm greeting is voluntary but to answer it is obligatory. If someone is being greeted he or she has no choice but to respond by answering wa alaikum saläm "peace be unto you too". The person who receives salām is obliged to give a better answer or at least return the greeting in a like manner to the salām giver (QS 4:86). The Prophet Muhammad has ordered us all to spread salām among people you know or do not know yet. It should be spread to chil- 
dren, to women whether they are muhrim ${ }^{190}$ or not or even to the meeting where there are non Muslims. Women are also allowed to say salām to men as already practiced by Ummu Hani. She uttered salām to the Prophet Muhammad as the town of Mecca was opened (fathu Mekkah).

All "fathers" and "mothers", the Prophet Muhammad further guided us that:person riding should say salām to a person on foot. People walking should say salām to a sitting person. Smaller groups should say salām to a large group. The one departing should say salām to those who are staying. When leaving or entering your home, say salām even if nobody is at home because angels will answer it. If meeting again and again, say salām again and again. This salam is better than the other form of greeting of love. The reason is that it is not only an expression of love but also the reason and logic for this love expressed in the form of supplication by wishing that the people greeted be saved from all forms of grief. Most importantly when somebody says I pray that you are at peace, he or she is declaring and promising that you will be safe from her or his hand, tongue and she or he will respect, honour and dignify your life.

All "fathers" and "mothers", it is clear that by saying salam, a Muslim is giving you safety and you have to give him this back in return. It is as if he says to you, "I am giving you safety and security," so you have to give him the same so that he does not get suspicious or think that the one to whom he has given salam is betraying him or ignoring him. The Prophet said that if Muslims ignore or forsake one another, this would end when one of them gives salām. The Prophet also said that it was not permissible for a Muslim to forsake his brothers for more than three days, each of them turning away from the other if they met. The better of them was the first one to say salām. Hence salām is a remembrance of Allāh and thus an expression of love between Muslims.

Let us follow and practise his sunnah because he is as an exemplary person whose life is of direct relevant to ours today.One of his sunnah is saying saläm and do not forget to pray for him as much as possible in order to get syafä'ah from him in the hereafter.

\section{The different valorizations of khanduri mò 'lot}

Basically, the ritual of khanduri mò 'löt is the expression of love and is to honor the Prophet Muhammad but these days this commemorative celebration has many elements to it so that it is celebrated based on the various intentions (Jam niaik; Ach niet) of the performers, for example, the case of Ahmad in the

190 Degree of consanguinity between a man and woman that renders marriage is impossible. 
village of Kutaiboh as I interview him. He says that he feels embarrassed if he does not bring food to the mosque on khanduri mò 'lōt ritual day because his all neighbours bring it on that day. The intention to hold the khanduri mò 'lōt has aready been talked about long time before it is held. Bang Sulaiman, a farmer in Blangporoh says that he has an intention for the khanduri mò'lōt when he plants rice. He says in his heart; if he gets a good harvest, he will hold the khanduri for "our leader" (Ach keu pang ulèe or keu saidina), that is the khanduri mò'lott. Pak Yusuf, a fisherman in Kutaiboh also says that he has an intention for the khanduri mò'lot if he catches a lot of fish. Ibu Laili, a seller in Blangporoh says that she will also hold the khanduri for the apostle of Allāh (Ach keu rasulullāh) if she gets benefits greatly from her selling. Other villagers say "when we make an intention like this; Allāh will usually accept our intentions because we try hard to earn money". They add the first important thing is that one should have the intention. If it is for Allāh, He then will grant it.

As has been observed in Blangporoh, Blangbaru, and Kutaiboh village nearly all villagers hold the khanduri mò 'lōt and even old men and widow also take part in the celebration. They bring their khanduri to the mosque even though they only have three or five parcels of wrapped rice (Ach bu kulah) with heated banana leaves and a set of stacked containers of side dishes. They say that if they do not take part in the khanduri mò'lōt it seems they do not agree with it and they feel that they are not in unity with society. Besides they argue that the celebration of khanduri mò'lot has a blessing power. Its baraka (Ach beureukat) is acknowledged everywhere in the Muslim world. The recitation of diké mò 'löt will grant the listeners not only worldly but also heavenly reward. My informant says that some villagers even prepare the khanduri mò'löt by borrowing money from other neighbors. The important thing for them is that they are able to bring the khanduri to the mosque on khanduri mò'lōt day.

The villagers in the above three villages are very enthusiastic about commemorating the Prophet Muhammad's birthday. This is because they have already known that the greatest mercy from Allāh in the world is the coming of the Prophet Muhammad to the earth. He has the universal message of mercy for the whole world (Arb rahmatan li al-'alamin). Welcoming the greatest mercy from Allāh with pleasure is strongly recommended by the Islamic religion. Any khanduri held for "receiving" of mercy Allāh, for instance the khanduri mò 'lōt celebration is not against Islamic teaching, explains Abu Nasir Waly. Pak Salèh had a different opinion in relation to khanduri mò lott. He holds it every year 
becausethe contents of diké read from the kitāb barzanji or recited through learning by heart by the diké reciters has a deep meaning to honour the Prophet Muhammad and to praise Allāh whocreated the universe in order to avoid all dangers, both on the earth and in the hereafter. Teungku Sulaiman has another argument why the khanduri mò'lōt has to be held by Muslims because the Prophet Muhammad has very good attributes; there are eight attributes of the Prophet. Four of these attributes are truthfulness (Arb sidiq), trustworthyness (Arb amanah), conveyence (Arb tabligh), and intelligence (Arb fathanah). All these "compulsory attributes" (Ach sipheuet wajéb) are attached to the Prophet. The other fours are negation of these attributes (Ach sipheuet mustahe). They are false heartedness (Arb kidzib), betrayal (Arb khianat), corruption (Arb kitman), and stupidity (Arb baladah).

All Muslims have to commemorate his birthday enthusiastically to exalt him because his soul called Nūr Muhammad is believed to be an embryo of the complex universe from which everything emerges so that the ritual of khanduri mò'lōt must be performed, says Teungku Abubakar, a seller in Kutaiboh. On the day of $m \dot{\prime}$ 'lōt he brings a big idang to the mosque. He spends Rp 700.000 on it. After giving the idang to the committee members of mò 'lōt with Rp 5000 for drinks, he sits down beside me. He looks so glad that he forgets all his problems for the moment. I ask him, why is he so happy today? He answers, "I have to be happy because I am able to bring the khanduri mò 'lot to the mosque this year". He says that he has heard once from a preacher who delivers a Friday sermon quoted from a $\underline{h}$ adith, the preacher says "the one who makes the Prophet Muhammad's birthday "greater", will be with him in paradise". He further says that he wants to be with him in the hereafter so that he holds the khanduri mò'lōt every year. Pak Abu has another reason why he holds the khanduri $m o ̀$ 'lōt every year. He says that holding the khanduri mò 'lot $t$ is an expression of love for the Prophet Muhammad because he truly loves his ummat. He further says that the Prophet Muhammad once said to Abubakar, the first caliph when he nearly passed away as follows:

Hanlon sayang keuFatimah, ke Aisyah han lon kira

Yang na sayang cit keumat, oh lon ingat ro ie mata

Sedang na lon matong jino, genap uro dalam dosa

Oh tan ulon saleh pakri, oh ya Rabbi hukum Gata
The Prophet did not love Fatimah as well as Aisyah

His love is only for ummah, as I remembered them I cried

When I was still alive, everyday my ummah committed sin

No idea when I was not alive. O Lord, it is up to You 
One old farmer in Blangporoh, Pak Daka has held the khanduri mò'lott since the first time he planted rice plants. He likes holding the khanduri as it is like giving charity (Ach seudeukah) to help the less fortunate which is also the same as giving money to someone else. The power of charity could ward off the coming of disaster to us all. Therefore, the khanduri mò 'löt needs to be performed in order that disasters never happen and a heavenly reward can be obtained, that is religious merit from Allāh. One thing that one should have is sincerity, only for the sake of Allāh. He is truly sure that Allāh will reward this sacrifice. Ibu Syarifah in Kuta Iboh, however, says that she prefers giving the khanduri mò'lot to the children because they have no sin yet, therefore we certainly get religious merit from Allāh". Teungku Jauhari says that the bigger idang the villagers bring to the mosque on the day of khanduri mò'lot the higher feeling of the donors ofhonouring the Prophet's birth but others argue that the bigger idang the people provide, the bigger religious merit receivedfrom Allāh. Teungku Thaib contends that a person who has an intention for khanduri $m o ̀ ' l o t$ and then makes his intention reality will certainly receive great religious merit from Allāh. At least when one provides the khanduri, he will definitely receive two religious merits. One religious merit he will get because of the intention he utters in his heart and another religious merit he will get because he provides khanduri. He adds that providing khanduri to other people is the "perfectness" of the intention in the heart that has been turned to reality. It does not matter who will eat the khanduri but it must have a sincere intention. However, one devout woman has different perception about the khanduri and religious merit. She contends that Allāh only gives religious merits to those who give khanduri if he or she gives it to those who bring about the five pillars of Islam (Ach rukôn Islam); syahadat (profession of faith), seumayang (praying), puasa (fasting), tithe jakeuet (tithe), and haji (Hajj). She adds that at least, the khanduri should be given to those who prayed five times a day and fast in the Ramadhān month. In addition, it is also better to give the khanduri to the poor who are faithful and perform prayers and fasting. That is the reason why she does not want to bring the khanduri mò'lōt to the mosque because she will not know who will eat her khanduri since she has to hand it to the committee members of the khanduri mò'lōt. Instead, she gives directly to the faithful poor and the orphans in the village; otherwise she will not get religious merit from Allāh. It can be seen that Islam here defines the ritual exchange of community. 
The vice village leader of Kutaiboh says that the khanduri mò'lōt is now no longer fair. It becomes like a competition. The villagers like showing off to everyone else that they are able to hold a khanduri so they bring a big idang on the day of mò'lot. If the villagers bring a small idang, they will feel embarrassed. In this case, the sincerity is no longer considered important. One said that providing idang gadang and sanggèn are just to show the good thing (Ach peuleumah gèt) to the world or to show people that he or she has a lot of money. Holding khanduri mò'lōt in Acèh tends to be done with grandeur (Ach mengagah-gagah) to show people that they owe money for the khanduri mò 'lot. Actually the villagers are not able to hold it, but when the khanduri date is announced, they are all willing and look for money in various ways so that the khanduri can be held. Such khanduri mò'löt is said as a symbol of materialismin which the Aneuk Jamee and the Acèhnese prioritize moretheir stomachs [eating] thanothers since there are more food stalls and coffee shops than book shops now in Acèh, while the Acèhnese remain stupid and will be left behind.

\section{Conclusion}

The ritual celebrating the Prophet Muhammad's birthday called khanduri $m o ̀ ' l o t$ is an innovation in Islam. It is disapproved of by conservative Muslims, but regarded as a 'praiseworthy innovation' (Arb bid'ah hasanah) and widely accepted in the villages. Although the Prophet Muhammad is also believed to have died on the same day, his death is not of significance to this ritual. The khanduri mò 'lōt is performed in all villages either in the mó 'lōt month (on or after the $12^{\text {th }}$ day of Rabī' al-Awwal - the third month of the year) or in one of the two following months. From this the two subsequent months derive their names of "younger brother mò 'lôt" (Ach adöe mò'lōt) and "final mò'loto" (Ach mò'lōt aké). During a, khanduri mò'lōt, a 'ritual meal' is also prepared and consumed. Those who live in other villages belonging to the same collection of villages (Ach mukim) are the guests of a single village and receive a formal invitation through a messenger of the head of the village.

The khanduri mò'lōt that takes place at the family level is held individually in the family houses. It is called vow mò'lōt (mò'lōt nadzar or mò'lōt kaōy). On this occasion the invitation to attend is extended to relatives, the imām, the head of the village and the orphans. It aims at releasing individual persons from a spiritual debt. Such debts are incurred when a vow is made, that, in return for a request granted by Allāh, an "offering" (Ach idang) will be made. Although 
uttering such a vow is not prohibited, the 'ulama' are not in favour of it as it expresses "hidden behaviour" which is not pure.

The khanduri mò'tot at the village level is held on behalf of the village community. The arrangement of an offering is governed by the same rules as those applying to the wedding ritual. The inhabitants of neighbouring villages are also invited. The latter will reciprocate with a counter invitation to their own khanduri mò'lot celebration in that or the following year. This is practiced by all villages in Acèh, so that the participation in the khanduri mò'löt is always done in pairs of villages, reciprocating each others' invitations, and aimed at beginning or affirming ties of friendship.

In the course of my fieldwork, I have observed khanduri mò 'lōt rituals in three different villages: Blangporoh, Blangbaru, and Kutaiboh in West Labuhan Haji. The khanduri mò'lōt in Blangporoh village was the best attended that year. All my informants agreed that the ritual is held to commemorate the Prophet's birth. Some villagers added that the 'essence' (Indon esensi) of the food provided "is also consumed by the angels who descend from the sky on the occasion of khanduri mó 'lot". For them, the core activity of the khanduri $m o ' l o t$ ritual is the preparation and display of the various foodstuffs (Ach daluang, sanggèng, idang nasi kunyik, idang gadang, idang golèk) offered to the guest villagers rather than listening to the Islamic lectures being delivered on this occasion. Others, however, emphasize the importance of the lectures and didactic discussions about the Prophet's life.

In the ritual of khanduri mò'lót, ideally, the whole village participates in all phases of the ritual. If this is the case the abundance of food displayed testifies to its success and to the joy it generates. The recitation of the dike mò 'lót stands out; it consists of appeals to Allāh to give the highest dignity (Indon kemuliaan) to the Prophet, his ancestors and descendants and merit to his companions, his followers, participants and to all Muslims. The diké mò 'lōt is recited because people believe that the 'spirit' (Indon roh) of the Prophet and his companions are present with them. Reciting the diké mò 'lot is considered the same as praying for the Prophet Muhammad's well-being in order to get 'help' (Ach syeufeuat) from him in the hereafter in return. For these reasons, many villagers are willing to go into serious debt in order to be able to join in the communal meal and at the same time to celebrate the Prophet's birth for the social commensality is always embedded in the wider cosmological frame. Nonetheless, the some modernists find the inclusion of any food on this occa- 
sion to be a dangerous reminder misleading people into seeing religious events as self-interested spiritual transactions, when in fact they should be primarily an act of obedience to Allāh (see Bowen 1993:229).

In performing this ritual, on the various intentions of the performers may have different valorizations. The khanduri mò 'lot at the family and the village level are not just perceived as a commemorative celebration but also as a part of several exchange relationships and the villagers have different interpretations of the various parts of the ritual. These interpretations range from understanding their actions as prayers to Allāh, to generating merit for the 'soul' of deceased family members by bringing offerings to the mosque, to allowing angels to enjoy a meal offered on this occasion, etc. A number of modernists, however, object to these interpretations as they object indeed to the interpretation of mò'tōt as a khanduri as well, and in didactic lectures they may expressdisdain thatthe distribution and the consumption of food is included in the ritual. "In their view Muslim holidays are primarily about remembering and celebrating events in Islamic history, conforming to the historical example set by the Prophet and demonstrating obedience to Allāh through worship, fast, and sacrifice". 


\section{ChAPTER 8}

\section{The ritual of khanduri bungong kayèe}

This chapter explores the ritual of khanduri bungong kayèe. It also describes the seasons, the winds, and their influence as well as the fertility of fruit-bearing trees.

\section{The seasons, the winds, and their influence}

In Jumadil Akhir (the sixth Islamic lunar month, June), a ritual called a 'khanduri of the tree blossom' (Ach bungong kayè) is performed; hence this month is called the 'month of the khanduri of the tree blossoms' (Ach buleuen khanduri bungong kayèe). ${ }^{191}$ The khanduri is held for fruit-bearing trees, such as nephelium (Ach bak rambôt), lansium (Ach bak langsat), mango trees (Ach bak mangga), durian trees (Ach bak drin), kuini trees (Ach bak kuini), mancang trees (Ach bak mancang), clove trees (Ach bak lawang), pepper trees (Ach bak lada) and so forth. It aims to ensure that Allāh will ensure that the trees will bear fruit and their blossoms will not fade and fall onto the ground prematurely, that they will not be attacked by pests (Indon hama) so that they will contribute to the livelihood (Ach reuseuki) of human beings. It is said that the winds cause the tree to blossom (Ach itebit bungong kayèe). Such winds are classified into four types; the northern wind (Ach angèn utara) is regarded as "evil" (Ach jahat); the southern wind (Ach angèn selatan) is regarded as "hot" (Ach su um); the eastern wind (Ach angén timu) as "patient" (Ach saba)/“cold" (Ach leupi); and the western wind (Ach angén barat) as "strong" (Ach angèn teuga). Therefore, the villagers say that the "husband" of the trees is the western wind (Ach lakô kayèe nakeh angén barat) whereas the "husband" of the turtle is the

191 In the ethnographic work of Snouck Hurgronje I (1906:216) on the Acèhnese in 1906, he mentioned that on Jumadil Akhir a khanduri of the tree fruit (Ach khanduri bòh kayèe) was held but not a khanduri of the tree blossom (Ach khanduri bungong kayèe). He wrote that the khanduri bòh kayèe owed its name to a custom common among the Acèhnese. "On one day of this month, they purchase fruit of every kind to be found in the market. These they bring as a khanduri or pious offering to the mosque or meunasah, where they are enjoyed by those of the faithful who are present in these places of worship, under the supervision of the attendants of the mosque or the teungku". Nevertheless, after a year research done in Blangporoh and in other villages in the West Labuhan Haji district, South Acèh, the ritual of khanduri bòh kayèe, which is held on Jumadil Akhir, is not found at all. Rather, what I found on Jumadil Akhir is the ritual referred to the khanduri bungong kayè (the khanduri of the tree blossoms). 
southern wind (Ach lakô punyi nakeh angèn selatan) because if that wind blows the female turtles will lay eggs. Each wind has its own function for the trees. The eastern wind functions as fertilizer (Ach pupok) for the trees, the northern wind strengthens the tree roots, the western wind will make the trees bear blossom (Ach bungong kayèe) while the southern wind can make the tree blossom fade (Jam layu;Ach layèe;) and fall down (Jam jatuh;Ach rot). One rice specialist of Blangporoh village (Ach keujruen blang) says:

If the wind does not shake the trees, the trees will not blossom. When the western wind blows, the tree trunks shake and their branches rub each other. As a result the hollow spaces in the tree trunks are opened and the wind penetrates the tree trunks causing the trees to bloom. Therefore, the villagers say that the western wind is "the husband of the tree. ${ }^{192}$

In fact, the western wind blows much stronger than the other ones. The western [wind] season (Ach musém barat) causes big waves at sea.The fish in the rivers swim into to the estuary to spawn. These eggs are then pushed by sea waves to the edge of the beach. The heat of the sands makes the fish eggs hatch. These are then flushed back into sea. That is why when the western wind blows there are many small fish in the river or in the sea. ${ }^{193}$

The eastern wind 194 "cannot oppose the western wind unless it is helped by the southern wind". The western wind "makes friends with the northern wind". The northern wind which is "helped" by the northwest wind (Ach angén barat laut) is "not a quiet wind" (Ach angèn hana tenang). When this wind blows, jaundice (Ach penyakét kuneng) will appear. The southern wind which is "helped" by the northeast wind (Ach angén timur laut) is the "hot wind"

192 Acèhnese, "Menyo hana diguncang le angén, kayèe han iteubit bungong. Watèe angèn barat dipot, kayèe meguncang dhen dan cabeng saling megesôk dengon dhen dan cabeng yang laén sehingga rongga kulet kayèe tebuka dan angén itamong lam bak kayèe meunyebabkan kayèe meubungong, makajih ureung-ureung gampōng geupegah angén barat nakeh lakô kayèe".

193 In the river of Krueng Baru in West Labuhan Haji it is the season of small fish called ungkôt bungkuh that go from the lower reaches to the upper reaches of rivers. In the sea it is the season of small shrimps called musém udeung sabèe. The villagers catch these fish for their own consumption and the rest are sold for income.

194 When the eastern wind (Ach angèn timu) blows, the sea is quiet. It is a good time for fishermen to sail and to catch fish or to drag their nets (Ach pukat). At night the eastern wind blows from the land to the sea and during the day time the eastern wind blows from sea to the land. The fishermen can quickly go to sea with the help of the eastern wind at night and can reach land quickly with the help of the eastern wind in the day time. 
(Ach angén su um). When this wind blows, pustular skin eruptions (Ach penyakét nie) may appear. The southern wind is also regarded as the "red wind" (Ach angèn mirah) having a hot temperature. When this blows the leaves of the tree turn yellow and the tree blossom fades and falls down; the tree blossoms that have turned into fruit will not be sweet when they are ripe.If rice plants flower during this time, the seeds will have no contents (Ach sanggong) ${ }^{195}$ It is said that if a farmer plants any seeds when the southern wind blows, they will not grow but decay. Not only the southern wind but also the reflection of lightening makes the trees' blossoms fade and fall from the trees. In this case, the Acèhnese expression is appropriate, "the tree blossoms can not stay on their stems because of lightning, rain, and keunong sa (Ach bungong kayèe hana meukemat sebab lé kilat hujen keunong sa). ${ }^{196}$ See the summary of a particular set of characteristics and functions of each wind in table 4 below.

\begin{tabular}{|l|l|l|l|}
\hline northern wind & eastern wind & southern wind & western wind \\
\hline $\begin{array}{l}\text { "evil" wind } \\
\text { strengthening tree } \\
\text { roots }\end{array}$ & $\begin{array}{l}\text { "cold"/"patient" } \\
\text { wind } \\
\text { making trees fertile }\end{array}$ & $\begin{array}{l}\text { "red"/"hot" wind } \\
\text { making tree blossom, } \\
\text { fade and drop off }\end{array}$ & $\begin{array}{l}\text { "strong" wind } \\
\text { making } \\
\text { treesblossom }\end{array}$ \\
\hline
\end{tabular}

Table 4. A particular set of characteristics and functions of each wind

In order to prevent this from happening and to secure the fruition of the trees the ritual of khanduri bungong kayè ritual is performed. Whereas the southern wind may harm the fertility of the fruit-bearing trees, it also has positive effects. When it blows all sorts of driftwood and flotsam are pushed ashore. The driftwood is taken from along the seacoast of Pulo Ie, Blangbaru and Blangporoh for firewood by the villagers. Collecting it provides a family income for the villagers living near the seacoast of South Acèh. However, carcasses (Ach bangké) are also thrown up onto the coast and the villagers collect

195 The southern wind is regarded as a dangerous wind (Jam angin bahayo;Ach angen bahaya) or "red wind" (Ach angèn mirah) for the tree blooms. The farmers often put kala trees (Ach bak kala) in the middle of their farm when the rice plants bear blooms to shield them from the southern wind (Ach angèn selatan).

196 Keunong or keuneunong "hitting" is the Acèhnese seasonal calendar. Keunong sa "hitting one" is from December, then the rain becomes heavier (Ach ie raya) followed by thunder and croaking frogs. Floods often occur at this time of "noisy wind" (Indon angin ribut) followed by heavy rain. At this moment, the fishermen cannot go fishing and remain on land to repair their fishing nets. 
the bones of squid to be used for medicine. Some are sold and others are for one's own use. ${ }^{197}$ Another positive effect of the southern wind is that the female sea turtles ${ }^{198}$ crawl above the high tide line, using their front flippers to lay their eggs in the sand. The female turtles arrive on the beach during the six months of the eastern wind season (Ach musém timu), especially when the southern wind blows. People search for the turtle eggs (Jam mancari talue tatuang). The turtle egg seekers know when the female turtles arrive on the seacoast and lay eggs by looking for signs, such as the pandan trees (Ach bak seukè) and dadap trees (Ach bak reudeup) are blossoming. One experienced turtle egg seeker explains:

The turtles come ashore in order to lay their eggs when the moon is still young (Jam bulèn mudo; Ach buleuen muda), during the first 15 days [of the month]. The turtles will come ashore when the moon sets. When the moon has become "old" (Jam bulén tuwo;Ach buleuen tuha), during the second 15 days, the turtles will come ashore when the moon rises; usually one hour before the moon rises and one hour before the moon sets. The turtles come ashore with high tide (Ach paseng diék) both when the moon is still "young" and the moon has become "old". 199

Another says that female turtles will surface at the coast when the southern wind blows heavily (Jam angin selatan kuwèk;Ach angén selatan kasèk) during the day time, and during the afternoon when the sun is red when it sets.

197 One old village woman says that the bone of squid is good to make a boil painless and to make it smaller (Ach bantôt) as well. The bone of squid should be scraped at first then mixed with lemon juice before they are placed around the boil so that the boil will be not exploded. She does this when her grandsons has boils on their thighs. One housewife also says that the squid's bone is a good medicine (Ach get keu u bat) for those who have a high temperature. In addition, one doctor also says that the squid's bone is good to cure those suffering from whooping cough (Ach batôk thō). The squid's bone should also be scraped at first then mixed with the lemon juice before drinking it.

198 Besides the sea turtles, the villagers also know two other kinds of turtles: 1). Terrapins (Ach baneng) are fresh water turtles that stay in the water most of the time. They can be found in rivers, streams, lakes, estuaries, ponds and even in the ditches. 2). Tortoises (Jam/Indon kura-kura darat; Ach baneng glée) are turtles that can be found on land and usually in forests. They are very bad swimmers and are clumsy on land. Some people slaughter them and eat this kind of turtle to cure skin diseases.

199 Acèhnese, "Punyi diek u panté untuk dijak tôh bòh selama enam buleuen. Menyô buleuen muda dari tanggai sa troh tanggai limongblah, punyi diek u panté watèe buleuen dilop. Sebalikjih menyo buleuen tuha punyi diek u panté mulai dari tanggai namblah sampai tanggai lhèploh, punyi diek u panté watèe buleuen teubit. Biasajih sijeum seugoloh tebiet buleuen sampai sijeum setelah teubit buleuen. Punyi diek u panté watèe paseng ek, get watèe buleuen muda maupun bak buleuen tuha". 
At night, the seashore is then like a market (Ach lagè pasa) because many turtle egg seekers come there. Sometimes the female turtles even come ashore during the day because "the stronger the southern wind blows, more female turtles come ashore to lay eggs due to the heat of the seawater". For the same reason, more fish hide in the muddy water as well as in the coral reef. When the southern wind blows tigers in the mountains will often be savage (Indon $g a$ nas). The tigers will come to the village attracted by the fragrance of tree blossoms and by the presence of a whorl of hair on someone's nape that is said to be a tiger's whorl (Ach pusa rimung). The presence of a whorl of hair on someone's forehead is called the wind's whorl (Ach pusa angén). It is dangerous for someone who has the tiger's whorl to go the mountains while for someone who has a whorl on the forehead it is dangerous to go to sea.

It is said that the tiger's whorl is "ripe" at the time when the trees are blossoming. The combination of the smell of the tree blossoms (Jam bungo kayu;Ach bungong kayè ) and the tiger's whorl "invites" the"grand mother" tiger (nénék) ${ }^{200}$ to descend from the mountain to the village. The families whose children have the tiger's whorl fear ${ }^{201}$ that their child's whorl may be also "ripe" during this season. On October 16 ${ }^{\text {th }}, 2007$, Muhammad Amin was attacked and eaten by a tiger in Gunung Rotan, Labuhan Haji while he was looking for nutmegs (Ach bòh pala) in his garden. ${ }^{202}$ The news of this tragedy quickly spread throughout Blangporoh society. School students at that time did not go to school because they were afraid of the tiger. Some villagers say that Allāh has already written in laukh makhfudz ${ }^{203}$ that the life of Muhammad Amin ends in the mouth of a tiger, so one should not worry about it, these things are predetermined. But others argue that Muhammad Amin had a tiger's whorl on his nape that he was not aware of and on the day of his death, the whorl on his nape was "ripe". Tigers will also attack people when someone makes a vow that he shall be eaten by a tiger. The tiger will remember the vow

200 When khanduri at the 'head of the ditch' (Jam kapalo banda;Ach ulèe lhueng) where the source of water comes out took place in batèe meucanang, West Labuahn Haji district in the past, some meat was placed on the front door of the cave of batèe meucanang for ureueng pho tempat "the owner of the place, that is a tiger.

201 I knew of one family whose son has a tiger's whorl on his nape. The wife is complained to her husband and told him to cut it off and throw it away. She was afraid that when it became ripe, something bad might happen to their son.

202 See Serambi Indonesia, Acèh daily newspaper, October $16^{\text {th }}, 2008$.

203 Laukh makhfudz refers to the tablet on which the record of the decisions of the divine are preserved, see Shorter Encyclopedia of Islam, pp. 287-288. 
and then the one who utters it he will be eaten by a tiger; or when one of the family members kills a tiger. The tiger is a vengeful animal. When one tiger is killed, other tigers will take revenge.

The tiger's whorl belongs to a tiger not to humans. When the humans have it, tigers will be angry with them. Therefore the tiger's whorl must be pried off from someone's nape and a "ritual of cooling" (Ach peusijuek) must be performed. The blood flowing from the spot where the whorl was removed must be retrieved and placed on the tiger's claw while the following phrase is uttered "this is your livelihood and please do not disturb this person anymore" (Ach nyo raseuki gata dan bèk neganggu lé ureueung nyo). One village healer has performed this ritual four times so far. "After the tiger's whorl is pried off away, one will be safe and the tiger will no longer pursue him or her". In return the child's parents have to give him 5 grams of gold. One time he says that one of the sons' parents did not have 5 grams of gold. The healer asked them to borrow the gold from their neighbor to give him and later on the gold should be returned to its owner. By doing so the $d o^{\prime} a$ to get rid of the tigers' whorl remains efficacious. Here it clearly shows that the act of exchange is more important than the object itself (see Platenkamp 1996).

Also the wind's whorl (Ach pusa angén) must also be pried off in order to cut the relation between that person and the wind. The ritual of prying off the wind's whorl and the "cooling ritual" has to be performed because the wind's whorl belongs to Sedang. ${ }^{204}$ The retrieved blood is then thrown into the sea while the following phrase is uttered "This is your livelihood; please take care of this person when he goes to sea" (Ach nyo raseuki gata dan neujaga ureueung nyo watèe dijak u laôt). Whirlpools in sea resemble a whorl. A fisherman pulled down by whirlpools will not be able to survive even if he is a good swimmer.

The retrieved blood is given to Sedang Shalèh who takes care of the sea wave and whirlpools. Sedang Shalèh is part of a group of four Sedang spirits, each with their own domain. Thus Sedang Mukmin takes care of the surface of the sea water, Sedang Shalihin of the sub aquatic level and Sedang Tetap of the coast. After the wind's whorl has been pried off, one is safe from the wind and can look for a livelihood in the sea.

204 People say Sedang is the name of a sea water spirit and a kind of jinn. 
The question to what extent the various winds and whorl found on someone's nape should be accepted to determine one's fate and means of livelihood is often debated in Blangporoh village. "If there is no livelihood, anything that has been placed in the mouth will fall to the ground" [i.e. anything that is to be eaten can not be swallowed], and "good luck is divided among everyone". A young village man, who has just finished his BA program in Islamic studies in the capital city of Acèh, says that these "expressions" have a theological meaning; they show how the Aneuk Jamee people realize that their livelihood comes from Allāh. The first "expression" is more fatalistic in that it reflects a jabariyah ideology ${ }^{205}$ deeming the livelihood of human beings to be determined by Allāh. The second expression assumes that the livelihood is truly from Allāh but the amount of it depends on someone's efforts. This thought tends to be more in line with a qadariyah ideology ${ }^{206}$ as in the Qur'ān 13:11, “...indeed, Allāh will not change the condition of people until they change what is in themselves". Others argue that the first important thing in life is making every effort in order to get a better life. They relate:

Menyo na ta useha

Adak han kaya taduk senang

Menyo hana ta useha

Pane teuka rôt dimanyang
If one has made an effort

If not rich, at least one will live happily

If no effort has been made to do something Impossible the livelihood falls down from the sky

One adds further that Allāh will give a livelihood to those who ask but one must work for it first. Every father is responsible for providing for his wife and children. Fulfilling this responsibility is obligatory (Ach wajéb) without which he will be committing a sin. Yet one also believes that it is better for the one who has a tiger's whorl not to go to the mountains and those who have a wind's whorl should not to go to sea. It is far better that a tiger's whorl or a wind's whorl is pried off from one's nape so that he or she can safely go anywhere to make the livelihood.

205 Jabariah a historical group in Islam which holds that humans have no power over their own destinies, but Allāh's power preempts any such control on humans' part.

206 Qadariyah in Islam are adherents of the doctrine of free will and free actions. The word is derived from qadr (power, or rights). Adherents maintain that Allāh has given man free will and free actions. Without it, one could not be fully accountable for ones actions. 


\section{The ritual of khanduri bungong kayèe}

On June 2007 I found three villages holding the khanduri for the tree blossoms: Ladang Tuhan II village, Teupinbatèe village in Manggéng district, and Blangporoh village in West Labuhan Haji district. The khanduri of the tree blossoms in Blangporoh and Ladang Tuha II were performed individually in the mango garden but in Teupinbatèe village it was performed on behalf of the village in the mosque. Here I shall describe the khanduri of the tree blossoms in these mentioned villages.

In Ladang Tuha II, a family head holds the khanduri of the blooms for his mango trees with his wife in his garden. First, he brings a medium-sized pot with rice and firewood. His wife brings coconut milk, sugar, salt, two big pails, and a gourd dipper.His son brings a tray containing ingredients for "cooling" and water vessels and plastic bowls and glasses. His daughter brings sitting mats, a handkerchief etc. He then cooks porridge (Ach kanji) in a mediumsized pot with the help of his wife and his two children in his mango garden. ${ }^{207}$

Unlike the 'asyüra porridge, the porridge for the khanduri of the tree blooms only consists of normal rice (Ach breuh ubit), coconut milk (Ach san$\tan u$ ) and water (Ach $i e$ ). This porridge is similar to that of the khanduri of the rice plants. They are mixed together in the pot then cooked. When the porridge has already cooked, it is poured into two containers. Sugar (Jam gulo;Ach saka) and salt (Jam garom;Ach sira), are added to the container for feeding the children, while the other container is left without sugar and salt. The invited children then come to his garden to eat the porridge that has been poured into many small containers for the village children by his wife. Before eating the porridge, the children sit in a circle (Ach melingka) and porridge with and without sugar and salt is placed in the centre. The family head chants shamadiyah ${ }^{208}$ and recites several verses of the Qur'ān. Only children are allowed to take the porridge. I ask him why he only invites the children, he answers that children are like angels; they have never committed sin and are innocent. This is, therefore, one of the reasons why Allāh's mercy (Indon nikmat Allāh) is sent down to earth. If children do something good then they get religious merit from Allāh,

207 The porridge must be cooked in the garden, not at home or other places.

208 Reciting the sürah al-Fätiha $\underline{h}$ and $\operatorname{ta} \underline{h} l \bar{l} l$, he then continues reciting the sürah al-Ikhlās thirty times, and after that continued reciting tahlill 50 times. These recitations are called shamadiyah. The children follow the shamadiyah's recitation performed in the mango garden. 
and the religious merit will be given to their parents; that is why children have to be treated well. His wife, however, has another reason. She says that children smile and are happy when the porridge is served to them. The children's happy expression compensates for the work involved in making the khanduri. In addition, they will never protest by saying it is not delicious (Ach hana mangat) because she has tried her best to prepare it. Another reason Allāh sends His mercy to the earth for the old people whose characters are like children. Allāh will give religious merit to those who take care of their parents and who are really old (Ach $k a u z o$ ). ${ }^{209}$ Another reason Allāh sends His mercy to the earth is because ofthe 'ulamā' who are always close to Allāh and the other reason is for animals which have no intellect (Ach $a k a i$ ) and always receive their livelihood from Him. ${ }^{210}$

The second step is the invocation of $d o^{\prime} a$ (Arb $\left.d u^{\prime} \bar{a}^{\prime}\right)$. The recited $d o^{\prime} a$ comprises of four parts. First, he praises Allāh and prays for the Prophet (Ach seulawet ke nabi) and his family. Second he asks for a good place in this world and the hereafter, beseeching that disaster be avoided, and requesting Allāh's perpetual blessing. Third, he seeks Allāh's forgiveness for the teachers, parents, grandparents, neighbors, and friends and all Muslims in the world who are still alive and those who have passed away. Fourth, he requests that Allāh listen and answer his $d o^{\prime} a$ especially asking Him to prevent damage from southern wind effect and from lightning. At the end of each recited $d o^{\prime} a$, his wife and the children intone $\bar{a} m \bar{i} n$ (please approve o Allāh).

The third step is pouring the porridge. The container with sugarless and saltless porridge is poured on the mango bases (Ach utom mangga) that are blooming. He says that this can be eaten by ants and other animals as alms (Ach seudeukah) but the primary significance is that the water of the porridge that contains the "blessing" can be taken in by the roots of the blooming mango trees. The water of the poured porridge goes from the roots through the trunk, through the branches up to the tree blossoms. It is believed that the porridge prevents the tree blossom from drying and dropping to the ground as verses of the Qur'ān and shamadiyah have been chanted in front of the cooked porridge so that the porridge contains the power to render the southern wind no longer poisonous. He refers to this power as beureukat, from the Arabic word bārakā,

209 The old people who are feeble from weakness and illness.

210 One family head argues that because of children, old people, 'ulamā, and animals that are on the earth, Allāh sends down His mercy to us all. 
"blessing". It is believed that this blessed porridge can take away the dangerous influence of the southern wind (Ach pengaroh angèn selatan). In this case another family head is also of the same opinion. He says "the poured porridge on the roots of the tree is a talisman (Ach tangké) against the southern wind so that the tree blossom will not fade and fall on the ground down on the earth". ${ }^{211}$

The fourth step is "cooling" the trees. First, a handful of the yellow sticky rice (Ach saboh gepai bu leukat kuneng) ${ }^{212}$ with coconut stir-fried with palm sugar (Ach ue mierah) ${ }^{213}$ is taken on a plate from the tray containing the ingredients for "cooling". He utters bismillāh "in the name of Allāh" then places it on the mango trees. At the same time he intones (Jam baniet;Ach meniet): "Lagèe bu lekatnyo mekeumat-keumat, bak mekeumatkeh bungong kayèe lon”, meaning "thissticky rice was sticky, so please stick and do not let my tree drop its blossom!" He then takes a bowl from the "cooling" tray containing several kinds of leaves; the leaves of an areca nut, ${ }^{214}$ a stalk of the leaves of manèk manoe, ${ }^{215}$ the leaves of cocor bèbèk, ${ }^{216}$ a stalk of coarse grass with its root, ${ }^{217}$ the leaves of bayam tuba, ${ }^{218}$ the medicinal leaves ${ }^{219}$ and the leaves of henna. ${ }^{220}$ These leaves and plants are tied in a bunch that is used as a whisk to spray the

211 In Acèhnese, "kanji yang ka beureukat dan diro bak utom kayèe sebagai tangkai angén selatan supaya bungong kayèe bèk layèe dan rôt bak tanoh".

212 The cooked sticky rice that has been colored with saffron flour is called bu leukat kuneng.

213 Coconut stir-fried with palm sugar (Ach ue mierah) symbolizes the completeness of life, sturdy and strong as coconut trees.

214 The villagers believe that this leaf is a talisman to shield the mangos' blossom from the southern wind.

215 A kind of plant that usually grows at the edge of the farm, its leaves are silvery. This leaf is a symbol of fertility.

216 The leaves are green in color. This leaf symbolizes a cold condition.

217 A kind of grass that has a strong root and heavy leaves, the Acèhnese call this glass naleng sambô or naleng pasak dônya. This grass symbolizes a strong and sturdy life. The grass root is very strong and can be grown in any circumstances and climate. It can withstand any disturbance and disaster. It also symbolizes a strong faith and self confidence.

218 Amaranth is used as a vegetable. The roots are medicinal and its stem is thorny. This amaranth is also called the "wild amaranth" (Indon bayam liar) because people do not plant it but it grows by itself.

219 Medicinal leaves (Ach on sitawa) against fever.

220 This leaf is quite often used by the Acèhnese to color the bride and bride groom's hands and feet before the day where the couples sit side by side. One old fisherman says that the bridal couples with henna on their feet and hands are not allowed to bathe in the sea because the smell of henna will attract sharks. He further says that the original history of henna and the blood of sharks are from Eve's menstruation. 
water of teupōng taweu ${ }^{221}$ on the base of the tree, trunk, branches, leaves, and to the blossom of the trees. The last step is that he takes a glass from the tray which has been filled with the mixed rice and unhusked rice. ${ }^{222}$ He scatters them at the base of a tree, on its trunk, branches, and blossoms of a tree, like when scattering rice to 'cool' a person. By doing so, he hopes that the tree blossom will become the livelihood for the mango trees' owner and for the villagers and that the mango trees will not be attacked by disease. I also witness an old widower doing the same thing in Blangporoh village.

For the khanduri of the tree blossom performed on behalf of the village in the Teupinbatèe village the porridge is cooked in a large pot. Teupinbatèe villagers do not hold a social gathering (Ach meuripe) for the khanduri. Normal rice (Jam barèh;Ach breuh ubit), coconuts (Jam karambi;Ach boh u) and sugar (Jam gulo; Ach saka) are collected from villagers who have trees that are blossoming. While the committee was cooking porridge, the invited reciters who

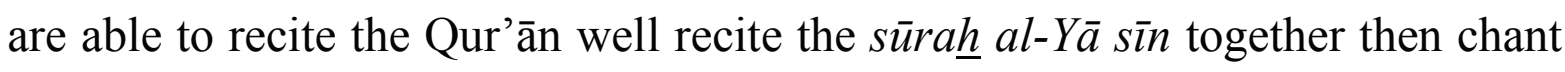
shamadiyah and end it with the do'a. Soon after finishing the recitation of the $d o ' a$, the porridge is ready. The cooked porridge with salt and sugar is placed on plates and is first served to the invited children then to the Qur'ānic reciters. After eating the porridge, the villagers whose trees are blossoming take the saltless and sugarless porridge and bring it to their respective gardens. In the garden they pour some porridge on blossoming tree bases. Some porridge is sprayed on tree trunks, branches, leaves, and even on the blossoms of the trees. The villagers refer to these actions as the "cooling of the tree trunk" (Ach peuphon taweuebak kayèe or peusijuk bak kayèe).

\section{Condition of fertility of fruit-bearing trees}

People perform the ritual of khanduri bungong kayèe so that the fertility of the tree will be safeguarded but the fertility is dependent upon much more important factors than just the willingness of the individual family to perform the ritual. The fertility of the tree is dependent upon collective village performance, dependent upon respecting jinn, dependent upon just leadership and dependent upon adat, particularly regarding prohibition and incest.

221 The water of teupōng taweu consists of water and rice flour. Sometimes the Acèhnese say tasteless flour (Ach teupong tabeu) in stead of teupōng taweu.

222 Rice and unhusked rice symbolize modesty and not arrogance; they also symbolize honor and glory. 
Many villagers whom I interview lament that even though they perform the khanduri of the tree blossoms, the result is no longer satisfactory because many tree lose their blossom and dry up before they become fruit. And sometimes the tree blossom that has become fruit also drops before they are ripe. They consider that it is because the khanduri of the tree blossom is not performed correctly and not performed collectively (Ach secara rame-rame; Indon secara berjama'ah). And some villages totally neglect this ritual. From a Muslim believers' point of view, Allāh's mercy (Indon nikmat Allāh) will be sent to people who do something collectively. For example if a prayer is performed collectively, twenty seven religious merits will be received from Allāh. If it is performed alone, only one religious merit will be received. One imām says "If we do something collectively, it means that we all have the same intention (Jam samo niet;Ach sama nit). Allāh will grant our request". Another example mentioned is prayer performed to ask for rain (Ach seumayang lake hujeun) in the fields. Cattle should be brought to the place of prayer because the people all want the same thing; they therefore hope that Allāh will give rain. I argue that performing a ritual collectively strengthens social solidarity. If the social solidarity is strengthened, fertility will be there. That is the fertility which is dependent upon the social forces.

Apart from the aim of the khanduri for the tree blossom to prevent their blossom from falling and prevent their trees being attacked by diseases, it is also to make jinn (Ach jén) who look after the trees happy, says one pawang laôt. There are three kinds of jinn that look after the trees: Ibrahim Tunggai, a sort of jinn who looks after tree trunks, Ibrahim Bapa, a sort of jinn who looks after the trees' fruit and Pang Itam, a sort of jinn who looks after the tree tops. $^{223}$ These kinds of jinn are also sometimes called hantuburu. They will sometimes strike a human who enters the garden without uttering $d o^{\prime} a$. In addition, hantuburu can also kill the one who enters the garden without saying do' $a$. If someone goes to the forest (Ach rimba) which is full of blossoming trees, the following Acèhnese $d o$ ' $a$ must be uttered before entering the gardens:

223 One pawang laôt says that if someone takes trees for a keel of boat (Jam sampan;Acèh peraho), he has to ask for permission from Ibrahim Tunggai, Ibrahim Bapa and Pang Itam by uttering, "please permit me to take this tree for the keel of a boat" (Ach ne pe izin lon keneuk cok kayèe nyo ke tuleungrung bot). When I ask him why we have to ask permission when we want to take trees for keels of a boat, or a canoe, he answers that if the fishermen are in trouble in the sea, for instance, a sudden storm or no fish [livelihood], they are "the people" to whom the fishermen report and seek help. 
Assalāmu'alaikom Ponikudandong

Gata ulon tung keu cédara

Ma gata kayèe ku gata batè

Gata meuteuntèe aneuk Naga

Surot gata disino

Nyo saleum nabi Sulaiman

Yang yu jak lon keuno

Berkat kalimah lāilāhaillallāh
Peace be on you, Ponikudandong 224

You are accepted as my brother

Your mother is wood and your father is stone

You are the son of Naga

Please step back from here

This is saleum from the Prophet Sulaiman ${ }^{225}$

A person who wants me to come here

With the "blessing" of the sentence of lāilāhaillallāh

This invocation is called saleum "peace". This saleum has to be uttered for peace with human beings. The person who enters the garden will be safe because jinn have been announced as his brother. One says "if we hold the khanduri of the tree blossom, these jinn will be happy because jinn regard the trees as their belongings and humans as their companions. Human beings merely pick the fruit whereas trees are where they live".

To the question why trees do not blossom at the same time, one imām supposes that now many trees will not blossom because as the leaders are not just (Ach pimpinan hana adé). The previous leader had keuramat ${ }^{226}$ but today's leader does not. One villager says that in the past kings were just (Ach adé). Therefore, all trees bore their fruit at the same time. Now the leaders are no longer just trees will not bear much blossom and will not bear fruit at the same time, adds the old man. In addition, there are not so many kinds of fruit in the villages as a number of people no longer take care of the orphans. They engage in illicit sex, gambling, stealing, being incestuous, illicit sex with their own daughter, corruption, etc. All these can cause trees not to bear their blossom at the same time and even some trees will bear no blossom at all. "We, the villagers believe that the blossoms are Allāh's mercy", explains one old man. "When people do not behave well, Allāh's mercy will then not to be sent down to earth", says one rice specialist. Bearing blossom is related to the justness of the leaders. The trees will bear blossom if the leaders are good. It is said that in 1940 when Raja Kanda was a king, there were so many kinds of fruit trees (Ach bòh kayèe) available in the villages. When he knew that one of his villagers were not able to pay tax to the Dutch colonial, the king would pay their taxes. The basic prosperity of the country is due to the leader. If the leader is

224 Teungku Yunus says that ponikudandong is the name of the grandfather of jinn.

225 Prophet Sulaiman is said to know about the jinn and could ask jinn to do something.

226 Keuramat from the Arabic word kärama means a miraculous gift and grace bestowed by Allāh and it is beyond the scope of human capabilities. 
fair, the country will then be good. All trees will bear blossom in the same season. One rice specialist relates as follows:

Salah tuha diboh ketua hana meusoso

Diboh keuchi' lagèe pik tan sago

Diboh mukim lagèe sikin hana go
The elders' mistakes appoint a chairman without a clear identity

The appointed keuchik resembles a squash having no sides

The appointed mukim resembles a knife having no handle

It is believed that the tree blossom does not appear at the same time because the leaders are no longer from good families. Some are not clear about their origins. Sometimes the leaders the offspring of illicit sex (Ach aneuk ranjadah or aneuk bajeung). That is why it is difficult to make a living now. There is a shortage of fruit as the tree loses a lot of blossom, laments one old man. In Suak Udeung, Manggéng district, a pregnant woman was beaten by the village women because she is pregnant without a husband. That night, the pregnant woman has to be brought to another village for safety by one of her families. In the past in West Labuhan Haji district, a brother who engaged in illicit sex or adultery (Ach mezina) with his younger sister was also chased away from the village. About 10 years ago in Lhokpawoh, also in Manggèng district, a father engaged in illicit sex with his own daughter. All of them were chased away from their villages because they had already transgressed the adat rules (Ach ka melangga hukom adat; Indon sudah melanggar hukum adat). The leader of Acèhnese adat council of West Labuhan Haji district says that among cases transgressing the Acèhnese adat are engaging in illicit sex between a brother and younger sister, engaging in illicit sex between a father and daughter, killing a mother, and killing pregnant women. People doing this must be thrown out of the village because they invite disaster (Ach bala) for the village. Therefore, they are no longer allowed to live in their own village. This sanction is given because these people are regarded as the people who do not know the adat rules (Ach ureueng han teupeu adat), the people who have no morals (Ach ureueng hana meakhlak). They have rejected the authority of adat. Their actions clash with the foundations of the Aneuk Jamee's thinking. If there is any social activity in a village, these people are neither invited nor greeted. The villagers will not come if they hold a life-cycle ritual or a mortuary ritual (Ach buet hudép atawa buet matée) in their house unless they have died. In addition, these people are expelled from the adat's surroundings where they live. Their 
social relations and adat are broken off for an unlimited time. Thus, if their mistakes have been shown to the other villagers, their families as well as their groups (Ach kaôm) will be embarrassed. Therefore the transgressors will live in the village as the following expression "Instead of living and seeing a corpse reflected in the mirror, it is better to die covered in soil" (Indon dari pada hidup bercermin bangkai lebih baik mati berkalang tanah). So it is better for them to leave their own village.

In 1988, a father (53 years) engaged in illicit sex with his own daughter was put in a canoe with his daughter by villagers. They did their daily activities on the canoe. When they stopped for a moment in their village, the villagers along the coast of Simpang Hilir refused to let them leave the canoeso that they had to go and look for another place to land where the people did notknow their problems. ${ }^{227}$ It is said that humans behaving as if they were animals (Ach lagèe binatang) such as gambling and fighting cocks, stealing, murdering and so on will truly invite disaster for the village (such as raping). One disasters given by Allāh is that most of the tree blossom will fade and drop before turning into fruit, and that which has turned into fruit will not be sweet when they are ripe. And it is even said that the tsunami disaster was connected to human behaviour.Human behaviour has to be taken into account because there is a connection between the fruit available and human actions. Bad behaviour is believed to influence trees and cause them not to bear their blossom at the same time; some trees will bear no blossom at all. In this context, a person's bad behaviour [sin] does not only harm him or herself but also harms others including the fertility of the fruit-bearing trees since the concept of sin in the Aneuk Jame and in the Acèhnese society is always related to hawa nafsu (desire or passion). These sins take the form of drunkenness, illicit sex, or adultery, being incestuous, stealing, and gambling and so on which are regarded as a major infringement on community life.

\section{Conclusion}

The khanduri ritual "of the tree blossom" is for flowering trees, and especially for trees bearing fruit such as nephelium, lansium, mango, durian, kuini, mancang, clove, pepper and so forth. It is performed to secure the fruition of

227 See Waspada, North Sumatra daily newspaper, September $15^{\text {th }}, 1988$. 
the trees despite the southern wind and lightning and aims to ensure that Allāh will take care that the trees will bear fruit and the blossom will not fade and fall onto the ground prematurely; that their trees will not be attacked by diseases so that they will ensure a livelihood for humans. The ritual is closely connected with the idea that it is the winds that cause the trees to blossom. Such winds are classified into four kinds: the northern wind, regarded as "evil" wind; the southern wind regarded as "hot"; the eastern wind regarded as "patient"/"cold"; and the western wind as "strong". Each wind has its own function for the trees. The eastern wind functions as fertilizer for the tree, northern wind strengthens the tree roots, the western wind will make the tree bear blossom while southern wind can make the blossom fade and drop off. If the wind does not shake the trees, the trees will not bear the blossom. When the western wind blows, the tree trunks shake and their branches rub each other. As a result the hollow spaces in tree trunks are opened and the wind penetrates the tree trunks causing the trees to blossom. Therefore, the villagers say that the western wind is the "husband of the tree", just like the "husband of the turtle is the southern wind" because "if the southern wind blows the female turtles lay eggs".

The western wind blows strongest. The eastern wind "cannot oppose the western wind unless it is "helped" by the southern wind". The western wind "makes friends with the northern wind". When the northern wind, "helped by northwest wind", blows, jaundice will appear. When the "hot" southern wind "helped by the northeast wind" blows, pustular skin eruptions will appear. When the "red" southern wind blows the leaves of the tree turn yellow and the tree blossom fades and drops off; the blossom that has turned into fruit will not be sweet when they are ripe. If rice plants flower then, the seeds will have no contents. If a farmer plants any seeds when the southern wind blows, they will not grow but decay. Not only can the southern wind make blossom fade but lightning can have this effect as well.

Although the southern wind may harm the fertility of the fruit-bearing trees, it also has a positive effect. When it blows all sorts of driftwood and flotsam are pushed ashore along the coast of Labuhan Haji district. Driftwood is sold as firewood, and collecting it provides a family income for the villagers who live near the seacoast of South Acèh. But also the bones of squid that are used for medicine are collected. Likewise, in South Acèh when the southern wind blows during six months of the east season, female sea turtles crawl above the high tide line in order to lay their eggs in the sand. 
Despite performing the ritual of khanduri bungong kayèe, it can still happens that the trees do not blossom, that is, the fertility of the fruit- bearing trees has not been safeguarded because there are several requirements for thefertility of the fruit bearing trees: fertility is dependent uponsocial collective ritual action, upon the "mercy" (Arb rạmah) of Allāh, upon the king's generosity, upon jinn, upon just political leadership, and upon respecting the adat rules particularly concerning exogamy and incest because they are the most serious crimes in adat law. 


\section{Chapter 9}

\section{The ritual of khanduri apam}

The seventh month of the Islamic lunar calendar is Ra'jab (July). This month is regarded as one of the sacred months during which the Prophet Muhammad forbade people to engage in battle. It is also a prelude to the month of Ramadhan, which follows after the intervening month of Sya'ban. The month of Ra'jab is called "the month of khanduri apam" (Ach buleuen khanduri apam) since during this period the apam cakes are baked in every house and distributed at the mosques or prayer houses. The term apam is said to derive from the word afwan "forgiveness". The Ra'jab lunar month is therefore called buleuen afwan or buleuen apam. ${ }^{228}$ This chapter explores the story of khanduri apam, the individual khanduri apam on the fifth night of the dead and the collective khanduri apam in Ra'jab lunar month.

\section{The story of khanduri apam}

According to some village people, the ritual of khanduri apam is performed to remind people of the initial days of the deluge during the Prophet Noah's time and to commemorate the Prophet Muhammad's ascension to receive prayers (Ach seumayang) from Allāh, as both these events occurred on the 27th day of Ra'jab; the deluge lasted until the day of 'assyürā on the 10th of Muharram (see Ch.5). During the deluge, Prophet Noah's ark being lifted up by the rising floodwaters resembles Prophet Muhammad being lifted by Allāh on his night journey (Arb israk mikraj). Others relate the khanduri apam to the construction of Noah's ark.On August $3^{\text {rd }}, 2007$, I attended a 'religious discussion' (pengajian) at Teungku Yunus's house in Suak, Tangan-Tangan. He said that the basic story of khanduri apam came from the story of ' $\mathrm{Ud}$, a grandson

228 According to the local imām, "Ra'jab is a month for cultivation, Sya'ban is the month for irrigating the fields, and the month of Ramadhan is a month for reaping and harvesting. Ra'jab is the month of Allāh. Sya'ban is the month of Muhammad and Ramadhān is the month of his followers". It is said that when the Prophet Muhammad sighted the moon of Ra'jab, he prayed the following words to Allāh : "O Allāh, make the months of Ra'jab and Sya'ban blessed for us, and let us reach the month of Ramadhan (i.e. prolong our life up to Ramadhan so that we may benefit from its merits and blessings)". It is said that whoever performs this ritual will receive more religious merit because this ritual is a way of thanking Allāh. 
of Noah ${ }^{229}$ when Allāh asked Noah to construct the huge ark. Below I present the story of khanduri apam I recorded from the 'religious discussion'. The story goes as follows:

Noah was 950 years old. At the time of his prophethood, Noah was no longer able to remind his followers because they always disobeyed him. He had been telling his followers to return to the right path for almost 900 years but only 18 people embraced Islam including his family members so he reported to Allāh and asked Him how to remind his followers: Allāh said, "Please say to them that Allāh will cause the tide to rise (Ach ie beuna) and they will have to build a huge ark that can save all believers, animals, and seeds for crops!" After hearing the Allāh's command, Noah went to find four craftsmen who were able to make the huge ark. In return the four craftsmen asked to marry Noah's daughter because they did not have wives yet. Noah was then confused as he had only one daughter. Gabriel came and said to Noah, "Do not be confused, just say that you have four daughters". This is Allāh's will is able to do so". Gabriel asked Noah to invite the four craftsmen to his house to see his daughter. When they were sitting at Noah's house, Noah went to the kitchen to see his daughter. Then, there were four similar daughters. Noah then asked, which one was his daughter? All four daughters raised their hands and acknowledged that they were all the daughters of Noah. Noah was truly surprised and asked Gabriel, "Where did they come from?" Gabriel answered that you had three animals: a cat was in the kitchen, a dog was under the house, and a horse was in front of the house. Now those animals have become daughters. These four daughters were married off to the four craftsmen. After that they started constructing the huge ark. One of the craftsmen then reported that they needed a huge tree trunk. Noah then looked for the person who was able to provide the huge tree trunk. He remembered his grandson Ud and called and asked him to take the huge tree trunk from the bank of the river Nile. 'Ud answered "I am ready. In return, a beautiful girl should be given to me". Noah was again confused. Gabriel then came and said to Noah "Please do not be confused, you should simply call a sculptor to sculpt a stony mountain like a beautiful girl. After the sculptor was found, the stony mountain was shaped in the form of a beautiful girl. Noah slaughtered 100 horses and the meat of those horses was taken and placed in the sculpture's vagina. ${ }^{230}$ ' $\mathrm{Ud}$ was invited to see the decorated stony mountain. When 'Ud saw it, how happy he was! The sculpture was very beautiful and stirred his desire. 'Ud could not withhold his desire and had sexual intercourse with the sculpture. ${ }^{231}$ After that ' $U d$ was tired and hun-

229 'Ud was a father of Jut Makjut and a grand son of the Prophet Noah. It was said that 'Ud was a giant human and he was not like a normal person.

230 See also Effendie (1979:137), "Berbagai Tafsiran tentang Ya'jut dan Ma'jud”, pp.136-138.

231 With the permission of Allāh, the sperm of ' $U d$ that had spilled in the sculpture's vagina mixed with the meat of the slaughtered horse then decayed and became maggots as big 
gry, he went back to Noah and asked for food, that was apam cakes. 'Ud would not be able to take the huge tree trunk to construct the ark if apam cakes were not given to him. Noah baked 100 apam cakes then invited 'Ud to eat. 'Ud said 100 apam cakes were not enough for him, adding, "If there were 1,000 apam cakes, I would be able to take the huge tree trunk". Noah said if he wanted to he would bake 10,000 apam cakes for him (but Ud should try to eat these cakes first by pronouncing bismillähirrahmānirrahìm (in the name of Allāh, the entirely merciful, the especially merciful). 'Ud uttered it then ate an apam cake. 'Ud was only able to eat half then he felt so full due to the baraka "blessing" of the word of bismillähirrahmānirrahim. Only after that was 'Ud able to take the huge tree trunk from the bank of the river Nile and bring it to the four craftsmen to build the huge ark for Noah. ${ }^{232}$

Before I discuss the collective khanduri apam celebrated in Ra'jab lunar month.I would first like to discuss the individual khanduri apam not in any particular month because a person does not have to die this particular month in order to understand the collective of the khanduri apam.

\section{The individual khanduri apam}

It is quite conceivable that the custom of khanduri apam had its origins in the mortuary ritual. One woman in Kutaiboh relates that the khanduri apam resembles giving an umbrella to the deceased's 'soul' in the Field of Gathering on the Day of Resurrection. The weather on that day will be too hot, because the sun "is only a hand span above the head". One man in Cot Manee also says that the khanduri apam is held with the intention of providing an umbrella to the deceased, meanwhile the khanduri $\operatorname{cindoi}^{233}$ after the death of a person aims

as human bodies. The maggot became cocoons then they hatched becoming living creatures. Their names are Jut Ma'jut. They went out through the vagina of that sculpture to seek their food. They ate whatever they found especially cattle (Effendie 1979:137). Based on the local belief, Jut Ma'jut is still now in the mountain but the villagers do not know which mountain they live. They will come out on the day of hereafter. The Qur'ān says, "When [the dam of] Gog and Magog has been opened and they, from every elevation, descend" (QS 21:96).

232 I hear the same version about the origins of the khanduri apam from Teungku A. Rahman Badar, the leader of the council of Indonesia 'ulamā' in Southwest Acèh. He also states that the original story of holding the khanduri apam is from the story of constructing the huge ark of Noah and the apam cakes were the special food baked by the Noah for ' $U d$ when he asked him to bring a huge tree trunk from the bank of the river Nile.

233 Cindoi is made of ordinary rice flour. The flour is first mixed with warm water so that it doesn't fall apart and then rubbed through a colander with small holes into the boiling water. Some forms of cindoi are straight and some others are like the handles of an umbrella. Its sauce (Ach kuwah) is made of coconut milk, sugar and salt. 
at providing the handle of an umbrella to the deceased because its form resembles an umbrella handle. The rice cakes are associated with the 'soul' of the deceased person. The khanduri apam is performed as if the apam cakes were given to the deceased's 'soul' (Ach aruwah). They are shared among the living but their essence is given to the deceased's "soul" in the grave (Bowen 1993:233). At the burial in Isak Central Acèh three rice cakes are thrown in after the body " as food for the deceased" (Bowen 1993:259) although local modernists deny that one can send food to the 'soul'; they do value the food's naturally symbolic qualities (ibid). A number of people in Blangporoh whom I discussed this with say that the religious merit received from performing the khanduri apam is destined for the deceased's 'soul'.

The offering of apam cakes lessens the torment the deceased receives in the grave. Older villagers say that the apam have the inner property of warding off the clubs of the interrogating angels on the day of torment (Bowen 1993:259). Snouck Hurgronje I (1906:220) wrote about the khanduri apam in Acèh as follows:

The story goes that once up a time a certain Achehnese, possessed by curiosity as to what befalls man in the tomb, and especially as to the investigations of the angels of the grave, Munkar and Nakir, and the punishments they are supposed to inflict, feigned death and was buried alive. The two angels soon subjected him to an enquiry as to his faith and works, and as he was found wanting in many respects, they began to smite/hit him with their iron clubs. None of the blows, however, reached him. Something that he could not clearly distinguish in the darkness of the tomb, but which seemed to resemble the moon in its circular form, interposed itself as a shield and warded off the blows. He contrived to work his way out of his narrow prison and hastened to relatives, who received him with amazement. After relating his adventures he came to know what caused his merciful deliverance from flagellation by the ghostly clubs. At the very moment when the moon-shaped shield was giving him its shelter, the members of his family were in the act of preparing the apam cakes for a kanduri which are in fact round like the moon. ${ }^{234}$

The apam cake is also called kuwe peutploh peut (the 44 cakes). "The cooked rice stands for life as long as I still eat rice I am alive" and the 44 cakes are offered on the $44^{\text {th }}$ day after a person's life finally ends" (Bowen 1993:233). The 44th day in Acèh is also the last day of confinement known as madeueng

234 It is interestingly associated with the moon, something to do with fertility since the growth of the rice is very often related to the coolness of the moon. 
or "warming" or "engaging in drying the infant's mother over the fire". On this day the infant and its mother are moved from the madeueng, that is, from the back verandah of the house (Ach seuramoe likot) to the main house (Ach rumoh inoeng). Also on the 44th day, the young rice plants called bijèh padé are moved from the seedbed where they are then transferred to the fields. In addition, on the 44th day, the tombstones are placed at the head and the feet of the grave (are "planted") which is also known as pula batèe replacing recinus plants (Ach bak nawah) these are put down as markers at the burial process. This discourse deals very much with fertility, growth and death. The number 44 is relevant because 44 relates to the newborn child, it deals with the growth of the rice. If the number 44 is connected to the growth of rice and a child, it make sense to offer the essence of the rice cakes to the dead because the dead take 44 days to decompose. In other words, 44 days refer both to the complete growing period for rice and to the completion of decay in human bodies. The number 44 thus symbolises both the period of growth for rice and humans and the period of decay for the body and the apam cake.

In Blangporoh village, the khanduri for the dead is held on the first, second, third, fourth, sixth, seventh, fourteenth, forty-fourth, and one hundredth evening of the dead. ${ }^{235}$ Especially on the fifth night after death, it is always performed after "the prayer at sunset" (Ach seumayang meugréb) at the deceased's house. It is assumed that "essence" of the apam cakes served on that occasion provide sustenance for the dead. This khanduri is said to be especially favourable in influencing the fortune of the dead. The deceased's 'souls' (spirit) remains near the household and "the 'souls' come when the rice is cooked". "They consume the essence of the rice through the fragrance and the steam rising from the rice. The merit of providing khanduri apam cakes will lessen their torment in the grave and Allāh will give His mercy to the dead. The dead person "is like someone who is thrown to the sea without a life raft or any other help", and a sincere khanduri apam held by the family adds to the deceased's good deeds. The more good deeds the dead has, the happier he/she will be in the grave. One imām in Suakberumbang contends that besides adding religious merit for the dead, holding the khanduri apam on the fifth day after death is to remind the living that the corpse has now swollen like an apam cake. The con-

235 The day of burial is counted as the first day. If the funeral is on Tuesday, the first khanduri falls on Wednesday night. The second is on Thursday night and so on, counted by the number of nights the corpse has lain in the grave. 
dition of the dead body in the grave is as follows; the first night, the body is still normal, the second night, it starts to smell, the third night, it smells, the forth night, it starts to swell, the fifth night, it swells, the sixth night, it nearly bursts, and the seventh night, it bursts". ${ }^{236}$ This condition is a lesson for the living that they will also die and their body will undergo the same process. The dead body will decompose and become earth again. The body is called maté (dead) because the nyawa 'soul' has left it. Although the body has decomposed, the nyawa never dies. It is believed that the nyawa that has left the body becomes roh (spirit) and will go back to his or her house from the first till the seventh night, and then on the fourteenth night, the forty-fourth night and the one hundredth night so that the deceased's family members have to hold khanduri on those particular nights to make the deceased's 'soul' (Ach aruwah) happy/to appease the deceased soul. Even the poorest family in the village hold the khanduri for the dead from the first till the seventh night and they will get into debt for the khanduri for the benefit of the deceased. The deceased's family is afraid that his or her fellow villagers will say "the khanduri has not been held for the deceased". This statement indicates how important the khanduri for the dead is whereby it is not merely for the benefit of the dead but also for the social life of the living.

The following description focuses only on the individual khanduri apam on the fifth night of the dead in Blangporoh village. The apam cakes were baked at the deceased's house by his relatives with the help of the village women on the fourth day after death. The ingredients were the same as those of the apam cakes offered on the night of the Prophet's ascension (see below). The next of kin of the dead and the neighbours donated the various ingredients needed to lessen the economic burden on the family. These relatives include the members of the household and the wider kin group, niniak mamak and wali hukum.

On March $26^{\text {th }}$, 2007 I attended the khanduri apam held for a deceased female. Before the prayer recital the apam cakes were served to the shamadi$y a h^{237}$ reciters who voluntarily came to the deceased's house. The imām of

236 Compare to Snouck Hurgronje (1906 I: 430), "The third day the body smells (Ach huròe lhèe-mubèe), the fifth it swells (Ach huròe limòng-keumòng), the seventh it bursts (Ach huròe tujōh-beureutōh), the tenth the worms devoured it (Ach huròe siplōh-ka ulat pajōh)".

237 The name of shamadiyah derives from the Arabic word shamad, meaning the one who is totally Self Sufficient, who is independent of all, all are dependent on Him; and He 
Blangporoh, known for his melodious voice and ritual skills, led the recital of shamadiyah as the heart of the funeral khanduri at 7.30 after "the sunset prayers" at the deceased's house. ${ }^{238}$ The men gathered in the large front room and the women gathered in the back room. Both rooms had been cleared of furniture and brightly coloured pandan mats covered the floor. The assembled guests chanted the shamadiyah in Arabic, including repetitions of Qur'anic verses and the phrase lā ilāha illa Allāh "there is no deity but Allāh," as well as long invocations to generate merit and destined for the deceased.

Before the shamadiyah was recited, a heap of white stones (Ach batèe putéh) bought from a seller at Kruengbaru River ${ }^{239}$ were placed in front of each shamadiyah reciters by the deceased's son. While the stones were distributed, the imām said to all attendants, "those who have not abluted themselves please do it now! We will recite shamadiyah and transfer its merit to the deceased". As this was about to begin, small white incense in coconut shells was burnt with charcoal and the fragrance helped intensify the spiritual and solemn atmosphere. A working woman in the kitchen said to another working woman and children keep quiet and listen to the shamadiyah recitation. The shamadi$y a h$ started as the smoke of the burned incense was rising. As the same time the imām started the chants, he requested pardon from Allāh, known as the istighfār from the opening phrase: "Astaghfirullāh...", meaning "I ask Allāh for pardon...". [Reciting istighfār is a must at the beginning of any recited do' $a$ as a means of enhancing the consciousness of Allāh and strengthening the relationship to Him because as it is uttered, the people turn to no one except to Allāh in repentance. Istighfär is one of the essences of the people's servitude and submission to Allāh since the people confess their greatest errors, shortcomings, failures, and sins to Him. The imām recited the phrase slowly till the end and others joined them for three repetitions.

After istighfär came a prayer in praise of the Prophet called shalawat, a word of salutation and blessing upon Allāh's messenger, the Prophet Muham-

depends on no one for His existence, The Indivisible, The Everlasting refuge. The word itself appears in the second line of the sūrah al-Ikhlās (Qur'ān 112): "Allāhus shamad" (Allāh, the Everlasting Refuge).

238 If the child of the dead is also a religiously learned man (Ach teungku), the shamadiyah is led by him because a child of the deceased can be especially effective in transmitting the benefit of the recitation to the deceased's 'soul' (Ach roh).

239 Many family members buy these stones to be placed on the grave of relatives after they are chanted with shamadiyah. 
mad. It was chanted together once slowly. The imām said after the khanduri that shalawat was the second requirement of any chanted do' $a$. Whenever a person says it for the Prophet, an angel informs the Prophet's 'soul' and says, "so and so's son or so and so's daughter" of your follower sends his or her salām (peace) and prays for you. The imām recommended that shalawat for the Prophet be uttered as often as possible and even Allāh and the angels say shalawat, so we should too. ${ }^{240} \mathrm{He}$ added further that there could not be a greater honour for the believers than this, who had been favoured with a share in this divine action by Allāh and His angels. The honour and reverence shown to the Prophet Muhammad is of a much greater degree than shown to the Prophet Adam to whom only angels were made to bow down in honour. For in honouring the Prophet Muhammad, Allāh attributed this honour to Himself, whereas in the case of the Prophet Adam Allāh asked only the angels to show honour.

Then came the recitations of the sürah al-Ikhlās [QS 112:1-4], "the Qul hu", from which its name derives. The imām and the shamadiyah reciters repeat the recitations as many times as the number of white stones that has been donated. Once they finished reciting this süra $\underline{h}$, they took a white stone and placed it next to their heap. They did this repeatedly while shaking their heads with their eyes shut till all the white stones were counted. They then put the stones in front of them till the recital of shamadiyah was over. ${ }^{241}$ Reciting this sürah is central to the shamadiyah session. One says that if the sürah al-Ikhlās is sincerely recited ten- thousand times, the deceased's sins would be forgiven by Allāh and "the deceased's life in the grave would be eased as though their sins were like foam in the sea". In other words, repeating sincerely the süra $\underline{h}$ al-Ikhlās ten thousand times, regardless of the actual number of recitations, is said to redeem the sins of the deceased completely. At first it was recited slowly then the recitation became faster and was then recited loudly to all white stonescounted with this sürah.

The previous imām of Blangporoh said that the sürah al-Ikhlās completely erased any polytheism (Arb shirk) that the people were committing and that it

240 What the imām said can be found in the Qur'ān, sürah al-Ahzāb, verse 56 which says "Indeed, Allāh confers blessing upon the Prophet, and His angels [ask Him to do so]. O you who have believed, ask [Allāh to confer] blessing upon him and ask [Allāh to grant him] peace".

241 The shamadiyah was counted 40 times with the white stones. The participants who got more than 40 white stones gathered together the stones that had a spell cast on them. The imām also said that they also contained beurekat (Arb baraka), after shamadiyah. 
moved Allāh away from the paganistic ideas and doctrines that had been ascribed to Him. It dealt essentially and exclusively with the unity of Allāh (Arb taunid). Many people in Blangporoh with whom I discussed the shamdiyah said that this sürah was equivalent in merit to a third of the Qur'ān, and that reciting it three times constituted "completing the Qur'ān". ${ }^{242}$

Next, two additional short sürah; the sürah al-Falaq [QS 113:1-5] and the sürah an-Nas [QS 114:1-6)] were recited together. Both sūra $\underline{h}$ are usually identified in such discussions by their first ayat (Arb āyātun) rather than by their titles. It is said that the sürah al-Ikhlās, al-Falaq, and an-Nās should not be separated and each has different virtue: the 'Qul hu' [QS 112:1-4] states that "Allāh is one. He neither begets nor is born. Nor is there any equivalent to Him "; the "Qul a'ūdzu birabbil falaq' [QS 113:1-5] asks Allāh's protection from all kinds of evil; the 'Qul a'ūdzu birabbin nās' [QS 114:1-6] asks Allāh to ward off devils who make evil suggestions and evil prompts that may come from men as well as from jinn. My respondent said that reciting these süra $\underline{h}$ three times at dawn and dusk would suffice in all respects, meaning that one would not need any other recitations for the remembrance of Allāh. The most important virtue of this sürah is that Allāh will protect the reciters from all danger. It is said that after lying in the bed, the Prophet used to recite these sürah, then blow on his hands and rub his body where he could.

Only after this, the imām and the shamadiyah reciters continued reciting tahlill, during which the participants chanted a zikir (Arb dhikr), a repetition of lā ilāha illa Allāh (there is no deity but Allāh) as the essence for tahlīl itself for one hundred repetitions. The recital of tahlīl is called meuratéb. The first three times of tahlīl was recited slowly together then somewhat more quickly, and in a loud voice with a different melody. The reciters shook their heads from right to left and then back again keeping their eyes shut. Sometimes a participant took the initiative to chant loudly. The louder their voice the faster their heads shook with their eyes closed, some people also do this without saying anything. The women gathered at the back divided their attention between the chanting

242 Like in Gayo, Central Acèh, this is said to be based on the story of how Alī ibn Abī Tālib, the son in-law of the Prophet Muhammad as well as the fourth caliph, first impressed the Prophet with this idea. The Prophet had asked his students to recite their way through the Qur'ān. As the others were just reciting to the next sūrah , 'Alī ibn Abī Tālib closed the Qur'ān said that he had finished reciting it. To the Prophet's query, he replied that he had simply read the "Qul hu" three times till the end and thus completed the Qur'ān. The Prophet was pleased with this reply (see Bowen 1993:265). 
and looking after the children, cooking the meal, baking apam and snacks. At the one hundredth recitation the imām clapped his hands in order to let the participants know they could stop chanting. After reciting tahlīl, the imām continued reciting do' $a$ to send requests to Allāh for the well-being of the deceased and to channel the merit of the entire session to the deceased's soul. ${ }^{243}$ The contents of $d o^{\prime} a$ recited by the imām are as follows:

He praised Allāh and prayed for the Prophet and his family's well-being. He asked for a good place in this world and the hereafter, beseeching that all disaster be avoided, and requesting Allāh's perpetual blessing.

He sought Allāh's forgiveness for their teachers, parents, grandparents, neighbors, and friends and all Muslims in the world, those who are still alive and those who have died.

He requested Allāh to protect the living present and absent.

He asked Allāh to protect the deceased, showing him mercy, keeping him in good condition, pardoning him, (honouring him, and enlargening his place of rest, washing him with water, and cleansing him from faults as a white cloth is cleaned of dirt (at this moment, he modulated his voice in a highly pleasant way and sometimes a tear-drop will roll down his face and then he takes a slight pause before resuming the $d o^{\prime} a$ ).

He asked Allāh to send the blessing of shamadiyah, tahlīl, and do' $a$ to the aruwah of the deceased directly (whilst saying this, he lowered his voice and said the deceased's name softly), to keep away the torment of the grave (Ach siksa kubu) experienced by the deceased's soul, release it from spiritual sins and the early debts and bestow on it as much of "the pleasure of grave" as possible.

He asked Allāh to grant that whoever dies may die in faith. O Allāh! Do not deprive us of this reward and do not make us fall into a trial.

He asked Allāh to bestow the happiness in the world and on the day of judgement upon the living.

At the end of each recited $d o$ 'a, all shamadiyah reciters intoned $\bar{a} m \bar{i} n$ (please approve oh Allāh) with individual prayers. He closed the do'a session with the collective chanting of verses of the süra $\underline{h}$ al-Fätihah (QS 1:1-7) "which contains the essence of the entire Qur'ān".

243 The role of the imām in the ritual of reciting shamadiyah is very significant. He does not just coordinate and lead the shamadiyah reciters in reciting $d o$ ' $a$ and verses. He is also responsible for transmitting their merits to Allāh. That is why the imām (the do' $a$ leader) must act correctly otherwise the merit of shamadiyah will not be accepted, says one man. He adds that in this case the imām must have a strong makripat (Arb ma'rifah), the intuitive knowledge concerning the relationship of the worshippers to Allāh, the mystics consider this knowledge superior to any acquired knowledge. 
After reciting $d o^{\prime} a$, the piles of white stones that had been counted with the sürah al-Ikhlās in front of the shamadiyah reciters were mixed and put into a small sack by the deceased's son. The apam cakes were then served on plates to the shamadiyah reciters. Some other shamadiyah reciters who had quickly finished eating apam cakes smoked and drank coffee while waiting for others who were still eating. The son of the deceased inserted an envelope containing money into the pocket of each shamadiyah reciter, and the khanduri apam for the dead was over at about $9 \mathrm{pm}$.

The imām and other shamadiyah reciters argued that the recitation of shamadiyah where the villagers referred to the recitation of the sürah al-Ikhlās, tahlill, and $d o$ ' $a$ is to generate merit for the deceased. The merit of those recitations was aimed directly at the 'soul' (Ach aruwah) of the deceased and each word of the chanting was $d o$ ' $a$ to lighten his/her suffering. Some said that the merit was aimed at adding to the number of the deceased's good deeds (Ach amai) and redeeming his sins. If the recital of shamdiyah was not performed when a person died in the village, that person was shown no respect.

In the early morning on the days following March $27^{\text {th }}, 2007$ the white stones were placed on the grave of the dead by the deceased's son. It is said that because both the sürah al-Ikhlās and tasbèh are in praise of Allāh, jinn will not dare to approach the grave because of the white stones symbolizing holiness and will become witnesses on the Day of Resurrection. The white stones acknowledge that shamadiyah has been recited for the deceased in front of Allāh. The ritual of placing the white stones is said not to be heretic as the Prophet Muhammad had asked his companions to collect small stones to be placed on the grave of his son, Ibrahim. The white stones that have been placed from the head to the foot of the grave are believed to be saying tasbèh (a prayer to the glory of Allāh) until the Day of Judgment and generate merit on the deceased's behalf after the grave has been left because at the beginning the sürah al-Ikhläs and tasbèh have been chanted with these stones.

\section{The collective khanduri apam}

Since the collective khanduri apam was not held in Blangporoh village on the $27^{\text {th }}$ night of Ra'jab lunar month in 2007, the following description refers to the collective khanduri apam held in Alurambot, the neighbouring village in Meunasahbarō's mosque. The collective khanduri apam is held for the collective dead. In this ritual collectively celebrated there two different discourses: the 
adat discourse and the Islamic discourse. Both are used in order to explain why this ritual is performed. The villagers claim that the name of the month of Ra'jab (Ra-Ja-B) consists of the three Arabic letters $\lrcorner$ (Ra), ج (J) and (B), substantiating the event of the Prophet's ascension from Mecca to Jerusalem. Each letter stands respectively for $R$-asulullah (the Messenger of Allāh), J-ibril (Gabriel) and B-uraq (the vehicle of ascension). Some people stress that the apam cakes which are served to the people on the $27^{\text {th }}$ night of Ra'jab originate in Acèhnese custom because these are believed to have been the cakes that the Acèhnese ancestors consumed. ${ }^{244}$ Some others said that the khanduri apam and their sauce (Ach kuwah) relates to the Prophet Muhammad's journey to heaven. On the night of the Prophet's ascension, he was offered three kinds of drink by Gabriel: milk, honey and arrack.He took the milk and the honey. Milk is a symbol of apam cakes; honey a symbol of its sweet sauce. The Prophet did not take arrack and nor did he drink it when it was offered to him. That is why Muslims are not allowed to drink arrack and alcohol. ${ }^{245}$ Some others say the apam symbolises the flesh of the body so when it is eaten, it must be made into a sauce symbolising the blood. Perhaps this interpretation is influenced by the Christian concept of Eucharist. They also stress that the essence of the apam cakes will be given to the ancestors as part of the adat discourse and at the same time the cakes also bring merit from Allāh as part of the Islamic discourse.

In Tangan-Tangan, the neighboring district of West Labuhan Haji, the villagers bring the apam cakes to the mosque on the night of the celebration of the Prophet's journey to heaven; they also bring the apam cakes to the mosque every Friday of the Ra'jab lunar month. After the Friday prayer, they eat together in the mosque in the hope that the donors and their deceased relatives will receive religious merit from preparing the apam. In the past khanduri apam was also performed after an earthquake occurred which was supposed to decompose the material remains of the deceased (Snouck Hurgronje I 1906:220). Part of the ritual is the baking of cakes in every house that are distributed at the mosques or prayer houses for the benefit of their ancestors and recently deceased relatives.

244 Other cakes such as seupèt, keutupèk and leumang which are now made on certain occasions by the Aneuk Jamee and the Acèhnese belong to the Minangkabau people.

245 One said that the khanduri apam in Minangkabau, West Sumatra is held without sauce and, therefore, is called apam serabi as they do not see a relation between offering milk, honey and arrack and the ascension of the Prophet to heaven. 
A week earlier, the village secretary announced to all followers of Friday communal prayer the following:

We are now in the middle of Ra'jab lunar month. It has become a custom that during every Ra'jab lunar month we will hold the khanduri apam. The members of the governing body of the village have decided that the khanduri apam will be held on Ra'jab 27 $7^{\text {th }}, 2007$, that is on August $2^{\text {nd }}, 2007$ and we hope every one will spread this news to all villagers. All families should bake apam cakes and bring them to the mosque at $8 \mathrm{pm}$. In addition, all villagers are invited to attend the khanduri apam and listen to the speech about the history of the Prophet's ascension (Ach sejarah nabi jak mè 'reuät) to heaven.

At midday on Ra'jab $27^{\text {th }}$, 2007, the village women baked apam cakes at their home. ${ }^{246}$ They are cakes made of lightly fermented rice flour and shouldbe eaten with a sauce of coconut milk, sugar, salt, ripe wak banana, and the leaves of civet cat's pandanus. The surfaces of apam cakes have small holes on them, symbolizing the rain causing the deluge at the time of the Prophet Noah. The offering is meritorious as it is considered to be a form of charity as well as maintaining brotherhood and community bonds.

At $8 \mathrm{pm}$ after 'night prayers' (Ach seumayang isya), the village men, women and children went to the mosque. Each family head brought the apam cakes in a set of stacked containers (Jam/Indon rantang) to the mosque and gave it with $\mathrm{Rp} 2,000$ to the committee members. The committee members placed these containers in the back left corner of the mosque and received money from each household head to buy tea and coffee; other cakes were later given to the speech deliverer.

At about $8.30 \mathrm{pm}$ the head of the committee members announced: Please come quickly to the mosque! Several minutes later the villagers arrived at the mosque. The men sit in lines at the front of the mosque; the women sit at the back. Some children sit with their fathers and some sit with their mothers and some others sit between men and women. The ceremony commenced promptly

246 It was made of ordinary rice flour (Jam tapuang bareh;Ach tepung breueh), coconut milk (Jam santèn karambi; Ach santan u), and salt (Jam garom;Ach sira), and yeast (Ach gis). The crushed yeast is mixed with ordinary rice flour in order to make the apam cakes raise as they are baked. A female apam baker told me how to make the apam cakes. It as follows; firstly, the coconut milk is heated then mixed with ordinary rice flour, salt and the crushed yeast are added. It is then stirred before being baked in an iron pot (Ach kuali beuso). She also said that many years ago every household in the village kept a special iron pot for baking the apam cakes in the Ra'jab lunar month. 
at $9 \mathrm{pm}$. First, a young boy recited verses 1 to 7 of the surrah al-Isrā' in the mosque's pulpit so that the ceremony could be blessed. Then the head of the committee stood up in front of all those attending to thank everyone who had contributed help, ideas and money. The history of israk mikraj (Ach iseurak mè 'reuät) was then recited. This speech consisted of a description of the ascension in rhyming prose and verse, similar to that about the birth of the Prophet (see Ch.7).

Below I present excerpts from the israk mikraj speech at Meunasahbaro's mosque I recorded this omitting just repetitive speech. It begins after the customary Arabic formulae "I take refuge in Allāh from the accursed devils", "In the name of Allāh the beneficent and merciful", with a Qur'anic verse, sürah al-Isrā' (QS 17:1). This says "Exalted is He who took His servant [i.e., Prophet Muhammad] by night from the Harām mosque to the Aqsā mosque whose surroundings We have blessed, to show him of Our signs. Indeed, He is the Hearing, the Seeing". The israk mikraj speech continues:

All 'fathers' (bapak) and 'mothers' (ibu), I wish that Allāh blesses you all for attending the israk mikraj celebration on this night. Before the story of israk and mikraj is told, it is important to know why our Prophet Muhammad was taken from the Harām mosque in Mecca to the Aqsā mosque in Jerusalem, Palestine. He was then lifted up to the seventh layer in the sky, to Sidratul Muntaha and at the end to Mustawa. Historically, in the eleventh year of his prophethood, the "year of profound sorrow" (Ach thon duka cita) occurred in which his beloved wife, Khadijah and his father's brother, Abi Thalib passed away. These losses affected him deeply because both his wife and uncle had supported his preaching from the beginning. At the same time the Quraisy group had increased their economic and political pressure on him and his followers. He and his followers really felt the ban imposed on them not to provide food or communication for around two years and that is why the year of israk mikraj was named as "the year of profound sorrow". In this condition, the scenario with Allāh took place. He was taken and lifted up to meet Allāh on the twenty seventh night of Rajab, about 18 months before "the flight" (Arb hijrah) ${ }^{247}$ to Medina.

All 'fathers' and 'mothers', israk (Arb isrā') was a miracle in which the Prophet Muhammad was taken from the Harām mosque in Mecca at night by a winged steed called buraq to the Aqsā mosque in Jerusalem, Palestine. Before he was taken, his breast was at first operated on by Gabriel, one of the four archangels. He cleaned the Prophet Muhammad's heart

247 Hijrah, "the flight", because of persecution, the Prophet Muhammad moved his community from Mecca to Medina in A. D 622. This marks the base date of the Muslim calendar. 
three times with the Zamzam well's water. A part of his heart called Satan (Ach syétan), was taken and thrown away and replaced by Gabriel with wisdom, knowledge, faith, and strength in order to guarantee his physical and mental condition for a very long journey at night penetrating the atmosphere and air from one planet to another. After operating, the Prophet's breast was closed and sealed with a prophetic stamp.

All 'fathers' and 'mothers', Gabriel was the guide who that night brought a buraq fro heaven for the Prophet. The vehicle named buraq meaning flash of lightning because it could fly as fast as a flash of lightning. The buraq has the face of a women, the body of a horse with four legs, two wings like a bird, and a tail like a peacock. This image is not strange for Muslims. Sometimes this picture is hung in a house or on the door. The questions are: is it right that the Prophet Muhammad mounted on such a being when he was taken from the Harām mosque in Mecca to the Aqsā mosque in Palestine during the night. Who created such a picture? Such a picture is merely an imaginary picture created by Jews. The Jews created such a picture aimed at undermining the Prophet Muhammad. Buraq's face is like a woman's because he practised polygamy. The wings are like a bird because the Buraq wanted to fly over everyone. Having a body like a horse meant he had a strong sexual desire. The Prophet Mohammad did not ride in such a vehicle when he was taken from the Harām mosque in Mecca to the Aqsā mosque in Palestine. ${ }^{248}$

All 'fathers' and 'mothers', the Prophet Muhammad was brought from the Harām mosque by the buraq to a place where date trees grew. Gabriel told him that the place's name was Thayyibah (now Medina), the place where you would hijrah later. Again the buraq flew until they arrived at Madyan (now Ghaza). Flying again till they arrived at Thursina hill, the place where Allāh and Moses spoke. Flying again till they arrived at Baitullahmi, the place where the prophet Isa (Jesus) was born. As the buraq stopped at the above places, the Prophet Muhammad was asked to get off and to perform a two-cycle voluntary prayer (Ach dua raka'at seumayang sunat). Each time whilst flying with the buraq, Jinn Ifriit ${ }^{249}$ went toward him with fire then Gabriel taught him the following do'a ; "I take shelter from Allāh with His perfect decrees which cannot be transgressed by pious or sinful men; from disasters falling from the sky, rising to the sky, happening onearth and something arising up from it, (such as slander during the day and at night) and other various events during the day and night except the events that bring goodness, o Allāh, the entirely merciful, the especially merciful". After uttering this $d o^{\prime} a$ the fire was extinguished and jinn Ifrit fell down.

248 Such statements about Jews are a part of general discourse among more general Islamic discourse in Indonesia, see "The Jew as a symbol in contemporary Muslim discourse in Indonesia" (see Dian 1994).

249 Ifrit (Arabic 'ifrit) is an evil jinn and is regarded as especially dangerous to humans. 
All 'fathers' and 'mothers', the journey was again continued till the Prophet Muhammad and Gabriel arrived at a group which were planting and harvesting on the same day. He asked Gabriel about it and he said "that is a symbol of people who strived to accomplish religious ends (Indon berjihad) for the sake of Allāh. Their goodness will be doubled by Allāh 700 times". The Prophet Muhammad smelt something fragrant; he then asked Gabriel about it. Gabriel said that this was the smell of Masyithah, a comber of the Pharaoh's daughters' hair who was thrown by Pharaoh into the bubbling oil because she did not acknowledge Pharaoh as a god. The Prophet Muhammad also saw people who ate the decaying meat although they had fresh meat in front of them. He asked Gabriel about it and Gabriel answered that this was a symbol of people who had their own wives but liked sleeping with other women. The Prophet Muhammad also saw people who swam in the bloody river. Gabriel said that this was a symbol of people who ate excessively He also saw the people cutting their own tongues. This was a symbol of people who enjoy slander, said Gabriel.

All 'fathers' and 'mothers', the Prophet Muhammad travelled till he arrived at Aqsā mosque in Palestine. He entered the mosque and became the imām of a two-cycle voluntary prayer. All souls of the earlier prophets and believers stood behind him and followed his prayers. After performing prayer, he was thirsty and Gabriel brought milk and arrack to him. The Prophet Muhammad cleverly chose milk. Gabriel said, "You have made the right choice". Milk is a symbol of Islam because it is good and the people drinking it will feel enjoyment. Gabriel further said, "If you chose arrack, your followers would be led astray (Ach sisat) and will follow their sexual desires and nobody would follow you". The history of mikraj then continues.

All 'fathers' and 'mothers', Mikraj (Arab mik'āj) means a ladder (Ach reunyeun) on which Muhammad ascended to heaven. It was brought from heaven. The Prophet and Gabriel stepped on the given ladder then they were lifted up to the door of the worldly sky. At the first layer of sky, he met the Prophet Adam. On the second layer of sky, he met the Prophet Isa, the third layer of sky he met the Prophet Yusuf, the fourth layer of sky, he met the Prophet Idris. On the fifth layer of sky, he met the Prophet Harun. On the sixth layer of sky, he met the Prophet Musa, and on the seventh layer sky, he met the Prophet Ibrahim. All earlier prophets he met uttered salām (Muslim's greeting) to him and prayed for him so that Allāh would prolong his age. They said that Muhammad was the best khalifah and he was the best visitor that ever came to the sky.

All 'fathers' and 'mothers', the Prophet Ibrahim said to the Prophet Muhammad that his ummat were very weak (Ach umat laèh). He suggested that he prayed for them and asked them to plant trees in heaven with tasbih (a prayer to the glory of Allāh) because the soil of heaven was very fertile and its water was fresh. Tasbìh consists of four phrases: 


$\begin{array}{ll}\text { Subhanallāh } & \text { Allāh is Holy } \\ \text { Wal hamaulillāh } & \text { and all praise is due to Allāh } \\ \text { Wālaillā haillallāh } & \text { and there is no deity except Allāh } \\ \text { Allāhu akbar } & \text { Allāh is the greatest. }\end{array}$

These phrases are for those who recited those sentences when they planted a tree and the more they recited these sentences the more trees they could plant in heaven. Their fruit would be picked later in the hereafter. After seeing many interesting events on his right hand (heaven) and sad events on his left hand (hell), he and Gabriel entered Baitul Makmur which was believed to be directly at Ka'bah in Mecca and performed a two-cycle voluntary prayer there.

All 'fathers' and 'mothers', the Prophet Muhammad was lifted up alone without Gabriel to Sidratul Muntaha, a huge tree where the river of Kautsar flows to heaven from the base of its roots. The colour of its trunk was like a very beautiful jewel that could change colour by itself. The Prophet Muhammad then entered into heaven. Heaven contained truly beautiful things; things that the eyes would have never seen, the ear would have never heard, and things that would have never crossed human's mind. Heaven is the place of happiness which is unexplainable for believers. $\mathrm{He}$ then went into $n \bar{u}$ (light) right on the top of the Sidratul Muntaha tree. From there he was lifted up to Mustawa and he looked at a man whose tongue was wet from reciting zikir and whose heart was hung on the mosque as he had always obeyed and never insulted his parents. The Prophet Muhammad then arrived at Hadhatul Qudus and Hadrat RabbulArbab and looked Allāh directly in the eyes. He bowed in front of Him and then a conversation took place:

Allāh: $\quad$ O Muhanammad

Muhammad: Labbaika (I come from my deep longing to fulfill your invitation)

Allāh: $\quad$ Please lift your head up and ask Me, I shall grant your requests

Muhammad: Ya Allāh, You have taken Ibrahim as khalilullāh (the closest companion of Allāh) and given him a big kingdom. You had a conversation with Moses. You gave Dawud who could bend iron a big kingdom. You gave a big kingdom to Sulaiman. You gave him knowledge to master jinn, human beings, Satan, and air. You taught Isa Taurat and Injil (Gospel). With your permission, he could heal blind people and those with skin discolorations you brought someone back from the dead and protected him and his mother, Maryam from Satan.

Allāh: $\quad$ I took you as habibullāh (my beloved), I want to introduce you as the one who delivers the happy news and My command to your followers. I have opened your chest and 
thrown your sin away. I made your followers the best ones. I gave them special treatment in the day after. I gave you and your followers 7 verses of süra $\underline{h}$ al- Fātih $\underline{h} \underline{h}$ which I did not give to anyone who came before you. I gave you liwaul hamdi (banner) so that Adam and others will be under your banner in the day after, and I asked you and your followers to pray 50 times a day and at night.

All 'fathers' and 'mothers', after having the conversation, the Prophet Muhammad went back to meet the Prophet Ibrahim and Musa and they asked the Prophet Muhammad to go back and asked Allāh to reduce the prayertimes because his followers are weak in body, breast, heart, sight and hearing. Following the advice of the Prophet Ibrahim and Musa, the Prophet Muhammad went back to Allāh nine times that night. And each he went back to Him, He reduced the prayers by five and at the end $\mathrm{He}$ required 5 prayers a day which have the same value as praying fifty times. After mikraj, he went back to the worldly sky and from there to Baitul Maqdis with Gabriel then again riding the buraq to go back to Mecca on the same night with a prescription from Allāh for Muslims to observe five daily prayers.

All 'fathers' and 'mothers', the history of israk mikraj contains mysterious messages from which one can learn lessons. These are as follows: Operating on the chest of the Prophet Muhammad before he was taken from Mecca to Jerusalem as preparation to meet the Holiest one, that is Allāh. This is a symbol of a wide chest sharpness of one's inner self. In reality the principle of "broad chest" by using sharpness of one's inner self with the society is very important. The agreements that have been made in our society may not be transgressed. A "broad chest", modesty and the sharpness of one's inner self practiced by the Prophet Muhammad were very important in his prophetic mission in order to change the society to become more ideal. They function to lighten the physical burden and to raise optimism. The moment of israk mikraj is hoped for to attain a positive attitude in life. Israk mikraj teaches us to learn from other experienced people. Meetings and conversation between the Prophet Muhammad and his seniors, Prophet Ibrahim and Musa and the questions and answers with Gabriel indicate that we should be modest and learn from success or failure taken from other people's experiences. The experiences of the earlier prophets were very useful for the Prophet Muhammad. For us, other people's experience should provide inspiration to solve our problems.

The highest valued command, that is salat (prayer). The Prophet Muhammad was directly lifted up to receive it while Allāh's other commands were only through revelations to him. Salat is one of the pillars of the Islamic religion. For those who perform it, he or she has chosen the Islamic religion and vice versa, for those who do not perform it, he or she 
thus has discarded the Islamic religion. It is felt that Allāh controls our actions otherwise these actions will not work. Israk mikraj indicates a very important spiritual value for our lives visions. A moral philosophy reminds us that a community can become be eternal together through morality. If there is no morality, the community will be thus lost together.

After delivering the lessons that can be learnt from israk mikraj's recitation, the session of the israk mikraj speech closed with a short $d o$ 'a considered to be the noblest act before Allāh. While standing up in the mosque's pulpit and holding up his two hands with palms as high as his breast followed by everyone, the imām began the $d o^{\prime} a$ by uttering 'in the name of Allāh, the entirely merciful, the especially merciful' (Arb bismillāhirrahnmānirrahīm). He praised Allāh by uttering 'all praise is due to Allāh, Lord of the world' (Arb alhamdulillähi rabbil 'àlaminn) and prayed for the Prophet Muhammad and his family by uttering 'Allāh, call down blessing on our leader Muhammad, the illiterate Prophet, and on his family and companions, and greet them with peace' (Arb allāhumma shalli 'alā saiyidinā Muhammadin nabi al-ummi wa 'alā alihi wa ashāabihi wa salam). He requested Allāh as follows:

O Allāh, on this day; place us among those who seek forgiveness. Place us among Your righteous and obedient servants, and place us among Your close friends, by Your kindness, Ya the most Merciful.

O Allāh, on this day, do not let us abase ourselves by incurring Your disobedience, and do not strike us with the whip of Your punishment, keep us from the causes of Your anger, by Your kindness and Your power, Ya the ultimate wish of those who desire.

O Allāh please gives us the happiness in the world and in the hereafter, and keeps us away from hell's torment.

At the end of each recited $d o^{\prime} a$, all attendants intoned amin (please approve oh Allāh) and the imām closed the $d o$ 'a session with the collective chanting of verses of the sürah al-Fatihah (QS 1:1-7).

At about $10.30 \mathrm{pm}$ at night, the speech was over. The children who slept on the floor during the speech were awoken; "get up", "get up, now eat khanduri apam". Most of the women went home although the head of the committee members said they should eat the apam cakes. The committee members mixed the stacked containers containing apam cakes and their sauce, placing them in front of the imām first, then in front of the preacher, the members of the governing body of the village and all attendants in the front part of the mosque, including in front of some of women who were waiting for their husbands and 
children at the back of the mosque. It is imperative that the participants do not eat the apam cakes they brought themselves. "I bring the apam cakes with their sauce to the mosque for others. If I eat the apam that I bring that is no longer khanduri". The point here is that people do not eat their own offerings.

At about $11 \mathrm{pm}$, eating the khanduri apam was over. Some apam cakes fell into the hands of the children that waited nearby and many were thrown away at the end because many of those attending went home after hearing the israk mikraj speech and some of the sauce was spoiled because it was not properly cooked. It was not surprising that the people who came to the mosque after the khanduri apam still suffered from the smell of the remains of the apam and sauce that were thrown out from the mosque's window. ${ }^{250}$

250 The following day, on August $3^{\text {rd }}, 2007$, I came to this village discussing with a number of people about the nature of the ascension in which the villagers claimed that the ascension involved the whole entity of Muhammad's human nature as a servant which therefore comprised of both his spiritual and physical elements. They considered the Muhammad's ascension as a test for all mankind. It was said that after the Prophet returned from the israk mikraj, the non-believers started to laugh at the Prophet and made a mockery of him because they found the incident humorous. For the believers, however, it was a trial; some of them accepted it and some had doubts. Those who accepted came to Abu Bakr, the first Caliph and related to him the israk mikraj of the Prophet. Abu Bakr said "By Allāh, if Muhammad himself has said so then it is true because the story came from the Prophet and he has never told a lie". From that day Abu Bakr was given the title of $a s-S h i d q$ (true) by the Prophet (see Haikal 1976:146-147). The imām contended that israk mikraj was a special work of Allāh which could not be found in ordinary human beings. "It was a miracle, a kind of unusual work which could be found only on the Prophet with the permission of Allāh. His knowledge was the highest, thus nothing was impossible when He wished it. Many proponents used the achievement of advanced space technology, which was unthinkable a few decades or centuries ago, yet had now become reality, as support for the acceptability of the ascension" (Muhaimin 2004:182). The imām further contended that if the ascension involved the soul of the Prophet only, that was not special. Another imām also said that the israk mikraj was a physical journey. The Qur'ān (17:1) which says that Allāh took His servant [Muham$\mathrm{mad}$ ] from Mecca to Jerusalem at night is itself evidence of this The word servant (Arb 'abdi) in this verse applies to the body and soul together. The soul itself is not called 'abdi. If the journey was a vision they did not deny it and the matter was not given such importance. Because in a vision one could go anywhere and see anything and no one could deny it or give importance to it. What had happened during the prophethood, it was said, could also happen now. The phenomenon was unthinkable and thus, beyond human rationality. In fact there was a disagreement among intellectuals on the nature of the ascension, whether it involved physical or spiritual ascension. The majority of Islamic scholars were of the opinion that the israk mikraj is not purely "spiritual". They believed that the Prophet did it physically, in body and spirit. Any traditional discussion in the village, "takes the event for granted as a part of Islamic belief, including how the Prophet underwent a heart operation from Gabriel prior to his ascension, met with the previous prophets in the heaven during the journey and then went back to Mecca with a 


\section{Conclusion}

The seventh month of the Islamic lunar calendar is Ra'jab commemorated by means of the ritual of baking apam cakes. This month is regarded as one of the sacred months during which in the days of the Prophet Muhammad it was forbidden to engage in battle. It is also a prelude to the month of Ramadhan because the latter follows after the intervening month of Sya'ban. The month of Ra'jab is called "the month of khanduri apam" since during this period the apam cakes are baked in every house and distributed at the mosques as special food in the interests of ancestors and recently deceased relatives. The apam cakes symbolize that someone is preserved/protected from torment and at the same time the cakesare seenas charity for those who come to the mosque and the deceased's house.

The ritual of khanduri apam is a communication ritual; it communicates with the living and ancestors, and also between the living and Allāh. This cake is taken as a symbol as it is made of rice and is thus of human origin. It is essentially a powerful symbol of human qualities. Perhaps for this reason the apam cake [rice] is considered especially effective in transmitting human desires to ancestors and recently deceased relatives. The ritual of khanduri apam is celebrated on two different occasions at two different settings: a) at the deceased person's house at his/her individual singular death; b) at the mosque, collectively for all those deceased that have become ancestors during the past year (figure 10).

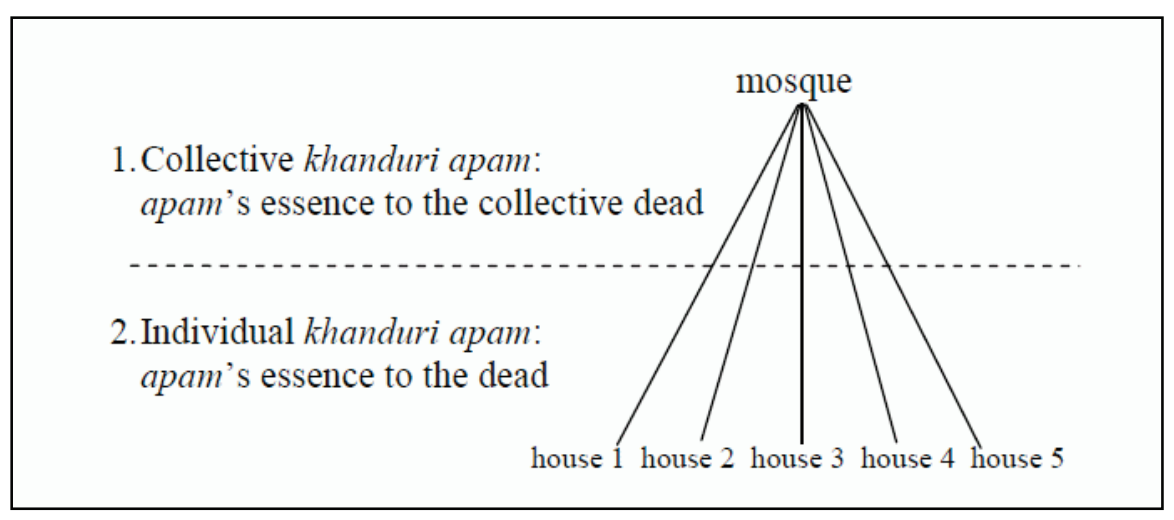

Figure 10. Two different occasions of khanduri apam

prescription from Allāh for the Muslims to observe the five daily prayers" (Muhaimin 2004:182). However, many western commentators may find this hard to believe because it involved supernatural powers and it was technically impossible so that many images of Muhammad as liar and fraud, deluded visionary, hysteric, epileptic Prophet were brought into play in the eighteen and nineteen centuries as possible explanations of the israk mikraj (see Almond 1989: 53-55). 
The collective khanduri apam can only be celebrated after the individual khanduri apam has been performed for each ritual for the dead. The relation between the living and ancestors has been taken care of. This is indeed a way of mediation between the living and ancestors. The ritual has various dimensions. The first dimension is that it takes care of the dead, on both occasions they are nourished with the spiritual essence of the rice. To that end, the rice cake is cooked and the smell of the rice cakes attracts the deceased and it is nourishment as spiritual nourishment for the dead. The second dimension is that the act of the performance of the khanduri apam generates merit and it is the merit transferred to the deceased; it protects the deceased in the grave from the interrogating angels. Khanduri apam is redeemed by linking the offering of the rice cakes with the recitation of the shamadiyah consisting of the recitation of the sürah al-Ikhlās, tahlīl, and do'a. They become the gift from Allāh to the performers and the third dimension is the modernists who reject the possibility of the living aiding the dead through shamadiyah recitation as reciting shamadiyah implied that one could produce merit for someone else. "The Prophet did say the tasbéh prayer, but we cannot just keep adding to that; that is heresy (Arb bid 'ah)" (see also Bowen 1993:269). The person can only help him or herself directly in relation to Allāh. In addition, modernists denied that one can send food to the souls but they did value the food's natural qualities. 


\section{Chapter 10}

\section{The ritual of khanduri bu}

Sya'ban is the eighth month of Islamic lunar month, which coincides with the month of August of the Gregorian calendar. During this month, an "atmosphere of joy" precedes the tasks of "committing oneself to the serious mood and demands" of the following month of Ramadhan. Sya'ban is "the month of the rice feast" (Ach buleuen khanduri bu). The authoritative warning pertaining to this celebrated occasion in Blangporoh village and other Acèhnese villages is believed to have been transmitted by the Acèhnese's ancestors (Ach endatu or Indon nénék moyang). The name of khanduri bu refers to the fact that rice forms the principal of all food dishes that are served to honour the dead and to

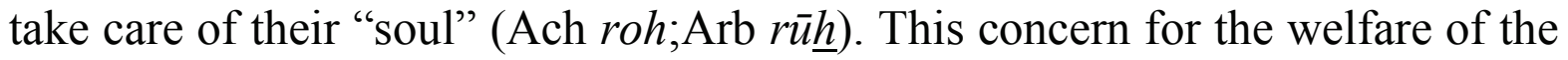
dead exhibits itself in the giving of a religious feast. Hence the Sya'ban lunar month is also known as "the month of khanduri for the old people" (Ach buleuen khanduri ke ureueng chi'), ${ }^{251}$ a name that also refers to the feasts offered to the ancestors. This term derives from the fact that one day during Sya'ban, every household prepares and serves a khanduri bu ("a rice feast") in order to remember their ancestors and show them that they have not been forgotten. It is performed to invoke the deceased as an expression of gratitude to "spirits of the departed" (Snouck Hurgronje 1906: 222). The villagers say that the religious merit gained from khanduri $b u$ is aimed at increasing the auspicious state of the ancestors, which the villagers themselves have procured by the "good deeds" (Ach amai ureueng chi') that they have performed during their lifetime.

It is said that the month of Sya'bān consists of four Arabic letters ش (syén) ش (a'in) and (ba), (alif), and (nun). Each letter stands respectively for $=\operatorname{syaraf}$ (honour), $\varepsilon=i z z a h$ (trust), $=\operatorname{bi} r$ (goodness), $\stackrel{l}{l}=$ ulfa (grace), and $=$ $n \bar{u} r$ (light). Whoever pays respect to their ancestors by means of holding khanduri bu, reciting Qur'ān, and $d o$ 'a will be trusted by others. When one receives trust, he or she will receive the goodness (Indon kebaikan). His or her life will

251 The Acèhnese word of ureung chi' (Jam urang tuwo) literally means "old people". The Acèhnese and the Jamee speaking people in Blangporoh do not make a distinction between the term to address for parents and ancestors. They are both called ureung chi'. In the context of khanduri bu, the word ureueng chi' refers to the ancestors or "spirits of the departed". 
be light. Be good to your ancestors otherwise your descendants later will not be good to you, says M. Nazar while smiling. Khanduri bu is regarded as a good way to invoke and to transmit the love of living people to ancestors. Through it, the performers communicate with the dead, particularly to obtain purity of the heart (Ach peugleh haté). Sya'ban lunar month is the month for cleansing the 'heart' (Ac haté) and Ramadhan lunar month is the month for cleansing the 'soul/mind' (Jam jiwo). In addition, khanduri bu must be performed with a very 'clean heart' (Ach beureuséh haté) for the ureueng chi' (ancestors) before people accomplish religious services during Ramadhan month to cleanse their 'soul/mind'.

In addition, the Sya'ban is one of the good months to hold wedding ceremonies. Hence, many wedding ceremonies take place in this month. Therefore, it is called the month of "wedding season" (Ach buleuen musém meukawén). Many couples who have agreed to get married that year prepare to do so before Ramadhan comes. Several reasons were given as why Sya'ban lunar month is preferably chosen for wedding ceremonies. First, there is a belief that the people who get married in this month will be happy. Second, the groom wants someone to prepare the breaking fast (Jam buko puaso;Ach buka puasa) for him. Third, Sya'ban is the blessed month so that it is very good time to get married. Fourth, the primary characteristic of Sya'ban is as a preparatory month to Ramadhan. Once one has decided to get married and to hold a big wedding, it is better to hold it before Ramadhan in order to "get it off one's mind and settle in with one's spouse". This shows that Sya'ban offers not only the last opportunity before Ramadhan to have a big feast but it is also the month during which all pending activities occupying their minds are completed before the fast begins.Fifth, it is good time on the festival of the fast breaking day or the day of 'idul fitri (Ach uroe raya puasa) to introduce the newly married couple to both sides of the family as on this day both everyone returns home to celebrate the festival. It is said that Sya'ban lunar month is also a good month to build a house as it is believed that the people who live in the house built in this lunar month will have no difficulties with their life. The owner of the house will experience ease in life (Ach mudah dalam hudép) and on the Day of Judgment (Ach uroe akhirat). 


\section{The aim of khanduri bu}

The aim of the khanduri bu held in every Sya'ban lunar month is to thank ancestors who have already transferred well-being (Indon kesejahteraan) onto the living. This is regarded as an important obligation from the living to their ancestors. Several families say "they always hold the khanduri bu in Sya'ban lunar month in order to thank their ureueng chi' (ancestors)". This ritual is not only for the benefit of the dead but also for that of the living whose prosperity, according to the popular belief, is directly dependent on the respect they pay to the dead (Snouck Hurgronje 1906:222). It is said that many villagers are now rich because they have received the benefits and the prosperity (ancestral gifts) called 'the dead's property' (Ach hareuta milék si matée [ureueng chi']. Such ancestral gifts of prosperity to the living remain "the dead's property". This prosperity would diminish and eventually be lost altogether if the living did not perform the khanduri bu ritual in acknowledgement of these ancestral gifts.

Feeding the 'souls' (roh) of the ancestors is by distributing rice and other food dishes to the poor and orphans to commemorate the services of the ureueng chi' who have collected the wealth in the past. There are villagers who used to be rich with the inherited wealth but then they gradually lost their wealth as they and their descendants were condemned by their ureueng chi' (Ach ka keunong seurapa le ureueng chi' jih) or by 'the dead's property'. One's wealth would, therefore, no longer be "blessed" (Ach beureukat) as descendants no longer thank their ancestors but neglect them. Thus, the food given to the poor and orphans is a social demontration of the sincere devotion to Allāh 'prevents calamities' (Indon meredam bala). It testifies to the fact that the givers" "heart is not hardened" (Ach hana kreuh haté) and he has not forgotten the ancestral origin of his well-being. His gifts, given in acknowledgement of these debts, are a means of 'cleansing his soul/mind' (Ach peugleh jiwa).

The ritual entails visits to the ancestral tombs (Ach jak bak kubu ureueng chi') which have its roots in various traditions of the Prophet. One of the traditions, which is based on a story, is that one day the Prophet went to Baqi' (a grave complex in Medina) and prayed there intensely with his tears flowing. He asked for Allāh's forgiveness for himself, for his ureueng chi' and for believers who might have sins. It is supposed that this tradition has been taken by villagers as an example that Sya'ban lunar month is the month of uttering do'a (pray- 
er) for themselves and their ureueng chi'. They visit the graves of their ureueng chi' including the founder of the village. I also observed that there are several people visiting the tomb of Syeikh Muda Waly (Angku Mudo) in this lunar month. They explain that the Syeikh whose father is Syeikh Muhammad Salim provided much service for the village. In the area of Blangporoh village, especially at the boarding school, there was brackish water in which there were many fish that were bloated (Jam bunta;Ach bukum) so that it is called suak bunta (an estuary that had many bloated fish). Because of the Syeikh's 'blessing' (Arb baraka), the village is now well known and many people come and learn there. One of the Syeikh's students from Blangporoh village says "Our coming to visit the Syeikh's tomb (called kubah after the kubah dome of the mosque) today is not on behalf of his students, but rather on behalf of the villagers to express thanks to him as the founding ancestor". This practice attributes religious merit both to the Syeikh and to living participants of the ritual.

The ritual of khanduri $b u$ is performed at family and village levels. It serves not only to express gratitude to the "spirits of the departed" but also to generate religious merit (Jam pahalo; Ach/Indon pahala) to those who partake in it. In addition, it also further enhances that auspicious state of being of the ancestors, which they themselves had obtained by the 'good deeds' (Ach amai ureueng $c h i$ ') they had performed during their lifetime.

\section{Khanduri bu at family level}

The khanduri bu taking place at family level is performed individually in a house in order to preserve and to strengthen the relation between the living and their ureueng chi'. The previous imām of Blangporoh, Teungku Ahmad says that Muslims believe that the link between the living and the dead still exists, particularly between parents and their children. He says a hadith which states that "When a descendant of Adam dies, all of his rewards are cut except for three; the reward of his alms (Ach seudeukah), the reward of his knowledge (Ach ileume) which is preached to the people, and the reward from prayer of his worthy children (Ach aneuk salèh)". Based on this hadith, the villagers believe that a descendant has an obligation to invoke for his ancestors since the best prayer is the prayer performed by his own descendants. The descendants who invoke Allāh in their prayers may indeed hear their prayers and descendants can be especially effective in transmitting the benefit of the recitations for the ancestors' 'soul'. Ustad Bustamam says that although the ancestors' bodies 
died long ago, their 'soul' (Ach roh) still know their descendents because they will never die and require attention from their descendants. They will be very happy if they are commemorated through a special offering of the khanduri bu for them whether in Ra'jab lunar month or in other lunar months.

Unlike the khanduri mò'lōt (the feast for commemorating the birth of the Prophet) and khanduri keu ureueng matée (the feast for commemorating the dead), in which anyone in the village (Ach gampōng) and even outside the village can come without any invitation, khanduri bu during Sya'ban lunar month is a very special feast in held only for the poor and the orphans. Therefore, Sya'ban lunar month for the poor and orphans people, is "the month for regaining nutrients" (Ach buleuen perbaikan gizi) because the villagers invite them to take part in their khanduri bu. The way in which this khanduri is held is by sharing the cooked rice with its side dishes with the needy.

In the past, the adat required that teungku meunasah (the religiously learned man who leads the prayer house) be invited to this feast. At this moment, the family members with the invited guests recite some Qur'anic verses and $d o^{\prime} a$ before having rice. I observed that several families still maintain these traditions and some others hold no Qur'anic recitations and $d o$ ' $a$, but they only serve the invited poor and the orphans with the cooked rice, meat, fish and vegetables. No special food is served for the khanduri bu. Rather; the families just offer the usual subsistence foods (Indon masakan biasa). They provide some food to offer the invited guests. The poor and the orphans are invited to eat at their house in the afternoon and some money is given to them before they leave. Others, however, do not invite the poor and orphans to their houses but they bring the cooked rice, meat, fish and vegetables in a set of stacked containers for transporting food (Indon rantang;Ach kèpa) with some money directly to their houses.

On August $27^{\text {th }}, 2008$, I observed a khanduri bu prepared by a family of the village. A special idang (special packet of food) was prepared on that day. It was said that the khanduri bu must be held for the ureueng chi' in Sya'ban lunar month. The idang which is also called kawén nasi or "friend of rice" is not considered to pose a problem. Rather the host said, "Whatever is easy to get or whatever we eat we give to the invited guests". About 40 village orphans were invited but only half are able to come to the house, the rest did not come because they are also invited by other families on that day. Soon after they arrived they were invited to sit on the floor covered with the pandan mats in a 
waiting room while waiting for the others to arrive. After a fifteen-minute waiting period, they are welcomed to consume the offered khanduri bu. An hour after that the khanduri was over. The invited orphans are given some money before they go home. The host also asks his son to give the kahanduri bu and some money as alms (Ach seudeukah) to the house of the invited orphans who are not able to come to his house on that day. No incense was burned, no $d o$ ' $a$ was recited and there was no special preparation of the glutinous rice either before or after the khanduri. The host insisted that invoking $d o$ ' $a$ is not important but this time the khanduri bu was performed differently. He said, "I only held the khanduri $b u$ for the orphans. I did not invite the poor and the imām (Jam tuangku imam;Ach teungku imum) like the previous year". He further added that Allāh knew that his intention (Jam niaik) of holding this khanduri bu was sincere, and, therefore, the religious merit from offering this khanduri as well as the religious merit of giving money will reach where he intends it to, that is to his ureueng chi'. He emphasized that the intention is the most important thing as Allāh knows whatever people intend.

It was said that in the past, the invited imām burns the benzoin incense in a coconut shell (Ach bruk $u$ ) with the $d o^{\prime} a$ of burning incense (see Ch.7 for this $d o$ 'a) to call the ancestors' 'soul' before the food is consumed at the khanduri $b u$ regardless of whether it is held during the day or at night. Some villagers say that burning incense is a tribute to the ancestors. Some say that burning incense is to call the angels to participate in the feast and send the prayers to Allāh and some others say that burning incense is to call the angels to take religious merit of the recited do' $a$ to be given to the ureueng chi's 'soul'. Many village people believe that the 'soul' of their ureueng chi' will return home and take this tribute. The incense is burned prior to consuming the provided food. While the smoke of the burning incense is rising from the coconut shell, the $d o^{\prime} a$ is then recited over the food.

On the following day, the tombs of ureueng chi' in the 'garden of the grave' (Ach lampôh jeurat) located in the backyard of the house are visited. Three small $Y \bar{a} \sin$ books are brought to be read at the graves. The wife brings a kettle (Ach cèrèk ie) containing fresh water mixed with flowers to be poured on the graves. The son brings small garden tools for cleaning the graves. As they enter the graveyard, the do' $a$ of entering the graveyard (Ach do'a tamong lampôh jeurat) is uttered by the husband on behalf of the family as follows: 
Assala mu'alaikum

Ya dāral qaumin mukminīn

Wa innā insyā Allāhu bikumul lāhiqūn

As-Alullāha lì walahum 'àtiyah
Peace be upon you

Ya occupants of this faithful house

We, if Allāh wills, will be with you later

I ask forgiveness for me and for you

As they arrived at the graves, they first clean the graves of their parents and their parents' parents' graves which lie on a north-south axis ${ }^{252}$. The flowerfragranced water (Jem aie bungo; Acèh ie bungong) is poured three times slowly from the head to the foot of each grave while uttering the $d o$ ' $a$ solemnly. The order of $d o$ 'a for pouring the water on the graves (Ach do'a siram ie ateuh $k u b u)$ is as follows:

Reciting bismillāh (in the name of Allāh)

Reciting seulawet (prayer to the prophet welfare)

Reciting the sürah al-Kawthar which consists of three verses:

- Indeed, We have granted you, [O Muhammad], al- Kawthar

- So pray your Lord and sacrifice [to Him alone]

- Indeed, your [Muslim] enemy is the one cut off (from all good in this world and hereafter).

The wife continues to water the grave from top to bottom with fragrant water reciting this $d o^{\prime} a$. The son does not perform it because the flower water runs out; instead he just takes the flowers in the watering kettle and sprinkles them on each grave. It is said that "as one pours water on the graves, the deceased will be cooled and refreshed just as the water is cooling" and the sprinkled flowers will pray for the dead in the graves as long as they have not yet faded. After pouring the flower-fragranced water, the man sits by the heads of the grave, while the wife sits on the left of the grave, and the son sits on the right of the grave. They then recite the verses of the sürah Yāsin from the Yāsin books brought from home.

After finishing reciting this sürah, a short $d o^{\prime} a$ is recited by the head of the household by holding up his two palm hands with his eyes shut. He begins his $d o$ 'a by reciting bismillāh (the name of Allāh) and closes it by reciting the sürah al-Fätiha $\underline{\text { h }}$ (QS 1:1-7) at the end of his recited $d o^{\prime} a$, the wife and son, seated on both sides of the graves, intone the word amin (please accept o Allāh), also by holding up their hands. The Allāhumma aushil tsawāba mā Qara'nāhu ilaihim is then recited by the man which means "Ya Allāh, please

252 All graves in Blangporoh lay on a north-south angle so that the heads face to the right as well as face kiblat (Mecca). 
deliver the merit as what we have just recited to them!" One of the important do' $a$ recited on the grave is to ask Allāh to bestow His mercy on their ureueng chi' so that their graves become "the park of paradise" (Jam taman curugo;Ach taman syuruga) as well as to ask Allāh not to let their graves becomes "the park of hell" (Jam taman nurako; Indon taman neraka).

In Blangporoh many graveyards, particularly the old tombs, can be found in the backyard or beside the houses. This indicates that the living do not want to be far from their ancestors. ${ }^{253}$ Usually, all graves belong to one lineage and cannot be mixed with other lineages. Although the families can always visit their ancestors' tombs every day to remind themselves about death (Ach matée) and the Day of Judgment (Ach uroe kiamat), a special visit should be made in the context of khanduri bu although the head of the council of ' $\bar{l} l a m \bar{a}$ says that the best day for visiting graves is on Fridays in any lunar month. ${ }^{254}$ Praying for the parents, parents' parents or whoever who has passed away can only be performed at the graves. Other places are also permissible except prohibited places, i.e. in a bathroom. Reciting $d o$ ' $a$ is better at recommended places such as at Raudhah in the mosque of Nabawi in Medina, at Multazam near Ka'bah. ${ }^{255}$ For many, however, reciting do'a for the ureueng chi' is preferably performed directly on their graves because when gazing at their graves, they feel deeply absorbed (Arb khusyu') while reciting and remembered the deceased. One of the key factors that the recited $d o^{\prime} a$ will be accepted is if it is recited in a deeply observant manner to Allāh. In other words, the one who recites $d o$ 'a should have a strong intuitive knowledge called ileumè makrifat, the knowledge between the worshiper and Allāh.

Lately, there has been a shift in the way people perceive the importance of this khanduri and their way of performing it, although people continue holding the khanduri $b u$ at family level. The fundamental nature of the feast as an expression of appreciation to the ureueng chi' has almost become lost. The khanduri bu remains only as an expression of gratitude to Allāh and happiness at the coming of Ramadhan. The evidence of this change can be seen in which some

253 In every New Year of Islamic lunar month, Muharram, besides khanduri asyura, the "ritual feast" for the graves (Ach khanduri jeurat) is held in every village in West Labuhan Haji district and elsewhere in Acèh. The aim of khanduri jeurat is no different to that of khanduri bu as discussed here. However, its name is not given to the name of Acèhnese month.

254 See "Ziarah Kubur", Serambi Indonesia, January $24^{\text {th }}, 2009$.

255 See “Ziarah Kubur”, Serambi Indonesia, January 24 $4^{\text {th }}, 2009$. 
people no longer prepare the special glutinous rice and burn incense when they hold this 'ritual feast'. Even more critical to the changing religious significance on the khanduri bu is the fact that many families now no longer recite the $d o$ ' $a$ before or after eating the khanduri. Several families say that khanduri bu is only an adat (tradition), and it is no longer considered as a religious service (Indon ibadat). Nonetheless, the shift in the way some people perceive the importance of the khanduri bu in Blangporoh is not accompanied by a substantial change in the aspect of this feast. For the majority, they still talk about khanduri bu as a feast that is a symbolic expression of human purification in the holy month of Ramadhan as well as the symbolic expression of their appreciation of their ancestral gifts.

\section{Khanduri bu at the village level}

On September $2^{\text {nd }}, 2007$, the khanduri bu was performed at 8 p.m at village level under the guidance of the imām and the village leader (Jam kapalo kampuang;Ach keuchik). Each household head brought his packet of food including rice and a variety of side dishes (Jam/Ach idang) with Rp 20.000 of money as alms (Ach seudeukah) to the committee members at the Blangporoh's mosque. The families who live near the mosque served the idang in trays (Jam talom;Ach talam) and those who live far from it brought the food in a rantang. These idang is meant to be shared with others at the mosque where all the invited poor, orphans, and villagers have already been assembled. The communal nature of the khanduri is expressed not just by the fact that everyone in the village participates, but also by the nature of their participation. The khanduri is performed on behalf of a community as a whole, and this ritual leads to a continuous, cooperative involvement in the various aspects of the khanduri. As a result a happy atmosphere is clearly evident and much pleasure is heard in the participants' voices.

The idang are mixed in a meunasah near the mosque. One old woman who works there takes out the rice from rantang and mixes it in a big container called kèna gadang before they are served to all attendants. She then places the curry and the cooked vegetables or 'the friends of rice' (Ach ngon bu) on trays. When I ask her "why do you mix the rice? She answers "she mixes the rice so that it does not spoil quickly". Another woman who sits besidese the old woman answers, "in order to let all attendants taste all the different rice". Another woman who had just arrived answered, "in order to avoid eating one's own 
rice". Here there is an obligation to exchange. The "friends of rice" (Jam kawen nasi), however, is not mixed. The working women just open the lid of rantang containing the "friends of rice" a little bit so that it does not evaporate. She says, "Because some has just finished cooking, the lid of rantang should be opened. If not, it will evaporate.

Meanwhile at the mosque, all orphans have been gathered in the front right corner of the mosque. The village leader stands on the pulpit of mosque to begin the khanduri bu ritual and he thanks the committee members, the village people who have brought khanduri or idang and some money to the mosque. Several verses of Qur'ān are then incited by a young boy in order to receive "blessing" with the hope the ritual of the khanduri bu will run smoothly. Next, the speech of khanduri bu is delivered at about 9 pm by Teungku Iswadi from the boarding school in Blangporoh. The following is an extract:

The content of this speech is about the religious merit (Jam pahalo;Ach/Indon pahala) of giving charity (Ach seudeukah) to the orphans and to the poor. The orphans are those whose fathers have passed away and who have not yet reached the age of puberty (Arb baligh). The Prophet gave particular instructions regarding the care of the orphans' life. There are many hadith, stating that how noble are those who raise and sympathize with the orphans! Such as a hadith narrated by Bukhari states "the people who raise the orphans will be in a paradise like this; the Prophet signed with his forefinger and middle finger". Many Acèhnese's children became orphans after the tsunami in December 26th, 2004. They are now in trouble as they lost their livelihood and the care and guidance of their parents. Islam has encouraged its adherents to have a noble character to give charity to the orphans or raising them is far better than giving charity to them.

The person who gives charity will get shelter on the Day of Judgment. Allāh will double the religious merit if one gives charity to the needy. It is as if one gives a loan to Him. Whoever helps to take on another person's burdens can be sure that Allāh will help that person. The preacher reminds us that in our livelihood given by Allāh contains the right of the orphans and the poor. Please take and give it to them! Allāh will love you. If the orphans in the village are miserable, the villagers will no longer receive the mercy of Allāh and the livelihood is no longer "blessed".

The religious merit of khanduri bu is written by the angels in the deed notebook (Indon buku catatan amal) as a good deed. What we give to the needy now is small and later will be big. If we give money as charity, the money will say, "Now you look after me, later I will look after you. Now I can be lost, later I will be eternal" so do not be ever tired of giving charity to the needy. The aim of the khanduri bu is for "feeding the deceased's roh of our ureueng chi"'. The preacher says that we cannot direckly feed the 
deceased who are already dead. "What we can do is to hold the khanduri $b u$ for their roh; we give charity to the needy with the 'intention' (niat) for their roh as well as pray for them". The khanduri bu is thus given to the orphans and the poor instead of "feeding the deceased's roh".

The speech goes on from one story to another, and at last, the preacher reminds all participants to participate actively in any social activities to help the needy. At last he reminds the participants to pray for themselves and for the deceased's roh as charity from the living people as the expression of cleanliness of the 'soul/mind' (Indon jiwa) before the coming of Ramadhān month.

At 22.30, the speech is over. The imām recites a specific $d o$ 'a [prayer] to end the ritual of khanduri bu. All invited orphans are told to stand up. All attention is centred on them. Each orphan receives charity (the money from the village donations) from the village elders. After receiving it, they sit down again. The orphans are invited to sit side by side in the front right of the mosque and the village participants sit side by side in the mosque and on the terrace, in a circular circle with their own idang in front of them. The participants of all communal feasts avoid eating their idang. It is regarded as shameful to eat one's own offering. Before eating, Teungku Usman gives a portion of benzoin incense to be burned in a coconut shell at the right corner of the mosque. The keuchik (village chief) invites the participants to eat by saying,"that which we have brought here must be finished, in the name of Allāh" (Ach peu yang kana ta peuhabeh, bismilläh). When the feast has finished, the participants collect their empty trays and food containers (Indon rantang) and talk among themselves before going home. Some rice with side dishes is taken home by the orphans and the students at the boarding school.

At last, when there are only three men still in the mosque I asked them their opinion about giving charity and the khanduri bu. One said that the religious merit from providing khanduri bu to the orphans and the poor is transferred to the deceased's 'soul' of the ureueng chi' as a gift from the living. Another one contended that giving charity to the orphans and the poor is to 'prevent calamities' (Indon meredam bala) that could fall on the village as well as to make the deceased's 'soul' (roh) of the ureueng chi' happy. The other suggested that "giving charity to the orphans at the occasion of the khanduri bu is to soften the giver's heart and to commemorate the ureueng chi' services". The persons who have given charity (done good deeds) for the orphans are those who have let feelings of happiness into their hearts, said the preacher. 
It may be argued that the secrecy of khanduri bu is still regarded as very important in the Acèhnese perception. Burning incense is still practiced before consuming rice and its side dishes but providing special glutinous rice on this night is not. This shift in Blangporoh is not accompanied by a substantial change in the aspect of this feast. For the majority, they still talk about khanduri $b u$ as a feast that is an expression of appreciation and acknowledgement given by living people to their ancestors and it expresses a human's purification in dealing with the Muslim's holy month, Ramadhan. It is understandable, especially during Ramadhan, that purity of the 'soul/mind' is an important concern. Islamic connotations have been attached to people's interpretation of cleanliness. Therefore, at the level of people's interpretation, the khanduri bu both at family and village level is regarded as a thread connecting living people and their ancestors as well as among them. It is also an instrument to 'cleanse the soul/mind' (Ach peugléh jiwa). The ritual of khanduri bu at family and village level thus constitutes a complex asymmetrical process of exchange. It not only binds the ancestors to the living, and Allāh to the believers; it also connects the wealthy to the orphan and poor in gift-giving relations that are embedded in these ancestral exchange relationships. This demonstrates how the value of the Aneuk Jamee/adat in combination with that of Islam/agama is applied. If one follows the order of Allāh, one also has to follow the adat (traditional customary practices). The logic of exchange value can be clearly seen in the following figure:

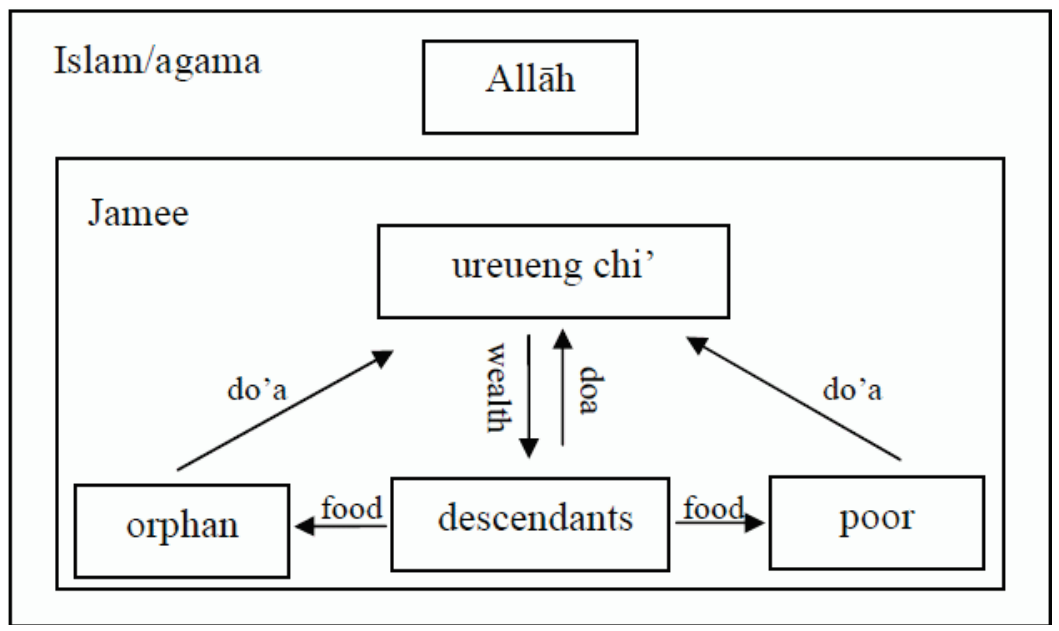

Figure 11. The logic of exchanges in khanduri bu 


\section{Khanduri beureu'at}

Khaduri beureu'at is another important khanduri held in the night in the middle of the month Sya'bān. This night is well known in Acèh as malam beureu'at, from the Arabic word baraah (the night of determination). In Arabic, the day and night in the middle of Sya'bān is called Nisfu Sya'ban. Nisfu means a half and Sya'ban is the eighth month in the Muslim calendar. In Blangporoh, Nisfu Sya'ban is usually held with the khanduri beureu'at and other religious services (Indon/Ach ibadat). Khanduri beure'at, however, was no longer performed at the time of the field research but religious services are still performed by the villagers on this night.

Several years ago, however, on the night of Nisfu Sya'ban, khanduri beureu'at was held. This communal feast was held by all villagers in a prayer house (Ach déyah) or small mosque (Ach meunasah) or mosque (Ach meuseujid) under the direction of the Islamic leader (Jam tuangku imam;Ach teungku iтиет). In this feast, all the families in the village came to the meunasah with their idang before sunset. After performing the 'sunset prayer' (Ach seumayang magréb), the participants sat side by side in a large, circular circle with their idang in front of them. The teungku began by explaining the importance of celebrating the night of Nisfu Sya'ban. The speech proceeded from one story to the next, and at last, the teungku reminds all participants to take part in Nisfu Sya'ban's observances which would be held after the 'evening prayer' (Ach seumayang isya') and to fast on the following day. In his speech, the teungku also mentioned the importance of Nisfu Sya'ban with regard to Ramadhan. The teungku, for instance, in his speech before the feast begins, advised the participant by saying "if we are still alive next year, Ramadhan is a good moment to renew our faith and our religious service". In his do'a (invocation), the teungku also asked Allāh to give all Muslims the opportunity to fast in the holy month of Ramadhan which would come soon. Furthermore, the keuchik (chief village) announced to all the feast's participants that in the morning of the last Friday of Sya'ban, all the villagers should take part in cleaning the mosque and meunasah. He emphasized this by saying "our great guest, Ramadhan, will arrive soon" (Jam tamu gadang mau sampai;Ach jamèe rayeuk ka rap trouk). When the feast has finished, the participants collected their empty trays and food containers and talked among themselves. 
They then performed the isya ' prayer and continue with Nisfu Sya'ban's observances.

Although no khanduri bereu'at was performed in the night of Nisfu Sya'ban in the year of 2007 at Blangporoh's mosque, I saw several people observing religious services in the mosque. Not many people come to the mosque that night because there was no khanduri. If there was khanduri bereu'at, many villagers would come as it is free of charge, said an informant. He added that he considered the khanduri to be important and observed that "although most people state that the khanduri is not important in the context of Nisfu Sya'ban, in fact, prayer and fasting which are regarded as the Prophet's tradition are becoming less important than the khanduri itself'. He remarked if there was the khanduri, the night of Nisfu Sya'ban would be lively (Ach hudép) and the deceased's 'soul' (roh) that returned would be very happy as well.

The khanduri bareu'at is not celebrated in Blangporoh, as the head of the village does not ask the villagers to celebrate it. Some villagers say that they want the khanduri bu to be held but some others say that khanduri bereu'at is not important but the religious service is the most important thing. When I asked the imām to why the khanduri bereu'at was no longer held, he replied that the adat head (Ach keuchi'/geuchie') had said nothing to him but the important things that needed to be told to the villagers on the Nisfu Sya'ban night had been said by a preacher on the first and the second Friday of Sya'ban. He added that even though no khanduri bereu'at is performed, the voluntary religious services (Ach/Indon ibadat sunat) are still carried out as it is a good time to observe religious services.

\section{The local meaning of nisfu Sya'ban}

The middle night of Sya'ban (a half Sya'ban lunar month) is 'noble' (Ach/Indon mulia) night. It is said that on this night, daily human activities recorded in "the deed notebook" (Ach buku catatan amai) during the year are given to Allāh by two angels Raqib and 'Atid. ${ }^{256}$ Some villagers says that it is lifted up to the sky and is exchanged for a new one each year. The villagers believe that "the deed notebook" of all humans or the records of all human activities is exchanged every year. The middle of Sya'bān is the night of ex-

256 As to how Raqib and 'Atid record all daily human's activities, words, action and event intention, see Ch.2. 
change for each human which is sent down from babul izzah (the first layer sky) to the earth. "The deed notebook" is sent down and the old one is taken back by the angels (some say by Allāh). "The notebook of good deeds" (Indon catatan amal baik) of humans is happily handed by Raqib to other angels (some say to Allāh) and saved in the highest level of Paradise called 'illiyūn. The Qur'ān in sürah at-Muthaffifin: 18-22 says "No! Indeed, the record of the righteous is in 'illiyūn. And what can make you know what is 'illiyyün? It is [their destination recorded in] a register inscribed which is witnessed by those brought near [to Allāh]. Whereas "the bad deed notebook" (Indon catatan amal jelék) of human being is handed angrily by 'Atid to other angels (some say also to Allāh) and saved in the lowest level of hell called sijjinn. After handing "these deed notebooks" of human being to other angels (some say to Allāh), both angels receive the new one from Him for the next coming year.

The imām of Blangporoh says that the word of Sya'ban is from the word Syi'ab means "street on the mountain". It is called Sya'ban because the various ways of getting "goodness" (Indon kebaikan) are found in Sya'ban lunar month. Many people with whom I discussed this said that in the night in the middle of Sya'bān, Allāh sends down some "goodness" for human beings who have performed good deeds (Ach amai get). On that night, "goodness" which is in the form of help (Arb syafä'ah), forgiveness (Arb maghfirah ) and freedom from the 'torment of the grave' (siksa kubu) are sent down. The middle night of Sya'bān is, therefore, called the night of aid, forgiveness, and freedom.

In relation to aid (Arb syafā'ah), the imām quoted from al-Ghazali's saying.Al-Ghazali (1058-1111) says that on the $13^{\text {th }}$ night of the Sya'bān, Allāh gives one third of aid to His servant (Ach/Indon hamba), on the $14^{\text {th }}$ night of Sya'bān, Allāh gives two thirds of aid to His servant, on the $15^{\text {th }}$ night of Sya'bān, Allāh gives complete help to His servant. The people who do not get aid from Allāh are those who intentionally run from Him while they are doing the bad things (al-Ghazali 1979:80). The night of the middle of Sya'bān is called the night of forgiveness because on this night Allāh sends down His forgiveness to all inhabitants on the earth. In a hadith transmitted by Ahmad "When the middle of Sya'bān arrives, Allāh will give His forgiveness to all inhabitants except to the people who turn away from Him and believe in more than one God". Another hadith transmitted by Tarmidzi states that "in the night of the middle of Sya'bān, Allāh descends to the lowest heaven and calls the mortals in order to grant them forgiveness". The night in the middle of Sya'bān 
is also called the night of freedom (Indon malam pembebasan) because in this night Allāh frees the deceased from hell. A hadith narrated by Ibn Ishak says," Ya Humaira (Aisyah, the Prophet's wife), what are you doing on this night? This night is the night in the middle of Sya'bān in which Allāh grants freedom from hell to everyone except for five types of persons; the person who does not stop drinking arrack, the person who scorns both his parents, the person who sets up places of prostitution, the person who raises prices and treats people badly (Indon secara aniaya), the custom officers who are not honest and the slanderers.

In addition, in the Acèhnese cosmology, it is believed that the fate of humanity will be determined through the divine appearance of a many-leafed tree in Heaven called Sidratul Muntaha which had been seen by the Prophet on the night of his journey to Heaven (Ach malam mè reuät). On every leaf of this tree is written the names of all human beings on earth, how many years they will live, when and where they will die. Thus the leaves of the tree represent people on the earth and the tree itself is a symbol of human fate (see Ch.2). Every year in the middle night of Sya'bān, Allāh (some says angels) shakes the tree till some of the leaves which have been yellow fall down. The fallen leaves foretell that the person represented will die within that year. One informant says that when the fallen leaves fall due to being shaken by angels and then descend upon other leaves, the people represented on the earth will sense a strange sound in their ear (Ach meu ie ie lam gulunyung) and often those people dream of something bad, for instance, loosing a tooth (Ach teuloh gigoe) or a destroyed house (Ach reuloh rumoh). He says further that if one dreams that a right upper tooth is lost, it means that one of his brothers from his father's side will die. If one dreams that a left upper tooth is lost, it means that one of his brothers from his mother's side will die. If one dreams that a right lower tooth is lost, it means that one of his brothers from his grandfather's side will die, and if one dreams that a left lower tooth is lost, it means that one of his brothers from his grandmother's side will die. Meanwhile, if one dreams that the front of his house collapses, it means that one of the males in the family will die. If it falls apart at the back, it means that one of the females in the family will die. If the right side collapses, it means that one of the brothers from the father's side will die and if the left side falls apart, it means that one of the brothers from the mother's side will die. 
Moreover, it is related that the night of Sya'ban has certain meanings in Islamic spirituality. Islamic followers recognize that this night is the night of changing kiblat (direction of prayer) from Aqsa mosque in Jerusalem, Palestine to Mecca's mosque in Mecca, Arab. It is also said that the Prophet Ismā'îl (Ibrāhīm's son) was born near Ka'bah (the direction to which Muslims pray) on this night. The middle of Sya'bān is called the harvest time of forgiveness (Indon malam panén pengampunan) and thus the Aneuk Jamee and the Acèhnese celebrate it by carrying out the religious services 'prayer of glorification' (Ach seumayang taseubèh), 'wish prayer' (Ach seumayang hajat) with certain do'a and or puasa Nisfu Sya'ban "fasting of Nisfu Sya'ban".

\section{Seumayang teuseubèh}

Seumayang teuseubèh (Arb shalat tasbīh) or "prayer of glorification" resembles all other prayers but it is distinguished by the constant repetition of a certain teuseubèh (Arb tasbīh) formula in praise of Allāh. Tasbīh that are recited consisted of four sentences:

Subhanallāh

Wal hamdulillāh

Wālaillā haillallāh

Allāhu Akbar

\author{
Allāh is Holy \\ and all praise is due to Allāh \\ and there is no deity except Allāh \\ Allāh is the greatest
}

I did not see this prayer performed at the Blangporoh's mosque. In the past, however, this prayer was performed together in the village mosque in which one who is present is chosen to act as an imām. Currently, this prayer is performed individually both at home and at the mosque. Some say that 'prayer of glorification' is now performed individually by some villagers in preference as they can freely choose how many cycles of ritual prayer (Arb raka'at) they like. Teungku Jauhari said that he performs this prayer in the night of the middle of Sya'ban at his house with four cycles of ritual prayer and recites the sürah al-Fätihha $\underline{h}$ in each cycle of ritual prayer then continues with other short sürah. As he finishes the Qur'anic recitation in the first cycle, he recites the tasbih with four sentences more than fifteen times while he was standing. He then performs the act of bowing and recites it (the same tasbihh) ten times while he is in the posture of bowing. After that he raises his head from bowing, and says it ten times. Then he performs the act of prostration, and recites it ten times. He then raised his head from the posture of prostration (Indon sujud) and repeated it a further ten times. Then he performs the second act of prostration, 
and recites it ten times. He then raised his head from the posture of prostration, and recited it again ten times. The total of tasbih is seventy-five in each cycle.He repeats this in the remaining three cycles of the ritual prayer.

Other villagers also perform the same ritual as the Teungku Jauhari but some perform only two cycles of ritual prayer, while others perform more then two cycles of ritual prayer. It is said that for those who recite the tasbih it is as if one plants a tree in heaven. The more one recites tasbih , the more he or she plants trees in the heaven. Their fruit will be picked later on the Day of Judgement. In addition, it is said that if one performs 'prayer of glorification', one hundred cycles (Indon raka'at) in the middle night of Sya'ban and recites the süra $\underline{h}$ al-Fätih $\underline{h} \underline{h}$ and the sürah al-Ikhlās in every cycle, Allāh will send down five thousand angels from heaven to write down the religious merit. One would be in 'flood of merit' (Indon banjir pahala). Another teungku who also performs this prayer says that the middle night of Sya'bān is the night of freedom. The deceased will be released from their torments if their descendents pray for them. He adds a hadìth narrated by Ibn Majah "When the middle of Sya'bān arrives, please get up, make the night lively, observe the fast during the day time because in this night Allāh comes down to the worldly sky when the sun sets and says; If someone asks for forgiveness, I will forgive him or her, If some one asks for livelihood, I will grant it, if some one is stricken by disaster, I will release and save him or her, and who ever asks for pardon will be forgiven". This call lasts till the dawn comes so that the $d o^{\prime} a$ should be recited not only for oneself but also for the ureueng chi'. The middle of the night of Sya'ban is a good time to invoke do' $a$. The person who calls for prayer (Ach bileu) in Blangporoh carries out this prayer individually in the mosque. He says that by performing this person's sins will be forgiven, the first sins and the last, the old and the new, the unintentional and the deliberate, the small and the great, the private and the public. It is also said that the aim of performing this prayer is not merely to gain religious merit from Allāh but also it is a good night sport.

\section{Seumayang hajat}

In Blangporoh there are several people who perform a special prayer called the 'wish prayer' (Ach seumayang hajat) after performing the prayer of glorification. In the past, this kind of prayer was celebrated by women with much greater zeal than by men. They sometimes performed it under a female 
imām or by themselves in the meunasah or in the mosque (Snouck Hurgronje 1906:223). On the middle night of Sya'ban, I went to the person who calls for prayer in the village mosque. He performed two 'cycles' (Indon raka'at) of 'wish prayer'. He said that after performing the prayer, for the first 'cycle' of the ritual prayer he recites the sürah al-Kafirün (QS 109:1-6), and for the second 'cycle' of the ritual prayer; he recites the sürah al-Ikhlās (QS 112:1-4). After praying he then seats himself on a praying mat facing toward Mecca (Indon kiblat). He then recites the sürah Yäsin (QS 36:1-83) three times, after which he performs the following do'a:

Asking Allāh to prolong his age (Ach beupanyang umu)

Asking Allāh to make his life easy (Ach beumudah dalm hudép)

Asking Allāh to save his faith (Ach beuseulamat iman)

He says that at 12 o'clock in the middle night of Sya'bān, Allāh orders His angels to exchange "the deed notebook" with the new one. He adds, "My old deed notebook will be closed and exchanged with the new one. I want the angels to write the last good deeds in my old deed notebook and I also want the angels to write the first good deeds in my new deed notebook before they are lifted up by the angels in the middle of this night". Another devout man, Teungku Juned, also performs a special prayer at his house on this night. He says that he performs two cycles of 'wish prayer'. The first cycle of the ritual prayer he recites is the sürah al-Ikhläs (QS 112:1-4) and the second cycle of prayer is the sürah al-Kafirūn (QS 109:1-6). After finishing praying, he recites the sürah Yāsin (QS 36:1-83) until three times after that he invokes $d o^{\prime} a$ asking the following particular requests:

Asking Allāh to prolong his life

Asking Allāh to give him an easy life

Asking Allāh to safeguard his strong faith

Asking Allāh to give him the "blessing end"

Asking Allāh to save him in this world and on the Day of Judgment

He says that we do not know when we die so that we always have to prepare for death by performing religious obligations and other voluntary ones. Invoking $d o$ 'a especially on the middle night of Sya'bān is very important. It is the 'core' of any religious service so that the Prophet performs a special prayer in this night, thus the prayer itself is the $d o^{\prime} a$, ensures on teungku. He adds that a person who does not want to invoke $d o^{\prime} a$ and ask Allāh is identified as a 
stingy person (Ach ureueng kriet). Another teungku also performs the religious service in the middle of Sya'ban which is more or less the same as what the others do but he invokes additional $d o$ ' $a$ for the safety of the deceased's 'soul' (roh) and asks Allāh to bestow His blessing on them. He said that just as on the night of lailatul Qadar "the night of power" in the last week of Ramadhan month, Allāh also gives permission to all the deceaseds' 'souls' to return to their houses to observe their family's behaviour. Even the 'souls' of people who are in violation of Allāh's law return to their houses but they cannot reach them. In contrast, the 'soul' of good people returns and can reach their houses and revisit the places they always frequented. The 'soul' will be very happy if the $d o$ ' $a$ is invoked for them. The deceased's 'soul' advises their grandsons and granddaughters to pray for them as well as to advise them to continue the good deeds and stop doing bad deeds. If they violate Allāh's law, the 'soul' asks them to return to the right path and observe good deeds. The living, however, cannot hear this advice of the deceased's 'soul's, says the imām. My informant also reports that many women in their own houses and students at village boarding schools also perform their special prayers and $d o^{\prime} a$ to Allāh in the middle of Sya'bān.

\section{Puasa nisfu Sya'bān}

The voluntary fasting on the day in the middle of Sya'ban is called puasa nisfu Sya'ban (Ach/Indon puasa: fasting;Arb nisfu Sya'ban: a half Sya'ban). The imām says that this fasting earns rewards and we should encourage each other to fast voluntarily. It is easy to find people who fast on this day but difficult to estimate how many people actually practice this voluntary fasting. I found a number of villagers engaged in this voluntary fasting on the day in the middle of Sya'ban. Some of them commented that the Prophet himself practiced this voluntary fasting. They like to follow his example. One said that he performs this voluntary fasting as a practice for fasting in the Ramadhān month as well as to reap the religious merit. Another says that performing voluntary fasting on this day is important because on that day Allāh decides who will live and who will die in the year to come. Like several other old men and women in the village, he also does fasts on the following days. It is also said that the predestined hour of death (Ach ajai) and age (Ach umu) is decided by Allāh in the middle of Sya'ban till the middle of the following Sya'ban. He suggests this voluntary fasting cleanses all bad characteristics from the heart; prejudice, re- 
venge, and the like. But many people whom I interviewed on this day say that they perform this voluntary fasting because they want their "deed notebook" to be lifted up to sky when they are fasting. ${ }^{257}$

Some teenagers of the villagers and students of the boarding school in Blangporoh also observe this voluntary fasting. A male student at the boarding school and a young village girl say that they observe fasting on this day as a 'mind exercise' (Indon latihan jiwa) for themselves. The girl says that she observes fasting in order to make herself get used to doing good deeds; fasting is prestigous for her although many people who observe fasting on this day discuss the religious merit of it. She also adds "the good things we do is not only to please Allāh but also has a good moral and social effect on ourselves and is a good deed in itself'. I also found several married women who did not observe this voluntary fasting because they are in the 'red date' (menstruation) some others gave no reasons. Later on an informant told me that they do not fast because their husbands do not allow them to do so. In this case married women are at a disadvantage in comparison to men. A woman cannot decide independently whether she observes fasting or not because she must ask permission from her husband in advance.

Voluntary fasting of women against the will of their husbands is not valid. The imām states that even the wife's obedience to her husband takes precedence over obedience to her parents. An imām mentions one hadīth stating "if a woman prays five times a day, observes fasting in the month of Ramadhan, guards her body and obeys her husband she can enter the Paradise from whichever doors she wishes on the Day of Judgment". He further explains that a married woman must serve her husband according to her ability; the first of such obligations is to satisfy her husband. She must be able to sleep with him whenever he pleases to keep each other "chaste". If she observes fasting, it could create a problem as she could not have an intercourse with her husband while fasting. Therefore, a woman always has to consult her husband about her plans to fast on days other than in the Ramadhan lunar month because it is generally the wish of the husband to have sexual intercourse. When I mention this to several village women, most of them just smiled and commented, "That is the

257 This idea is based on a hadīth narrated by an-Nasai': “The Sya'ban lunar month is the month that is usually forgotten by many people because it is between the month of Ra'jab and Ramadhan. It is the month in which Allāh lifts up the deeds of a person. I want my good deed to be lifted up when I am fasting”. 
way this world is" (Jam cit alah begitu nien dunia ko) or "Allāh is merciful" (Indon Allāh maha pemurah). He will not hold it against us. Some stated that Allāh blames husbands who keep their wives from fasting. ${ }^{258}$

On this night, many villagers go to the mosque or 'prayer house'(Ach meunasah) to perform the 'sunset prayer' (Ach seumayang megréb) and continue with the 'night prayer' (Ach seumayang isya) and later on continue with the voluntary prayers for the middle of Sya'bān (Ach seumayang sunat Nisfu Sya'ban); the prayer of glorification (Ach seumayang teuseubèh), and prayer of wish (Ach seumayang hajat). During the day many devout people fast which has become part of village tradition. The situation is also the same in the capital city of Acèh, Banda Acèh, where many people; men and women go to the great mosque Masjid Raya Baiturrahman in the night in the middle of Sya'ban to observe various kinds religious services there to cleanse their 'soul/mind' before the coming Ramadhan month. ${ }^{259}$

The good believers always want to the fill the new "deed notebook" with good deeds (Ach amai salèh) and from that night they start filling their "deed notebook" with 'ubudiyah "making one close to Allāh" and vice versa, the godless people (Ach ureueng pasèk) and hypocritical ones (Ach ureueng munape') do not bother with this historical night. They always continue doing immoral things (Ach but maksit), says the imām. In the boarding school in Blangporoh, the night in the middle of Sya'ban is very lively and much celebrated and during the day voluntary fasting is observed. This is a good tradition to maintain, adds the imam. The focus of the conversation that night is to remind all students not busy themselves with useless things and to be well prepared to welcome Ramadhan in a half-month time.

Muslims in many Islamic societies have attempted to elucidate the importance of pray in the middle of Sya'ban, to explain why the Prophet performed the special prayer. The Yoruba people of Nigeria, for instance, believe that in the middle of Sya'ban, Allāh will alter the human qadr (power or right) and provide a new program for humanity (Ryan 1978:276). Similarly the people in Blangporoh, Blangbaru, and Kutaiboh in West Labuhan Haji district believe that in the middle of Sya'ban Allāh will predetermine the fate of humanity for the year ahead. Therefore, a special ritual is performed to cleanse

258 Here I find some similar ideas about the voluntary fasting in Morocco, see Buitelaar (1993:28-29).

259 See Waspada, August 19 ${ }^{\text {th }}, 2008$. 
the "soul/mind" as part of the preparation for welcoming Ramadhan or to prepare the good deeds for happiness on the Day of Judgment. In addition, the imām says that through doing good deeds (Indon amal baik) one's life will be prolonged by Allāh. He hears what we ask for therefore we have to recite some good $d o$ ' $a$ to Him in the middle of Sya'ban. "Perhaps some of the good $d o$ 'a recited on this night will change our suffering and difficulties in our life". He adds "Insya Allāh" or "if Allāh wills" admitting that Allāh has a power to determine all events.

\section{Peugléh meunasah}

Another form of communal activity in the Sya'ban lunar month in Blangporoh village is peugléh meunasah (cleaning the prayer house) or mosque (Ach meuseujid). Meunasah plays a strategic role in the life of Acèhnese and has a very significant function, both religious and social (Snouck Hurgronje 1906; Alfian 1977; Nur 1996). The meunasah serves as a house for prayer, school, village guesthouse, meeting place or occasionally as a place to formalize important ceremonies such the signing of marriage contracts (Dall 1982:36). Here in Blangporoh, Blangbaru, Kutaiboh and other villages in Acèh, meunasah helps to build the character, behavior and lifestyle of the people of Acèh. It is not the same as mushalla, the mini mosque found in many villages in Java. ${ }^{260}$ It is the center of all community activities: holding community meetings, performing religious feasts such as khanduri bu, mo'lot, apam, khanduri padé etc and performing marriages for members of the community. ${ }^{261} \mathrm{~A}$ decision made by the village head is not legal until it is endorsed in the meunasah. And it goes without saying that such decisions will be more quickly disseminated and supported. In addition, meunasah also functions as a centre of learning, both formal and informal. The name meunasah has its origin in the Arabic word madrasah, meaning 'religious Islamic school'. It is not only a place where people go to learn, but

260 Tengku Ibrahim Samahani, an 'ulamā' from Samahani in Acèh Besar, says that foreign cultures include those brought by migrants from Java. "They build mushalla (minimosques) that are not the same as meunasah", he says. What is in a name, some might ask. "For me, the name is important because it also motivates people to observe its true functions". See the Jakarta Post, January $19^{\text {th }}, 2005$.

261 Muhammad Insya says, "There was a time when people got married in meunasah, he recalls, citing that his two children were probably among the last to do so". There is a belief that if one does not get married in a meunasah, it could affect one's life and marriage. One will not be so prosperous, and may not even conceive a child. 
also a place where learned people impart their knowledge to their respective communities. Besides being a sleeping place for boys it is a place where men spend the rest of the day after doing daily activities. Here, young boys receive religious instruction and learn about morality, ethics and social relations.

Unlike bersih désa (cleansing the village) carried out within Javanese culture which cleans the village from any dangerous spirits by offering foods to the guardian spirit of the village at the spirits' place of burial (Geertz 1976:81-3; Nur 1996:35), the tradition of peugléh meunasah in Blanporoh village is solely intended to clean the meunasah from dust, wild grass in its yard including repainting and hanging a banner written with the word marhaban ya Ramadhan (welcome o Ramadhan) in front of it as parts of activities for welcoming Ramadhan. The meunasah is not only utilized by people (during Ramadhan) as a place to perform religious services (Arb ' $i b \bar{a} d a h$ ), particularly daily prayers, but also as a place where mature teenagers can spend their time during the day and gather after sundown.

The tradition of peugléh meunasah in the village is performed on the last Friday of Sya'ban. On the last two Fridays of Sya'ban, the head of the village (Ach keuchik), Anasjuddin announces to Friday followers using a microphone and loudspeaker after praying by saying the "big guest" (Jam tamu gadang;Ach jamee rayeuk), that is Ramadhan month will come soon". On the last Friday morning of Sya'ban, peugléh meunasah is held until the Friday prayer. The village head asks for all villagers, especially men to come there. In addition, in his Friday sermon performed earlier, the preacher, Tgk Iswadi talks about the importance of purification and asks a question "how can we pray during Ramadhan if the meunasah is unclean?" In his sermon, he says that peugléh meunasah is a compulsory tradition which should be carried out to find the real meaning of Ramadhan, that is, the forgiveness of Allāh. Allāh will not grant forgiveness if "His house" is not cleaned. At the end of his sermon, he prays to Allāh in order that every Muslim is given the opportunity to "meet" in Ramadhan month which will come soon.

The tradition of peugléh meunasah involves social solidarity in the life of the community as well as uniting society to achieve a better solidarity, like in other khanduri that are performed. Teungku Usman, who lives next to the meunasah recounts that the tradition of peugléh meunasah is held annually. He says that Blangporoh village has appointed a khadam (cleaning service) for it. However, this tradition remains to be done on behalf of the village, as it is spe- 
cial to welcome Ramadhan. Although there is no particular punishment given to those who do not participate, almost everybody is involved in this work. Some villagers say that they feel embarrassed if they do not participate in this tradition to welcome Ramadhan. As has been observed on that day some villagers offer cakes, some offer dry breads, some offer tea and some others working as civil servants are asked to offer a flask of coffee (Ach saboh cirik kupi) or money (Jam kipieng;Ach pèng) to buy cakes. This communal work is held on Friday. The money is a replacement for those who cannot participate.

Besides peugléh meunasah, the focus on cleansing in Blangporoh also affects every household. This is the same with the Acèhnese society in Lamno district, West Acèh written by Nur (1996:37). There are two times that people have to renew or repair their houses, namely before Ramadhan, and when a father marries off his daughter (ibid). The marriage tradition of Aneuk Jamee in West Labuhan Haji district takes a matrilocal form in which the groom will live in the bride's house. As part of the preparation for the wedding reception, a family should clean and repair the house to honor the coming of the son-in-law. This is, on the one hand, a reflection of the respect of the bride's family toward the groom. On the other hand, this is also a reflection of the last responsibility of a father toward his daughter since after marriage a woman obtains legal possession of the house (Ach rumoh). Two household fathers say that they feel truly embarrassed if their houses are not cleaned and repaired as they marry off their daughters. Therefore, the resemblance between the coming of Ramadhan and the coming of the son-in-law are expressions of happiness and honor. The tradition of peugléh meunasah shares that expression. Besides, most importantly, purification is an aspect of preparation to welcome the Ramadhan month since it is considered a holy month.

\section{Meugang}

Two days preceding the coming of the Ramadhan lunar month are recognized by the Aneuk Jamèe as hari meugang (some say hari mamagang from Ach uroe meugang or uroe makmeugang) or "meugang day or makmeugang day". ${ }^{262}$ The meugang day is also called hari mambantai (Ach uroe seumeusie)

262 In the capital city of Acèh, meugang is done three days preceding Ramadhan called meugang kanto or "office meugang", meaning meugang is collectively done a day earlier for the government officers. 
or "slaughtering day". The meugang tradition which is practiced by the Aneuk Jamèe in Blangporoh, West Labuhan Haji district is unique. ${ }^{263}$ Much preparation is performed on this special day and buying meat becomes a special tradition as many villagers admit that they are not used to eating meat. In addition, it is practically a cultural "obligation" on that day that all households should have meat to cook, particularly beef or buffalo. At this time, meat is more expensive than usual. Nevertheless, high prices are not obstacles. The tradition of slaughtering animals for the meugang day has existed for hundreds of years in Acèh, say some villagers. Others say that it began at the time of the Acèhnese Sultan. The number of slaughtered animals at this time is massive. ${ }^{264}$ People will also journey home prior to the start of the fasting for the meugang celebration. It is around this time that all the family members return home (Indon mudik) to be together with their families.

The meugang tradition, which centres on the gathering of the extended family to eat and drink together, occurs three times a year in Acèh; two days preceding the coming of the fasting month called meugang puasa. This meugang indicates how deeply enjoyable it is to perform the religious service in Ramadhan month. A day before the celebration of Idul Fitri (Arb 'id al-Fitr) called meugang uroe raya puasa on the final day of Ramadhan when the family ends the Ramadhan month together. This meugang is performed with the assumption that people have already successfully cleansed their 'soul' (Jam jiwo) during Ramadhan month. A day before the celebration of Idul Adha (Arb ' $i d$ al-Adhā) called meugang uroe raya haji.

It is said that meugang done at the moment of hari rayo (Ach uroe raya from the Indon hari lebaran $)^{265}$ is a way of thanking Allāh for receiving victory

263 The tradition of meugang day is also performed by all tribes in Acèh, especially in the southern and western coast of Acèh, such as in Southwest Acèh, South Acèh, West Acèh, Nagan Raya, and Acèh Singkil, marked with slaughtering cattle (Emtas 2008:78). The tradition of meugang day is very strong for the society in the southern and western coast of Acèh to welcome Ramadhan month. See Serambi Indonesia, November $9^{\text {th }}$, 2007.

264 There will be a lot of cattle in transit on the roads before the meugang day. Sellers from West to South sell them. Population and cattle movement cause traffic jams. Apparently the sellers are too "embarrassed" to sell them to their own neighbours at exorbitant ridiculous prices.

265 Both the day of Idul Fitri (Arb 'id al-Fitr) or "the celebration of making the end of fasting month, Ramadhan" and Idul Adha (Arb 'id al-Adha) or "the major feast day held on the $10^{\text {th }}$ day of the month of Zulhijjah" are called hari lebaran or "wide day" in Indonesia. 
(Indon kemenangan) from Him. The latter meugang is not as important as the former two. The reason for this is those four days after meugang uroe raya haji people from wealthy backgrounds will slaughter animals for those less fortunate - an obligation referred to as ibadah qurban. Meugang puasa is the most sacred tradition discussed here, during which large quantities of meat are purchased by the Aneuk Jamèe and the Acèhnese. Half of the meat will be cooked and eaten while the other half will be used to make 'boiled meat' (Ach sie ruboh) or 'dried meat with palm sugar and coriander' (Ach/Indon dèndèng). These two types of meat dishes are eaten with rice and can last for several days.

From the middle of Sya'ban, meugang puasa day becomes a focus of people's conversation whether in the 'prayer house' or in the coffee shop (Ach keudè kupi). Usually the conversation starts with types of meat and the prediction of the price of a kilogram of meat and later the conversation touches on many aspects of social life such as about the types of meat. There are three types of meat available in West Labuhan Haji district on meugang day: sie meukilo, sie plah patèe, and sie tumpok:

\section{Sie meukilo}

Sie meukilo literally means the meat (Ach sie) sold by weight. ${ }^{266}$ The slaughtering is done in the field near the market. The butchers only sell the pure meat and the buyers can freely choose which part of meat from the slaughtered buffalo or cows they want to buy. This kind of meat should be paid for in cash to sellers at the market stall. This practice is merely a commodity exchange. Commodities are exchanged strictly in relation to other commodities without any implied residual obligations or relationships between the people involved (Gregory 1982). The villagers as buyers do not make an appointment with the butchers as sellers in advance and they do not even know each other. The meat sellers alienate themselves from the selling of the meat.

\section{Sie plah patèe}

Sie plah patèe literally means the meat which is divided up (Ach plah) then wrapped (Ach patèe). It is also called sie meripèe (meat of communal sharing), which is done by the village organizations, such as by "religious dis-

266 Sie meukilo begin to be known in the period of New Order because before that the villagers did not recognize scales (Ach céng). 
cussion groups" (Indon kelompok-kelompok pengajian) in the villages in West Labuhan Haji district.One of the members of an organization buys one or two buffalos. After slaughtering, all members of the organization work together to skin, to chop and to divide the meat, skin, liver, heart, intestines and other internal organs into equal amounts for each member. My respondent says that some of sie plah patè is sometimes contributed to the poor and orphans on meugang day but it must be done with the agreement of all members of the organization.

\section{Sie tumpok}

Sie tumpok literally means meat which is heaped (Ach tumpok) after being slaughtered. It is also called sie adat in which a person who has several buffalos or cows will invite villagers to buy meat from him on meugang day. The slaughtering is done in the village. The owner of the cattle does not benefit from this. Each family in the village is asked how much he intends to buy in order accurately know how much cattle must be slaughtered. He then writes down the names of those who buy meat from him. After slaughtering, he calls the buyers one by one to welcome them to take the meat that has been divided up. Sie tumpok are mixed among meat, skin, liver, heart, intestines and other internal organs which are turned into favourite dishes for the Aneuk Jamèe and for the Acèhnese.

The tradition of sie tumpok does not only benefit the owners of the cow or buffalo but also the villagers. The owners neither have to pay the market tax nor hire a market stall as slaughtering is done in the villages. On the other hand, this tradition enables the buyers to have meat on meugang day even though they do not have money on that day. Sie tumpok is a form of loaned meat which can be paid for at certain times during the next several months or after harvesting. Also, sie tumpok can be paid for not only with money, but also with rice in order that the villagers can have meat on that day. Comparing the price of sie tumpok with other kinds of meugang meat (Ach sie meugang), for instance; sie meukilo sold in the market and sie plah patèe sold in the village, sie tumpok is more expensive. But this is compensated for with social solidarity. Some of the sie tumpok is contributed to poor people, and orphans in the village who are unable to provide meat on meugang day. Here one can see that the social aspect is more important than making a profit (Ach mita untong). 
The buffalos or cows are slaughtered by each village teungku for these three types of meat in West Labuhan Haji district because the teungku know well the do' $a$ of slaughtering cattle. Ahmad in Kutaiboh says that because teungku is close to Allāh it is one of the ways to help him, as he does not receive any salary from the government. In the early morning of meugang day, the teungku together with the owners of cattle go to the places where the buffalos or cows are going to be slaughtered. After slaughtering, the teungku is given a three-finger length of the slaughtered buffalo's neck.The teungku then shares it with the village mosque staff: the village khatib (preacher), the village bileu (the one who call for prayer), and the village khadam (cleaning service). The more buffalos from their villages are slaughtered on meugang day, the more meat the teungku and the village mosque staff receive. My respondent says that sometimes even the village teungku who gets the meat from the slaughtering sells it to other people on the meugang day because many cattle from his village have been slaughtered by him.

The meat cost from $\mathrm{Rp} 100.000$ to $\mathrm{Rp} 120.000$ on meugang days in 2007 in West Labuhan Haji district. It is Rp 20.000 to Rp 40.000 more expensive than usual. This is because the request for meat on the meugang day is so high that the price increases. This has become a tradition in West Labuhan Haji. One butcher says that although the fulfilment of all meat required on this day is difficult the families must have it. The village people "attack" the butchers at the markets in Blangkeujèrèn, the capital city of West Labuhan Haji in order to get meat on this day. Another butcher says that the meat on the day of meugang is more expensive but the price will go a little bit down in the afternoon. Like the people of coastal areas of West Acèh, Simeulue, Acèh Jaya, Nagan Raya, and Southwest Acèh, the people of West Labuhan Haji, and the people of South Acèh prefer buffalo meat. The beef is consumed less here. However, the people in the capital city, Banda Acèh, Acèh Besar, North Acèh and East Acèh prefer beef and consume less water buffalo meat. On this day, many visitors go to the meat market. But less people are interested in going to the fish market although the fish sellers have brought down the price. For example, a tuna fish (medium size), which is usually sold for Rp 35.000, becomes Rp 20.000 on that day. The same applies to the chicken sellers on this day. Usually they are visited by many buyers, yet on this day the chicken market is slack (Indon lengang) and the price remains the same as on days prior to meugang day. 
It is the fact that every person especially the family head makes a big effort so that on meugang day they are able to buy meat. The poor people usually save money a month or two months prior to meugang day to buy one or two kilograms meat. In the village sometimes rich people buy a buffalo or cow whose meat is contributed to the poor and orphans after being slaughtered. One says that in the capital city of Acèh, Banda Acèh this practice is sometimes also done by the local officials on meugang day. The meugang tradition has become a part of the culture of the Aneuk Jamèe particularly and for the Acèhnese as a whole. It does not only influence the dynamics of the Aneuk Jamèe culture but also brings many consequences to the changing economy and social of the Aneuk Jamèe society. From the economic perspective, this tradition promotes local economic development with the development of animal husbandry besides this tradition also has the effect of strengthening the social links of the Aneuk Jamèe society in West Labuhan Haji district.

It is not considered very good to begin performing the religious service in the fasting month without meat at home. Therefore, every family head buys high quality meat at the market on meugang day and every housewife bakes leumang and makes other traditional Acèhnese cakes such as keutupèk, leupèk, bada and tapee. These activities on meugang day remind people that "the guest of Allāh" (Ach jamee Allāh), the Ramadhan month will come soon. He adds that people who do not buy meat and do not make traditional cakes on mengang day are those who do not respect the "the guest of Allāh" which will come in two days time. Meugang is a happy occasion for a family to welcome Ramadhan month. Therefore, families should have at least one kilogram of meat during this time. Otherwise, the celebration of meugang to welcome Ramadhan will be virtually meaningless, says one of the family heads in Blangporoh. Like the Acèhnese in Lamno district, West Acèh (Nur 1996:42), the Aneuk Jamèe people in Blangporoh regard meat as a very special food, not only because of its benefit for human health, but also because meat is an expensive meal compared with other dishes. Hence, as a part of the happiness associated with the coming of Ramadhan, people celebrate by having meat. Therefore, from the Aneuk Jamèe and the Acehnese's perspective as written by Nur, "a person cannot properly speak about Ramadhan month without following a meugang tradition which is considered as a phase between everyday life and a special time of Ramadhan". 
The existence of meugang to welcome Ramadhan gives poor people the opportunity to enjoy the delicious taste of meat at least once a year. Poor people usually eat meat only at a khanduri whether in khanduri ureueng matèe or at wedding receptions which are held by rich people. Some villagers say that they only experience 'big meal' (Ach pajoh rayeuk) when someone invites them to the khanduri. Therefore, Sya'ban is regarded as a happy month since this month is characterized as 'the month of the rice feast' (Ach buleun khanduri $b u$ ). Furthermore, since meugang is considered as a transition between everyday life and the liminal time of Ramadhan, everyone saves extra money to be spent on this tradition. One father of a household in Blangporoh says that he has been saving money for meugang day for two months. Even some fathers of households in Blangporoh and Kutaiboh village borrow money from their neighbors to buy meat on meugang day. Even though the price of meat on meugang day is more expensive than on ordinary days, it does not decrease the people's demand for it.

Meugang day is also celebrated by people returning home. I often hear people sitting in the coffee shop (Ach warōng kupi) or in the prayer house (Ach meunasah) asking each other about their family in rantau (away from the home town) and whether they can come home or not on meugang day. A woman whose husband is in rantau will be very worried if on the days preceding meugang her husband has not returned home. She worries not only about how to buy meugang meat, but most significantly, because a family should be together on that day. The same is the case with families whose children are in rantau, parents in the village will also be very worried if their children do not return home on the days preceding meugang. I find that the Aneuk Jamèe in Blangporoh stress the importance of the meugang ritual to the family's sense of togetherness. One father of a household says that togetherness is the happiness that is difficult to describe in words, it can only be felt. For him, happiness can only be found if all the family members including the return of deceased's 'soul' (roh) can be together on meugang day. The high price of meugang meat and other foodstuffs on meugang day are not obstacles if compared to the immeasurable value found when families, either small or large, gather together on meugang day to start the fasting month. Therefore, the children in rantau should rightly return to their village to be together with their parents in order that all family members can taste all varieties of the cooked food prepared by their mother. This shows that meugang is a time of rebuilding a social community. 
Many household wives shed tears as their beloved children are for some reason in rantau. They cannot come home to taste the food cooked by their beloved mother. ${ }^{267}$ In addition, many parents are sad and even cry if their children are not together with them on that day. The wife of Hayyan, Sa'diyah in Blangporoh says that if her son does not come back from the city on meugang day she will invite her son' friends in the village instead of feeding her own son with the cooked meugang meat she prepares. By doing so, her deep longing (Ach meuchén) for her son to be together will disappear a little bit. In addition, my respondent says that there are parents in Blangporoh who go to the imām a month prior meugang day and asking him to recite shamadiyah in orderthat their children in rantau remember their parents and come back on the day of meugang because their parents want to eat a meal together with their children. If the shamadiyah is accepted by Allāh, the son's heart in rantau will be gentle (Ach leumoh) and he will remember his parents and come back to his house on meugang day. There is, however, a different case with Mawardi and his wife. When they know that their son cannot be together on meugang day, they go to their son's house in Banda Acèh prior to meugang day and celebrate the meugang day together there. When I asked why people should be together on meugang day, many people repeat the saying "That is a good day and a good month" (Ach uroe get, buleun get). My respondent, however, answers by saying "because meugang is about good meat and good traditional cakes, all these good things should be tasted together by all family members".

As a tradition that has been passed down from one generation to another, the meugang tradition for the Aneuk Jamèe does not merely mean buying and eating meat but also reflects the pride and esteem of the head of the family, especially a father at the head of his family. If the father cannot provide the family with meat which is relatively expensive, his esteem will fall dramatically as is admitted by M. Nazar in Blangporoh. In 2005 in Leunké - Banda Acèh, a pedicab driver cut off his penis in front of his wife because he could not bring meat to his family on meugang day (Nur 1996:44). From this shocking incident it can be understood that bringing the raw meat home is a sign of men's honor. The man who is not able to bring the raw meat home on meugang day implies that he is not able to hold his honour as husband towards his wife. Because the meat of meugang is a sign of men's honour, men will do the shopping on

267 See Serambi Indonesia, November $9^{\text {th }}, 2007$. 
meugang day, particularly to buy meat. Therefore on meugang day the general picture in West Labuhan Haji and in other parts of Acèh, whether in the market or in the villages, is of men carrying the meugang meat (Ach sie meugang).

For a man who is just getting married, meugang day can be a prestigious day and can also be an unhappy day since all expenses on meugang day fall to him. On that day, he should show his wife's family that he is able to provide meugang meat. Usually, if a family already has a son-in-law (Jam minantu laki;Ach meulintè agam), he is the person responsible for providing meugang meat. Based on the village tradition, the man who has just got married is obliged to bring home meat and complete cooking spices called aweuh lengkap ("complete coriander"). The aweuh lengkap consists of coconut (Ach bòh u), calamondin (Ach bòh kuyun), salt (Ach sira), chilli (Ach campli), onion (Ach bawang merah), garlic (Ach bawang putéh), ginger (Ach bòh halia), coriander (Ach aweuh), turmeric (Ach kunyet), pepper (Ach lada), galingale (Ach langkuweuh), fennel (Ach jintan maneh), stern-anis (Ach lawang kléng), fried grated coconut (Ach $u$ neuleu), bay leaves (Ach on salam), cardamom (Ach kapulaga), coconut oil (Ach minyuek u), lemon grass (Ach bak reu), several lime leaves (Ach on kruet), cattapa (Ach keutapang kléng), candlenut (Ach bòh kiro), and dried carambolas (Ach asam sunti). After having been cooked by the wife with the help of her female family or her female neighbours, the cooked meat with rice and other side dishes are placed in rantang (set of stacked containers for transporting food) then it is given to the husband's mother (Jam bisan padusi) together with traditional wet cakes such as leupèk, leumang, keutupèk, tapè, timphan or asoe kaya and bada. All these are placed in an ayan (a tin can) and are wrapped with cloths. Sometimes some dried bread made with butter is also placed in the ayan. By giving these, she wants to express her loyalty in front of her husband's family and also to show that her husband is still responsible for his family as a symbol of care or family ties.

After receiving the rantang containing the cooked food and ayan containing wet cakes and dry bread from her daughter-in-law (Jam minantu padusi), the mother's husband (Ach mak tuan agam) estimates the price of the cooked food, traditional cakes and dried bread given by her daughter-in-law. In return, the husband's mother then places an amount of money in the rantang and ayan to be returned on that or the following day without her daughter-in-law noticing. Sometimes the returned rantang and ayan new clothes, sugar, and coffee are also added. The money given by the husband's mother belongs to the 
daughter-in-law's mother; meanwhile some cooked meat, the baked traditional cakes and dried bread are brought by the daughter-in-law are shared with neighbours by her husband's mother on this day. This implies that meugang tradition is an opportunity to strengthen relationships not only between the sonin-law and wife's family by bringing raw meat home, but also between the daughter-in-law and the husband's families including neighbours through sharing some of the cooked meat together with cooked wet cakes and dry bread on meugang day. Here is a clearly gift exchange in which a link is developed through the given rantang and ayan in otherwise separate family groups. Hence, the gift from the daughter-in-law implies an intention to maintain a social relationship between the families. The classic example of a gift is a daughter given in marriage: One's daughter remains one's daughter, even as she becomes the wife of a man.

If the son-in-law does not follow the adat by bringing raw meat home to his wife's family on meugang day, his honour will be decreased in front of his wife's family. He is then identified as bawok lari panggang or "bringing grilled meat away" meaning the person who avoids his obligations and is afraid of suffering a financial loss. ${ }^{268}$ In addition, bringing the cooked meat with various side dishes together with wet cakes and dry bread to the husband's families on the meugang day is to avoid scorn (Ach/Indon èjèkan) from the neighbours onto the newly married couple. The new couple will certainly be ashamed if this happens. He adds this tradition has become adat defining the newly married man on the one hand, and proving the ability of the man to provide the meugang meat to his wife's family in the other hand. Although a man still has an equal obligation to take care of his original family as well as his married family, since he stays in his wife's house, his obligations to his wife's family are greater. Therefore, the ability of a man to provide the meugang meat to his wife's family is not just to follow the adat rule but, at the same time, also to increase the man's honour in front of his wife' s family. It is also a symbol of care (Indon keperdulian).

Like the Acèhnese women in Lamno district, West Acèh (Nur 1996:44), the honour of Aneuk Jamee women in the context of meugang is equally strong

268 It is also the same case if one of his wife's parents has passed away; a son-in-law does not go back and only goes back after khanduri on the seventh day. He is also identified as bawok lari panggang or "bringing grilled meat away" means he is stingy and afraid of spending money on the khanduri. 
as that of the men as there is certain happiness for the village women in Blangporoh in cooking meat in the kitchen on the meugang day. Ibu Fauziyah as a housewife in Blangporoh says she is very sad if her husband does not bring meat home on meugang day. If there is no pure meat, bony meat is also fine because children are waiting for it and they swarm over it if it is brought home. The children's expression makes her proud. She adds that even though she works all the time in the kitchen on meugang day, she will be happy as she can cook meat in the kitchen which can later on be served to her families and to her husband's families. Another housewife says that if there is no meat on meugang day she will feel awful because the aroma of the cooking meat comes from all the other neighbour's kitchens. She adds "When there is meat, I am busy cooking in the kitchen and at the same time I can forget my own problems for a moment and the important thing is I can serve the cooked meat to my husband's families to show them that I do not forget them on meugang day". Therefore, the meugang tradition, again like the Acèhnese in Lamno (Nur 1996:44), symbolizes the honour of both men and women in the family.

Moreover, besides improving relationships with the extended families, the existence of the meugang tradition is an opportunity to improve relationships with the deceased relatives. The living will not forget them and always wants to be close to them.In Blangporoh, Kutaiboh and Blangbaru village, a small khanduri for aruwah (deceased's soul) is performed at home. A teungku is invited. Shamadiyah is then recited after burning incense and the shamadiyah session is closed with do'a for 'soul' (roh) asking Allāh to 'widen their graves' (Ach lakèe beuluwah kubu) and to release them from torment (Ach/Indon bebas dari siksaan). In addition, the teungku asks Allāh to grant prosperity (Indon kemakmuran) and long life (Ach panyang umu) for the living before ending his $d o ' a$. The teungku is then served with the cooked meugang meat with various dishes and other wet meugang traditional cakes.

It is worth mentioning that the meugang tradition in the context of Ramadhan is the symbol of slaughtering a cow or buffalo. The slaughtering of a cow or buffalo is not only to have its meat, but also to express the killing of hawa $n a f s u$ or carnal desire (Nur 1996:46). In line with this, Siegel (1969:98-105) points out that a man's nature in the Acehnese' conception consists of akal or rationality and hawa nafsu. When man responds to hawa nafsu, he is led away from Allāh, and behaves like an animal. On the other hand, through the use of akal, man can know Allāh's command and control man's instinctive nature that 
is hawa nafsu. However, between hawa nafsu and akal there is always a struggle. Therefore, man needs religion in order to guide his akal.

The resemblance between animal behavior and hawa nafsu can be best understood in the saying "like cow" (Ach lagèe leumoe) or "like buffalo" (Ach lagèe keubeu). These two words often appear in daily conversation when people want to talk about someone else with bad behaviour or someone who has done something wrong (Nur 1996:46). The reason for the comparison with a cow or buffalo is because those animals are only endowed with hawa nafsu. Furthermore, since people use both animals in ploughing rice fields, those two animals have become a symbol of stupidity (ibid). In relation to the meugang tradition it is not the endowment of hawa mafsu and the symbol of this animal as written by Nur, but, most importantly, bringing home its meat on meugang day is a valuable gift. It testifies the relationship of the household and the sonin-law to strengthen the affinal relation in which he brings home the raw meat and aweuh lengkap to his wife's family and his wife's family gives back the cooked meat with aweuh lengkap. The following figure 12 showing the affinal relation in the context of meugang tradition.

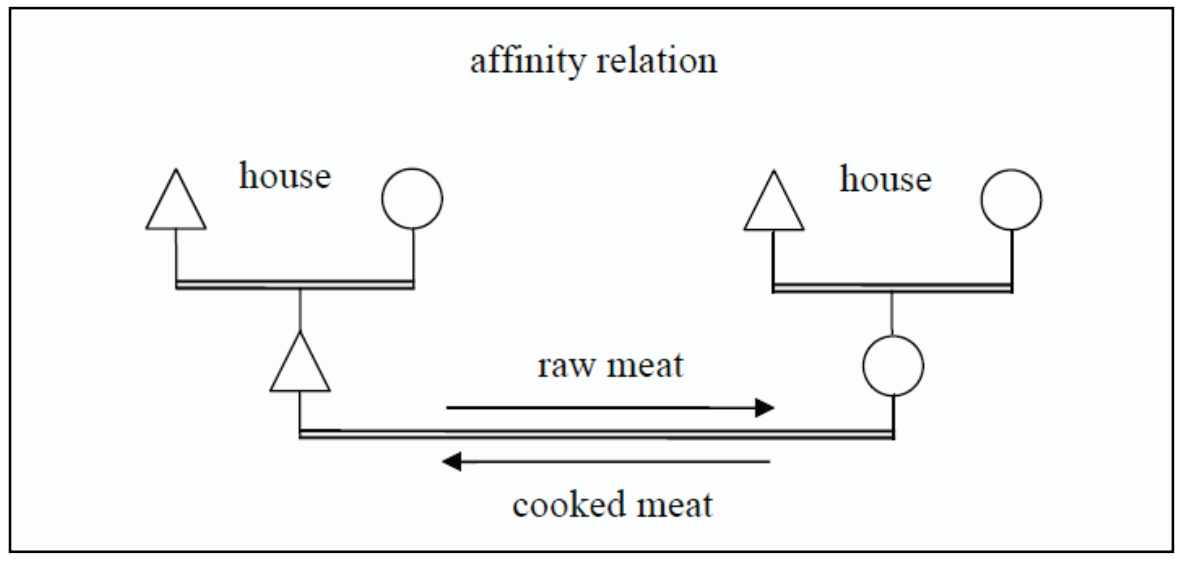

Figure 12. The affinal relation in the context of meugang tradition

\section{Pajoh-pajoh}

A day preceding the coming of the Ramadhan lunar month is recognized as uroe pajoh-pajoh (Jam hari makèn makèn) or "the day for eating". People in great numbers spend their day having pajoh-pajoh in open areas especially along river banks and seashores known as places of recreation. Pajoh-pajoh, sometimes known by the term meurumok or meuramien, is a happy excursion undertaken by two families together in a recreation area. As has been observed 
on this day, Blangporoh village and other neighbouring villages are empty (Indon sepi) even the government offices in Blang Keujèrèn, the capital city of West Labuhan Haji are also empty as many officers are absent. In addition, businesses, kiosks, and other shops are closed as their owner picnic on the river banks or seashores. On this day, the picnic locations will become "seas of humans" (Indon lautan manusia) performing the pajoh-pajoh tradition. In south Acèh, the locations visited on the day of pajoh-pajoh are Krueng Baru, Air Dingin in Sawang, Kolam Aroya, Tingkat Tujuh and Lhok Rukam sea shore in Tapaktuan, Pasie Kuala Ba'u in Klut Utara and Lhokjamin in Bakongan. ${ }^{269}$

The villagers prefer to visit locations along the river bank of Krueng Baru on pajoh-pajoh. The existence of this river is interesting enough as it is a border between the region (Indon kabupaten) of South Acèh and Southwest Acèh. On the south is the district of West Labuhan Haji and on the west is the district of Lembah Sabil. If the weather is fine, visitors standing on this river bridge can clearly see the peak of Gunung Leuser National Park (Indon Taman $\mathrm{Na}$ sional Gunung Leuser (TNGL). ${ }^{270}$ In addition, Krueng Baru has clear (Indon bening) water so that it becomes an object of interest to the visitors. They can take long baths and enjoy its cold water flowing from the mountain of TNGL. Moreover, from the Krueng Baru bridge visitors can also see many other things, such as groups of household wives washing clothes on both of its banks, truck drivers take stones and sand for building projects and farmers go back and forth with their canoes to their gardens in the upper reaches of river. There are coffee shops and small kiosks selling various food, drink and fruit for the visitors on both sides of the river bank. There is also a mosque at the head of the bridge for prayers. In short, Krueng Baru offers many attractions so that thousand of visitors decide to go there, have a meal, bathe, dive etc on the day of pajoh pajoh to welcome Ramadhan.

Like the Acèhnese, the Aneuk Jamèe celebrates pajoh-pajoh twice in a year. Both are based on the lunar calendar. First, pajoh-pajoh is held on the final Wednesday of Safar lunar month called uroe rabu habéh. Safar lunar month in Acèh is considered an unlucky month (Ach buleuen hana untong)

269 See Serambi Indonesia, September $11^{\text {th }}, 2007$. In the southwest region, places visited on the day of pajoh-pajoh are Ujung Serangga beach, Jilbab beach in Susoh, Bendungan Irigasi in Kuta Tinggi, Krueng Beukah in Blangpidie, Krueng Babahrot in Lama Inong, and Krueng Baru at the border between Southwest Acèh and South Acèh and Krueng Seumanyam at the border between Southwest Acèh and Nagan Raya.

270 See Serambi Indonesia, March 18 ${ }^{\text {th }}, 2007$. 
because historically in this month, the Prophet Muhammad was very ill. Therefore, on rabu habéh day, in order to avoid any misfortune, people go to the river or sea to bathe and clean themselves. They sometimes come with pieces of paper with certain verses of the Qur'ān to be mixed with the water. Pajohpajoh on the day of rabu abéh is not solely an expression of happiness, but most importantly, it is a ritual which is intended to purify the body from any dangerous spirits. Second, pajoh-pajoh is held on the last day of Sya'ban or a day preceding Ramadhan. Pajoh-pajoh on this day is purely a joyful activity with the aim of "throwing off all carnal desires" (Ach peuleh hawa nafsu) to welcome Ramadhan because the following day the fasting month begins and all people have to fast. Arbi says that pajoh-pajoh is a day in which one satisfies him or herself with everything but stays within permissible limits and does not collide with the Islamic teaching as well as with the adat tradition.

Pajoh-pajoh is held communally. The villagers do meuripèe ${ }^{271}$ (share money) to pay for all expenses, particularly for the public transportation costs. Nonetheless, people go to the river banks or seashores in their own vehicles on this day. M. Nazar says that the money for the day of pajoh-pajoh has been saved at the time he saves money for the meugang day. The aim of this tradition is to release hawa nafsu to welcome the Ramadhan month. Some old men whom I talk to, say that the expression of happiness on the day of pajoh-pajoh by feasting on the river banks or seashores is not only merely to welcome Ramadhan month but also because people have already "met" the 'souls' (roh) of their deceased families returning as the teungku burned incense and recited $d o$ ' $a$ at the meugang night, the night prior to the day of pajoh-pajoh.

Pajoh-pajoh in the context of Ramadhan both for the Aneuk Jamèe and for the Acèhnese can be considered as a form of the their interpretation of one of the Prophet's hadìth narrated by Ahmad and Nasai, "if a person welcomes Ramadhan with a feeling of happiness; his or her body will be saved from the heat of hell on the Day of Judgment". Since pajoh-pajoh is an expression of satisfaction, the people regard it as a good way to carry out the Prophet's suggestion even though the Prophet celebrates in welcoming Ramadhan. I observe that soon after people arrive at the riverbank of Kruengbaru, mats are spread out and tents erected. They then have a meal enjoying a fresh feeling, the pre-

271 In Aneuk Jamee and Acèhnese community, meuripèe (voluntary contribution) is always a solution in communal activities, both ritual and social, such as in religious khanduri and in building a prayer house (Ach meunasah) or mosque (Ach meuseujid). 
pared delicacies and the natural beauty around them. Many talk to each other while eating and sometimes laugh while eating various delicious foods which are only consumed occasionally. Besides the cooked meugang meat, there is also food such as fruit salad (Ach nicah or cinicah;Indon rujak) with a pungent dressing; e. g, unripe mango with a tangy sauce or fruit salad with sweet sauce. After the meal, most of them take a bath, and dive in the Krueng Baru River. They enjoy the coldness of the river water and sometimes go onto the river bank and jump down into the water again. Here it is clear that the communal nature of pajoh-pajoh is expressed not just by the fact that so many people participate, but also by the nature of their participation. It can be seen in the happiness on their faces and in the tone of their voices.

One of the unfavourable aspects of the tradition, which is criticised by some people, is the way people carry out the pajoh pajoh tradition. Some old men in Blangporoh, Kutaiboh, and Blangbaru village whom I discuss with lamented that it is not appropriate to welcome Ramadhan in such a way. Instead, they suggest learning more about ibadah Ramadhan (the religious service of Ramadhan) and visiting and asking forgiveness from each other to "clean the soul/mind" (Ach peugléh jiwa) before beginning to fast in Ramadhan or looking to see how the students at the Islamic boarding school (Ach aneuk dayah) celebrate the days preceding Ramadhan. Furthermore, they say that what people do on the day of pajoh pajoh is not what the Prophet practiced when he was alive. Hence they categorize this practice as heresy (Arb bid'ah). They prohibit their children from taking part in this tradition and also believe that spending the day of pajoh-pajoh on the river banks or seashores as an expression of happiness is clearly sinful because men and women mix together, beginning in the truck and then bathing in the rivers. Such a tradition was not recognized at the time of the Prophet and his companions. This tradition belongs to non-Muslims, says Teungku Bustamam. He also says that nowadays, people tend to express happiness without considering that their actions go against Islamic teaching and the adat rules. However, apart from going against Islamic teaching, the day of pajoh-pajoh at the river banks or seashores provides an opportunity for marriageable young men and women to meet and to talk to each other and choose their prospective spouses. My informant says that it is common soon after the day of pajoh-pajoh; that the traditional matchmakers are busy in arranging marriage proposals with the parents of the interested parties in West Labuhan Haji district, South Acèh. 
The following figure 13 shows that the practice of pajoh-pajoh is one of the opportunities to construct the next generation.

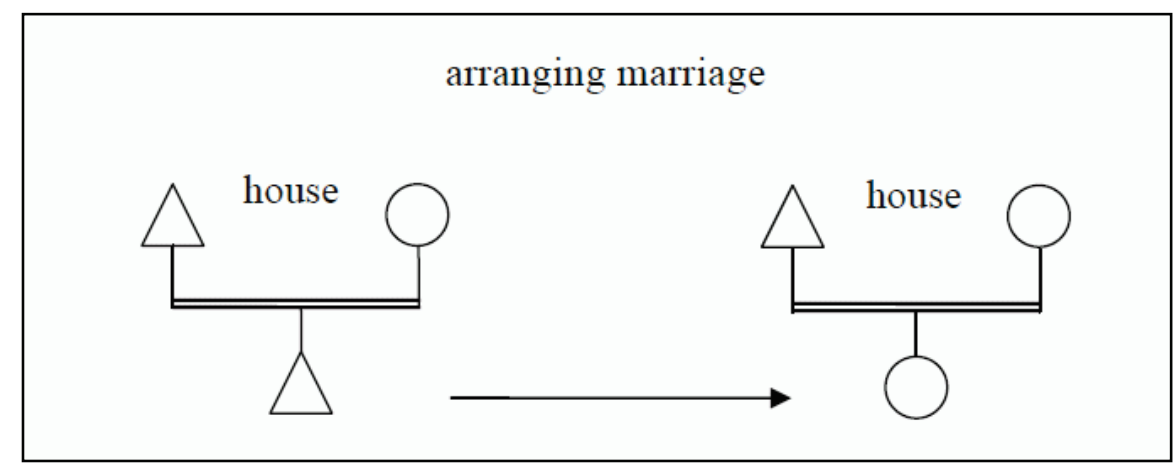

Figure 13. The practice of pajoh-pajoh constructs the next generation

Furthermore, the pajoh-pajoh also shares a major characteristic of khanduri this being that neighbours come together on the riverbanks or seashores and share their food. This is usually conducted communally among several neighbours who do meuripee to pay for the cost of transportation. At the riverbank or seashores, there is not just recreation available, but the pajohpajoh itself can also be considered as an act of purification. This is because almost everyone, men or women, children or young people, bathe and clean their bodies in the river on the day of pajoh-pajoh.

My female respondent says that in the past on a day preceding Ramadhan, the Aneuk Jamee women especially performed mandi balimau (bathing with citrus fruit) to purify their bodies. This is done by mixing several kinds of fragrant flowers; frangipani, jeumpa flower, seulanga flower, fragrant lemongrass, nubbled lime, kabèlue, leaves of civet cat's pandanus (Ach on seukè musang) and other fragrant grasses. All these 'ingredients' are cut into small pieces and placed in a tin can (Jam timbo) that has been filled with water. Limes are cut into slices. They are then mixed in the water together with flowers in the tin can till the water is fragrant. This is done two nights preceding Ramadhan in order that all the fragrant smells are mixed with water to be used to bathe at their houses on the day preceding Ramadhan. This tradition is no longer often practiced. Instead, the village women use shampoo as they take a bath in the river of Krueng Baru on the day of pajoh-pajoh. Nonetheless, my male respondent says, however, that in Acèh Singkil, on the day preceding Ramadhan that women perform mandi balimau to purify their bodies. It is done by mixing several kinds of fragrant flowers including the leaves of civet cat's 
pandanus. They are then pounded and filtered to get between one and two litres of water which is then used as shampoo. This water is used to rinse off (Indon membilas) after bathing with river water so that the fragrance from the rinsing water remains on their bodies. The Acèh Singkil women perform mandi balimau together by lining up at the riverbank of Elsoraya in Acèh Singkil. Cheering is appeared at the moment. They bathe laughing together. In addition, M. Yamin, a Minangkabau man who has just migrated from West Sumatra to Blangporoh village says that Minangkabau people of West Sumatra also recognize the tradition of mandi balimau to welcome Ramadhan. Several days before Ramadhan begins, many people bathe in a river or sea in order to purify their bodies. On this occasion, they clean their bodies with citrus fruit. Moreover, in Morocco, as another example, on the days preceding Ramadhan people visit the public baths and scrub themselves to purify their bodies for the coming of Ramadhan (Buitelaar 1993:38; Nur 1996:40).

Pajoh-pajoh tradition is not only a joyful activity to express gladness in the context of welcoming the 'king of the month' (Ach panghule buleun), that is Ramadhan month but it is also an expression of gladness as people have "met" the aruwah of deceased families when they perform khanduri for them at the night of meugang. In addition, this tradition is an opportunity to improve their social relationships with the living by going to the river banks or seashores together. Pajoh-pajoh tradition is an opportunity to purify their bodies from external dirt (Ach kotoran lahée) through bathing together in a river or sea before they fully concentrate on fasting in Ramadhan.

\section{Conclusion}

The series of rituals during Sya'ban lunar month is intended to welcome Ramadhan. Since Ramadhan is regarded as a holy month, purification becomes an important aspect especially in the Aneuk Jamee activities and in the Acèhnese activities in general which involve a process of gift and commodity exchange. The ritual of khanduri bu, both at family and village level, khanduri beureu'at in the middle of Sya'ban, religious services such as 'prayer of glorification' (Ach seumayang taseubèh), 'wish prayer' (Ach seumayang hajat) with certain prayers (do'a) and 'fasting of Nisfu Sya'ban' (Ach puasa Nisfu Sya'ban) require purification as requisite for being valid. It is understandable that purification emerges as a part of the important preparations for Ramadhan since, during this month; Muslims have to perform many series of rituals. If the 
performing of khanduri bu, khanduri beureu'at, religious services and slaughtering buffalos or cows on meugang day symbolize the process of purifying the 'soul/mind' (inner human self) as well as rebuilding the social communities and strengthening the social and affinal relationships (see figure 12), peugléh meunasah and rumoh (house) emphasizes the purification of material things (outside the self). Both imply the importance of purification in welcoming Ramadhan. Furthermore, Sya'ban can be regarded as a preliminary phase leading people away from their everyday life into the liminal time and space of Ramadhan. And the practice of pajoh-pajoh, on the one hand, is an expression of a border between secular and secret happiness, but on the other hand, the practice of pajoh-pajoh shows how relationships amongst the next generation are constructed (see figure 13) since the pojoh-pajoh tradition at the river banks or seashores provides an opportunity for the marriageable young men and women to meet and to talk each other and choose their future prospective spouse. 


\section{CHAPTER 11}

\section{The ritual of Ramadhan}

Ramadhan is the ninth month of the Muslim calendar, which coincides with the month of September. The exact date of Ramadhan is variable, sometimes falling in the dry season, and sometimes in the wet or rainy season. The first day of Ramadhan is also variable since Sya'ban, the preceding lunar month sometimes has twenty-nine days, and sometimes thirty days. Therefore, in the last few days of Sya'ban, predicting the first day of Ramadhan becomes the main topic of conversation. The Aneuk Jamee wait until there is official information either from the government or from teungku dayah "Islamic scholars of the boarding school" for confirmation of the first day of Ramadhan, although it has already been indicated on the Gregorian calendar. ${ }^{272}$ In 2007, when this research was conducted both the teungku dayah and the government agreed on the timing of the first day of fasting. Hence, everyone began fasting together. After 'sunset prayers' (Ach seumayang meugréb), some people turned on their televisions and evening radio to hear the government's determination of the new moon (Arb $\left.r \bar{u}^{\prime} y a h\right)^{273}$ by the National Team for Visual Observations of the Ministry of Religious Affairs, followed by a speech about the merits of fasting that urges everyone to do good deeds and avoid evil. This chapter describes the religious services and events taking place during Ramadhan month in the village and in the dayah "boarding school" complex. In the latter the suluk ${ }^{274}$ ritual is practiced.

\section{Fasting}

From the first evening the fasting month creates a distinction between everyday life, in which the villagers gather at the village mosque to perform vari-

272 In the past, the government's decision on the first day of Ramadhan was sometimes contradicted by the decision made by several teungku. Therefore, people who have a strong commitment to the dayah - those who belong to PERTI (Persatuan Tarbiyah Islamiyah) - will follow the teungku's decision, whereas the majority of people will follow the government's decision (Nur 1996:48). The contradiction emerged because of different techniques used to observe the coming of the moon.

273 Sighting of the new moon to start or close the fasting month, as opposed to mathematically calculating the date.

274 The practical method to guide the seekers by tracing a way of thought feeling, and action, leading through a succession of 'stages' to experience the Divine Reality (Trimingham 1971:4). 
ous religious services. Many villagers and more than one thousand people from various districts in Acèh come to the (boarding school) dayah of Sheikh Muda Waly to perform the suluk ritual and other religious services in the dayah's mosque. ${ }^{275}$ People stay awake until it is time to have an early morning meal (Jam sahur), just before day-break. Afterreligious services, some people go to warung (small coffee shops or rice-eating stalls) but many others remain in the dayah mosque spending the time uttering 'religious chants' (dzikir), some others chat with each other. During this night people in the village and the dayah's mosque perform additional prayers to Allāh. They believe that Ramadhan is an occasion to wipe out one's sins and enjoy Allāh's unlimited mercy.

Some men in the warung, generally, spend the night drinking coffee, tea and talking. Although they go to sleep later than usual, women (particularly housewives) must get up much earlier than usual on the first day of Ramadhan since they have to prepare an early morning meal for their families (Nur 1996:50). For men, the first night of Ramadhan marks the beginning of a time of relaxation as their usual activities during the month are reduced, whereas for women, the first night of Ramadhan signals the beginning of a busy time since Ramadhan activities require them to work harder than usual (ibid). Men in the village mosque, the coffee shop or 'rice stall' (Ach warong bu) will go back home after having an early morning meal. Once at home, a husband wakes up his wife and helps her cook. The suluk followers (called sālék "traveler") in the dayah complex also sleep very late, spending a long time at the mosque during

275 Participating in the suluk "retirement from the world" involves practising the dzikir (religious chants) as well as performing other religious services under the guidance of the dayah leader. For this ritual, the suluk followers have to separate themselves temporarily from their wives and children with the aim of coming close to Allāh. During suluk, the followers chant the recital of the confession of faith (Ach meratéb) to invoke the Prophet Muhammad, and recite the Qur'ān completely as well as praying together day and night. The goal of this strenuous meditation exercise is to lessen the indescribable distance between man and Allāh. "Members of a suluk have no other goal than to come closer to Allāh; only that, there is no other purpose". The practice of this suluk is based on the 'seclusion' (Indon khalwat) of the Prophet Muhammad at the Hira' cave (Indon gua Hira') and the Prophet Moses at Sinai hill (Indon bukit Sinai). Some people perform suluk for 40 days; some perform suluk for the whole Ramadhan month; some perform for twenty days and the majority perform it for the last ten days of Ramadhan. The majority performed suluk on the last ten days of Ramadhan because there was a particular moment called lailatul qadar "the Night of Decree". Lailatul qadar is better than a thousand months (QS 97:3). By performing suluk on the last ten days of Ramadhan, the sālik believe that they will receive a greater religious merit, both the religious merit of performing suluk and that of lailatul qadar night. 
the night. They do not cook themselves as the suluk committee prepares their meal.

Before dawn, a young man in the village mosque calls "wake up, wake up, sahur, sahur" (Ach beudoh-beudoh, saho-saho) over loud speakers. One is not allowed to eat or drink one hour after this call an hour before the moment one may not eat and drink (Indon imsak), all family members have woken up to have early morning meal. In Blangporoh, many families have their meal sitting on a plaited mat side by side, including their son-in-law who normally never eats with his parents-in-law. Before having their meal, a father usually reminds his children to say the "intention" (Indon niat) to fast in Arabic. This translates as "I intend to fast tomorrow, to fulfill my duty during the fasting month this year for Allāh's sake". Uttering niat is very important for the validity of worship. Children who are unable to utter niat in Arabic may utter it in Jamee or Acèhnese. In the dayah complex, the suluk followers also have meals together, thus acting as if they were kin. They share cooked rice and vegetables, for they are not allowed to consume any food that has a 'soul' (nyawa) such as fish, shrimps and meat, "so that their own 'soul' (jiwa) is always focussed on Allāh". Eating food that has a 'soul' (nyawa) during suluk's performance is said "to close the door of the heart, make the body heavy, and strengthen the hawa nafsu or "carnal desire" (see below). When a human acknowledges his hawa nafsu, he or she is led away from Allāh. ${ }^{276}$

After the early morning meal, a father insists that all the children avoid sleeping prior to performing the 'sunrise prayers' (Ach seumayang suboh). Later, when the call is broadcasted over the radio followed by the voice of the drum (Indon bedug) from the dayah mosque, people stop eating, drinking, smoking and chewing betel vine. This is a sign that the fasting time has begun. After performing the 'morning prayer' in the village mosque, the village men return home and sleep, whereas several village women stay in the mosque reciting the Qur'ān. Some young men and women in village and many in the capital city of West Labuhan Haji, Blangkeujèrèn, do not immediately go back home, but spend the morning walking around excitedly. This tradition is called 'walk-

276 Another reason why the suluk followers are not allowed to consume meat or something that has a 'soul' (nyawa) is that it is related to the validation of the dzikir (religious chants) chanted during the suluk performance. Some male suluk followers said that if they do so, it may provoke a dream of sexual intercourse and ejaculation. When that happens, their $d z i k i r$ is no longer valid. 
ing in the morning' (Jam bajalèn subuah) and takes place only during Ramadhan. It is only done by young people and sometimes referred to as 'love in the morning' (asmara subuah). ${ }^{277}$ In the dayah mosque, however, the suluk followers practice the method of suluk, dzikir and perform additional recommended religious services under the direction of the dayah leader.

Unlike the scene in the dayah complex, which is full of people reciting prayers, the scene in Blangporoh village is very quiet, particularly during the first week of Ramadhan. ${ }^{278}$ Schools are closed and the village market only starts around midday. Moreover, the working hours in the government offices are shortened so that civil servants can catch up on sleep. ${ }^{279}$ Moreover, the coffee shops, canteens and rice-eating stalls are closed but in Tapaktuan, the capital city of South Acèh, some are secretly open to cater for those whose cannot fast for different reasons such as having to do hard physical work. However, they would never eat or drink in public as a sign of respect for people fasting.

The village men usually wake up from their morning sleep around 10 or 11 o'clock. After taking a bath, they leave the house and go to the village or district market in Blangkeujèrèn or to the mosque. An hour before the 'midday prayer' (Ach seumayang leuho), many men gather in the mosque and converse while lying on the floor. Men's behavior during Ramadhan is characterized by lale puasa, that is, the effort to distract the mind from food for instance by sleeping during the day. After performing the 'midday prayer', everyone lies down on the floor and sleeps. Usually they wake up before or during the time for 'afternoon prayer' (Ach seumayang asa). In the dayah mosque after per-

277 Similarly, in Lamno district, West Acèh, after performing subuh prayer 'morning prayer', in Ramadhan, women and men walk around the village to get to know each other and this often results in them falling in love. In a society where women are forbidden to go outside alone, this tradition functions as an escape from a secluded life. Their excuse is that they must go to the mosque to perform the 'morning prayer'; no one can forbid this, not even their fathers (Nur 1996:52).

278 The suluk followers practice how the (Indon tatacara pengamalan) the suluk is implemented and end with $d z i k i r$ and the $d o$ ' $a$ till 9 o'clock. Sometimes they are asked by the leader of dayah to collect stones on the sea coast of Blangporoh to be placed in the yard of the mosque complex. After that they may take a rest for 2 hours then again gather at the dayah mosque for the "midday prayer" (Indon sembahyang zuhur).

279 On regular days, office hours start at 8 am and end at 5 pm. However, during Ramadhan offices in the capital city of West Labuhan Haji, Blangkeujèrèn begin activities at 9 am and stop at $3 \mathrm{pm}$. 
forming the 'midday prayer', the suluk followers again put the dzikir ${ }^{280}$ into practice and perform additional recommended religious services under the direction of the dayah leader. After this they may go back and sleep in their own "places" 281 before the 'midday prayer'.

Before the 'afternoon prayer' (Ach seumayang asar), the village men wake up from their midday sleep and then go to the market to buy vegetables and side dishes or they return to their homes. Shopping activities during Ramadhan are generally carried out by men, instead of women. During Ramadhan, the village women spend their time inside the house; whereas village men remain outside the house. After performing the 'afternoon prayer', the market is crowded with people, most of whom are men. This special market only sells snacks for breaking the fast (Jam buko puaso), especially, traditional snacks such as boh rom-rom, timphan, leumang and tapè these are rarely sold at other times. Also in the dayah complex village sellers, most of them are women, sell fruit, snacks for breaking the fast, cooked vegetables for dinner and the daily needs of the suluk followers. This market is called 'suluk market' (Jam pasar suluk) and the cooked vegetables sold are called 'suluk vegetables' (Jam sayur suluk).

On the first day of Ramadhan, all members of a family break the fast in their house; no one does this in the mosque. As the days of Ramadhan continue, however, many men tend to choose the mosque as a place to break the fast since the mosque committee has made a schedule whereby three households give food to the village mosque every afternoon for those breaking their fast there. Serving food for those fasting are a good deed and it is said that the people doing so will receive the same religious merit as the fasting people themselves. The reason why they choose to break the fast in the mosque is to meet other people. But all agree that food served in the mosque is better than those served at home because everyone will serve other people with their best food.

280 The word dzikir in the Qur'ān in has difference meanings. Apart from its general connotation of remembering Allāh at all times, as expressed in the words' standing, sitting and reclining (QS 3:191), it also refers to a specific rite of the prayer (salat). Thus in the verse, "When the call to prayer on Friday hastens remembrance of Allāh (dzikir) (QS 62:9), the words "dzikir Allāh" indicates the congregational Jum'at prayer. But the main purpose of all forms of dzikir is the same i.e. purification of the heart and spiritual development of man. In fact all the four rituals of prayer, fasting, alms giving and the pilgrimage aim at spiritual exaltation of Muslims.

281 All suluk followers make a place to sleep with mosquito nets (Jam kelambu) in the room of dayah. 
Several minutes before breaking fast, all members of the family are at home and sit on the plaited mat; in front of them are various snacks. They wait for the sound of the alarm broadcasted over the radio and the sound of drums from dayah as a sign that the time for breaking the fast has come. After performing the 'sunset prayer' (Ach seumayang magréb), the family members return to their plaited mat to have dinner. Some families, however, have dinner before performing the 'sunset prayer'. In the dayah complex, the suluk followers break the fast, share and taste each others food together. After performing the 'sunset prayer', they have their dinner. Generally, people consume less than usual during Ramadhan. After performing tarawè and witir prayer, they once again have a meal.

According to the villagers and suluk followers, fasting serves various purposes. It is a means of learning self-control not to be preoccupied with the satisfaction of bodily appetites during daylight hours. It is also a measure of the ascendancy of a spiritual nature; a means of coming closer to Allāh. Experiencing hunger develops compassion for the less fortunate, and teaches one to be thankful and appreciative of all Allāh's bounties. It provides a break with rigid habits and is thus advantageous for the health. It guides and controls the part of a human's nature that one shares with the animals called hawa nafsu or $n a f s u^{282}$ so that human beings are led to do God-fearing (Arb taqwa) or positive things. This last aim of fasting is strongly emphasized. One teungku argued that nafsu may not be allowed to be a 'king' (Jam rajo) in one's self. The nafsu must be subordinate to intelligence. A person who is not able to restrain his nafsu has thus taken his own nafsu for his God. One elderly suluk follower described the creation of $n a f s u$ as follows:

Allāh created $n a f s u$, He then asked it; "Hi nafsu, who are you? (Arb man anta?) and who am I? (Arb man ana?)" Nafsu answered, "I am I" (Arb ana, ana) and you are you (Arabic anta, anta). This "uncultured answer" caused the nafsu to enter hell. After a long period, Allāh took the nafsu out of hell. Allāh asked it the same question. Nafsu also still answered "I am I" and "you are you". Because of its behavior, Allāh then punished it[nafsu] by not giving it food and drink for a certain period of time. Allāh then asked the nafsu again; "who are you?", and "who am I?" Nafsu answered

282 In the Qur'ān, nafsu has two meanings. Sometimes nafsu means 'self' (Indon diri) and in certain cases it means 'soul' (Indon jiwa). Nafsu does not always have a negative meaning. It is both strength and "moving energy" in life so that nafsu does not need to be killed but must be guided and controlled so that human beings are led to do Godfearing (Arb taqwa) or positive things. 
"I am a creature" (Arb ana makhluq) and "you are the Creator" (Arb anta khaliq).

This story demonstrates the nature of nafsu. It did not fear being thrown into hell's fire but it was aware of not being given food and drink for a certain period. The village teungku classified nafsu, corresponding to three stages of a person's development, from physical to moral and then to spiritual.

1. Nafsu ammarah is "the nafsu prone to evil and lust, inciting people to evil doings". A person who has this nafsu releases himself from religious deeds and does not oppose evil. He surrenders to his lust (Indon syahwat) and the invitation of syétan. Such persons happily transgress Allāh's orders and are greedy and boastful and have other "reprehensible" traits.

2. Nafsu lawwamah is "the self accusing soul". A person who has this nafsu condemns and hates every form of evil but sometimes succumbs to it. He is then aware of this and asks forgiveness from Allāh. He knows his own mistakes but he regrets them. If he does wrong he wants to be pardoned, it is difficult for him to get rid of his jealousy and pride, and he is too happy when being praised. Such a person finds himself weak in controlling carnal desires. It resembles the physical weaknesses of a child who does not want to fall but whose weak legs are unable to support him. But through spiritual training, this nafsu can be purified and become capable of attaining the final stages of its development, called nafsu mutmainnah.

3. Nafsu mutmainnah is "the nafsu at rest". It is at peace and protected from all forms of doubt caused by desires instigated by nafsu. In other words, at this stage a man becomes content. The teungku recited the Qur'ān to explain this state of nafsu, "[To the righteous it will be said],"O reassured soul, return to your Lord, well-pleased and pleasing [to Him] (QS 89:27-28). The character of a person who has this nafsu is generous and not stingy. He or she feels Allāh's mercy on him or herself always worships Allāh asking His forgiveness for his/her sins. This person has patience when calamities befall him/her and other praiseworthy traits which are reflected in his/her speech and actions.

The people are strongly advised to not follow the nafsu ammarah and the nafsu lawwamah. The human's nafsu should be in the state of nafsu mutmainnah so that they are able to protect themselves from hunger and illicit sexual yearning. The person who has this nafsu uses his/her intelligence (akal) guided by religion so that he or she can know Allāh's commands. This nafsu is able to guide $\mathrm{him} / \mathrm{her}$ to the right path by means of intelligence. It is said that the month of fasting is a way of guiding human beings to a good nafsu [nafsu mutmainnah]. The imàm quoted a hadìth saying, "A matter that I am afraid of for you, is when hawa nafsu and day-dream take over. Hawa nafsu prevents one 
from doing a good thing; meanwhile overactive day-dreaming causes one to forget the hereafter".

\section{Tarawèh prayer}

The interval between the 'sunset prayer' (Ach magréb) and the 'evening prayer' (Ach seumayang isya) is approximately one and a half hours. During this time, men rest at home, while women are busy washing. Everyone in the house then gets ready to go to the mosque to perform the 'evening prayer' and the 'special night prayer' (Ach tarawéh). Women wear a white cloak covering their heads and body (Ach teulekong) when they leave the house. On the way to the mosque, a husband usually walks behind his family. Arriving at the mosque, some people who have taken ablutions enter the mosque directly, and the rest stay outside to finish their cigarettes. Children chase each other in the yard of the mosque. When the call to prayer (Indon azan) is intoned by the bileu (Arb muazzin), all these activities cease, and everyone enters the mosque and sits side by side in several rows (Indon saf). The place for men and women is separated by a white cloth called a tabir "curtain" which is suspended from one side to another so that the women cannot see the men. The bileu invokes well-being for the Prophet (Ach seulawet) while waiting for people who come late. One of the texts recited is, "O Umar, Usman, Ali and Abubakar are the companions of the Prophet. Tuan Fatimah is the daughter of the Prophet and the Messenger of Allāh is our adoration". ${ }^{283}$ Several minutes later, the bileu pronounces the call to begin the prayer (Indon kamat) and everyone stands up and straightens their rows. Boys stand in the last row behind the men and girls stand in the last row behind the women. They are reminded by the leader of prayer to be quiet and not to make any noise while people are praying.

The tarawéh prayer is performed around fifteen minutes after the "evening prayer". There is no religious sermon (Indon ceramah agama) between the two

except on the first night and several nights in the middle of Ramadhan. ${ }^{284}$ The tarawéh prayer is performed in 20 raka'at (10x 2 raka'at) ${ }^{285}$ followed by witir

283 Indonesian, "Ya Umar Usman Ali, Abubakar sahabat nabi, Tuan Fatimah binti Rasuli, yā Rasulullāh junjungan kami”.

284 In other regency cities such as Tapaktuan and Blangpidie, this interval is filled by an Islamic sermon (Indon ceramah agama) which is carried out every night by different people on different topics.

285 See note 18 of Ch. 5 and note 8 of Ch. 12 about the definition of raka'at. 
performed in three raka'at. There are are thus 23 raka'at alltogether. Twentytwo raka'at is predominant in the village and in the dayah mosque as it represents the hallmark of proper practice among Perti or dayah people, whereas Muhammadiyah people perform 8 raka'at (4x 2 or $2 \mathrm{x} 4$ ) followed by witir three raka'at. ${ }^{286}$ In addition, beginning from the 16th day onward, the qunut, an innovation uttered at the "morning prayer" (Ach seumayang suboh), is uttered at the end of raka'at of witir prayer in the village and dayah mosque in Blangporoh.

Concerning the practice of the tarawè prayer traditionalists and modernists exhibit their differences quite publicly, although now, unlike in the past (Baihaqi (1983:146), the difference between these two beliefs do not cause any conflict, but only occurs at the level of opposing argumentation. Both groups regard the special "night prayer" as recommended but not compulsory which may be observed in the recitation of 11 raka'at or 23 raka'at. One said "I believe 11 raka'at or 23 raka'at are legitimate (Indon sah), most importantly, there is no difference in the amount of religious merit". One traditionalist in Blangporoh said "Not performing tarawèh at all is not a sin, but if someone would like to perform it, the more the better". He added, "Performing 8 raka' at is essentially good and lawful but it is only a minimum and, therefore, implies laziness". According to modernists, performing 20 raka'at of tarawèh prayer is heresy (bid'ah).The work is useless because unlike modernists practicing the tarawè prayer which is performed slowly and well, the 20 tarawè are usually performed badly and hurriedly.

Along with 20 raka'at of tarawéh prayer, the traditionalist follows more elaborate procedures. After each of their two units, the bileu utters the glorification of Allāh and praises the Prophet Muhammad, to which the others respond in chorus. After completing the tarawèh, the imām leads his congregation to express the intention (Jam niaek; Indon niat) for tomorrow's fasting (to prevent

286 Similarly, in Java the traditionalists (represented Nahdlatu Ulama or NU) practice 23 raka'at, whereas the modernists (represented by Muhammadiyah and Masyumi) adhere to the practice of 11 raka'at (Geertz 1976:221). I did not find that people perform 8 raka'at of tarawè prayer followed by 3 raka'at of witir prayer in Blangporoh but I found many people performing them in the Tutong and Panton Pawoh village, the neighboring village of Blangporoh. In addition, many people perform 8 raka'at of tarawèh prayer followed by 3 raka'at of witir prayer in Manggéng district, the neighboring district of West Labuhan Haji. Manggéng is one of the strongest bases of Muhammadiyah in South Acèh (Hasimi 2002:25). 
the people in the congregation from missing their intention). After uttering the niat in chorus the tarawè congregation is over. The elaborative tarawèh performed in the village mosque takes approximately one and a half hours (till 9.30). The tarawè in the dayah mosque takes longer as some special long prayer poems are uttered at the end of tarawèh and witir prayer.

\section{Tadarus}

The tradition of reciting the Qur'ān at night during Ramadhan is known by the term of tadarus (Ach meudaroh). This term derives from the Arabic tadarrasa, which means "to study". In Blangporoh, the term tadarus refers to the tradition of reciting the Qur'ān in the mosque or prayer house during Ramadhan only. During other months it is called baco Qur'ān (Ach beuet Qur'ān).

After performing tarawè prayer, women return home whereas many men stay in the mosque, where they form several groups, each having a special topic of conversation. Several people serve coffee and snacks to men sitting around cross legged facing each other on plaited mats in the middle of the mosque. Each person has a small bench (Ach reuhai) in front of him on which the Qur'ān is placed. The imām then opens the tadarus by reciting the first surah of

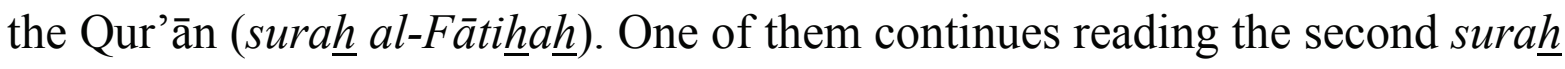
while some others follow him by memory and correct any misread verses or wrong utterances. He who carefully listens to the Qur'anic verses being read receives the same religious merit as the person who reads them. Between the readings of the verses, the others yell Alläh, Allāh or Allāh ya Rasulullāh. In addition, the better the rhythm the reciter puts into his reading, the louder the others yell Allāh, Allāh or ya Rasulullāh. When the reader feels tired he stops and someone else in the group takes his turn; the former reader listens (Ach simak) and becomes the corrector. The tadarus reciters use a loudspeaker. As a result, the sound of tadarus can be heard throughout the villages. The sound of tadarus being broadcasted from every mosque brings the night to life so that no one including children is afraid to go out in the dark night.

In tadarus every one can take a place and leave the group whenever he wants. Also, any reciter can stop reciting when he feels tired. It is common for one person to stop for a moment to have a drink or smoke a cigarette, after which he will return to his place in the group again and continue to recite the Qur'ān. In the past, in every Ramadhan month there were three groups of tadarus in the village mosque. One was for old people, another one was for adults 
and the other one was for the adolescents. Now they are mixed into one group so that those who know how to recite the Qur'ân well can guide other reciters who are "weak". The tadarus may proceed until late in the evening or until early morning. This depends on the number of those attending. Many devout people, however, read the Qur'ān individually at home.

When the whole Qur'ān has been read, people in the village prepare a feast called khanduri khatam Qur'än "khanduri for the completion of the Qur'ān". This khanduri is not as elaborate as other khanduri (such as khanduri bu (Ch.10)/khanduri mò'lot (Ch.7)) where a large meal is provided. Instead, men sit joyfully together in the mosque and eat snacks with coffee or tea. They eat the khanduri [food] served by the volunteering households. After eating, a special $d o^{\prime} a$ is invocated by the imām. In many villages in West Labuhan Haji, the khatam Qur'ān "the completion of the Qur'ān" is held on the last ten days of Ramadhan especially on the uneven nights of the 21st, 23rd, 25th, 27th or 29th. When this research was conducted in 2007, the khanduri khatam Qur'än in Blagporoh village was held on the 25th night of Ramadhan.

Unlike in the village mosque, there is no tadarus held after tarawè prayer in the dayah mosque since the suluk followers recite more dzikir, shamdiyah, tahlil, and do'a (see Ch.9). They recite the Qur'ān individually during the day and sometimes in the early morning since reading the Qur'ān during Ramadhan is considered very meritorious. Especially in the last ten days of Ramadhan more suluk followers, remain in the mosque (Indon iktikaf) to receive merit and many others combine praying or reading the Qur'ān in order to receive even more merit.

\section{Nuzul Qur'ān}

It was in the Ramadhan period that the Qur'ān was revealed to the Prophet Muhammad. Thus the holiness of the Ramadhan period is said to stem from the fact that it hallmarked the day when the angel Gabriel began the transmission of Allāh's message to the Prophet Muhammad. The exact date has never been identified, but is believed to be one of the last ten days of this month, which Muslims call lailatul qadar "the night of the power". According to Qur' anic explanation, the night of lailatul qadar is better than a thousand months, in that each good deed performed on that night will receive the same rewards as those done over a period of a thousand months (QS 97:3). Although the Prophet Muhammad explained that the night of lailatul qadar will occur during odd nights 
in the last ten days of Ramadhan, many Muslims believe that lailatul qadar only comes on the night of the twenty- seventh of Ramadhan (Nur 1996:63). ${ }^{287}$ In Blangporoh many suluk followers and villagers visit the Syeikh's tomb on this night to offer prayer to him and receiving 'blessing' from him in return. ${ }^{288}$ They claim that the Syeikh has received numerous followers, intangible knowledge and power associated with Islamic mystical practice as gifts from Allāh. People thus pay homage to the Syeikh in part by means of gift-giving to the Syeikh. According to them, being blessed, in such a manner is close to Allāh in the hierarchy of authority. "What one finds then is not unlike the situation described by Ibn Khaldun (1967:304) in which persons with a reputation for piety are frequently the recipients of the gifts because "the great mass believes that when they give the Sheikh presents, they serve Allāh" (Soares 1996). "By giving gifts to others, people are generally seeking to assure their place in the next world, but they frequently wish to obtain merit and Allāh's blessings in the world where they are living as well" (ibid).

In the Acèhnese perception, at a particular moment of lailatul qadar, all trees will bow to the ground in the direction of Mecca (kiblat). ${ }^{289}$ Since the lailatul qadar is "better than a thousand months" and the Qur'ān was presumably revealed to the Prophet Muhammad on this night, Blangporoh villagers hold a small ritual meal (khanduri) and the nuzul Qur'än celebration on this night in the hope that this will be on the "night of the power" which is believed to occur on the $27^{\text {th }}$ night of Ramadhan. By doing so, they believe that they will receive greater religious merit, both the religious merit of nuzul Qur'ān's commemoration and of lailatul qadar. The ritual marks the Qur'ān as the way

287 In Saudi Arabia, many people believe that the lailatul qadar will occur on 27th of Ramadhan. During the night, around one million people come to the Great Mosque at Mecca and at Medina to observe the tarawè prayer. Almost everyone spends the night by reciting $d o^{\prime} a$ and $d z i k i r$ (religious chant to remember Allāh) (Yamani 1937:85; Nur 1996:64).

288 Similarly, in Morocco, for example, many people pay a special visit to the shrine tomb during this night for gift-giving exchange. They believe that the spirits who have been locked up during Ramadan are released on the twenty-seventh and return to earth (Buitelaar 1993:68).

289 In the past, according to Snouck Hurgronje (1906:235), on the evening of the twentyseventh of Ramadhan every household sets a special lamp and puts it in front of the door of a house. However, this tradition has not survived. Nur's informant said that Snouck Hurgronje was wrong, the lamp was not a part of lailatul qadar, but it was intended as an expression of happiness at the coming of the uroe raya "id day". In the past, because there were no candles, children in Acèh played with lamps (Nur 1996:64). 
of life for Muslims, regulating all their actions. Unlike other holy books, the content of the Qur'ān is still believed to be authentic from the day of its revelation by Allāh through the messenger of Gabriel to the Prophet Muhammad. The nuzul Qur'ân's celebration has always been a sacred tradition for the community. People believe that Allāh placed much religious value on the night of revelation. Therefore the night should be celebrated and older people advise the young not to forget to perform the ceremony annually. When the imām announces the date of celebration, the people in Blangporoh then tell each other about their plans to prepare certain cakes for the night of celebration, and to go to the market to buy their ingredients. ${ }^{290}$

On the night of nuzul Qur'ān, a well known preacher is officially invited via letter by the village imam to the mosque. Meanwhile the young males and females decorate the podium with colorful paper and traditional clothes. The nuzul Qur'ān is held in the village mosque after tarawèh prayer at about 21.30 $\mathrm{pm}$. The hall of the mosque is divided into two parts, the front part for men and the back part for women. As when praying tarawèh, a curtain is suspended between the men and the women to avoid contact and communication that could lead to lack of attention to the nuzul speech. In the mosque's yard, some menstruating women, having come to listen to the speech, sit on plaited mats brought from their homes. They not allowed to enter the mosque.

Before the speaker delivers the speech, the imām warns all attendees to be silent and to pay attention to the speaker. Preceding the speech, a young man recites several Qur'anic verses in order to receive blessing from Allāh. The reciter is famous in the region for being able to read with a good rhythm. After several verses of the Qur'ān have been recited, the speaker comes to the podium to deliver his lecture on nuzul Qur'ān. In his speech, he mainly emphasizes the history of the revelation of the Qur'ān at the time of the Prophet. He mentions that the Qur'ān was revealed in two places; Mecca and Medina. The verses revealed in Mecca are called Makiyah and those in Medina Madaniyah. He tells how the Qur'ān was revealed gradually and consists of 114 chapters or surah. Each surah contains verses called ayat. The surah are not in the order in

290 Besides bringing the food to the mosque on the night of celebration, some households invite public figures of the village to come to their houses to enjoy the meal. If the invited people do not attend due to certain reasons, instead, they invite students of the village boarding school to replace them. Before eating, the imām recites $d o$ ' $a$ to seek the "goodness" from Allāh. Reciting $d o$ 'a on this night brings much strength and benefits due to the moment of nuzulul Qurān. 
which the revelation was received. In general, the longer surah were revealed in Medina; the shorter in Mecca. It is Allāh's miracle and incapable of being imitated and sublime in its form and content. The total number of its verses is 6,666. The speech ends after two hours when the entire history of the Qur'ān has been told.

During the speech, the audience remains silent and listens carefully. The speech is taken as "knowledge" by the audience as the content is full of advice and religious values that are useful in Muslims' daily life. At the end of the speech, the speaker recites $d o^{\prime} a$ asking for long life, strength of faith, and acceptance of all good deeds. The master of ceremony closes the program. On the way home, people talk to each other and discuss the speech that they have just heard.

Meanwhile at the dayah, the celebration of nuzul Qur'ān is celebrated by more than a thousand suluk followers because many of them enter the suluk ritual on the last ten days of Ramadhān. One day before the celebration, the dayah leader has informed the followers about nuzul Qur'ān. The people are asked to prepare cakes. At sunset on the night of nuzul Qur'ān, the suluk followers break the fast together. Several minutes before the fast is broken, many suluk followers are ready with their bowls into which cakes are piled. When the bileu calls, all the participants set about finishing their drink and cakes. After breaking the fast, all suluk followers return to their "own place" to have dinner. Afterwards everyone comes into the dayah again to perform religious services under the direction of the dayah leader.

Nuzul Qur'ān is celebrated after "evening prayer" and tarawèh prayer at about 10 o'clock at night. The celebration is begun by the speaker in Acèhnese, the language of most suluk followers. He is a religious leader who knows the Islamic law and understands the suluk's performance well. Like the celebration in the village mosque, the celebration of nuzul Qur'ān at dayah mosque begins with reciting Qur'ānic verses by a person selected from among the followers. Therefore all attendees listen with interest due to its fluency and good rhythm. Next, the main speaker steps onto the podium and begins to describe the history of the Qur'ān revelation and how to practice its teaching in real life. The program is closed by reading do 'a by an appointed person.

The attitude of the listeners in the village and dayah mosque varied. Some of them concentrated on the speaker, particularly people who sat near the podium. Some old men were sleepy and sometimes even fell asleep for a moment. 
Some others, particularly young people sometimes whispered amongst themselves while the speaker was speaking. In general, the attitude of listeners at this celebration is similar to that of listeners at any other public sermon (Indon ceramah) in the district.

\section{Zakat fitrah}

The zakat fitrah ritual (from Arb zakat "to purify" and fitrah "the purity") completes the process of purification for fasting. It serves to atone for any involuntary negligence on the part of people fasting during Ramadhan and to provide food for the poor and the needy people on the day of idul fitri. The Blangporoh people consider it to be very important since it is not just a religious obligation but it is also considered to complete the fasting. One teungku said, "One's fasting is not valid until after one has paid the zakat fitrah. The fasting rewards remain hanging between earth and paradise". Therefore, every fasting person must pay it; otherwise the fast has no meaning for him/her and the deed of fasting (Ach/Indon amalan puasa) cannot reach Allāh.

The zakat fitrah is called "zakat of the soul" (Indon zakat nafsi or jiwa) because every 'soul' should pay for it, even a newly born baby. Besides obeying Allāh's command, its function is said to purify those fasting from useless or 'dirty words' (Jam kato kotor) and to eliminate "the meaness in the human heart". A hadìth says, "Those who give it before the 'id prayer, give the accepted zakat fitrah, meanwhile those who give it after performing the 'id prayer, give as normal charity and not as the zakat fitrah". A teungku told this story "Usman bin Affan (the third caliph) once forgot to give it before performing the 'id prayer. He freed a slave. He then went to the Prophet and said, "O Prophet I forgot to pay the zakat fitrah before the 'id prayer. I then freed a slave", the Prophet answered, "If you freed one hundred slaves, your action still did not reach the value of the zakat fitrah which is paid before performing the 'id prayer". This story demonstrates that paying the zakat fitrah before the 'id prayer is very significant in order that "there are no impoverished inhabitants left without staple food on this joyful occasion [i.e 'ìd day]".

The zakat fitrah also functions to cleanse the givers (muzakki). One teungku claimed that fasting brings the Muslim only to the door of paradise, and no one can enter paradise before giving the zakat fitrah. He said that by giving it, Muslims become cleansed, and therefore can enter into paradise. Perhaps, this idea has become the strong motivation for the Aneuk Jamee to 
arrange a special stock of rice on the last few days of Ramadhan to give as their zakat fitrah.

Giving the zakat fitrah takes place in the village mosque after the performance of tarawè prayer. ${ }^{291}$ Several days before giving it, the committee announces the schedule to all tarawèh praying in the mosque. The zakat fitrah given consists of either rice or money. The gift in rice is 1,5 bamboos per 'soul' (about 3, 5 liters) and the gift in money is about Rp 17, 500 per "soul" (jiwa). Most villagers pay it in rice since many teungku say that the true zakat fitrah consists of the main staple food of the people, since the Prophet $\mathrm{Mu}$ hammad paid it by using wheat as the staple food at that time.

The family head gives the zakat fitrah directly to the teungku, as one of the zakat fitrah's collectors, in the mosque. Should he have no time; the zakat fitrah can be given by his son. In giving it one must declare to the teungku that the rice is the zakat fitrah from all members of his family. Teungku Usman who has five children for instance explained to the teungku, "This is our zakat fitrah that Allāh requires us to give. I give it to teungku on behalf of my family, which comprises of seven people (I, my wife, and my five children)". After that, the teungku measures the rice by using a special tin to determine whether it is the correct amount. If that is correct, both the teungku and the giver of zakat fitrah shake hands. At this moment, the teungku says to the giver: "I receive your zakat fitrah (by mentioning the name of giver) and the zakat fitrah from your family. May Allāh bless you and your family".

For the parents whose children learn the Qur'ān with certain teungku in the village or at dayah, their zakat fitrah will be given directly to that teungku. It is to receive the religious merit as well as to receive the 'blessing' (beureukat) from the teungku who are close to Allāh and even sometimes deemed as saints (Indon aulia). In addition, the housewives give their children's zakat fitrah to the village midwife who has helped them in the process of delivery.

The zakat fitrah that has been collected is kept by the treasurer of the mosque for several days. The treasurer also prepares the requirements of the committee members such as plastic bags, gunnies, a tool for measuring rice

291 The zakat fitrah's committee does not collect the zakat fitrah from each of the givers' house. They are passive and only sit and wait at the mosque. Whereas in a hadith from Ibnu Abbas it is clearly stated, "Zakat is taken from the rich and given to the poor amongst them" In the Qur'ān (9:103) it says, "Take, [o Muhammad], from their wealth charity (zakat) by which you purify them and bring them prosperity and invoke [Allāh's blessing] upon them..." 
(Ach arèe) etc. On the night when the zakat fitrah is distributed the treasurer prepares 'light food' (Indon makan ringan), such as porridge from green beans, cakes and drink. The last task of the zakat fitrah collector is to make a report to the society about the number of portions (Arb snif) in which it has been divided and distributed. According to the Qur'ān, the zakat fitrah must be given to eight categories of people (snif) Qur'ān (9: 60) says:

Zakāt donations are only for the poor and for the needy and for those employed to collect [zakāt] and to bring hearts together [for Islām] or to free captives [or slaves] and for those in debt and for the [stranded] traveler-an obligation [imposed] by Allāh. And Allāh is knowing and Wise".

In Blangporoh, the zakah fitrah is divided into 4 categories of people; needy (Indon fakir) ${ }^{292}$, poor (Indon miskin), ${ }^{293}$ zakat collectors (Indon 'amil zakat) ${ }^{294}$ and religious functionaries (sabilillah) because other categories such as freeing slaves are no longer required.

The portions for the needy and the poor are distributed onthe night of meugang, a night preceding the night of idul fitri while other portions are distributed on the night of idul fitri. On the night of meugang the zakat fitrah's gifts of rice and money are distributed to each receiver by using pedicabs. These portions are intentionally distributed on this night so that on the following day [the meugang day] the receivers can buy clothes for their children, and the needy families are able to attend to the mosque on the day of idul fitri happily.

In distributing the zakat fitrah, the committee is helped by the village people as this work is said is to be a religious service to Allāh when the deeds of religious service are multiplied. The recipients of the zakat fitrah are women. Receiving the rice, the committee on behalf the teungku urges the woman and all her family members to increase their religious service and reminds all the recipients that every portion of fitrah rice contains Allāh's blessings. Hence, no portion of the zakat fitrah rice should be wasted.

292 The term fakir here is a person who does not have wealth or has wealth but less than half of what they need to live on.

293 Meanwhile miskin the person who has half of what he needs but it is not enough.

294 Amil are the persons who get an official letter from the village head to collect and to distribute the zakat fitrah. 


\section{Conclusion}

In this chapter, I have described how the people and the suluk followers in Blangporoh adjust their lives during the month of Ramadhan. From an anthropological perspective, Ramadhan can be regarded as a "liminal time" in the Islamic calendrical rituals. Liminality is a time and place of withdrawal from the social world to another world (van Gennep 1960) (or normal modes of social action) or as an interstructural situation (Turner 1979:234). The liminal period as defined by Turner is an ambiguous condition, dissolution of all categories and classifications, a suspension of normative obligations, and a period of seclusion (Morris 1993:253; Nur 1996:82). Therefore, during liminality, room is created for the members of a society to re-evaluate their basic assumptions into new meaningful wholes (Buitelaar 1993:129; Nur 1996: 82). Regarding Ramadhan ritual activities from the view point of the people and the suluk followers in Blangporoh village, there are three notions which lend meaning to the performance of Ramadhan rituals.

The first notion is Ramadhan as a month in which to purify the heart, the controller of the mind and source of all actions. During Ramadhan, the Aneuk Jamee's perceptions about the importance of purity become apparent. This concern with the importance of purification emerges not just because all religious services would be invalid unless the conditions of purity were met, but also because the core of Ramadhan itself is a month of forgiveness. Fasting people fear that they will not attain the core of Ramadhan if they are impure. In this context, people refer to this purification in the Prophet's word that "Indeed in the body there is a piece of flesh, when it is reformed (purified) the whole body becomes purified; if it remains corrupted the whole body becomes putrid; that (piece of flesh) is the heart (Arb qalb)". The Qur'ān also exhorts the purification of the heart when it says: "Successful is the man who purifies himself (QS 87:14), and "Surely, the successful one is the one who purified his/her soul (QS 91:9), and Allāh loves those who keep themselves purified (QS 2:222).

The second notion is Ramadhan as a month of religious service in order to receive spiritual training. Abstaining from eating, drinking, and sex for a limited number of hours during the whole month of Ramadhan provides a practical training for their moral elevation. During this month, spiritual training becomes more intensive when observing the voluntary last ten days worship of $i$ 'tikaf. By temporarily severing family contacts and confining oneself within the 
boundary of the mosque one comes closer to Allāh and feels the pleasure of inner worship. It is believed that each good deed performed during Ramadhan brings the performer one step closer to Paradise. Thus, during Ramadhan worship is intensified. Religious practice and moral values are strengthened.

The third notion is Ramadhan as a month of joy. This can be seen in the joy experienced by families reuniting and the joy associated with the many khanduri held during Ramadhan such as the khanduri of khatam Qur'än and nuzul Qur'ān. Joy is experienced when people enjoy a common meal of rice and various special meats in a khanduri during Ramadhan. For men, the significant joy of Ramadhan is in withdrawing from the usual work necessary to earn a living. Instead, they gather day and night with friends in the mosque, and also spend time in the warung during the night. For a woman, the great joy of Ramadhan is above all in being able to serve the family an abundance of special food and to redecorate the house. The greatest happiness of Ramadhan is, of course, the celebration at the end of Ramadhan.

These three notions are interrelated and as a result, to some extent, it is difficult to make a distinction between them. I consider that the Blangporoh Muslim fast of Ramadhan in the light of Turner's theory in which Blangporoh society endeavors to achieve the harmony of communitas, a particular sense of being united. It is important to recognize that these notions on a practical level do not contradict the core of Ramadhan on a normative level. Indeed, these three notions can be deemed as an ideal path for the Aneuk Jamee and the suluk followers to achieve the core of Ramadhan as revealed in the Qur'ann and the hadith. Ramadhan offers people the opportunity to renew and invigorate their moral as well as their physical lives. Ramadhan is a moment for the Aneuk Jamee and the suluk followers in Blangporoh to return to their basic identity as an Islamic and social community. Through (experiencing a special life during) Ramadhan, they endeavor to proclaim to themselves and to other people that their basic identity as Muslims and as the Aneuk Jamee have not changed. 


\section{Chapter 12}

\section{The ritual of uroe raya puasa}

Syawwal is the tenth month of the Islamic lunar calendar, which coincided with the month of October in the Gregorian calendar. The celebration on the first day of this month marks the end of Ramadhan. In Islam the celebration of the end of Ramadhan is called 'id al-Fitr (Indonesianized Arabic idul fitri), when the fasting is "broken" with special prayer and festivities. Fitr is derived from the word fatar meaning breaking. Another connotation of fitr is derived from fitrah or "alms" meaning nature, purification. "Id al-Fitr thus means "breaking the fast" and "returning to nature or purity" as if a baby had just been born. In the Acèhnese, 'id al-Fitr is called uroe raya puasa, "the great day after Ramadhan". It is the celebration of Allāh's magnanimity in providing nature and purity to human.

\section{The ritual of the uroe raya puasa}

The ritual of the uroe raya puasa cannot be separated from the religious services performed by Muslims during Ramadhan lunar month. The relation between fasting (Jam puaso) and the uroe raya puasa can be understood as the relationship between "struggle" and "victory". Fasting is primarily the act of willingly abstaining from basic human urges; eating, drinking, and having sexual intercourse and it is a spiritual journey to release the human body from satanic powers. Meanwhile uroe raya puasa is a "victory feast" a day in which those fasting are freed from satanic desire. They have successfully observed the fast and have passed all kinds of "tests" that could break their fast. In the Acèhnese culture, men are characterized as possessing both rationality (Indon akal) and passion or carnal desire (Indon hawa nafsu). Uroe raya puasa is a time when men feel renewed and in full possession of themselves (Siegel 1969:188). This happiness is clearly seen on their faces during the celebration.

Like the day of uroe raya haji (Arb 'i $d$ al-Adha or "the festival of sacrifice"), the day of uroe raya puasa is a national holiday. In the context of Indonesian Muslim social life, it is regarded as an important moment to give and to receive forgiveness from others. During the days prior to the day of uroe raya, Indonesian Muslims are always eager to return to their hometowns (Indon 
mudik lebaran $)^{295}$ to spend their holidays with their relatives and close friends during this special day to enjoy freedom from tight working schedules and normal activities. The return to their villages of origin as well as the wearing of new clothes is a sign of the significance of the uroe raya in the life of Indonesian Muslims. In addition, the Acèhnese in general, and the Aneuk Jamee in West Labuhan Haji district in particular, regard it as obligatory to acquire "everything new" (Indon serba baru) on the uroe raya day. Everything new from a car, a motorbike, bike, furniture, clothes, and newly-painted houses to a new haircut is acquired in order to celebrate the "victory day" after the fasting month. ${ }^{296}$ Young and old men go to barbers. Some have their beards shaved, some only have their moustaches trimmed and many have their hair cut. As there are many people at the barber shop, they sometimes have to queue up on the days preceding uroe raya in Blangkeujèrèn, the capital city of West Labuhan Haji district.

Some affluent families in Blangkeujèrèn buy new things for the celebration of uroe raya such as furniture, praying mats as well as several new sets of clothing for the children and repaint the walls of the houses. Using new furniture at uroe raya has long been practiced. One housewife said "when my parents were still alive, we received several pieces of furniture to replace the old ones; the walls of the house had to be repainted in a different color, not to mention wearing new clothes at uroe raya". In the past prior to the conflict between the Acèh liberation movement and the Indonesian government, many women would go to the hairdresser to have their hair cut and/or straightened and their face made up for the "festival day". Nowadays they seldom go to the hairdresser's as women are obliged to wear a head scarf (Indon jilbab). There is no need for them to have their hair or face done. A young man in Kutaiboh village told me that "I am happy as my parents have bought me a motor bike even though it is bought on credit. It is good so that I do not have to go on foot or go with other friends' motor bikes to visit to my family's house or my friend's house". There is a different feeling when things are bought for the uroe raya "festival

295 Mudik lebaran refers to the tradition of those who live in urban areas returning to their home area during 'id al-fithri as many villagers migrate to cities and live there for long or short periods. Once a year, these people return to their homeland, especially during 'id al-fithri. Through mudik lebaran, the migrants maintain close ties with their home village, and bring their earnings to their families in the village (Blackwood 1993:10; Nur 1996:75).

296 See Waspada, September $21^{\text {st }}, 2007$. 
day" and when they are not bought for the uroe raya. This feeling of a difference, according to an informant, is strongly felt by many people in the village, particularly poor people who are only able to change their old clothes for new ones on the uroe raya day.

The enthusiastic celebration of the uroe raya with "everything new" influences the economy through increased purchase of certain consumer products such as cars, motor bikes, bikes, furniture and clothes. Motorbikes and furniture are sold out prior to this occasion. Cloth sellers say that in the month of Ramadhan month, ten times more profit is made compared ordinary days since many people buy new clothes, praying mats, and rimless caps at the end of this month. "When people have money to spare they buy not only new clothes but also chairs and dining tables for receiving guests on the uroe raya. It is not surprising that several days preceding the uroe raya, street markets are filled with people. Here it is clear that the concern is the acquisition of new things. In contrast, the secretary of Islamic scholar (Arb 'ulamā') association in Acèh, Teungku Faisal Ali says that according to religious teaching there is no obligation to buy "everything new" to celebratethe "festival day" but more importantly 'idul fitri (from $\bar{l} d$ al-Fitr) means "a return to cleanliness". This idea must be present when celebrating "idul fitri. ${ }^{297}$ The imām pointed out that celebrating the uroe raya with "everything new" is of religious concern as jealousy might arise when people show off their new things. He further added that the "festival of breaking the fast" is the happy day after a person has fasted for a month. The religious service of fasting along with other religious services is certainly a joy for people who perform it sincerely so that the uroe raya is an appropriate moment to ask for forgiveness from Allāh and at the same time to ask and to receive forgiveness from fellow Muslims, and that it is surely not the time to act grandly and to show off new possessions. Celebrating the uroe raya to ulama $\bar{a}$, is therefore an opportunity to cleanse and renew the moral state of being.

With regard to asking and receiving forgiveness, the previous imām of Blangporoh village contends that "it is better to forgive a person who comes and asks for forgiveness from you". A person who wants to forgive others has a fabulous "soul/mind" (Indon berjiwa hebat). He is reminded of the Prophet's hadith narrated by Bukhari and Muslim saying, "Those who believe in the doomsday should "mend friendships". Friendship can ease the earnings of a

297 See Waspada, September 21 ${ }^{\text {st }}, 2009$. 
livelihood and allows one's service to be remembered by others. The victory from Allāh comes as long as human beings are united among themselves. In contrast, people who like breaking the bonds of friendship will be defeated by syétan (Satan). It is said that friendship is the "soul/mind" (Indon jiwa) of Islam. The uroe raya is a noble day as the day of "returning to cleanliness" for the people who have just finished observing a month of fasting. Those who exalt Allāh with special chanting will be the winners as well as clean, that is why the uroe raya should be "associated" with the recitation of the phrase of praise "Allāh is great" (Arb takbir), the devotional repetition of the utterance "Praise be to Allāh" (Arb tahmid), and sentences glorifying Allāh (Arb tasbih ). This day is a spiritual day of joy because Allāh eliminates people's sins. Wearing new clothes, using new prayermats, smelling of fresh perfume, sitting and eating on brand new furniture on uroe raya does not only make people happy; it also makes them feel clean expressing they are freed from sin.

\section{The preparations for the "festival day"}

The preparations for celebrating the "festival day" are underway from the beginning of Ramadhan. As the day of the uroe raya approaches, it becomes a more frequent topic for conversation. Generally, women talk about uroe raya in relation to the preparation of traditional cakes which will be served to guests as well as using new furniture and decorating the rooms. Devout Muslims talk about uroe raya in terms of forgetting all past grievances. A household head talks about uroe raya in terms of how to obtain the money to buy meat, new sets of clothes, new furniture. Newly married couples talk about uroe raya in terms of paying a visit to both their families, the village elders, neighbors, close friends and how and when to go to their houses. Children excitedly anticipate wearing new clothes, shoes or sandals and visiting family members to receive money. Teenagers are allowed to smoke and go out with their friends. Whenever people sit and talk, such as in a coffee shop (Ach warung kupi), a prayer house (Ach meunasah), at markets, or at home, the uroe raya is discussed, either as a problem or as an anticipated holiday. ${ }^{298}$

298 The preparations for celebrating the uroe raya in West Labuha Haji district, South Acèh are much similar to those for celebrating the uroe raya in Lamno district, West Acèh, see Nur (1996:76). 
The most important activity in the celebration of the uroe raya in the village is the preparation of a variety of traditional cakes which has been planned by housewives since the middle of Ramadhan. Parents who have married off their daughter just before Ramadhan begin to prepare traditional cakes from the beginning of Ramadhan as they have to revisit the daughter's husband's parents' house and bring cakes to husband's parents on the uroe raya. Preparation of these cakes is not an easy task and people in Blangporoh solve this problem by "helping each other" (Indon gotong royong) by cooking together during the day to strengthen their social relationships. As a result, the nature of the preparation of the uroe raya traditional cakes is similar to that of other communal activities as practiced in ritual of khanduri bu, apam, bungong kayèe, padé, $m o ̀ ' l \bar{o} t$, etc. "Everything is performed as a community, and this leads to continuous, cooperative involvement in various aspects of social life" (Nur:76).

Walking around the villages in West Labuhan Haji district during the last week of Ramadhan, one can find many groups of women busy cooking traditional cakes individually at night and collectively during the day so that they are not able to perform seumayang tarawè ${ }^{299}$ in the mosque at night. Cooking traditional cakes for uroe raya is considered to be a necessity in the Aneuk Jamee society. If they do not do so, there is "no taste" (Indon tidak ada rasa) in the welcoming of uroe raya (Emtas 2008:83). One housewife argues that sincerely preparing cakes for the family and the guests on the uroe raya is a source of religious merit (Jam pahalo;Ach/Indon pahala) for the women as the men cannot make them. Nur's female informants say that women's religious merit is even greater than men's because women's activities during Ramadhan are greater than usual, whereas during Ramadhan men only teunget ("sleep") which she refers to not only as "sleep" but also connotes laziness (Ach beu oe) (Nur 1996:77). From the women's perspective, therefore, men are regarded as lazy during Ramadhan as all their activities are reduced. On the other hand, women have their own way of receiving more religious merit, that is, through increasing their activities during Ramadhan (ibid).

On the last two days preceding the uroe raya the markets in West Labuhan Haji district are full of people. Many of them also go the market in Manggèng and Blangpidie, the neighboring district's markets. They purchase new items

299 A special prayer is performed in the evening of the Ramadhan month which is alternate Qur'anic recitations and private prayers. 
necessary for the uroe raya such as clothes, prayer mats, rimless caps, shoes and sandals. Most parents accompany their children to buy the new clothes and other new items at the market but many husbands let their wives do their own shopping as their husbands do not know which clothes they prefer. All transactions are done in cash where commodity exchange takes places where there are no implied residual obligations or relationship between the buyers and the sellers. It is regarded as inauspicious however for men to buy their wives' clothes, therefore women have to buy the clothes themselves. As in Lamno district, West Aceh, although women are not generally permitted to go out during fasting, the approach of uroe raya requires them to depart from this practice (Nur 1996:78). Here a contradiction emerges between the joy of the festival day and religious values as women are allowed to go out shopping and mix with other men in the markets as part of their preparations for uroe raya. This leads to a loss of religious values and only the "joyous atmosphere" remains apparent (ibid).

The final day of Ramadhan is also recognized as meugang for the "festival of breaking fast" (Ach meugang uroe raya puasa). Less meat is prepared for this meugang than in the two days preceding the coming of Ramadhan month (Ach meugang puasa). The difference in the amount of the meat prepared is related to the purpose of serving meat at the meugang. Prior to the fasting month, meugang meat is intended as a specific side dish for the family throughout Ramadhan indicating how deeply enjoyable it is to perform religious service in Ramadhan month (see Ch.10), whereas the meat of meugang for the uroe raya puasa ("festival of breaking fast day") is intended to celebrate the joy of the uroe raya itself because it is assumed that people have already successfully cleansed their "soul/mind" (Jam jiwo) during the Ramadhan month. On the day for meugang of the uroe raya puasa, once again a newly married man must provide his wife's family with raw meugang meat as a symbol of care and the wife's family gives the cooked meat, sugar and cakes to her husband's family as a counter gift.

\section{Reciting the takbir on the final day of Ramadhan}

After sunset on the last day of Ramadhan, the imām together with a group of people attend the Blangporoh mosque and recite special religious chants proclaiming Allāh's greatness called takbir (Ach teukeubie). Exalting Allāh in 
Arabic follows the tradition in other parts of the Muslim world although the chanting melody must be local. The verses of takbir are translated as follows:

Allāh is the greatest (3x)

There is no deity except Allāh

Allāh is the greatest, Allāh is the greatest

And praise be only to Him.

Surely Allāh is the greatest

The abundant praise be only to Him

Glory be to Him, day and night.

There is no deity except Allāh, the One true God,

He fulfilled His promise, He supported His servant,

He granted his soldiers a manifest victory,

And He inflicted decisive defeats on allied enemies.

There is no deity except Allāh,

And we worship none but Him, with sincere devotion,

Even though the disbelievers may resent it.

The takbir is recited using a microphone and loudspeakers. The sound of men reciting resounds throughout the villages. The takbir is also performed in the boarding school's mosque and in neighboring villages' mosques. In the past, after the "noon prayer" (Ach seumayang 'ashar) on the last day of Ramadhan a large drum (Indon bedug) was suspended horizontally at the village mosque. It was used by a group of young men which created the expression "the drum is beaten as a sign that the "festival day" is coming" (Ach gedamgedum tambo di pèh, tanda jadèh uroe raya).

On this night, two hours after the "night prayer" (Ach seumayang isya), groups of people from the capital city of West Labuhan Haji district, Blangkeujèrèn recite takbir while driving round and round the villages on large and small trucks equipped with sound systems, led by a car with a loudspeaker. The takbir is called out over and over again. The sound of men reciting takbir can be heard everywhere in all villages till $11.00 \mathrm{pm}$ so that this night is called malam teukeubie (the night recital of the prayer of praise "Allāh is great"). The sound of bamboo cannon (Ach beudée trieng) lit by the young men of the village enlivens this evening. Children light candles in the yards, young boys light sparklers on the village streets, while women remain in the houses preparing special food such as lontong, tapèe, keutupek, etc and iron dresses for the morning congregational service of worship at uroe raya. The ending of Ramadhan is 
thus acoustically marked by the evening's amplified proclamations building up a sense of expectancy for the next morning's worship.

By about six o'clock on the following morning, that is the morning of the first day of uroe raya [the first day of Syawwal] several of the best Quranic reciters begin to chant the takbir over loudspeakers in the village mosque. Everyone takes a bath to clean the body after the completion of Ramadhan fasting. Men, women, and children are dressed in their finest: men in fine new clothes and sarong ${ }^{300}$ with some wearing white garments that leave only their faces visible; women in brightly colored clothes, sarong blouses and wearing perfume. They have something to eat, preferably something sweet, before walking in new sandals to the village mosque for a special communal prayer called seumayang uroe raya "the congregation for $\bar{i} d$ prayer".

\section{Seumayang uroe raya, "the congregation for ìd prayer"}

This recommended communal prayer is performed by everyone as part of the acts necessary for the day of the uroe raya; men and women, adults and young children are present at the mosque with the men and boys filling the front spaces and the women and girls in the back. ${ }^{301}$ Due to the presence of two mosques in Blangporoh village - one is in the boarding school complex, the other in the village center - some villagers perform this communal prayer in the boarding school's mosque but most go to the village's mosque to perform this congregational worship. The communal prayer is no different from ordinary prayer except that the beginning of the first and second raka'at, ${ }^{302}$ takbir of "Allāh is greatest" (Arb Allāhu akbar) ${ }^{303}$ is uttered twelve times respectively in an audible voice, instead of only once as is done during ordinary prayer. The takbir is uttered seven times during the first raka'at and five times during the second raka'at. After saying takbir at the beginning of the prayers (Arb takbiratul ihram) in the first raka'at, takbir is recited seven times, with hands lifted with each takbir. After the seven recitations of takbir, the prayers are

300 Skirt made from a piece of fabric wrapped around the body and fastened at the waist (worn by men and women).

301 The imām says "even menstruating women are encouraged to the prayer's ground but they should keep away from the actual place of prayer".

302 The essential unit of the prayer ritual, consist of bows and prostration of bows and prostrations performed a prescribed number of times.

303 Recitation of laudation, "Allāh is great" (Arb Allāhu akbar) or the act of glorifying Allāh by declaring in an audible voice: "Allāh is great". 
performed in the usual way (reciting the sürah al-Fätihă $\underline{h}$ (QS 1:1-7) and one surah from other elective sürah. In the beginning of the second raka'at, five takbir are recited in the usual way. Between takbir the chanting as a part of the confession of faith (Indon zikir) is recited as follows:

\author{
Subhanallāh \\ Wal hamdulillāh \\ Wālaillā haillallāh \\ Allāhu akbar
}

\author{
Allāh is Holy \\ And all praise is due to Allāh \\ And there is no deity except Allāh \\ Allāh is the greatest
}

This special communal prayer is followed by a sermon which stresses those significant lessons that must be learned by performing good deeds during Ramadhan- Below is an extract of the sermon delivered by the imām in the village mosque:

There are five important lessons that must be defended in every day life by every individual in order to become a clean individual: Do not take and use unlawful wealth; During Ramadhan we have to keep away from unlawful goods. Thus there is no reason to take the unlawful one. The society that lives with unlawful goods is a fragile society. If Allāh shows that the unlawful wealth resembles dirt, intelligent human will never take it because that wealth is never the same as the lawful one. The unlawful wealth destroys the orderly life while the lawful one spreads the "goodness" (Indon kebaikan).

Restraining hawa nafsu (carnal desire): During Ramadhan we have successfully restrained ourselves from being immoral. This indicates that $h a-$ wa nafsu is very weak. Human beings are not creatures that are restrained by hawa nafsu, but rather they who restrain their hawa nafsu. There is a difference from animals that have no mind (Indon akal). Human beings are creatures that regulate their hawa nafsu's distortion.

Subduing syètan (Satan): We have proven that during Ramadhan syètan has no power. Look at mosques; they are full of people during the nights of Ramadhan. In houses, prayer houses, mosques and other places people are heard reciting the Qur'ān. This is evidence that syetan is in fact very weak so that it is not proper that the people who believe in Allāh and in doomsday still follow syètan and his activities. Trying seriously to follow Allāh; during Ramadhan we have successfully obeyed Him. When Allāh orders us to fast, we fast. Actually fasting is very hard because what hold up are the things which are actually lawful and may be done. This indicates that there is no reason not to follow Allāh after Ramadhan because $\mathrm{He}$ is the One who knows everything.

Leaving sin and immorality: Ramadhan is a hard month to be far from sin. We have successfully proven during Ramadhan that we can leave all forms 
of sin and immorality and even can leave everything that does not contain religious merit. It is impossible that dirty individuals living in the sinful world can form a good society. One of the ways to develop a clean and civilized society as well as helping each other in "goodness" and Allāhfearing (Arb taqwā) (together keeping away from badness and sin) is therefore to return to the inherent disposition towards virtue in humanity, to return to fully following Allāh and glorify Him, to return to making mosques prosper, to "make friends with the Qur'ān", to restrain carnal desire from sin and syètan, to make nights alive with religious service. Ramadhan is a true example of life and show the real personality of a true Muslim. That is the secret why Allāh allows the good deeds of Ramadhan to be used as a ladder to become righteous because through Ramadhan one will have the maximum consciousness of a Muslim as the slave of Allāh, spreading affection to all human beings, saving them from brutal and illtreatment, and asking them to return to Allāh.

The sermon is concluded with do'a. Everyone stands up to return home. While standing they shake hands with each other and, in this instance, the congregation turns into a mass of people shaking hands. They then return home to express the depth of their family ties.

\section{Requesting forgiveness}

The members of the family ask forgiveness from each other. There is a particular pattern to this performance. In one household I observed a husband sitting on a chair in the living room. His wife kisses and buries her head in her husband's hands asking forgiveness from him. The wife then sits on another chair near her husband. Children perform in the same manner asking forgiveness (Ach lakè ampon) and receiving blessings from their parents. The mother in particular is moved to tears and laments over the bowed heads of her last child because of his bad behavior telling him you must learn to behave better (see also Bowen, 1993). Other family members ask forgiveness from those senior to them in the same manner, sometimes briefly and other times for a long exchange of caresses and tears. At the boarding school, however, this is performed slightly differently with the suluk followers and the boarding school students queuing up in order to shake hands with the teungku sitting on a chair while bowing their bodies and asking for forgiveness and blessing from him.

The term for asking forgiveness is "meuah lahé batén" (forgive me for any external and internal sins), and the response is "lahé batén" (me too, from external and internal sins). Some boarding school's students who do not return 
to their villages on the uroe raya day greet their friends with common Arabic greetings such as "blessed $\bar{\imath} d$ " (Arb $\bar{i} d$ mubarak) and "May Allāh accept sincerity from us, and the one from you" (Arb taqabballallahu minna wa mingkum) while they shake hands on the day of uroe raya. Before visiting their neighbors and receiving guests, many families perform the ritual of visiting the graves of their ancestor's (Ach ureueng chi') and other deceased relatives where they recite $d o$ ' $a$ for the safety of their 'souls' (Ach roh) and for the mercy of Allāh. They sprinkle the graves with water perfumed with flowers. They place flowers between the grave stones in the same manner as during the ritual of khanduri $b u$ in the Sya'ban lunar month (see Ch.10). This ritual is called jak saweu ureung chi' (go and see ureueng chi') to honor as well as not to forget them, says one of the visitors to the ancestors' grave at the uroe raya in Blangporoh. Another visitor says that it is not necessary that other people are visited on the uroe raya but that it is important to visit the ureueng chi's graves. "We have to prioritize visiting the families who have already passed away and recite $d o$ ' $a$ for them". The other visitor says, "Visiting graves is not only to remember the ureueng chi' but also to honor them as we did when they were still alive and when they passed away". 304

After returning from visiting the ancestors' graves, men visit the imām of the village, village leaders, village elders and close neighbours. They then go around with their family members visiting their elders and relatives on the husband and the wife's side, especially those in the same village, while the elders and relatives in other villages are visited at a later date. For those who have many relatives, visiting them may take a few days. Omitting to visit some particular relatives or elders on the uroe raya day or the subsequent days without reason is considered contemptuous and something that everyone should avoid. Sending the uroe raya cards by mail is not enough and this is common only between friends and relatives living at different localities (see also Muhaimin, 2004). It is even considered an insult to send the uroe raya cards to a father-inlaw (Ach yah tuan) or a mother-in-law (Ach mak tuan). An ordinary handwritten letter, not a card, however, is acceptable for those who do not live in Acèh or in Acèh but when difficulties make a visit impossible.

304 Many people also visit kuburan masal "massive graves" in Banda Acèh and Acèh Besar on the festival of breaking fast (Arb $\bar{i} d$ al-Fitr) and during the "festival of sacrifice" (Arb $\bar{i} d$ al-Adha). See Serambi Indonesia, November 30 ${ }^{\text {th }}, 2009$. 
Close friends are then visited. They use the visits to feel nostalgia and to reunite as they have not seen each other for a year or more. They are served with food and drink while talking, chanting, joking, teasing, sharing happiness and cheering each other up. One says that this joyous moment cannot be had if close friends are not visited. In addition, children who learn how to read the Qur'ān and other Islamic knowledge at the prayer house (Ach meunasah) visit their teacher. At first, they gather at the prayer house and then go together in groups to their teacher's house to shake hands and to ask for forgiveness. This tradition in Blangporoh is called manjalang. It is believed that the teacher, from whom they learn to recite Qur'ân and at the same time acquire Islamic knowledge, is a person who guides them to paradise. Visiting him on the "festival day" is said to be a symbol of honor from the students. ${ }^{305}$

\section{The ritual sending of SMS}

Families with phones make calls to distant relatives to send well-wishes for uroe raya should there be no time to visit families or close friends on the third or the forth day of the uroe raya. As making phone calls is expensive, short message services (SMS) are sent instead of visiting. This is done by many village people. Sending an SMS is an alternative to a physical visit. It is sometimes sent with a lebaran card (Indon kartu lebaran) in the form of traditional poetry, advice etc. The following are several examples of SMS in which such poetic and romantic verses are sent to close friends on this occasion:

Leumang boh labu pasoi lam buloh

Saleum ulon boh made in Cina

Lon kirém saleum takôt hana troh

Lon kirém bungkoh takôt meu tuka

Lon kirém lagu kasèt ka putoh

Saleum lon peutroh lewat Nokia

Lon mumat jaro posisi jioh

Me'ah rakan boh ubé na dosa

Pulo Sumatra gunong meurentang

Bukét Barisan geu rasi nama

Nyou karab abéh bulan Ramadhan

Talakè bak Tuhan beu ampon désya
Leumang made of pumpkin is impaled in bamboo

Greetings I make in China

I send a greeting fearing it does not reach

I send a handkerchief fearing it gets accidently exchanged

I send a song fearing the cassette is broken

Greeting are sent through Nokia

I shake hands from a distant place

Please forgive all sins

Sumatra Island has mountains in a row

Bukit Barisan is a good name

Now the Ramadhan month nearly ends

Asking Allāh to forgive sin

305 See also Emtas (2008:82), about manjalang tradition in the Aneuk Jamee both in the festival of breaking fast (Arb $\bar{i} d$ al-Fitr) and in "festival of sacrifice" (Arb $\bar{l} d$ al-Adha). 
Sepuluh jari tersusun rapi

Bersihkan diri setulus hati

Tak terasa idul fitri

SMS dikirim pengganti silaturrahmi

Berharap padi bertemu lesung

Bertanak beras menjadi nasi

Hasrat hati bertemu langsun

Tetapi tiada daya di dalam diri

Umpama dosa bagaikan daun kayu

Sebelum layu yang lain sudah tumbuh muda

Umpama dosa bagaikan gelombang di laut

Sebelum surut yang lain sudah tiba

selamat idul fitri dan permohonan maaf

Seiring terbenam mentari di akhir Ramadhan

tibalah kini bulan Syawwal

adat jauh berkirim kata

adat dekat puji memuji

andai ada tersilap kata

maaf dipinta sepuluh jari

Yang jauh itu waktu, yang dekat itu mati

yang besar itu nafsu, yang berat itu amanah

yang mudah itu berbuat dosa

yang panjang itu amal shalih

dan yang indah itu saling memaafkan

Orang yang mulia di antara kamu sekalian

adalah orang yang selalu memaafkan

dan tidaklah ada rasa dendam

Walau kita tak saling jumpa

dan tangan pun tak saling berjabat

Kami memohon maaf lahir batin
Ten fingers are arranged in orderly fashion

Purifying the self sincerely

Suddenly idul fitri arrives

SMS are sent instead of visiting

Hoping rice meets a mortar

Cooking unhusked rice to be cooked

Wishing to meet directly

But there is no power in me

Sin is like the three leaves

Before they are faded others have grown

Sin is like the sea waves

Before subsiding others have arrived

Congratulations on idul fitri and requesting forgiveness

Along with the sun setting at the end of Ramadhan

Now the Syawwal lunar month arrives

The adat of far is sending words

The adat of proximity is praising each other

If there is a wrong word

Forgiveness is asked with ten fingers

What is far is time, what is close is dead

What is big is passion, what is heavy is trusteeship

What is easy is sinning

What is long is good deeds

And what is beautiful is to forgive each other

The noble persons among you

are those who always forgive

and there is no revengeful feelings

Although we do not meet

and do not shake hands each other

We ask for complete forgiveness ${ }^{306}$

The SMS receivers send a reply, which is similar to that of the senders even though the sentences are simpler with standard phrases containing the words of sincere forgiveness for all the sins they have ever done. In the context of one's relationship to Allāh (Arb hablumminallāh), one should always ask for forgiveness from Him through recited $d o$ 'a. In the context of one's relationship

306 See also Serambi Indonesia, the "sociology of forgiving each other" (Indon maaf memaafkan), September $26^{\text {th }}, 2009$. 
to human beings (Arb hablumminannās), the forgiveness only can be received by asking forgiveness from the people whom we have wronged. If the forgiveness is not received from him or her, one is sinful till the end of his or her life. In this case Allāh cannot forgive that particular person. Thus a person asks for forgiveness from others, especially on the day of the uroe raya. When the forgiveness is obtained from human beings, pardon from Allāh is automatically also obtained so that a person is said to have achieved "victory" and is purified. After receiving forgiveness, life will run well, peacefully and pleasurably. Otherwise, boastful attitudes, envy, spite, slander, anger and the like become a "prison" for him or her not allowing them be accepted by others. In addition, for the newly married man as well as providing his wife's family with meugang meat as anexpression of the harmonization of the relationship between the husband's and the wife's family, he together with his wife has to visit their family, neighbors, and close friends on the uroe raya. Their hosts, in turn, perform a tamuntuak (Ach teumuntuk) for them.

\section{The teumuntuak ritual}

Teumuntuak is the introduction performed by the bride (Jam binie; Ach bino) and the groom (Jam laki; Ach lako) to their respective parents, village elders, neighbors, and close friends by shaking hands. Each person shaking hands with the newlywed couple will give them money (Jam agih kipieng; Ach jok pèng) by inserting it either in the wife's hand or the husband's. ${ }^{307}$ Prior to performing teumuntuk, the husband's side informs their family, neighbor, and close friends that the newly married couple will perform the teumuntuak tradi-

307 Teumuntuak tradition performed at the time of the uroe raya puasa "festival of the breaking fast" is the continuation from the first teumuntuak tradition performed at the time of the marriage ritual when the groom with village elders arrives at the bride's house to fetch the bride. Before the bride goes together with her group to the groom's house, teumuntuak is held for the groom by the bride's side consisting of her relatives, neighbors, the wife of imām and the village leader. When the bride wants to return to the groom's house, she is first introduced to the family of the bride, wears the adat dress, performs obeisance and introduced to the family and close friends of the bride side that have waited the coming of the groom at the back verandah of the house. Each person from the bride's side holds money to give to the groom by way of shaking hands (Alamsyah 1991:54). The amount of money given to the bride is not set but the groom's side has to give more money to the bride at the time of teumuntuak at the bride's house. This is done under the guidance of an old woman called penganjo who asks one by one the bride's side to say the congratulatory word to the couple. It is then followed by giving utensils to the bride at least one set by an old woman. 
tion. About two weeks preceding the "festival day", the husband's side sends "ingredients" for making traditional cakes such as glutinous flour (Jam tapuang sipluik; Ach teupong leukat), sugar (Jam gulo; Ach saka), egg (Jam talue; Ach bòh manok), coconut oil (Jam minyak karambi; Ach minyek u), coconut (Jam karambi; Ach bòh $u$ ) and so on. Meanwhile the wife's side prepares banknotes for tamuntuak for the husband, as well as preparing many kinds of traditional cakes such as juadah, wajéb, keukarah, dodoi, meuseukat, leumang and so on.

On the uroe raya puasa "festival day of breaking fast", these traditional cakes are placed in a special tin can called jambalomang (a pack containing traditional cakes). They are then brought to the husband's parents' house by one of women from the wife's side. Such tradition on the uroe raya is called "repeating the trace" (Jam meulang jajak), that is to revisit her parents-in-law accompanied by other women from her family, neighbors and circle of close friends. When the group from the wife's side arrives at the husband's house, they are served with the cooked food and the ritual of returning jambalomang is performed by an old woman on behalf of the wife's side by the husband's side. The husband's side then takes all contents of jambalomang and places money and clothes in it as a return gift. The wife performs obeisance (Indon sembah) by shaking hands with the husband's parents followed by her group one by one while asking permission to leave the house afterwards. After shaking hands, her group leaves the husband's house by taking back the jambalomang that has been filled with counter gifts from the husband side. This tradition has been passed down from one generation to another. After returning from her husband's house, the wife and the husband then visit the neighbors, adat elders, and close friends accompanied by small children. For this visit, they also bring traditional cakes wrapped in a container. When arriving, the wife gives the wrapped container containing the traditional cakes to the visited house after shaking hands. When they leave the visited house, the hosts shake hands with the newlywed couple by inserting banknotes into the wife's and the husband's hands. As they go back, the container of the given traditional cakes is filled with clothes as a counter gift for the houses that are visited. The closer the newlywed couples are to the people whom they visit, the more valuable gifts [traditional cakes] are brought and the more valuable gifts they receive in return. According to several old people in West Labuhan Haji district, in the past, the new couple would be given a chicken or a duck when they visited their families on the "festival day". This gift was a reflection of the closeness of their family 
relationship. Similarly, when children visit family members, they are given some money. For children, receiving money from their relatives during the uroe raya is a certain kind of joy.

The teumuntuak ritual is an adat that has a deep influence on the society. If the newly marriage couple do not perform this ritual, they feel that their marriage ritual has not been completely performed. They are also afraid that their families or neighbors or close friends will say "why do you not visit and introduce your wife to my house" (Ach ék hana ijak dan peuturi inong jih u rumoh lon). If this ritual is not performed, society will say that the newly married couple is "uncultured". It is considered shameful and results in bad gossip about the newly married couple in the society as they have not performed the ritual in accordance with a tradition that has been passed down from one generation to another.

\section{The aims of the teumuntuak ritual}

The villagers interpret the aims of the teumuntuak ritual in term of Islamic values:

1. Introducing (Ach jak meuturi) the wife to the husband's side and introducing the husband to the wife's side in order to get to know each other so that a brotherhood relation is well preserved. Knowing each other is the basic relation among humans. In line with this the Qur'ān (49:13) says "O mankind, indeed We have created you from male and female and made you peoples and tribes that you may know one another. Indeed, the most noble of you in the sight of Allāh is the most righteous of you. Indeed, Allāh is Knowing.

2. Developing the bonds of friendship (Arb silaturrahmi) as well as applying Allāh great mercy towards humans as a model for relationships among humans (Arb silaturrahīm).

Strengthening the brotherhood relationship (Arb ukhuwah Islämiyyah) and preventing dissolution. The Qur'ān (49:10) says, "Believers are brothers, so make a settlement between your brothers. And fear Allāh that you may receive mercy."

3. Preserving culture that has been developed for years so that this tradition is continuously maintained and becomes characteristic of the Aneuk Jamee culture.

The teumuntuak's performance on the uroe raya provides the family with something strengthen their relationships. Such visiting develops relationships among villagers. It also has a good influence, especially for developing a sense of togetherness within a family. In addition, it can also create brotherhood relationships in society life which cannot be separated from certain habits that have become a tradition in the village. This can be seen in the performance of the 
teumuntuak tradition which involves gift-giving as a manifestation of the social interaction in strengthening the kinship relations and brotherhood among them. An individual has to adapt him or herself to their environment with the rules that have been given in society life. Such rules are often known as a social norm. One of the important social norms is ethic and behaviour as the manifestation of the activities which are reflected in teumuntuak tradition. In addition, the performance of teumuntuak tradition can "plant" a sense of high solidarity in religion and for society in society life and can lead to a sense of brotherhood. This has a good influence on society and leads to happiness for both sides. Visiting both family sides and reciprocating the traditional cakes can create a strongbrotherhood relationship, create unity, create a sense of love, and preserve reconciliation among families besides increasing the sense of solidarity among villagers.

\section{Conclusion}

The celebration on the first day of Syawwal, the tenth month of the Islamic lunar month, marks the end of Ramadhan. The celebration of the end Ramadhan is called uroe raya puasa or 'id al-Fitr (Indonesianized Arabic idul fitri) "the festival of breaking fast" which is one of several Islamic calendar ritual part of the purification process of Ramadhan.

The ritual of the uroe raya puasa cannot be separated from the religious services performed by Muslims during the month of Ramadhan. The relation between fasting (Ach/Indon puasa) and the uroe raya puasa can be understood as the relationship between "struggle" and "victory". Puasa is a spiritual journey to release the human body from satanic powers. This journey is represented by restraining basic human urges: one must stop eating, drinking, and having sexual intercourse. On the other hand, uroe raya puasa is a "feast of victory" where fasting people are freed from satanic desire.

The series of activities performed at the uroe raya puasa "the festival of breaking fast" marks the end of the liminal time of Ramadhan lunar month and the beginning of normal time. The core of Ramadhan is the opportunity for Muslims to eliminate their past sins. It is therefore during Ramadhan that people conduct their business with more religious services to receive forgiveness from Allāh. Even though forgiveness is the right of Allāh, which means that only Allāh can eliminate human sin, asking for pardon is a reflection of the human awareness of its weaknesses. Having fasted people feel as if they have 
been reborn into this world because all their sins have been eliminated. Hence the uroe raya puasa is a "feast of victory" and a new opportunity for all Muslims to enter into a new life. In addition, wearing new clothes, wearing perfume, buying new furniture, vehicles to visit each other, reciprocating gifts, sharing and eating traditional cakes are regarded as imparting a physical joy of the uroe raya puasa. The elimination of sins by Allāh on that day is deemed as the spiritual joy of the idul fitri. The chanting of takbir (Allāh is the greatest) and $\operatorname{ta} \underline{h} \bar{l} \bar{l}$ (there is no god but Allāh), which is followed by the performance of a special prayer on the morning of uroe raya puasa, is an expressions of the purity of a Muslims' faith from any kind of false worship. If wearing new clothes and perfume are symbols of physical purity at the end of Ramadhan, the chanting of takbir, the special prayer of uroe raya puasa and asking pardon from other people, are the symbols of spiritual purity (Nur 1996:90). Moreover, bathing on the morning of uroe raya puasa, for instance, can be deemed as a climax of the purification process of Ramadhan. To express this condition of purity, people wear new clothes on the day of uroe raya puasa.

The people relate the uroe raya puasa to the tradition of visiting others in order to ask for pardon. Asking for pardon reflects the awareness that everyone has faults and weaknesses. In order to be in harmony with others, one has to acknowledge his or her faults, weaknesses and wrong deeds toward others by asking for forgiveness preferably on uroe raya puasa. Newlyweds visit their parents, neighbors, close friends, shake hands and give money. The uroe raya puasa is a good opportunity to introduce the bride and the groom to both sides of the family as they return to their homeland to celebrate uroe raya puasa.

It is viewed positively if people ask for forgiveness and forgive each other either directly or through various media communication. In this sense, the uroe raya puasa is valued as a moment to develop communication, both with Allāh and among human beings. Communicating with Allāh is attained through continuously maintaining (taqwā) "Allāh-fearing" during the fasting month. Communicating with human beings is gained through the bonds of friendship, giftgiving relationships and forgiveness. The acts of purification during uroe raya puasa can be seen as a point of transition from the liminal time of the sacred month back into everyday life as people feel that they have be reborn and are without sin. 


\section{Chapter 13}

\section{The ritual of uroe raya haji}

Dzulhijjah is the twelfth month of the Islamic lunar month, which coincides with the month of December in the Gregorian calendar. This month in the Acèhnese and in the Islamic calendar begins with the completion of the pilgrimage to Mecca. The celebration on the tenth day of this lunar month is called 'i $\bar{l}$ al-adh $\bar{a}$, "the feast of sacrifice", one of the two major yearly holidays in Islam. The Aneuk Jamee refer to it as hari rayo qurban or in Indonesianized Arabic idul adha (Arb 'ìd al-adhā), commemorating the willingness of the Prophet Ibrāhīm to sacrifice his son, Isma'îl for the sake of Allāh. The villagers often talk simultaneously about the sacrifice the pilgrims undergo in the city of Mina and their own sacrifice. In this context the Aneuk Jamee also refer to this local event as the "pilgrimage holiday" (Jam hari rayo haji; Ach uroe raya haji). Like uroe raya puasa, "festival of breaking the fast", uroe raya haji is recognized as a national holiday. School holidays begin a few days earlier and last a few days after the festival. This chapter describes the celebration of uroe raya haji.

\section{The celebration of uroe raya haji and the performance of animal sacrifice}

The Aneuk Jamee celebrates uroe raya haji for four days. The day preceding the actual four days or the $9^{\text {th }}$ of Dzulhijjah is called hari Arafah (Ach uroe Arafah). On this day all pilgrims gather together to perform the ceremony by gathering in the field of Arafah in Saudi Arabia, during the hajj (Indon wukuf) and wearing the same clothes, that is a consecration cloth (Indon pakaian ihram). The imām whom I discuss this with says that hari Arafah is the best day in the year to fast. All Muslims are recommended to fast on this day to cleanse themselves from their sins. Minimal, "small sins" (Indon dosa kecil) are eliminated which occurring during last year and which will occur in the year ahead.

In contrast to the uroe raya puasa which is marked by "staple food" (Indon zakat fitrah). The uroe raya haji is marked by sacrificing cattle; rams, sheep, buffalos and oxen. Slaughtering these animals is the "emphasized recommendation" (Arb sunnah muakkadah). However, there it is not a sin if you do not slaughter an animal. It should be done by Muslims who have feel 
obliged to observe the precepts of religion (Arb mukallaf) and have enough money. If affluent people do not perform the sacrifice, they have passed an opportunity to gain much religious merit (Jam pahalo). A hadith transmitted by Abu Hurairah states, "Those who are affluent and do not perform sacrifice, do not approach Our mosque". In addition, the sacrifice becomes obligatory if parents request their children to perform a sacrifice for them when they are still alive. In this case, their children must fulfil their parents' request using their parent's money.

Moreover, it is not an obligation to perform the sacrifice for those who are already dead. If the sacrifice is performed, it is then considered to be a gift for the dead. The sacrifice is obligatory if one has uttered a sacrificial vow/promise (Indon qurban nadzar). A hadìth narrated by Bukhari and Muslim states, "The one who has uttered a vow to adhere to Allāh, they must do so" and the Qur'ān (22:29) states "fulfil your vows". If the person who has uttered the vow passes away before performing his/her sacrificial vow, his/her heir (Indon ahli waris) must perform it for him/her. As this sacrifice is performed, his/her heir must say that the sacrifice is for that person.

The sacrifice is performed following in the footsteps of the Prophet Ibrāhīm. It is performed on the day of uroe raya haji after the congregation performs "id prayer" (Ach seumayang uroe raya). It can also be continued on three consecutive days; day 11, 12 and 13 of Dzulhijjah, these days are known as tasyrék days. On these days, the sacrifice can be performed in the morning, at midday or at night. It is important to note that if the sacrifice is performed prior to performing the $\bar{i} d$ prayer it is not considered to be a sacrifice. The aim of the sacrifice is to "come close" (Arb qaraba) to Allāh. The sacrifice is said to give an abundance of love directly to Allāh so that there are no boundaries between a person and Allāh such as wealth, a wife or a degree. But if it is performed after the tasyrék days it is considered as charity (Ach seudeukah).

Unlike the aim of the akikah sacrifice which is the redemption of a child, the aim of sacrifice on uroe raya haji is the redemption of oneself. Therefore, sacrifice and akikah cannot be united. The entire sacrificial ritual celebrates the sacrifice made by the Prophet Ibrāhīm, who is believed to have dreamed that Allāh asked him to sacrifice his son, Isma'îl. The Qur'ān says Ibrāhīm said to his son "O my son, indeed I have seen in my dream that I [must] sacrifice you, so see what you think." He said, "O my father, do as you are commended. You 
will find me, if Allāh wills, steadfast." (QS 37:102). ${ }^{308}$ As Ibrāhīm really was about to kill Isma' 1 l, the angel replaced him with an animal. So an animal was slaughtered by Ibrāhīm instead of Isma'il. The sacrificed animals are usually male, they must be healthy and in perfect condition with a reasonable weight. They can be obtained quite easily everywhere because many people sell them for this. On this occasion the price of cattle increases by 30 percent, ${ }^{309}$ because the people search the the perfect sacrificial buffalo, cow, sheep or ram. Many customers also buy buffalo or oxen for slaughtering on meugang day (a day preceding uroe raya haji) so that there is not enough livestock for these occasions. A lot of good cattle are slaughtered on meugang day (9 Dzulhijjah) which is concurrent with the sacrificial day; 10-13 Dzulhijjah, a day or two days preceding the uroe raya haji. This influences the number of good cattle available to be sacrificed on the day of sacrifice.

\section{Meugang versus uroe raya haji}

There are two rituals performed by the Aneuk Jamee in relation to the uroe raya haji. These are meugang (eating meat before uroe raja haji) and qurban (slaughtering sacrificial animals). Although they are performed nearly at the same time, those two activities have two different meanings. Meugang derives from an adat tradition, while the sacrifice is prescribed by the syari'ah. In the context of the uroe raya haji, the meugang ritual is marked by the family's obligation to consume meat together (see Ch.10). After uroe haya haji, the celebration of eating meat is continued with the sacrificial meat (Indon daging qurban). Hence a double portion of meat is consumed.

Meugang before the uroe raya day is seen as an expression of happiness to welcome the coming of the uroe raya haji, here the family eat together. In syari'ah law, however, the day preceding the uroe raya haji (on 9 Dzulhijjah) is the day of Arafah. All Muslims are recommended to fast on this day to rid

308 The order of the sacrifice is based on the Qur'ān in the sürah al-Kawthar (QS 108: 2) "So pray to your Lord and sacrifice [to Him alone]", also in the sürah al-Hajj (QS 22:36) "And the camels and cattle we have appointed for you as among the symbols [i.e., rites,] of Allāh; for you therein is good. So mention the name of Allāh upon them when lined up [for sacrifice]; and when they are [lifeless] on their sides, then take from them and feed the needy and the beggars. Thus have we subjected them to you that you may be grateful".

309 A buffalo or cow costs Rp 6 to 15 million. Ram or sheep costs Rp 1.2 to 2.5 million (Serambi Indonesia, November $28^{\text {th }}, 2009$ ). 
them of their sins. Here there is a contrasting pattern in welcoming the day of uroe raya haji between adat and syari'ah. At the beginning the meugang ritual is held in order to prepare food for 'breaking fast' (Jam buko puaso) for people who observe fasting on the day of Arafah but this is less prominent because the meugang meat usually has been already cooked at midday and immediately consumed bythe family. According to syari"ah law, the "culture of eating" (Indon budaya makan) is recommended for up to 3 days after performing the $\bar{i} d$ prayer. Fasting on these days is thus not allowed, for the Prophet said "These days are the days for eating and drinking".

In addition, meugang's meat is prepared for one's family whereas the sacrificial meat is also shared by others, especially with the poor and orphans. Meungang is performed to strengthen family relationships through sharing meugang's meat and its focus is on one's own family rather than on society at large. The sacrifice, however, is performed to strengthen the bonds of friendship and social solidarity.

Sacrifice is best performed on the uroe raya haji day as the sacrifier's sins are eliminated when the sacrificial blood flows. Meanwhile meugang is a special adat in the society performed three times a year (before Ramadhan, before the uroe raya puasa, and before the uroe raya haji), it has no relation to religious service (see Ch.10). Meugang is a burden opeople as the meat is costly on the meugang day so that the needy queue up for hours in front of the governor's office in order to get a piece of meugang meat. ${ }^{310}$ Sacrifice, on the other hand, is performed by people who can afford to do so. The meat is then shared free of charge to the needy so that people can enjoy the uroe raya haji day without being burdened economically. Although the "essence" (Indon essensi) of meugang is different from that of sacrifice, this differentiation indicates the cultural uniqueness of the Aneuk Jamee society.

\section{İd prayer and strengthening bonds of friendship}

Like the celebration of uroe raya puasa, the celebration of uroe raya haji is a joyful occasion. It marks the state of enhanced piety. It is also a day of forgiveness, moral victory and peace, of congregation, fellowship, brotherhood and unity. One should forget old grudges and ill-feelings towards one's fellow men. People wear their finest white clothes symbolizing purity and austerity

310 Serambi Indonesia, August 22 $2^{\text {nd }}, 2009$. 
and attend the $\bar{l} d$ prayer in the mosque in the morning, reciting takbir. ${ }^{311}$ It is then followed by a sermon called khutbah uroe raya haji. In his sermon, the imām implores people to remember the trials and triumphs of the Prophet Ibrāhīm when facing Allāh's command to kill his son Isma'îl and to reflect on the lesson behind this command as willingness to make a sacrifice in all areas of life in order to stay on the straight path of faith. The sermon then focuses on the meaning of sacrifice. This meaning is not only based on textual exegesis but also on all deeds performed which bring one closer to Allāh. The imām stresses the value of 'sincere devotion' (Arb ikhlās) in any sacrifice performed, linking this to the obedience displayed by the Prophet Ibrāhīm. In addition, he encourages people at $\bar{l} d$ to end any past animosities they may have, to forgive others and to release any feelings of enmity or ill-feeling towards others. At the end of his speech, the imām recited a hadith in Shahih al-Bukhari no 1623, 1626 and $6361^{312}$ about the last sermon of the Prophet in front of a large gathering of people during hajj. Here is a translation:

O people, just as you regard this month, this day, this city as sacred, so regard the life and property of every Muslim as sacred trust. Return the goods entrusted to you to their rightful owners. Hurt no one so that no one may hurt you: Remember that you will indeed meet your Lord, and that $\mathrm{He}$ will indeed reckon your deeds. Allāh has forbidden you to take usury/interest; therefore, all obligations shall henceforth be waived. Your capital, however, is yours to keep. You will neither inflict nor suffer any inequity. Allāh has judged that there shall be no interest and that all interest due to Abbas Ibn Abd al Muttalib (the Prophet's uncle) shall henceforth be waived.

Beware of Satan for the safety of your religion. He has lost all hope that he will be able to lead you astray in big things, so beware of following him in small things.

O people, it is true that you have certain rights in regard to your women, but they also have rights over you. Remember that you have taken them as your wives, only under Allah's trust and with His permission. If they abide by your rights then they have the right to be fed and clothed in kindness. Do treat your women well and be kind to them, for they are your partners and committed helpers. And it is your right to see that they do not make friends with anyone of whom you do not approve, as well as never to be unchaste.

311 I no longer here describe how the $\bar{l} d$ prayer is performed and the takbir is recited as they are similar to uroe raya puasa (see Ch.12).

312 See shahih imām Muslim referring to this sermon in hadīth number 98. 
O people, worship Allāh, perform five prayers a day (salat), fast during the month of Ramadhan, give your wealth in zakat.

Perform hajj if you can afford to.

All mankind is from Adam and Eve, an Arab has no superiority over a non-Arab nor a non-Arab has any superiority over an Arab; also a white has no superiority over a black, nor a black has any superiority over a white - except by piety and good action. Learn that every Muslim is a brother to every Muslim and that the Muslims constitute one brotherhood. Nothing shall be legitimate to a Muslim, which belongs to a fellow Muslim unless it was given freely and willingly. Do not therefore, do injustice to yourselves.

Remember one day you will appear before Allāh and answer for your deeds, so beware, do not stray from the faith of righteousness after I am gone. People, no prophet or apostle will come after me and no new faith will be born. Reason well, therefore, o people, and understand words which I convey to you. I leave two things behind, the Qur'ān and the Sunnah (hadith), if you follow these you will never go astray. All these who listen to me shall pass on my words to others and those to others again; and may the last ones understand my words better than those who listened to me directly. Be my witness, o Allāh, that I have conveyed your messages to your people.

The $\bar{l} d$ sermon is concluded with $d o^{\prime} a$, after which everyone stands up to shake hands with each other. Some hug each other and wish a happy $\bar{i} d$. They then return home to concentrate on family ties. The members of the family ask pardon from each other. Then, people visit each other's homes, asking forgiveness and partaking in the festive meals with special dishes, beverages, and desserts. Children receive gifts and sweets on this occasion. It is common to greet people with "Selamat Hari Rayo". Many people also greet one another with mohon maaf lahir dan batin "please forgive my external and internal [being]". This is the time to cleanse themselves from sin and strengthen their bonds of friendship (Arb silaturrahmi) with relatives and friends. Another phrase of greeting is minal aizin wal faidzin "May you be part of the people who return to purity and part of the people who are granted glory". The latter Arabic phrase is usually used in conjunction with the former; thus, "Minal aidzin wal faidzin, mohon maaf lahir dan batin". ${ }^{313}$ Like pilgrims at Mecca's performing a sacrifice, the Aneuk Jamee who can afford to do so offer domestic animals such as ram, sheep, and buffalo as a symbol of Ibrāhīm's sacrifice.

313 Other greetings aturoe raya, see Ch.12. 


\section{The ritual of animal sacrifice}

One thing that distinguishes the uroe raya haji from the uroe raya puasa celebration is the sacrificial ritual performed during this month only. The sacrifice of an animal commemorating the ram sacrificed by Ibrāhīm in place of his son is the most important feature of this celebration. It is based on the Qur'anic idea that Allāh asked Ibrāhīm to sacrifice his own son, Isma'īl. ${ }^{314}$ All Muslims in the world join in celebrating "the feast of sacrifice". The sacrifice is not compulsory. It is, however, considered an obligation for those who can afford it and they understand their act as a part of Islamic history; "indeed the rich imagary of eschatology assures many people of the ritual's ultimate efficacy" (Bowen 1992:276).

On December $20^{\text {th }}, 2007$, at about 2 o'clock, a sacrificial ram was slaughtered for M. Arsyad who passed away two years earlier in Blangporoh village. Before being sacrificed, the sacrificial ram was bathed, dried, combed then had its body sprayed with perfume and its face powdered. The sacrificial ram was then fed with steamed glutinous rice and traditional cakes. A ritual identity between Isma' $\overline{1}$ and the sacrificial ram is established for it is said that these acts are performed to repeat the actions of Isma'ill's mother, Hagar (Hajar) before Isma'îl was taken to be sacrificed. The deceased's wife, Nurlaili then brought a tray called talam containing tools for "cooling" (Ach peusijuek) close to the sacrificial ram. On the tray, there were several articles:

1. Rice (breuh) and unhusked rice (padé) and so-called breueh padé in a glass. These breueh padé are scattered on the ram as the cooling ritual is performed.

2. There are three kinds of grass leaves:

1. Several leaves of coarse grass (Ach naleueng sambō) with its roots

2. Several leaves of cocor bèbèk (Ach on sisijuek)

3. Several leaves of manèk manòe.

All these leaves are tied in a bunch placed in one bowl (Ach cawan) with ordinary rice flour (Ach teupong taweue). The function of these three kinds of leaves is to

314 Ibrāhīm did not ever once think "why" or that he might say "no"- if that was Allāh wanted, he trusted Him no matter what! His faith was rewarded when his son's life was spared by Allāh at the very last minute. Just as the knife was coming down, there was a lamb in the place of Isma'īl and that was what Ibrāhīm actually sacrificed, explained one teungku. He added, "The ram sacrificed by Ibrāhīm was taken from Paradise by Gabriel. The sacrificial ram belonged to Habil (Abel), the son of Adam that was accepted by Allāh because of his sincere sacrifice to Him". 
sprinkle the liquid rice flour on the sacrificial ram as it is "cooled" during the ritual of "cooling" (Ach peusijuk).

3. Glutinous rice (Ach bu leukat) with coconut, stir-fried with palm sugar (Ach $u$ mirah). The glutinous rice is coloured with pounded turmeric to make it yellow (Ach pulôt kuneng or bu leukat kuneng) as an offering for the sacrificial ram. Glutinous rice (Jam nasi kunyik or pulot kunieng) is placed behind both ears of the sacrificial ram as a symbol of peusunténg (it is ritually purified with such a flour mixture).

4. Teupōng taweue, fresh water which has been mixed with the ordinary rice flour, is placed in bowl together with three kinds of the above leaves. Teupōng taweue is sprayed on the sacrificial ram which is "cooled" with a bunch of the above three leaves that represent unity and a cool condition.

5. It is said that the ritual "cooling" of the sacrificial ram is recommended by the 'ulam $\bar{a}$ '.

The ram is then "cooled" by the imamm, the deceased's wife and the deceased's first son. The ram is brought by the deceased's second son from his house to a hole dug in the house's front yard. Another tray containing articles wrapped in a white cloth called ayapan is brought near to the hole by the deceased's wife. Ayapan contains a comb, soap, a tooth brush, a mirror, a knife, face powder, a bottle of shampoo, a tube of toothpaste, a bottle of perfume, an umbrella, hair cream, scissors, a blanket, a slipper, and a shirt. These articles are destined for the beneficiary on Judgement Day. All these articles are wrapped in a white cloth as a symbol of holiness and sincerity from his wife and children for the deceased. A Rp 10,000 note is placed at every end of the white cloth as if it were for sewing the deceased's clothes on the Judgement Day. In addition, one says "This money is for shopping on the Judgement Day".It is also said that this money should cover all costs for the sacrificial ram if anything is lacking (Ach meunyo na kureueng). In other words, placing money at every end of the white cloth is to complete what is incomplete since the sacrifice must be perfect. Besides these articles, the tray also contains various traditional cakes. The ram is again fed by the imām with several of these cakes. $^{315}$ This action refers to Isma'îl who was told to eat fully before he was brought by Ibrāhīm to be sacrificed.

Soon after the ram is brought to the hole, the deceased's second son gives a sharp knife to the imām without allowing the ram to see it so that the sacrifi-

315 One says that the beneficiary's name is sometimes placed in the cake which is then fed to the ram before it is sacrificed. 
cial ram is not aware of its imminent death. With his right hand, he hands over the sacrificial ram together with its rope to the imām. While his left hand he grasps the rope circling the ram's neck and utters "This is the sacrificial ram for my father, M. Arsyad bin Muhammad Daud" (Jam iko kambing qurban untuk ayah ambo, M. Arsyad bin Muhammad Daud). The imām answers, qabiltu "I have accepted it". The deceased's first son strongly grasps the ram's feet placing it in the direction of Mecca emulating the Prophet who placed his sacrifice in this direction as he performed the ritual of sacrifice. The imām as the knife wielder then solemnly utters takbir as follows:

Allāhu akbar (3x)

Là ilāha illallāh

Wallāhu akbar

Allāhu akbar

Wa lillāhi al-hamd
Allāh is the greatest $(3 \mathrm{x})$

There is no deity except Allāh

Allāh is the greatest

Allāh is the greatest

and praise only be to Allāh. ${ }^{316}$

This takbir is repeated three times respectively by the deceased's family while holding onto the white cloth over the ram and other participants standing around. The imām dedicates the sacrificial ram as follows: "This is the ram for the deceased M. Arsyad bin Muhammad Daud" (Jam iko kambiang akikah untuk almarhum M. Arsyad bin Muhammad Daud). At the moment when the knife is brought to the sacrificial ram's throat, the bismillähirrahmānirrahīm (in the name of Allāh, the merciful, the compassionate) and shalawat "praying for the Prophet's well-being" are uttered in a murmur by the imām just before cutting its throat. At the completion of the dedication, he slits the sacrificial ram's throat with a horizontal movement so that the knife remains unseen. After slaughtering, the imām recites a $d o$ ' $a$, "O Allāh, this is from You and returns to You, so please accept the sacrificial ram for M. Arsyad bin Muhammad Daud", (Arb Allāhumma minka wa ilaika fataqabbal min M. Arsyad bin Muhammad Daud). The attendants then utter āminn "please approve o Allāh" in chorus.

According to the imām, the fact that the sacrificial ram is handed over with a rope tied around it indicates "that the animal belongs to that person's family who provided it". The rope is "a connector between the animal and its

316 The imām explained that Allāhu akbar "Allāh is the greatest" 3x was uttered by Ibrāhīm then continued with Lä ilāha illallāh wallāhu akbar "There is no deity except Allāh and Allāh is the greatest" by his son, Isma'îl and then continued with Allähu akbar wa lillāhi al-hamd "Allāh is the greatest and praise only be to Allāh" by Gabriel when Isma'il wanted to be sacrificed by his father, Ibrāhīm. This is deemed as the origin of takbir which is now uttered by Muslims. 
owner" so that the family who are the beneficiaries of the sacrificial animal hold on to their rope before it is sacrificed as a symbol of the connection with the afterlife. The idea here is that people want to be together not only when they are on earth but also in the afterlife.

The ram sacrificed in Blangporoh village did not utter a sound when it was slaughtered. From its conduct, the sacrifice was believed to reach its spiritual destination as the people found it ready and willing for the knife. Just before death, the ram suddenly became tame (Indon jinak) and the people could "see in its eyes" that it was willing to be sacrificed. Many villagers said "This is a good sacrifice". The sacrificial ram is said to "see how the beneficiary is". If it utters a sound, it means the "soul" (Indon roh) of the sacrificial ram does not want to be a vehicle for the beneficiary on the Judgement Day; this is because the beneficiary is still sinful and Allāh will certainly not accept it. ${ }^{317}$ The name of the sacrifier the person in whose name the sacrifice is performed) ${ }^{318}$ is often written on a piece of paper that is dropped in the hole with the blood of the sacrificial ram which is witnessed by the sacrifier's family. Throwing the name of the sacrifier in the blood is said to be like "sending the sacrifier's name" to Allāh. Some claim that the blood of the sacrificed ram will reach Allāh to later become a horse, but others say that the sacrifiers' fear of God (Indon ketaqwaan) and his sincere intention will reach Him. This last idea can be found in the Qur'ān "it is neither their meat nor their blood that reaches Allāh; it is your piety (Indon kealiman) that reaches Him" (QS 22:37). In several villages teungku argue that the blood is destined for the earth, the flesh is for the poor and the "soul" (nyawa) is for Allāh. The God-fearing, the sincere intention of sacrifice will be a vehicle for the beneficiary on Judgment Day (see figure 14).

317 On one sacrificial ram at the mosque of Meunasah Baru, the neighbor village's mosque says that the sacrificial ram uttered a sound when it was sacrificed. The villagers whom I interview with say that it is because the sacrifier did not pray properly five times daily (Ach semayang limong watee) when the sacrifier was still alive.

318 See Hubert and Mauss (1964:9-28); the person in whose name the sacrifice is performed ("the sacrifier") and the knife wielder ("sacrificer"). 


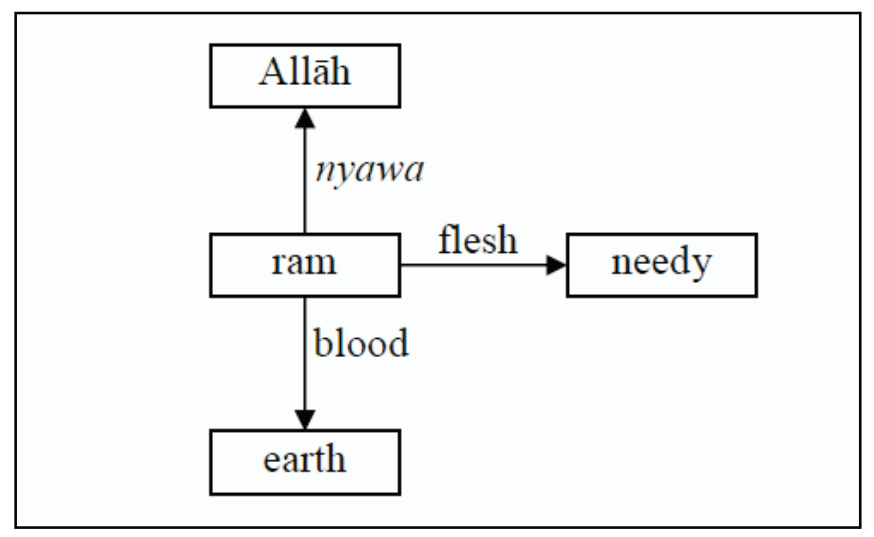

Figure 14. The destination of the parts of the sacrificial ram

As the akikah ram is being slaughtered, a white cloth is held over the sacrificial animal. The white cloth is a symbol of the sincerity of the family performing the sacrifice for the deceased's benefit as well as to honour the sacrificial ram. It also symbolizes Arash, "a place where Allāh sits". It is said that the religious merit of the sacrifice penetrates the Arash from the place where the ram is sacrificed. Like the blood of the sacrificial ram that flows down onto earth, the white cloth held over the sacrificial ram is also believed to ask for forgiveness on behalf of the beneficiary. The white cloth acts as an umbrella to protect the beneficiary from the sunshine which is extremely hot on Judgement Day. Some villagers, however, say that holding the white cloth over the ram is to honour the ram's "soul" (Indon nyawa) that leavesthe body of the ram and goes to Allāh besides it also resembles a cloud because when Isma'îl was sacrificed by Ibrāhīm, the cloud resembling an umbrella protected him.

The white cloth is held over the sacrificial ram by the following four people; the front right of the cloth is held by the deceased's wife; the front left is held by the deceased's first son; the back right of the cloth is held by the deceased's second's son. The back left is held by the husband of the deceased's sister (diagram 14).

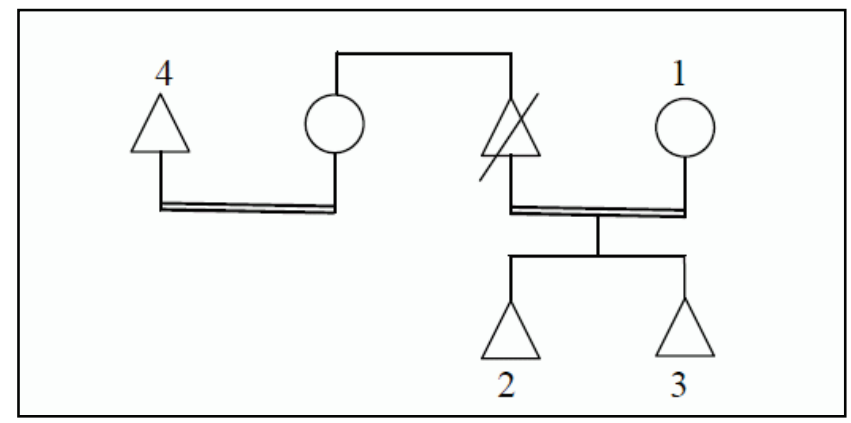

Diagram 14. Kinship relations of those holding the white cloth over the sacrificial ram 
After slaughtering the sacrificial ram, the white cloth is rolled and placed back on the tray. The white cloth with the ayapan articles are given to the imām by the deceased's wife as a gift with the following words: "This ayapan is for you" (Jam ayapan ko pulang ka tuangku imam) and he answers "I receive this ayapan" (Jam alah ambo tarimo ayapan ko). The contents of ayapan are later divided between the imām, the preacher, the person who calls for prayer (bilāl) and the mosque's care taker (khadam).

On the same day in the afternoon, the sacrifice ritual is also performed in Kutaiboh village. Two sheep are slaughtered. A white cloth and a white umbrella are held over the sacrificial sheep. The umbrella is said to be a symbol of sky protecting the beneficiary from the sun's heat which is spanned over their heads on Judgment Day.

The next day, on November $21^{\text {st }}, 2007$, in the village of Ladang Tuha II in Manggéng district, the neighbour district of West Labuhan Haji a buffalo was sacrificed for seven consanguinal relatives. Five beneficiaries had already passed away, while two are still alive. For several days before slaughtering, the buffalo is well treated, fed, and bathed. On the day of slaughter, it is also treated in the same way as the sacrificial ram mentioned above. It is slaughtered in the middle of the main residential area near the prayer house (Ach meunasah), with the active participation of many individuals. Several men tie the buffalo's legs together with rope and then topple it on its side. One of the living beneficiaries then spiritually cleanses the buffalo by sprinkling it with healing leaves and water and powdering its face. These acts prepare the buffalo to "meet" Allāh. The buffalo is then slaughtered by the imām after completing the dedication to the beneficiaries, uttering bismillāh (in the name of Allāh) and praying for the Prophet's well-being (Ach seulawet). Like the sacrificial ram in Blangporoh, a white cloth is also prepared in Ladang Tuha II village but it is not held over the sacrificial buffalo due to strong protest by one of the attendants who insist that "This is not recommended by the Prophet". Later on the white cloth with some money at each corner is given to the imām who slaughters it.

In Meunasahbaro, another neighboring village, the sacrifier himself acts as the knife wielder. He slaughters a sacrificial buffalo for his family. The sacrifice is held without the ritual of "cooling" and the white cloth and umbrella as the sacrifier is a modernist. Although his wife wanted to have the imām perform a "cooling" ritual, her husband - a modernist Muslim - refused to do so. Many villagers, however, do not agree and condemn the sacrifier by saying 
"The sacrifier does not respect the "soul" (nyawa) of the sacrificial animal that goes to Allāh. The sacrificial buffalo is not spiritually cleansed by sprinkling it with healing leaves and water. Its face is not powdered neither is a white cloth held over it before it is sacrificed". Additionally, "since the sacrificial animals will meet their sacrifiers in the condition they were sacrificed on Judgment Day, these acts must be well performed before they "meet" Allāh".

The buffalo is killed in the yard of the village's mosque where a festive mood prevails with many men helping tie the animal down. Before slaughtering, takbir is then recited by the sacrifier followed by his family and all the attendants. Just prior to cutting the buffalo's throat, the sacrifier dedicates the sacrificial buffalo for the benefit of his own name then those names of his wife and children. He then pronounces bismillāh and the confession of faith ("I attest that there is no deity but Allāh and that Muhammad is His messenger"). At the completion of the dedication he slits the buffalo's throat as quickly as possible with a horizontal movement so that the sacrificial knife is hidden from the animal's view. ${ }^{319}$ The sacrifice is performed in such manner so as to acknowledge the fact that only Allāh has the right to take a life, and that animal may only be killed by humble human members of Allāh's creation. This indicates that the condition of the sacrificial animals needs to be perfect in both the physical and the spiritual sense of the word (al-Sekhaneh 2006:141). In addition, Allāh has given human beings power over the animals and allows them to eat their meat, but only if His name is pronounced at the solemn act of taking life. Muslims slaughter animals in the same way throughout the year, so that by saying the name of Allāh at the time of the slaughtering, people are always reminded that life is sacred.

Meanwhile, the living beneficiaries stand aside together with other participants while continuing to recite takbir, witnessing the sacrifice being slaughtered. It is believed that the blood, the grass, and the ground at the slaughtering place ask for forgiveness from the beneficiaries. A drop of blood from the sacrificed ram that falls on earth is said to have the same religious merit as that from a dead martyr. In addition, witnessing the sacrifice by its beneficiary is recommended by the hadīth. The imām recalls one hadīth narrated by alHakim, "Hai Fatimah [the Prophet's daughter], get up and witness the slaughter

319 Among the Bedouin of Jordan, the camel is killed by a vertical upward stab in the throat so that the sacrificial knife remains unseen (al-Sekhaneh 2005:141). 
of your sacrificed animal! From the first blood drops, Allāh has forgiven the sins you have made. Please say; "my prayer, religious service [sacrificed], life and death are only for Allāh, Lord of the world. I am the first person from the people who surrenders to Him". Soon after slaughtering, a set of prayer is recited by the imām:

I turn my face to the Creator of the heavens and earth. And I am not of the polytheists. Surely, my prayer, my devotion, my life and my death, belong (solely) to Allāh, master of the whole universe. None is comparable to Him, and for that I am ordered, and I (certainly) belong to the Muslims.

All attendants raised their hands as high as their breast and intoned $\bar{a} m \bar{m}$ (please approve o Allāh) at the end of each recited $d o^{\prime} a$. The ritual of sacrifice is then over. At night, a khanduri is held at the sacrifier's house, at which spiritual and future benefit is produced by reciting shamadiyah, tahlilil and $d o$ ' $a$ for the sacrifier.

\section{Families and judgement day}

Like the akikah sacrifice, the sacrificial ram, sheep, cow or buffalo is believed to provide a future vehicle. On Judgment Day (Jam kiamet), the sacrificial animals will meet their masters next to their cemeteries in the condition in which they have been sacrificed. Many teungku said that on Judgment Day the persons named as sacrificial beneficiaries will be able to ride on the animal to the place of judgment, Padang Masya (Arb al-mahsyar), and visit the Prophet Muhammad to ask for syafa'ah ("help") from him and then travel on to "meet"Allāh. This exegesis is more or less the same as that which I received from the village imām. He says that the Prophet Daud begged Allāh, "Oh my God what is the reward given to the Muhammad's followers for their sacrifice? Allāh replied, for each of the animal's fur one receives ten rewards; and it erases ten sins. Each fur is replaced by a building in Paradise, one fairy (Indon bidadari), and one mount with wings so that the riders can fly it everywhere they want." Only one person can ride a goat, sheep, ram to the Mahsyar field, but seven can ride on a buffalo, cow, or camel. "The sacrifice of an animal thus provides the opportunity to bring together parents, children, and grand children on the back of the afterlife's mount" (Bowen 1992). Besides, riding on the sacrificial animal is said to prevent danger on Judgment Day when they pass over the bridge (Indon sirat) into the Hereafter. 
Like people in Gayo, Central Acèh, the Aneuk Jamee couples also shape their sacrificial performances with a sociability in the afterlife in mind, trying to provide a mount for themselves, their children, and if possible, for their parents and grandparents. "Parents feel a particularly strong obligation to provide a mount for a child who dies young, as do children for those parents and grandparents who have no resources to make a sacrifice in their own names" (Bowen 1993). The midwife in Blangporoh says that "without a sacrifice there is no tie between parents and children". On Judgment Day, the children bring the certificate containing their parents' name and look for their parents. For example, if their parents are in hell then the child comes to pick them up and brings them to paradise. Without a sacrifice there is no tie between parents and children.

The prospect of future abandonment by one's children horrifies most people and provides further encouragement to perform the sacrifice. It also leads people to include in their dedications even those parents or children who already have a vihecle provided for them, in order to ensure that family ties will be preserved during the harsh time of Judgment. In the past, just before a sheep was sacrificed all the close relatives of the beneficiary would grasp its tether rope, thereby strengthening their tie in the after life (Bowen: 1992).

Like the people in Gayo in Central Acèh, the Aneuk Jamee also project the imagery from the ritual event onto the family's fate in the afterlife.

\section{The requirements of the sacrificial animals}

There are strict rules determining the nature and the condition of sacrificial animals. It should be of a particular age: at least six months for a lamb, one year for a goat or a sheep, two years for a cow, buffalo and five years for a camel. Male animals are preferable. A Muslim can offer either a goat or sheep, or one seventh of a cow, buffalo or camel as the sacrifice, seven people agree to offer a cow, buffalo or camel at the same time and it must be sacrificed where the sacrifier lives. These animals must be in perfect condition. Impaired animals such as animals that are blind, crippled, sick, and thin cannot be slaughtered for sacrifice. This accords to what the Prophet said, "There are four kinds of animals that cannot be sacrificed: a one-eyed animal whose defect is obvious, a sick animal whose sickness is obvious, a lame animal whose limp is obvious, and an emaciated animal that has no marrow in its bones". 
The hadith prescribes the following; it is "reprehensible" (Arb makruh), to sacrifice defective animals, missing for example, a horn or an ear. As Allāh is perfect, He is entitled to a perfect sacrifice only. The sacrificial animals may not be exchanged or sold. Such rules are followed in different Islamic societies. For example, Sekhaneh (2005) found among the Bebouin of Jordan that they follow such rules. The people of the Aneuk Jamee in west Labuhan Haji-South Acèh also follow such rules. As with the Bedouin, the perfection of the sacrificial animal must be matched by the proper moral condition of the sacrifier and the mental condition of the animal to be sacrificed. The act must be performed with piety (Indon kealiman) in the heart and in such a way that the animal is not unduly frightened but killed in quick manner. Most significant is the rule that "oncethe animal has been selected for sacrifice; it may no longer be sold or otherwise alienated, except in order to exchange it for a more adequate specimen" (al-Sakhaneh 2005:141). "If an animal purchased for sacrifice has been lost, stolen, or has died then another animal must be purchased instead. If that animal has been sacrificed and the first subsequently recovered, it should be sacrificed as well. Thus once an animal has been dedicated to Allāh it may not be the object of any other exchange transaction" (ibid). If the sacrifier does not know how to slaughter an animal, he may hand over the task to another person who is devout and knows about sacrifice. When giving the mandate, the sacrifier says, "This is my sacrifice that I give to you to be sacrificed and then distribute its meat to those who have the right to accept it". It is considered favourable (Arb mustahab), however, for sacrificier to be present during the sacrifice.

After the sacrifice has been made, it is better for the sacrifier to distribute the sacrificial meat (Indon daging qurban) if he can but he may ask for help from those who understand how to divide and distribute it as regulated by Islamic law.

\section{The distribution of the sacrifice}

The distribution and consumption of the sacrifice form an important part of the total ritual. If a sheep, ram, cow or buffalo is killed, the animal's meat must be divided and shared in a fixed fashion for the sacrifice to be complete. The sacrifier with the help of the committee members skin the animal and distribute the sacrificial meat for the consumption on the uroe raya haji day. It is mostly given to others and it is even far better if the sacrifier gives everything to the needy as charity. The meat is cut up arbitrarily and mixed in such a man- 
ner that no special part of the animal will be allocated to any particular recipient. It means that the receivers receive similar mixed contents of the animal. What is important here is that there is no social distinction. Everybody gets the same share. Social distinctions between persons are neutralized and all receivers are equal in relation to Allāh. "Thereupon the meat is carefully divided into three parts of equal weight; one part is distributed among the sacrificer's own household, one part among non-co resident relatives, and one part among nonrelated neighboring households" (al-Sakhaneh 2005:141). "Allāh as the giver of the meat thus negates the distinction between these categories, giving each person - irrespective of his creed or kinship - the gift of meat" (ibid). The act symbolizes the willingness to give up things that are of benefit to the people in order to follow Allāh's command. It also symbolizes our willingness to give up some of the sacrifier's bounties in order to strengthen ties of friendship and help those who are in need. One sacrificer says "I recognize that all blessing comes from Allāh, and I should open my heart to sacrifice the animals and share with others".

The existence of the committee members for slaughtering animals is needed so that the sacrificial ritual can be performed smoothly. However, they are not allowed to take skin or other parts of the sacrificial meat except if they are poor or have received meat from the sacrifiers as a gift (Arb hadiya). It is said that when the sacrifier delivers the meat to the poor, he or she will get the same reward that he or she would get from releasing a slave from his/her master. As has been observed, the sacrificial meat in the cluster (Ind dusun) of Darussalam of Blangporoh village is divided into 25 heaps suitable for the poor families in that cluster. Meanwhile, the sacrificial buffalo's meat Ladang Tuha II is divided into 150 heaps and in Meunasah Baro it is divided into 170 heaps suitable for the poor families including the orphanages in these villages. The sacrifier does not divide the sacrificial meat into three equal portions as described above because there are more poor people in the village. Most importantly, this charitable practice is demonstrated by the concerted effort to see that no impoverished inhabitants are left without sacrificed food during this joyful occasion.

It is also permissible to give the sacrificial meat to non-Muslims as charity since they do not fight against Muslims. The Qur'ān says" Allāh does not forbid you from having contact with those who do not fight you because of religion and from those who do not expel you from your homes; you should be righteous toward them and act justly towards them. Indeed, Allāh loves those 
who act justly (QS 60:8). In contrast, it is forbidden to give the sacrificial meat to non-Muslims who fight against Muslims. The Qur'ān says, "Allāh only forbids you from having contact with those who fight you because of religion and expel you from your homes and aid in your expulsion. He forbids you to make them your allies and whoever makes allies of them are then the wrongdoers (QS 60:9). The sacrifier is allowed to receive and consume a part of the meat of the animal in order to receive 'blessing' from Allāh. The animal is a sacrificial gift to Allāh and it is in His name that the meat is distributed among other people. It is significant that "in principle the social vicinity of the sacrifier entitles people indiscriminately to an equal part of the meat, be they Muslims or Christians, or whatever their social standing" (al-Sakhaneh 2005:141). On this occasion many households perform sacrifices. It is clear that it leads to an intensive process of gift-giving among the entire inhabitants in the name of Allāh. Hence it is forbidden (Arb haram) to alienate any part of the sacrificial meat by selling it or giving any part of it as payment for services. This is based on a hadith from Ali, "The Prophet has ordered me to handle the sacrificed camel and I divide its skin and meat and I do not give the butcher any part of it. He said "we give from our own belongings". Thus the butcher, skinner, or cleaner should not be given any part of the animal in reward for his services but should be paid separately.

\section{Conclusion}

The uroe raya haji is one of the two major yearly holidays in Islam. It falls on the $10^{\text {th }}$ day of the Islamic lunar month of Zulhijjah and it is the "feast of sacrifice" which symbolically marks the willingness of the Prophet Ibrāhīm to sacrifice his son, Isma'îl in obedience to Allāh. This twelfth month in the Acèhnese calendars or in the Islamic calendars follows on from the completion of the pilgrimage to Mecca. The Aneuk Jamee refer to it as hari rayo haji or in Indonesianized Arabic, idul adha (from Arabic ' $i d$ al-adhā). They talk about the sacrifice which the pilgrims perform in the city of Mina in Mecca simultaneously with their own sacrifices. In this context the Aneuk Jamee also refer to this local event as the "pilgrimage holiday" (Ach oroe raya haji).

There are two rituals performed by the Aneuk Jamee related to the uroe raya haji. They are meugang (eating meat before idul adha) and slaughtering sacrificial animals. Although they are performed nearly at the same time, these two activities have two different dimensions. Meugang is from an adat tradi- 
tion, while sacrifice (Arb qurbān) is from syari'ah. In the context of uroe raya haji, the meugang ritual is marked by eating meat together in the family. After uroe raya haji, the celebration is continued by sacrificing the meat. The Aneuk Jamee's custom of performing meugang before the uroe raya haji day is to welcome the coming of uroe raya haji. Welcoming it is done through eating together with their families. However, in syari'ah law, a day preceding the uroe raya haji (on 9 Dzulhijjah) is the day of Arafah. On this day all Muslims are recommended to fast to eliminate their sins. In the syari'ah law the "culture of eating" is recommended after the idul adha prayer for 3 days respectively, (1113 Dzulhijjah) called tasyréd days. Thus fasting on the tasyréd days is not allowed, as the Prophet said "these days are the days for eating and drinking". Here there is a different pattern in welcoming the day of uroe raya haji between adat and syari'ah. The meugang's meat (Ach sie meugang) is prepared for one's family whereas sacrificial meat (Ach sie kureubeun) is shared amongst others, especially the needy. Meungang is performed to strengthen family relationships, whereas, the sacrifice is performed to strengthen the bonds of friendship, its focus is also on social attention to the needy.

Like the Gayo people in Central Acèh, the Aneuk Jamee couples also "shape their sacrificial performances with the afterlife in mind, trying to provide a mount "vehicle" to heaven on Judgment Day for themselves, their children, and, if possible, their parents and grandparents. Parents feel a strong obligation to provide a mount for a child who dies young, as do children whose parents and grandparents have no resources to make sacrifices in their own names" (Bowen, 1992). Like the akikah (Arb 'aqiqqa) sacrifice, the sacrificial ram, sheep or buffalo provides a future gift. On Judgment Day, the sacrificial animals will meet their sacrifiers next to their cemeteries in the condition in which they have been sacrificed. Only one person can ride a goat or a sheep to the place of Judgment, but seven can ride on a buffalo or a cow. A buffalo sacrifice or a cow thus provides the opportunity to bring together parents, children, and grandchildren on the back of the sacrificial mount. In addition, like the Gayo people in Central Acèh, the Aneuk Jamee also "projects the imagery from the ritual event onto the family's fate in the afterlife" (Bowen, 1992). This specific image is proof that the ritual of sacrifice performed on uroe raya haji in Aneuk Jamee society involves not just the offering but much more than that, it includes the moral bonds uniting them as they come together to sacrifice livestock such as a ram, sheep or buffalo to Allāh. 
In this single sacrificial ritual, there are two different dimensions, the Aneuk Jamee's adat dimension and the Islamic dimension. In the Aneuk Jamee's adat dimension there is a discourse on the "cooling" ritual and in the Islamic dimension the "cooling" ritual is not relevant. In the Islamic dimension the ritual of sacrifice is based up the first animal sacrifice made, that is the sacrificed ram instead of Isma'īl this we may call the Ibrāhīm tradition. Here both these ritual discourses are united in the same sacrificial ritual but modernists want to purify Islam from adat and therefore insist that the "cooling" ritual should be removed. 


\section{CHAPTER 14}

\section{Concluding remarks}

The society of the Aneuk Jamee is composed of people who mostly originate from Minangkabau, West Sumatra. During their settlement in the southern and western coast of Acèh over the last hundred years, some of them have mingled with other migrants who, for the most part, were descendants of inhabitants from the region of Acèh. During this long period of separation from their native Minangkabau area and due to geographic circumscription, they found that certain dimensions of their inherited culture were changing. In addition, the joining of two different traditions in that area - the Acènnese adat and the Minangkabau adat - has resulted in a mutual giving and receiving of aspects of each respective adat. Aspects of the Acèhnese's adat were incorporated into that of the Aneuk Jamee since the southern and western coast of Acèh has always been a part of Acèh's sphere of influence. These factors cannot be ignored in understanding the changes taking place within the Aneuk Jamee society. As a result the adat of the Aneuk Jamee is difficult to classify either as the Minangkabau adat or the Acèhnese adat. Elements from both have been integrated into a distinct, coherent and particular system of adat that can be identified as specific for the Aneuk Jamee. Such is reflected in the ritual calendar that is the object of this study.

The specificity of the Aneuk Jamee adat is correspondingly reflected in the structure and process in the Aneuk Jamee's ritual calendar. Throughout this thesis, I have presented a wide-ranging discussion of the Aneuk Jamee's ritual calendar constituting in its totality the annual ritual cycle that forms the foundation of the socio-religious order of the society of South Acèh. This discussion includes what the local people believe as well as what they do. Exceptions do occur, but by and large, what people believe, do, and enact are complementary. What they believe motivates what they do and how they act, while what they do and how they act reflects in verbal as well as in non-verbal expressions what they believe.

Careful examination of these rituals shows that the Aneuk Jamee society in South Acèh reflects different perspectives: the traditional adat perspective, the historical Islamic perspective, and the modernist Islamic perspective. This suggests that the Aneuk Jamee society is comparable to other societies in Indonesia in that they have a culture and identity that makes them different from 
others while at the same time sharing characteristics that makes them comparable.

Whereas the facts covered in this study are connected with traditional customary practices (Indon adat istiadat), the thesis endeavours to demonstrate that many, if not most, acts or expressions have scriptural roots or find their justification in the basic sources of Islamic doctrine: the Qur'ān and the hadith and the works of the 'ulamā' in which operational meanings of the Qur'ān and the hadith are elaborated. Whether or not this basis and justification are considered applicable and acceptable to other Muslims is a matter of theological debate within the Muslim community rather than a subject for judgment by observers. The relation between adat and Islam in Acèh has been influenced by the following guidance: "Adat bak Poe Teumeureuhom [Sultan Iskandar Muda], Hukom bak Syiah Kuala. Hukom ngon adat lagèe zat ngon sipheut" (Adat is with Poe Teumeureuhom, Law is with Syiah Kuala. Law and adat are like substance and its character). This expression means that questions concerning social and political order are decided by the wisdom of the Sultan and his advisors, in this case symbolized by Sultan Iskandar Muda. Islamic law is in the hands of religious leaders, symbolized by the great and well-known, Teungku Syiah Kuala (Syeikh 'Abd Al-Ra'ūf Al-Singkī11). “Zat ngon sipheut” means that laws and traditional customary practices are tied up firmly like substance and character. Adat and Islamic law are thus inseparable. Some Aneuk Jamee and Acèhnese are sometimes confused what belongs to adat and what to Islam, saying that customary law (adat) in Acèh is derived from Islam.

The order of adat varies in different areas in Acèh. For instance, adat in Central Acèh may vary from the ones in coastal areas such as the adat of the Aneuk Jamee in West Labuhan Haji district, South Acèh. Yet this does not create a conflict because one subscribes to the principle that adat is where you are; wherever you walk on this earth it is under this sky that you live [and it is rules that you obey] (adat itu adalah domisili, dimana bumi dipijak, disitu langit dijunjung)". Adat is the customary means to create an ordered life within society and all that surrounds it. According to the Jamee elders in West Labuhan Haji district, adat aims to uphold the teachings of Islam. They insist that, "the law of religion without adat is tasteless; adat without religion is canceled" (hukom/agama hana adat tabeu, adat hana agama bateu). Adat is understood as a flavor of religion. If it is violated, it brings sanctions. It has the highest status in a community and is sacred. 
Adat in Blangporoh society forms, and is expressed in all forms of, social interaction, ranging from concrete settlement patterns to vernacular language, kinship terms and marriage systems, rituals and games, arts and weapons etc. This thesis has focused, however, on the adat of the annual ritual calendar. A brief review of what the analysis has highlighted is useful to explore to what extent the society's core ideas and values reveal pre-Islamic elements as well as those central to historic Islam.

In chapter 2, the Aneuk Jamee cosmology revealed that there are categories of cosmological beings interacting with the living. The Aneuk Jamee believes that the universe consists of two interconnected parts: the visible and the invisible. Human beings live on the visible level, while God and spiritual beings, such as malaikat (angels), iblis (devils), syètan (Satan) and jinn (genies), exist on the invisible level. Both levels are interrelated and they interact through the belief and rules given by God. The Aneuk Jamee idea of God derives entirely from Islam. The essence of the Aneuk Jamee's theology is its monotheism - the belief in Allāh as the creator of all things. Nothing has happened or shall happen without His knowledge or His will. He is the only everlasting and unique reality, the eternal and absolute, to whom alone all worship is due. Central to the Aneuk Jamee ideas is the belief in the unity of God and His attributes which explains Himself and His existence. Striking is the total absence of Hindu deities.

However, malaikat are believed to act as intermediaries between the divine world and the human world working at the command of Allāh. Belief in malaikat is closely connected to the belief in other spiritual beings such as iblis, jinn, syètan and makhluk halus. The two realms are opposed but complementary so that each makes the other understandable and acceptable. Malaikat, iblis, jinn, syétan have their roots in the Qur'ān but makhluk halus do not. Although the Aneuk Jamee believe and maintain that makhluk halus are part of the spirits that have their original roots in the Qur'ān, it may be argued that these beliefs are maintained and derived from a pre-Islamic Aneuk Jamee sociocosmological view of the universe that has been integrated into the local Muslim belief system. As detailed information about these spiritual beings is incomplete and speculative, their nature, essence and actions are described differently by different people.

Chapter 3 demonstrated that the Aneuk Jamee system of kinship is expressed and enacted during life-cycle rituals such as weddings, circumcisions, 
and funerals. In addition, hari rayo idul fitri, the celebration at the end of the fasting month of Ramadhan and hari rayo haji, the celebration of the "feast of sacrifice" are the media through which kinship connections are acknowledged. The recognition of consanguneal kinship is limited to three descending and three ascending generations. Beyond these boundaries, kin are not terminologically acknowledged. In addition, the recognition of kinship is "horizontal" rather than "vertical", in that an apical ancestor is not the point of orientation rather it is siblingship. Relatives are commonly distinguished as close or distant, but seldom with precision. The descendants of a single grandparent usually regard one another as close, but the descendants of siblings of grandparents are distant and can be forgotten. In explaining a distant link, an individual traces the connection until a sibling relationship at the third ascending generation and stops there. The farthest back the kinship reckoning goes is to say that "our ancestors (muyang/moyang) are siblings", rather than identifying the relationship between persons as descendants of a linking ancestor. In other words, the Aneuk Jamee tends to say that, "We descend from siblings".

The order of birth is an important principle for the relationships between siblings and the orientation in time is a main principle for ordering the relations among siblings. The children's absolute order of birth is not subordinated to the order of birth of their respective parents. Therefore, this principle cannot be spoken of as an "inherited" one. The children do not take on their respective parents' birth order and are not subordinated under their parents' age but depend on the order of their own respective moment of birth. Absolute age, therefore, can be identified as a main structuring principle for the relationships among parents' siblings' children. The children designate their parents' siblings according to their relative age and respect the order of birth of their parents' generation. Hence the orientation in time is a main characteristic of their relationship. Not only is the relative age important to this relationship, but also a gender specific distinction is made clear.

The ritual of marriage described in chapter 4 demonstrates that the authority in conducting a marriage relationship does not derive from the patrilineal relatives (wali hukum) but from the matrilineal ones (niniak mamak). Patrilineal relatives do not seem to play a significant role in the establishment of affinity. Most parts of the ritual are performed by niniak mamak of both the bride and groom. Never are a bride and groom represented by wali hukum. Niniak mamak are responsible for the marriage; most ritual transactions are 
performed by them. The siblings of the bride and groom are not given any formal roles in the wedding ceremony.

The Aneuk Jamee wedding is accompanied by an elaborate series of gift exchanges between the groom's parents and the bride's. Apart from the transfer of money and jewelry, the gifts given from the groom's side to the bride's called hantaran are goods such as cloth, cosmetic products, fruit, toilet articles, trinkets, etc. These gifts are reciprocated by the bride's side to the groom's. These are not distinguished by special terms but consist of cooked food which is prepared by women in the kitchen. The notion of marriage for the Aneuk Jamee is, therefore, significant in understanding the domestic life of the Aneuk Jamee society. The wife provides the home as well the cooked food for the husband. This exchange is conceptualized as a relation between the host (wife) and the guest (husband).

Chapter 5 discusses the ritual of khanduri 'asyūrā performed on the tenth day of the first lunar month, Muharram (i.e. January). The people associate the events of Muharram and 'āsyūrā with different mythical contexts. Some stress the myth of Husén, others stress the myth of Moses and Pharaoh and some others stress the myth of Noah's ark. The myth of Noah, in particular, is important because it was deemed to be the occasion when the first porridge was cooked. The Blangporoh villagers cook the porridge and celebrate having been saved from the deluge by Allāh. This ritual consists of four activities: 1) Preparing the 'assyūra porridge commemorating the first meal consumed after the ark ran aground; 2) Observing the tasu'a (fasting on the ninth day) and the 'ásyūrā (fasting on the tenth day) of the Muharram month; 3) Caressing the orphans' head and; 4) Performing the 'āsyzurrā prayer. The interpretations of the meaning and the value of distributing ' $\bar{a} s y \bar{u} r \bar{a}$ porridge in the ritual of ' $\bar{a} s y \bar{u} r \bar{a}$ are twofold. Firstly, the ritual has a social meaning and value, in that it strengthens the community ties by cooking the 'āsyūra porridge and by sharing it. The villagers offer the 'assyürā porridge to be distributed to neighbors, nextof-kin and people who pass through the community on that day. Secondly there is the religious meaning and value, that is the merit that one receives from Allāh when one performs the ritual of 'āsyūrā. One does it for one's fellow people, for one's community and because Allāh saved Noah and his followers and Moses and his followers. The religious merit received from performing this ritual is meant to be transferred to Hasan and Husén, the martyred grandchil- 
dren of the Prophet Muhammad, while begging Allāh to forgive their sins and allow them a "wide grave", that is, to release them from torment.

Chapter 6 shows how the ritual of tulak bala ("warding off calamity") is celebrated annually on the last Wednesday of the second lunar month of Safar (February). During this period there is an interdiction on house building, on performing marriage rituals etc. Accidents, epidemics and disasters are believed to occur during this month and particularly on the last Wednesday which is considered inauspicious. Such catastrophic events are attributed to Satan and other evil supernatural beings attacking human beings and cattle. The ritual of tulak bala performed during this Safar month is therefore considered crucially important to ward off all kinds of evil and misfortune by strengthening the social relations among the people. On this day young men and women as well as the elderly hold a social gathering at the seashore or at a river bank. They bring various kinds of food with them and entertain themselves by singing to the accompaniment of guitar music. On the actual day of the ritual, some young men play football, and then take a bath in the river or in the sea called manoe sapha. This ritual bath may have been originally a secular bathing festivity providing an opportunity for the nubile young men and women to see and to get to know each other. It would also seem possible that such a festivity might well have been part of Jamee traditions before it was endowed with an Islamic significance. It is, however, worth mentioning that most performances of the tulak bala ritual in Blangporoh have changed as culture in the coastal area is more open to foreign influences. This change is also caused by the rigorous criticism from the local modernists and 'ulamā', claiming that constructing a banana raft with offerings placed on it and then releasing it to the sea or river on the day of tulak bala is a pre-Islamic act. Therefore, at present, the recreational aspect is stressed more than the ritual aspect.

The ritual of khanduri mo'lot "the ritual celebrating the Prophet's Muhammad birthday" described in chapter 7 held either in the mò'lot month (on or after the 12th day of Rabì' al-Awwal - the third month of the year (March) or in one of the two following months (April and May). It is performed in light of generating happiness manifested in the society as a whole that participate in all aspects of the khanduri so that the more abundant the khanduri [food] is, the more happiness that is felt and displayed. The recitation of the diké mò'lōt consists of appeals to Allāh to give the highest dignity to the Prophet, his ancestors and descendants and to give merit to his companions, his followers, participants 
and to all Muslims. The diké mò'lōt is recited because people believe that the 'spirit' (Indon roh) of the Prophet and his companions are present with them.Reciting the diké mò'lōt is considered the same as praying for the Prophet's well-being in order to get 'help' (syafä'ah) from him in the hereafter in return. For these reasons, many villagers are willing to go into serious debt in order to be able to join in the communal meal and at the same time to celebrate the Prophet's birth, for the social commensality is always embedded in the wider cosmological frame. Nonetheless, the orthodox 'ulam $\bar{a}$ ' find the inclusion of any food on this occasion to bedangerous, misleading people into seeing religious events as self-interested spiritual transactions, when in fact they should be primarily an act of obedience to Allāh.

In performing this ritual, the performers various intentions may have different valorizations. The khanduri mó'lōt at the family and village level are not just perceived as a commemorative celebration but also as a part of several exchange relationships and the villagers have different interpretations of the various parts of the ritual. These interpretations range from understanding their actions as prayers to Allāh, to generating merit for the 'soul' (roh) of deceased family members by bringing offerings to the mosque, to allowing angels to enjoy a meal offered on this occasion. The 'ulamā', however, object to these interpretations as they also object to the interpretation of mó 'lōt as a khanduri, and during didactic lectures they may express a disdain for including the distribution and the consumption of food in the ritual. In their view, Muslim holidays are primarily about remembering and celebrating events in Islamic history, conforming to the historical example set by the Prophet and demonstrating obedience to Allāh through worship, fast, and sacrifice.

Chapter 8 is devoted to the ritual of khanduri bungong kayëe "the ritual for flowering trees". It is performed especially for fruit bearing trees such as nephelium, lansium, mango, and so forth in Jumadil Akhir (June) to protect the fruition of the trees from the southern wind and from flashes of lightning. It aims at ensuring that Allāh will take care that the trees will bear fruit, the blossoms will not fade and fall onto the ground prematurely and that the trees will not be attacked by diseases but will benefit human beings. The ritual is closely connected with the idea that the winds cause the trees to blossom. Such winds are classified into four kinds: the northern wind, regarded as "cold", the southern wind regarded as "hot"; the eastern wind regarded as "patient"; and the western wind as "strong". Each wind has its own function for the trees. The 
eastern wind functions as fertilizer for the tree; the northern wind strengthens the tree roots; the western wind will make the tree bear blossoms; while the southern wind can make the tree blossoms fade and fall to the ground. If the wind does not shake the trees, the trees will not bear blossom. When the western wind blows, the tree trunks shake and their branches rub each other. As a result the hollow spaces in the tree trunks are opened and the wind penetrates the tree trunks causing the trees to bloom. Therefore, the villagers say that the western wind is the "husband of the tree", just like the "husband of the turtle is the southern wind" because "if the southern wind blows the female turtles lay eggs".

Even when performing the ritual of khanduri bungong kayèe, it may still happen that the trees do not blossom, that is, that the fertility of the fruitbearing trees has not been safeguarded. For there are several further requirements for the fertility of the fruit bearing trees: it is dependent upon collective ritual action, the "mercy" of Allāh, the actions of jinn, fair political leadership, and respecting the adat rules particularly concerning exogamy and incest which is the most serious crime in adat law.

Chapter 9 describes the ritual of khanduri apam performed in the seventh lunar month, Ra'jab (July). It is commemorated by baking apam cakes in every house and distributing them at the mosques or prayer houses as special food in the interest of ancestors and recently deceased relatives. The ritual is celebrated on two different occasions: for the deceased of a house and collectively, for all deceased that have become ancestors. The collective khanduri apam can only be celebrated after the individual khanduri apam has been performed for each deceased person. Thus, first the relation between the living and ancestors of a particular house is established, and only then the relation between the living as a whole and the ancestors of the society as a whole are expressed. This is indeed the way of mediation between the living and ancestors. The ritual has various dimensions. The first dimension is that it takes care of the dead, on both occasions they are nourished with the spiritual essence of the rice. To that end, rice cakes are cooked, the smell of which attracts the deceased and whose fragrance is intended as nourishment for the deceased. The second dimension is that performing the khanduri apam generates merit that is transferred to the deceased in order to protect his or her in the grave from the interrogating angels. It is redeemed by linking the offering of the rice cakes with the recitation of the shamadiyah. They generate the gift from Allāh to those performers. This 
third dimension is denied by modernists who reject the possibility of the living aiding the dead through the shamadiyah recitation. They argue that "the person can only help him or herself directly in relation to Allāh". The modernists also deny that one can send food to the souls but they do value the food's natural qualities.

Chapter 10 is devoted to the ritual of khanduri bu, performed in the eighth lunar month, Sya'ban (August). This is aimed at thanking the ancestors (ureueng chi') who have already transferred well-being to the living. This is regarded as an important obligation to the ancestors. The ritual entails visits to the ancestral tombs and feeding the 'souls' (roh) of the ancestors by distributing rice and other food dishes to the poor and orphans to commemorate the services of the ancestors who have accumulated and generated wealth in the past. The Aneuk Jamee state that there are villagers who used to be rich but who gradually lost their wealth as their ancestors condemned them for not commemorating them. In such a case one's wealth would no longer be 'blessed' (beureukat) as their descendants no longer expressed their gratitude to their ancestors but neglected them instead. Thus, the food given to the poor and orphans is regarded to be a social demonstration of the sincere devotion to Allāh in order to "prevent calamities". It testifies to the fact that the givers' "heart is not hardened" and that he has not forgotten the ancestral origin of his well-being. His gifts, given in acknowledgement of these debts, are a means of "cleansing his soul/mind". Many villagers are now rich because they have received the benefits and the prosperity as ancestral gifts called "the deceased's property. Such ancestral gifts of prosperity to the living remain "the deceased's property". This prosperity would diminish and eventually be lost altogether if the living did not perform the khanduri bu ritual in acknowledgement of these ancestral gifts.

The ritual of Ramadhan analysed chapter 11 is performed in the ninth lunar month (September), consisting of fasting, tarawèh prayer, tadarus, nuzul Qur'an and zakat fitrah. It is regarded as a "liminal time" in the Islamic calendrical rituals. The Aneuk Jamee do not only understand Ramadhan on the normative level but have specific interpretations on the practical level. There are three notions which give meaning to the performance of Ramadhan rituals. The first notion is Ramadhan as a month of purification in which to purify the heart, the "controller of the mind" and source of all actions. The second notion is Ramadhan as a month of religious worship to get the best spiritual training. 
During Ramadhan, people become more aware of performing religious worship. The belief is that each good deed performed during Ramadhan brings the performer one step closer to Paradise. Thus, during Ramadhan worship is intensified and religious practice and moral values are strengthened. The third notion is Ramadhan as a month of joy. This can be seen in the joy experienced by families reuniting and associated with the many khanduri held during Ramadhan. The greatest happiness of Ramadhan is, of course, the celebration at the end of Ramadhan. It is interesting that all these joyous activities do not contradict Islamic teaching but rather are acknowledged as part of religious service. These three notions are interrelated and as a result, to some extent, it is difficult to make a distinction between them. Ramadhan is, thus, a moment for the Aneuk Jamee and the suluk followers in Blangporoh to return to their basic identity as an Islamic and social community. Through experiencing a special life during Ramadhan, they endeavor to proclaim to themselves and to other people that their basic identity as Muslims and as the Aneuk Jamee has not changed.

The ritual of uroe raya puasa "the festival of breaking fast" examined in chapter 12 is the major annual holiday of Islam and is performed on the first day of the tenth lunar month, Syawwal (October). The celebration called uroe raya puasa marks the end of Ramadhan. The ritual of uroe raya puasa cannot be separated from the religious services performed by Muslims during the Ramadhan lunar month. The relation between fasting and uroe raya puasa is perceived as a relation between "struggle" and "victory". Fasting is a spiritual journey to release the human body from satanic powers. This journey involves restraining basic human urges: one must stop eating, drinking, and having sexual intercourse. Uroe raya puasa, then is a "feast of victory" celebrating that people have been freed from satanic desire.

It is worth mentioning that uroe raya puasa is valued as a moment to develop communication, both with Allāh and among human beings. Communication with Allāh is attained by continuously carrying out 'Allāh-fearing' prayers (taqwā) during the month of fasting. Communication with human beings is achieved through the bonds of friendship, gift-giving and forgiving each other. In addition, the purification performed during uroe raya puasa can be seen as a point of transition from the 'liminal time' of the sacred month back into everyday life. As people feel that they are reborn and without sin, uroe raya puasa is for the Aneuk Jamee not only the climax of the purification process but also the starting paint for the return to everyday life. 
Chapter 13 is devoted to the ritual of uroe raya haji ("pilgrimage holiday"), another major yearly holiday inIslam, performed on the 10th day of the twelfth lunar month, Zulhijjah (December). It is the "feast of sacrifice" which commemorates and represents the willingness of the Prophet Ibrāhīm to sacrifice his son, Isma'îl in obedience to Allāh. The Aneuk Jamee couples conduct their sacrificial performances with their after life in mind. They aim to provide a "vehicle" to Heaven on Judgment Day for themselves, their children, and, if possible, their parents and grandparents. Parents feel a strong obligation to perform the sacrifice for a child who dies young, as do children whose parents and grandparents have no resources to make sacrifices in their own names. Like the akikah sacrifice, the sacrificial ram, sheep or buffalo represent a gift. On Judgment Day, the sacrificial animals will meet their sacrifiers next to their cemeteries in the condition in which they have been sacrificed. Only one person can ride a goat or a sheep to the place of Judgment, but seven can ride a buffalo or a cow. The sacrifice of a buffalo or a cow thus provides the opportunity to bring together parents, children, and grandchildren on the back of the sacrificial mount. This specific image bears witness to the idea that the ritual sacrifice performed on uroe raya haji in the Aneuk Jamee society involves not just the sacrificial slaughter but above all it strengthens the moral bonds between those who come together to sacrifice livestock to Allāh.

It seems clear at this stage that the Aneuk Jamee cannot be separated from the ritual performance of these manifold khanduri rituals. They consider the performance of calendrical khanduri as the most important parts of social action. It is of vital importance for the continuity and reproduction of all social life. The Aneuk Jamee deem the ritual calendar of fundamental importance for their very existence as a society. As local adat elders say, "if the ritual calendar were not be performed, it would be as if there was something wrong with the village people; they would feel uneasy that there is something incomplete in their lives, for the rituals have become part of adat in the society".

Islam has entered the adat of the society, influencing this annual ritual calendar. As a result, the concept of agama "religion" and that of adat "customary order" cannot be separated. They have become united as two sides of the same coin. Pre-Islamic representations, however, still have a strong root in the praxis of adat, such as when performing rituals of tulak bala ("warding off calamities") and in the belief in the differenct categories of cosmological beings even though the Aneuk Jamee have strong faith in Islam as a religion. The 
adat of the ritual calendar has a foundation in the ideas and values of the Aneuk Jamee. The Aneuk Jamee adat acts as a framework of guidance and reference in life. The ideas and values are expressed in and through all acts aimed at earning a livelihood and in the enactment of all rituals accompanying their lives.

Apart from the proposal by some groups of people, that the adat of the ritual calendar should be abandoned since it is old-fashioned or even hampers development, the reality is that the adat remains an essential part of and a guide for every step in the life of community members. Acèh is well known as a special area with regard to education and adat. The autonomy of the Acèhnese adat in the past and in the present is evident from the fact that nearly all their life activities are carefully arranged by adat, starting from life in the household and exploiting the means of livelihood, to community life and religion practice. For them, the adat is a guide as well as a frame used as a flavour to give a good taste to life.

The guidance and grandeur of adat contributes to a sense of self-esteem and self-confidence. As Guru Budiman, the head of Acèh adat council in West Labuhan Haji district has put it; "We are great nation, foreigners will be amazed and respect us if we are able to maintain life in the environment of law and adat" and a local proverb says, "the people who have no adat resemble a ship that has no a captain" (ureueng tan adat lagè kapai tan nahkoda). Life which is not protected by adat is barren, a life without passion. Especially for the village farmers and fishermen, the adat of their ritual calendar is of crucial importance both for "digging for knowledge" and for societal relations. Through "digging for knowledge" one can acquire ritual knowledge if one has learnt the theory of the ritual either in formal or in non-formal teaching, and it will be quickly mastered if the opportunity is given to practice the ritual in social life. This opportunity is provided if one is involved directly in adat activities.

The Aneuk Jamee adat acts as a glue, uniting people's lives together. Adat has "planted" the attitude of mutual assistance to solve the many problems facing the society. People know that the main economic activities of farming and fishing not only bring many risks but may also easily lead to various conflicts among each other. For farmers these risks include the problem of channelling and dividing water and maintaining the dikes between rice fields. For fishermen, these are the problems of catching fish and other marine species and the problem of exploiting the coral reefs and other sea resources. Adat enables 
them to solve these conflicts and provides the opportunity to enjoy holidays and the company of others even if there is not enough money to support themselves.Therefore, adat is one of the coordinating institutions requiring a person to be mutually responsible and to overcome problems and disputes in the society. The adat of the ritual calendar enables conflicts to be solved, people to gather together, tension to be released and soothes exhausted souls enslaved by everyday responsibilities toward one's family. Eating together during the rituals binds social relations closer and enhances a sense of understanding towards one another. It is, therefore, not an exaggeration to insist that this adat of the ritual calendar should be maintained, as it contributes to the sense of sociability, and to the identity of the Aneuk Jamee. It enables the society to unite in facing problems and catastrophes that might appear in the future. Society should respect the adat as long as it does not collide with religious teaching, the nation's laws and development. As the Aneuk Jamee themselves insist, living without adat is like eating curry without salt, living a life without flavour, without pleasure, and without passion. 



\section{BIBLIOGRAPHY}

\section{Abbreviations:}

BKI $=$ Bijdagen tot de Taal-,Land-en Volkenkunde

KITLV = Koninklijk Instituut voor Tall-Land-en Volkenkunde

LAKA $=$ Lembaga Adat Kebudayaan Aceh

LP3ES = Lembaga Penelitian, Pendidikan dan Penerangan Ekonomi dan Sosial

CNWS = Concord Naval Weapons Station

Aceh, A.

1994 Pengantar Ilmu Tarekat, Kajian Historis Tentang Mistik. Solo, Ramadhani.

Ahmad, S.M.

1992 Ketika Pala Mulai Berbunga, Seraut Wajah Aceh Selatan. Pemda Aceh Selatan.

Ahmad, Z.A.

1949 "Malay Festivals and Some Aspects of Malay Religious Life: Mandi Safar", in The Malayan branch of the Royal Asiatic Society 22: 103-104.

Al -'Azma, 'Azīz (Azis al-Azmeh) (eds.).

2000 Ibn Taymīya, Bairut: Riyād ar-Rayyis.

Al-Ghazali

1979 The Mysteries of Fasting, Translated by Nabih Amin Faris, Lahore, Pakistan: SH. Muhammad Ashraf.

Al-Sekhaneh, W.

2005 Bedouin of Northern Jordan, Kinship, Cosmology and Ritual Exchange, Ph.

D. Thesis. Institute of Ethnology, Münster, Germany.

Alamsyah, T \& Alibasyah, T. (eds.)

1991 Pedoman Umum Adat Aceh, Banda Aceh, LAKA

Alland, A. J.

1980 To Be Human: An Introduction to Anthropology. New York: John Wiley \& Sons.

Almond, P.

1989 Heretic and Hero, Muhammad and the Victorian, Wiesbaden: Otto Harrassowitz.

An-Nablusi, A.G.

2004 Keutamaan Hari dan Bulan dalam Islam, Mitra Pustaka.

Apridar

2005 Tsunami Aceh, Adzab atau Bencana? Pustaka Al-Kautsar, Jakarta.

\section{Ash-Shiddieqy, H.T.M.}

1950 Tuntutan Qurban. Jakarta: Bulan Bintang.

1983 Pedoman Hajji. Jakarta: Bulan Bintang.

1990 Pedoman Puasa. Jakarta: Bulan Bintang.

Baihaqi, A. K.

1983 "Ulama dan Madrasah", in Taufik Abdullah (eds.), Agama danPerubahan Sosial, Yayasan Ilmu-Ilmu Sosial, Jakarta: CV. Rajawali. 


\section{Barraud, C. \& Platenkamp, J. D. M.}

1990 'Rituals and comparison of societies'. In: Barraud, C \& J. D. M. Platenkamp (eds.), Rituals and socio-cosmic order in Eastern Indonesian societies, Part II: Maluku, Special Issue Bijdragen tot de Taal-Land-en Volkenkunde 146/1: 130-123.

Basri, $\mathbf{H}$.

1998 Praktik Suluk di Kalangan Nelayan Desa Blangporoh, Kecamatan Labuhan Haji Kabupaten Aceh Selatan, Pusat Penelitian Ilmu Sosial dan Budaya, Universitas Syiah Kuala Darussalam, Banda Aceh (Laporan Penelitian).

Blackwood, E.

1993 The Politics of Daily Life: Gender, Kinship and Identity in A Minangkabau Village, West Sumatra, Indonesia, Michigan, UMI Dissertation Information Service.

\section{Bowen, J.R.}

"On Scriptural Essentialism and Ritual Variation: Muslim Sacrifice in Sumatra and Morocco", in Imagining Identities: Nation, Culture, and the Past. Special Issue American Ethnologist. Vol 19, No. 4, pp 656-671.

1993 Muslim through Discourse, Religion and Ritual in Gayo Society, Princeton: New Jersey.

1994 Death and the History of Islam in Highland Aceh, no 38 (October), Cornell Southeast Asia Program, pp 21-38.

\section{Brown, R.}

1979 “Taboo" in William A. Lessa and Evon Z. Vogt eds., Reader in Comparative Religion, An Anthropological Approach, pp. 46-56, New York: Harper Collins Publishers.

\section{Bruinessen, M. van}

1990 "The Original and Development of the Naqsybandi Order in Indonesia", in Der Islam, Zeitschrift für Geschichte and Kultur des Islamischen Orients. Band 67.Heft 1.

\section{Buitelaar, M.}

1993 Fasting and Feasting in Morocco, Women's Participation in Ramadan, Oxford: Berg.

\section{Dall, G.}

1982 "Traditional Acehnese House" in J. Maxwell ed., The Malay Islamic World of Sumatra, Centre for Southeast Asian Studies, Monash University.cari pp nya

Denny, M. F.

1985 "Islamic Ritual: Perspective and Theories", in Richard C. Martin ed., Approaches to Islam in Religious Studies, pp. 63-77, Tucson: University of Arizona Press.

\section{Dian}

1993 "Yahudi sebagai symbol dalam wacana Islam Indonesia masa kini" ["The Jew as a symbol in contemporary Muslim discourse in Indonesia"], in Spiritual baru: Agama dan aspirasi rakyat. pp. 253-268, Yogyakarta.

\section{Durkheim, E.}

1915 The Elementary Forms of the Religious Life. Translated by J. W. Swain, New York: George Allen \&Unwin. 
Eickelman, D. F.

1976 Moroccan Islam, Traditional and Society in a Pilgrimage Centre, Austin and London: University of Texas Press.

1981 The Middle East. An Anthropological Approach, Princeton NJ: Prentice-Hall.

Effendie, $M$.

1979 Berita Alam Gaib, Sebelum dan Sesudah Hari Kemudian, M.A. Jaya. Jakarta.

Emtas, M.U.

2005 Suku dan Adat Aneuk Jamee di Aceh, Yayasan BUSAPAT Banda Aceh.

Evans-Pritchard, E. E.

1973 The Sanusi of Cyrenaica, Oxford: Oxford University Press.

Federspiel, H.M.

1995 A Dictionary of Indonesian Islam, Athens, Ohio: Center for International Studies, Ohio University.

Fierro, $\mathbf{M}$.

1992 "The treatises against innovations (Arabic kutub al bida)", in Der Islam 69: 207-209.

Gardet, L.

1980 Encyclopaedia of Islam: E. J. Brill.

Geertz, C.

1968 Islam Observed; Religious Development in Morocco and Indonesia. New Haven and London: Yale University Press.

1973a "Religion as a Cultural System", in The Interpretation of Cultures, pp 87125. Basic Books.

$1973 \mathrm{~b}$ Ethos, World View, and the Analysis of the Secret Symbol, in The Interpretation of Cultures, pp.126-41, Basic Books.

1976 The Religion of Java, Chicago and London: University of Chicago Press.

Gennep, A. van

1960 The Rites of Passage. Translated by Monika B. Vizedom and Gabrielle L. Caffee, Chicago: University of Chicago Press.

Gibb, H. A. R \& Kraemer, J. H. (eds.)

1961 Shorter Encyclopaedia of Islam, Leiden: E. J. Brill.

Gladney, Dru C.

2006 Salafiyya Movement in Northwest China: Islamic Fundamentalist among the Muslim Chinese? in Muslim Diversity, Local Islam in Global Contexts, pp 119-120. Nordic Institute of Asian Studies.

Gregory, C. A.

1982 Gifts and Commodities, London: Academic Press.

Haikal, M. H.

1976 The life of Muhammad, Translated by Ismail Raji al-Faruqi. American Trust Publication.

Hasimi

2002 Perkembangan dan Pengaruh Tarekat Naqsyahbandiyah di Aceh (19401982), Balai Kajian Sejarah dan Nilai Traditional Banda Aceh. 
Hasjmy, A.

1989 Kebudayaan Aceh pada Hakikatnya Kebudayaan Islam, Aceh Selatan Dalam

Tatawarna Kebudayaan Aceh. Makalah yang Disampaikan Dalam Forum

Seminar Sejarah dan Kebudayaan Aceh Selatan,yang berlangsung di Tapaktuan Tanggal 14-16 Mei.

Hoesin, M.

1970 Adat Aceh, Dinas Pendidikan dan Kebudayaan Propinsi Daerah Istimewa Atjeh.

\section{Hubert, H \& Mauss, M.}

1964 Sacrifice: Its Nature and Function. W. D. Halls, trans. Chicago: University of Chicago Press. [1898]

Hurgronje, C. S.

1906 The Achehnese, translated by A. W. S. O'Sullivan, 2 Vols, Leiden: E.J.Brill.

[1893]

\section{Ibn Khandun}

1967 The Muqaddimah: An Introduction to History, trans. F. Rosenthal N. J. Dawood ed., Princeton: Princeton University Press).

\section{Isma'il al-Bukhari, A.A.M.}

1971 [ca.] Shahīh al-Bukhārī bi Syarah as-Sanadī, Dar al-Ihya' al-Kutub al 'Arabiyyah, Kairo.

\section{Ismail al-Fathani, $M$.}

1987 Al-Bahjatul Mardhiyah, Isa al-Babai Al-Halabi, Mesir.

Jamhari.

1994 To Visit A Sacret Tomb: The Practice of Ziarah to Sunan Tembayat's Resting Place in Klaten, Java, Master of Art Thesis, Camberra, Austalian National University.

Jayawardena, Ch.

1977 “Achehnese Marriage Customs”, Indonesia 23, pp 157-173.

1977 "Women and Kinship in Acheh Besar, Northern Sumatra", Ethnology 16. pp 21-38.

Josselin de Jong, P.E. de (ed.)

1977a Structural Anthropology in the Netherlands; A Reader. KITLV Translation Series 17, The Hague: Martinus Nijhoff.

1984a Unity in Diversity; Indonesia as a field of Anthropological Study. VerhandelingenKITLV 103, Dordecht: Foris Publications.

1980b Minangkabau and Negri Sembilan; Socio-Political Structure in Indonesia, 3rd [1951] impression, The Hague: Martinus Nijhoff.

Ka'bah.

1999 The Prophet Muhammad's Birthday Celebration in Focus, Muslim Executive and Expatriate, no.2.

Krathwohl, D.R.

1993 Method of Educational and Social Science Research. New York: Longman.

Labib \& Ali, $\mathbf{Z}$.

2003 Berkenalan Dengan Jin dan Cara Menundukkannya. Bintang Usaha Jaya Surabaya. 


\section{Manaf, M.}

1977 Adat Perkawinan di Tapak Tuan dan Islam. (Unpublished BA thesis of IAIN Ar Raniry Banda Aceh.

\section{Martin, D. G.}

1992 The Woven Land of Laboya: Ideas and Values in West Sumba, Eastern Indonenesia. Leiden: CNWS.

\section{Masud, M. K.}

1990 "The Obligation to Migrate: the Doctrine of Hijra in Islamic Law" in D.F. Eickelman and James Piscatory eds. Muslim Travellers: Pilgrimage, Migration, and the Religious Imagination, London, Routledge.

Mauss, $\mathbf{M}$.

1980 The Gift. Forms and Functions of Exchange in Archaic Societies, London: Routledge \& Kegan Paul.

\section{Mawardi.}

2005 Adat Upacara Safar dalam Masyarkat Labuhan Haji Barat Ditinjau dari Segi Pendidikan Islam, unpublish BA thesis, Fakultas Tarbiyah Universitas Muhammadiyah Aceh.

\section{Memon, M.U.}

1976 Ibn Taimìya's Struggle against Populer Religion, With an Annotated Translation of his Kitāb iqtidā'as-sirāt al-mustaqīm mukhālafat ashāb al-jahìm, The Hague and Paris: Mouton.

\section{Morris, B.}

1993 Anthropological Studies of Religion, An Introductory Text, Cambridge: Cambridge University Press,

Muhaimin A. G.

2004 The Islamic Tradition of Cirebon, Ibadat and Adat Among Javanese Muslims, Jakarta: Religious Research, Development, and Training.

\section{Murdock, G. P.}

1949 Social Structure. New York: Macmillan Co.

\section{Muslim, Imām}

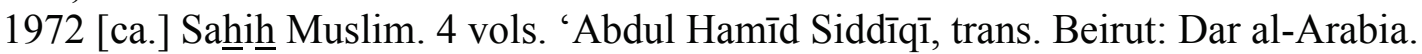

\section{Noer, $\mathbf{D}$.}

1973 The Modernist Muslim Movement in Indonesia 1900-1942. Singapore: Oxford University Press.

Nur, A.

1996 Fasting and Feasting in Lamno Aceh, Unpublished MA thesis of the Australian National University.

\section{Ortner, S. B.}

1978 Sherpas through Their Rituals. Cambridge: Cambridge UniversityPress.

1984 Theory in Anthropology since the Sixties. Comparative Study in the Societyand History, pp.126-166.

\section{Ossenbruggen, P.D.E. van}

1977 Java's monca-pat: Origins or a Primitive Classification system, in: P. E. de [1917] Josselin de Jong (eds.), Structural Anthropology in the Netherlands, pp. 32-60. The Hague: Martinus Nijhoff. 
Parkin, D.

1994 "Ritual as Spatial Direction and Bodily Division", in Daniel de Coppet ed., Understanding Rituals Understanding Rituals.pp. 11-25. London: Routledge.

\section{Patrick J. R.S.J.}

1978 Imale: Yoruba Participation in the Muslim Tradition, Harvard: Scholar Press.

\section{Platenkamp, J.D.M.}

1988 Tabelo, Ideas and Values of a North Molucan society. Leiden: Repro Psychologie.[Ph. D. thesis, Leiden University].

1992 "Transforming Tobelo Ritual", in Daniel de Coppet ed., Understanding Rituals.pp. 74-96. London: Routledge.

1996 "The Healing Gift", in S. Howell (ed.), For the sake of our future; Sacrifice in eastern Indonesia, pp. 318-336, Leiden: Centre of Non-Western Studies.

2001 "Temporality and Male-Female Distinctions in the Tobelo Vocabulary of Relationships" in: C. Alès and Barraud eds., Sexe relative ou Sexe Absolu? De la distinction de sexe dans les Sociétés, pp. 241-266. Paris: Éditions de la Maison des Science de l'homme [reprint of 1998a].

2006 "Spirit Representations in Southeast Asia: A Comparative view". In: Frederic Laugrand \&Jarich Oosten (eds.), The "Nature of Spirits": Human and Nonhuman Beings in Aboriginal Cosmologies, pp. 99-129. Quebec: Les Presses de l'Universite de Laval.

\section{Qur'an}

1997 Translated by Saheeh International-Riyadh, Abulqasim Publishing House (AlMuntada Alislami).

Rahman, F.

1985 "Approach to Islam in Religious Studies: Review Essay", inRichard C. Martin ed., Approaches to Islam in Religious Studies, pp. 189-202, Tucson: University of Arizona Press.

\section{Rappaport, R.A.}

1999 Religion and Ritual in the Making of Humanity: Cambridge: Cambridge University Press

\section{Rosman, A. \& Rubel, P. G.}

2004 The Tapestry of Culture. An Introduction to Cultural Anthropology, New York: Mcgraw Hill.

\section{Rusmali, M.}

1985 Kamus Minangkabau Indonesia, Pusat Pembinaan dan Pengembangan Bahasa,Departemen Pendidikan dan Kebudayaan Jakarta.

Ryan, $\mathbf{P}$.

1978 Imale:Yaruba Participation in the Muslim Tradition, Harvard, Scholar Press.

Salim, H.

1987

Qishashul Anbiya', PT Alma’arif Bandung.

Samad, A.

1991 "Modernism in Islam in Indonesia with Special Reference to Muhammadiyah", in Ricklefs M.S. (eds.), Islam in Indonesian Social Context, Victoria, Australia: Centre of Southeast Asian Studies, Monash University. 


\section{Schimmel, A.}

1985 And Muhammad is His Messenger, the Veneration of Prophet in Islamic Piety, The University of North Carolina Press.

Siegel, T. J.

1969 The Rope of God. Berkeley and Los Angeles: University of North California Press.

\section{Singaravelu, $\mathbf{S}$.}

1986 The Malay-Tamil Cultural Contacts with Special Reference to the Festival of "Mandi Safar", in Asian Folklore Studies 45 (1):67-78.

Soares, B.F.

1996 The Prayer Economy in a Malian Town. Cahiers d'Études Africaines 36, Special Issue Mélanges Maliens 144, pp. 739-753.

Soelaiman, D.A.

1989 Kompilasi Adat Aceh, Laporan Penelitian, Yayasan Toyota.

\section{Sulaiman, M.I.}

1978 Adat dan Upacara Perkawinan di Daerah Adat Istidat Aneuk Jamee, PusatDokumentasi dan Informasi Aceh, Laporan Penelitin, Banda Aceh.

1997 Modernization and Bureaucratization in Development the village: The Acehnese Experience, Unpublished Paper.

\section{Trimmingham, J.S.}

1969 The Ritual Process. Structure and Anti Structure, Chicago: Aldine Publishing Company.

1971 The Sufi Order in Islam, Oxford and London, Oxford: Clarendon Press.

Turner, W. V.

1979 The Ritual Process. Structure and Anti Structure, Chicago: Aldine Publishing Company.

Waadenburg, J. D. J.

1979 "Official and Popular Religion as a Problem in Islamic Studies", in Pieter H. Vrijhof and Jacques Waardeburg, eds., Official and Popular Religion, Analysis of a Theme for Religious Studies, pp. 340-385, Paris: Mouton.

Waly, Dj.

2003 Panduan Zikir dan Do`a Bersama, Banda Aceh.

Waly, M.

1993 Ayah Kami Maulana Syeikh Haji Muda Waly al-Khalidy (Teungku Syeikh MudaWaly). Malaysia, Kulliyah of Laws. International Islamic University.

1997 Maulana Teungku Syeikh Haji Muhammad Waly al-Khalidy, Ulama Besar Aceh dan Perannya dalam Pembangunan Pendidikan, Intermasa, Jakarta.

Yamani, $\mathbf{Z}$.

1987 "Fasting and Feasting: Some Social Aspects of the Observance of Ramadan in Saudi Arabia", in Ahmed Al- Shahi eds., The Diversity of the Muslim Community, Anthropological Essays in Memory of P. Lienhardt, pp. 80-91, London: Ithaca Press.

Young, $\mathrm{K}$.

1994 Islamic Peasants and the State: The 1908 Anti-Tax Rebellion in West Sumatra. Monograph 40/Yale Southeast Asia Studies. 


\section{Zainuddin, A. and Asrori, A. M.}

1997 Al-Imam Taqiyuddin Husain, Kafayatul Akhyar Jilid 2, PT. Bina Ilmu, Surabaya.

\section{Zainuddin, H. M.}

1961 Tarich Atjeh dan Nusantara, Iskandar Muda.

\section{Newspaper}

Serambi Indonesia, January $24^{\text {th }}, 2009$.

Serambi Indonesia, August 22 $2^{\text {nd }}, 2009$.

Serambi Indonesia, September $26^{\text {th }}, 2009$.

Serambi Indonesia, November 30 $0^{\text {th }}, 2009$.

Serambi Indonesia, November $9^{\text {th }}, 2007$.

Serambi Indonesia, November $30^{\text {th }}, 2009$.

Serambi Indonesia, November $28^{\text {th }}, 2009$.

Serambi Indonesia, February $13^{\text {th }}, 2007$.

Serambi Indonesia, February $17^{\text {th }}, 2007$.

Serambi Indonesia, March $18^{\text {th }}, 2007$.

Serambi Indonesia, March $17^{\text {th }}, 2007$.

Serambi Indonesia, March $8^{\text {th }}, 2007$.

Serambi Indonesia, March $8^{\text {th }}, 2007$.

Serambi Indonesia, April 14 ${ }^{\text {th }}, 2007$.

Serambi Indonesia, September $11^{\text {th }}, 2007$.
Serambi Indonesia, October 16, 2007.

Serambi Indonesia, October 16, 2007.

Serambi Indonesia, November $9^{\text {th }}, 2007$

Serambi Indonesia, December 30 ${ }^{\text {th }}, 2007$.

Waspada, September 21, 2009.

Waspada, September 21, 2009.

Waspada, August 19 $9^{\text {th }}, 2008$.

Waspada, September 15, 1988.

Waspada, September 15, 1988.

Kompas, May 20 $0^{\text {th }}, 2005$.

Kompas, May 20 ${ }^{\text {th }}, 2005$.

Harian Pikiran Rakyat, May $2^{\text {nd }}, 2007$.

The Jakarta Post, January $19^{\text {th }}, 2005$.

\section{Website}

Detik. Com, June 30 2008.

Website ofPondok Pesantrén Dayah Darussalam in

http://www.al-shia.com/html/id/service/Info-Hauzah/Dayah\%20Darussalam.htm.

http://matanews.com/2009/09/20/shalat-id-di-aceh/

map od Aceh in www.c-r.org/our-work/accord/aceh/map.php 


\section{APPENDIX 1}

\section{The poem at menendai ceremony by the groom's side}

\author{
Biduak dikayuh kamuaro \\ manyawuak ayie mamakai timbo \\ alah putieh uban dikapalo \\ bungo yang kambong balun basuwo \\ Bakato kato dalam hati \\ terbayang-bayang dikalopak mato \\ tabayang didalom mimpi \\ dapek barito sakatiko \\ barito dibawok unggeh tabang \\ ada kambang sakumtum bungo \\ yang sedang kambang ditangkainyo \\ ditanamdirumah iko \\ bungo yang dijaga niniak mamak \\ ayah jok bundo
}

\section{Anak padusi ibarat kato urang sarupo buah durian \\ kamano disimpan babaun juo}

Bak pihak hati yakin ka bungo walau dilintang tujuah lurah dan bukik namun bungo tatok kami turuit juo indak kami tahu jok litak badan banyak kampuang kami lalui puluhan koto yang kami singgahi banyak sungai kami seberangi baliku jalan yang kami tampuah kini kami tibo dikampuangko kami tahimbau tibo dirumahko lantran cahayo bungo kambang dirumahko

Dari jauah kami datang manjalang mambawok sarato saikue kumbang kumbang pandan banamo sikumbang jadi sayoknyo hijau kamerahan tabangnyo tinggi manambuih awan tigo kali dalam sahari tabang ka Aceh babalik hari tabang ka Arab mancari makan tingganyo jauah dari yang ramai indak sabarapo diom di nagari banyak badiom dikampuang urang hitom balakangnya banyak bajalan sirah muko banyak bapaneh
The Canoe is rowed into the estuary drawing water with a bucket a pat on the head that is gray-white the blossoming flower has not been met

Saying in the heart imagine in the eye's eyelid imagine in the dream getting news instantly news carried by flying birds there is a flower which is blossoming on its stalk it is planted in this house a flower guarded by niniak mamak father and mother.

People say a girl resembles the durian fruit stored away but whose scent is in the air

Because the heart is sure about the flower although it is blocked by 7 villages and hills however the flower shouldbe followed we do not know that our body is tired many villages we pass dozens of cities we stop at many rivers we cross winding roads we travel now we arrive in this village we are called to arrive at this house due to the light of flower in bloom in this house

From far we come we bring along a beetle the pandan beetle named sikumbang jadi its wing is reddish green it flies high in the clouds three times a day flying to Acèh returning on the same day flying to Arabia searching for food it lives far from the crowd it does not stay much in the realm it stays more in other people's villages black on its back because it walks more its face is red because it stays in the heat more 
bajalan kumbang kian kamari

bak pihak paruik indak baisi

ibarat ayom maken mangakeh-ngakeh

indak mangakeh indak ado maken

Kami ingin mampasunting bungo kambang semerbak bawangi didalom taman harumnyo sampai katapian mandi bila bungo indak dapek kami pasunting untuk selamo-lamonyo

Kami malu pulang ka kampuang dari pado hiduik maracun hati biarlah mati baputuh tulang izinkanlah kami kini batanyo apakah bungo balun bapunyo? jiko ado kumbang manjago izinkan kami bagantuang dirantiangnyo bapacik kami didaunnyo itulah mohon jok pintak kami kironyo keuchik jok niniak mamak bak rela jok ikhlas mengabulkannyo

Buruang tampuo duo sajoli tabang mancari tampek basarang berilah kami kato yang pasti untuk pesambahan kami bawok pulang the beetle walks here and there because its stomach is empty it is like a chicken, scratching no scratching no food

we want to engage the blossoming flower the fragrant scent in the garden its scent reaches the edge of a bathing place if we cannot pick the flower forever

We will be ashamed to go back to the village better that it poisons the liver better to die by having one's bones dissembled please allow us now to ask the question does the flower have an owner if there is a beetle that protects please allow us to hang on to its twig we graspits leaf this is our hope and request hopefully keuchik and niniak mamak are willing and sincerely agree

Tampuo birds fly side by side flying to look for a nest please give us certain words as a gift to bring home

\section{The response to the poem by the bride's side}

Iyo bana sabagai kato yang disampaikan tadi kumbang tabang diateh kampuang kami bamacom corak warna bulunyo

Ramo-ramo duo sakawan hinggok dibatang kayu mati bungo lah lamo kambang ditaman

menanti kumbang idaman hati

Mandanga kato niniak mamak cako hati kami harok-harok cameh sabob kumbang masiah tabang tinggi

Menuruik barito yang kami danga bukan kumbang sambarang kumbang kumbang batuah sarato sakti disagan kawan maupun lawan kumbang kasayangan ayah jok umak pagi dimandikan jok aie ambun
This is right what has just been said there are beetles flying over our village they have many colors on their wings

The butterflies are flying in pairs perching on the dead wood the flower has long been in blossom in the garden

waiting for an ideal beetle

Hearing the words of niniak mamak our heart is happy and anxious because the beetle is still flying high

According to the news we heard it is not a normal beetle it is blessed and magic it is respected by opponents and friends the beloved beetle to its mother and father in the morning it is bathed with dew 
patang dimandikan jok aie bungo malom basalimuik jok kain bugih pagi dibaduang jok sutro haluih makan dibari ditapak tangan minum manyusu dibungo kuku

Pikie kan bana kek niniak mamak jangan manyasa dikemudian hari tiliak anak, caliak calon minantu elok-elok pak keuchik mamanjek jangan tapajek rumpun buluah baduri badan luko baju cabiak lapeh naiak indak lapeh turun nandak malompek takuik patah alamat sangsaro badan salamonyo

Kami paingek sakali lai jangan tinggal carat badusanak sabalun kaki dilangkahkan sabalun lengan diayunkan kato sapatah dipikiekan sasa dahulu ado manfaatnyo sasa kamudian indak ado gunonyo at noon it is bathed with flowery water at night it is covered with bugis cloth in the morning it is wrapped with fine silk eating from the palm of a hand drinking, sucking on the $k u k u$ flower

Please do think niniak mamak do not regret it later look at the son, look at the daughter-in-law pak keuchik please be careful when climbing do not climb the thorny bamboo the body is injured and the clothing is torn can go up but cannot getdown want to jump but afraid of getting hurt the body will be miserable forever

We remind you once more do not forsake the brotherhood before the foot steps before the arm swings a single word must be thought regret in advance has an advantage regret later is of no use 


\section{APPENDIX 2}

The poem of greeting the groom (Jam marapulai)

Assalamu'alaikum kami ucapkan kapado linto sarato rombongan jok bahaso jamu kato diucapkan dimano yang salah tolong maafkan

Assalamualaikum hai marapulai baru sampai pado malomko anak daro alah duduk diateh kursi linto dinanti dari sanjo cako

Anak daro kini alah rancak alah bacalak dibulu mato calak dimuko gincu dibibie tangan jok kaki bainai pulo

Bak pihak sayang inyo ka abang siang jok malam mangkhayal sajo cako batanyo ka mak pangapik kabilo sampai linto kasiko

Waktu didanga linto alah datang hatinyo sanang gamuruah dado anak daro kini basamo pangapik tangan bapacik jalen basamo

Assalamualaikum hai mak pangapik payuang dipacik takambang pulo nandak manabu sibareh kunyik jangan tapaciak kabaju linto

Assalamualakum hai anak daro pado malomko lah sanang hati abang tabayang siang jok malom. didalam tidue manjadi mimpi mimpi baranang di aie banjie badan tasenak hari lah pagi
Peace be upon you we utter to the groom and his companions in Jamee we announce where there are mistakes, please forgive

Peace be upon you 'hai' the groom just arrived on this night the bride has already sat on a chair the groom is awaited from sunset

The bride is now adorned has mascara on her eyelids makeup on her face and lipstick on her lips henna on her hands and feet

Because the bride loves her brother [the groom] day and night she fantasizes just now she asks her best companion when does the groom arrive

When the bride hears the groom arrive her heart is happy the bride is now with her best companion her hand is held and they walk together

Peace be upon you 'hai' best companion the umbrella is held and opened up want to scatter the yellow rice do not litterthe groom's cloth

Peace be upon you 'hai' the bride on this night, your heart is happy the brother [groom] is imagined day and night in sleep he becomes a dream dreaming about swimming in a flood the body jerks, the day has already dawned 


\section{APPENDIX 3}

The poem of handing over the groom by the groom's side

Kami serahkan bulek sarupo bola dapek bagolek kamana sajo kok batangkai dapek dijinjing kok batali dapek di helo kok bakarajo buliah disuruah-suruah mambantu karajo apa sajo disuruah mahalau ayom katiko manjamue padi disuruah manumbuak padi disuaruah kapakan untuak mabali bilo ado silop jok salah mohon diajari ditegur dibari patunjuak dinasehati

Paie kaladang mamatiak patai ambiak ampang katampek palo janji kini lah sampai alah basatu kumbong jok bungo isi bingkisan mintak diparekso
We hand over [the groom] round like a ball which can be rolled everywhere if there is a handle he can be carried if there is a rope he can be pulled if there are activities, the groom can be invited to help with whatever work asked to shoo away chickens when drying unhusked rice asked to pound unhusked rice asked to go shopping if he makes a mistake, please teach him, reprove him, give guidance and advice

Going to the field to pick up Petai takes a pandan sack to collect nutmegs the promise is now due the beetle and flower have been united the containers of gifts should be checked

The response to the poem by the bride's side

\author{
Mandanga kato bapak cako \\ sarupo aie alah dijaniahkan \\ kok batali alah buliah kami helo \\ kok batangakai alah buliah kami jinjiang \\ kok talatak cit alah ditampeknyo \\ kami alah pacayo kasadonya \\ indak ado laie yang kami ragukan \\ alah panuah jok sampurno
Bukan kami batanom naneh kami batanom si anak palo kami indak mamandang harato jok ameh yang kami pandang sanak saudaro

Hearing the words the man just said it is like water that has been clarified if there is a rope, we may pull it if there is a stalk, we may wield it if it is placed, it has been put in its place we believe everything there is nothing that we worry about it has been full and perfect

We do not plant pineapple we plant nutmeg we do not see wealth and gold we see the brotherhood 


\section{GLOSSARY OF ANEUK JAMEE TERMS}

The glossary includes the terms in Jamee, Acèhnese, Indonesian, and Arabic that are frequently used in this dissertation. When it is considered to be an Acèhnese term or name it is marked as (Ach), an Indonesian as (Indon), an Arabic as (Arb) but when it is Jamee is unmarked.

\author{
A \\ Adat (Arb from 'adah) \\ Al-Fātiha $\underline{h}$ (Arb) \\ Akikah (Arb from aqiqah) \\ Alim \\ Al-ikhās (Arb) \\ Akal (Arb from aqal) \\ Amil zakat (Indon) \\ Aneuk Jamee \\ Ashar \\ Asyura \\ Aulia (Arb pl. walī) \\ Aurat \\ Aruwah (Arb arwāh, pl. of ruh $)$ \\ Azan (Arb adhān) \\ B \\ Batin (Arb bātin) \\ Barakaèk (Arb from baraka) \\ Bid'ah hasanah (Arb) \\ Bid'ah madzmumah (Arb) \\ Bileu (Ach) \\ Bismillāh (Arb basmala)
}

Buko puaso

Bulèn

Bupati (Indon)

C

Camat (Indon)

\section{D}

Dayah

$D o ' a\left(\right.$ Arb from $\left.d u^{\prime} \bar{a}\right)$

Doso

Dusun (Indon)

Dunio customary order

the opening chapter of the Qur'ān

the seven-day naming ritual

$a$ person with some learning of Islam but not as learned as 'ulamā'

chapter 112 of the Qur'ān

reason, rationality

the collector of alms

the "children of the guest"

afternoon, afternoon prayer

the 10th day of the first Islamic lunar month, Muharram

saints

parts of human body that have to be covered when a person is outside the confines of the family.

the spirits of the deceased

call to prayer

inner, spiritual, esoteric

spiritual blessing

an innovation regarded as beneficial

an innovation regarded as blameworthy.

the person who says the azan

the invocation of bismillahirrahmanirrahīm: "In the name of Allāh, the Merciful, the Compassionate".

the time for breaking the feast; cakes for the time of beaking the fast

month, moon

the regency (Indon kabupaten) head

the district (Indon kecamatan) head

the common term for the Islamic religious boarding school in Acèh, similar to the pesantren in Java prayer usually in the sense of supplication to Allāh, as opposed to liturgical prayer, spell, recitation sin, sinful

"cluster"

the world; this world, as opposed to the hereafter 


\section{Dukun (Indon)}

$\boldsymbol{F}$

Fikh

H

Hadis (Arb from hadith)

Hari rayo haji

Hari rayo puaso

Hawa nafsu

Hawa nafsu

\section{I}

Ibadah (Arb from 'ibādāt)

Idah (Arb iddah)

Ikhlās (Arb)

Imam (Arb imām)

Imuem mukim (Ath)

Ibadat (Arb ibadah)

Idang

Ikhlas (Arb ikhlās)

Imam (Arb imām)

Israk mikrāj

\section{$\boldsymbol{J}$}

Jin (Arb jinn)

Jalèn subuah

Jubah (Arb jubbah)

\section{$\boldsymbol{K}$}

Kabupaten

Kecamatan

Keucik

Kadha

Kadhi (Arb qādī) a practitioner of a magic who claims to possess secret powers which he or she employs in a variety of functions

the science of Islamic jurisprudence

traditions of the Prophet, those reports from the first generations of Muslims regarding the words and actions of the Prophet Muhammad, judged as genuine, constitutes a second scripture in Islam.

the feast of sacrifice

the feast of breaking the Ramadhan fast

carnal desire, passion

the part of man's nature that he shares with animals; everything within man that arises spontaneously

religious services that referring to the "five pillars of Islam"

the waiting period after a woman is divorced during which she must wait before being eligible for remarriage.

sincere devotion

leader in performing prayer; and everything which is related to religious duties.

see mukim

religious service)

a packet of food that includes rice and a variety of side dishes which is served at a communal feast absolute devotion to Allāh in religious faith, practice and action

religious official in villages, prayer leader

the celebration of the Prophet's ascension to heaven

spirit

the tradition of walking in the morning during the month of Ramadhan

a frock often worn by saintly individuals among Muslims

an administrative unit, a regency headed by a $b u$ pati

a subdivision of a regency or district headed by a camat

village head

the power of Allāh to determine all events

a judge in Islamic law, a religious official 
Kampuang

Kapalo kampuang

Kemukiman

Khatīb (Arb)

Khanduri

Kitab (Arb kitāb)

Kujruenblang

Kurafat (Arb khurāfā)

\section{$\boldsymbol{L}$}

Lahi

Lailatul qadar

Laukh makhfudz

Luhu

Latihan kejiwaan (Indon)

M

Marantau

Makèn-makèn

Makrifat (Arb ma'rifah)

Magrib

Meugang

Meunasah (Ach)

Meuratéb (Ach)

Mo'lot (Ach)

Muazin (Arb muazzin)

Muhammadiyah (Indon)

Mukim

$N$

Nadzar (Arb nadhr)

Nièt

\section{$\boldsymbol{P}$}

Pengajian

Pahalo

Pakan

Puaso

$Q$

Qurban (Arb Qurbān) urban compound

the head of the village

a collection of several villages, headed by imuem mukim

a preacher

a ritual meal, a comunal feast

writing; scripture, abook

rice ritual specialist

applied by purist Muslims to many aspects of historic Islam

outer self, born

"the Night of Decree"

the tablet where the record of the decisions of the divine are preserved

noon the prayer observed at noon

training 'soul'

staying outside one's home area

an excursion to the beach or river; a social gathering with food during an excursion

intuitive knowledge concerning the relationship of worshipers to Allāh

sunset, prayer observed at sunset

the tradition of slaughtering cow or buffalo two days preceding Ramadhan, idul adha and idul fitri celebration

prayer house

religious chants

the Prophet's birthday and its celebration

the person who calls to prayers

modernist Islamic organization

see kemukiman

a vow to undertake a religious action

a short declaration of the intention pronounced audibly or mentally

religious discussion

religious merit

market

fasting

the ritual offering of livestock to commemorate Ibrahim's willingness to sacrifice his son Ismail to Allāh 
$\boldsymbol{R}$

Raka'a (Arb)

Reusam

Ripèe

$S$

Salék

Sahur

Sarung

Sawah

Sadakah (Arb sadaqah)

Salawat (Arb salawāt)

Saidina (Arb sayyidinah)

Seumayang

(Indon sembahyang; Arb salāt)

Sharī'a (Arb)

Shirk (Arb)

Sunnah (Arb)

Shamadiyah (Arb shamad)

Subuah

Suluk

Sunat (Indon),

Syahadat (Arb)

Syari'ah (Arb sharī'a)

Syafa'at (Arb syafā'ah)

Syahbanda, the harbor master

Serambi Mekkah

Syeikh (Arb)

$T$

Tadarus

Tauhīd (Arb)

Tahlill (Arb) the prescribed unit ofprayers and accompanying bows and prostrations of the prayer ritual, how a villager behaves during the village activities voluntary contribution for a communal feast

the suluk followers

the meal taken just before day break

a wrap-around lower garment

wet rice field

giving charity, alms to the less fortune

Allāh wishes or salutations: The Arabic expression (Arabic Allāhumma salli 'alā Muhammad wa 'alā āli Muhammad) "Blessing on Muhammad and his family".

the title 'our leader' designating important personages in Muslim history, such as the Prophet and the righteous caliphs

Islamic prescribed prayer

Islamic law; lit., "path"

idolatry, polytheism

the way of Prophet

eternal

daybreak, prayer observed at daybreak

the practical method to guide seekers by tracing a way of thought, feeling, and action, leading through

a succession of 'stages' to experience the Divine Reality (Trimingham; 1971:3-4).

Islamic services which are recommended but not obligatory

Islamic confession of faith ("There is no god but Allāh, and Muhammad is his Messenger")

the Islamic law code

the intercession of the Prophet on behalf of Muslims on Judgement day

"the verandah of Mecca", a nickname applied to Acèh because of its historical ties with the Islamic holy land, especially in the seventeenth and eighteenth centuries when pilgrims from Southeast Asia passes through Aceh

an exemplary religious figure

the tradition of reciting the Qur'an during the night of the Ramdahan month

the oneness of Allāh

reciting la ilaha illa Allāh, "there is no deity but God" 
Takbīr (Arb)

Tasbīh (Arb)

Tarawèh

Takdir

Tahlil (Arb tahlīl)

Tuangku imam

Tulak bala

$U$

Ulama (Arb 'ulamā')

Uraung karamek

$W$

Wājib (Arb)

Y

Yāsinn (Arb)

Zakāt (Arb)

Zikir (Indon dzikir;Arb dhikr) proclaiming Allāhu akbar, "God is great"

repeating subhanallāh

special night prayer during the month of Ramadhan the recognition that all matters of creation are determined by Allāh

recitation of the phrase "la iläha illallāh" (there is no god but Allāh). Tahayyul (Arb takhayyul), a concept applied by purist Indonesian Muslim to many folk practices in Indonesian life

a leader in Islamic prayer

"pushing back danger", "warding off calamities"

scholars of religious sciences in Islam and generally acknowledged leaders of the community in matters of religion

a person who has supernatuaral qualaities

required

a specific chapter of the Qur'an

religious tithe

the repetition of the names of Allāh and certain religious formulae as a means of demonstrating piety or, as in the case of mystics, to induce a mystical trance 


\section{MAPS}

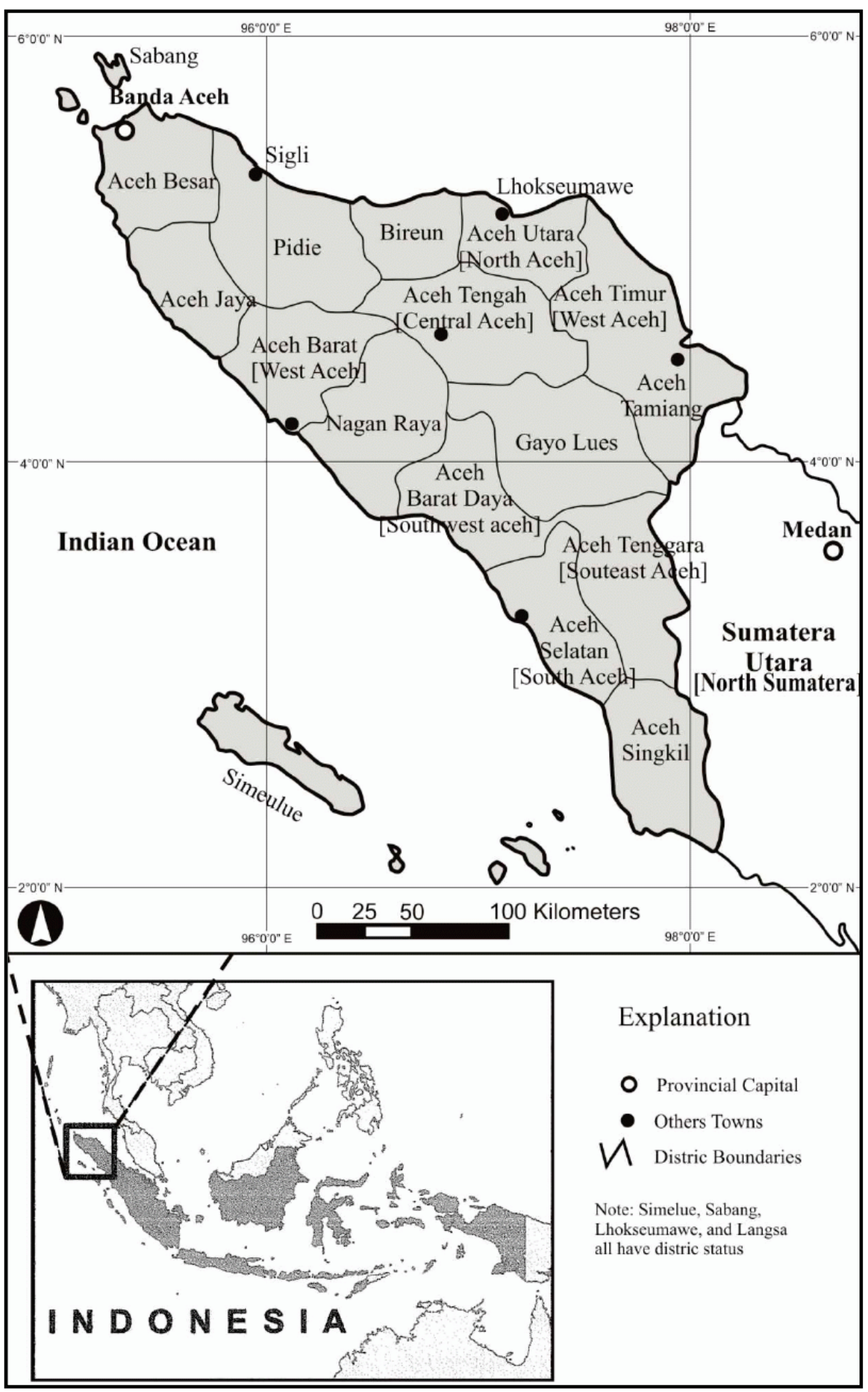

\section{Map 1. Aceh-Indonesia}

Source: www.c-r.org/our-work/accord/aceh/map.pph 


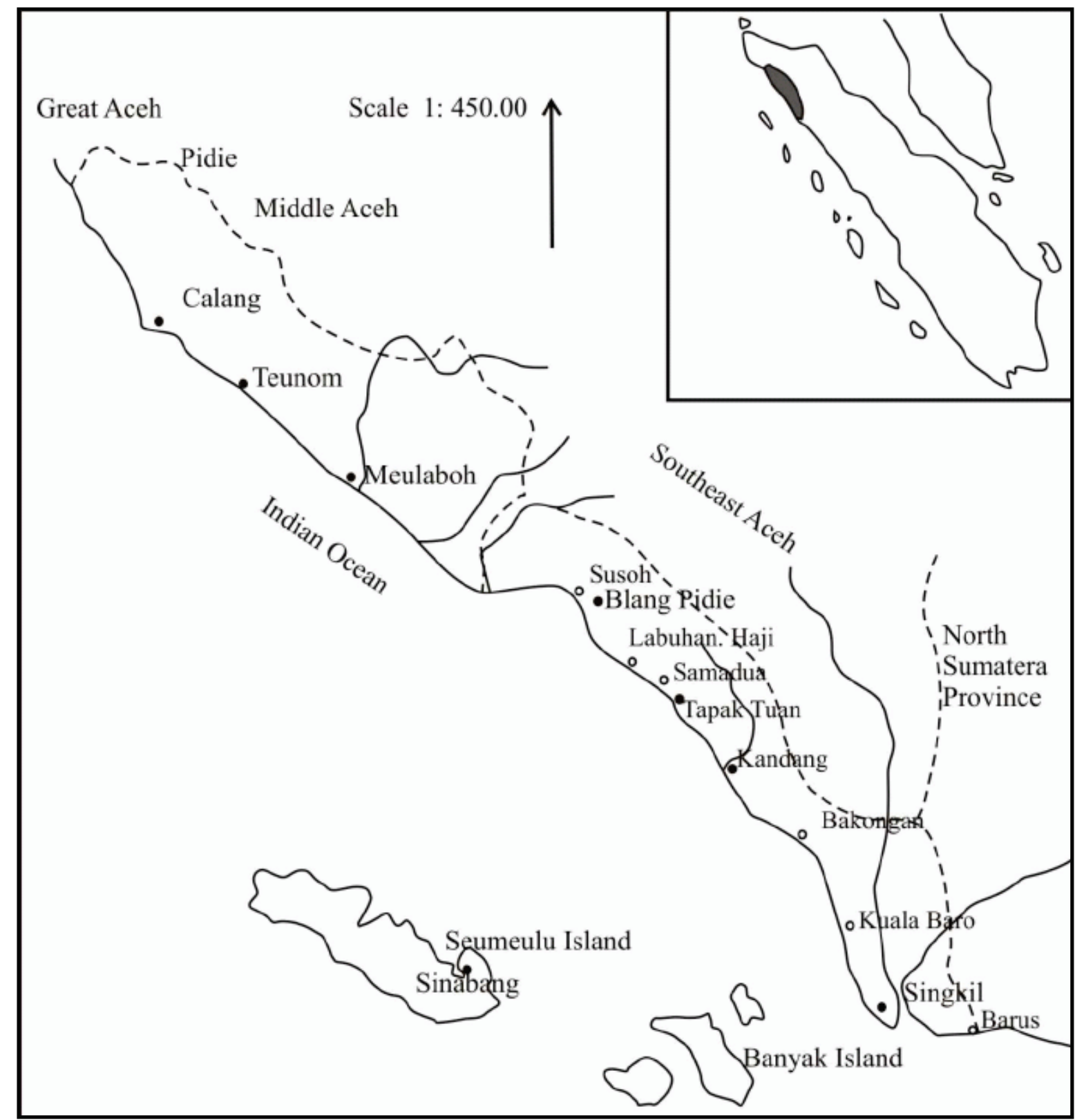

Map 2. The distribution of Aneuk Jamee population in the southern and western coast of Acèh.

Source : Sulaiman $(1978: 51)$ 


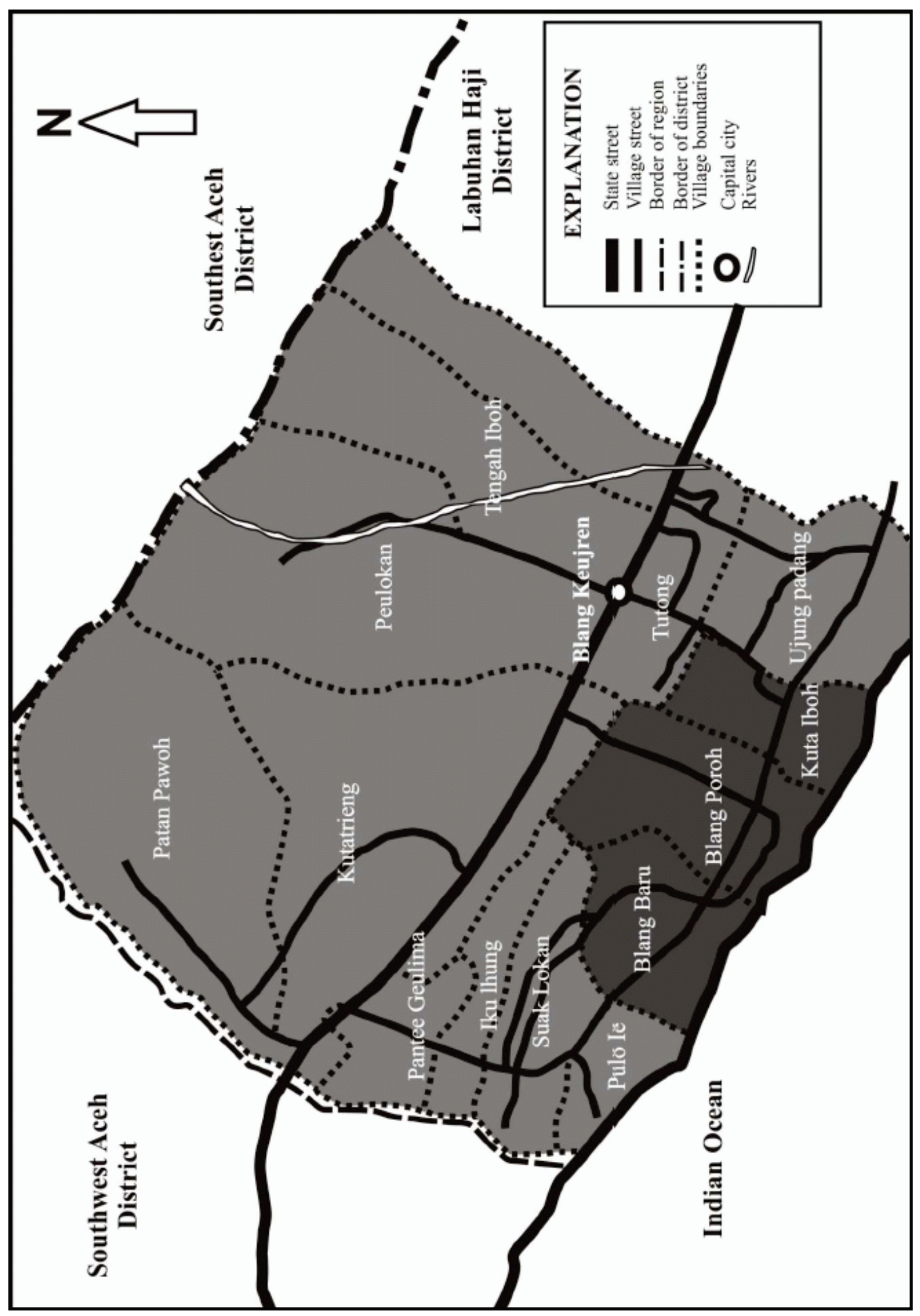

Map 3. West Labuhan Haji district

Source: the Camat office of West Labuhan Haji district 


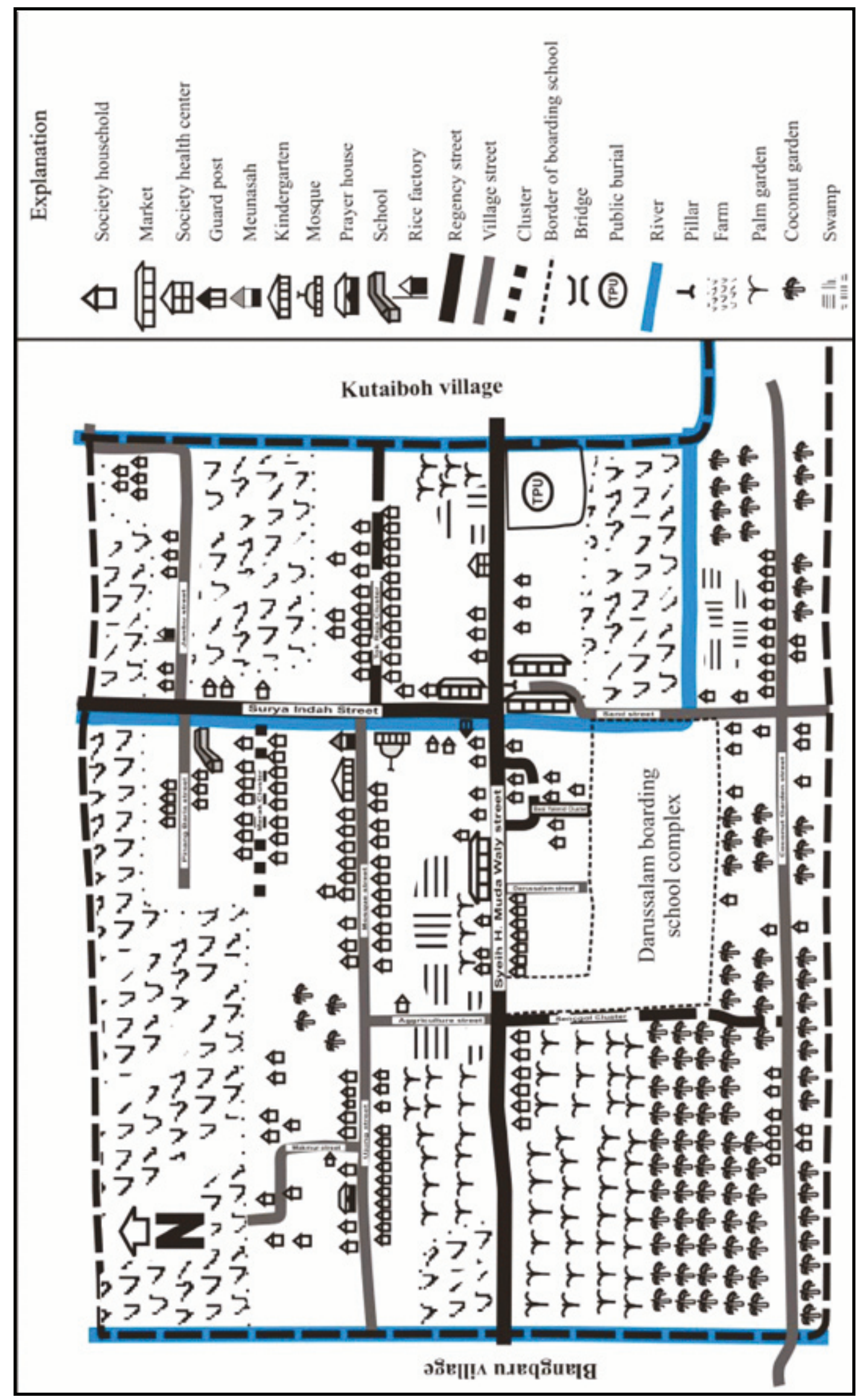

Map 4. Blangporoh village 


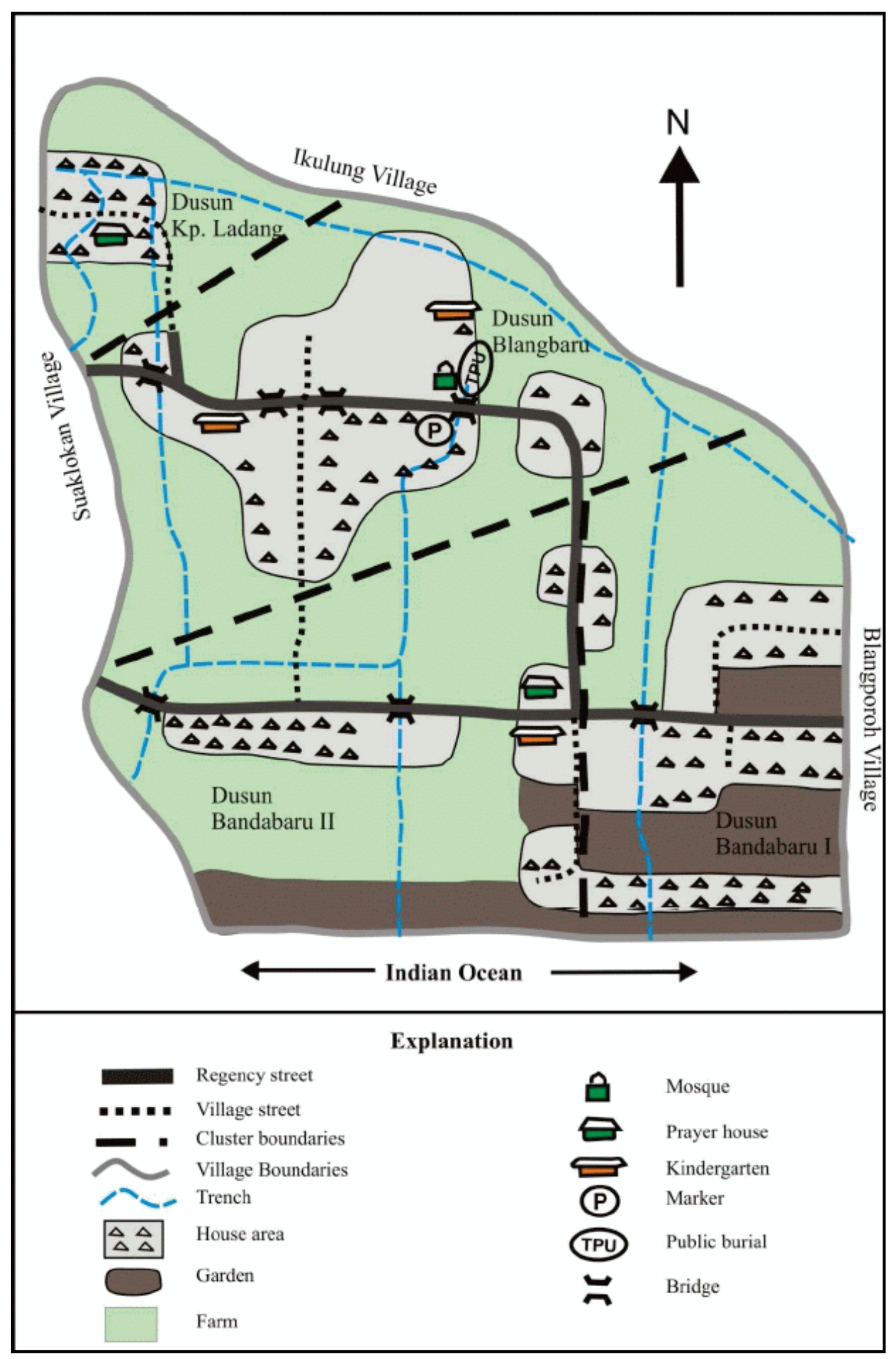

Map 5. Blangbaru village 


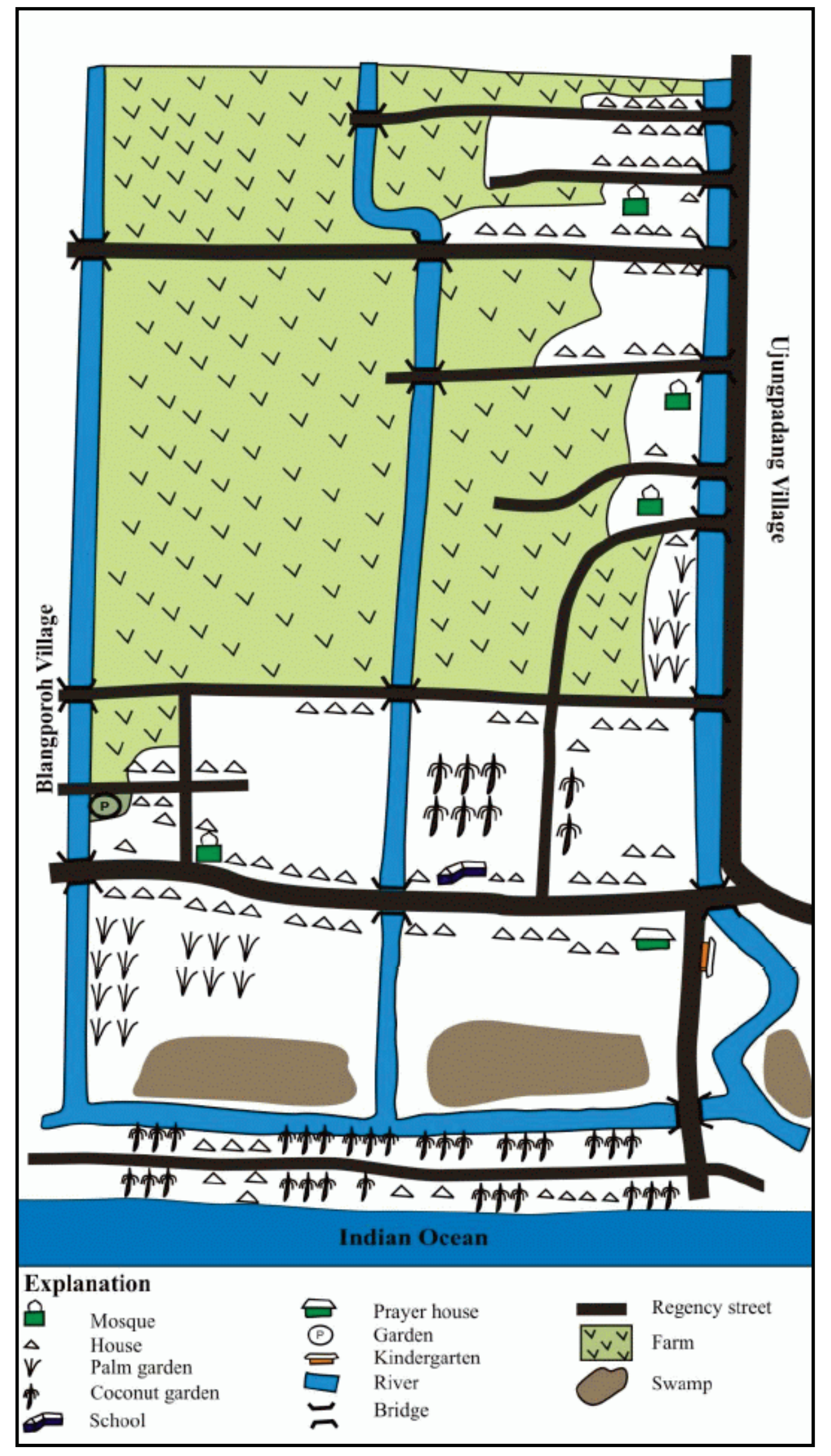

Map 6. Kutaiboh village 


\section{PhotographS}

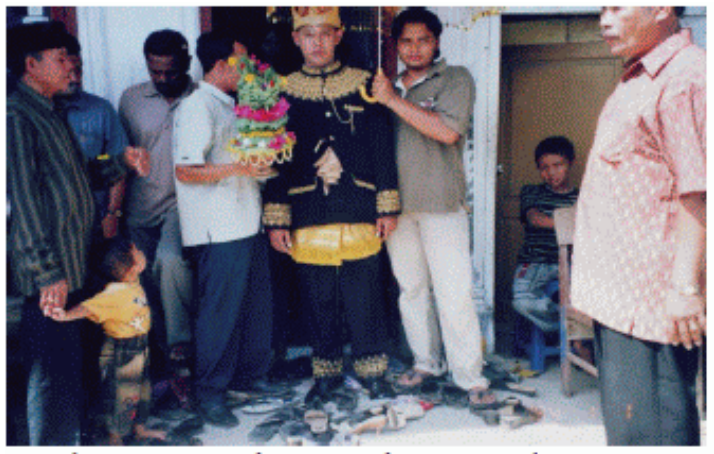

1. The groom about to depart to the bride's house.

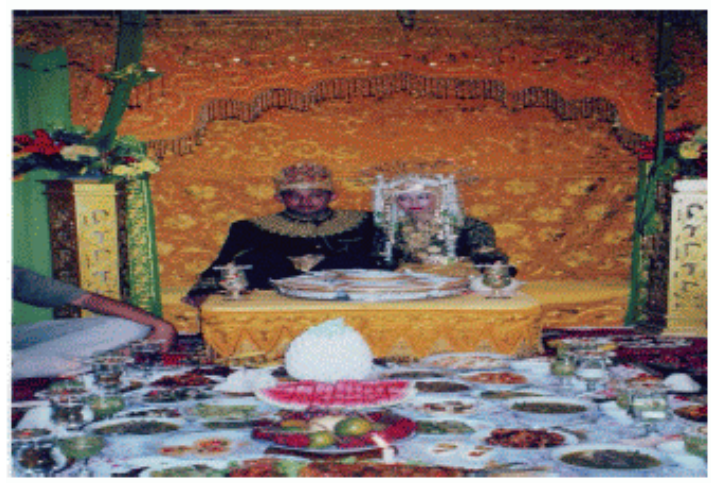

3. Bride and groom seated on the dais.

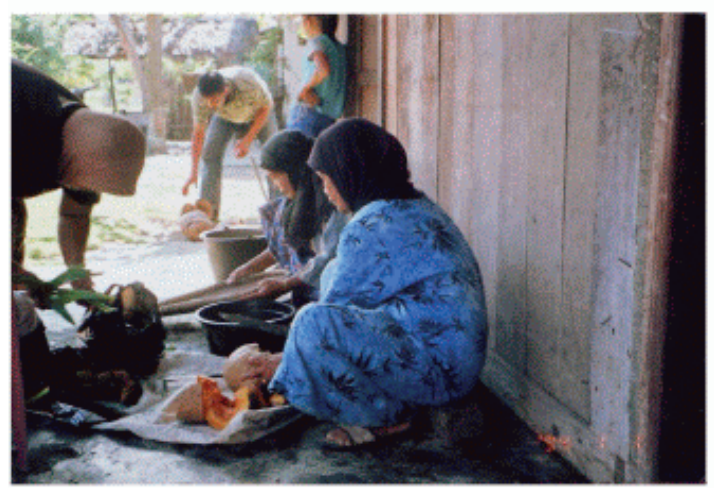

5. Women preparing khanduri 'āsyürāa.

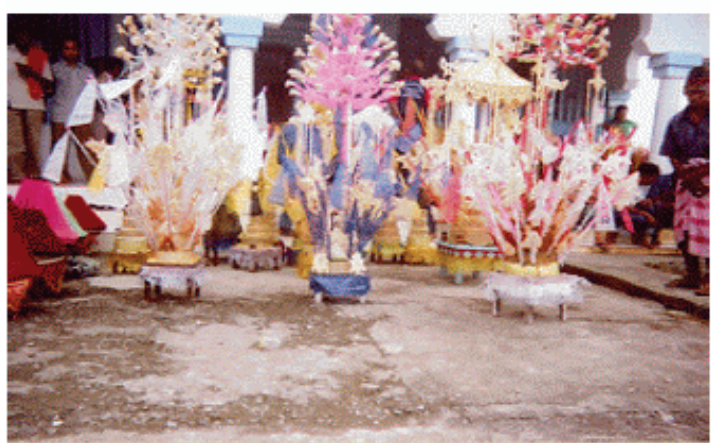

7. Idang gadang offerings on the verandah of the mosque for the mo'lot celebration.

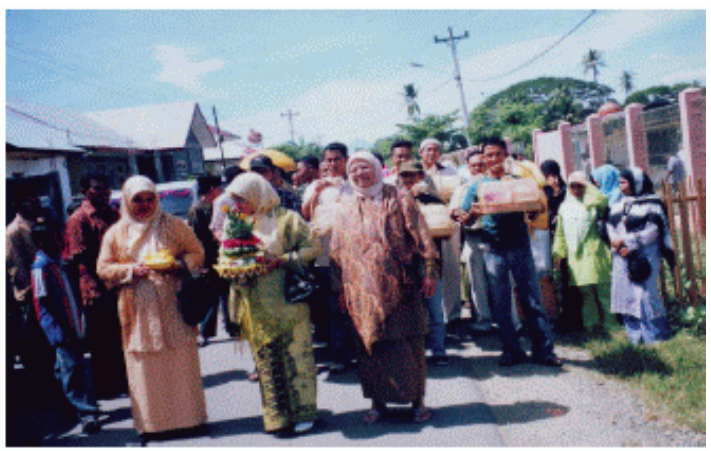

2. Groom's relatives bearing gifts to the bride's house.

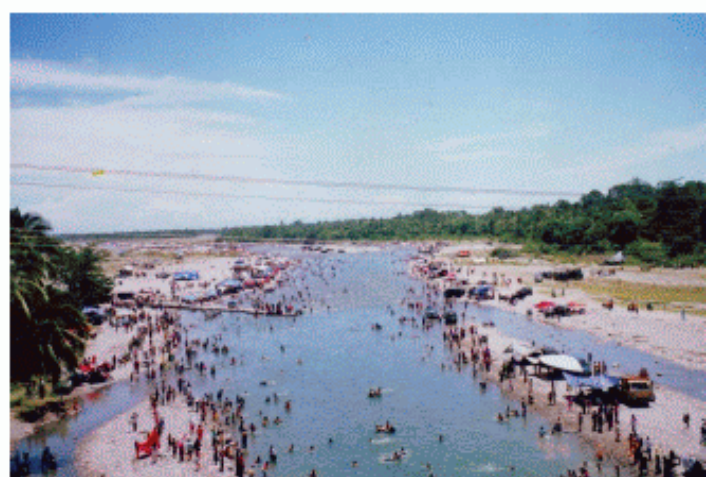

4. The ritual bathing during tulak bala day.

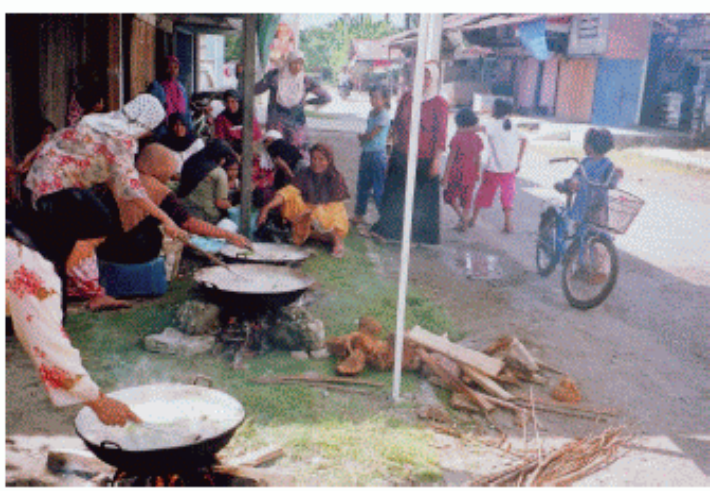

6. Women cooking the 'ásyürā porridge.

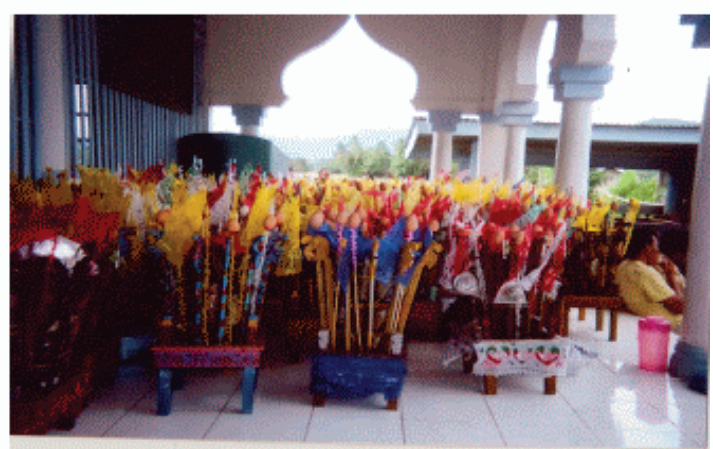

8. Sanggèn offerings on the verandah of the the mosque. 


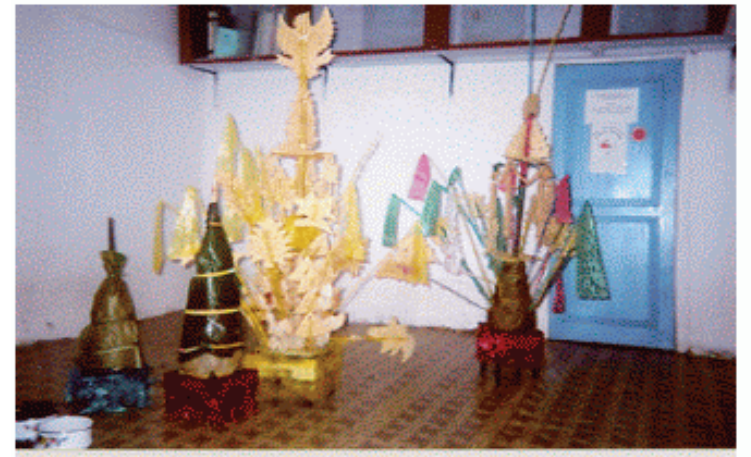

9. Idang nasi kunyik offerings in a house near the mosque.

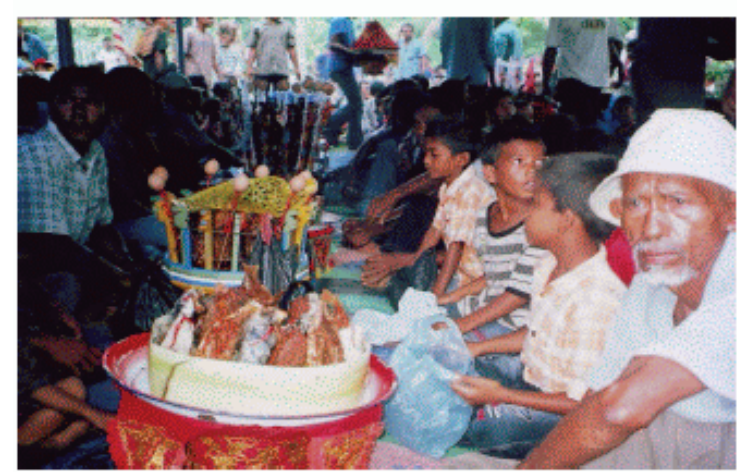

11. Awaiting the signal to eat the daluang.

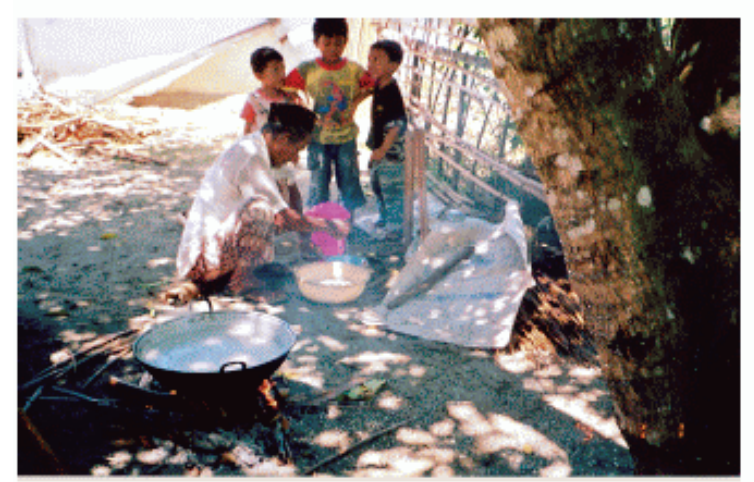

13. Preparing the khanduri bugong kayè offerings.

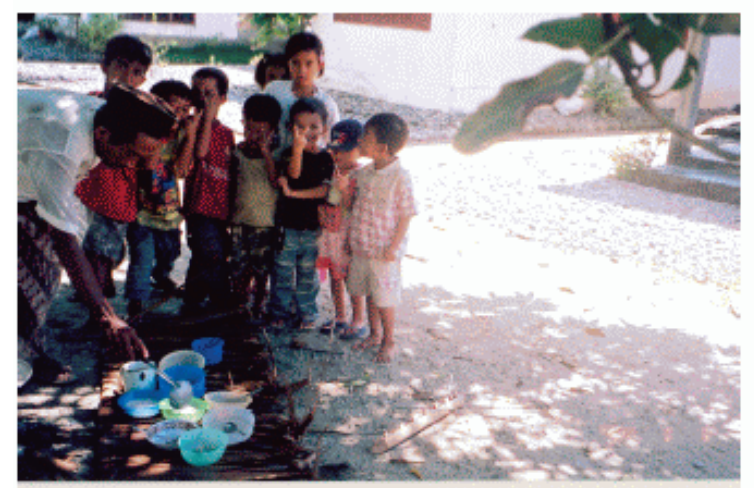

15. Kanji distributed to children.

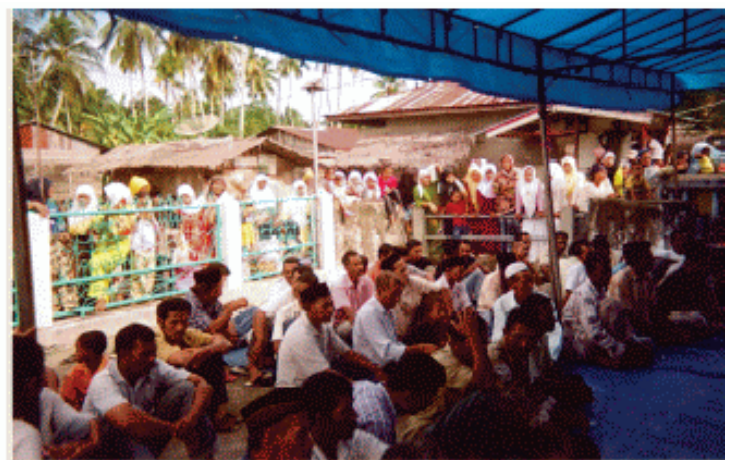

10. Spectators of dikémo 'lot (the Prophet's birthday celebration).

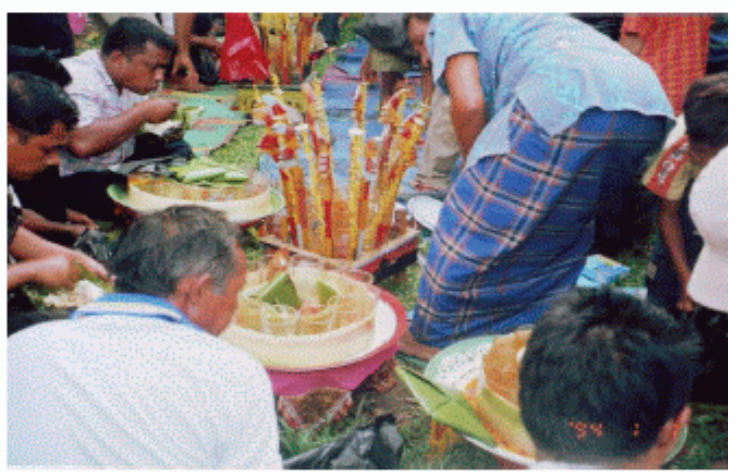

12. Commensal eating of the daluang and sanggèn offerings.

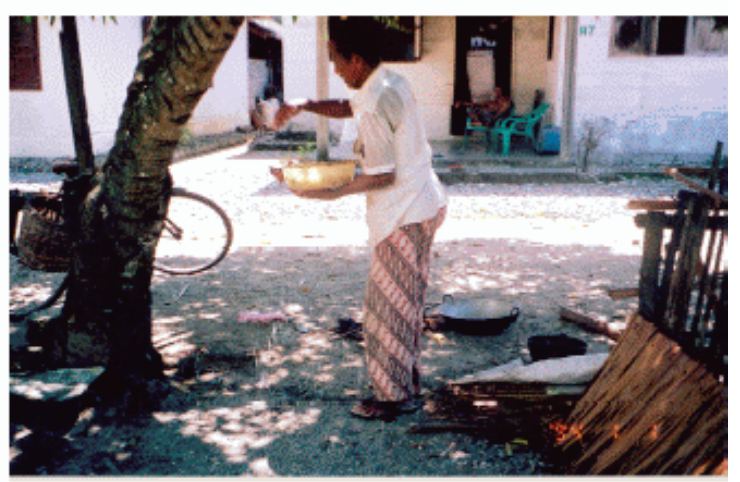

14. Pouring the kanji on the base of the mango tree.

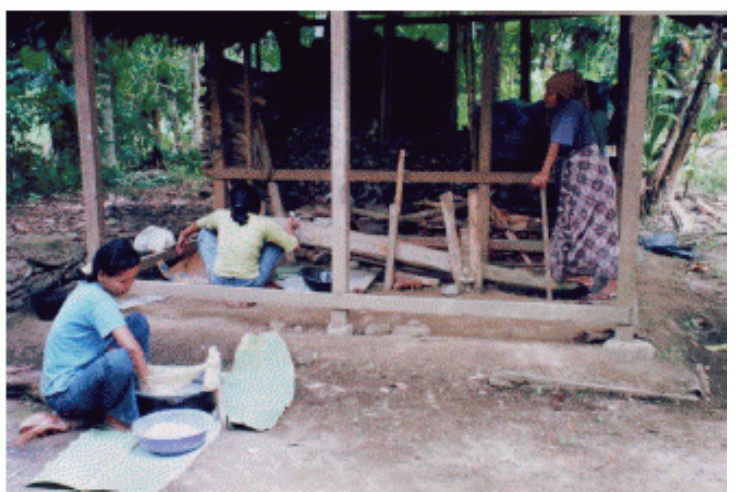

16. Women pounding rice for the apam cakes. 


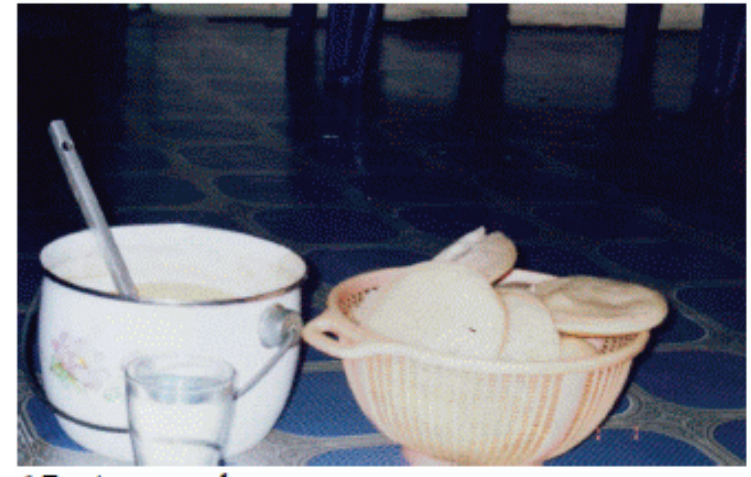

17. Apam cakes.

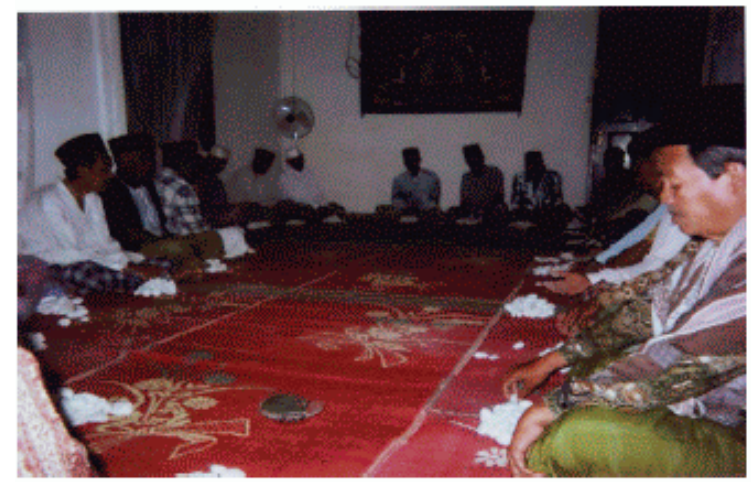

19. Reciting shamadiyah with white stones.

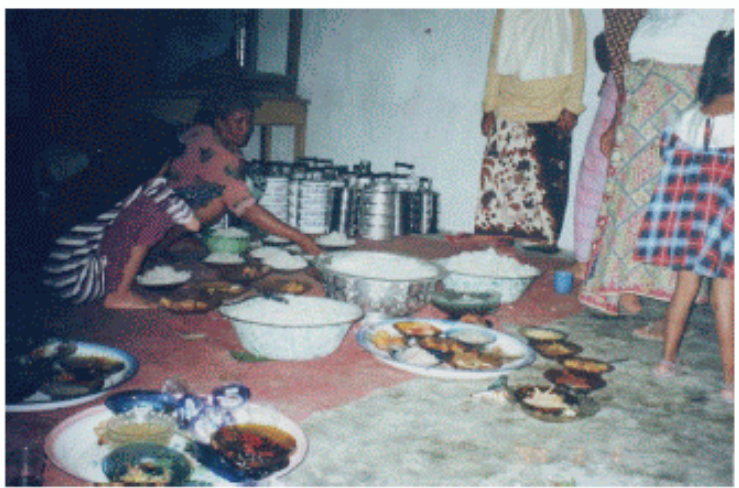

21. Preparing rice for khanduri bu.

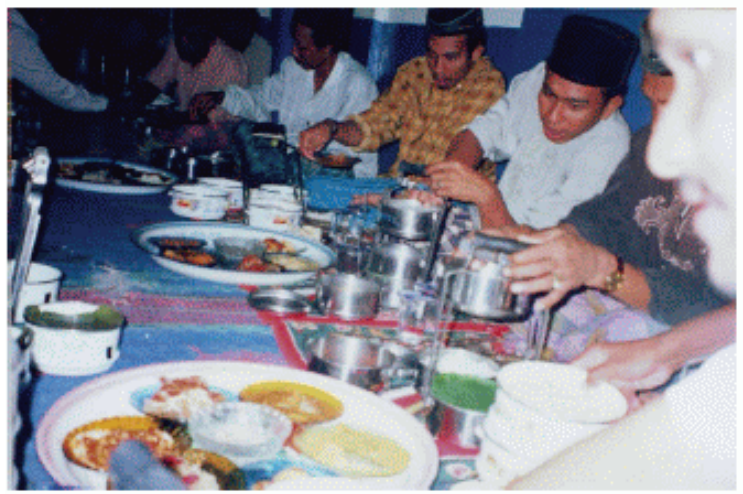

23. Men eating khanduri bu in the mosque.

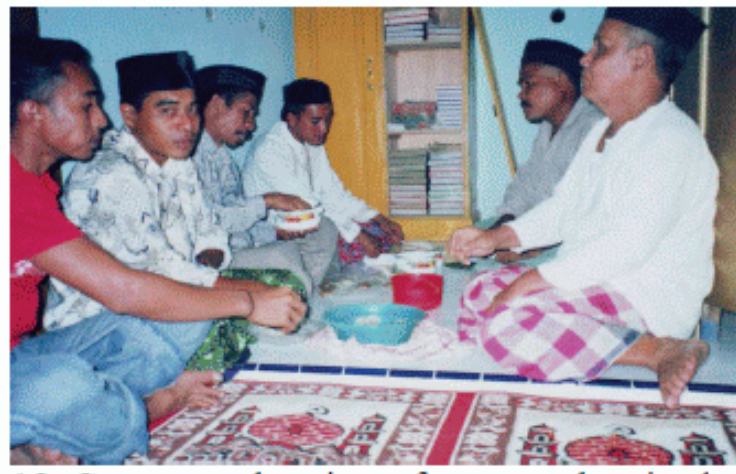

18. Commensal eating of apam cakes in the mosque.

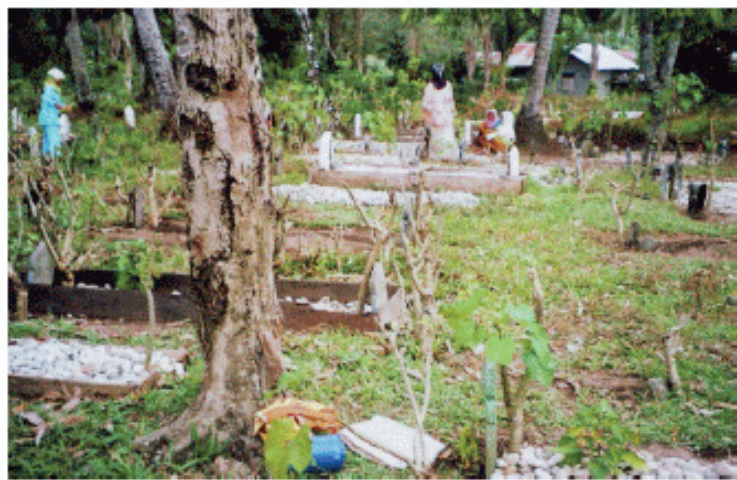

20. Placing the shamadiyah chanted stones on graves.

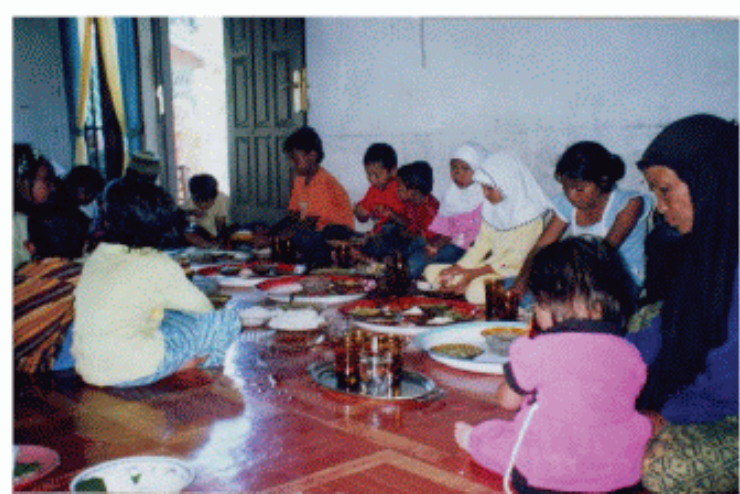

22. Orphans eating khanduri bu.

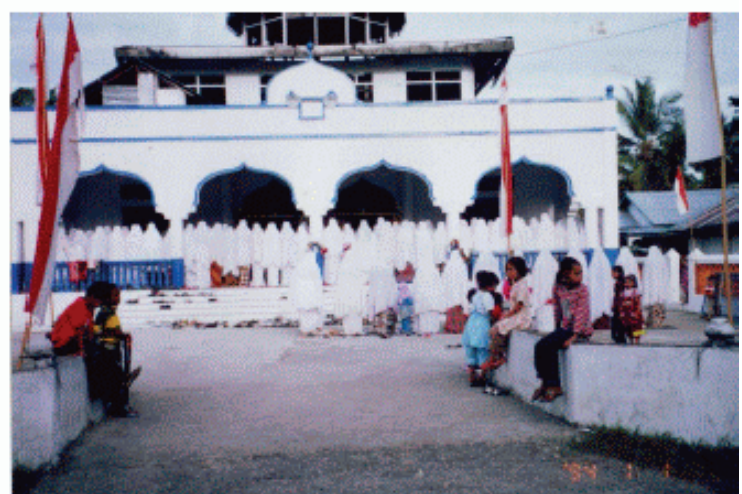

24. Performing 'idul fitri prayers at the village mosque. 


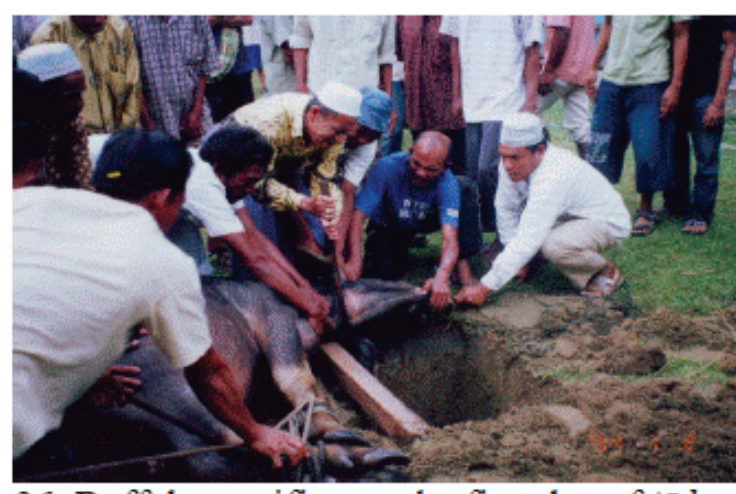

26. Buffalo sacrifice on the first day of ' $\bar{i} d$ ul adha.

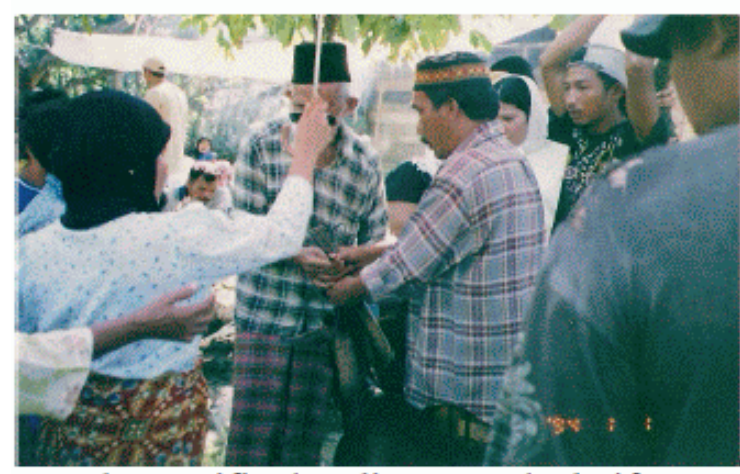

27. The sacrifier handing over the knife

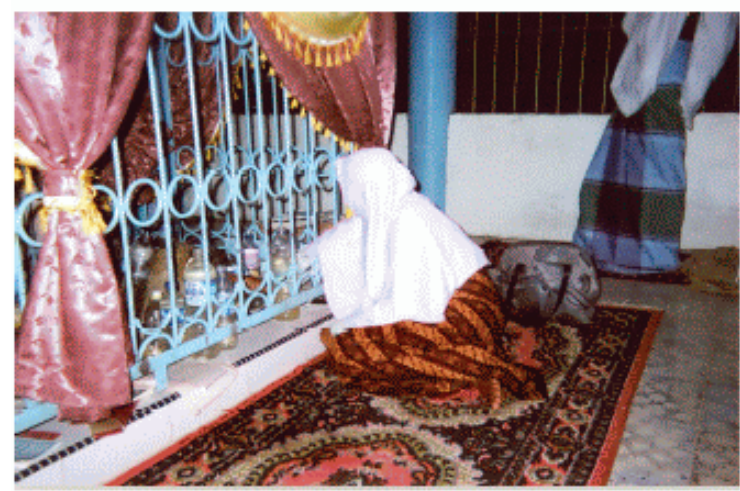

29. A woman placing water on the Sheikh's grave to receive baraka ('blessings').

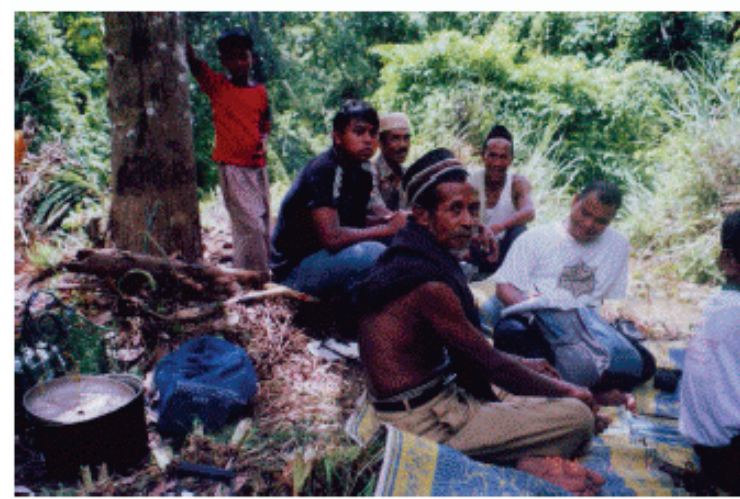

31. Researcher collecting data from men.

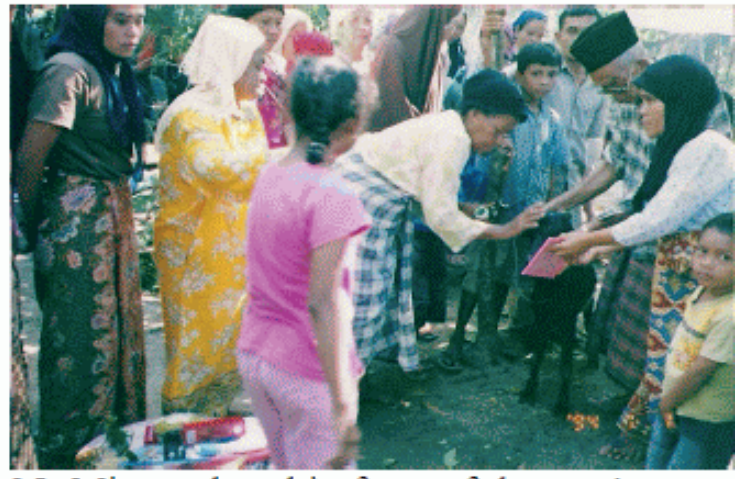

25. Mirror placed in front of the ram's gaze.

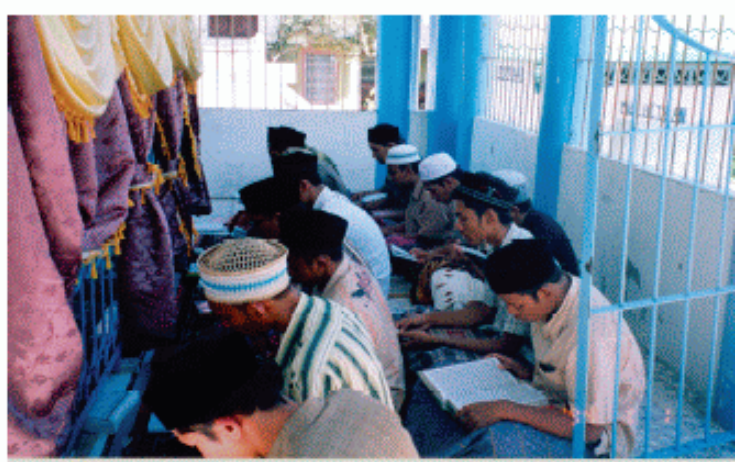

28. Dayah students praying at the Sheikh's grave.

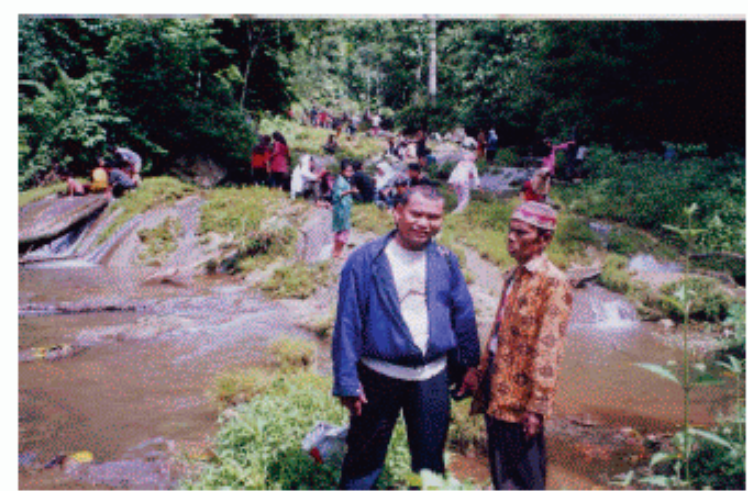

30. Researcher with one of his informants.

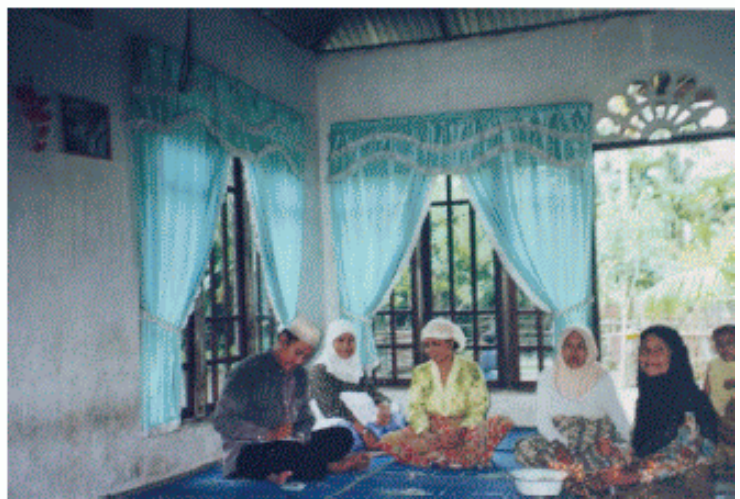

32. Researcher collecting data from women. 


\section{Curriculum Vitae}

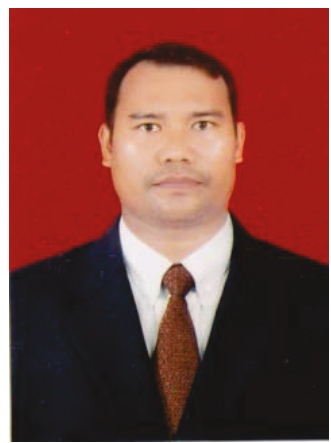

Dr. Phil. Abdul Manan, M.Sc., MA was born in Alurambut, Manggeng district (now Lembah Sabil district), South West Aceh (SumatraIndonesia) on Juni $21^{\text {st }}$, 1972. His ethnicity is Acèhnese. He finished his Islamic Elementary School (MIN) Suakberumbang-South West Aceh in 1985, State Junior High School (Sekolah Menengah Pertama Negeri) Manggeng-South West Aceh in 1988, Teacher Training School (Sekolah Pendidikan Guru) Tapaktuan-South Aceh in 1991, Under Graduate Program of English Language Education at the State Institute for Islamic Studies Ar-Raniry (S. Ag) (now State Islamic University (UIN) Ar-Raniry) Banda Aceh in 1997, Master in Educational and Training System Design (M.Sc-Scholarship from Student Netherland (StuNED)) at the Faculty of Educational Science and Technology of the University of Twente, Enschede, Holland in 2001, Master in Islamic Studies (MA-Scholarship from Indonesian Cooperation in Islamic Studies (INIS) at the Faculty of Letters and Theology of the University of Leiden, Leiden, Holland (2003) and Dr. Phil - Scholarship from Deutscher Akademischer Austauschdienst (DAAD Bonn) in Ethnology at the Westfälische Wilhelms-Universität Münster, Germany in 2010. In 2015 again he got scholarship for alumni from DAAD Bonn called Wiedereinladung Scholarship for two months (June-July) to design his post-doctoral program proposal at the Institute for Ethnolgy at the Westfälische Wilhelms-Universität Münster, Germany. From 1995-1999 he worked as teaching staff of Langange Development Center of UIN ArRaniry. From 2004-2011 he worked as a methodology of Islamic Studies lecturer at Syaria Faculty of UIN Ar-Raniry and from 2012 till now he works as a cultural anthropology lecturer at Adab and Humanities Fakulty of UIN Ar-Raniry Banda Aceh. Among of his selected scientific publications are:

\section{Books}

Ritual Kalender Aneuk Jamee di Aceh Selatan (Vol I) ISBN Ar-Raniry Press, First Edition October 2012. Rabbani Wahid: Bentuk Seni Islam di Aceh ISBN Balai Pelestarian Nilai Budaya Aceh-Sumut, First Edition March 2012. Ritual Kalender Aneuk Jamee di Aceh Selatan (Vol II) ISBN Ar-Raniry Press, First Edition December 2013. Syari'at Islam di Aceh (Realitas dan Respon Masyarakat) ISBN Ar-Raniry Press, First Edition October 2014.

\section{Journals}

“Syura Menurut Perspektif Al-Qur'an" (Interpretasi Q. S. Al-Syura: 38) in Al-Mu'asyirah Vol. 2 No, 2 June 2005, Ushuluddin Faculty of UIN Ar-Raniry. "Eksistensi Dar Al-Hikmah dan Pengembangan dalam Konteks Kekinian" in ADABIYA Vol. 7 No. 13 August 2005 Adab and Humanities Faculty of UIN Ar-Raniry. "At-Tahniah Bi'idil Krismasi" (A Study on the Fatwa of Sheikh Muhammad bin Shalil al-Utha imin) in Sosio-Religia, Vol. 6. No. 4 August 2007 LinkSAS, Yogyakarta. "The Mortuary Ritual in West Labuhan Haji-South Aceh" in Islamic Studies Vol. 2 No.1 June-December 2012. Senat Pasca Sarjana of UIN Ar-Raniry Banda Aceh. "Keuneunong (The Acehnese Seasonal Calendar)" in ADABIYA Vol. 7 No. 13 August 2013 Adab and Humanities Faculty of UIN Ar-Raniry. "Larangan Ngangkang Naik Motor bagi Wanita (Persepsi dan Respon Mansyarkat tentang Efektifitas Implementasi PERDA Kota Lhoukseumawe)" in Islamic Studies Vol.2, No. I January 2014. Senat Pasca Sarjana of UIN Ar-Raniry Banda Aceh and "Ritual dan Institusi dalam Islam" in $A D A B I Y A$ Vol. 16 No. 28 February 2015 Adab and Humanities Faculty of UIN Ar-Raniry Banda Aceh. 


\section{The Ritual Calendar of South Acèh, Indonesia}

Abdul Manan

This publication addresses the manner in which Islam manifests itself in the culturally specific representations and actions of the society of Aneuk Jamee of South Acèh, Indonesia. Based on long-term socialanthropological field research it explores the relations between the so-called normative Islam - as that has been laid down in the canonical texts of the Qur'ān and hadīth- and the ways in which these normative ideas, locally understood and valued, are expressed in the rituals conducted. The research has revealed how in local perception these ritual actions generate a reproduction of the social relationships and the moral foundation that make up this society. The meticulous examination of the village ritual calendar shows that three different perspectives on this social and moral order prevail: a traditional adat perspective, the historical Islamic perspective, and the modernist Islamic perspective. This attributes to Aneuk Jamee a complex dynamic socio-religious identity within the field of Indonesian cultures.

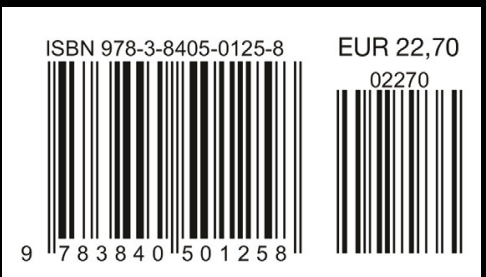

